\title{
The mineralogy and chemistry of modern shallow-water and deep-sea corals
}

\author{
by \\ Gabriela A. Farfan \\ B.S. Geological and Environmental Sciences, Stanford University, 2009 \\ Submitted in partial fulfillment of the requirements for the degree of \\ Doctor of Philosophy \\ at the \\ MASSACHUSETTS INSTITUTE OF TECHNOLOGY \\ and the \\ WOODS HOLE OCEANOGRAPHIC INSTITUTION
}

February 2019

(C) 2019 Gabriela Aylin Farfan. All rights reserved.

The author hereby grants to MIT and WHOI permission to reproduce and to distribute publicly paper and electronic copies of this thesis document in whole or in part in any medium now known or hereafter created.

Signature of Author.

Joint Program in Oceanography/Applicd Occan Science and Engineering Massachusetts Institute of Technology and Woods Hole Oceanographic Institution October 14, 2018

Certified by

Dr. Colleen M. Hansel Thesis Supervisor Woods Hole Occanographic Institution

Accepted by

Dr. Shuhci Ono

Chair, Joint Committee for Chemical Oceanography Woods Hole Oceanographic Institution 


\title{
The mineralogy and chemistry of modern shallow-water and deep-sea corals
}

\author{
by
}

\author{
Gabriela Aylin Farfan
}

Submitted to the Massachusetts Institute of Technology and the Woods Hole Oceanographic Institution on October 14, 2018 in partial fulfillment of the requirements for the degree of Doctor of Philosophy in Geochemistry

\section{Abstract}

The architecture of coral reef ecosystems is composed of coral skeletons built from the mineral aragonite $\left(\mathrm{CaCO}_{3}\right)$. Coral reefs are currently being threatened by ocean acidification $(\mathrm{OA})$, which may lower calcification rates, reduce skeletal density, and increase aragonite dissolution.

Crystallography and chemistry are what govern the materials properties of minerals, such solubility and strength. Thus, understanding the mineralogical nature of coral aragonite and how it forms are important for predicting bulk skeletal responses under climate change.

Different models based on geochemical versus biological controls over coral skeleton biomineralization propose conflicting predictions about the fate of corals under OA. Rather than investigating the mechanism directly, I use a mineralogical approach to study the aragonite endproducts of coral biomineralization. I hypothesize that coral mineralogy and crystallography will lend insights into how coral aragonite crystals form and how sensitive coral aragonite material properties may be to OA.

Here I compare the crystallography, bonding environments, and compositions of coral aragonite with aragonite produced by other organisms (mollusk), synthetically (abiogenic precipitation in aragonite-supersaturated seawater and freshwater), and in natural geological settings (abiogenic). Coral aragonite crystallography does not resemble mollusk aragonite (aragonite formed with a strong biological influence), but rather is identical to abiogenic synthetic aragonite precipitated from seawater. I predict that the material properties of coral aragonite are similar to that of abiogenic synthetic seawater aragonites and that coral aragonite formation is sensitive to surrounding seawater chemistry. To test the effect OA on coral aragonites, I studied deep-sea corals from a natural $\Omega_{\mathrm{sw}}$ gradient (1.15-1.44) in the Gulf of Mexico and shallow-water corals across a natural $\Omega_{\mathrm{sw}}(2.3-3.7)$ and $\mathrm{pH}$ (7.84-8.05) gradient in Palau. Minor shifts in crystallography are expressed by coral aragonite in these natural systems, likely governed by skeletal calcite contents, density, and $\Omega$ of the coral calcifying fluid.

My results are most consistent with a geochemical model for biomineralization, which implies that coral calcification may be sensitive to OA. However, further work is required to determine whether the modest crystallographic shifts I observe are representative on a global scale and whether they could influence bulk skeletal material properties.

Thesis supervisor: Dr. Colleen M. Hansel

Title: Associate Scientist with tenure, Marine Chemistry and Geochemistry Department, Woods Hole Oceanographic Institution 


\section{Acknowledgements}

I sincerely thank my advisor, Dr. Colleen Hansel, for her endless support and for being such an amazing role model to me. Thank you for turning me into a better scientist and for giving me such amazing opportunities to do research at the synchrotron, go to sea, and see corals in the wild. I also extend a huge thank you to my thesis committee, Dr. Amy Apprill, Dr. Anne Cohen, and Dr. Tanja Bosak, for their encouragement, construcive feedback, and access to amazing coral and carbonate samples. I would also like to acknowledge and thank Dr. Meg Tivey for continuing to be a valuable honorary committee member and Dr. Tristan Horner for chairing my defense and providing thoughtful feedback on this thesis.

This thesis depended on many collaborators and was made so much richer by their insights and by their generosity in providing me with coral and aragonite samples from around the globe. Many thanks to Dr. Eric Cordes and Dr. Rhian Waller for all of the deep-sea coral samples as well as Dr. Amy Apprill and Dr. Anne Cohen for the shallow-water samples. Thank you to Dr. Thomas DeCarlo and Dr. Michael Holcomb for giving me some of the seawater synthetic aragonites that they created in Dr. Glenn Gaetani's lab at WHOI. I would especially like to thank Dr. Thomas DeCarlo for his insight and support over the years. Many thanks to Nathan Mollica for sharing his Palau dataset and knowledge with me. I would also like to thank Dr. Sebastian Mergelsberg and Dr. Patricia Dove for their time and generosity in creating freshwater synthetic aragonite sample (along with other samples) used in this thesis. The Harvard Mineral Museum played a big role in lending me many mineral samples over the past five years and I would like to thank Dr. Raquel Alonso-Perez, Theresa Smith, Kevin Czaja, and Caroline Im for their kindness and encouragement. I would also like to thank Gretchen Swarr, Dr. Jeffrey Post, Dr. Adam Sarafian, Dr. Natalie Cohen, and Dr. Andrew Solow for their help with instrumentation and statistics.

In addition to my committee, I have been so lucky to have many other mentors at WHOI, MIT, and my previous institutions who have continuously influenced my scientific style, given me their time, and offered their constructive critique. Thank you to my WHOI instructors, Dr. Bernhard Peucker-Ehrenbrink, Dr. Mak Saito, Dr. Daniel McCorkle, Dr. Ben Van Mooy, Dr. Scott Doney, Dr. Amanda Spivak, Dr. Bill Martin, Dr. Liz Kujawinski, Dr. Frieder Klein, Dr. Stefan Sievert, and Dr. Jeff Seewald for teaching me about the ocean and for helping me place mineralogy in the context of ocean and environmental questions. I would also like to thank my former mentors and mineralogy heros, Dr. Huifang Xu (UW Madison), Dr. Jillian Banfield (UC Berkeley), Dr. Wendy Mao (Stanford), Dr. Gordon E. Brown Jr. (Stanford), Dr. Cara Santelli (former Smithsonian, currently at U Minnesota), and Dr. Jeffrey Post (Smithsonian), for their continued support over the years.

It has been a huge honor being a part of the Hansel-Wankel lab family. I offer my thanks and love to all past and present members of the two lab groups who have made my time at WHOI truly special. A special thanks to my "big sister" Emily Estes, and my "little siblings" Kevin Sutherland and Kalina Grabb for being so wonderful. I also thank postdocs, Vero Oldham, Julia Diaz, Carly Buchwald and Tong Zhang for their friendship. To my academic "Twinnie," Net Charoenpong, thank you for being my rock. And Jen Karolewski, thank you for the epic geode thesis cake! Thank you Colleen and Scott for creating such great lab groups.

I would like to thank the other members of JP Chem 7: Lauren Kipp, Daniel Gruen, Net Charoenpong, Paul Lerner, Cristina Schultz, and Tyler Rohr for being such an amazing crew. I'm so happy that we worked as a team to help each other survive our Generals exams and 
gradschool life. I would also like to send a special thanks to Erin Black for being a gem of a friend and for offering sage advice throughout my time in the JP.

Of course, I must thank the WHOI Academic Programs Office, including Dr. Meg Tivey, Dr. Jim Yoder, Dr. Delia Oppo, Julia Westwater, Lea Fraser, Maura Burke, Valerie Caron, and Christine Charette. An extra special thanks to Mary Zawoysky for keeping the Watson Building running and Shiela Clifford for the coffee hours. I would also like to thank the WHOI Geodynamics Program for giving me the opportunity to learn about hydrothermal vents at Yellowstone National Park and the chemistry of the ocean microbiome in the Bahamas.

I have been very lucky to have had such a supportive mineralogy and geology community throughout my life with the Madison Gem and Mineral Club (especially Scott Moss, Gerry Gunderson), Burnie's Rock Shop (Burnie Franke, Nevin Franke, Sonali Franke), the community at Dust Devil Mining Co. (Don and Patsy Buford, Terry and Judy Clark, Steve Hackler), the many other mines I have had the pleasure of visiting, and the UW Geology Museum (Dr. Klaus Westphal, Dr. Richard Slaughter, Brooke Norsted, Carrie Eaton). Thank you, Klaus, for sparking my interest in mineralogy back in 1997.

Finally, I'd like to thank my friends (Dianna, Audra, Fiona, Alec, Valerie, Matthaeus, Ryan, Andrea, Julianne, Demoni, and many others) for their support. Muchas gracias a mi familia en Chile por su apoyo, los quiero mucho. And a huge thanks to my parents, Abigail Farfan and Carlos Peralta for their endless love and support.

I would like to thank my funding sources for making this thesis possible. A National science foundation graduate research fellowship (Grant No. 1122374), a Ford Foundation Dissertation Fellowship, and the WHOI Academic Programs Office funded my stipend and tuition over the past five years. My research was supported by a Mineralogical Society of America Edward Krauss Crystallography Reseach Grant and a WHOI Ocean Ventures Fund Grant. Samples provided to me by my collaborators were collected thanks to funding by the National Science Foundation (Grant No. OCE-1220529 and OCE-1031971 to Anne Cohen, Grant No. BIO-OCE1220478 to Erik Cordes, Grant No. 1245766 and 1127582 to Rhian Waller), NOAA Ocean Exploration Deep Atlantic Stepping Stones (to Rhian Waller) and the WHOI Dalio Explore Fund (to Amy Apprill and Anne Cohen). 


\section{Table of Contents}

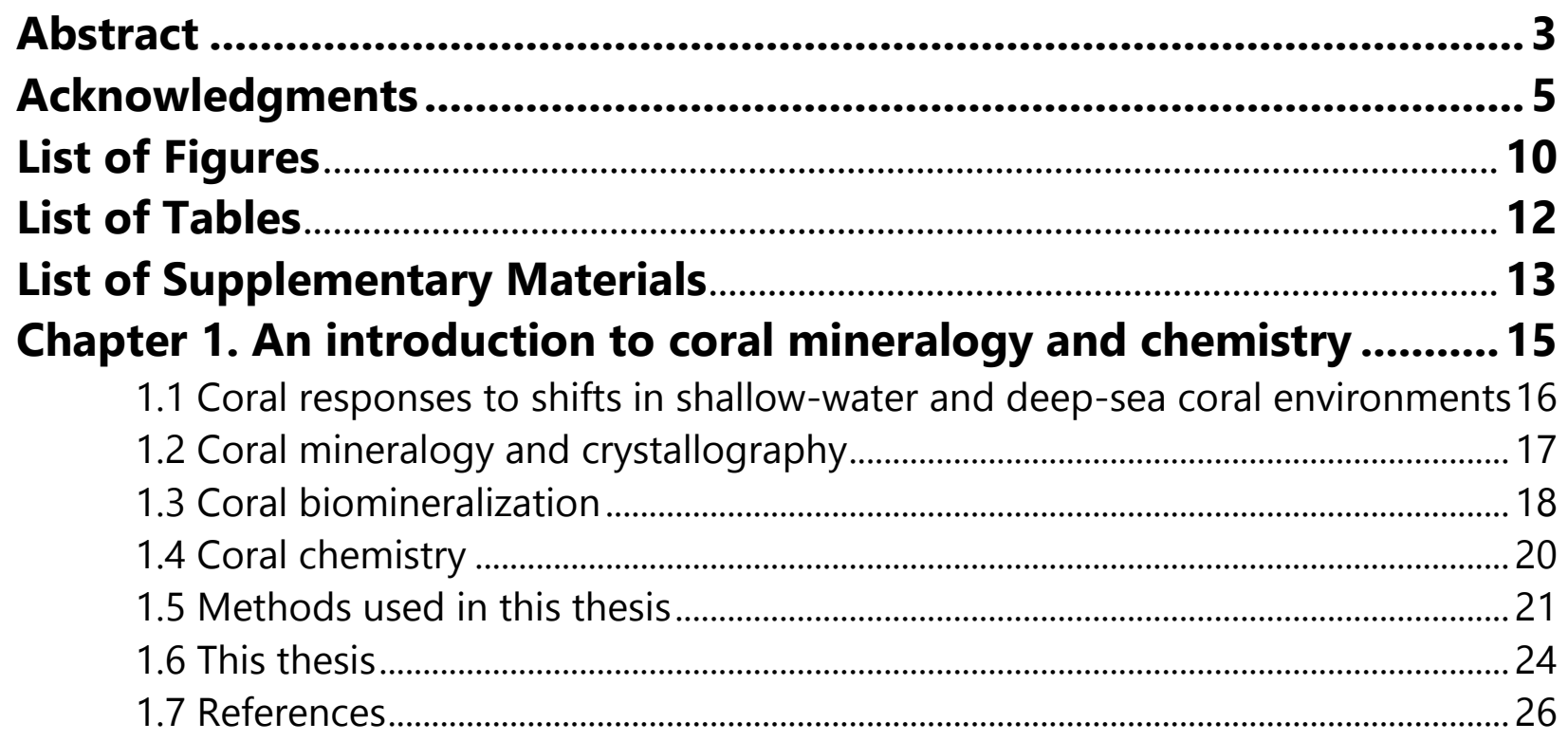

\section{Chapter 2. Crystallographic evidence for a geochemical control over} coral aragonite formation.................................................................... 33

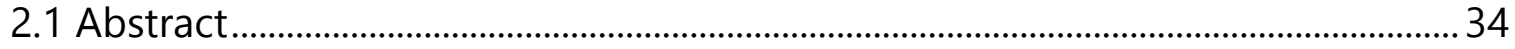

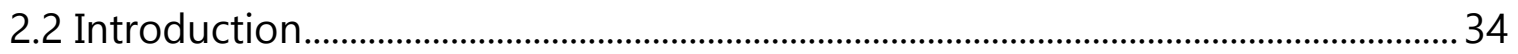

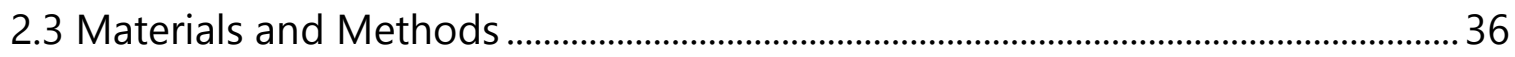

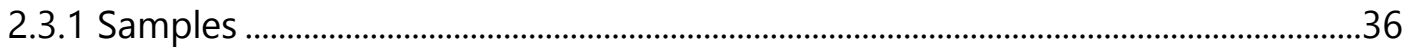

2.3.1.1 Natural deep-sea corals ...............................................................................

2.3.1.2 Natural shallow-water corals............................................................................

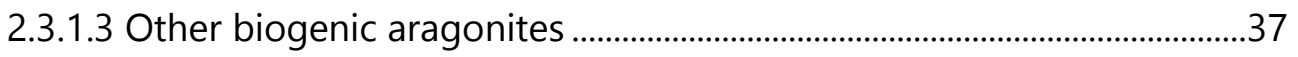

2.3.1.4 Synthetic aragonites .......................................................................................

2 3.1.5 Geological aragonites ....................................................................................

2.3.2 Coral skeleton sampling and removal of organics ...................................................39

2.3.3 Instrumentation and Analysis ....................................................................................39

2.3.3.1 X-ray diffraction ...............................................................................................

2.3.3.2 Rietveld analysis .................................................................................................40

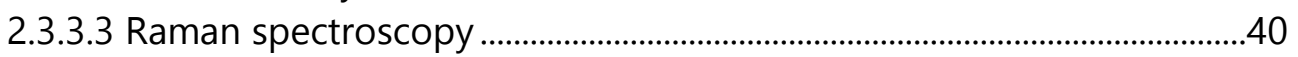

2.3.3.4 Inductively-coupled mass spectroscopy (ICP-MS)...................................40

2.3.3.5 Statistics .......................................................................................................

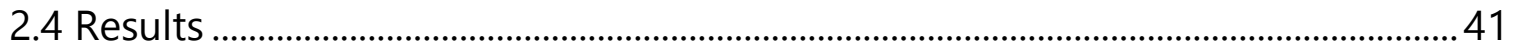

2.4.1 Crystallography of aragonites from different formation origins via X-ray diffraction ................................................................................................4 41

2.4.2 Differences in aragonite bonding environments via Raman Spectroscopy …………………………………………………………………....4

2.4.3 Trace metal incorporations into aragonites of different origins ........................49 
2.5.1 Crystallographic evidence for geochemically-driven aragonite formation in corals.

2.5.2 Differences in crystallography between corals and geological aragonites not driven by organic incorporations

2.5.3 Relationships between trace element incorporations and

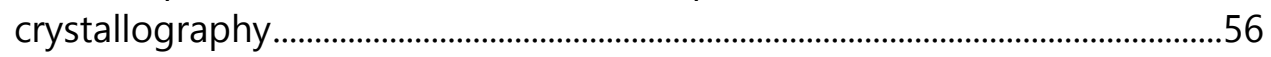

2.6 Conclusions 57

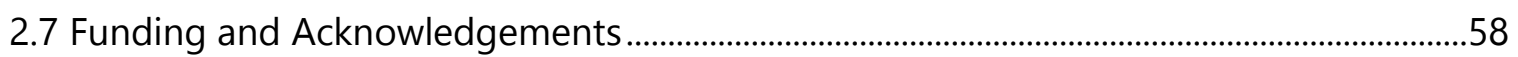

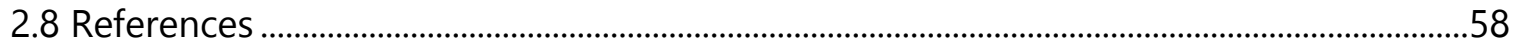

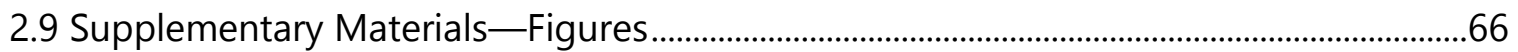

2.10 Supplementary Materials_Tables ..............................................................................................72

\section{Chapter 3. Mineralogy of deep-sea coral aragonites as a function of} aragonite saturation state ..................................................................83 83

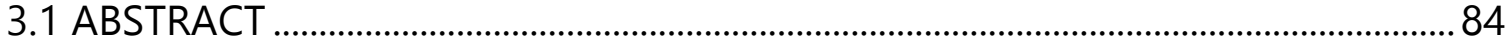

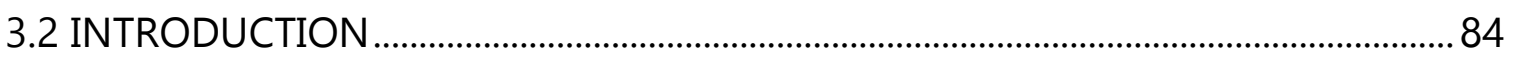

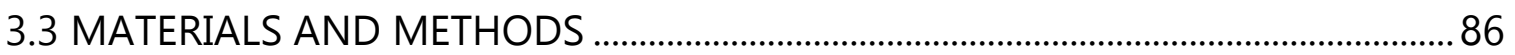

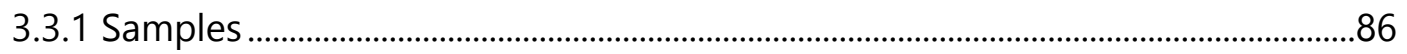

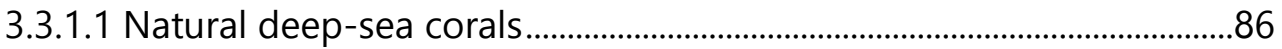

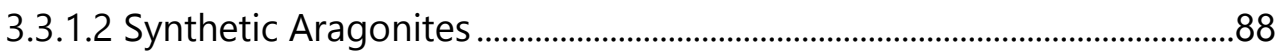

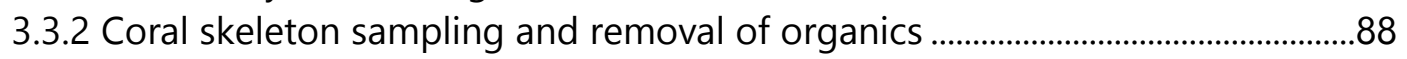

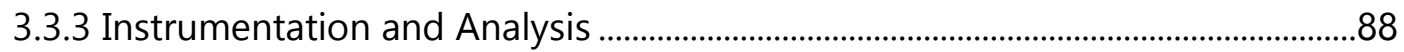

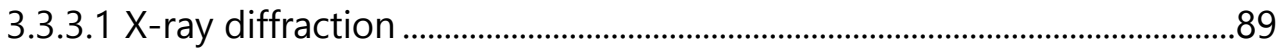

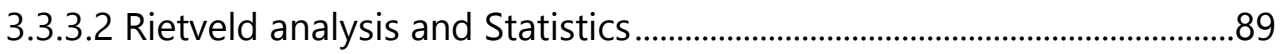

3.3.3.3 Inductively-coupled mass spectroscopy (ICP-MS) ………………...........89

3.3.3.4 Environmental Scanning Electron Microscopy (ESEM.)..........................89

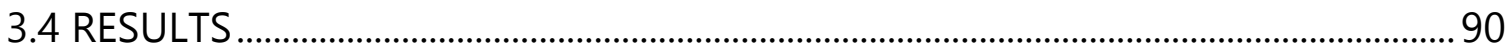

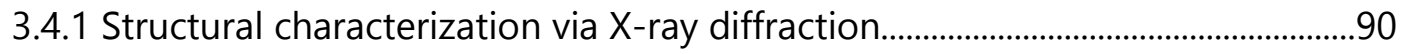

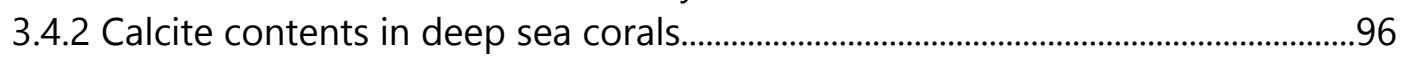

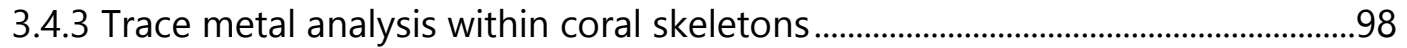

3.4.4 Scanning Electron Microscopy of Coral Morphologies...........................................98

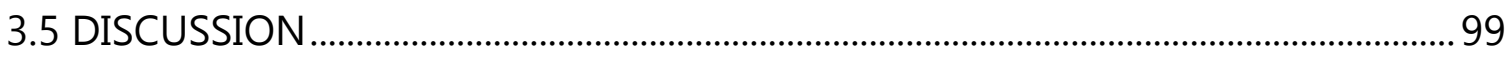

3.5.1 Aragonite crystallography from corals of different species and localities, sampling regions, and collection states

3.5.2 Aragonite mineralogy and crystallography as a function of seawater aragonite saturation state.

3.5.3 Models of substitutions for Ca into aragonite as a function of aragonite saturation state

3.5.4 Calcite contents in deep-sea corals as a function of crystallography and aragonite saturation state.

3.5.5 Relationship between aragonite saturation state in seawater and the internal calcifying fluid of deep-sea corals............................................. 103 


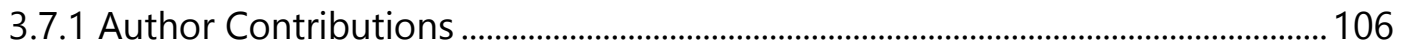

3.8 References ........................................................................................................................... 106

3.9 Supplementary Material_Figures..................................................................................... 112

3.10 Supplementary Materials_Tables .............................................................................................. 120

Chapter 4. The influence of skeleton growth parameters and internal calcifying fluid chemistry on the mineralogy and crystallography of shallow-water corals across a natural seawater pH gradient in Palau .....................................................137

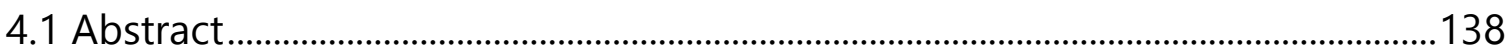

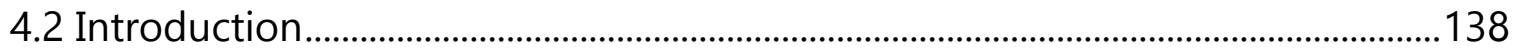

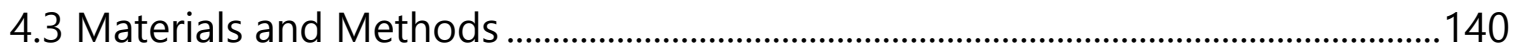

4.3.1 Samples and sample treatments............................................................................ 140

4.3.2 Instrumentation ....................................................................................................... 142

4.3.2.1 X-ray diffraction ........................................................................................... 142

4.3.2.2 Rietveld analysis and statistics................................................................ 143

4.3.2.3 Inductively-coupled mass spectroscopy (ICP-MS)............................... 143

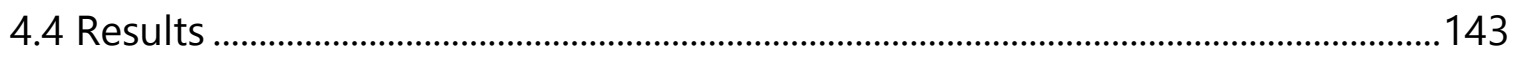

4.4.1 Crystallography at Dropoff ....................................................................................... 144

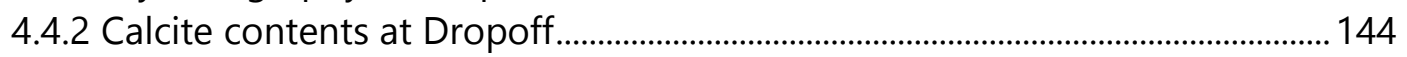

4.4.3 Trace element incorporations at Dropoff.................................................................. 149

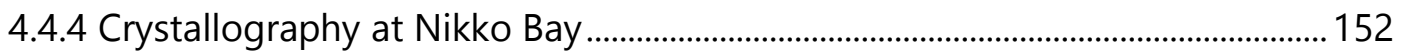

4.4.5 Calcite contents at Nikko Bay .................................................................................. 152

4.4.6 Trace element incorporations at Nikko Bay ............................................................ 154

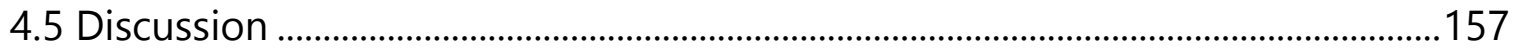

4.5.1 Coral crystallography as a function of skeletal growth parameters................157

4.5.2 Calcite contents in corals as a function of skeletal growth parameters and how calcite contents influence coral crystallography ………………………….. 157

4.5.3 Trace element incorporations in coral skeletons as functions of skeleton growth parameters and how they influence coral crystallography ................158

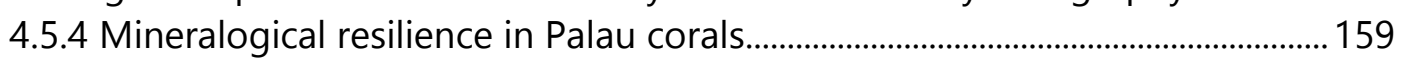

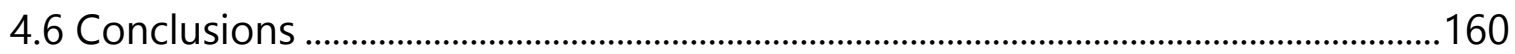

4.7 Funding \& Acknowledgments .............................................................................................. 160

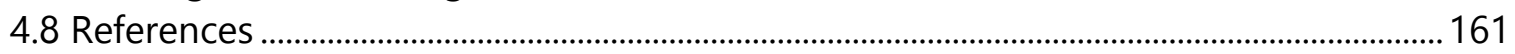

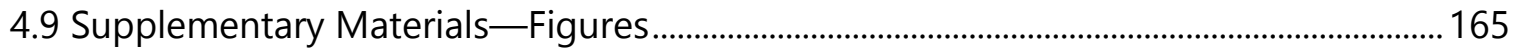

4.10 Supplementary Materials_Tables..................................................................................... 173

Chapter 5. Coupled X-ray fluorescence and X-ray absorption spectroscopy for microscale imaging and identification of sulfur species within tissues and skeletons of scleractinian corals................181

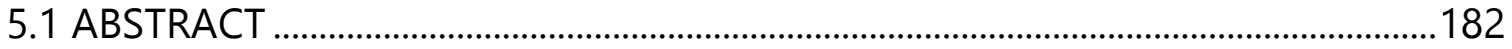

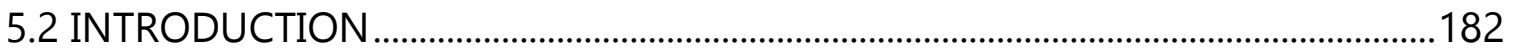

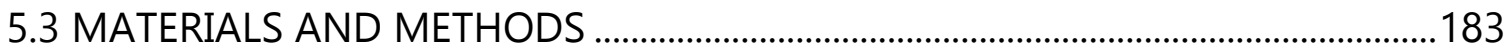




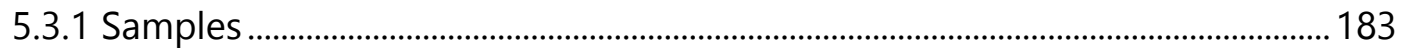

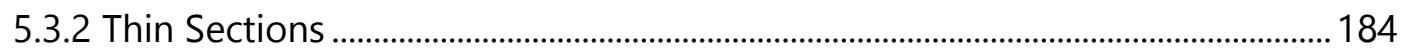

5.3.3 Low Energy X-ray $\mu$ XRF mapping ……………………………………………….... 184

5.3.4 Fitting Sulfur ME Maps with S XANES.................................................................. 185

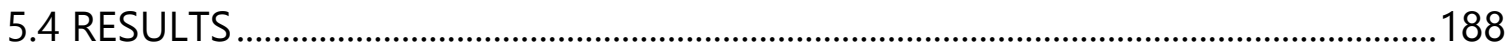

5.4.1 Reduced sulfur species ......................................................................................... 188

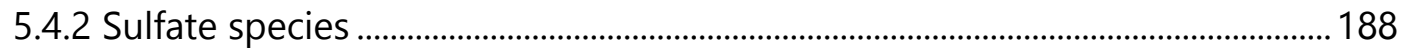

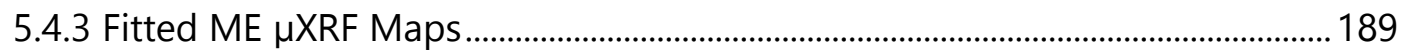

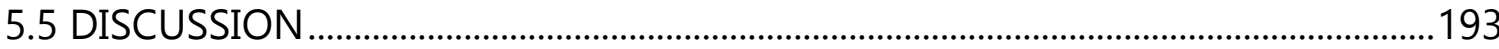

5.5.1 Comparison to previous XRF mapping techniques ............................................... 193

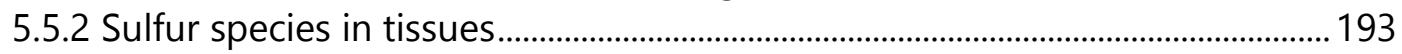

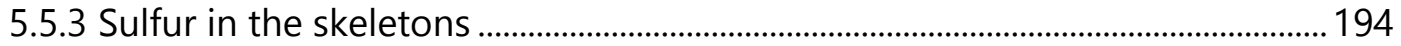

5.6 CONCLUSIONS .........................................................................................................195

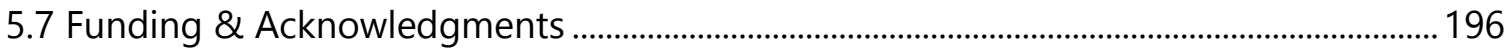

5.7.1 Author Contributions .................................................................................................. 196

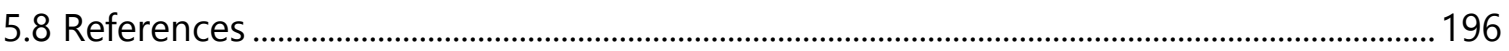

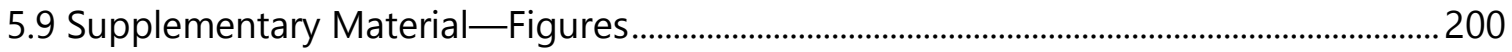

5.10 Supplementary Material-Tables ............................................................................................2.

Chapter 6. Conclusions...............................................................211

6.1 Biomineralization via geochemical processes..........................................................212

6.2 Minor anisotropic lattice distortions in coral aragonites growing in natural low $\Omega_{\text {sw }}$ conditions driven by skeleton growth parameters............................212

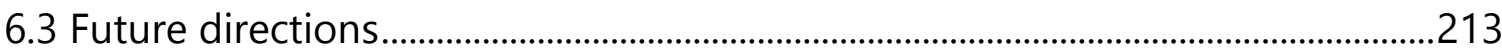

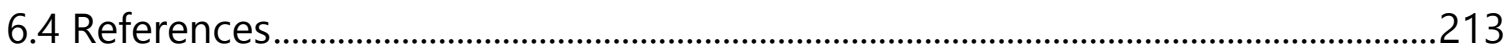




\section{List of Figures}

\section{Chapter 1}

Figure 1.1 The aragonite unit cell lattice with potential distortions ........................................................18

Figure 1.2 Schematics of possible coral biomineralization mechanisms ................................................19

Figure $1.3 \mathrm{X}$-ray diffraction pattern and crystallographic planes.............................................................21

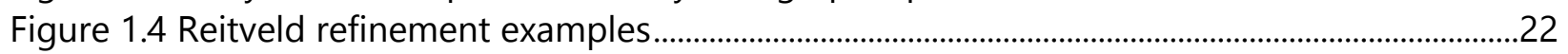

Figure 1.5 FWHM of the (111) XRD peak .............................................................................................22

Figure 1.6 Raman spectroscopy and FWHM of the $v_{1}$ mode....................................................................23

Figure 1.7 Synchrotron-based X-ray fluorescence and X-ray absorption spectroscopy ...................24

\section{Chapter 2}

Figure 2.1 Representative XRD patterns of various aragonites ...............................................................42

Figure 2.2 Unit cell lattice parameters of coral aragonites and other aragonites ...............................43

Figure 2.3 Unit cell volumes as a function of anisotropic shifts along individual axes ......................45

Figure 2.4 Raman spectroscopy results of coral aragonites and other aragonites.............................47

Figure 2.5 FWHM v1 and Raman derived $\Omega_{\mathrm{cf}}$ versus unit cell a- and b-axis lengths.........................48

Figure 2.6 Trace element incorporation in coral aragonites and other aragonites ............................50

Figure 2.7 Unit cell volumes versus trace element incorporations............................................................51

Figure 2.8 Crystallography and bonding environments versus $B / C a$ ratios...........................................52

\section{Chapter 3}

Figure 3.1 Representative XRD patterns of deep-sea corals and synthetic aragonites......................92

Figure 3.2 Unit cell lattice parameters of deep-sea corals .......................................................................93

Figure 3.3 PCA Bipolt of deep-sea coral samples and varibles measured .............................................94

Figure 3.4 Unit cell lattice parameters vs $\Omega_{\text {sw, }} \mathrm{pH}_{\text {sw }}$ and distance from seeps .....................................95

Figure 3.5 Calcite contents by collection state (live vs. dead) with depth.............................................96

Figure 3.6 Calcite contents live samples versus seawater chemistry, depth, unit cell volume ........97

Figure 3.7 FWHM (111) peak vs. ${ }^{138} \mathrm{Ba}: \mathrm{Ca}$ in live septa samples...........................................................98

Figure 3.8 Potential model for crystallographic distortion by element incorporations ................... 102

\section{Chapter 4}

Figure 4.1 Map of Nikko Bay and Dropoff sites in Palau

Figure 4.2 Down-core profiles of skeletal growth parameters, crystallography and element:Ca ratios in all samples.

Figure 4.3 Dropoff unit cell parameters as a function of growth parameters

Figure 4.4 Dropoff calcite contents and trends with crystallography and growth parameters

Figure 4.5 Dropoff element:Ca ratios as a function of growth parameters

Figure 4.6 Dropoff crystallography and calcite contents as a function of element:Ca ratios

Figure 4.7 Nikko Bay crystallography as a function of growth parameters 
Figure 4.8 Nikko Bay calcite contents and trends with crystallography and growth parameters

Figure 4.9 Nikko Bay element:Ca ratios as a function of growth parameters.

Figure 4.10 Nikko Bay crystallography and calcite contents as a function of element:Ca ratios

\section{Chapter 5}

Figure 5.1 Normalized standard S XANES spectra used for ME map fitting 185

Figure 5.2 Linear combination fits of coral S-XANES spectra with standards

Figure 5.3 Maps of S-bonding environments via multiple energy (ME) map fitting with

S-XANES standards 190

Figure 5.4 Tricolor maps of various S-bonding environment distributions in corals

Figure 5.5 Correlations between zooxanthellae and sulfoxide distributions.

\section{List of Tables}

\section{Chapter 2}

Table 2.1 Samples of coral, other biogenic, synthetic and geological aragonites measured in this study

Table 2.2 Mean values of aragonite lattice parameters of different aragonites

\section{Chapter 3}

Table 3.1 Deep-sea corals and synthetic aragonites analyzed in this study

Table 3.2 Estimated $\Omega_{\text {cf }}$ calculated from unit cell lattice parameters.

\section{Chapter 4}

Table 4.1 All Nikko Bay and Dropoff samples of Porites sp. used in this study. 141

Table 4.2 T-tests of significant differences between Nikko Bay and Dropoff sites for growth parameters, parameters, crystallography, and trace element incorporations 


\section{List of Supplementary Materials}

\section{Supplementary Figures}

\section{Chapter 2}

Figure S2.1 Unit cell lattice parameters of coral aragonites and other aragonites.............................66

Figure S2.2 Raman spectroscopy results of coral aragonites and other aragonites ...........................67

Figure S2.3 Raman spectroscopy results versus unit cell lattice parameters ........................................68

Figure S2.4 Element trace incorporation in coral aragonites and other aragonites............................69

Figure S2.5 Unit cell parameters versus element trace incorporations ..................................................70

Figure S2.6 Raman spectroscopy results versus element trace incorporations .....................................71

\section{Chapter 3}

Figure S3.1 Photograph of L. pertusa samples used in this study.........................................................112

Figure S3.2 Crystallogrpahy of DSCs and synthetic aragonites as a function of $\Omega_{\text {sw }} \ldots \ldots \ldots \ldots \ldots \ldots \ldots \ldots . . .113$

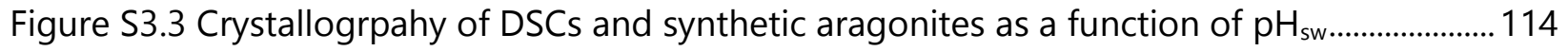

Figure S3.4 Calcite content as a function of all variables measured .....................................................115

Figure S3.5 Trace element incorporations as a function of all variables measured...........................116

Figure S3.6 SEM images of L. pertusa septa regions.............................................................................117

Figure S3.7 SEM images of L. pertusa outer-polyp regions..................................................................118

Figure S3.8 Close-up SEM image of lowest- $\Omega_{\mathrm{sw}} L$. pertusa sample........................................................ 119

\section{Chapter 4}

Figure S4.1 Whole XRD patterns for all samples.................................................................................... 165

Figure S4.2 Dropoff all crystallographic data versus growth parameters.............................................166

Figure S4.3 Dropoff element:Ca ratios versus growth parameters .........................................................167

Figure S4.4 Dropoff all crystallographic data versus element:Ca ratios ................................................. 168

Figure S4.5 Nikko Bay all crystallographic data versus growth parameters ........................................169

Figure S4.6 Nikko Bay element:Ca ratios versus growth parameters.....................................................170

Figure S4.7 Nikko Bay all crystallographic data versus element:Ca ratios........................................171

Figure S4.8 Calcite:aragonite mixed standards crystallography test for Rietveld refinement errors

\section{Chapter 5}

Figure S5.1 Example S- $\mu$ XRF maps with individual points were S XANES were collected ..............200

Figure S5.2 S-XANES of all points in the example map (Figure S5.1) ................................................2. 201

Figure S5.3 Comparison of reference spectra collected at two different beamlines.........................202

Figure S5.4 Validation step for ME map fittings versus S-XANES linear combination fitting.......203

Figure S5.5 Potential contamination from the polishing process ………………………………….....2. 204

Figure S5.6 Single energy maps versus ME-fitted maps .......................................................................204 


\section{Supplementary Tables}

\section{Chapter 2}

Table S2.1 All individual unit cell parameters, FWHM (111) peak and calcite contents .72

Table S2.2 Raman spectroscopy results for all samples

Table S2.3 Element:Ca ratios in all samples

\section{Chapter 3}

Table S3.1 Two-tailed T-test and One-way ANOVA results..

Table S3.2 Results of linear regressions

Table S3.2 Deep-sea coral lattice parameters, FWHM (111) peak, calcite contents, and element:Ca ratios

\section{Chapter 4}

Table S4.1 All unit cell lattice parameters, FWHM, and calcite content

\section{Chapter 5}

Table S5.1 Individual points from Figure S5.1 fit with S XANES standards using linear combination fitting. 206

Table S5.2 Individual points from Figure S5.1 fit with ME map fittings 208 
Chapter 1. An introduction to coral mineralogy \& chemistry 
Coral reefs in both shallow-water and deep-sea environments are essential marine ecosystems that are estimated to support approximately $25 \%$ of known marine species (Fisher et al., 2015; Hoegh-Guldberg, 2015). Although they cover less than $1 \%$ of the ocean floor, they serve an important economic role valued at close to one trillion dollars (Hoegh-Guldberg et al., 2017). Coral reefs currently face many pressures including increasing sea surface temperatures and coral bleaching, ocean acidification, rising sea levels, an increased frequency of strong storms, anthropogenic physical destruction, and contamination and pollution. These pressures are expected to lead to an elevated risk of extinction for approximately one-third of reef-building corals and eliminate most warm-water coral reefs by 2040-2050 (Carpenter et al., 2008; HoeghGuldberg et al., 2017). As scleractinian "stony" corals make up the architecture of coral reefs by forming mineral skeletons, understanding the mineralogy and chemistry of coral skeletons is essential for assessing coral reef health and for predicting how reefs will continue to build and decay under ocean stressors.

\subsection{Coral responses to shifts in shallow-water and deep-sea coral environments}

Already, there are coral habitats in the ocean experiencing abnormally low aragonite saturation states of seawater $\left(\Omega_{\mathrm{sw}}\right)$ and altered chemical conditions compared to most healthy reefs. Deepsea corals are expected to face the effects of a shoaling "acid horizon" where the seawater $\Omega_{\mathrm{sw}}$ drops below 1, making aragonite precipitation thermodynamically unviable in those surrounding seawater conditions. How these slow-growing ( 1-2 mm extension/year) corals adapt or fail to adapt to ocean acidification conditions is being investigated in incubation experiments (Hennige et al., 2015; Kurman et al., 2017) and field observations (Lunden et al., 2013; Rodolfo-Metalpa et al., 2015) with conflicting results of both robust and fragile skeletons resulting from being exposed to low $\Omega_{\mathrm{sw}}$ conditions.

In shallow water systems, it is expected that zooxanthelate shallow-water corals will be even less capable of adapting to low aragonite saturation conditions since they are faster-growing than deep-sea azooxanthellate corals and are unaccustomed to declining $\Omega_{\mathrm{sw}}$ (Hoegh-Guldberg et al., 2017). For example, $\delta^{11 / 10} \mathrm{~B}$ isotopes of internal calcifying fluid $\mathrm{pH}\left(\mathrm{pH}_{\mathrm{cf}}\right)$ conditions show that shallow-water corals (Porites spp. and Acropora spp.) struggle to raise their internal $\mathrm{pH}_{\mathrm{cf}}$ relative to $\mathrm{pH}_{\mathrm{sw}}(\Delta \mathrm{pH}=\sim 0.35-0.65 \mathrm{pH}$ units $)$ as high as deep-sea corals can $(\Delta \mathrm{pH}=\sim 0.7-1.1 \mathrm{pH}$ units) (McCulloch et al., 2012a). Local low $\Omega_{\text {sw }}$ reef environments, such as Nikko Bay in Palau, provide natural laboratories for scientists to measure the adaptation (or lack thereof) of coral species and coral skeletal health across natural $\mathrm{pH}$ and $\Omega_{\mathrm{sw}}$ gradients (Shamberger et al, 2014; Barkley et al., 2015; DeCarlo et al., 2015; Mollica et al., 2018). Bulk skeletal responses to low $\Omega_{\mathrm{sw}}$ conditions include lower skeletal density (Mollica et al., 2018), suggesting that corals form weaker reef architecture under $\Omega_{\mathrm{sw}}$ stress conditions that could therefore be more prone to breakage and dissolution in the face of large storms and further declines in $\Omega_{\text {sw. }}$. Still, some shallow-water corals have been observed to acclimatize to low $\Omega_{\mathrm{sw}}$ (Camp et al., 2017).

Most studies investigating the health of coral skeletons under environments of varying $\Omega_{\mathrm{sw}}$ have focused on bulk properties such as net calcification and net dissolution of skeletons (Rodolfo-Metalpa, 2015), and biological responses, such as carbonic anhydrase upregulation (Kurman et al., 2017), but few have examined how mineralogy and crystallography might be shifting under low $\Omega_{\mathrm{sw}}$ (Hennige et al., 2015; Cohen et al., 2009; Foster et al., 2016). Further 
mineralogical and crystallographic perspectives on coral skeletal shifts as a function of changing ocean chemistry can help to pinpoint the mechanisms for what is driving bulk properties such as precipitation and dissolution and will help us to predict how sensitive coral skeletons will be under shifting ocean climate.

\subsection{Coral mineralogy and crystallography}

Scleractinian corals form their skeletons out of the mineral aragonite, a metastable polymorph of calcium carbonate. Climate and coral reef studies predict that aragonite skeletons will be adversely impacted by a rapid decline in seawater aragonite saturation states (Chan and Connolly, 2013; Langdon et al., 2000). Net dissolution of coral skeletons in natural settings and incubation experiments is driven by a combination of decreased skeletal precipitation rates and increased dissolution rates of coral aragonite (Eyre et al., 2014). The material properties of aragonite, such as solubility, strength and more, are at least partially governed by mineralogy and crystallography (Hennige et al., 2015). Nevertheless, relatively little is known about the crystallography and resulting material properties of coral aragonite, specifically.

Previous studies on coral skeleton mineralogy have characterized the mineral and organic components of the skeleton as aragonite with up to a few weight percent calcite (or high- $\mathrm{Mg} / \mathrm{Ca}$ phase) (Meibom et al., 2008; Roger et al., 2017; Farfan et al., in review), 0.5 weight percent strontianite (Sowa et al., 2008) and <1 weight percent organics (Cuif et al., 2004; Cohen and McConnaughey, 2003). Most coral studies that utilize X-ray diffraction (XRD) and other mineralogical and crystallographic tools do so as a fingerprinting method to confirm that the coral skeletons are aragonite and to identify any contributions from these other carbonate minerals. More detailed studies of coral skeleton mineralogy have used high-resolution scanning electron microscopy and transmission electron microscopy to image and describe the bundles of acicular crystallites formed in coral skeletons which follow the same crystallographic orientation (i.e., Benzerara et al., 2011; Holcomb et al., 2009; Stolarski et al., 2007).

Few studies have investigated coral aragonite crystallography on an atomic scale. Pokroy et al. $(2004 ; 2006 ; 2007)$ observed anisotropic crystallographic distortions of lengthening along $a$ - and $c$-axes of the aragonite unit cell and a shortening along the $b$-axis in mollusk aragonite, compared to geologically-formed aragonites (Figure 1.1A). They suggest that this distortion in mollusk aragonites could be due to the incorporation of intracrystalline biomolecules, an assumption that has since been extended to coral biomineralization studies (i.e., Przeniosło et al., 2008; Cuif et al., 2013; Stolarski et al., 2007; Zolotoyabko et al., 2016) (Figure 1.1B). Yet, Pokroy et al., (2006) suggest that other abiotic factors such as crystal growth rate and element trace incorporations could still play a role in accounting for these anisotropic lattice distortions in biogenic aragonites (Figure 1.1C). 
A
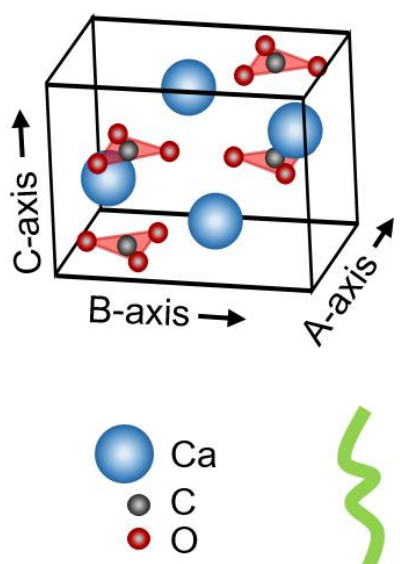

B

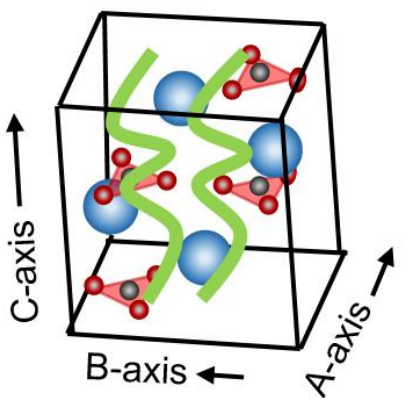

C

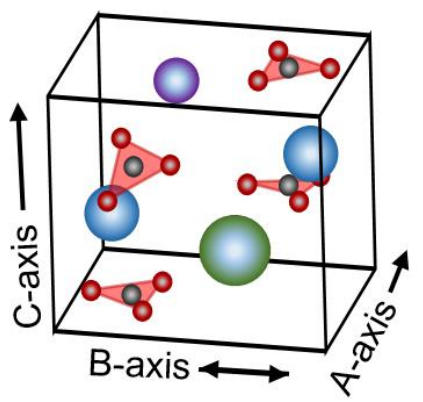

Organic compound incorporation

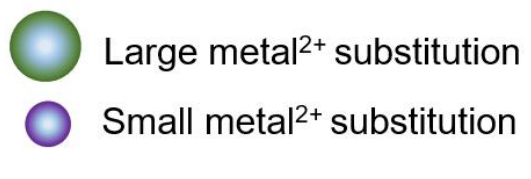

FIGURE 1.1 A) The orthorhombic unit cell lattice of aragonite composed of $\mathrm{Ca}^{2+}$ surrounded by trigonal-planar carbonate groups, with proposed lattice distortions in the unit cell lattice due to B) organic molecules and C) element trace incorporations in the $\mathrm{Ca}$ site.

\subsection{Coral biomineralization}

Biomineralization is the process by which organisms precitate minerals. Mineral formation by organisms may have a specific function, such as for building a skeleton or shell (i.e., ), or may even be an accidental bi-product of a metabolic pathway (i.e., Hansel et al., 2012). Currently there are two main mechanisms by which oragnisms form minerals. The first is "biologicallyinduced" or "geochemically-controlled" biomineralization, where the organism modify surrounding chemistry to favor the abiotic precipitation of minerals (i.e., Cohen and McConnaughey, 2003; Hansel et al., 2012). The second is "biologically-controlled" biomineralization, where organisms actively control the formation of minerals by utilizing specific biomolecules to template, precipitate, and build crystals (Veis, 2003), often times via an ACC precursor phase shaped by intracellular vessicles (i.e. Wiener et al., 2009; Young and Henriksen, 2003).

How scleractinian corals form their skeletons and how skeletal mineralogy may be impacted by shifts in ocean conditions is essential for predicting the fate of coral reefs in a changing ocean. Models for the mechanisms of coral biomineralization range from geochemically-driven (Cohen and McConnaughey, 2003; Gaetani and Cohen, 2006; DeCarlo et al., 2018) to biologically-driven (Von Euw et al., 2017; Mass et al., 2017; Cuif et al., 2005; 2013), each predicting a different outcome for coral calcification sustainability under stressful conditions such as low $\Omega_{\mathrm{sw}}$ and high temperatures.

Geochemically-controlled models for biomineralization suggest that corals form aragonite abiotically by allowing aragonite to precipitate in a calcifying fluid within the coral which is thermodynamically and kinetically favorable for aragonite formation (Cohen and McConnaughey, 2003; Cohen and Holcomb, 2009). While corals control the geochemistry of their calcifying space by active ion pumping via $\mathrm{Ca}^{2+} \mathrm{ATPase}$ to raise their internal calcifying fluid $\mathrm{pH}$ and $\Omega_{\mathrm{Ar}}$ (Allemand, et al., 2004; Zoccola et al., 2004; McCulloch et al., 2012b), this 
process is still linked and dependent on surrounding seawater chemistry (Cohen et al., 2009; Gagnon et al., 2012; McCulloch 2012a; Figure 1.2A). Some corals have even been shown to precipitate calcite, rather than aragonite, when grown in altered seawater chemistry (Higuchi et al., 2014). Evidence for geochemical controls on aragonite biomineralization come from similarities between coral aragonites with synthetic aragonites precipitated from seawater in terms of crystal habit (Holcomb et al., 2009; Cohen and Holcomb, 2009), carbonate bonding environments (DeCarlo et al., 2017), and patterns of Rayleigh fractionation of element trace incorporations partitioned between the calcifying fluid and coral skeleton (Cohen et al., 2006; Gaetani and Cohen, 2006). Under chemical stressors such as ocean acidification, coral recruits fail to calcify robust skeletons under lowered aragonite saturation states, increased $\mathrm{pCO}_{2}$ levels, and increased temperatures (Cohen et al., 2009; Foster et al., 2016). Thus, a geochemicallydriven biomineralization process means that corals will be susceptible to decreased calcification rates, increased dissolution, and ultimately death under ocean acidification trends predicted over the next century (Doney et al., 2009).
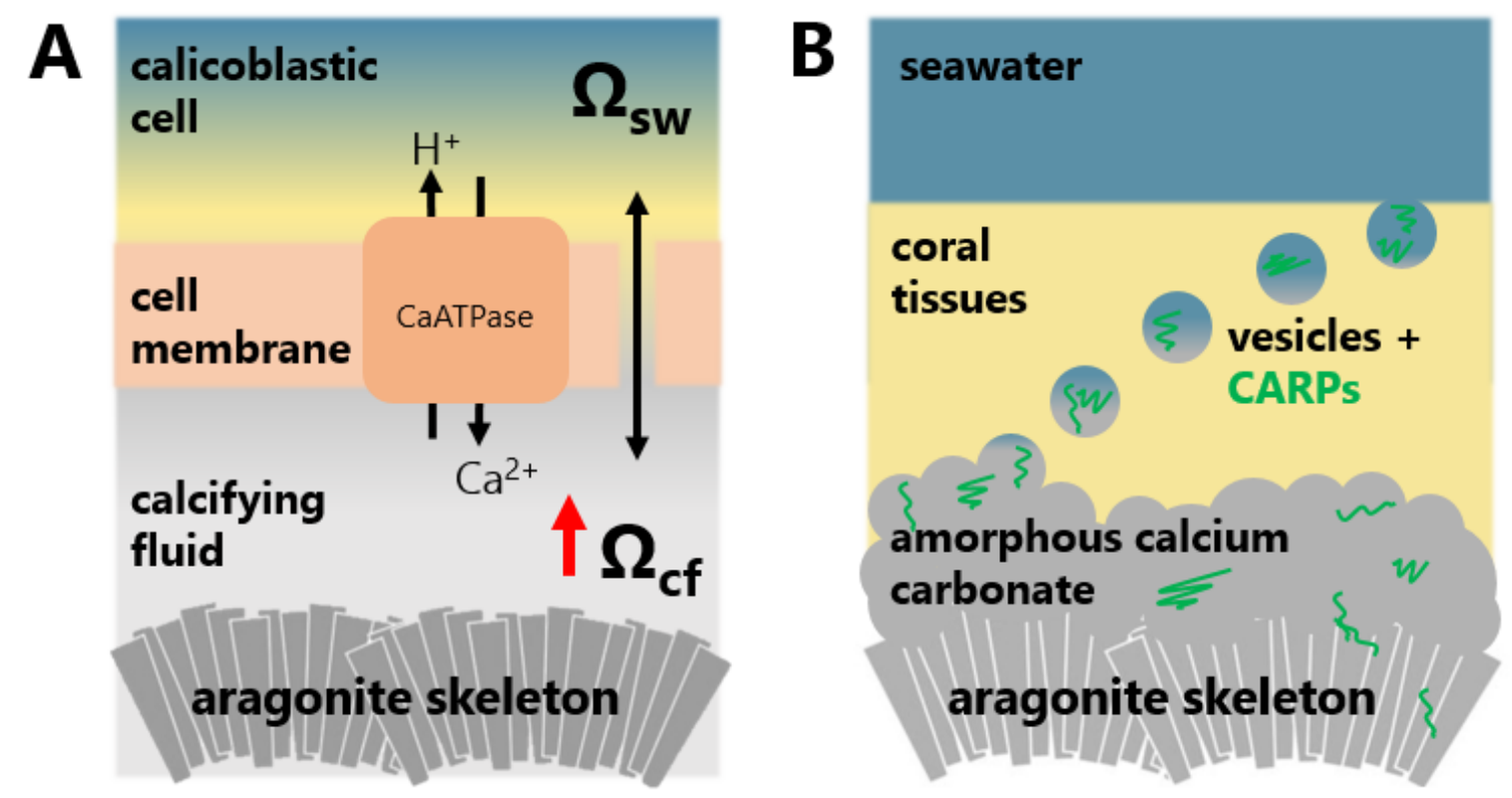

FIGURE 1.2. Simplified schematics of possible coral biomineralization models. A) geochemicallycontrolled model based on Cohen and McConnaughey, 2003; Allison et al., 2009; McCulloch et al., 2017. B) biologically-controlled model based on Von Euw et al., 2017; Mass et al., 2017.

In contrast, biologically-controlled biomineralization models propose that corals exert a great amount of biological control in templating and precipitating aragonite via the help of coralspecific coral acid rich proteins (CARPs) (Mass et al., 2013) to precipitate skeleton regardless of surrounding ocean chemistry, as evidenced by CARPs having the ability to precipitate aragonite in vitro from aragonite undersaturated water (Von Euw et al., 2017). Mass et al., (2017) even suggest this process happens through an amorphous calcium carbonate (ACC) precursor phase, as has been shown to be the case in motile aragonite biomineralizing organisms such as crustaceans (Becker et al., 2003) and mollusk (Marxen et al., 2003) larvae (Figure 1.2B). A biologically-mediated model for biomineralization would likely mean that corals are more resilient to ocean chemical stressors than predicted by geochemical models and that they may even sustain current aragonite calcification rates in aragonite undersaturated seawater. 
More studies will be needed in the future to confirm which of these models, or combination of these models, dominates the coral biomineralization process and will control the reaction that corals and corals reef structures have to ocean acidification conditions. In this thesis, rather than tackle the biomineralization mechanism directly, we examine the mineral endproducts of coral biomineralization to determine their crystallographic properties and deduce how the crystals themselves may have formed.

\subsection{Coral chemistry}

\section{Trace element incorporation in coral skeletons}

Coral aragonites are known to incorporate various elements in trace quantities. These elements are used by paleoproxy studies to calculate past ocean temperatures and light availability $(\mathrm{Sr} / \mathrm{Ca})$ and calcifying fluid saturation states (B/Ca) (Hathorne et al., 2013; Reynaud et al., 2007; Cohen et al., 2001; McCulloch et al., 2014; Gaetani and Cohen, 2006). These incorporations are most likely in the form of substitutions for $\mathrm{Ca}$ in the aragonite crystal lattice (Finch and Allison, 2007). Depending on the size, charge, and abundance of the substituting ion, this incorporation can be involved in anisotropic distortions observed in coral aragonite lattice structures (Figure 1.1C). However, studies that correlate metal/Ca ratios with bio-aragonite crystallography are rare (Roger et al., 2017).

\section{Sulfur chemistry in coral skeletons and tissues}

The other potential site for incorporating elements into the aragonite crystal lattice is the trigonal-planar carbonate group (Figure 1.1A). Sulfate groups have been suggested as a possible inorganic substitution for carbonate groups in carbonate minerals and this incorporation is referred to as carbonate-associated sulfate (CAS) or structurally substituted sulfate (SSS) (Nguyen et al., 2014; Tamenori et al., 2014; Kampschulte and Strauss, 2004; Vielzeuf et al., 2013; Pingitore et al., 1995). Inorganic sulfate, likely in CAS form, has been observed to dominate the S signal in coral skeletons via synchrotron-based X-ray absorption near edge spectroscopy (Pingitore et al., 1995). Some studies suggest that S-incorporation via organic Scompounds in coral skeletons can be used as evidence for organic templates used in the coral biomineralization process from their observations of higher organic-S content along coral calcifying centers in the skeletons (Cuif et al., 2003; 2005). Most of these synchrotron-based S studies differentiate between reduced (presumably organic) and oxidized (presumably inorganic) at high resolution (Perrin et al., 2017), while other bulk studies accurately speciate and quantify S-compounds but lack the spatial information attained by synchrotron studies (Vielzeuf et al., 2013). In order to better understand the role of $S$ in coral skeletons and tissues and whether $S$ can be used as a proxy for organic incorporations in coral skeletons, a combination of detailed speciation and high resolution imaging are needed to confirm the spatial location of various $S$ species. 


\subsection{Methods used in this thesis}

\section{X-ray Diffraction}

$\mathrm{X}$-ray diffraction (XRD) uses monochromatic X-rays (usually $\mathrm{Cu}$, Mo, or synchrotron-based Xrays) to measure the angles at which $\mathrm{X}$-rays diffract off of crystallographic planes of atoms in a crystal structure. In this study, we use Mo Ka radiation $(\lambda=0.709300 \AA)$, which has a higher resolution (shorter wavelength) than $\mathrm{Cu} \mathrm{K} \alpha$ radiation commonly used in many mineralogical studies. The angle at which an X-ray is diffracted is recorded on an imaging plate and is integrated into a diffraction pattern (Figure 1.3) as intensity (counts, arbitrary units) versus angle of diffraction as $2 \theta$ (degrees). Typically, X-ray diffraction patterns are used a fingerprinting technique to idenitify mineral species present in a sample. Beyond using XRD as a fingerprinting technique, diffraction angles $(\theta)$ of crystallographic planes collected at a known X-ray wavelength $(\lambda)$ can be converted into d-spacings between the crystallographic planes $(\AA)$ using Bragg's Law $(\mathrm{n} \lambda=2 \mathrm{~d} \sin \theta)$. Whole pattern Rietveld refinement analysis can be utilized to model all of the crystallographic planes together to arrive at quantitative measurements for unit cell axis lengths by comparing raw data to model structures (Figure 1.4). In our Rietveld refinements we model against aragonite (Antao and Hassan, 2009) and calcite (Markgaf and Reeder, 1985) structures using the program GSAS II (Toby and VonDreele, 2013). Our XRD system at the Woods Hole Oceanographic Institution, a Rigaku D/MAX Rapid II, is considered to be a "micro" XRD since it can accurately measure diffraction patterns for very small samples, on the order of $1 \mathrm{~mm}$. As we are sample-limited with many of our corals and other aragonites in this study, this instrument is ideal for taking quantitative crystallographic measurements.

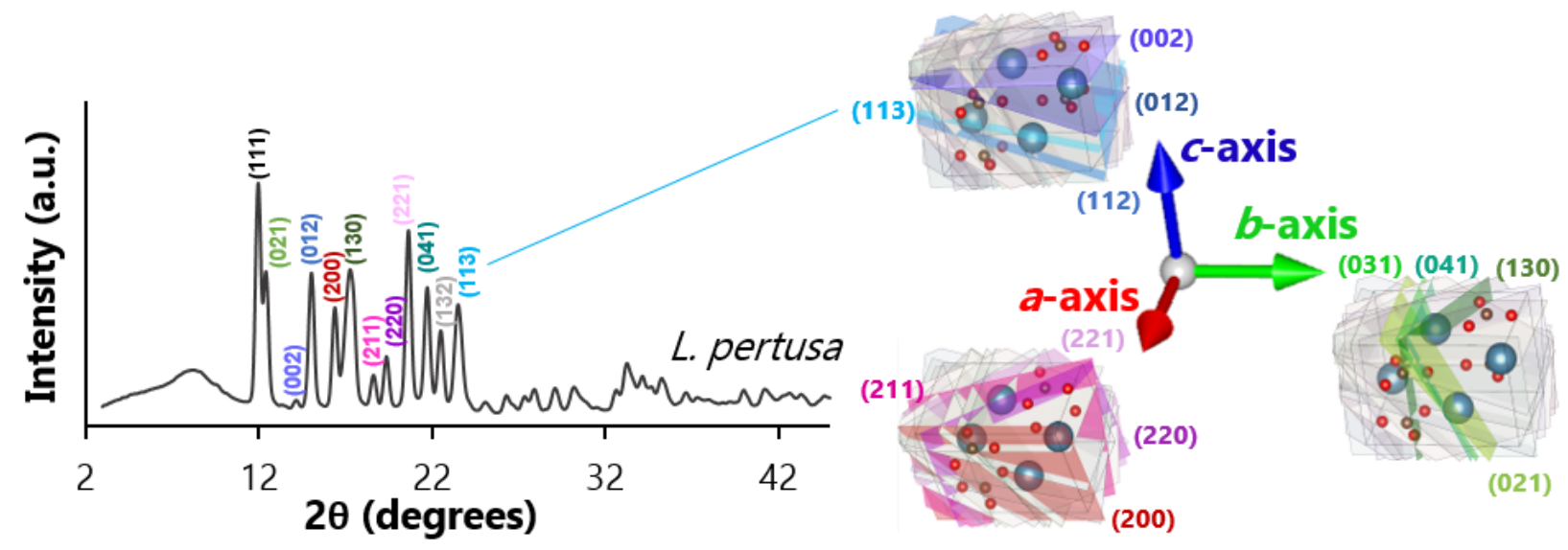

FIGURE 1.3 An example X-ray diffraction pattern of Lophelia pertusa aragonite (left). Each diffraction peak represents a crystallographic plane (right) in the aragonite unit cell, labeled using Miller indices. 


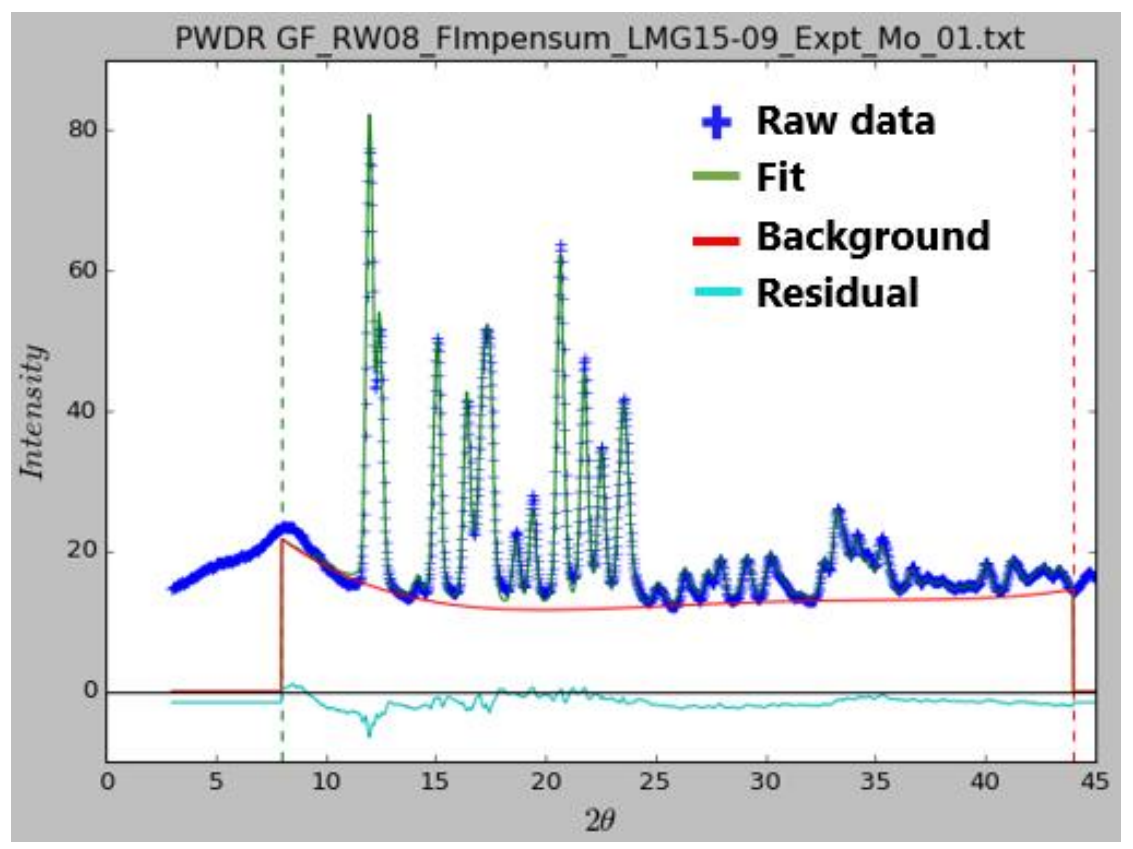

FIGURE 1.4. An example of whole-pattern Rietveld refinement using GSAS II with raw data (blue plus signs) fit against a known model structure (green solid line). The residual (mint-green solid line) helps to signify the effectiveness of the fit (Residual $=$ Raw data - Background - Fit $)$.

In order to assess overall disorder in the crystal symmetry, we can utilize measurements of the full-width at half-maximum (FWHM) of the (111) main diffraction peak. Since the (111) plane intersects all three $a$-, $b$-, and $c$-axes of the aragonite unit cell, it can give an overall representation of disorder in the crystal (Figure 1.5). Typically, narrow diffraction peaks on an XRD pattern (smaller FWHM) indicate more perfect reflections of X-rays across a plane of a crystal with ideal symmetry. More disorder in the crystal symmetry (due to dislocations, trace element incorporations, etc.) leads to a slightly wider range of possible reflection pathways for a single plane and creates diffraction peaks with wider FWHM. There are several caveats for using FWHM of peaks to define disorder in a crystal, including crystallite size, crystallite orientation, and instrument/sample alignment, which may also influence FWHM of peaks, thus we only use FWHM as a qualitative representation for disorder in this study.
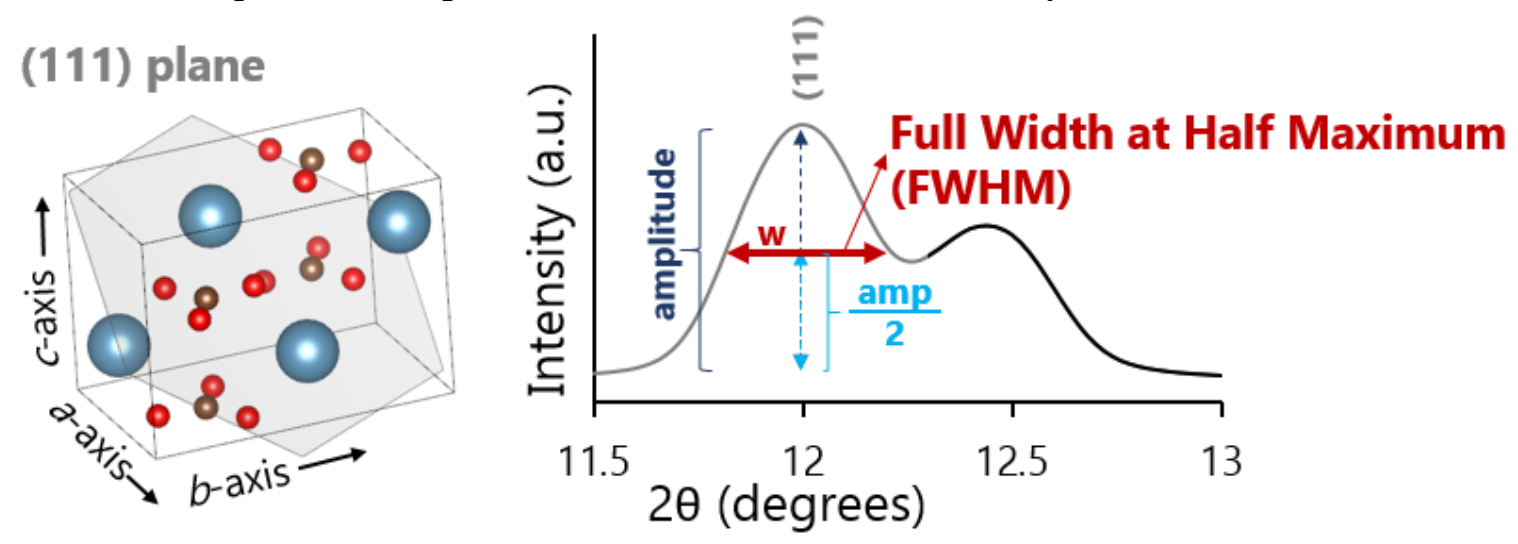

FIGURE 1.5 The (111) XRD plane (left) represented at $\sim 12$ degrees in the XRD pattern (right). Measuing the FWHM of the (111) peak may lend insight into the amount of disorder in the crystal symmetry of a sample. 


\section{Raman spectroscopy}

Raman spectroscopy can be used to assess the bonding environment in a crystal lattice by measuring the frequency of Raman-active vibrational modes. In carbonates, Raman spectroscopy is mainly used to measure the symmetric stretching ( 1 1), asymmetric stretching (v) and out-ofplane rotation modes of the trigonal-planar carbonate groups (Figure 1.6). While shifts in Raman frequency are typically observed in more extreme high pressure and temperature environments, FWHM of the $v_{1}$ mode has been shown to correlate closely with the $\Omega_{\mathrm{Ar}}$ of aragonites forming at ambient environments (DeCarlo et al., 2017). Thus, FWHM $v_{1}$ can be used to directly calculate estimates for coral calcifying fluid $\Omega_{\mathrm{Ar}}$. Wider FWHM of the $v_{1}$ mode indicates increased disorder in the symmetric stretching of the three $\mathrm{C}-\mathrm{O}$ bonds of the carbonate group.

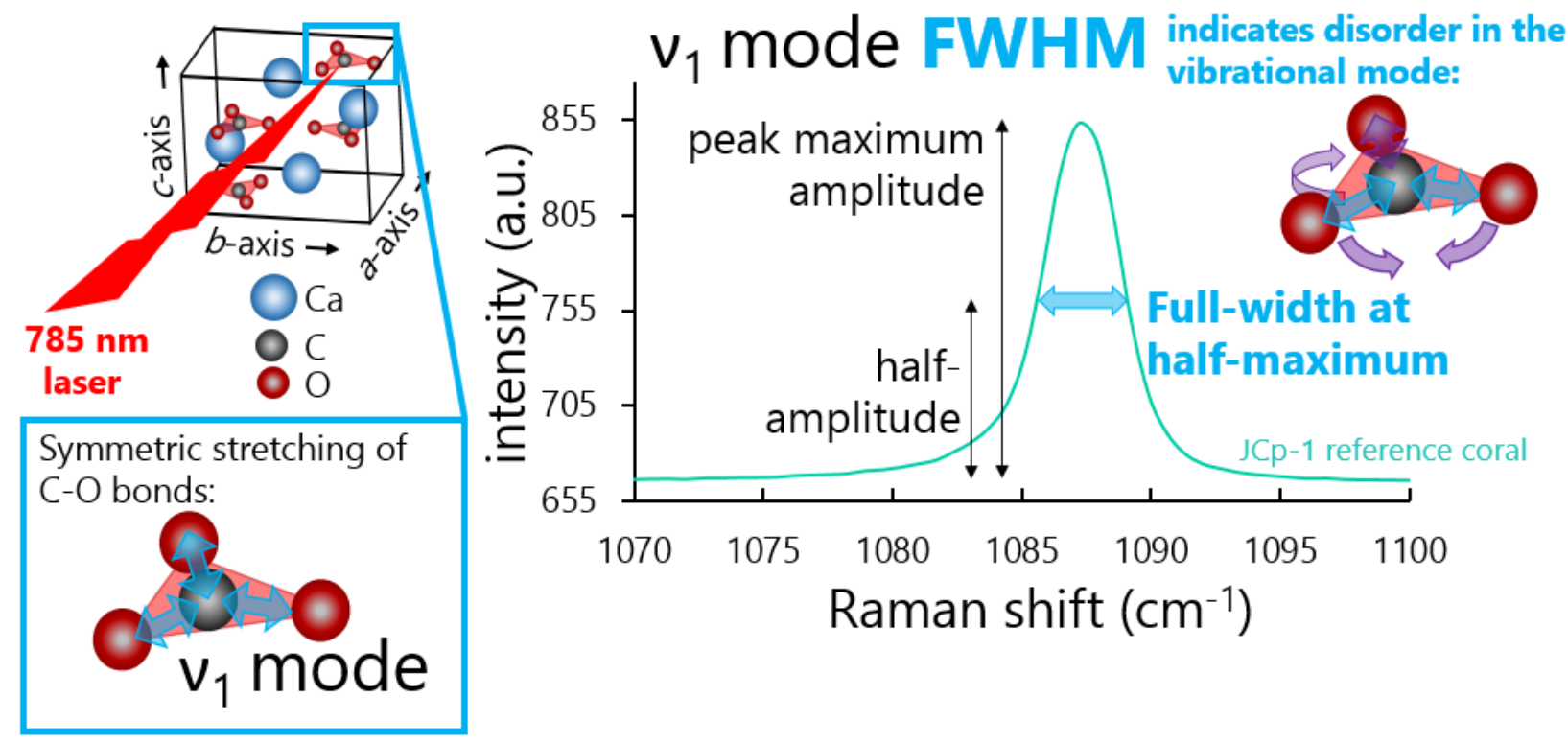

FIGURE 1.6 Raman spectroscopy measures carbonate-bonding vibrational modes in aragonite. Here we use it to measure disorder in the $v_{1}$ symmetric stretching mode (blue arrows, left) of the carbonate trigonal planar group, by measuring the FWHM of the $v_{1}$ peak. Wider FWHMs indicate increased disorder (i.e., violet arrows, right) in this vibrational mode.

\section{Synchrotron-based X-ray Fluorescence and X-ray Absorption Spectroscopy (XAS)}

In addition to the classical XRD and Raman spectroscopy mineralogical tools used in this study, we also used state-of-the-art synchrotron-based X-ray tools such as X-ray Fluorescence (XRF) and X-ray Absorption Spectroscopy (XAS) at the Stanford Synchrotron Radiation Lightsource (SSRL). The X-ray absorption near-edge structure (XANES) of the XAS spectrum (Figure 1.7) allows for identifying elements, binding energies, and oxidation states at specific points within a heterogenous sample at very high resolutions $(2-5 \mu \mathrm{m}$ spot sizes). Coupling XAS with highresolution XRF raster maps, we are able to visualize the distributions of specific bonding environments of sulfur across a complex coral sample with both tissues and skeleton. 


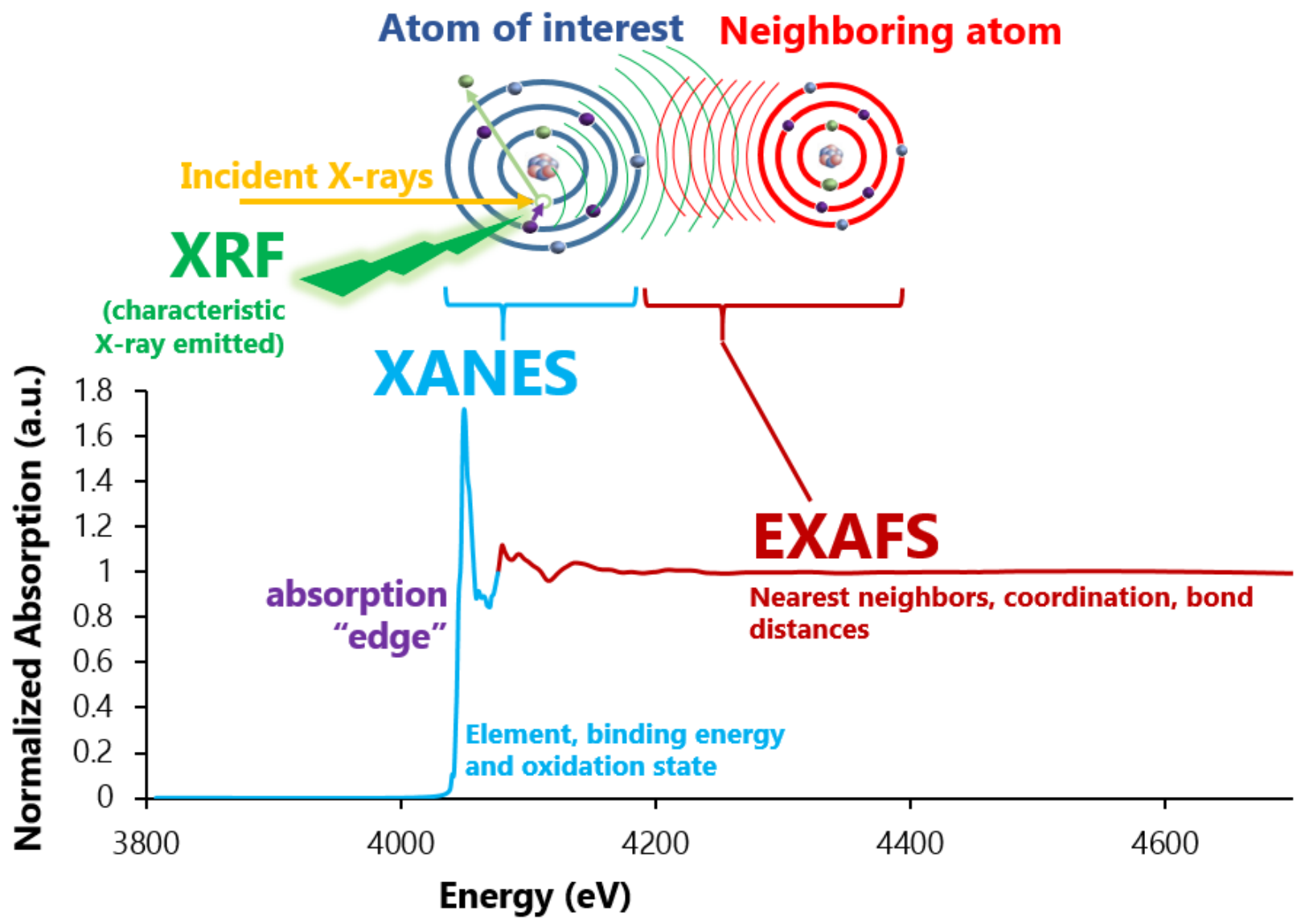

FIGURE 1.7 A visualization of synchrotron-based X-ray Fluorescence (XRF, in green) and Xray Aborption Spectroscopy (XAS) methods. As incident X-rays, aimed at the atom of interest, increase in energy $(\mathrm{eV})$, a core electron is ejected. An outer-orbit eletron fills the vacancy, releasing a characteristic X-ray (XRF) and photoelectron wave. Energy that is absorbed during this process is recorded in the X-ray Absorption Near-Edge Structure (XANES, in blue) region of the XAS spectrum. As incident X-ray energy continues to increase, the XAS spectrum begins to record the interactions between the photoelectron wave with the neighboring atoms in the Extended X-ray Absorption Fine Structure (EXAFS, red) region.

\subsection{This thesis}

This thesis seeks to provide insight into how corals form aragonite crystals in their skeletons and how sensitive aragonite crystal formation may be changes in surrounding ocean chemistry. To do this, we add a new mineralogical and crystallographic perspective on the nature of coral aragonite and correlate this with the trace element incorporations and variables that influence overall skeletal growth. We our crystallographic approach and chemical observations to corals growing in natural low to high $\Omega_{\mathrm{sw}}$ in both deep-sea and shallow-water environments to understand how prone coral mineralogy is to changing under different ocean environments. Finally, we present a new method for mapping specific S-bonding environments at highresolution as a way to better trace the role of $S$ compounds in biomineralization. 
Chapter 2 characterizes the crystallographic nature of coral aragonite compared to other biogenic aragonite (mollusk aragonite), synthetic aragonite precipitated from seawater and freshwater, and geologically-formed aragonite. We observe that coral aragonite resembles aragonites synthetically precipitated from seawater in terms of crystallography and chemistry. This suggests that coral biomineralization is primarily driven by geochemical processes, rather than biological molecules. Furthermore, coral aragonites are significantly distinct from mollusk aragonite and synthetic aragonites precipitated from freshwater with regards to crystallography, chemistry, and background fluorescence (a proxy for organic content).

Chapter 3 uses crystallographic observations of deep-sea coral skeletons growing in a natural $\Omega_{\mathrm{sw}}$ gradient in the Gulf of Mexico $\left(\Omega_{\mathrm{sw}}=1.15-1.44\right)$ in order to determine whether deepsea coral skeletons express crystallographic distortions as a function of decreasing $\Omega_{\mathrm{sw}}$, shifts in seawater chemistry (trace incorporations of metals), and the presence of added calcite phases in the skeleton associated with this natural $\Omega_{\text {sw }}$ gradient. We observe that aragonite unit cell volumes are slightly smaller in Lophelia pertusa growing at low $\Omega_{\mathrm{sw}}$. Shifts in crystallography do not correlate with other variables such as calcite contents or element incorporations in the skeletons.

Chapter 4 investigates a well-studied, shallow-water $\mathrm{pH}$ gradient from Nikko Bay $(\mathrm{pH}=$ $7.84, \Omega_{\mathrm{sw}}=2.3$ ) to Dropoff ( $\mathrm{pH}=8.05, \Omega_{\mathrm{sw}}=3.7$ ) sites in Palau to determine whether known shifts in skeletal density and seawater chemistry (Mollica et al., 2018; Shamberger et al., 2014) between these sites are manifested in skeletal crystallography and chemistry. This dataset has the added benefit of containing information on calcifying fluid aragonite saturation states $\left(\Omega_{\mathrm{cf}}\right)$ of the coral samples, in addition to $\Omega_{\mathrm{sw}}$, which are representative of the $\Omega$ that the coral aragonites are precipitated from. In this study we observe that aragonite unit cells shift anisotropically along the $a$-axis as a function of calcite contents in the coral aragonite skeleton. Calcite contents vary with respect to skeletal growth parameters such as density, growth rate, and $\Omega_{\mathrm{cf}}\left(\Omega_{\mathrm{cf}}\right.$ is calculated from $\left.\mathrm{pH}_{\mathrm{cf}}\right)$.

Chapter 5 presents a new method for mapping sulfur bonding environments across coral skeletons and tissues at high-resolution. These speciation maps may serve as evidence to determine the role of $\mathrm{S}$ in coral skeletons and whether it may be involved in coral biomineralization or is merely an inorganic substitution for carbonate in the aragonite lattice. We observe that $\mathrm{S}$ signals in coral skeletons are dominated by a carbonate-associated sulfate, which is most likely an inorganic substitution of sulfate groups in place of the carbonate groups in the aragonite crystal lattice.

Overall, this thesis addresses critical questions on coral aragonite formation that will allow for better prections of how coral skeletal material properties and health may respond to projected stressful ocean environments. This thesis takes a crystallographic, mineralogical, and chemical perspective to find that coral aragonite forms via geochemical controls, which suggests that the material properties of coral aragonite, such as solubility and strength, may shift as a function of calcifying fluid and surrounding seawater chemistry. Changes in solubility and strength of the aragonite mineral could influence how vulnerable coral reef structures are to physical damage and dissolution under ocean acidification conditions. Geochemical controls on crystal formation may also imply a strong chemical influence on coral biomineralization. In natural systems undergoing low $\Omega_{\mathrm{sw}}$, we do observe small crystallographic shifts in deep-sea and shallow-water coral aragonites across $\Omega_{\text {sw }}$ gradients. More work is required to determine whether or not these 
crystallographic and mineralogical shifts (such as calcite contents) will translate into detrimental changes for the physical properties of coral skeletons growing under stressful ocean conditions.

\section{References}

Allemand, D., Ferrier-Pages, C., Furla, P., Houlbreque F., Puverel, S., Reynaud, S., Tambutté, E., Tambutté, S. and Zoccola, D. (2004). Biomineralisation in reef-building corals: from molecular mechanisms to environmental control. C. R. Palevol. 3, 453-467. doi:10.1016/j.crpv.2004.07.011

Antao, S.M. and Hassan, I. (2009). The orthorhombic structure of $\mathrm{CaCO}_{3}, \mathrm{SrCO}_{3}, \mathrm{PbCO}_{3}$ and $\mathrm{BaCO}_{3}$ : Linear structural trends. Can. Mineral. 47, 1245-1255. doi:10.3749/canmin.47.5.1245

Barkley, H. C., Cohen, A. L., Golbuu, Y., Starczak, V. R., DeCarlo, T. M., and Shamberger, K. E. (2015). Changes in coral reef communities across a natural gradient in seawater $\mathrm{pH}$. Science advances, 1(5), e1500328. Doi:10.1126/sciadv.1500328

Becker, A., Bismayer, U., Epple, M., Fabritius, H., Hasse, B., Shi, J., and Ziegler, A. (2003). Structural characterisation of X-ray amorphous calcium carbonate (ACC) in sternal deposits of the crustacea Porcellio scaber. Dalton Trans, (4), 551-555. doi:10.1039/B210529B

Benzerara, K., Menguy, N., Obst, M., Stolarski, J., Mazur, M., Tylisczak, T., Brown, G., and Meibom, A. (2011). Study of the crystallographic architecture of corals at the nanoscale by scanning transmission X-ray microscopy and transmission electron microscopy. Ultramicroscopy, 111(8), 1268-1275. doi:10.1016/j.ultramic.2011.03.023

Carpenter, K. E., Abrar, M., Aeby, G, Aronson, R. B., Banks, S., Bruckner, A., Chiriboga, A., Cortés, J., Delbeek, J. C., DeVantier, L., Edgar, G. J., Edwards, A. J., Fenner, D., Guzmán, H. M., Hoeksema, B.W., Hodgso,n G., Johan, O., Licuanan, W. Y., Livingstone, S. R., Lovell, E. R , Moore, J. A., Obura, D. O., Ochavillo, D., Polidoro, B. A., Precht, W. F., Quibilan, M. C., Reboton, C., Richards, Z. T., Rogers, A. D., Sanciangco, J., Sheppard, A., Sheppard, C., Smith, J., Stuart, S., Turak, E., Veron, J. E. N., Wallace, C., Weil, E., and Wood, E. (2008). One-third of reef-building corals face elevated extinction risk from climate change and local impacts. Science 321(5888), 560-563. doi:10.1126/science.1159196

Camp, E. F., Nitschke, M. R., Rodolfo-Metalpa, R., Houlbreque, F., Gardner, S. G., Smith, D. J Zampighi, M., and Suggett, D. J. (2017). Reef-building corals thrive within hot-acidified and deoxygenated waters. Sci. Rep., 7(1), 2434. doi:10.1038/s41598-017-02383-y

Chan, N. and Connolly, S. R. (2013). Sensitivity of coral calcification to ocean acidification: a meta-analysis. Glob. Change Bio. 19, 282-290. doi:10.1111/gcb.12011

Cohen, A. L., Gaetani, G. A., Lundälv, T., Corliss, B. H., and George, R. Y. (2006). Compositional variability in a cold-water scleractinian, Lophelia pertusa: New insights into "vital effects". Geochemistry, Geophysics, Geosystems, 7(12). doi:10.1029/2006GC001354

Cohen, A. L., and Holcomb, M. (2009). Why corals care about ocean acidification: uncovering the mechanism. Oceanography, 22(4), 118-127. doi:24861029 
Cohen, A. L., McCorkle, D. C., de Putron, S., Gaetani, G. A., and Rose, K. A. (2009). Morphological and compositional changes in the skeletons of new coral recruits reared in acidified seawater: Insights into the biomineralization response to ocean acidification. Geochem. Geophys. Geosyst. 10(7), 1-12. doi:10.1029/2009GC002411

Cohen A. L. and McConnaughey T. (2003). Geochemical perspectives on coral mineralization. In Biomineralization (eds. P. Dove, S. Weiner and J. Yoreo). Rev. Mineral. Geochem. 54, 151-187.

Cohen, A. L., Layne, G. D., Hart, S. R., and Lobel, P. S. (2001). Kinetic control of skeletal Sr/Ca in a symbiotic coral: Implications for the paleotemperature proxy. Paleoceanography, 16(1), 20-26. doi:10.1029/1999PA000478

Cuif, J. P., Bendounan, A., Dauphin, Y., Nouet, J., and Sirotti, F. (2013). Synchrotron-based photoelectron spectroscopy provides evidence for a molecular bond between calcium and mineralizing organic phases in invertebrate calcareous skeletons. Anal Bioanal Chem, 405(27), 8739-8748. doi:10.1007/s00216-013-7312-4

Cuif, J. P., \& Dauphin, Y. (2005). The Environment Recording Unit in coral skeletons-a synthesis of structural and chemical evidences for a biochemically driven, stepping-growth process in fibres. Biogeosciences, 2(1), 61-73. doi:10.5194/bg-2-61-2005

Cuif, J. P., Dauphin, Y., Berthet, P., and Jegoudez, J. (2004). Associated water and organic compounds in coral skeletons: quantitative thermogravimetry coupled to infrared absorption spectrometry. Geochem Geophy Geosy, 5(11). doi:10.1029/2004GC000783

Cuif, J. P., Dauphin, Y., Doucet, J., Salome, M., \& Susini, J. (2003). XANES mapping of organic sulfate in three scleractinian coral skeletons. Geochim. Cosmochim. Acta, 67(1), 75-83. doi:10.1016/S0016-7037(02)01041-4

DeCarlo, T. M., Ren, H., and Farfan, G.A. (2018). The origin and role of organic matrix in coral calcification: insights from comparing coral skeleton and abiogenic aragonite. Front Mar Sci, 5, 170.

DeCarlo, T. M., Cohen, A. L., Barkley, H. C., Cobban, Q., Young, C., Shamberger, K. E., Brainard, R.E., and Golbuu, Y. (2015). Coral macrobioerosion is accelerated by ocean acidification and nutrients. Geology, 43(1), 7-10. doi:10.1130/G36147.1

DeCarlo, T. M., D'Olivo, J. P., Foster, T., Holcomb, M., Becker, T., and McCulloch, M. T. (2017). Coral calcifying fluid aragonite saturation states derived from Raman spectroscopy. Biogeosciences 14, 5253. doi:10.5194/bg-14-5253-2017

Doney, S. C., Fabry, V. J., Feely, R. A., and Kleypas, J. A. (2009). Ocean acidification: the other $\mathrm{CO}_{2}$ problem. Annu. Rev. Mar. Sci. 1, 169-192. doi:10.1146/annurev.marine.010908.163834

Eyre, B. D., Andersson, A. J., and Cyronak, T. (2014). Benthic coral reef calcium carbonate dissolution in an acidifying ocean. Nat Clim Chang 4(11), 969. doi:10.1038/NCLIMATE2380

Farfan, G. A., Cordes, E. E., Waller, R. G., DeCarlo, T. M. and Hansel, C. M. (in review). Mineralogy of deep-sea coral aragonites as a function of aragonite saturation state. Front Mar Sci. 
Finch, A. A., \& Allison, N. (2007). Coordination of $\mathrm{Sr}$ and $\mathrm{Mg}$ in calcite and aragonite. Mineral. Mag., 71(5), 539-552. doi:10.1180/minmag.2007.071.5.539

Fisher, R., O'Leary, R. A., Low-Choy, S., Mengersen, K., Knowlton, N., Brainard, R. E., and Caley, M. J. (2015). Species richness on coral reefs and the pursuit of convergent global estimates. Curr. Biol. 25, 500-505. doi:10.1016/j.cub.2014.12.022

Foster, T., Falter, J. L., McCulloch, M. T., and Clode, P. L. (2016). Ocean acidification causes structural deformities in juvenile coral skeletons. Sci. Adv. 2(2), 1-7. doi:10.1126/sciadv.1501130

Gagnon, A. C., Adkins, J. F., and Erez, J. (2012). Seawater transport during coral biomineralization. Earth Planet Sci Lett. 329-330, 150-161. doi:10.1016/j.epsl.2012.03.005

Gaetani, G. A., and Cohen, A. L. (2006). Element partitioning during precipitation of aragonite from seawater: a framework for understanding paleoproxies. Geochim. Cosmochim. Acta, 70(18), 4617-4634. doi:10.1016/j.gca.2006.07.008

Hansel, C. M., Zeiner, C. A., Santelli, C. M., \& Webb, S. M. (2012). Mn (II) oxidation by an ascomycete fungus is linked to superoxide production during asexual reproduction. Proc. Natl. Acad. Sci. U.S.A. 109(31), 12621-12625. doi:10.1073/pnas.1203885109

Hathorne, E. C., Gagnon, A., Felis, T., Adkins, J., Asami, R., Boer, W., Caillon, N., Case, D., Cobb, K. M., Douville, E., deMenocal, P., Eisenhauer, A., Garbe-Schönberg, D., Geibert, W., Goldstein, S., Hughen, K., Inoue, K., Kawahata, H., Kölling, M., Cornec, F. L., Linsley, B. K., McGregor, H. V., Montagna, P., Nurhati, I. S., Quinn, T. M., Raddatz, J., Rebaubier, H., Robinson, K., Sadekov, A., Sherrell, R., Sinclair, D., Tudhope, A. W., Wei, G., Wong, H., Wu, C. and You, C. (2013). Interlaboratory study for coral $\mathrm{Sr} / \mathrm{Ca}$ and other element/Ca ratio measurements. Geochem. Geophys. Geosyst. 4, 3730-3750. doi:10.1002/ggge.20230

Hennige, S. J., Wicks, L. C., Kamenos, N. A., Perna, G., Findlay, H. S., and Roberts, J. M. (2015). Hidden impacts of ocean acidification to live and dead coral framework. Proc. R. Soc. Lond. [Biol] 282, 1-10. doi:10.1098/rspb.2015.0990

Higuchi, T., Fujimura, H., Yuyama, I., Harii, S., Agostini, S., and Oomori, T. (2014). Biotic control of skeletal growth by scleractinian corals in aragonite-calcite seas. PLoS One, 9(3), e91021. doi:10.1371/journal.pone.0091021

Hoegh-Guldberg, O., Poloczanska, E. S., Skirving, W., and Dove, S. (2017). Coral reef ecosystems under climate change and ocean acidification. Front Mar Sci, 4, 158. doi:10.3389/fmars.2017.00158

Hoegh-Guldberg, O. (2015). Reviving the Ocean Economy: the Case for Action - 2015. Gland: WWF International.

Holcomb, M., Cohen, A. L., Gabitov, R. I., \& Hutter, J. L. (2009). Compositional and morphological features of aragonite precipitated experimentally from seawater and biogenically by corals. Geochim. Cosmochim. Acta, 73(14), 4166-4179. doi:10.1016/j.gca.2009.04.015 
Kampschulte, A.; Strauss, H. (2004). The sulfur isotopic evolution of Phanerozoic seawater based on the analysis of structurally substituted sulfate in carbonates. Chem. Geol. 204, 255-286. doi.org/10.1016/j.chemgeo.2003.11.013

Kurman, M. D., Gómez, C. E., Georgian, S. E., Lunden, J. J., and Cordes, E. E. (2017). Intra-specific variation reveals potential for adaptation to ocean acidification in a cold-water coral from the Gulf of Mexico. Front Mar Sci, 4, 111. doi:10.3389/fmars.2017.00111.

Langdon, C., Takahashi, T., Sweeney, C., Chipman, D., Goddard, J., Marubini, F., Aceves, H., Barnett, H., and Atkinson, M. J. (2000). Effect of calcium carbonate saturation state on the calcification rate of an experimental coral reef. Global Biogeochem Cycles, 14(2), 639-654. doi:10.1029/1999gb001195

Lunden, J. J., Georgian, S. E., and Cordes, E. E. (2013). Aragonite saturation states at cold-water coral reefs structured by Lophelia pertusa in the northern Gulf of Mexico. Limnol. Oceanogr. 58, 354-362. doi:10.4319/lo.2013.58.1.0354

Markgaf and Reeder (1985). High-temperature structure refinements of calcite and magnesite. Amer. Mineral. 70, 590-600.

Marxen, J. C., Becker, W., Finke, D., Hasse, B., and Epple, M. (2003). Early mineralization in Biomphalaria glabrata: microscopic and structural results. J. Molluscan Stud., 69(2), 113-121. doi:10.1093/mollus/69.2.113

Mass, T., Giuffre, A. J., Sun, C.-Y., Stifler, C. A., Frazier, M. J., Neder, M., Tamura, N., Stan, C. V., Marcus, M. A., and Gilbert, P. U. P. A. (2017). Amorphous calcium carbonate particles form coral skeletons. Proc. Natl. Acad. Sci. U.S.A. 114, E7670-E7678. doi:10.1073/pnas.1707890114

Mass, T., Drake, J. L., Haramaty, L., Kim, J. D., Zelzion, E., Bhattacharya, D., and Falkowski, P. G. (2013). Cloning and characterization of four novel coral acid-rich proteins that precipitate carbonates in vitro. Curr. Biol., 23(12), 1126-1131. doi:10.1016/j.cub.2013.05.007

Meibom, A., Cuif, J. P., Houlbreque, F., Mostefaoui, S., Dauphin, Y., Meibom, K. L., and Dunbar, R. (2008). Compositional variations at ultra-structure length scales in coral skeleton. Geochim. Cosmochim. Acta, 72(6), 1555-1569. doi:10.1016/j.gca.2008.01.009

McCulloch, M. T., Holcomb, M., Rankenburg, K., and Trotter, J. A. (2014). Rapid, high-precision measurements of boron isotopic compositions in marine carbonates. Rapid Commun. Mass Spectrom., 28(24), 2704-2712. doi:10.1002/rcm.7065

McCulloch, M., Trotter, J., Montagna, P., Falter, J., Dunbar, R., Freiwald, A., Försterra, G., López Correa, M., Maier, C., Rüggeberg, A., and Taviani, M. (2012a). Resilience of cold-water scleractinian corals to ocean acidification: Boron isotopic systematics of $\mathrm{pH}$ and saturation state up-regulation. Geochim. Cosmochim. Acta, 87, 21-34. doi:10.1016/j.gca.2012.03.027

McCulloch, M., Falter, J., Trotter, J., and Montagna, P. (2012b). Coral resilience to ocean acidification and global warming through $\mathrm{pH}$ up-regulation. Nat Clim Chang, 2(8), 623.

doi:10.1038/nclimate1473 
Mollica, N. R., Guo, W., Cohen, A. L., Huang, K. F., Foster, G. L., Donald, H. K., \& Solow, A. R. (2018). Ocean acidification affects coral growth by reducing skeletal density. Proc. Natl. Acad. Sci., 115(8), 1754-1759. doi:10.1073/pnas.1712806115

Nguyen, L. T., Rahman, M. A., Maki, T., Tamenori, Y., Yoshimura, T., Suzuki, A., Iwasaki, N., and Hasegawa, H. (2014). Distribution of trace element in Japanese red coral (Paracorallium japonicum) by $\mu$-XRF and sulfur speciation by XANES: Linkage between trace element distribution and growth ring formation. Geochim. Cosmochim. Acta, 127, 1-9. doi:10.1016/j.gca.2013.11.023

Perrin, J., Rivard, C., Vielzeuf, D., Laporte, D., Fonquernie, C., Ricolleau, A., Cotte, M., and Floquet, N. (2017). The coordination of sulfur in synthetic and biogenic Mg calcites: The red coral case. Geochim. Cosmochim. Acta. 197, 226-244. doi:10.1016/j.gca.2016.10.017

Pingitore, N. E., Meitzner, G., Love, K. M. (1995). Identification of sulfate in natural carbonates by X-ray absorption spectroscopy. Geochim. Cosmochim. Acta, 59, 2477-2483.

Pokroy, B., Quintana, J. P., El'ad, N. C., Berner, A., and Zolotoyabko, E. (2004). Anisotropic lattice distortions in biogenic aragonite. Nat. Mater. 3, 900. doi:10.1038/nmat1263

Pokroy, B., Fitch, A. N., Lee, P. L., Quintana, J. P., El'ad, N. C., and Zolotoyabko, E. (2006). Anisotropic lattice distortions in the mollusk-made aragonite: a widespread phenomenon. $J$. Struct. Biol. 153, 145-150. doi:10.1016/j.jsb.2005.10.009

Pokroy, B., Fieramosca, J. S., Von Dreele, R. B., Fitch, A. N., Caspi, E. N., and Zolotoyabko, E. (2007). Atomic Structure of Biogenic Aragonite. Chem. Mater. 19, 3244-3251. doi:10.1021/cm070187u

Przeniosło, R., Stolarski, J., Mazur, M., \& Brunelli, M. (2008). Hierarchically structured scleractinian coral biocrystals. J. Struct. Biol., 161(1), 74-82. doi:10.1016/j.jsb.2007.09.020

Reynaud, S., Ferrier-Pages, C., Meibom, A., Mostefaoui, S., Mortlock, R., Fairbanks, R., \& Allemand, D. (2007). Light and temperature effects on $\mathrm{Sr} / \mathrm{Ca}$ and $\mathrm{Mg} / \mathrm{Ca}$ ratios in the scleractinian coral Acropora sp. Geochim. Cosmochim. Acta, 71(2), 354-362. doi:10.1016/j.gca.2006.09.009

Rodolfo-Metalpa, R., Montagna, P., Aliani, S., Borghini, M., Canese, S., Hall-Spencer, J. M., and Houlbrèque, F. (2015). Calcification is not the Achilles' heel of cold-water corals in an acidifying ocean. Global change boil.gy, 21(6), 2238-2248. doi:10.1111/gcb.12867

Roger, L. M., George, A. D., Shaw, J., Hart, R. D., Roberts, M., Becker, T., McDonald, B. J., and Evans, N. (2017). Geochemical and microstructural characterisation of two species of cool-water bivalves (Fulvia tenuicostata and Soletellina biradiata) from Western Australia. Biogeosciences, $14,1721$.

Shamberger, K. E. F., A. L. Cohen, Y.Golbuu, D. C. McCorkle, S. J. Lentz, and H. C. Barkley (2014), Diverse coral communities in naturally acidified waters ofa Western Pacific Reef, Geophys. Res. Lett. 41, 499-504. doi:10.1002/2013GL058489 
Sowa, K., Watanabe, T., Motai, S., Seto, Y., \& Nagai, T. (2008). Mineral phase of COCs and fibers in coral skeletons. In: Proc. 11th Int. Coral Reef Symp. (eds. Riegl, B. and Dodge, R. E.), 11, 74-77.

Stolarski, J., Przeniosło, R., Mazur, M., \& Brunelli, M. (2007). High-resolution synchrotron radiation studies on natural and thermally annealed scleractinian coral biominerals. J Appl Crystallogr, 40(1), 2-9. doi:10.1107/S002188980604489X

Tamenori, Y.; Yoshimura, T.; Luan, N. T.; Hasegawa, H.; Suzuki, A.; Kawahata, H.; Iwasaki, N. (2014). Identification of the chemical form of sulfur compounds in the Japanese pink coral (Corallium elatius) skeleton using $\mu$-XRF/XAS speciation mapping. J. Struct. Biol. 186(2), 214-23.

Toby, B. H., and Von Dreele, R. B. (2013). GSAS-II: the genesis of a modern open-source all purpose crystallography software package. J. Appl. Crystallogr. 46, 544-549. doi:10.1107/S0021889813003531

Veis, A. (2003). Mineralization in organic matrix frameworks. In Biomineralization (eds. P. Dove, S. Weiner and J. Yoreo). Rev. Mineral. Geochem. 54, 151-187. doi:10.2113/0540249

Vielzeuf, D., Garrabou, J., Gagnon, A., Ricolleau, A. Adkins, J., Günther, D., Hametner, K., Devidal, J. L., Reusser, E., Perrin, J., and Floquet, N. (2013). Distribution of sulphur and magnesium in the red coral. Chem. Geol. 355, 13-27. doi.org/10.1016/j.chemgeo.2013.07.008

Von Euw, S., Zhang, Q., Manichev, V., Murali, N., Gross, J., Feldman, L. C., Gustafsson, T., Flach C., Mendelsohn, R., and Falkowski, P. G. (2017). Biological control of aragonite formation in stony corals. Science, 356, 933-938. doi:10.1126/science.aam6371

Weiner, S., Mahamid, J., Politi, Y., Ma, Y., \& Addadi, L. (2009). Overview of the amorphous precursor phase strategy in biomineralization. Frontiers of Materials Science in China, 3(2), 104. Doi: 10.1007/s11706-009-0036-x

Young, J. R., \& Henriksen, K. (2003). Biomineralization within vesicles: the calcite of coccoliths. Reviews in mineralogy and geochemistry, 54(1), 189-215. doi:10.2113/0540189

Zoccola, D., Tambutté, E., Kulhanek, E., Puverel, S., Scimeca, J. C., Allemand, D., and Tambutté, S. (2004). Molecular cloning and localization of a PMCA P-type calcium ATPase from the coral Stylophora pistillata. Biochim. Biophys. Acta. 1663(1), 117-126. doi:10.1016/j.bbamem.2004.02.010

Zolotoyabko, E. (2016). Anisotropic lattice distortions in biogenic minerals originated from strong atomic interactions at organic/inorganic interfaces. Advanced Materials Interfaces, 4(1), 1600189. doi:10.1002/admi.201600189 
CHAPTER 2. Crystallographic evidence for a geochemical control over coral aragonite formation 


\subsection{ABSTRACT}

The controls on the underlying mechanism for coral aragonite formation has important implications for skeletal growth and structural stability under rapidly shifting ocean chemistries and physical processes. However, the nature and relative contribution of chemical and biological controls on coral biomineralization and the nature of coral aragonite remain hotly debated. Here we take a mineralogical approach using quantitative X-ray diffraction (XRD) and Raman spectroscopy along with ICP-MS measurements of trace elements to assess the crystallography and bonding environments of coral aragonites. Our analysis of the aragonite end-products of coral biomineralization point to predominantly geochemical control on $\mathrm{CaCO}_{3}$ production from the calcifying fluid. The evidence is as follows: first, the aragonite crystallography, carbonate bonding environment, crystal habit morphology, and trace element composition of coral aragonites are not statistically distinct from synthetic aragonites precipitated from seawater. In this study, coral aragonite and synthetic aragonites precipitated from aragonite supersaturated seawater solutions $\left(\Omega_{\mathrm{Ar}}=11-25\right)$ have statistically similar anistortopic unit cell lattice distortions, whereas geologically-formed aragonite (formed in the absence of biology) are statistically dissimilar from both. Coral aragonites are also statistically dissimilar from mollusk shell aragonite and synthetic aragonite precipitated from freshwater. This crystallographic difference between coral and mollusk aragonite, as well as a lack of background fluorescence observed in coral aragonites compared to the very high background fluorescence in mollusk aragonite, indicates that anisotropic lattice distortions in corals are unlikely to be due to inter or intracrystalline organics, as is suggested to be the case in mollusk aragonite. Instead of biological controls, we propose that physical and chemical parameters play a dominant role in observed crystal lattice and carbonate bonding environment distortions across aragonites from different formation origins. This is evidenced by corellations between increased trace-incorporations of elements such as B and Sr and aragonites from different origins, which are often observed as a function of faster crystal growth rates and other growth parameters. Our crystallographic findings suggest that coral aragonite formation is dependent on the geochemistry of the coral calcifying fluid and may be sensitive to shifts in calcifying fluid chemistry responding to predicted changes in surrounding ocean chemistry over the next century.

\subsection{INTRODUCTION}

Coral skeletons form the framework of coral reefs ecosystems, which serve as enormous diversity of marine organisms, help to support the livelihoods of hundreds of millions of people, and make up an economic value of almost one trillion dollars (Carpenter et al., 2008; Fisher et al. 2015; Hoegh-Guldberg, 2015; Hoegh-Guldberg et al., 2017). Ocean conditions are changing rapidly as carbon dioxide emissions rise, leading to mounting concerns that these changes will have devastating impacts on coral reefs, with some studies even predicting the extinction of these valuable ecosystems by mid-century (Carpenter et al., 2008; Hoegh-Guldberg et al., 2017). Scleractinian corals build their skeletons out of the mineral aragonite, a polymorph of calcium carbonate, which renders them vulnerable to ocean acidification and shifts in ocean carbonate chemistry (Doney et al., 2009). However, there is considerable debate over the defree of control 
corals exert over the biomineralization process, control that could "buffer" calcification against changes occurring in the external environment.

Geochemical models of coral biomineralization (e.g., Cohen and McConnaughey, 2003) suggest that corals precipitate skeletons in an extracellular space between the base of the polyp and the top of existing skeleton. Seawater enters the space via paracellular channels (e.g., Tambutté et al., 2011) and the coral elevates the $\mathrm{pH}$ and saturation state of the seawater using $\mathrm{Ca}^{2+}$-ATPase pumps located in the calicoblastic epithelium (Zoccola et al., 2004). Measurements of calcifying fluid $\mathrm{pH}\left(\mathrm{pH}_{\mathrm{cf}}\right)$ and aragonite saturation state $\left(\Omega_{\mathrm{cf}}\right)$, using $\mathrm{pH}$-sensitive dyes (Venn et al., 2011), microsensors (Al-Horani et al., 2003; Cai et al., 2016) and boron isotopes (Allison and Finch, 2010; McCulloch et al., 2012b) indicates that corals elevate conditions well above that of surrounding seawater. This assumption that corals utilize seawater as the initial fluid to create their aragonite is essential for paleoproxy studies which rely on coral aragonite faithfully recording surrounding seawater chemistry, despite any vital effects introduced by biomineralization (Meibom et al., 2006; Gagnon et al., 2007; Tambutté et al., 2011). This geochemical model for biomineralization is supported by several lines of evidence: 1) spherules of synthetic aragonites precipitated from seawater exhibit the same acicular crystal bundle habits observed in coral skeletons (i.e., Cohen and McConnaughey 2003, Cohen et al., 2009, Cohen and Holcomb 2009, Holcomb et al., 2009), 2) The crystal habit response of coral aragonite to abnormal conditions mirrors that of synthetic aragonites, with juvenile corals precipitating blocky crystal habits that mimic synthetic aragonites formed from lower aragonite saturation states (Cohen et al., 2009), 3) Coral geochemistry matches that of synthetic aragonites precipitated from seawater (Gaetani and Cohen, 2006), and 4) carbonate bonding environments, as measured by Raman spectroscopy, are the same for corals and synthetic aragonites precipitated from seawater (DeCarlo et al., 2018).

Studies of organic molecules found in coral skeletons have been used to formulate an alternative "biological" model of coral biomineralization. These models suggest that biomolecules found in coral skeletons (Meibom et al., 2008; Benzerara et al., 2013) which make up to $<1$ weight $\%$ of the skeleton (Cohen and McConnaughey, 2003; Cuif et al., 2004) play a much larger role in skeleton precipitation by actively templating (Cuif and Dauphin, 2005) and catalyzing aragonite formation with coral acid-rich proteins (CARP), regardless of surrounding seawater chemistry (Mass et al., 2013; Von Euw et al., 2017). One model even suggests that vacuoles filled with seawater and CARPs form an amorphous calcium carbonate (ACC) precursor phase which is transported to the surface of the skeleton where it rapidly matures to aragonite (Mass et al., 2017).

Rather than focusing on the mechanism for biomineralization, in this study we focus our effors on the end-products of coral biomineralization: the aragonite crystals. While mineralogical habits and general crystallite orientation of coral aragonites have been determined by previous studies using high-resolution scanning electron microscopy (SEM) (Cohen et al., 2009; Foster et al., 2016; Hennige et al., 2015; Brahmi et al., 2012) and transmission electron microscopy (TEM) (Benzerara et al., 2011; van de Locht et al., 2013), differences in mineral habits do not necessarily translate into differences in crystallography. Crystallography and chemistry are what determine the material properties of a mineral and can have dramatic effects on how a mineral responds to the environment. For example, the incorporation of trace elements may cause distortions in the crystal lattice and molecular bonding environments (Bischoff et al., 1985; Wopenka \& Pasteris, 2005), which may influence the material properties of a mineral such as strength (Hennige et al., 2015). Previous studies on biogenic aragonite crystallography via X-ray 
diffraction (XRD) have been mainly focused on mollusks and have observed that mollusk aragonites (Pokroy et al., 2004; 2006; 2007; Antao, 2012; Rao et al., 2016) and coral aragonites (Stolarski et al., 2007) have elongated unit cell axes compared to geological aragonites (Caspi et al., 2005; Dickens and Bowen, 1970). Recently, Roger et al. (2017) began to combine crystallographic data with measurements of trace element incorporation to find that substitution of $\mathrm{Mg}^{2+}$ for $\mathrm{Ca}^{2+}$ in the lattice may be responsible for observed crystalline distortions in bivalves.

In this study we quantitatively determine the crystallography and chemical bonding environments of coral aragonite from corals which were collected from cold, low $\Omega_{\mathrm{Ar}}$ deep-sea environments to warm, high $\Omega_{\mathrm{Ar}}$ shallow-water environments around the globe. The different species of corals we selected for this study represent a range of coral skeletal habits from reefbuilding massive corals to solitary benthic corals. We compare these coral aragonite crystallographies to synthetically-formed, geologically-formed and other biogenically-formed aragonites to determine whether any similarities between these different forms of aragonite may shed light on the coral aragonite formation mechanism. Better understanding the formation of coral aragonite crystals may aid in determining the dominant controls in coral biomineralization and will add an important perspective on the physical nature of coral aragonite.

\subsection{MATERIALS AND METHODS}

\subsubsection{Samples}

The purpose of this study is to compare the crystallography of coral aragonite with other, non-coral biogenic aragonites, synthetic aragonites and geologically-formed aragonites. Coral aragonites are represented from a range of coral species, different skeletal architectures and locations. All samples and their localities and mode of formation are listed in Table 2.1. Most coral and biogenic samples are treated to remove any residual organics in a procedure outlined in Section 2.3.2. Samples having undergone this procedure are referred to as "organic-removed" in this study.

\subsubsection{Natural deep-sea corals}

All deep-sea corals are sampled from the most recent growth along the septa. Lophelia pertusa colonies were collected from the Northern Gulf of Mexico by HOV Alvin in May 2014 $\left(\Omega_{\mathrm{Ar}, \mathrm{sw}}=1.15-1.44\right)$ and are described in detail by Lunden et al., (2013) and Georgian et al., (2016). Another L. pertusa colony was collected off of the coast of Southern California Bight (SCB) between April and May 2015 (33 $\left.{ }^{\circ} 55^{\prime} 7.6794^{\prime \prime} \mathrm{N} ; 119^{\circ} 28^{\prime} 18.84^{\prime \prime} \mathrm{W}\right)$ in aragonite undersaturated waters $\left(\Omega_{\mathrm{Ar}, \mathrm{sw}}=0.81, \mathrm{pH}=7.66\right)$. Another colony-forming coral, Enallopsammia rostrata, was collected from North-West Atlantic waters (Kükenthal Peak, sample KUK220-1). Solitary deep-sea coral samples were collected from Antarctic waters (Burdwood Bank, sample NBP08-05, and the Western Antarctic Peninsula Shelf samples NBP09-02 and LMG15-09).

\subsubsection{Natural shallow-water corals}

Similar to the deep-sea coral samples, in order to represent the range of possible growth environments in shallow-water corals, we sampled shallow-water corals from many localities (Micronesia, Cuba, and Australia) with different local seawater chemistry and species that represent an array of skeletal habits (massive, branching) and different skeleton growth rates. 
Each shallow-coral species has three sample replicates (Table 2.1). One sample from each of the species was treated with bleach to remove any excess intercrystalline organics. All shallow-water corals and deep-sea corals were sub-sampled from the septa or as close to the septa as possible so that sub-samples contain the newest skeletal growth and to assure consistency across coral aragonite samples in this study.

\subsubsection{Other biogenic aragonites}

We used a commonly-utilized reference biogenic aragonite, JCp-1 Porites sp. coral from Japan (Okai et al., 2002) in both untreated and organic-removed forms. In order to compare our coral crystallography to other biomineralized aragonites, we have included a sample of marine mollusk nacre aragonite (pearl) from an unknown locality (HARVARD-99527 specimen) in both untreated and organic-removed forms.

\subsubsection{Synthetic aragonites}

As a comparison to coral and other naturally-formed aragonites, we have included a suite of synthetic aragonites (f06, g04, g09, and h01) precipitated abiogenically from aragonite supersaturated seawater at controlled aragonite saturation states and $\mathrm{pHs}$. These synthetic aragonites were precipitated at $25{ }^{\circ} \mathrm{C}$ with carbonate chemistry modified by $\mathrm{NaHCO}_{3}$ and $\mathrm{Na}_{2} \mathrm{CO}_{3}$ solutions. Samples were precipitated from natural, $0.2 \mu \mathrm{m}$ filtered Vineyard Sound (MA, USA) seawater at the Woods Hole Oceanographic Institution and are described in detail in DeCarlo et al., 2015 and Holcomb et al., 2016.

In contrast to synthetic aragonites precipitated from seawater, we have also included a synthetic aragonite formed from freshwater conditions by dionized water supersaturated with respect to aragonite. This synthetic aragonite is a nine-month transformation product from an amorphous calcium carbonate (ACC) precursor phase created with $25.41 \% \mathrm{Mg}$ at the Virginia Polytechnic Institute in a procedure described in Blue et al., 2017.

\subsubsection{Geological aragonites}

Natural aragonite samples, presumably formed by geological processes, were acquired from the Harvard Mineralogical Museum and Virginia Tech Geosciences Museum collections and were collected from various localities around the globe (Table 2.1). In this study, we assume that all aragonites labeled as "geologically-formed" are formed via geological processes without any biological influence. The aragonite sample from Buchanan, VA (VT-M1010) came in powedered form and likely originates from solution cavities which occur on the faces of the James River Hydrate Quarry of the Cambrian Age Shady dolomite formation (Gooch et al., 1960). The Washington Co., UT aragonite (HARVARD-116162) occurs in a massive habit and likely originates from re-precipitated dolomotized Pennsylvania Callville limestone, which occurs adjacent to germanium and copper mineral deposits at the Apex Mine (Bernstein, 1986). The aragonite from West Goshen, PA (HARVARD-129393) also occurs in a massive habit and was mined from Marshall's Quarry, which is known for serpentine and other metamorphic minerals formed at higher pressures (Rand et al., 1892). The Tsumeb Mine, Namibia known for $\mathrm{Cu}$ and precious metal minerals is hosted by the Neoproterozoic Otavi dolomite formation and mined at depths of $1000 \mathrm{~m}$, which could explain the formation of high pressure aragonite transparent euhedral crystals of sample HARVARD-143853 (Geier et al., 1974; Weber and Wilson, 1977). 
TABLE 2.1. Samples of coral, other biogenic, synthetic and geological aragonites measured in this study.

\begin{tabular}{|c|c|c|}
\hline Sample names & $\begin{array}{l}\text { Coral species/Type of } \\
\text { aragonite }\end{array}$ & Locality \\
\hline LOPH-CAL & Lophelia pertusa & Southern California Bight \\
\hline LOPH-GC354 & Lophelia pertusa & Gulf of Mexico \\
\hline LOPH-GB535 & Lophelia pertusa & Gulf of Mexico \\
\hline LOPH-VK906 & Lophelia pertusa & Gulf of Mexico \\
\hline LMG15-09 & Flabellum impensum & Antarctica, Western Antarctic Peninsula \\
\hline KUK220-1 & Enallopsammia rostrata & North-West Atlantic \\
\hline NBP09-05 & Flabellum curvatum & Antarctica, Burdwood \\
\hline NBP08-05 & Balanophyllia malouensis & Antarctica, Western Antarctic Peninsula \\
\hline 132 & Pocillopora verrucosa & Micronesia \\
\hline $133^{*}$ & Pocillopora verrucosa & Micronesia \\
\hline $134^{*}$ & Pocillopora verrucosa & Micronesia \\
\hline N3-63 & Stylophora pistillata & Australia \\
\hline N3-65* & Stylophora pistillata & Australia \\
\hline $\mathrm{N} 1-52^{*}$ & Stylophora pistillata & Australia \\
\hline GB-113 & Orbicella faveolata & Cuba \\
\hline GB-148* & Orbicella faveolata & Cuba \\
\hline $\mathrm{GB}-174^{\star}$ & Orbicella faveolata & Cuba \\
\hline GB-144 & Acropora palmata & Cuba \\
\hline GB-145* & Acropora palmata & Cuba \\
\hline GB-146* & Acropora palmata & Cuba \\
\hline GQ-47 & Acropora cervicornis & Cuba \\
\hline GQ-48* & Acropora cervicornis & Cuba \\
\hline GQ-50* & Acropora cervicornis & Cuba \\
\hline GB-103 & Montastrea cavernosa & Cuba \\
\hline GB-105* & Montastrea cavernosa & Cuba \\
\hline $\mathrm{GB}-141^{*}$ & Montastrea cavernosa & Cuba \\
\hline$J C p-1 *$ & Porites sp. & Ryukyu Islands, Japan \\
\hline $\begin{array}{l}\text { JCp-1 organic- } \\
\text { removed }\end{array}$ & Porites sp. & Ryukyu Islands, Japan \\
\hline pearl* & pearl from marine mollusk & HARVARD-99527, unknown locality \\
\hline $\begin{array}{l}\text { pearl organic- } \\
\text { removed }\end{array}$ & pearl from marine mollusk & HARVARD-99527, unknown locality \\
\hline f06 & synthetic seawater aragonite & synthesized ${ }, \Omega_{\mathrm{Ar}}=11 \pm 1, \mathrm{pH}=8.38 \pm 0.01$ \\
\hline g04 & synthetic seawater aragonite & synthesized ${ }^{\prime}, \Omega_{A r}=25 \pm 3, p H=8.48 \pm 0.01$ \\
\hline g09 & synthetic seawater aragonite & synthesizedt, $\Omega_{\mathrm{Ar}}=23 \pm 5, \mathrm{pH}=7.78 \pm 0.02$ \\
\hline h01 & synthetic seawater aragonite & synthesizedt, $\Omega_{\mathrm{Ar}}=21 \pm 4, \mathrm{pH}=8.86 \pm 0.01$ \\
\hline ArgSyn & $\begin{array}{l}\text { synthetic freshwater } \\
\text { aragonite }\end{array}$ & synthesized§ \\
\hline
\end{tabular}




\begin{tabular}{|c|c|c|}
\hline VT-M1010 & geologically formed & Buchanan, VA, USA \\
\hline HARVARD-116162 & geologically formed & Washington County, UT, USA \\
\hline HARVARD-129393 & geologically formed & $\begin{array}{l}\text { Marshall's Quarry, West Goshen, PA, } \\
\text { USA }\end{array}$ \\
\hline HARVARD-143853 & geologically formed & $\begin{array}{l}\text { Tsumeb Mine, Tsumeb, Oshikoto, } \\
\text { Namibia }\end{array}$ \\
\hline
\end{tabular}

\subsubsection{Coral skeleton sampling and removal of organics}

Powdered coral septa samples were treated with bleach to remove any excess tissue or potential crystal scaffolding organic material (skeletal-bond organics which do not interfere with the aragonite crystal structure itself) using a procedure modified from Gaffey and Bronnimann (1993) and Politi et al., (2006): 1). Powdered coral samples (approximately 1-2 mg) were placed in $0.5 \mathrm{~mL}$ microcentrifuge tubes, 2). $20 \mu \mathrm{L}$ of $5 \%$ free chlorine sodium hypochlorite (ACROS) was added, 3). Tubes were vortexed four times to ensure that all powder surfaces were exposed to the bleach. The powders sat in the bleach for a total of 45 minutes. 4). Powders were thoroughly rinsed 6 times to remove any bleach residues by adding $200 \mu \mathrm{L}$ of MilliQ water, vortexing, allowing powder to settle, centrifuging, and carefully removing supernatant water. 5). Samples were air-dried before being run on X-ray instruments. XRD measurements and analyses were run on both organics-removed and untreated samples to assure that this procedure itseld did not alter the crystals apart from removing any organics.

\subsubsection{Instrumentation and Analysis}

\subsubsection{X-ray diffraction}

Powder X-ray diffraction (XRD) was conducted on a Rigaku D/MAX Rapid II micro Xray diffractometer with a 2D imaging plate detector in the Hansel Lab, Woods Hole Oceanographic Institution using Mo K $\alpha$ radiation $(\lambda=0.709300 \AA)$. Samples were carefully aligned and run for 10 minutes with omega fixed at 0 and phi rotating at 1 degree per second. Four sample replicates were run for each sample.

All samples were gently re-ground in an agate mortar and pestle to achieve an even smaller powder grain size, to keep methods consistent between coral and non-coral samples, and to confirm that we were not inducing phase transformations by using a mortar and pestle. Our natural and synthetic aragonites showed the same results pre- and post- grinding. Powders were mounted on Kapton tips by MiTeGen by using a very thin layer of mineral oil on the tips. A subset of samples were also loaded into $0.8 \mathrm{~mm}$ Kapton capillaries and compared to results from Kapton tips to assure that results did not vary due to sample mounting methods. 
XRD image files were background corrected (manual setting= 5) and integrated into intensity versus $2 \theta$ patterns from 3.0 to $45.02 \theta$ degrees and 81.6337 to $430.00 \beta$ using $2 \mathrm{DP}$ software.

Full width at half maximum (FWHM) measurements were performed on the main (111) peak of the coral aragonite diffraction pattern using PDXL 2 Rigaku software by referencing Caspi et al., (2005) for aragonite and Swanson and Fuyat (1953) for calcite.

\subsubsection{Rietveld analysis}

Rietveld analysis allows for quantitative measurements of unit cell parameters by modeling the whole XRD pattern against a known model structure. Quantitative Rietveld refinement analysis was run on full-patterns from 8 to $442 \theta$ degrees (Bish and Post, 1993) using GSASII (Toby and Von Dreele, 2013). We used a Chebyschev polynomial background and aragonite (Antao and Hassan, 2009) and calcite (Markgaf and Reeder, 1985) as model structures.

A synthetic aragonite reference (ArgSyn, Table 2.1) was used for calibration and refinement of the numbers obtained in Rietveld analysis in response to the specific alignment of the XRD. All Rietveld results are shifted by: $a$-axis $=-0.003375 \AA, b$-axis $=-0.012724 \AA, c$-axis $=$ $-0.005675 \AA$, and volume $=-0.7435 \AA^{3}$, leading to corresponding results between the XRD instrument in the Hansel lab at the Woods Hole Oceanographic Institution and an equivalent instrument in the Department of Mineral Sciences, Smithsonian Institution. Since shifts were applied to all samples, the shifts did not affect the relative differences between samples. Errors in Rietveld refinements are represented as estimated standard deviations and exceed standard deviations between sample replicates.

\subsubsection{Raman spectroscopy}

Powdered samples were measured for Raman spectroscopy by Thomas DeCarlo at the Centre for Microscopy, Characterisation, and Analysis (CMCA) at the University of Western Australia with a WITec Alpha300 RA+ confocal Raman microscope detailed in DeCarlo et al., (2017; 2018). The instrument uses a Andor iDUS $401 \mathrm{CCD}$ detector maintained at $-60^{\circ} \mathrm{C}$ and measurements were made using a $785 \mathrm{~nm}$ laser, 20× objective with numerical aperture of 0.5 , and a $1200 \mathrm{~mm}^{-1}$ grating with measurements calibrated using a silicon chip. Background fluorescence signals from organics in the aragonite samples were quantified using a green (532 $\mathrm{nm})$ laser as described in DeCarlo et al., (2018).

\subsubsection{Inductively-coupled mass spectroscopy (ICP-MS)}

Trace metal concentrations of a subset of natural L. pertusa samples were measured using an iCAP ICP-MS at the Woods Hole Oceanographic Institution. Samples were digested with a solution of 5\% trace metal grade nitric acid (J.T. Baker ULTREX® II Ultrapure Reagent) with Milli-Q water and a 2 ppb In spike in trace metal-cleaned $15 \mathrm{~mL}$ Falcon centrifuge tubes. To account for matrix effects, trace element to Ca ratios for samples in this study were calculated based on known ratios in the JCp-1 reference Porites sp. coral (determined from an intercalibration study, Hathorne et al., 2013). The JCp-1 reference coral was repeatedly measured alongside the other samples in this study as a standard over the course of the ICP-MS run. Each measurement was taken as an average of ten analytical replicates. Due to limited sample quantities, only one sample replicate was run for each sample. 


\subsubsection{Statistics}

Regression analyses were run on crystallographic results from XRD and Raman analyses versus factors that could potentially influence the crystallography of the samples, such as trace element incorporations. Relationships were considered to be statistically significant if $\mathrm{p}<0.05$. Unequal variance T-tests were run on crystallographic lattice parameters to determine whether differences in crystallography between corals and aragonites from other origins are statistically significant. We used Levene's tests for homogeneity of variances and Kolmogorov-Smirnov tests to confirm normality of residuals.

\subsection{RESULTS}

\subsubsection{Crystallography of aragonites from different formation origins via X-ray diffraction}

XRD patterns confirm that all of the samples measured in this study are aragonite, with some samples exhibiting small calcite (104) peaks (Figure 2.1), indicating up to an $~ 8 \%$ calcite phase contribution to the samples, as quantitatively determined by dual-phase Rietveld refinements (Supplementary materials, Table S2.1).

Rietveld refinement analysis of XRD patterns (Figure 2.1) reveal both statistically significant differences and similarities in crystal lattice parameters between aragonites of different formation origins (Figure 2.2; Supplementary Materials, Table S2.1). Mean values for lattice parameters of different origins are listed in Table 2.2, with all data values listed in the Supplementary materials, Table S2.1, and averages for both organics-removed and untreated samples are plotted in the Supplementary materials, Figure S2.1.

Within our range of coral samples, two-tailed T-tests confirm that the crystallography of coral aragonites from deep-sea environments (Figure 2.2, violet circles) are statistically similar $(p<0.001)$ to coral aragonites from shallow-water environments (Figure 2.2, green squares; Table 2.2) along all three axes (unit cell volume $\mathrm{t}(37)=2.026, \mathrm{p}=0.717 ; a$-axis $\mathrm{t}(37)=2.026, \mathrm{p}=$ $0.012 ; b$-axis $\mathrm{t}(53)=2.006, \mathrm{p}=0.002, \mathrm{p}=0.00024 ; c$-axis $\mathrm{t}(39)=2.023, \mathrm{p}=0.366)$.

Comparing shallow-water and deep-sea corals to geologically-formed aragonites, we observe that corals have statistically significantly larger unit cell volumes and longer unit cell axes compared to geological aragonites $\left(\Delta\right.$ Volume $=0.62 \AA^{3} ; \Delta a$-axis $=0.0038 \AA ; \Delta b$-axis $=$ $0.0033 \AA ; \Delta c$-axis $=0.0088 \AA$ ) (Figure 2.2 , grey stars) (two-tailed T-tests for coral versus geologically-formed aragonites: unit cell volume $\mathrm{t}(18)=2.101, \mathrm{p}=1.06 \mathrm{E}-11 ; a$-axis $\mathrm{t}(20)=2.086$, $\mathrm{p}=9.34 \mathrm{E}-12 ; b$-axis $\mathrm{t}(17)=2.11, \mathrm{p}=3.71 \mathrm{E}-05 ; c$-axis $\mathrm{t}(19)=2.093, \mathrm{p}=2.44 \mathrm{E}-15)$.

In contrast, coral (both shallow-water and deep-sea) aragonite crystallography is statistically similar to seawater synthetic aragonite crystallography in overall unit cell volume and along the $a$ - and $c$ - axes (differences between corals and seawater synthetic aragonites: $\Delta$ Volume $=0.01 \AA^{3} ; \Delta a$-axis $=-0.001 \AA ; \Delta b$-axis $=0.0019 \AA ; \Delta c$-axis $=-0.0001 \AA$ ) (Figure 2.2, blue triangles) (two-tailed T-tests for coral versus seawater synthetic aragonites: unit cell volume $\mathrm{t}(25)=2.06, \mathrm{p}=0.773 ; a$-axis $\mathrm{t}(30)=2.042, \mathrm{p}=9.9 \mathrm{E}-6 ; c$-axis $\mathrm{t}(27)=2.052, \mathrm{p}=0.764)$. Only the $b$ axis is statistically different. 


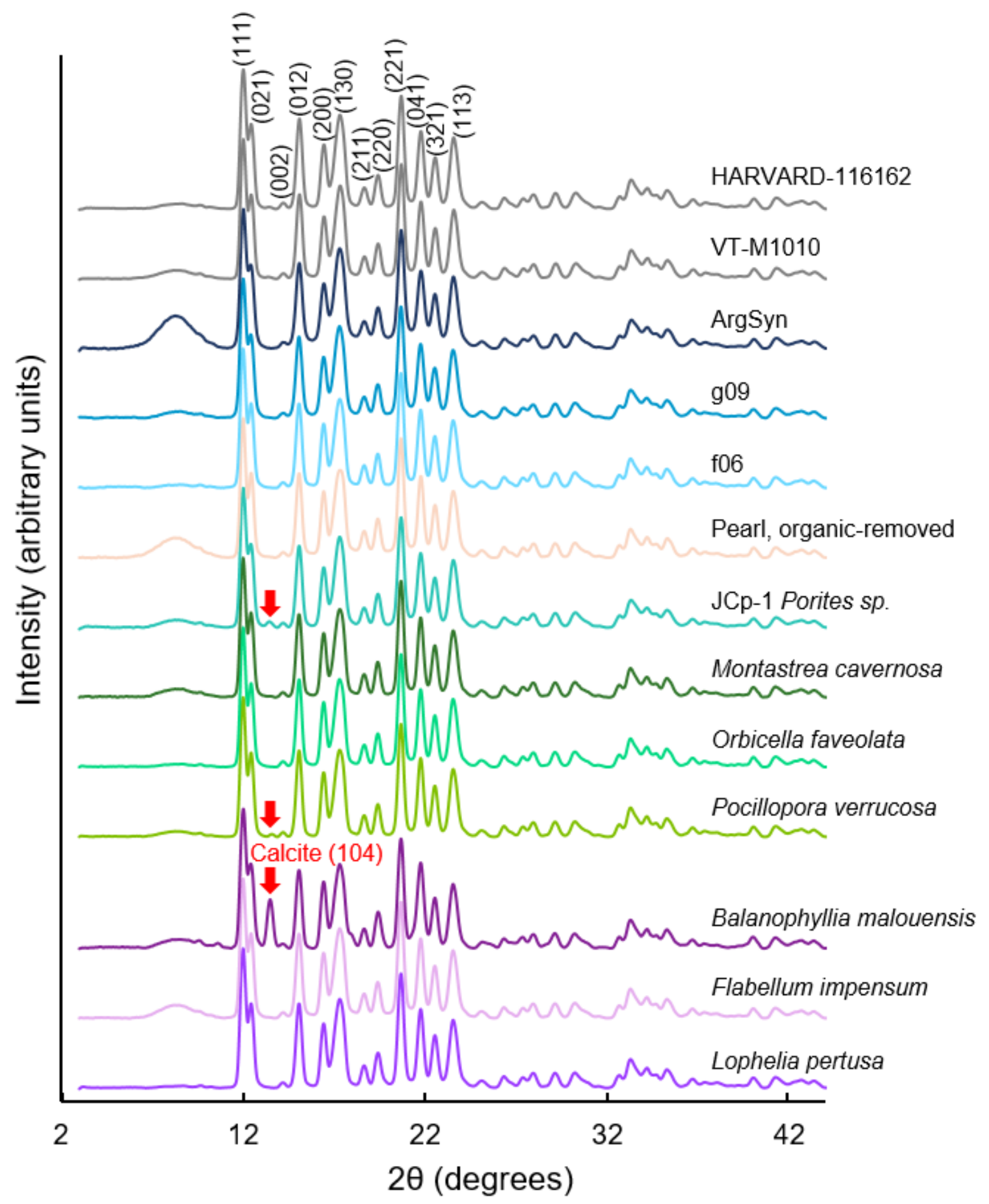

FIGURE 2.1. Representative XRD patterns of deep-sea corals (violets), shallow-water corals (greens), reference biogenic aragonites (JCp-1 and pearl), synthetic aragonites precipitated from seawater (light blues) and precipitated from freshwater (ArgSyn, dark blue), and geologically-formed (greys) aragonites using Mo K $\alpha$ radiation ( $\lambda=0.709300 \AA$ ). Miller indices are labeled on the HARVARD-116162 XRD pattern and all patterns are normalized to the (111) peak heights. Calcite (104) peaks are highlighted with red arrows on samples with visible calcite contents. 


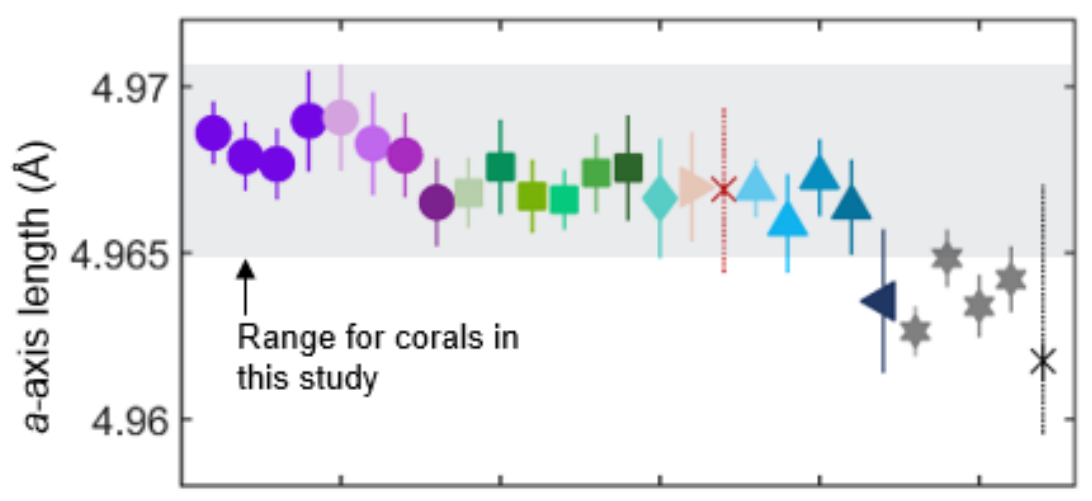

Key

Deep-sea corals

Lophelia pertusa

Flabellum impensum

Enallopsammia rostrata

Flabellum curvatum

Balanophyllia malouensis

\section{Shallow-water corals}

Pocillopora verrucosa

Stylophora pistillata

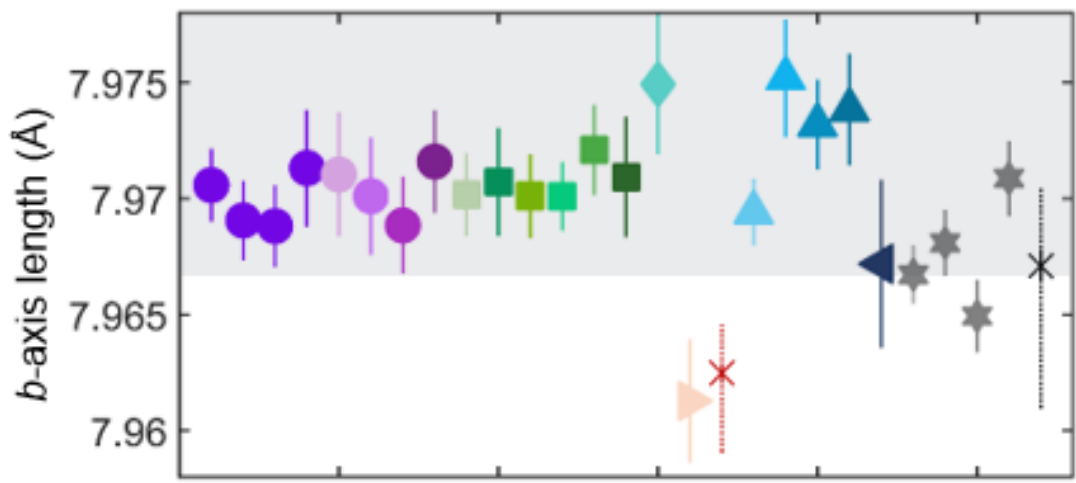

Orbicella faveolata

Acropora palmata

Acropora cervicornis

Montastrea cavernosa

\section{Reference coral}

JCp-1 Porites sp., organic-removed

\section{Other biogenic} aragonite

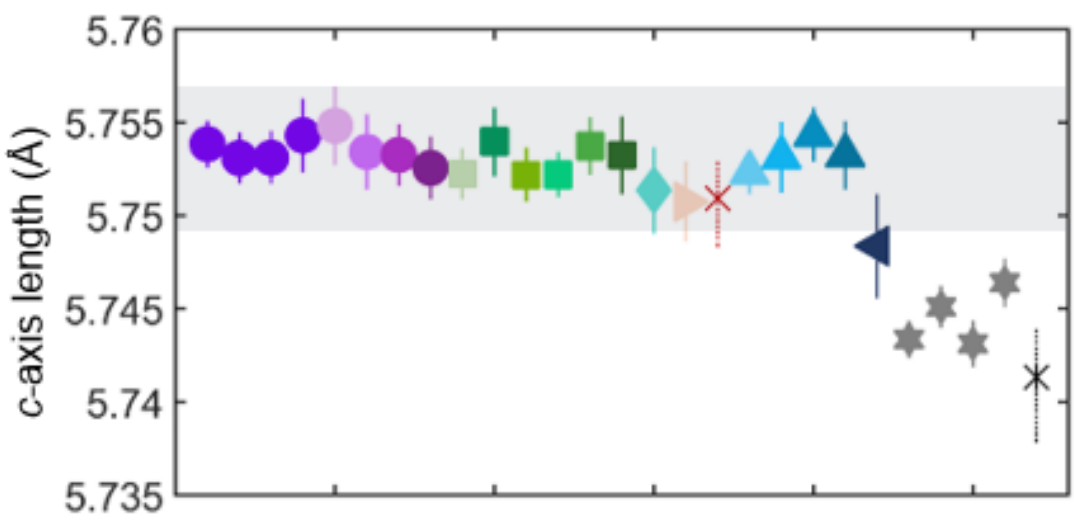

Pearl, organicremoved

\section{Synthetic}

\section{aragonites from}

seawater

f06

g04

$\Delta$ g09

$\Delta \mathrm{h} 01$

\section{Synthetic} aragonite from freshwater

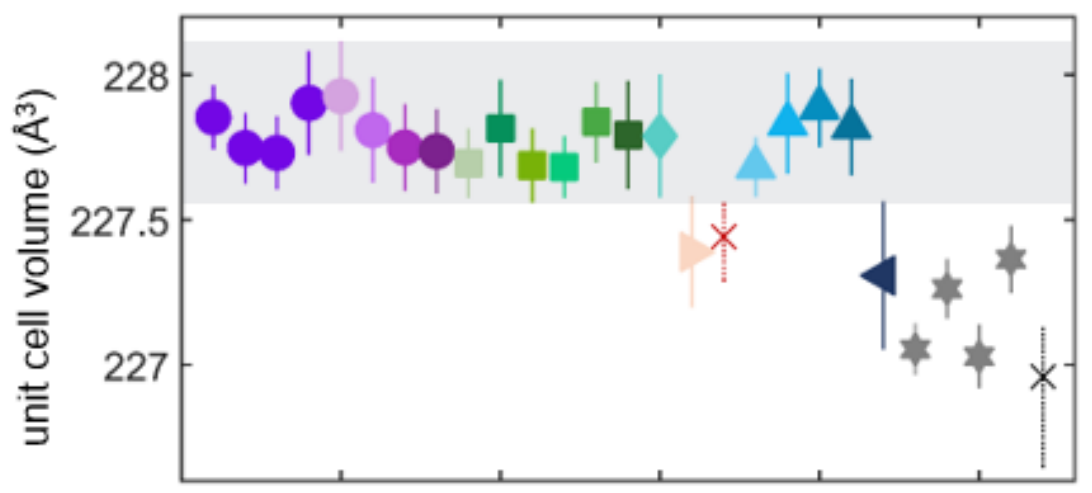

\section{Geological} aragonites

Previous studies

$\times$ Biogenic aragonites

Range in biogenic aragonite studies

$\times$ Geological aragonites

Kange in geological aragonite studies

FIGURE 2.2. Crystallographic lattice parameters (axis lengths and overall unit cell volume) of coral aragonite samples compared to other biogenic, synthetic, and geologically-formed aragonites. The range in lattice parameters for corals in this study is outlined in grey. All biogenic samples are organicsremoved. Each point is an average of four replicates. Error bars represent estimated standard deviations. 
TABLE 2.2: Mean values ( \pm standard deviations) for aragonite lattice parameters for various biogenic, synthetic, and geologically-formed aragonites as determined by Rietveld refinements of whole X-ray diffraction patterns.

\begin{tabular}{|c|c|c|c|c|}
\hline Variety of aragonite & $\begin{array}{l}\text { a-axis } \\
\text { length }(\AA) \\
\pm \text { s.d. }\end{array}$ & $\begin{array}{l}\text { b-axis } \\
\text { length }(\AA) \\
\pm \text { s.d. }\end{array}$ & $\begin{array}{l}\text { c-axis } \\
\text { length }(\AA) \\
\pm \text { s.d. }\end{array}$ & $\begin{array}{l}\text { unit cell } \\
\text { volume (̊̊3) } \\
\pm \text { s.d. }\end{array}$ \\
\hline deep-sea corals $(n=32)$ & $\begin{array}{l}4.9681 \pm \\
0.0015\end{array}$ & $\begin{array}{l}7.9702 \pm \\
0.0017\end{array}$ & $\begin{array}{l}5.7535 \pm \\
0.0018\end{array}$ & $227.81 \pm 0.18$ \\
\hline shallow-water corals $(n=80)$ & $\begin{array}{l}4.9674 \pm \\
0.0007\end{array}$ & $\begin{array}{l}7.9713 \pm \\
0.0016\end{array}$ & $\begin{array}{l}5.7532 \pm \\
0.001\end{array}$ & $227.79 \pm 0.09$ \\
\hline all corals $(n=112)$ & $\begin{array}{l}4.9676 \pm \\
0.0011\end{array}$ & $\begin{array}{l}7.971 \pm \\
0.0017\end{array}$ & $\begin{array}{l}5.7533 \pm \\
0.0013\end{array}$ & $227.8 \pm 0.12$ \\
\hline JCp-1 reference coral $(n=8)$ & $\begin{array}{l}4.9666 \pm \\
0.0005\end{array}$ & $\begin{array}{l}7.9747 \pm \\
0.0012\end{array}$ & $\begin{array}{l}5.7516 \pm \\
0.0006\end{array}$ & $227.79 \pm 0.08$ \\
\hline mollusk nacre, pearl $(n=8)$ & $\begin{array}{l}4.9672 \pm \\
0.0004\end{array}$ & $\begin{array}{l}7.962 \pm \\
0.0011 \\
\end{array}$ & $\begin{array}{l}5.7509 \pm \\
0.0004\end{array}$ & $227.43 \pm 0.05$ \\
\hline $\begin{array}{l}\text { seawater synthetic aragonites } \\
(n=16)\end{array}$ & $\begin{array}{l}4.9666 \pm \\
0.0006\end{array}$ & $\begin{array}{l}7.9729 \pm \\
0.0022\end{array}$ & $\begin{array}{l}5.7532 \pm \\
0.0008\end{array}$ & $227.81 \pm 0.08$ \\
\hline $\begin{array}{l}\text { freshwater synthetic aragonites } \\
(n=4)\end{array}$ & $\begin{array}{l}4.9636 \pm \\
0.0003\end{array}$ & $\begin{array}{l}7.9672 \pm \\
0.0006\end{array}$ & $\begin{array}{l}5.7484 \pm \\
0.0003\end{array}$ & $227.31 \pm 0.03$ \\
\hline geological aragonites $(n=16)$ & $\begin{array}{l}4.9638 \pm \\
0.001\end{array}$ & $\begin{array}{l}7.9677 \pm \\
0.0023\end{array}$ & $\begin{array}{l}5.7445 \pm \\
0.0014\end{array}$ & $227.18 \pm 0.15$ \\
\hline $\begin{array}{l}\text { Range in previous biogenic } \\
\text { aragonite studies* }\end{array}$ & $\begin{array}{l}4.96444- \\
4.9694\end{array}$ & $\begin{array}{l}7.9591- \\
7.9645\end{array}$ & $\begin{array}{l}5.7484- \\
5.7528\end{array}$ & $\begin{array}{l}227.291- \\
227.556\end{array}$ \\
\hline $\begin{array}{l}\text { Range in previous geological } \\
\text { aragonite studies }\end{array}$ & $\begin{array}{l}4.9596- \\
4.967\end{array}$ & $\begin{array}{l}7.961- \\
7.9705\end{array}$ & $\begin{array}{l}5.7379- \\
5.744\end{array}$ & $\begin{array}{l}226.649- \\
227.131\end{array}$ \\
\hline
\end{tabular}

*Previous biogenic aragonite studies: Pokroy et al., 2004; Pokroy et al., 2007; Stolasrki et al., 2007; Douka et al., 2010; Antao, 2012; Rao et al., 2016; Roger et al., 2017

+ Previous geological aragonite studies: Antao and Hassan, 2009; DeVilliers, 1971; Pokroy et al., 2004; 2007; Dickens and Bowen, 1970; Martinez et al., 1996; Caspi et al., 2005; Jarosch and Heger, 1986; Ye et al., 2012

Conversely, the synthetic aragonite precipitated from freshwater has a statistically smaller unit cell volumes and shorter unit cell axes compared to corals (Differences from corals to freshwater synthetic aragonite: $\Delta$ Volume $=-0.49 \AA^{3} ; \Delta a$-axis $=-0.004 \AA ; \Delta b$-axis $=-0.0038 \AA ; \Delta c$-axis $=$ -0.0049 $\AA$ ) (Figure 2.2, left-pointing dark blue triangle) (two-tailed T-tests for coral versus freshwater synthetic aragonites: unit cell volume $\mathrm{t}(6)=2.447, \mathrm{p}=4.83 \mathrm{E}-7 ; a$-axis $\mathrm{t}(6)=2.447, \mathrm{p}=$ $4.83 \mathrm{E}-7 ; b$-axis $\mathrm{t}(4)=2.776, \mathrm{p}=5.9 \mathrm{E}-4 ; c$-axis $\mathrm{t}(6)=2.447, \mathrm{p}=7.15 \mathrm{E}-7)$.

Comparing coral aragonite to a bio-aragonite originated by an organism of another phylum, we observe that the mollusk pearl nacre aragonite in this study has significantly shorter $b$ - and $c$-axis lengths and overall unit cell volume (Differences from coral aragonite to mollusk aragonite: $\Delta$ Volume $=-0.37 \AA^{3} ; \Delta a$-axis $=-0.0004 \AA ; \Delta b$-axis $=-0.009 \AA ; \Delta c$-axis $=-0.0024 \AA$ ) (Figure 2.2, right-pointing salmon triangle) (two-tailed T-tests for unit cell volume: $\mathrm{t}(12)=2.179$, $\mathrm{p}=1.852 \mathrm{E}-9 ; b$-axis: $\mathrm{t}(9)=2.262, \mathrm{p}=6.61 \mathrm{E}-09 ;$-axis: $\mathrm{t}(20)=2.086, \mathrm{p}=4.92 \mathrm{E}-11)$. 
Our coral lattice parameter results are near the range of previous biogenic aragonite studies (Figure 2.2, red x with a dotted red line) for $a$-and $c$-axis lengths, but longer $b$-axis lengths and overall unit cell volumes. Our measurements of pearl aragonite, however, do align with previous biogenic aragonite studies along all axes. Measurements of geological aragonites in this study also fall within or near the range of previous studies of geologically-formed aragonites (Figure 2.2, black x with dotted line).

Across all samples, shifts in overall unit cell volume are mainly driven by anisotropic changes in $a$ - and $c$-axis lengths, as evidenced by the close relationship between volume as a function of $c$-axis length $\left(\mathrm{R}^{2}=0.93\right)$ and $a$-axis length $\left(\mathrm{R}^{2}=0.78\right)$ compared to the relationship with $b$-axis length $\left(\mathrm{R}^{2}=0.48\right)$ (Figure 2.3 ).

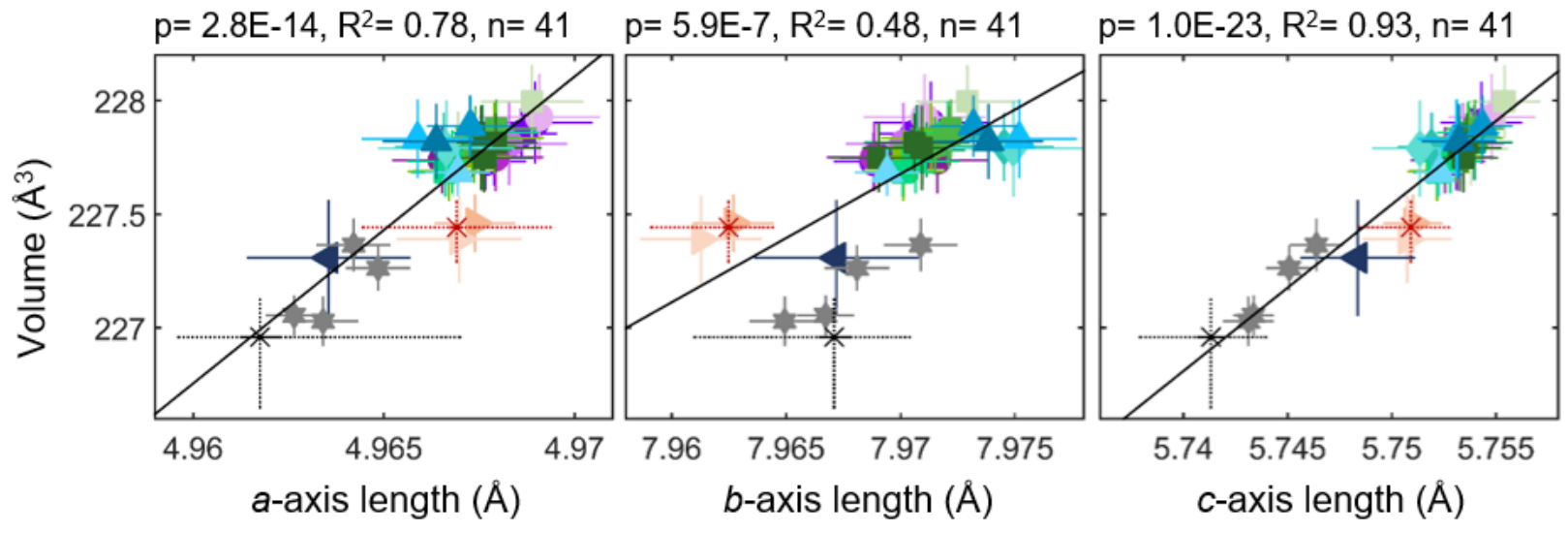

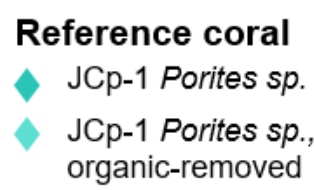

\section{Other biogenic} aragonite

Pearl

Pearl, organicremoved

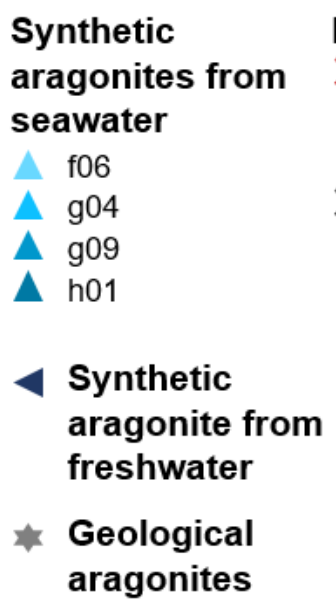

\section{Previous studies $X$ Biogenic aragonites \\ Range in biogenic aragonite studies \\ $X$ Geological aragonites \\ : Range in geological aragonite studies}

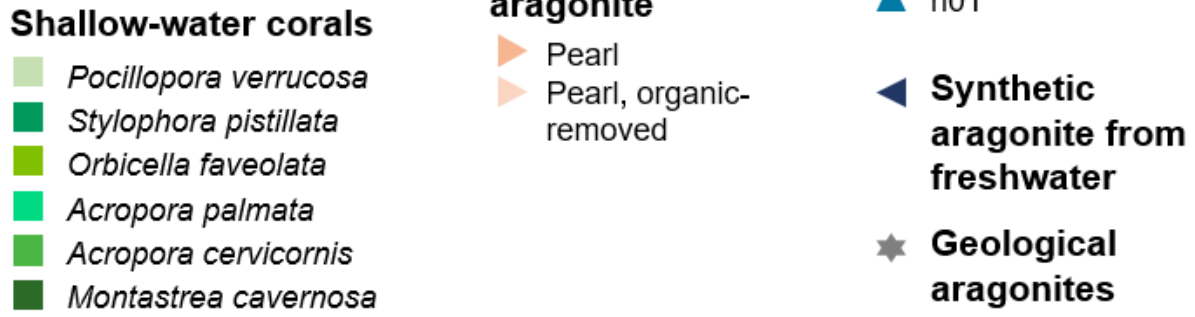

FIGURE 2.3. Shifts in overall aragonite unit cell volume driven by anisotropic elongations of $a$-, $b$-, and $c$-axes for all samples measured in this study and mean values and ranges from previous studies. Trend lines for simple regressions are plotted in black solid lines.

\subsubsection{Differences in aragonite bonding environments via Raman spectroscopy}

We conducted Raman spectroscopic analysis on all of our samples to complement the XRD crystallographic analysis with information on aragonite bonding environments with results of 
only organics-treated biogenic aragonites samples plotted in Figure 2.4. All samples are plotted and listed in the Supplementary materials, Figure S2.2; Table S2.2. The full width at half maximum (FWHM) of the Raman-active $v_{1}$ symmetric stretching mode of the trigonal planar carbonate group has been used to trace the aragonite saturation state $(\Omega)$ at formation in synthetic aragonites and in the calcifying fluid of corals $\left(\Omega_{\mathrm{cf}}\right)$ (DeCarlo et al., 2017). We observe that FWHM $v_{1}$ and $\Omega_{\text {cf }}$ values derived from FWHM $v_{1}$ are significantly higher in shallow-water corals compared to deep-sea corals (shallow-water corals: FWHM $v_{1}=3.5 \pm 0.03 \mathrm{~cm}^{-1}$; Ramanderived $\Omega_{\mathrm{cf}}=11.9 \pm 0.6$; deep-sea corals: FWHM $v_{1}=3.43 \pm 0.05 \mathrm{~cm}^{-1}$; Raman-derived $\Omega_{\mathrm{cf}}=$ $10.5 \pm 0.9$ ) (Figure 2.4, top two panels, violet circles and green squares). There is also a $0.1 \mathrm{~cm}^{-1}$ shift in raw Raman wavenumber between these corals (two-tailed T-test: $\mathrm{t}(9)=2.262, \mathrm{p}=2.9 \mathrm{E}-4)$ but no difference in background fluorescence (two-tailed T-test: $\mathrm{t}(8)=2.306, \mathrm{p}=0.4$ ) (Figure 2.4, bottom two panels, violet circles and green squares).

Since the seawater synthetic aragonites precipitated at high- $\Omega$ (Figure 2.4, second panel, blue triangles) fall well above the range for coral $\Omega_{\mathrm{cf}}$, we observe that mean seawater synthetic aragonite $\Omega$ and raw wavenumbers are significantly higher than those observed in corals (twotailed T-test for corals versus seawater synthetic aragonites: Raman-derived $\Omega \mathrm{t}(3)=3.182, \mathrm{p}=$ 0.048); raw wavenumber $\mathrm{t}(5)=2.571, \mathrm{p}=0.007)$. The exception to this is the f06 seawater synthetic aragonite, which was precipitated at $\Omega=11$ and comparable to coral $\Omega_{\mathrm{cf}}=8.5-13.7$ based on previous $\delta^{11 / 10} \mathrm{~B}$ isotope-derived and Raman-derived estimates (McCulloch et al., 2012b; DeCarlo et al., 2017). Pearl carbonate bonding environments only appear to shift towards lower raw wavenumbers compared to coral aragonites $\left(\Delta\right.$ wavenumber $\left.=-0.03 \mathrm{~cm}^{-1}\right)$ (two-tailed T-test: $\mathrm{t}(2)=4.303, \mathrm{p}=0.00059)$ (Figure 2.4, third panel, salmon right-pointing triangle), likely due to its abnormally high background fluorescence signal (Figure 2.4, bottom panel).

Carbonate bonding environments for geologically-formed aragonites do not differ significantly compared to corals with regards to shifts in raw wavenumbers or background fluorescence (two-tailed T-tests: wavenumber shift $\mathrm{t}(3)=3.182, \mathrm{p}=0.92$; background fluorescence $\mathrm{t}(3)=3.182, \mathrm{p}=0.29)$, however FWHM $v_{1}\left(3.1 \pm 0.1 \mathrm{~cm}^{-1}\right)$ and Raman-derived $\Omega(6$ \pm 0.8 ) values for geologically formed aragonites are significantly lower than coral values (twotailed T-test for geological versus coral aragonites: Raman-derived $\Omega \mathfrak{t}(4)=2.776, p=0.0003$; FWHM $v_{1} \mathrm{t}(3)=3.182, \mathrm{p}=0.003$ ) (Figure 2.4, grey stars).

Comparing these Raman-spectroscopy results of carbonate-group bonding environments with XRD results, we observe that there are significant trends between increasing Ramanderived $\Omega$ and FWHM $v_{1}$ as functions of lengthening $b$-axes in both coral and seawater synthetic aragonites samples (Figure 2.5, blue dotted trend lines) as well as with the addition of geological aragonite samples (Figure 2.5, red dashed trend lines). These relationships cease to be statistically significant when pearl aragonite and freshwater aragonite are added. Ramanparameters are also sensitive to changes in $a$-axis length, but this relationship changes depending on whether geological aragonite samples are included in the regressions. All other significant trends between Raman and XRD data are plotted in the Supplementary Materials, Figure S2.3. 


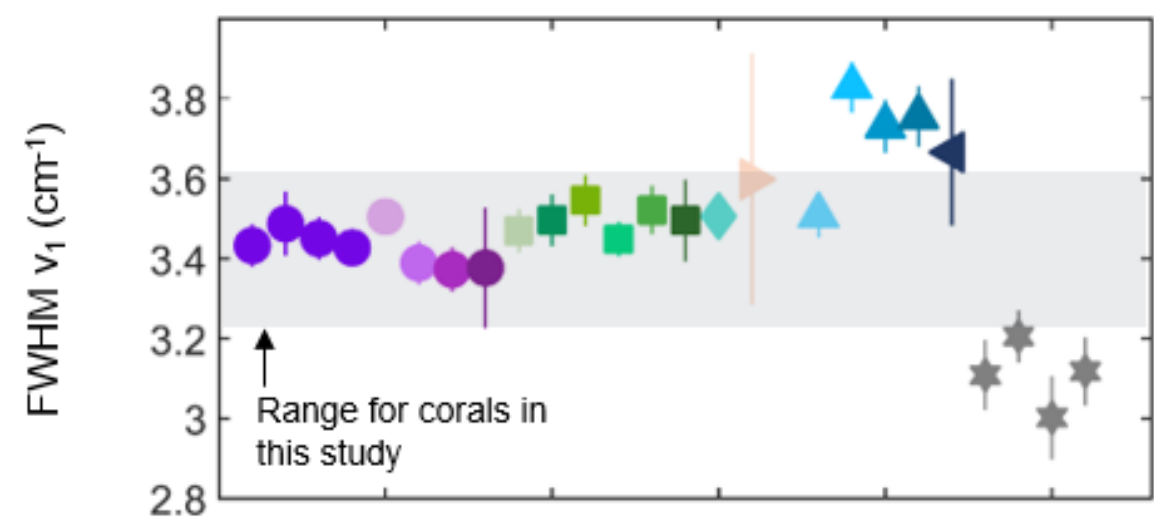

Key

Deep-sea corals

- Lophelia pertusa

Flabellum impensum

Enallopsammia rostrata

Flabellum curvatum

Balanophyllia malouensis

Shallow-water corals

Pocillopora verrucosa

Stylophora pistillata

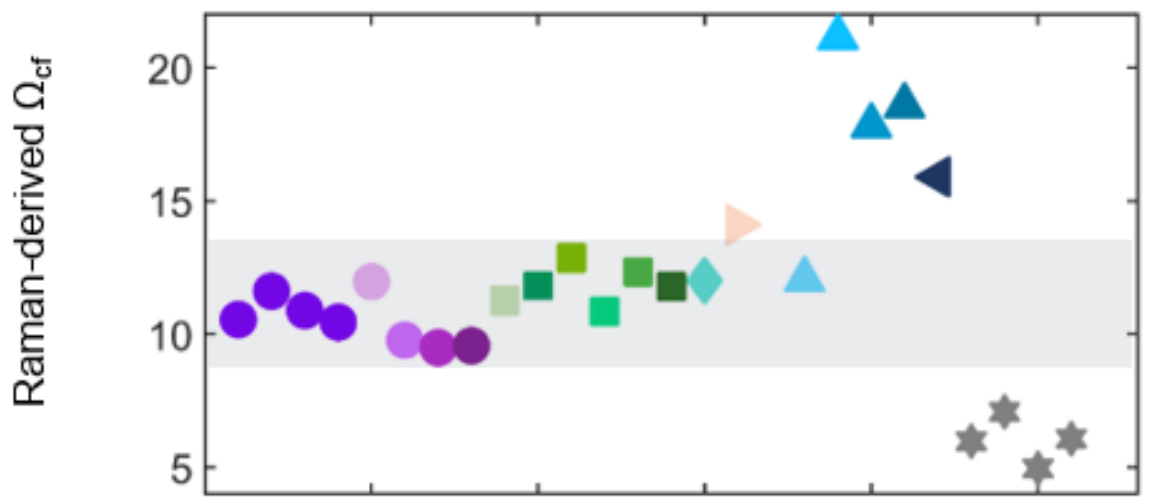

Orbicella faveolata

Acropora palmata

Acropora cervicornis

Montastrea cavernosa

\section{Reference coral}

JCp-1 Porites sp., organic-removed

Other biogenic aragonite

Pearl, organicremoved

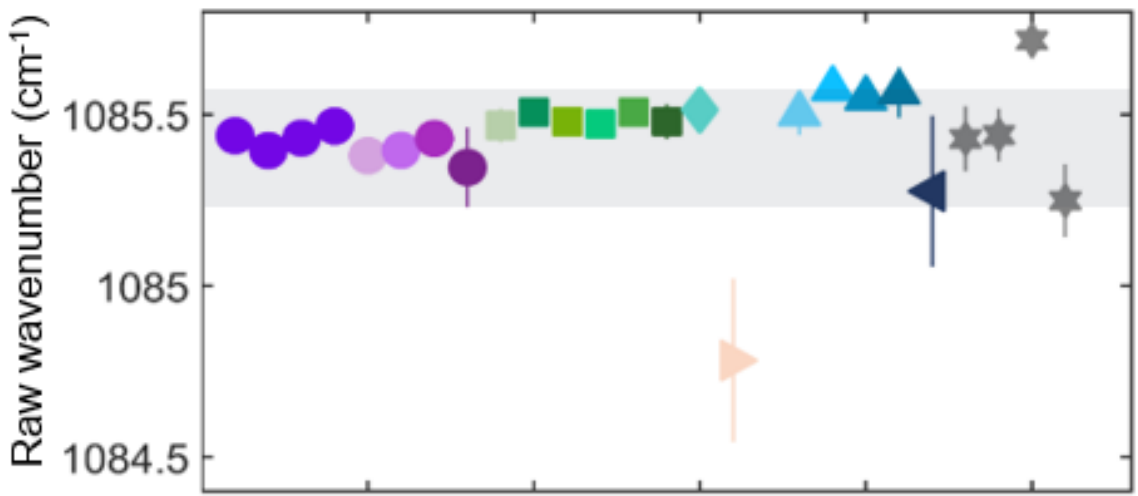

\section{Synthetic} aragonites from seawater

A 06

$\triangle \mathrm{g04}$

A g09

A h01

1084.5

\section{Synthetic} aragonite from freshwater

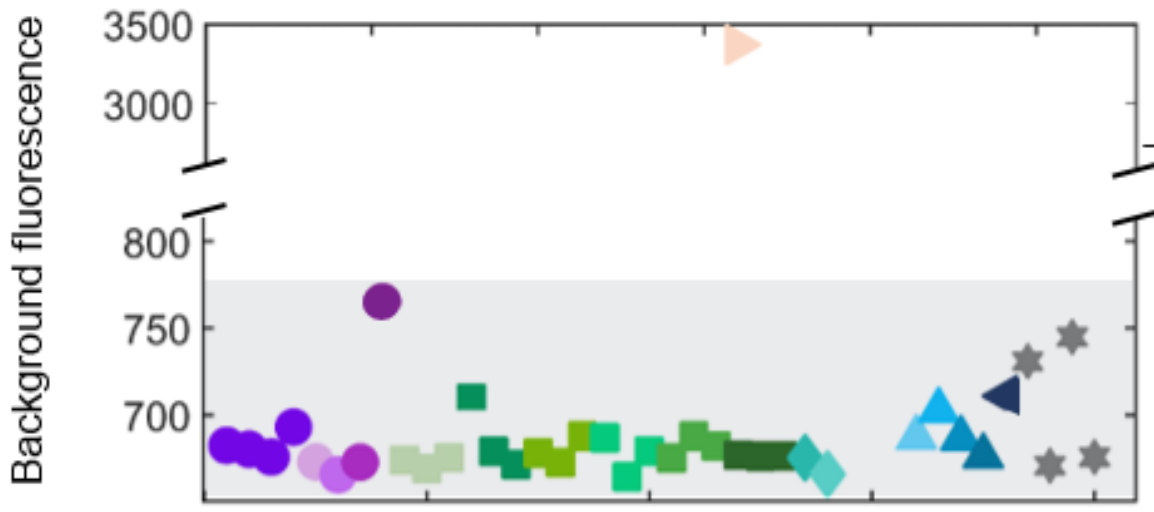

* Geological aragonites

FIGURE 2.4. Raman spectroscopy results of carbonate bonding environments in aragonite of different origins. 

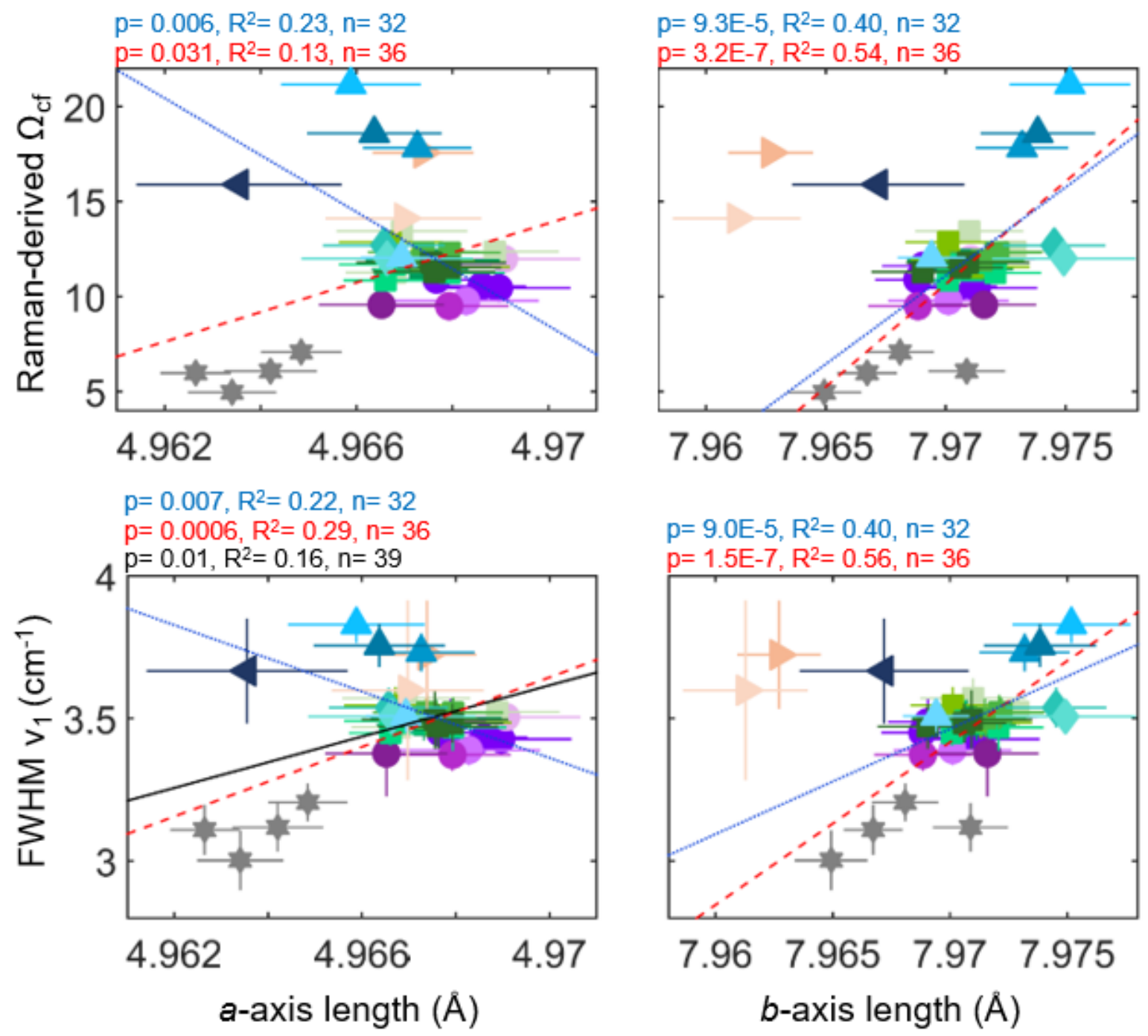

Key

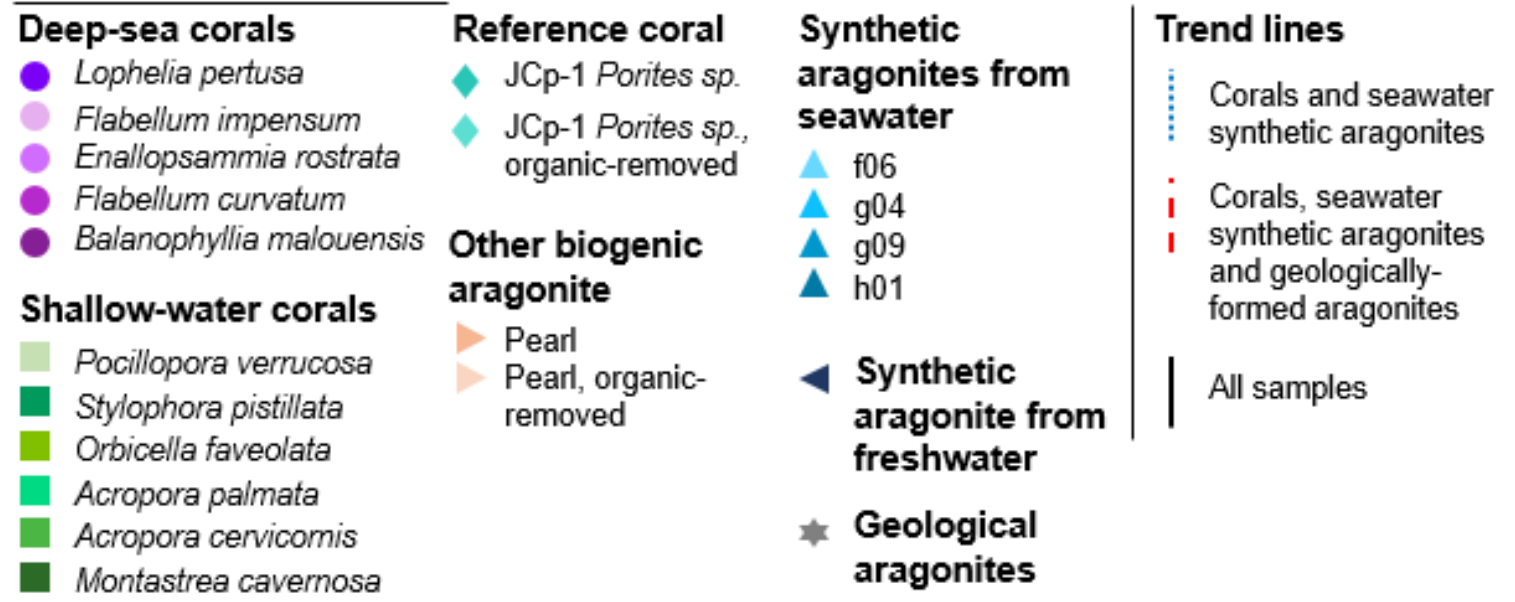

FIGURE 2.5. Comparison between crystallography along $a$-and $b$-axes versus carbonate bonding environments (FWHM $v_{1}$ ) and Raman-derived $\Omega$, with significant relationships plotted in blue dotted lines for coral and seawater synthetic aragonite samples, red dashed lines for corals, seawater synthetic aragonites and geological aragonites, and black solid lines representing relationships between all samples. 


\subsubsection{Trace metal incorporations into aragonites of different origins}

We measured the trace incorporations of elements commonly measured in corals for paleoproxies (B, $\mathrm{Mg}, \mathrm{Sr}$, and $\mathrm{Ba}$ ) as ratios of element concentration:Ca concentration based on known ratios of these elements in the JCp-1 coral reference material measured by an intercalibration study (Hathorne et al., 2013). These ratios are plotted by different aragonite origins for organics-removed biogenic aragonites in Figure 2.6. Trace element incorporations for all aragonites (organics-removed and untreated) are plotted and listed in the Supplementary materials: Figure S2.4; Table S2.3.

$\mathrm{B} / \mathrm{Ca}$ ratios in corals span a range of approximately $300-800 \mu \mathrm{mol} / \mathrm{mol}$, which includes two of our seawater synthetic aragonites in this range. B/Ca ratios in deep-sea corals (Figure 2.6, top panel, violet circles, mean \pm standard deviation: $699 \pm 64 \mu \mathrm{mol} / \mathrm{mol}$ ) are significantly higher than values for $\mathrm{B} / \mathrm{Ca}$ ratios is shallow-water corals (Figure 2.6, top panel, violet circles, mean \pm standard deviation: $524 \pm 75 \mu \mathrm{mol} / \mathrm{mol}$ ) (Two-tailed t-test for deep-sea versus shallow-water coral aragonites: $\mathrm{t}(14)=2.145, \mathrm{p}=4.2 \mathrm{E}-5)$. Freshwater aragonite falls directly below the range for all corals, followed by the other two seawater synthetic aragonites. Pearl mollusk aragonite and geological aragonites fall significantly below the range for coral $\mathrm{B} / \mathrm{Ca}$ with values (Two-tailed ttest for geological and pearl aragonites versus coral aragonite: $\mathrm{t}(26)=2.06, \mathrm{p}=7.5 \mathrm{E}-18)$ for geological aragonite reaching very low B/Ca values (Figure 2.6, top panel, grey stars, mean \pm standard deviation: $22 \pm 8 \mu \mathrm{mol} / \mathrm{mol}$ ).

$\mathrm{Mg}$ content is significantly higher in deep-sea corals (Figure 2.6, second panel, violet circles, mean \pm standard deviation: $2.5 \pm 0.6 \mathrm{mmol} / \mathrm{mol}$ ) compared to shallow-water corals (Figure 2.6, second panel, green squares, mean \pm standard deviation: $4.2 \pm 0.6 \mathrm{mmol} / \mathrm{mol}$ ) (Two-tailed ttest for deep-sea versus shallow-water coral aragonites: $\mathrm{t}(15)=2.131, \mathrm{p}=1.5 \mathrm{E}-5)$. Synthetic aragonite $\mathrm{Mg} / \mathrm{Ca}$ ratios (mean \pm standard deviation: $5.1 \pm 2.4 \mathrm{mmol} / \mathrm{mol}$ ) are not statistically different from overall coral values (mean: \pm standard deviation: $3.7 \pm 1 \mathrm{mmol} / \mathrm{mol}$ ) (Two-tailed ttest for seawater synthetic aragonites versus coral aragonites: $\mathrm{t}(3)=3.182, \mathrm{p}=0.38)$. Geological aragonites fall just below and well above the range for $\mathrm{Mg}$-content in corals. $\mathrm{Mg}$ in our freshwater synthetic aragonite falls well above coral Mg contents $(16.9 \mathrm{mmol} / \mathrm{mol})$. An outlier of geological aragonite also falls well above all other samples $(25.3 \mathrm{mmol} / \mathrm{mol})$ while other geological aragonite fall below the range for coral $\mathrm{Mg} / \mathrm{Ca}$ ratios $(0.41 \pm 0.13$ ) (Figure 2.6, second panel, grey stars).

$\mathrm{Sr} / \mathrm{Ca}$ ratios are also consistent across corals and three of our four seawater synthetic aragonites, ranging from approximately $6-10.5 \mathrm{mmol} / \mathrm{mol}$ (Figure 2.6, third panel). Deep-sea coral values are not significantly different from those for shallow-water corals (Two-tailed t-test for deep-sea versus shallow-water coral aragonites: $\mathrm{t}(10)=2.228, \mathrm{p}=0.19)$. Geological, pearl and freshwater synthetic aragonite $\mathrm{Sr} / \mathrm{Ca}$ ratios (mean \pm standard deviation: $2.2 \pm 1.9,1.51 \pm 0.15$, 0.087233 , respectively) fall significantly below values for coral $\mathrm{Sr} / \mathrm{Ca}$ ratios (mean \pm standard deviation: $8.5 \pm 1$ ) (Two-tailed t-test for geological, pearl and freshwater aragonites versus coral aragonites: $\mathrm{t}(7)=2.365, \mathrm{p}=1.8 \mathrm{E}-5)$ (Figure 2.6, third panel).

Finally, $\mathrm{Ba} / \mathrm{Ca}$ ratios are consistently low for all corals (mean \pm standard deviation: $13 \pm$ $10 \mu \mathrm{mol} / \mathrm{mol}$ ), pearl aragonite $(2.2 \pm 0.5 \mu \mathrm{mol} / \mathrm{mol}$ ), and seawater (mean \pm standard deviation: $6.2 \pm 2.8 \mu \mathrm{mol} / \mathrm{mol})$ and freshwater $(2.9 \mu \mathrm{mol} / \mathrm{mol})$ synthetic aragonites, with only a couple 


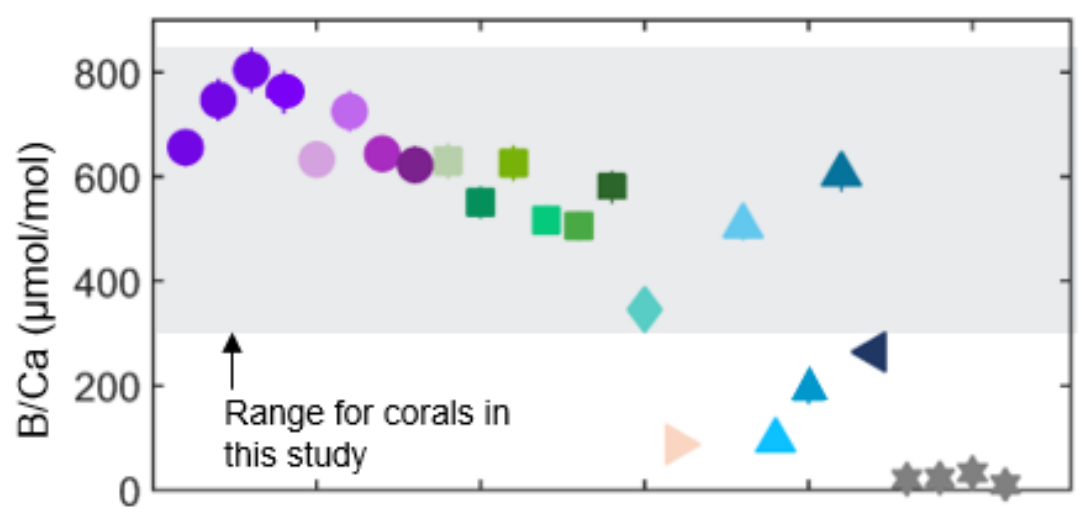

Key

Deep-sea corals

Lophelia pertusa

Flabellum impensum

Enallopsammia rostrata

Flabellum curvatum

Balanophyllia malouensis

Shallow-water corals

Pocillopora verrucosa

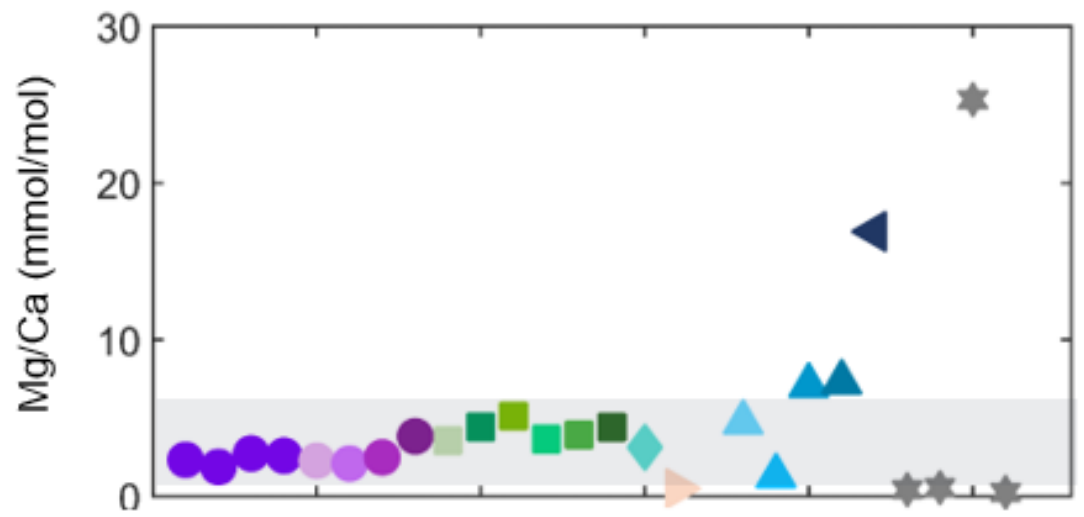

Stylophora pistillata

Orbicella faveolata

Acropora palmata

Acropora cervicornis

Montastrea cavernosa

Reference coral

JCp-1 Porites sp., organic-removed

Other biogenic aragonite

Pearl, organic-

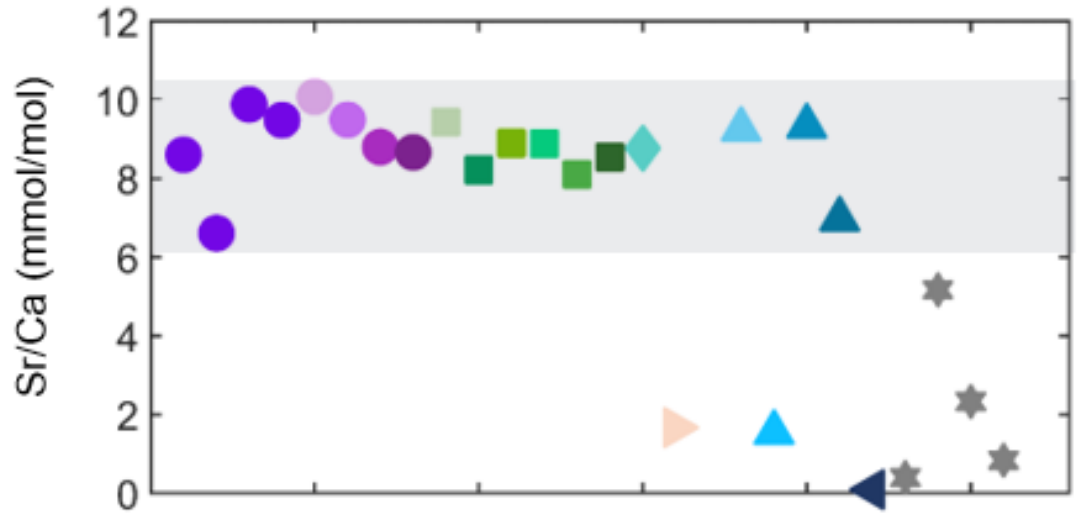
removed

Synthetic aragonites from seawater

f06

g04

g09

$\Delta$ h01

$\checkmark$ Synthetic aragonite from freshwater

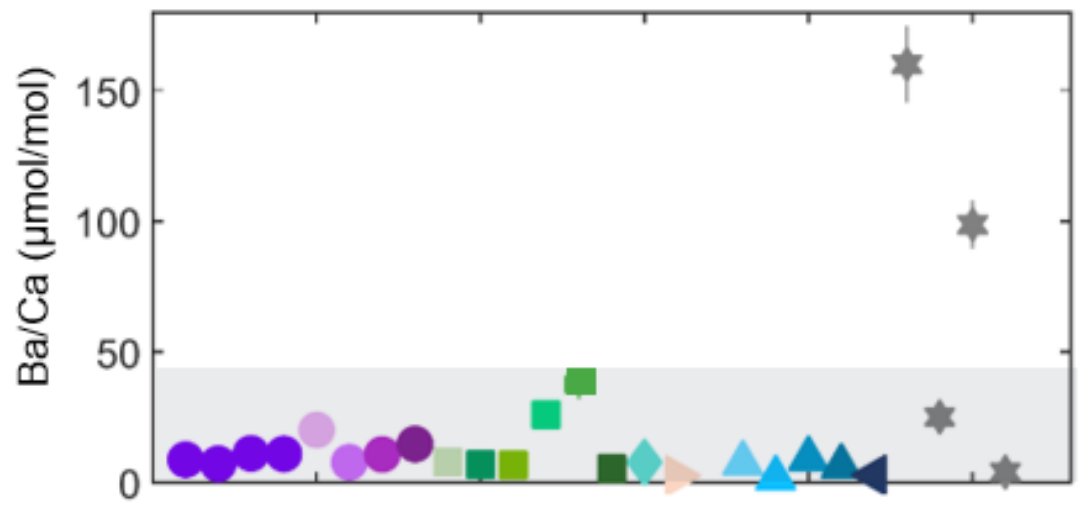

\section{Geological} araconites

FIGURE 2.6. Trace element incorporations into aragonites of different origins. $\mathrm{B} / \mathrm{Ca}$ ratios, $\mathrm{Mg} / \mathrm{Ca}$ ratios, $\mathrm{Sr} / \mathrm{Ca}$ ratios and $\mathrm{Ba} / \mathrm{Ca}$ ratios are calculated based on element/Ca ratios in the $\mathrm{JCp}-1$ reference coral (Hathorne et al., 2013), using concentrations of ${ }^{11} \mathrm{~B},{ }^{24} \mathrm{Mg},{ }^{88} \mathrm{Sr}$ and ${ }^{138} \mathrm{Ba}$, respectively. 

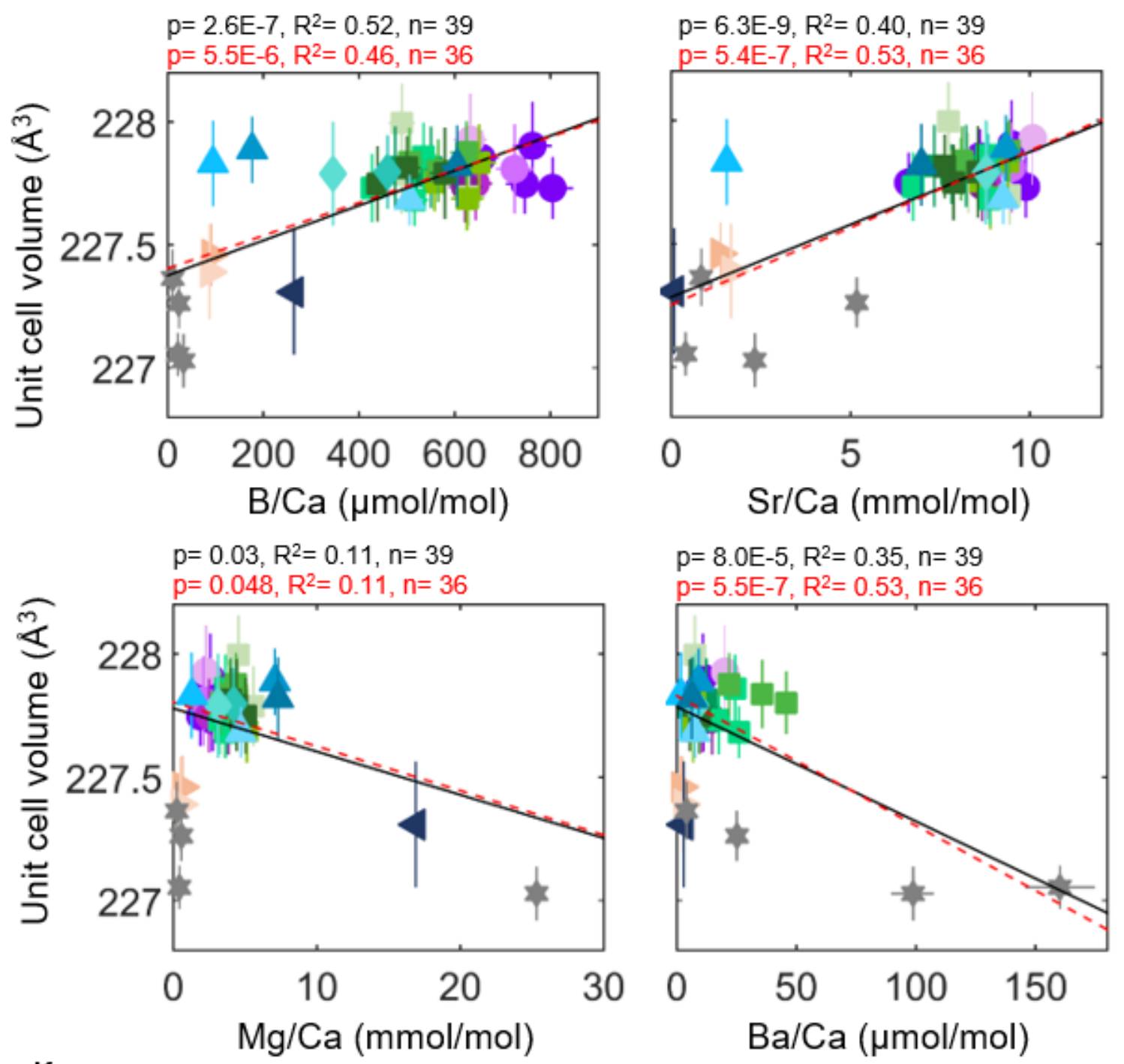

Key

\begin{tabular}{ll}
\hline Deep-sea corals & Reference coral \\
Lophelia pertusa & JCp-1 Porites sp. \\
Flabellum impensum & JCp-1 Porites sp., \\
Enallopsammia rostrata & organic-removed \\
Flabellum curvatum & \\
Balanophyllia malouensis & Other biogenic \\
Shallow-water corals & aragonite \\
Pocillopora verrucosa & Pearl \\
Stylophora pistillata & Pearl, organic- \\
Orbicella faveolata & removed \\
Acropora palmata & \\
Acropora cervicomis & \\
Montastrea cavernosa &
\end{tabular}

\section{Synthetic}

aragonites from

seawater

$\Delta$ f06

A $\mathrm{g} 04$

A 09

$\Delta \mathrm{h} 01$
Synthetic aragonite from freshwater

* Geological aragonites

FIGURE 2.7. Trace element incorporations into aragonites of different origins. B/Ca ratios, $\mathrm{Mg} / \mathrm{Ca}$ ratios, $\mathrm{Sr} / \mathrm{Ca}$ ratios and $\mathrm{Ba} / \mathrm{Ca}$ ratios are calculated based on element/Ca ratios in the $\mathrm{JCp}-1$ reference coral (Hathorne et al., 2013), using concentrations of ${ }^{11} \mathrm{~B},{ }^{24} \mathrm{Mg},{ }^{88} \mathrm{Sr}$ and ${ }^{138} \mathrm{Ba}$, respectively. 

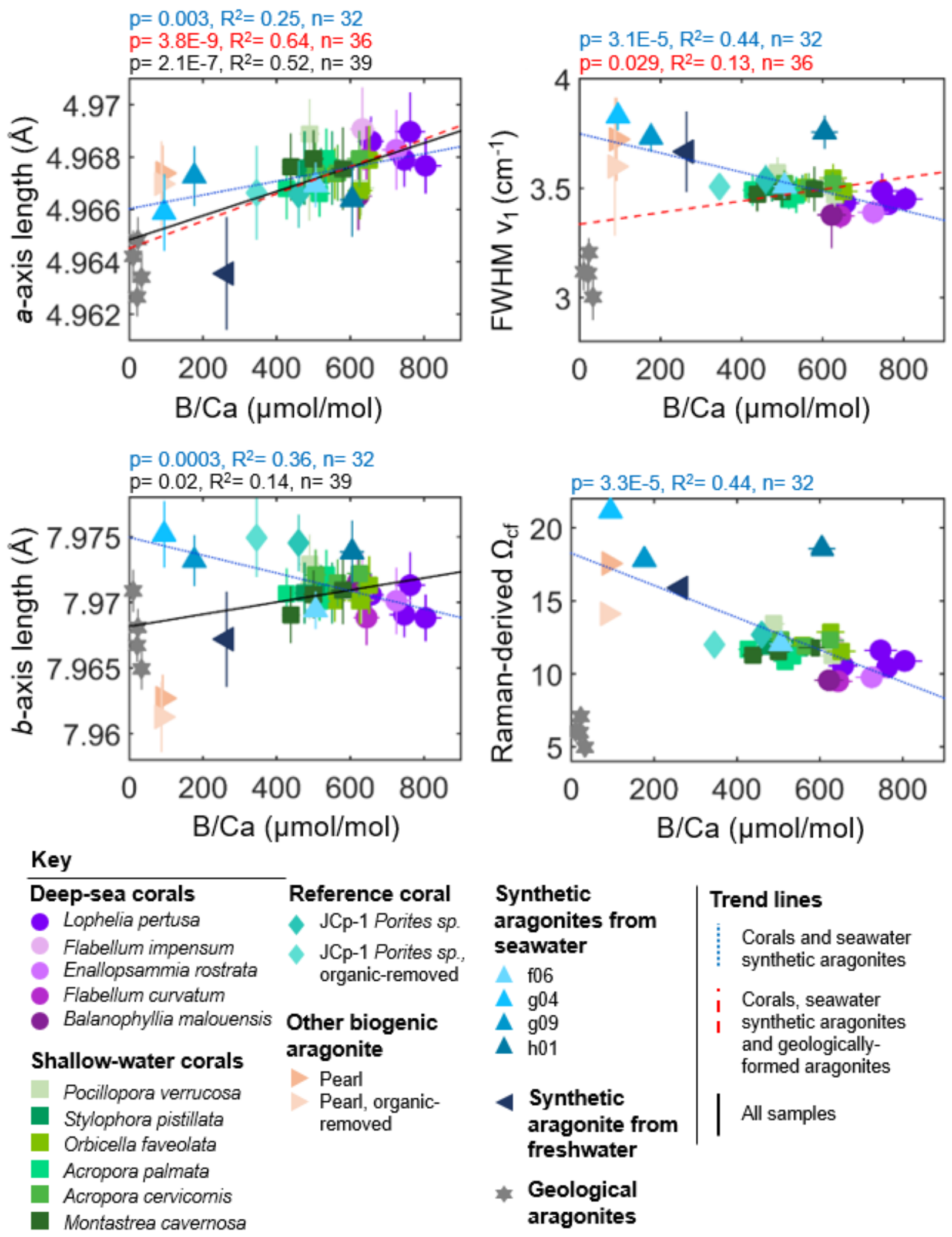

FIGURE 2.8. Crystal lattice parameters and carbonate bonding environments and derived $\Omega_{\mathrm{cf}}$ as a function of $\mathrm{B} / \mathrm{Ca}$ ratios. 
geologically-formed aragonite outliers extending well above the range for our other samples (VT-M1010= $160 \mu \mathrm{mol} / \mathrm{mol}$; HARVARD-129393= $99 \mu \mathrm{mol} / \mathrm{mol}$ ) (Figure 2.6, bottom panel). There are no significant differences between deep-sea and shallow-water corals (Two-tailed ttest for deep-sea versus shallow-water coral aragonites: $t(26)=2.056, p=0.44)$.

Testing the relationships between trace element incorporations and crystallography and carbonate group bonding environments, we find that shifts towards larger overall unit cell volumes trend with increasing $\mathrm{B} / \mathrm{Ca}$ and $\mathrm{Sr} / \mathrm{Ca}$ ratios and decreasing $\mathrm{Mg} / \mathrm{Ca}$ and $\mathrm{Ba} / \mathrm{Ca}$ ratios for all samples (black solid trend lines) as well as for only coral, seawater synthetic aragonite and geological aragonites (red dashed trend lines) (Figure 2.7).

$\mathrm{B} / \mathrm{Ca}$ ratios have especially interesting trends with more nuanced anisotropic shifts in crystallography and the carbonate bonding environment (Figure 2.8). For all samples (black solid trend lines) we observe that $a$ - and $b$-axis lengths increase as a function of increasing $\mathrm{B} / \mathrm{Ca}$ ratios. This trend continues for the a-axis lengths as we measure a subset of samples (red dashed and blue dotted trend lines), but the trend shifts to shortening $b$-axis lengths when we only plot the relationship between corals and seawater synthetic aragonites versus $\mathrm{B} / \mathrm{Ca}$ (blue dotted trend line). The strongest relationships we observe between $\mathrm{B} / \mathrm{Ca}$ ratios and aragonite mineralogy exist between decreasing FWHM $v 1$ and $\Omega_{\mathrm{cf}}$ in coral and seawater synthetic aragonites as a function of increasing B/Ca ratios (Figure 2.8, blue dotted trend lines). All other trends between metal incorporations and crystallography (Supplementary materials, Figure S2.5) and bonding environments (Supplementary Materials, Figure S2.6) are plotted with statistically significant trends plotted both coral and seawater synthetic aragonites samples (blue dotted trend lines), coral, seawater synthetic aragonites, and geological aragonite samples (red dashed trend lines), and all samples (black solid lines).

\subsection{DISCUSSION}

\subsubsection{Crystallographic evidence for geochemically-driven aragonite formation in corals}

In this study we characterize the crystallography and chemistry of coral aragonites compared to other forms of aragonite in order to better predict the physical nature of these aragonites and how these end-products of coral biomineralization may have formed. Rather than corals exhibiting the same aragonite crystallography as other biogenic aragonites (mollusks), our Rietveld refinement analyses of different aragonite XRD patterns indicate that coral aragonite unit cell parameters are distinct form mollusk aragonite (Figure 2.2, pearl= salmon right-pointing triangles) as well as geologically-formed aragonites (grey stars) and freshwater synthetic aragonite (dark blue leftfacing triangles). Instead, coral aragonite is crystallographically indistinguishable from synthetic aragonites precipitated from seawater under a range of controlled $\mathrm{pH}$ and $\Omega$ conditions (Figure 2.2, blue triangles). Both corals and synthetic aragonites express the same magnitude of anisotropic elongations along all three axes relative to geologically-formed aragonites (Table 2.2). These similarities between coral and seawater synthetic aragonites observed by XRD measurements are supported by Raman spectroscopy measurements of coral aragonites exhibiting the same FWHM $v_{1}$ mode as the f06 synthetic aragonite precipitated at a similar $\Omega$ as the $\Omega_{\text {cf }}$ predicted for corals (Figure 2.4). 
Our findings that coral aragonite crystallography and bonding-environments resembles that of aragonite crystals inorganically formed from seawater suggests that coral aragonite is similarly formed via precipitation from aragonite-supersaturated seawater. A crystal formation mechanism that depends on seawater chemistry agrees with previous studies which suggest that corals draw in seawater as the initial ingredient to create aragonite (Gagnon et la., 2007; Tambutté et al., 2011). This is supported by Rayleigh fractionation models which observe similarities between coral and synthetic aragonite trace element incorporation (Cohen et al., 2006; Gaetani and Cohen, 2006). Our observations that coral aragonite crystallography resembles seawater synthetic aragonites but not freshwater synthetic aragonite (Figure 2.2) further serves as evidence that corals likely precipitate aragonite that reflect seawater chemistry. Finally, juvenile scleractinian corals have been shown to reflect their seawater geochemical environments by precipitating calcite skeletons over aragonite skeletons when grown in Cretaceous-like, "calcite sea" seawater with lower Mg/Ca ratios (Higuchi et al., 2014).

Based on their crystallographic dissimilarity, the material properties and mode of formation for coral aragonites are likely different from that of mollusk aragonites (Figure 2.4). Crystallographic distinctions between coral and mollusk aragonites reflect the clear morphological differences between the acicular mineral habit of coral aragonite versus the tabular habit of mollusk aragonite (Holcomb et al., 2009; Gilbert et al., 2015). Mollusk aragonite formation is well-known to be biologically-controlled via ACC precursors (Weiss et al., 2002; Pokroy et al., 2006; 2007; Gilbert et al., 2015). In contrast, our crystallographic analyses corroborate previous crystal habit, carbonate bonding environment, and geochemical observations comparing the similarities between synthetic and coral aragonites (Constantz, 1986; Holcomb et al. 2009; Cohen et al., 2009; DeCarlo et al., 2018) that point to coral aragonite formation as a geochemically-driven process. Our crystallography results do not corroborate results by Stolarski et al., (2007) which observe the same crystallographic trends in coral aragonite lattice distortions as mollusk aragonite results reported by Pokroy et al., (2006; 2007). Instead, we suggest that the physical response of coral skeletal aragonite to surrounding ocean conditions and stressors, such as ocean acidification, should follow similar responses as synthetic seawater aragonites. As the end-products of coral biomineralization, a dominant geochemical control over coral aragonite mineral formation may similarly indicate a strong geochemical influence on coral skeleton growth.

While previous studies have demonstrated how coral aragonite resembles synthetic aragonites both morphologically and chemically (Holcomb et al., 2009; Gaetani and Cohen, 2006), this study goes beyond mineral morphology to prove that coral aragonite is identical to seawater synthetic aragonites from a quantitative crystallographic perspective. Based on this information, we suggest that coral aragonite formation is geochemically controlled and speculate that coral biomineralization is dependent on calcifying fluid chemistry and is sensitive to seawater chemistry.

\subsubsection{Differences in crystallography between corals and geological aragonites not driven by incorporation of organics}

Recent studies on the nature of organics in coral skeletons have presented conflicting assumptions about the role of organics in biomineralization and how organics become incorporated into the skeleton as a skeletal organic matrix (SOM) (DeCarlo et al., 2018; Von 
Euw et al., 2017). In this study we present a mineralogical perspective to addressing the role of organics in coral crystallography, which complements a recent Raman spectroscopy study, which observed no clear differences in organic content in coral aragonite and seawater synthetic aragonites by measuring the background fluorescence signal in these aragonites (DeCarlo et al., 2018).

In previous study, the nature of coral aragonite has been assumed to follow the same crystallographic trends as other biogenic aragonites, where the difference in lattice parameters between mollusk aragonite and geologically-formed aragonite has been attributed to the $0.1-5$ $\mathrm{wt} \%$ incorporation of intercrystalline organic molecules in aragonite known to make up mollusk composite biominerals (Pokroy et al., 2004). This organic content in mollusk aragonite is evidenced in our study by the very high fluorescence signal in the pearl sample as observed with Raman spectroscopy, whereas coral aragonites exhibit the same low levels of fluorescence as synthetic and geologically-formed aragonites (Figure 2.4). When we plot the background fluorescence signals of all of the aragonite samples (except for the pearl sample) in this study, we observe a weak trend of decreasing fluorescence as a function of increasing unit cell volumes, due to the slightly higher fluorescent signals observed in geological aragonites compared to the corals (Supplementary Materials, Figure S2.3). This trend is the opposite of what we would expect if the larger unit cell volumes of corals compared to geological aragonites were due to the incorporation of organic molecules, as qualitatively assessed by increased fluorescent background signals. As for the nature of mollusk aragonite, our XRD results do confirm observations by Pokroy et al., (2004) on the crystallographic nature of mollusk nacre, that overall unit cell volume increases are due to an elongation along the $c$-axis and $a$-axis as well as a shortening along the $b$-axis relative to geological aragonites (Figure 2.2). This is very different from our observations of coral aragonite, which expands along all axes relative to geological aragonite (Figure 2.2). This likely points to a different cause for anisotropic lattice distortions observed in corals relative to geological aragonites. We pwculate that lattice fistortions in coral with respect to geologically-formed aragonites could be driven by crystal growth parameters, such as crystal growth rate, which may introduce crystallographic distortions and incorporate more trace elements in faster-forming coral aragonite crystals, which would increase overall aragonite unit cell volumes. Our mollusk nacre sample also has a marked lower frequency Raman shift compared to our coral and geological aragonite samples (Figure 2.4), likely due to the organic content, however these values may not be entirely accurate because of the abnormally high fluorescence background. In the future we would have to quantitatively measure the organic content of all of the aragonites in order to confirm that mollusk aragonite has higher organic contents than coral and other aragonites, but our findings do align with previous studies that estimate at least a $5 \times$ higher organic content in mollusk nacre versus coral skeletons (Gilbert et al., 2005; Pokroy et al., 2004). Finally, our organics-removal treatment to dissolve excess intercrystalline organic material from our biogenic aragonite samples did not have a significant effect on the background fluorescence or crystallography of our coral samples, but did have a marked effect on the mollusk pearl sample (Supplementary Materials, Figure S2.2), indicating that organics play a larger role in mollusk aragonite than they do in coral aragonite. While corals may use still use biomolecules to template skeletal architecture and aragonite precipitation by lowering the Gibbs free energy barrier with heterogeneous nucleation (De Yoreo et al., 2015), coral crystallography does not support the presence of significant inter- or intra-crystalline organics in skeletal aragonite (Pokroy et al., 2004; 2007). This has important implications for the 
material nature of skeletal aragonite and how sensitive it may be to changing ocean chemistry and coral growth dynamics.

\subsubsection{Relationships between trace element incorporations and crystallography}

As we suggest that the anisotropic lattice distortions in coral aragonites with respect to geologically-formed aragonites are not caused by the incorporation of organic matter, we measured the trace incorporations of elements $(\mathrm{B}, \mathrm{Mg}, \mathrm{Sr}, \mathrm{Ba})$ into coral skeletons and other aragonites in order to assess whether they may be associated with distortions in coral crystallography and carbonate bonding environments. We do observe that unit cell volumes increase as functions of $\mathrm{B} / \mathrm{Ca}$ and $\mathrm{Sr} / \mathrm{Ca}$ ratios yet decrease as functions of $\mathrm{Mg} / \mathrm{Ca}$ and $\mathrm{Ba} / \mathrm{Ca}$ ratios (Figure 2.7) with anisotropic responses along the three axes to these incorporations (Supplementary materials, Figure S2.5). All three unit cell axes respond most strongly to incorporations of $\mathrm{B}$ and $\mathrm{Sr}$, which also happen to be significantly more abundant in coral and synthetic aragonites precipitated from seawater than in geological aragonites (Figure 2.6). We also observe a slight decrease in FWHM $v 1$ and Raman-derived $\Omega_{\mathrm{cf}}$ as functions of increasing $\mathrm{Ba} / \mathrm{Ca}$ incorporations in all samples and a slight increase in FWHM $v_{1}$ as a function of increasing $\mathrm{Sr} / \mathrm{Ca}$ ratios for corals, seawater synthetic aragonites and geological aragonites (Supplementary materials, Figure S2.6). Thus, it is possible that these B and Sr incorporations may be associated in the process distorting unit cell lattices and driving the larger unit cell volumes and carbonate bonding environment disorder that we observe in coral and synthetic aragonites. Varying trace element incorporations in coral aragonites versus geological aragonites may be a byproduct of crystal growth parameters, such as faster crystal growth rates for coral aragonite crystals, which may lead to increased crystalline disorder accompanied by more trace incorporations of metals trapped during rapid mineral accretion (Watson, 2004; Gabitov et al., 2008; DeCarlo et al., 2015).

In coral aragonites, crystallographic distortions may be linked to $\Omega_{\mathrm{cf}}$, which could influence crystal growth rates. This is supported by our observations of $\mathrm{B} / \mathrm{Ca}$ ratios trending moderately with both increasing FWHM $\mathrm{v}_{1}\left(\mathrm{R}^{2}=0.44\right)$ and $b$-axis lengths $\left(\mathrm{R}^{2}=0.36\right)$, which suggests that $\mathrm{B}$ incorporations may be linked to crystallographic changes along the $b$-axis and distortions in the $\mathrm{v}_{1}$ carbonate-group stretching mode (Figure 2.8). FWHM $\mathrm{v}_{1}$ is used to derive estimates for $\Omega_{\mathrm{cf}}$ using Raman spectroscopy (DeCarlo et al., 2017). As expected from studies which utilize $\delta^{11 / 10} \mathrm{~B}$ isotopes to estimate $\Omega_{\mathrm{cf}}$, we also observe a relatively strong trend between B and $\Omega_{\mathrm{cf}}$ for coral and synthetic seawater aragonites (Figure 2.8, $\mathrm{R}^{2}=0.44$ ) (Holcomb et al., 2014; McCulloch et al., 2014). $\delta^{11 / 10} \mathrm{~B}$ isotope-based estimates of $\Omega_{\mathrm{cf}}$ are derived from $\delta^{11 / 10} \mathrm{~B}$ isotopebased estimates of $\mathrm{pH}_{\mathrm{cf}}$ and assume that salinity, temperature, and the $\mathrm{pK}_{\mathrm{B}}$ of boric acid are constant and that $\delta^{11 / 10} \mathrm{~B}$ of the calcifying fluid is that same as that of seawater (McCulloch et al., 2014). Raman-based estimates for $\Omega_{\mathrm{cf}}$ are drawn from the relationship between $\delta^{11 / 10} \mathrm{~B}$-derived $\Omega_{\mathrm{cf}}$ and the FWHM of the $v_{1}$ Raman mode (DeCarlo et al., 2017). Note that B/Ca is not the same as $\delta^{11 / 10} \mathrm{~B}$ used in boron isotope studies. Similar to how Mg-incorporation in $\mathrm{Mg}$ calcites drives disorder in the $\mathrm{v}_{1}$ Raman mode due to out-of-plane rotations of the carbonate groups (Bischoff et al., 1985), B-incorporations may be involved in causing the $\Omega_{\mathrm{cf}}$-driven disorder in coral aragonite measured by Raman spectroscopy in this study via widening of the FWHM of the $v_{1}$ mode. Further evidence that crystallographic disorder may be tied to $\Omega_{\mathrm{cf}}$ comes from comparisons of deep-sea corals to shallow-water corals. In our trace element incorporation measurements, deep- 
sea corals incorporate more $\mathrm{Mg}$ and $\mathrm{B}$ into their skeletons while growing in seawater with markedly lower aragonite saturation states and slower growth rates than seawater environments for shallow-water corals. In our plot of decreasing Raman-derived $\Omega_{\mathrm{cf}}$ (a measure of disorder in the carbonate bonding environment by FWHM $v_{1}$ mode) as a function of increasing B/Ca (Figure 2.8), we confirm that deep sea corals (violet circles) precipitate their skeletons at lower calcifying fluid aragonite saturation states with higher B/Ca ratios compared to shallow-water corals (green squares) (McCulloch et al., 2012b).

\subsection{CONCLUSIONS}

Understanding the formation mechanism and material properties of coral aragonite is critical for predicting how sensitive coral aragonite will be to rapidly changing ocean conditions, such as ocean acidification. In this study we quantitatively characterize the crystallography of coral aragonite and compare it to the crystallography of synthetic aragonites precipitated from seawater, synthetic aragonite precipitated from freshwater, another biogenic mollusk aragonite and geologically-formed aragonites, in order to deduce which mechanism of formation is most likely for coral aragonite based on crystallographic similarities and dissimilarities. We observe that coral aragonite crystallography most closely resembles that of synthetic aragonites precipitated from seawater and that both of these aragonites have significantly larger unit cell volumes due to anisotropic lengthening of all unit cell axes compared to geologically-formed aragonites. Similarities between synthetic aragonites and coral aragonites indicate that coral aragonite crystal formation is likely geochemically-driven in the coral internal calcifying fluid, similar to that of synthetic aragonites, which from an aragonite supersaturated seawater solution. This may have implications for a dominant role of carbonate chemistry in coral skeleton formation and could suggest that coral biomineralization is sensitive to surrounding seawater geochemistry.

While mollusk aragonite unit cell lattices are also larger than the unit cells of geological aragonites due to the incorporation of organics in mollusk aragonite, the anisotropic distortions along the $b$-axis and the resulting unit cell volume of mollusk aragonite is significantly smaller than coral aragonite $b$-axes and unit cell volumes. We suggest that this disparity indicates that coral lattice parameter distortions compared to geological aragonites are not driven by inter- or intra-crystalline organics in coral skeletons, as is proposed in mollusk aragonite. Furthermore, coral aragonites also have very low fluorescent backgrounds as observed by Raman spectroscopy, on the same order of magnitude as geological and synthetic aragonites, while mollusk aragonite has significantly higher fluorescence signals and organic content.

Element/Ca ratios in aragonites demonstrate that increasing unit cell volumes in aragonites trend with increasing incorporations of B and Sr. B is especially sensitive with regards to unit cell $a$ - and $b$-axis lengths, FWHM $v_{1}$ mode, and Raman-derived $\Omega$, for coral and seawater synthetic aragonites.

Our mineralogical approach to studying the end-products of coral biomineralization suggests that coral aragonite crystals are formed by geochemical processes, as opposed to by biological controls, which reflect surrounding seawater chemistry and could make coral calcification vulnerable to rapidly shifting ocean chemistries predicted over the next century. 


\subsection{Funding and Acknowledgments}

Funding for this project was made possible by Mineralogical Society of America Edward H. Kraus Crystallographic Research Fund and the WHOI Ocean Ventures Fund. G. Farfan was supported by a National Science Foundation Graduate Research Fellowship Grant No. 1122374 and a Ford Foundation Dissertation Fellowship. Sample collections from Rhian Waller were funded under NSF grant numbers 1245766, 1127582 and NOAA Ocean Exploration Deep Atlantic Stepping Stones. Collections from the Gulf of Mexico were supported by NSF BIOOCE grant \#1220478 to Erik Cordes. Sample collections of shallow-water corals by Amy Apprill were funded by the WHOI Dalio Explore Fund.

I would like to acknowledge Thomas DeCarlo for running all of the Raman spectroscopy measurements and for precipitating the seawater synthetic aragonite samples with Dr. Michael Holcomb in the laboratory of Dr. Glenn Gaetani, (WHOI). I also thank Dr. Sebastian Mergelsberg for precipitating the freshwater synthetic aragonite sample in the Dr. Patricia Dove Laboratory (Virginia Polytechnic Institute) and for giving me the natural VT-M1010 geological aragonite sample. I thank Dr. Raquel Alonso Perez and Theresa Smith at the Harvard Mineralogical Museum for the other natural aragonite samples.

I would like to thank Dr. Jeffrey Post from the Smithsonian Nation Museum of Natural History for training me on Rietveld Refinement analysis, Gretchen Swarr for help with ICP-MS analyses at WHOI, and Katherine Sisson for helping to prepare coral powder samples in the Hansel Lab (WHOI).

\subsection{References}

Al-Horani, F. A., Al-Moghrabi, S. M., \& De Beer, D. (2003). The mechanism of calcification and its relation to photosynthesis and respiration in the scleractinian coral Galaxea fascicularis. Mar. Biol. 142(3), 419-426. doi:10.1007/s00227-002-0981-8

Allison, N., Cohen, I., Finch, A. A., Erez, J., and Tudhope, A. W. (2014). Corals concentrate dissolved inorganic carbon to facilitate calcification. Nat. Commun. 5, 1-6. doi:10.1038/ncomms6741

Allison, N., and Finch, A. A. (2010). $\delta 11 \mathrm{~B}, \mathrm{Sr}, \mathrm{Mg}$ and B in a modern Porites coral: the relationship between calcification site $\mathrm{pH}$ and skeletal chemistry. Geochim. Cosmochim. Acta. 74(6), 17901800. doi:10.1016/j.gca.2009.12.030

Antao, S. M. (2012). The crystal structure of a biogenic aragonite from the nacre of an ammonite shell. RSC Adv. 2, 526-530. doi:10.1039/c1ra00568e

Antao, S.M. and Hassan, I. (2009). The orthorhombic structure of $\mathrm{CaCO}_{3}, \mathrm{SrCO}_{3}, \mathrm{PbCO}_{3}$ and $\mathrm{BaCO}_{3}$ : Linear structural trends. Can. Mineral. 47, 1245-1255. doi:10.3749/canmin.47.5.1245

Benzerara, K., Menguy, N., Obst, M., Stolarski, J., Mazur, M., Tylisczak, T., Brown, G., and Meibom, A. (2011). Study of the crystallographic architecture of corals at the nanoscale by scanning transmission X-ray microscopy and transmission electron microscopy. Ultramicroscopy. 111(8), 1268-1275. doi:10.1016/j.ultramic.2011.03.023 
Berstein, L. R. (1986). Geology and mineralogy of the Apex germanium-gallium mine, Washington County, Utah. U.S. Geological Survey Bulletin 1577. doi:10.3133/b1577

Bischoff, W. D., Sharma, S. K., and MacKenzie, F. T. (1985). Carbonate ion disorder in synthetic and biogenic magnesian calcites: a Raman spectral study. Am. Mineral. 70, 581-589.

Blue, C. R., Giuffre, A., Mergelsberg, S., Han, N., De Yoreo, J. J., and Dove, P. M. (2017). Chemical and physical controls on the transformation of amorphous calcium carbonate into crystalline $\mathrm{CaCO}_{3}$ polymorphs. Geochim. Cosmochim. Acta. 196, 179-196. doi:10.1016/j.gca.2016.09.004

Bish, D. L., and Post, J. E. (1993). Quantitative mineralogical analysis using the Rietveld fullpattern fitting method. Am. Mineral. 78, 932-940.

Brahmi, C., Koppa, K., Domart-Coulon, I., Stolarski, J. and Meibom, A. (2012). Skeletal growth dynamics linked to trace-element composition in the scleractinian coral Pocillopora damicornis. Geochim. Cosmochim. Acta. 99, 146-158. doi:10.1016/j.gca.2012.09.031

Cai, W. J., Ma, Y., Hopkinson, B. M., Grottoli, A. G., Warner, M. E., Ding, Q., Hu, X., Yan, H., Schoepf, V., Xu, H., Han,C., Melman, T. F., Hoadley, K.D., Pettay, T., Matsui, Y., Baumann, J. H., Levas, S., Ying, Y., and Wang, Y. (2016). Microelectrode characterization of coral daytime interior $\mathrm{pH}$ and carbonate chemistry. Nat. Commun. 7, 11144. doi:10.1038/ncomms11144

Carpenter, K. E., Abrar, M., Aeby, G, Aronson, R. B., Banks, S., Bruckner, A., Chiriboga, A., Cortés, J., Delbeek, J. C., DeVantier, L., Edgar, G. J., Edwards, A. J., Fenner, D., Guzmán, H. M., Hoeksema, B.W., Hodgso,n G., Johan, O., Licuanan, W. Y., Livingstone, S. R., Lovell, E. R , Moore, J. A., Obura, D. O., Ochavillo, D., Polidoro, B. A., Precht, W. F., Quibilan, M. C., Reboton, C., Richards, Z. T., Rogers, A. D., Sanciangco, J., Sheppard, A., Sheppard, C., Smith, J., Stuart, S., Turak, E., Veron, J. E. N., Wallace, C., Weil, E., and Wood, E. (2008). One-third of reef-building corals face elevated extinction risk from climate change and local impacts. Science 321(5888), 560-563. doi:10.1126/science.1159196

Caspi, E. N., Pokroy, B., Lee, P. L., Quintana, J. P., and Zolotoyabko, E. (2005). On the structure of aragonite. Acta Cryst. B 61, 129-132. doi:10.1107/S0108768105005240

Cohen, A., and Holcomb, M. (2009). Why corals care about ocean acidification: Uncovering the mechanism. Oceanography 22, 118-127. doi:10.5670/oceanog.2009.102

Cohen, A. L., McCorkle, D. C., de Putron, S., Gaetani, G. A., and Rose, K. A. (2009). Morphological and compositional changes in the skeletons of new coral recruits reared in acidified seawater: Insights into the biomineralization response to ocean acidification. Geochem. Geophys. Geosyst. 10, 1-12. doi:10.1029/2009GC002411

Cohen A. L. and McConnaughey T. (2003). Geochemical perspectives on coral mineralization. In Biomineralization (eds. P. Dove, S. Weiner and J. De Yoreo). Rev. Mineral. Geochem. 54, 151187.

Constantz, B. R. (1986). Coral skeleton construction: a physiochemically dominated process. Palaios. 152-157. doi:10.2307/3514508 
Cuif, J. P., Dauphin, Y., Berthet, P., and Jegoudez, J. (2004). Associated water and organic compounds in coral skeletons: quantitative thermogravimetry coupled to infrared absorption spectrometry.

Geochem. Geophy. Geosy. 5(11). doi:10.1029/2004GC000783

Cuif, J. P., and Dauphin, Y. (2005). The Environment Recording Unit in coral skeletons-a synthesis of structural and chemical evidences for a biochemically driven, stepping-growth process in fibres. Biogeosciences 2(1), 61-73. doi:10.5194/bg-2-61-2005

DeCarlo, T. M., Gaetani, G. A., Holcomb, M., and Cohen, A. L. (2015). Experimental determination of factors controlling $\mathrm{U} / \mathrm{Ca}$ of aragonite precipitated from seawater: Implications for interpreting coral skeleton. Geochim. Cosmochim. Acta, 162, 151-165. doi:10.1016/j.gca.2015.04.016

DeCarlo, T. M., D'Olivo, J. P., Foster, T., Holcomb, M., Becker, T., and McCulloch, M. T. (2017). Coral calcifying fluid aragonite saturation states derived from Raman spectroscopy. Biogeosciences 14, 5253. doi:10.5194/bg-14-5253-2017

DeCarlo, T. M., Ren, H., and Farfan, G. A. (2018). The origin and role of organic matrix in coral calcification: insights from comparing coral skeleton and abiogenic aragonite. Front. Mar Sci. 5, 170. doi:10.3389/fmars.2018.00170

De Villiers, J. P. R. (1971). Crystal structures of aragonite, strontianite, and witherite. Amer. Mineral. 56, $758-767$.

De Yoreo, J. J., Gilbert, P. U. P. A., Sommerdijk, N. A., Penn, R. L., Whitelam, S., Joester, D., Zhang, H., Rimer, J. D., Navrotsky, A., Banfield, J. F., Wallace, A. F., Michel, F. M., Meldrum, F. C., Cölfen, H., and Dove, P. M. (2015). Crystallization by particle attachment in synthetic, biogenic, and geologic environments. Science 349(6247) 498. doi:10.1126/science.aaa6760

Dickens, B. and Bowen, J. S. (1971). Refinement of the Crystal Structure of the Aragonite Phase of $\mathrm{CaCO}_{3}$. Journal of Research, National Bureau of Standards - A. Physics and Chemistry, $75 \mathrm{~A}(1)$ $27-32$.

Doney, S. C., Fabry, V. J., Feely, R. A., and Kleypas, J. A. (2009). Ocean acidification: the other $\mathrm{CO}_{2}$ problem. Annu. Rev. Mar. Sci. 1, 169-192. doi:10.1146/annurev.marine.010908.163834

Douka, K., Hedges, R. E. M., and Higham, T. F. G. (2010). Improved AMS 14C dating of shell carbonates using high-precision X-ray diffraction and a novel density separation protocol (CarDS). Proceedings of the 20th International Radiocarbon Conference, A J T Jull (ed.). Radiocarbon, 52(2-3) 735-751. doi:10.2458/azu_js_rc.52.3707

Fisher, R., O'Leary, R. A., Low-Choy, S., Mengersen, K., Knowlton, N., Brainard, R. E., and Caley, M. J. (2015). Species richness on coral reefs and the pursuit of convergent global estimates. Curr. Biol. 25, 500-505. doi:10.1016/j.cub.2014.12.022

Foster, T., Falter, J. L., McCulloch, M. T., and Clode, P. L. (2016). Ocean acidification causes structural deformities in juvenile coral skeletons. Sci. Adv. 2, 1-7. doi:10.1126/sciadv.1501130

Gabitov, R. I., Gaetani, G. A., Watson, E. B., Cohen, A. L., and Ehrlich, H. L. (2008). 
Experimental determination of growth rate effect on $\mathrm{U}^{6+}$ and $\mathrm{Mg}^{2+}$ partitioning between aragonite and fluid at elevated $\mathrm{U}^{6+}$ concentration. Geochim. Cosmochim. Acta, 72, 4058-4068.

doi:10.1016/j.gca.2008.05.047

Gagnon, A. C., Adkins, J. F., and Erez, J. (2012). Seawater transport during coral biomineralization. Earth Planet Sci. Lett. 329-330, 150-161. doi:10.1016/j.epsl.2012.03.005

Gagnon, A. C., Adkins, J. F., Fernandez, D. P., \& Robinson, L. F. (2007). Sr/Ca and Mg/Ca vital effects correlated with skeletal architecture in a scleractinian deep-sea coral and the role of Rayleigh fractionation. Earth and Planetary Science Letters, 261(1-2), 280-295.

doi:10.1016/j.eps1.2007.07.013

Gaetani, G. A., and Cohen, A. L. (2006). Element partitioning during precipitation of aragonite from seawater: a framework for understanding paleoproxies. Geochim. Cosmochim. Acta 70, 4617-4634. doi:10.1016/j.gca.2006.07.008

Gaffey, S. J., and Bronnimann, C. E. (1993). Effects of bleaching on organic and mineral phases in biogenic carbonates. J. Sediment. Res. 63, 752-754. doi:10.1306/D4267BE0-2B26-11D7$8648000102 \mathrm{C} 1865 \mathrm{D}$

Geier, B. H., Kautz, K., and Müller, G. (1971). Tsumcorit(e) PbZnFe(AsO4) 2 H 2 O, ein neues Mineral aus den Oxidationszonen der Tsumeb-Mine, Südwestafrika. Neues Jahrbuch für Mineralogie, Monatshefte, 305-309.

Georgian, S. E., DeLeo, D., Durkin, A., Gomez, C. E., Kurman, M., Lunden, J. J., and Cordes, E. E. (2016). Oceanographic patterns and carbonate chemistry in the vicinity of cold-water coral reefs in the Gulf of Mexico: Implications for resilience in a changing ocean. Limnol. Oceanogr. 61, 648-665. doi:10.1002/lno.10242

Gilbert, P. U. P. A., Abrecht, M., and Frazer, B. H. (2005). The organic-mineral interface in biominerals. Rev. Mineral Geochem. 59(1), 157-185. doi:10.2138/rmg.2005.59.7

Gooch, E. O., Wood, R. S., and Parrott, W. T. 1960. Sources of aggregate used in Virginia highway construction: Virginia Division of Mineral Resources. Mineral Resources Rept. 1.

Hathorne, E. C., Gagnon, A., Felis, T., Adkins, J., Asami, R., Boer, W., Caillon, N., Case, D., Cobb, K. M., Douville, E., deMenocal, P., Eisenhauer, A., Garbe-Schönberg, D., Geibert, W., Goldstein, S., Hughen, K., Inoue, M., Kawahata, H., Kölling, M., Cornec, F. L., Linsley, B. K., McGregor, H. V., Montagna, P., Nurhati, I. S., Quinn, T. M., Raddatz, J., Rebaubier, H., Robinson, L., Sadekov, A., Sherrell, R., Sinclair, D., Tudhope, A. W., Wei, G., Wong, H., Wu, H. C., and You, C. F. (2013). Interlaboratory study for coral $\mathrm{Sr} / \mathrm{Ca}$ and other element/Ca ratio measurements. Geochem. Geophys. Geosyst. 4, 3730-3750. doi:10.1002/ggge.20230

Hennige, S. J., Wicks, L. C., Kamenos, N. A., Perna, G., Findlay, H. S., and Roberts, J. M. (2015). Hidden impacts of ocean acidification to live and dead coral framework. Proc. R. Soc. Lond. [Biol]. 282, 1-10. doi:10.1098/rspb.2015.0990

Higuchi, T., Fujimura, H., Yuyama, I., Harii, S., Agostini, S., and Oomori, S. (2014). Biotic Control of Skeletal Growth by Scleractinian Corals in Aragonite-Calcite Seas. PLoS One 9(3), e91021. doi:10.1371/journal.pone.0091021 
Hoegh-Guldberg, O., Poloczanska, E. S., Skirving, W., and Dove, S. (2017). Coral reef ecosystems under climate change and ocean acidification. Front Mar Sci, 4, 158. doi:10.3389/fmars.2017.00158

Hoegh-Guldberg, O. (2015). Reviving the Ocean Economy: the Case for Action - 2015. Gland: WWF International.

Holcomb, M., Cohen, A. L., Gabitov, R. I., and Hutter, J. L. (2009). Compositional and morphological features of aragonite precipitated experimentally from seawater and biogenically by corals. Geochim. Cosmochim. Acta. 73(14), 4166-4179. doi:10.1016/j.gca.2009.04.015

Holcomb, M., Venn, A. A., Tambutté, E., Tambutté, S., Allemand, D., Trotter, J., and McCulloch, M. (2014). Coral calcifying fluid pH dictates response to ocean acidification. Sci. Rep. 4, 1-4. doi:10.1038/srep05207

Holcomb, M., DeCarlo, T. M., Gaetani, G. A., and McCulloch, M. (2016). Factors affecting $\mathrm{B} / \mathrm{Ca}$ ratios in synthetic aragonite. Chem. Geol., 437, 67-76. doi:10.1016/j.chemgeo.2016.05.007

Janiszewska, K., Stolarski, J., Benzerara, K., Meibom, A., Mazur, M., Kitahara, M. V., and Cairns, S. D. (2011). A unique skeletal microstructure of the deep-sea micrabaciid scleractinian corals. J. Morphol. 272, 191-203. doi:10.1002/jmor.10906

Jarosch, D. and Heger, G. (1986). Neutron diffraction refinement of the crystal structure of aragonite. TMPM Tschermaks Min. Petr. Mitt. 35. 127-131. doi:10.1007/BF01140844

Lunden, J. J., Georgian, S. E., and Cordes, E. E. (2013). Aragonite saturation states at cold-water coral reefs structured by Lophelia pertusa in the northern Gulf of Mexico. Limnol. Oceanogr. 58, 354-362. doi:10.4319/lo.2013.58.1.0354

Markgaf and Reeder (1985). High-temperature structure refinements of calcite and magnesite. Amer. Mineral. 70, 590-600.

Mass, T., Giuffre, A. J., Sun, C.-Y., Stifler, C. A., Frazier, M. J., Neder, M., Tamura, N., Stan, C. V., Marcus, M. A., and Gilbert, P. U. P. A. (2017). Amorphous calcium carbonate particles form coral skeletons. Proc. Natl. Acad. Sci. U.S.A. 114, E7670-E7678. doi:10.1073/pnas.1707890114

Mass, T., Drake, J. L., Haramaty, L., Kim, J. D., Zelzion, E., Bhattacharya, D., and Falkowski, P. G. (2013). Cloning and characterization of four novel coral acid-rich proteins that precipitate carbonates in vitro. Curr. Biol., 23(12), 1126-1131. doi:10.1016/j.cub.2013.05.007

Martinez, I., Zhang, J., and Reeder, R. J. (1996). In situ X-ray diffraction of aragonite and dolomite at high pressure and high temperature: Evidence for dolomite breakdown to aragonite and magnesite. Am. Mineral. 81, 611-624

McCulloch, M. T., D’Olivo, J. P., Falter, J., Holcomb, M., and Trotter, J. A. (2017). Coral calcification in a changing World and the interactive dynamics of $\mathrm{pH}$ and DIC upregulation. Nat. Commun. 8, 15686. doi:10.1038/ncomms 15686

McCulloch, M. T., Holcomb, M., Rankenburg, K., and Trotter, J. A. (2014). Rapid, highprecision measurements of boron isotopic compositions in marine carbonates. Rapid Commun. Mass Spectrom. 28, 2704-2712. doi:10.1002/rcm.7065 
McCulloch, M., Falter, J., Trotter, J., and Montagna, P. (2012a). Coral resilience to ocean acidification and global warming through $\mathrm{pH}$ up-regulation. Nat. Clim. Change 2, 623. doi:10.1038/nclimate1473

McCulloch, M., Trotter, J., Montagna, P., Falter, J., Dunbar, R., Freiwald, A., Försterra, G., López Correa, M., Maier, C., Rüggeberg, A., and Taviani, M. (2012b). Resilience of cold-water scleractinian corals to ocean acidification: Boron isotopic systematics of $\mathrm{pH}$ and saturation state up-regulation. Geochim. Cosmochim. Acta, 87, 21-34. doi:10.1016/j.gca.2012.03.027

Meibom, A., Yurimoto, H., Cuif, J. P., Domart-Coulon, I., Houlbreque, F., Constantz, B., Dauphin, Y., Tambutté, S., Tambutté, E., Allemand, D., Wooden, J., and Dunbar, R. (2006). Vital effects in coral skeletal composition display strict three-dimensional control. Geophysical Research Letters, 33(11). doi:10.1016/j.jembe.2011.07.026

Meibom, A., Cuif, J. P., Houlbreque, F., Mostefaoui, S., Dauphin, Y., Meibom, K. L., and Dunbar, R. (2008). Compositional variations at ultra-structure length scales in coral skeleton. Geochim. Cosmochim. Acta. 72(6), 1555-1569. doi:10.1016/j.gca.2008.01.009

Morse, J. W., and Mackenzie F. T. (1990), The Geochemistry of Sedimentary Carbonates, 707 pp., Elsevier, Amsterdam.

Mucci, A. (1983). The solubility of calcite and aragonite in seawater at various salinities, temperatures, and one atmosphere total pressure. Am. J. Sci. 283, 780-799.

Okai, T., Suzuki, A., Kawahata, H., Terashima, S., and Imai, N. (2002). Preparation of a new Geological Survey of Japan geochemical reference material: Coral JCp-1. Geostandards newsletter, 26(1), 95-99. doi:10.1111/j.1751-908X.2002.tb00627.x

Politi, Y., Levi-kalisman, Y., Raz, S., Wilt, F., Addadi, L., Weiner, S., and Sagi, I. (2006). Structural characterization of the transient amorphous calcium carbonate precursor phase in sea urchin embryos. Adv. Funct. Mater. 16, 1289-1298. doi:10.1002/adfm.200600134

Pokroy, B., Quintana, J. P., El'ad, N. C., Berner, A., and Zolotoyabko, E. (2004). Anisotropic lattice distortions in biogenic aragonite. Nat. Mater. 3, 900. doi:10.1038/nmat1263

Pokroy, B., Fitch, A. N., Lee, P. L., Quintana, J. P., El'ad, N. C., and Zolotoyabko, E. (2006). Anisotropic lattice distortions in the mollusk-made aragonite: a widespread phenomenon. $J$. Struct. Biol. 153, 145-150. doi:10.1016/j.jsb.2005.10.009

Pokroy, B., Fieramosca, J. S., Von Dreele, R. B., Fitch, A. N., Caspi, E. N., and Zolotoyabko, E. (2007). Atomic Structure of Biogenic Aragonite. Chem. Mater. 19, 3244-3251. doi:10.1021/cm070187u

Rand, T. D., Jefferis, W. W., and Cardeza, J. T. M. (1892). Mineral Localities of Philadelphia and Vicinity. Proceedings of the Academy of Natural Sciences of Philadelphia. 44, 174-202

Rao, D. V., Gigante, G. E., Y. Manoj Kumar, Y., Cesareo, R., Brunetti, A., Schiavon, N., Akatsuka, T., Yuasa, T., and Takeda, T. (2016). Synchrotron-based crystal structure, associated morphology of snail and bivalve shells by X-ray diffraction. Radiat. Phys. Chem. Oxf. 167, 155-164. doi:10.1016/j.radphyschem.2016.06.024 
Roger, L. M., George, A. D., Shaw, J., Hart, R. D., Roberts, M., Becker, T., McDonald, B. J., and Evans, N. J. (2017). Geochemical and microstructural characterisation of two species of cool-water bivalves (Fulvia tenuicostata and Soletellina biradiata) from Western Australia. Biogeosciences 14, 1721-1737. doi:10.5194/bg-14-1721-2017

Stolarski, J., Przeniosło, R., Mazur, M., and Brunelli, M. (2007). High-resolution synchrotron radiation studies on natural and thermally annealed scleractinian coral biominerals. J. Appl. Crystallogr. 40, 2-9. doi:10.1107/S002188980604489X

Swanson, H. E., and Fuyat, R. K. (1953). ICDD PDF 05, 0586, Calcite. Natl. Bur. Stand. (US), Circ, 539, 51.

Tambutté, S., Holcomb, M., Ferrier-Pagès, C., Reynaud, S., Tambutté, E., Zoccola, D., and Allemand, D. (2011). Coral biomineralization: from the gene to the environment. J. Exp. Mar. Biol. Ecol. 408, 58-78. doi: 10.1016/j.jembe.2011.07.026

Toby, B. H., and Von Dreele, R. B. (2013). GSAS-II: the genesis of a modern open-source all purpose crystallography software package. J. Appl. Crystallogr. 46, 544-549. doi:10.1107/S0021889813003531

Van de Locht, R., Verch, A., Saunders, M., Dissard, D., Rixen, T., Moya, A., and Kröger, R. (2013). Microstructural evolution and nanoscale crystallography in scleractinian coral spherulites. $J$. Struct. Biol., 183(1), 57-65. doi:10.1016/j.jsb.2013.05.005

Venn, A., Tambutté, E., Holcomb, M., Allemand, D., \& Tambutté, S. (2011). Live tissue imaging shows reef corals elevate $\mathrm{pH}$ under their calcifying tissue relative to seawater. PloS one 6(5), e20013. doi:10.1371/journal.pone.0020013

Von Euw, S., Zhang, Q., Manichev, V., Murali, N., Gross, J., Feldman, L. C., Gustafsson, T., Flach, C., Mendelsohn, R., Falkowsk, P. G. (2017). Biological control of aragonite formation in stony corals. Science, 356, 933-938. doi:10.1126/science.aam6371

Watson, E. B. (2004). A conceptual model for near-surface kinetic controls on the trace-element and stable isotope composition of abiogenic calcite crystals1. Geochimica et Cosmochimica Acta, 68(7), 1473-1488. doi:10.1016/j.gca.2003.10.003

Weber, D. and Wilson, W. E. (1977). Tsumeb IV. Geology. Mineralogical Record, 8(3), 14-16.

Weiss, I. M., Tuross, N., Addadi, L., and Weiner, S. (2002). Mollusc larval shell formation: amorphous calcium carbonate is a precursor phase for aragonite. J. Exp. Zool., 293(5), 478-491. doi:10.1002/jez.90004

Wopenka, B., and Pasteris, J. D. (2005). A mineralogical perspective on the apatite in bone. Materials Science and Engineering: C, 25(2), 131-143. doi:10.1016/j.msec.2005.01.008

Ye, Y., Smyth, J. R., and Boni, P. (2012). Crystal structure and thermal expansion of aragonite-group carbonates by single-crystal X-ray diffraction. Amer. Mineral. 97, 707-712.

doi:10.2138/am.2012.3923 707 
Zoccola, D., Tambutté, E., Kulhanek, E., Puverel, S., Scimeca, J. C., Allemand, D., and Tambutté, S. (2004). Molecular cloning and localization of a PMCA P-type calcium ATPase from the coral Stylophora pistillata. Biochim. Biophys. Acta. 1663(1), 117-126.

doi:10.1016/j.bbamem.2004.02.010 
2.9 Supplementary Materials-FIGURES
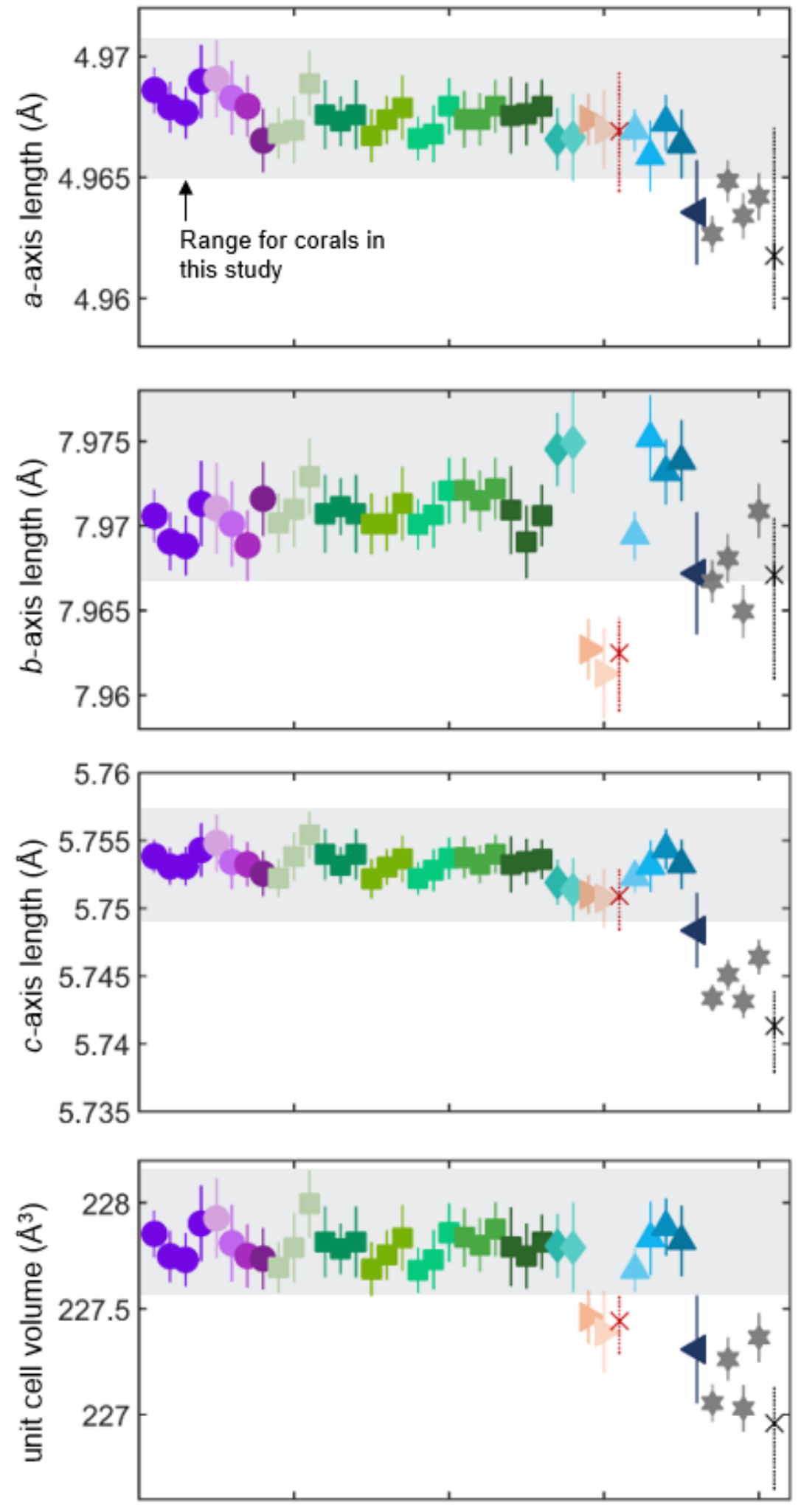

Key

Deep-sea corals

- Lophelia pertusa

Flabellum impensum

Enallopsammia rostrata

Flabellum curvatum

Balanophyllia malouensis

\section{Shallow-water corals}

Pocillopora verrucosa

Stylophora pistillata

Orbicella faveolata

Acropora palmata

Acropora cervicornis

Montastrea cavernosa

\section{Reference coral}

- JCp-1 Porites sp.

JCp-1 Porites sp. organic-removed

Other biogenic aragonite

Pearl

Pearl, organicremoved

\section{Synthetic}

aragonites from

\section{seawater}

f06

A04

g09

A h01

\section{Synthetic} aragonite from freshwater

\section{Geological} aragonites

Previous studies

$\times$ Biogenic aragonites

Range in biogenic aragonite studies

$\times$ Geological aragonites

Range in geological aragonite studies

FIGURE S2.1. Crystal lattice parameters (via Reitveld refinement analysis) plotted for all aragonite samples, (both organics-removed and untreated biogenic aragonites). 


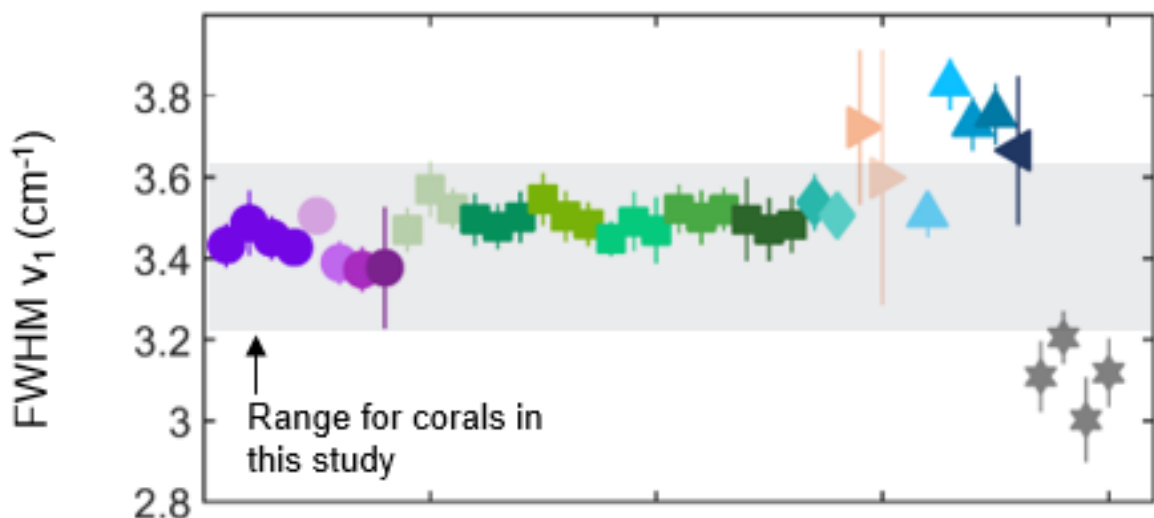

Key

Deep-sea corals

Lophelia pertusa

Flabellum impensum

Enallopsammia rostrata

Flabellum curvatum

Balanophyllia malouensis

Shallow-water corals

Pocillopora verrucosa

Stylophora pistillata

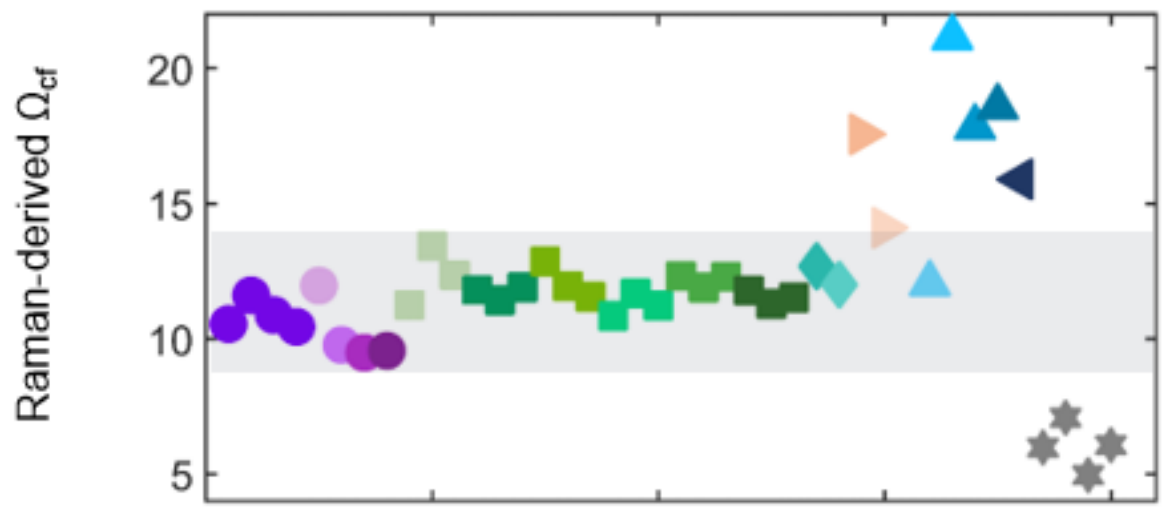

Orbicella faveolata

Acropora palmata

Acropora cervicornis

Montastrea cavernosa

Reference coral

JCp-1 Porites $s p$.

JCp-1 Porites sp., organic-removed

Other biogenic aragonite

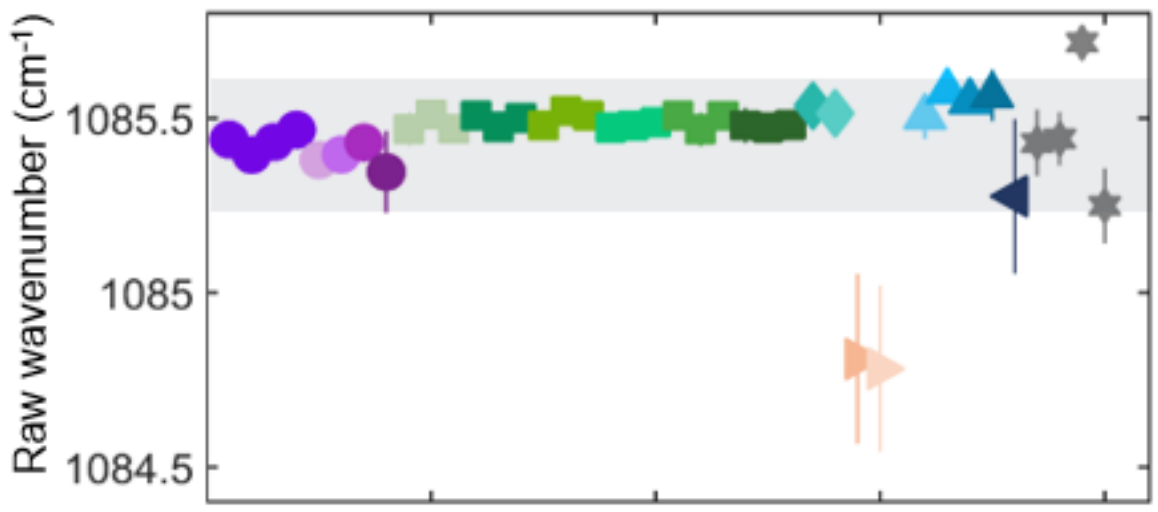

Pearl

Pearl, organic-

removed

\section{Synthetic}

aragonites from

seawater

f06

g04

g09

h01

ญ

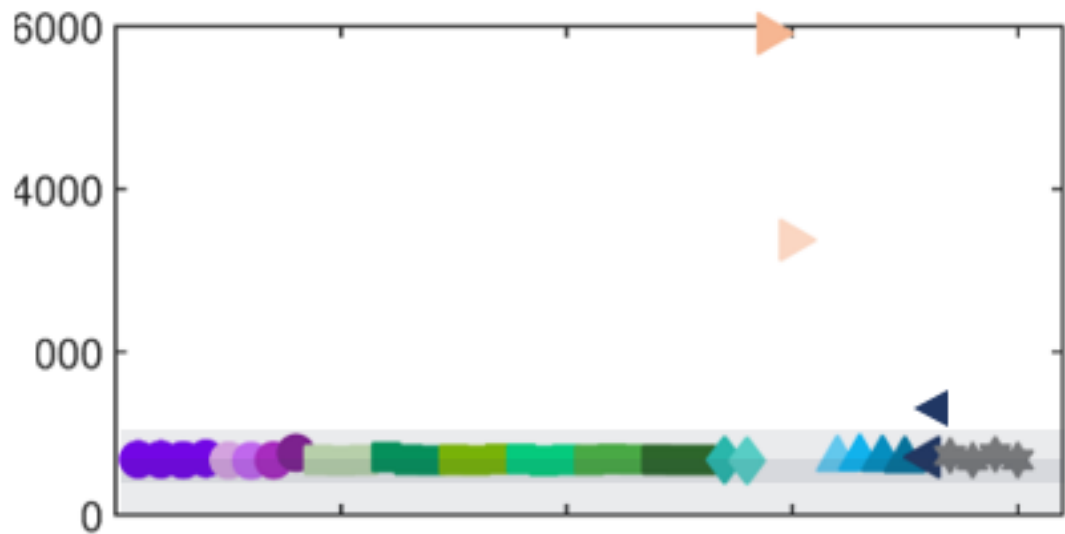

Synthetic aragonite from freshwater

Geological aragonites

FIGURE S2.2. Chemical bonding environments in all samples by Raman spectroscopy. 

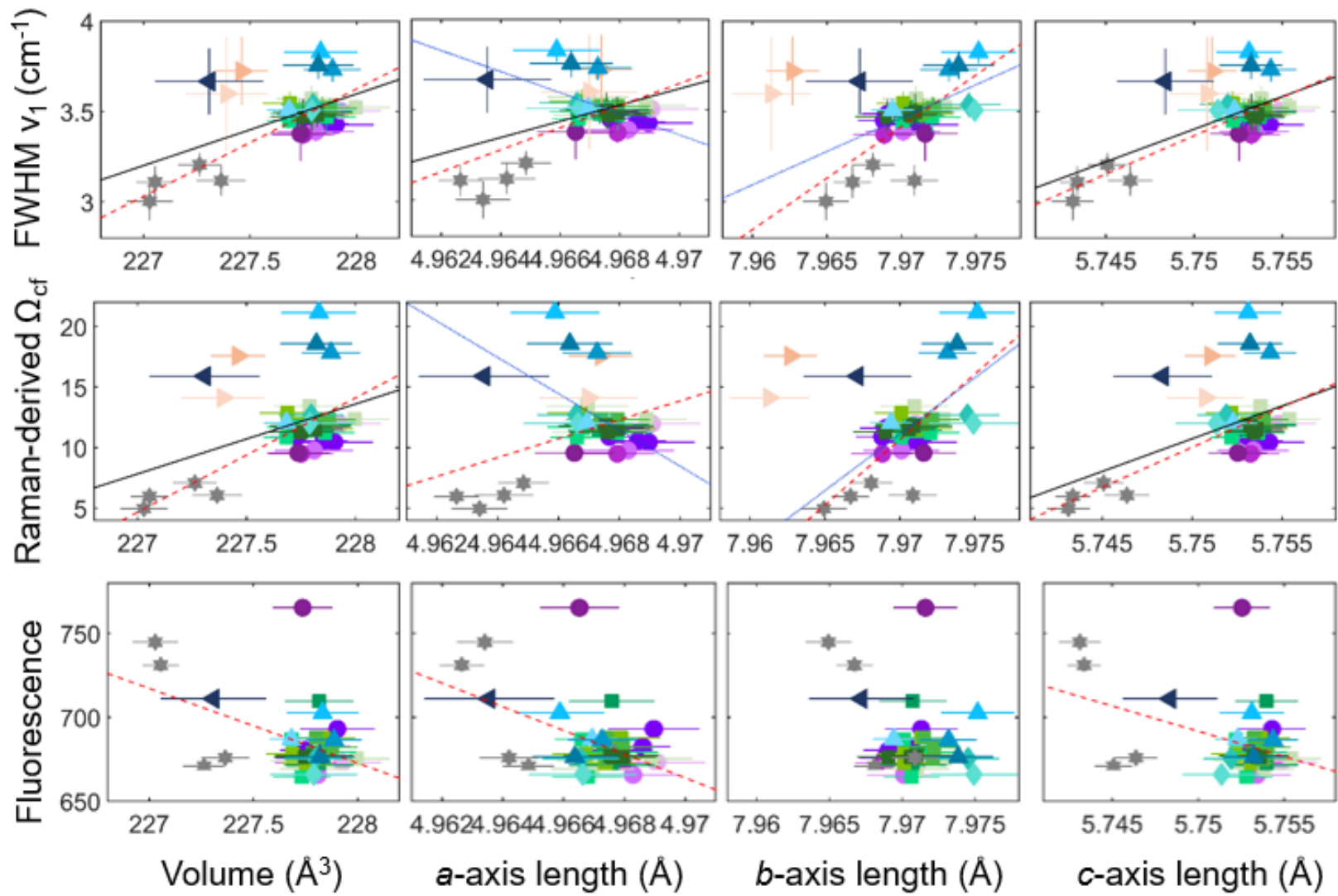

a-axis length $(\AA) \quad b$-axis length $(\AA)$

$c$-axis length $(\AA)$
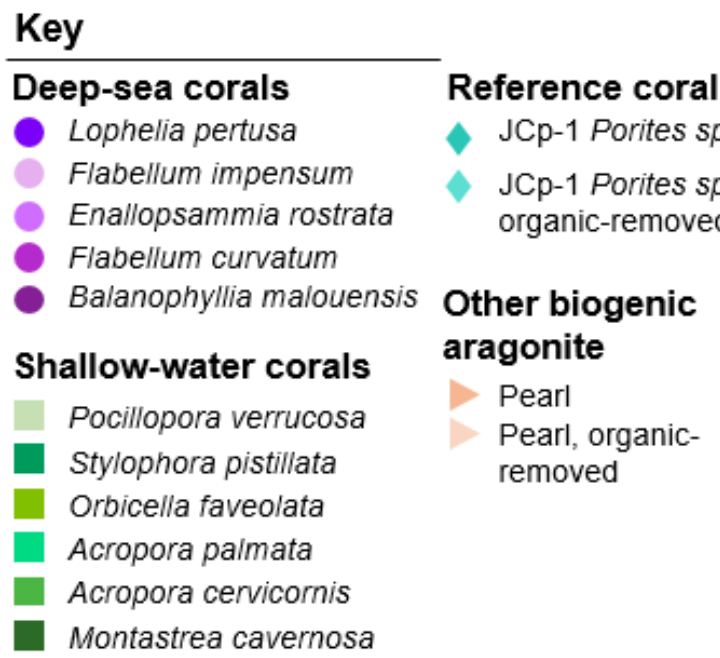

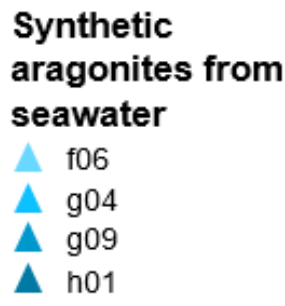
Synthetic aragonite from freshwater

\section{Geological} aragonites

FIGURE S2.3. Relationships between crystal lattice parameters via X-ray diffraction measurements and carbonate-group bonding environments via Raman spectroscopy measurements. FWHM of the $v_{1}$ Raman peak represents the symmetric stretching of the trigonal planar Raman group, Raman-derived internal calcifying fluid aragonite saturation state $\left(\Omega_{\mathrm{cf}}\right)$ is derived from the FWHM $v_{1}$ (DeCarlo et al., 2017), and the background fluorescence likely indicates the presence of organic material. Note that the pearl sample of mollusk nacre is not included in the plots for fluorescence versus lattice parameters because the fluorescence is too high. 

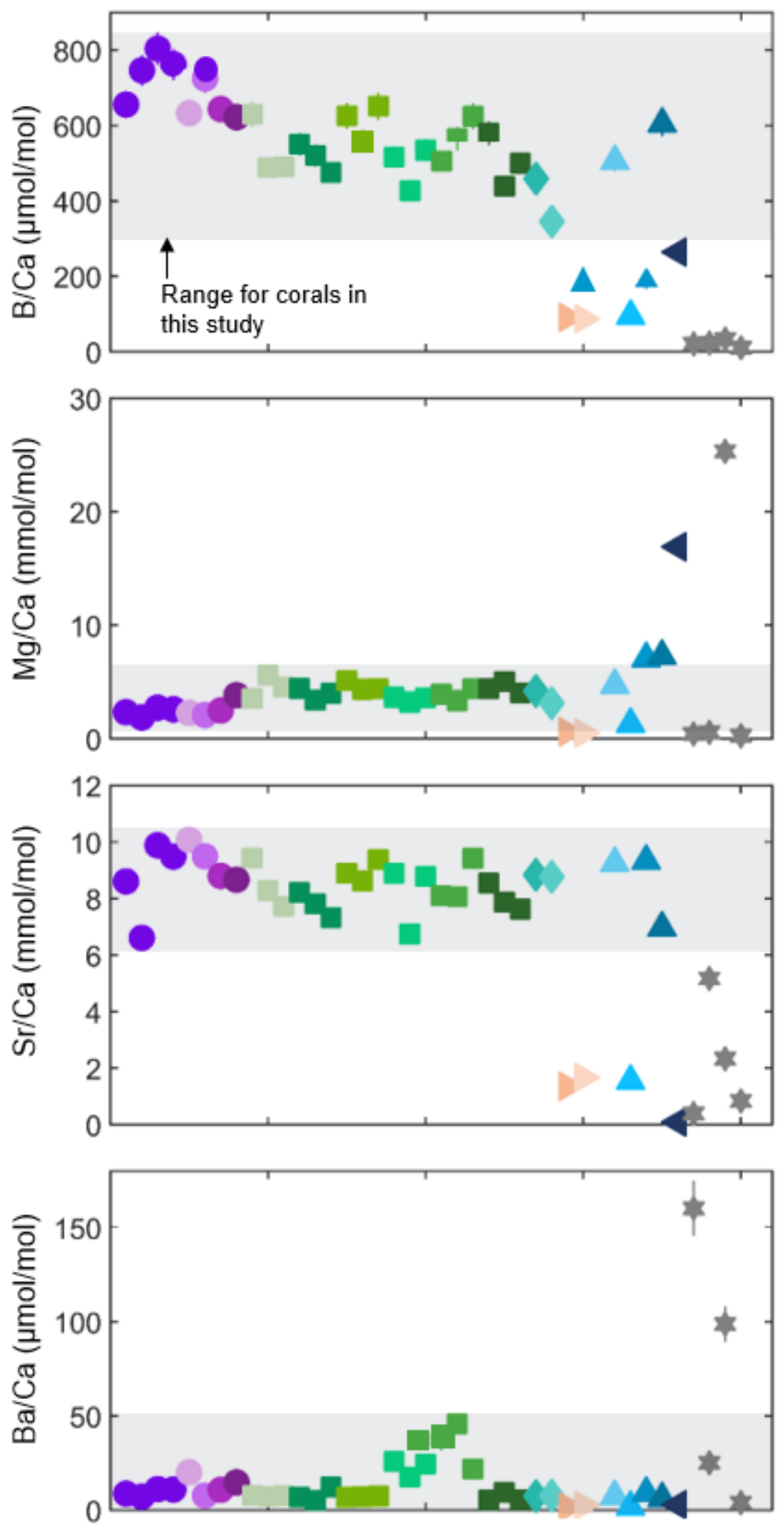

Key

Deep-sea corals

Lophelia pertusa

Flabellum impensum

Enallopsammia rostrata

Flabellum curvatum

Balanophyllia malouensis

\section{Shallow-water corals}

Pocillopora verrucosa

Stylophora pistillata

Orbicella faveolata

Acropora palmata

Acropora cervicornis

Montastrea cavernosa

\section{Reference coral}

- JCp-1 Porites sp.

JCp-1 Porites sp., organic-removed

\section{Other biogenic} aragonite

Pearl

Pearl, organicremoved

\section{Synthetic} aragonites from seawater

f06

$\Delta \mathrm{g} 04$

$\Delta \mathrm{g} 09$

$\Delta \mathrm{h} 01$

\section{$\checkmark$ Synthetic} aragonite from freshwater

\section{Geological} aragonites

FIGURE S2.4. Trace element incorporations into aragonite of different origins as element:Ca ratios, based on measured ${ }^{11} \mathrm{~B},{ }^{24} \mathrm{Mg},{ }^{25} \mathrm{Mg},{ }^{88} \mathrm{Sr}$, and ${ }^{138} \mathrm{Ba}$ concentrations and known element:Ca ratios in the JCp-1 reference coral (Hathorne et al., 2013). 

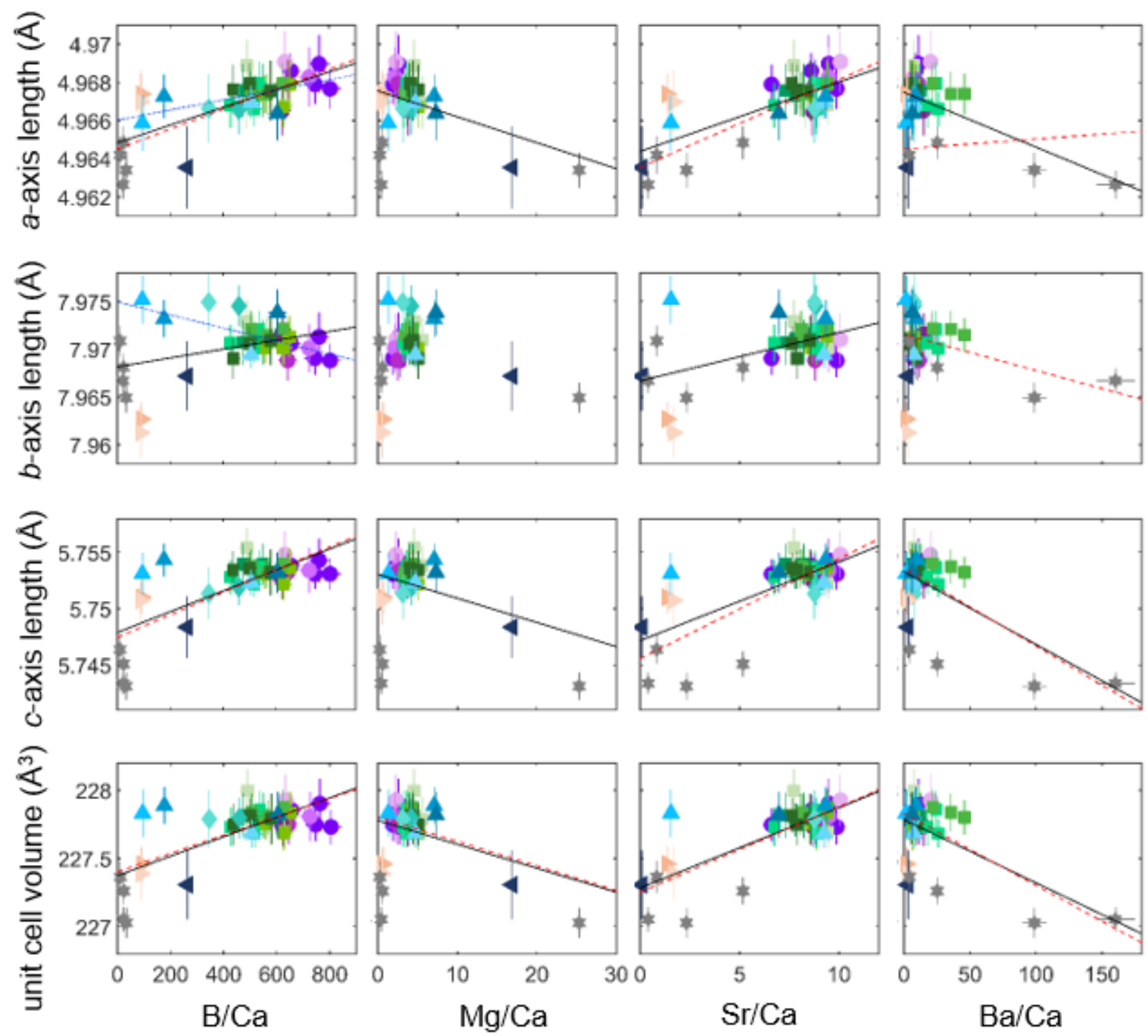

Key

\section{Deep-sea corals \\ - Lophelia pertusa \\ Flabellum impensum \\ Enallopsammia rostrata \\ - Flabellum curvatum \\ Balanophyllia malouensis}

Shallow-water corals

Pocillopora verrucosa

Stylophora pistillata

Orbicella faveolata

Acropora palmata

Acropora cervicomis

Montastrea cavernosa
Reference coral

- JCp-1 Porites sp.

- JCp-1 Porites sp., organic-removed

Other biogenic aragonite

Pearl

Pearl, organicremoved
Synthetic aragonites from seawater

A 06

$\triangle \mathrm{g} 04$

A $\mathrm{g} 09$

$\Delta \mathrm{h} 01$

Synthetic aragonite from freshwater

* Geological aragonites

FIGURE S2.5. Coral crystal lattice parameters as a function of trace element incorporations. 

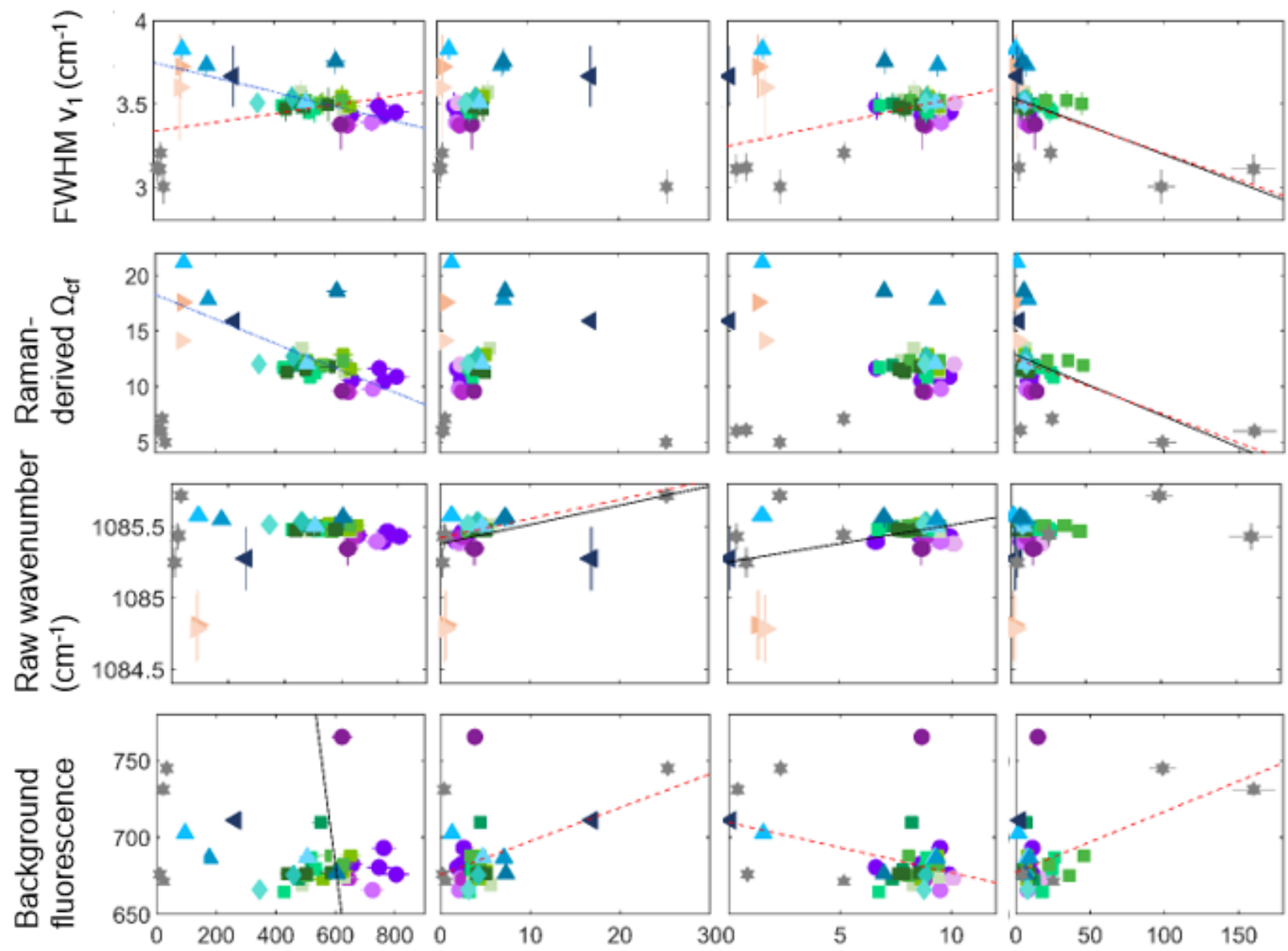

$\mathrm{B} / \mathrm{Ca}(\mu \mathrm{mol} / \mathrm{mol}) \mathrm{Mg} / \mathrm{Ca}(\mathrm{mmol} / \mathrm{mol})$

$\mathrm{Sr} / \mathrm{Ca}(\mathrm{mmol} / \mathrm{mol}) \mathrm{Ba} / \mathrm{Ca}(\mu \mathrm{mol} / \mathrm{mol})$

Key

Deep-sea corals
Lophelia pertusa
Flabellum impensum
Enallopsammia rostrata
Fabellum curvatum
Shallowophyllia malouensis
Pocillopora verrucosa
Stylophora pistillata
Orbicella faveolata
Acropora palmata
Acropora cervicomis
Montastrea cavernosa

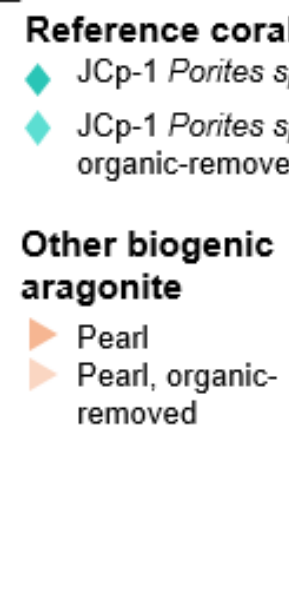

\section{Synthetic} aragonites from seawater

$\triangle \mathrm{f06}$

$\Delta \mathrm{g} 04$

A 09

$\Delta \mathrm{h} 01$

\section{Synthetic aragonite from} freshwater Geological aragonites

FIGURE S2.6. Coral carbonate bonding environments and Raman spectroscopy data as function of trace element incorporations. 


\subsection{Supplementary Materials-TABLES}

TABLE S2.1: Crystal lattice parameters, FWHM of the (111) XRF peak and calcite contents determined by X-ray diffraction and Rietveld refinements for all sample replicates. Errors are estimated standard errors.

\begin{tabular}{|c|c|c|c|c|c|c|c|}
\hline $\begin{array}{l}\text { Sample } \\
\text { Name }\end{array}$ & $\begin{array}{l}\text { a-axis } \\
\text { length } \\
(\AA)\end{array}$ & $\begin{array}{l}\text { b-axis } \\
\text { length } \\
(\AA)\end{array}$ & $\begin{array}{l}\text { c-axis } \\
\text { length } \\
(\AA)\end{array}$ & $\begin{array}{l}\text { unit } \\
\text { cell } \\
\text { volume } \\
(\AA \mathbf{3}) \\
\end{array}$ & $\begin{array}{l}\text { FWHM } \\
(111) \\
\text { peak } \\
\text { (degrees) }\end{array}$ & $\begin{array}{l}\text { calcite } \\
\text { content } \\
\text { (phase \%) }\end{array}$ & $\begin{array}{l}\text { calcite } \\
\text { content } \\
\text { (wt \%) }\end{array}$ \\
\hline \multirow[t]{4}{*}{ LOPH-CAL } & $\begin{array}{l}4.9684 \pm \\
0.0004\end{array}$ & $\begin{array}{l}7.9704 \pm \\
0.0007\end{array}$ & $\begin{array}{l}5.7536 \pm \\
0.0005\end{array}$ & $\begin{array}{l}227.83 \\
\pm 0.05\end{array}$ & $\begin{array}{l}0.3434 \\
\pm 0.003\end{array}$ & $\begin{array}{l}0.32 \pm \\
0.08\end{array}$ & $\begin{array}{l}0.49 \pm \\
0.12\end{array}$ \\
\hline & $\begin{array}{l}4.969 \pm \\
0.0004\end{array}$ & $\begin{array}{l}7.9711 \pm \\
0.0007\end{array}$ & $\begin{array}{l}5.7544 \pm \\
0.0006\end{array}$ & $\begin{array}{l}227.91 \\
\pm 0.05\end{array}$ & $\begin{array}{l}0.3312 \pm \\
0.0021\end{array}$ & $\begin{array}{l}0.29 \pm \\
0.09\end{array}$ & $\begin{array}{l}0.44 \pm \\
0.13\end{array}$ \\
\hline & $\begin{array}{l}4.9684 \pm \\
0.0005\end{array}$ & $\begin{array}{l}7.9704 \pm \\
0.0008\end{array}$ & $\begin{array}{l}5.7538 \pm \\
0.0006\end{array}$ & $\begin{array}{l}227.84 \\
\pm 0.06\end{array}$ & $\begin{array}{l}0.3273 \pm \\
0.0024\end{array}$ & $\begin{array}{l}0.27 \pm \\
0.09\end{array}$ & $\begin{array}{l}0.41 \pm \\
0.14\end{array}$ \\
\hline & $\begin{array}{l}4.9686 \pm \\
0.0005\end{array}$ & $\begin{array}{l}7.9705 \pm \\
0.0008\end{array}$ & $\begin{array}{l}5.7536 \pm \\
0.0006\end{array}$ & $\begin{array}{l}227.84 \\
\pm 0.06 \\
\end{array}$ & $\begin{array}{l}0.3245 \pm \\
0.0022\end{array}$ & $\begin{array}{l}0.31 \pm \\
0.09\end{array}$ & $\begin{array}{l}0.47 \pm \\
0.14\end{array}$ \\
\hline \multirow[t]{4}{*}{ LOPH-GC354 } & $\begin{array}{l}4.9677 \pm \\
0.0005\end{array}$ & $\begin{array}{l}7.9682 \pm \\
0.0008\end{array}$ & $\begin{array}{l}5.7524 \pm \\
0.0006\end{array}$ & $\begin{array}{l}227.69 \\
\pm 0.06 \\
\end{array}$ & $\begin{array}{l}0.3401 \pm \\
0.0031\end{array}$ & $\begin{array}{l}0.5 \pm \\
0.1\end{array}$ & $\begin{array}{l}0.74 \pm \\
0.14\end{array}$ \\
\hline & $\begin{array}{l}4.9679 \pm \\
0.0005\end{array}$ & $\begin{array}{l}7.9692 \pm \\
0.0008\end{array}$ & $\begin{array}{l}5.7534 \pm \\
0.0006\end{array}$ & $\begin{array}{l}227.76 \\
\pm 0.06\end{array}$ & $\begin{array}{l}0.352 \pm \\
0.004\end{array}$ & $\begin{array}{l}0.5 \pm \\
0.09\end{array}$ & $\begin{array}{l}0.74 \pm \\
0.14\end{array}$ \\
\hline & $\begin{array}{l}4.9684 \pm \\
0.0005\end{array}$ & $\begin{array}{l}7.9699 \pm \\
0.0009\end{array}$ & $\begin{array}{l}5.7536 \pm \\
0.0007\end{array}$ & $\begin{array}{l}227.82 \\
\pm 0.06\end{array}$ & $\begin{array}{l}0.3392 \pm \\
0.0024\end{array}$ & $\begin{array}{l}0.54 \pm \\
0.11\end{array}$ & $\begin{array}{l}0.81 \pm \\
0.16\end{array}$ \\
\hline & $\begin{array}{l}4.9676 \pm \\
0.0005\end{array}$ & $\begin{array}{l}7.9689 \pm \\
0.0008\end{array}$ & $\begin{array}{l}5.7529 \pm \\
0.0006\end{array}$ & $\begin{array}{r}227.73 \\
\pm 0.06 \\
\end{array}$ & $\begin{array}{l}0.347 \pm \\
0.003\end{array}$ & $\begin{array}{l}0.32 \pm \\
0.09\end{array}$ & $\begin{array}{l}0.48 \pm \\
0.14\end{array}$ \\
\hline \multirow[t]{4}{*}{ LOPH-GB535 } & $\begin{array}{l}4.9675 \pm \\
0.0008\end{array}$ & $\begin{array}{l}7.9684 \pm \\
0.0013\end{array}$ & $\begin{array}{l}5.7547 \pm \\
0.0011\end{array}$ & $\begin{array}{l}227.78 \\
\pm 0.1\end{array}$ & $\begin{array}{l}0.332 \pm \\
0.0029\end{array}$ & $\begin{array}{l}-0.02 \pm \\
-0.07\end{array}$ & $\begin{array}{l}-0.04 \pm \\
0.11\end{array}$ \\
\hline & $\begin{array}{l}4.9672 \pm \\
0.0004\end{array}$ & $\begin{array}{l}7.968 \pm \\
0.0006\end{array}$ & $\begin{array}{l}5.7518 \pm \\
0.0005\end{array}$ & $\begin{array}{l}227.63 \\
\pm 0.04\end{array}$ & $\begin{array}{l}0.355 \pm \\
0.003\end{array}$ & $\begin{array}{l}0.09 \pm \\
0.03\end{array}$ & $\begin{array}{l}0.13 \pm \\
0.05\end{array}$ \\
\hline & $\begin{array}{l}4.968 \pm \\
0.0004\end{array}$ & $\begin{array}{l}7.9695 \pm \\
0.0006\end{array}$ & $\begin{array}{l}5.7527 \pm \\
0.0005\end{array}$ & $\begin{array}{r}227.75 \\
\pm 0.04 \\
\end{array}$ & $\begin{array}{l}0.375 \pm \\
0.005\end{array}$ & $\begin{array}{l}0.14 \pm \\
0.03\end{array}$ & $\begin{array}{l}0.2 \pm \\
0.05\end{array}$ \\
\hline & $\begin{array}{l}4.9681 \pm \\
0.0004\end{array}$ & $\begin{array}{l}7.9693 \pm \\
0.0006\end{array}$ & $\begin{array}{l}5.7531 \pm \\
0.0005\end{array}$ & $\begin{array}{r}227.76 \\
\pm 0.04 \\
\end{array}$ & $\begin{array}{l}0.361 \pm \\
0.004\end{array}$ & $\begin{array}{l}0.12 \pm \\
0.03 \\
\end{array}$ & $\begin{array}{l}0.17 \pm \\
0.05\end{array}$ \\
\hline \multirow[t]{4}{*}{ LOPH-VK906 } & $\begin{array}{l}4.9689 \pm \\
0.0007\end{array}$ & $\begin{array}{l}7.9706 \pm \\
0.0011\end{array}$ & $\begin{array}{l}5.7544 \pm \\
0.0009\end{array}$ & $\begin{array}{l}227.86 \\
\pm 0.08\end{array}$ & $\begin{array}{l}0.348 \\
\pm 0.003\end{array}$ & $\begin{array}{l}-0.04 \\
\pm-0.07\end{array}$ & $\begin{array}{l}-0.06 \pm \\
0.1\end{array}$ \\
\hline & $\begin{array}{l}4.9689 \pm \\
0.0007\end{array}$ & $\begin{array}{l}7.9713 \pm \\
0.0012\end{array}$ & $\begin{array}{l}5.7539 \pm \\
0.0009\end{array}$ & $\begin{array}{l}227.89 \\
\pm 0.09\end{array}$ & $\begin{array}{l}0.348 \\
\pm 0.003\end{array}$ & $\begin{array}{l}-0.13 \\
\pm-0.08\end{array}$ & $\begin{array}{l}-0.2 \pm \\
0.11\end{array}$ \\
\hline & $\begin{array}{l}4.9686 \pm \\
0.0008\end{array}$ & $\begin{array}{l}7.9711 \pm \\
0.0013\end{array}$ & $\begin{array}{l}5.7541 \pm \\
0.001\end{array}$ & $\begin{array}{l}227.88 \\
\pm 0.09 \\
\end{array}$ & $\begin{array}{l}0.361 \\
\pm 0.005\end{array}$ & $\begin{array}{l}-0.13 \\
\pm-0.08\end{array}$ & $\begin{array}{l}-0.2 \pm \\
0.12\end{array}$ \\
\hline & $\begin{array}{l}4.9695 \pm \\
0.0008\end{array}$ & $\begin{array}{l}7.9723 \pm \\
0.0013\end{array}$ & $\begin{array}{l}5.7548 \pm \\
0.001\end{array}$ & $\begin{array}{l}227.98 \\
\pm 0.09 \\
\end{array}$ & $\begin{array}{l}0.3429 \pm \\
0.0029\end{array}$ & $\begin{array}{l}-0.07 \pm \\
0.08\end{array}$ & $\begin{array}{l}-0.1 \pm \\
0.12\end{array}$ \\
\hline LMG15-09 & $\begin{array}{l}4.9687 \pm \\
0.0007\end{array}$ & $\begin{array}{l}7.9707 \pm \\
0.0012\end{array}$ & $\begin{array}{l}5.7546 \pm \\
0.0009\end{array}$ & $\begin{array}{r}227.89 \\
\pm 0.08\end{array}$ & $\begin{array}{l}0.3389 \pm \\
0.003\end{array}$ & $\begin{array}{l}-0.03 \pm \\
0.07\end{array}$ & $\begin{array}{l}-0.05 \pm \\
0.11\end{array}$ \\
\hline
\end{tabular}




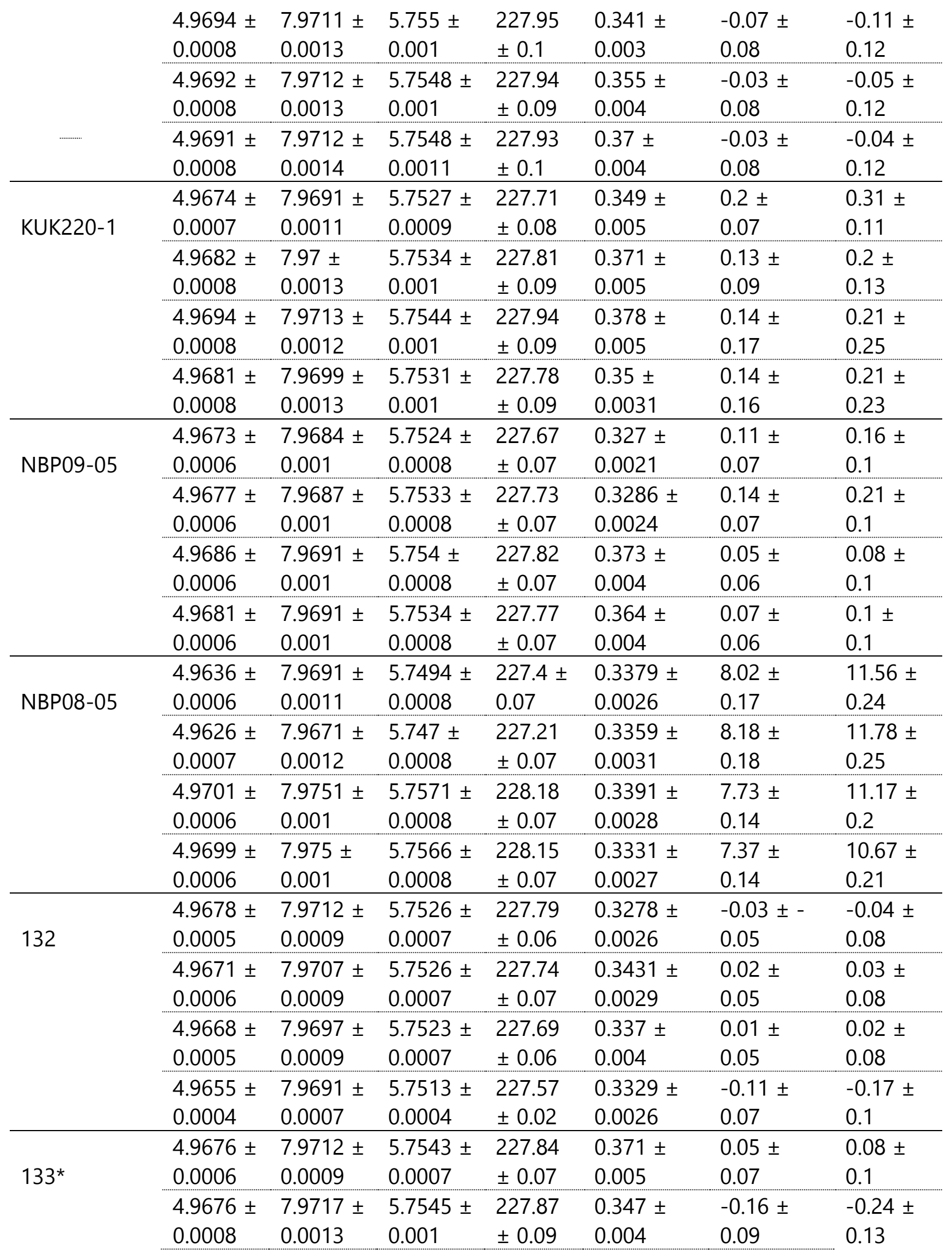




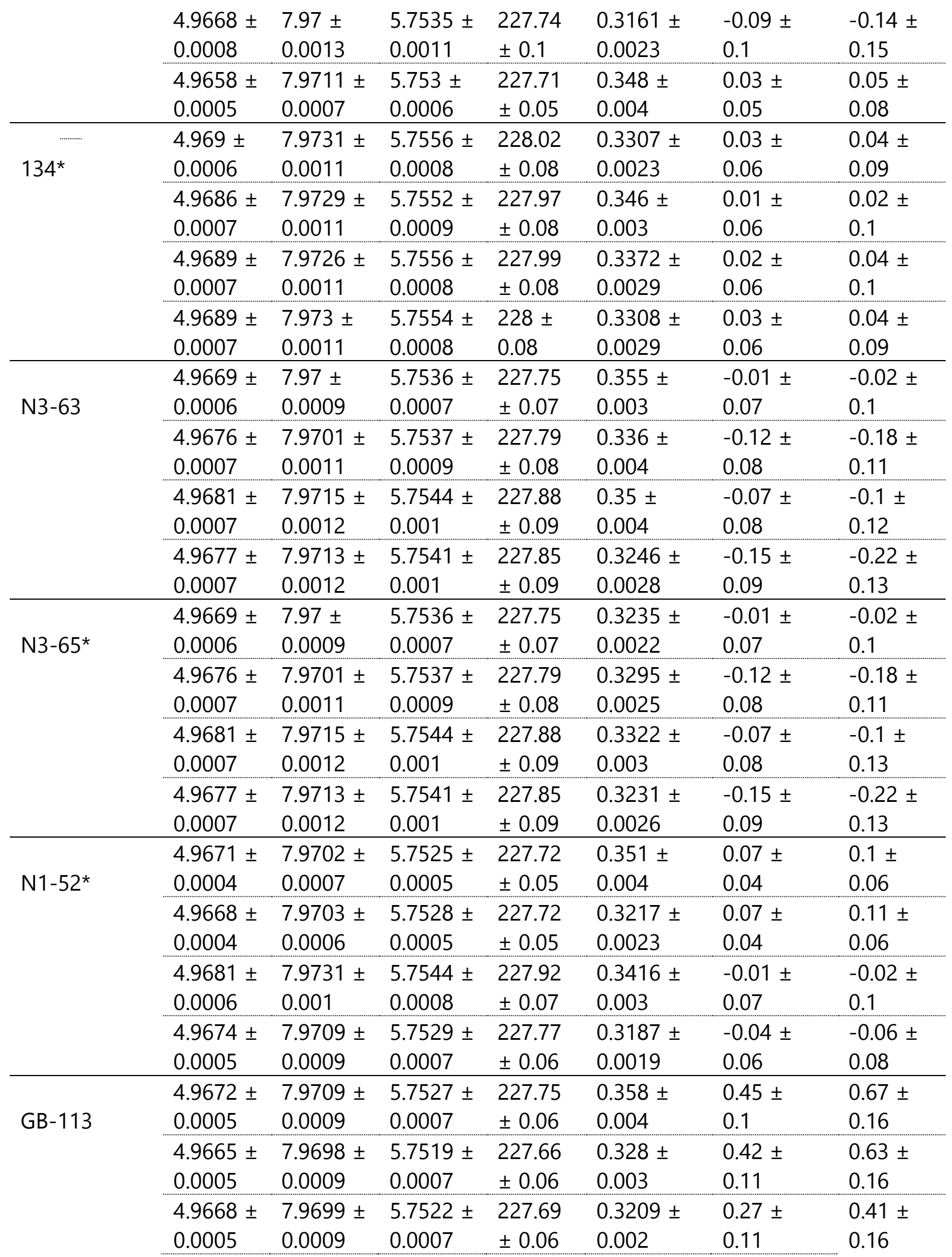




\begin{tabular}{|c|c|c|c|c|c|c|c|}
\hline & $\begin{array}{l}4.9663 \pm \\
0.0005\end{array}$ & $\begin{array}{l}7.9698 \pm \\
0.0009\end{array}$ & $\begin{array}{l}5.7519 \pm \\
0.0007\end{array}$ & $\begin{array}{l}227.65 \\
\pm 0.06\end{array}$ & $\begin{array}{l}0.328 \pm \\
0.0023\end{array}$ & $\begin{array}{l}0.32 \pm \\
0.1\end{array}$ & $\begin{array}{l}0.48 \pm \\
0.15\end{array}$ \\
\hline \multirow[t]{4}{*}{ GB-148* } & $\begin{array}{l}4.9674 \pm \\
0.0004\end{array}$ & $\begin{array}{l}7.9698 \pm \\
0.0006\end{array}$ & $\begin{array}{l}5.7531 \pm \\
0.0005\end{array}$ & $\begin{array}{r}227.75 \\
\pm 0.05\end{array}$ & $\begin{array}{l}0.348 \pm \\
0.004\end{array}$ & $\begin{array}{l}0.08 \pm \\
0.04\end{array}$ & $\begin{array}{l}0.12 \pm \\
0.06\end{array}$ \\
\hline & $\begin{array}{l}4.9674 \pm \\
0.0004\end{array}$ & $\begin{array}{l}7.9704 \pm \\
0.0007\end{array}$ & $\begin{array}{l}5.7533 \pm \\
0.0006\end{array}$ & $\begin{array}{l}227.77 \\
\pm 0.05\end{array}$ & $\begin{array}{l}0.339 \pm \\
0.004\end{array}$ & $\begin{array}{l}0.06 \pm \\
0.05\end{array}$ & $\begin{array}{l}0.08 \pm \\
0.07\end{array}$ \\
\hline & $\begin{array}{l}4.9674 \pm \\
0.0005\end{array}$ & $\begin{array}{l}7.9704 \pm \\
0.0008\end{array}$ & $\begin{array}{l}5.7531 \pm \\
0.0006\end{array}$ & $\begin{array}{l}227.77 \\
\pm 0.06\end{array}$ & $\begin{array}{l}0.341 \pm \\
0.003\end{array}$ & $\begin{array}{l}-0.01 \pm \\
0.05\end{array}$ & $\begin{array}{l}-0.02 \pm \\
0.08\end{array}$ \\
\hline & $\begin{array}{l}4.9672 \pm \\
0.0005\end{array}$ & $\begin{array}{l}7.9699 \pm \\
0.0009\end{array}$ & $\begin{array}{l}5.7526 \pm \\
0.0007\end{array}$ & $\begin{array}{r}227.72 \\
\pm 0.06\end{array}$ & $\begin{array}{l}0.3186 \pm \\
0.0022\end{array}$ & $\begin{array}{l}-0.04 \pm \\
0.06\end{array}$ & $\begin{array}{l}-0.06 \pm \\
0.09\end{array}$ \\
\hline \multirow[t]{4}{*}{ GB-174* } & $\begin{array}{l}4.9677 \pm \\
0.0006\end{array}$ & $\begin{array}{l}7.9712 \pm \\
0.001\end{array}$ & $\begin{array}{l}5.7535 \pm \\
0.0008\end{array}$ & $\begin{array}{l}227.82 \\
\pm 0.07\end{array}$ & $\begin{array}{l}0.3376 \pm \\
0.003\end{array}$ & $\begin{array}{l}0.09 \pm \\
0.06\end{array}$ & $\begin{array}{l}0.14 \pm \\
0.09\end{array}$ \\
\hline & $\begin{array}{l}4.9679 \pm \\
0.0006\end{array}$ & $\begin{array}{l}7.9711 \pm \\
0.001\end{array}$ & $\begin{array}{l}5.7539 \pm \\
0.0008\end{array}$ & $\begin{array}{l}227.84 \\
\pm 0.07\end{array}$ & $\begin{array}{l}0.335 \pm \\
0.003\end{array}$ & $\begin{array}{l}0.05 \pm \\
0.06\end{array}$ & $\begin{array}{l}0.08 \pm \\
0.1\end{array}$ \\
\hline & $\begin{array}{l}4.9683 \pm \\
0.0007\end{array}$ & $\begin{array}{l}7.9713 \pm \\
0.0011\end{array}$ & $\begin{array}{l}5.7536 \pm \\
0.0008\end{array}$ & $\begin{array}{r}227.85 \\
\pm 0.08\end{array}$ & $\begin{array}{l}0.339 \pm \\
0.003\end{array}$ & $\begin{array}{l}0.02 \pm \\
0.06\end{array}$ & $\begin{array}{l}0.04 \pm \\
0.1\end{array}$ \\
\hline & $\begin{array}{l}4.9677 \pm \\
0.0007\end{array}$ & $\begin{array}{l}7.9716 \pm \\
0.0011\end{array}$ & $\begin{array}{l}5.7536 \pm \\
0.0009\end{array}$ & $\begin{array}{l}227.84 \\
\pm 0.08 \\
\end{array}$ & $\begin{array}{l}0.343 \pm \\
0.003\end{array}$ & $\begin{array}{l}0.01 \pm \\
0.07\end{array}$ & $\begin{array}{l}0.02 \pm \\
0.1\end{array}$ \\
\hline \multirow[t]{4}{*}{ GB-144 } & $\begin{array}{l}4.9666 \pm \\
0.0005\end{array}$ & $\begin{array}{l}7.9699 \pm \\
0.0008\end{array}$ & $\begin{array}{l}5.7522 \pm \\
0.0006\end{array}$ & $\begin{array}{l}227.68 \\
\pm 0.05\end{array}$ & $\begin{array}{l}0.337 \pm \\
0.003\end{array}$ & $\begin{array}{l}-0.03 \pm \\
0.05\end{array}$ & $\begin{array}{l}-0.04 \pm \\
0.07\end{array}$ \\
\hline & $\begin{array}{l}4.967 \pm \\
0.0005\end{array}$ & $\begin{array}{l}7.971 \pm \\
0.0008\end{array}$ & $\begin{array}{l}5.7527 \pm \\
0.0006\end{array}$ & $\begin{array}{r}227.75 \\
\pm 0.05\end{array}$ & $\begin{array}{l}0.339 \pm \\
0.004\end{array}$ & $\begin{array}{l}-0.03 \pm \\
0.05\end{array}$ & $\begin{array}{l}-0.04 \pm \\
0.07\end{array}$ \\
\hline & $\begin{array}{l}4.9662 \pm \\
0.0004\end{array}$ & $\begin{array}{l}7.9691 \pm \\
0.0007\end{array}$ & $\begin{array}{l}5.7516 \pm \\
0.0005\end{array}$ & $\begin{array}{l}227.61 \\
\pm 0.05\end{array}$ & $\begin{array}{l}0.3317 \pm \\
0.0026\end{array}$ & $\begin{array}{l}0.08 \pm \\
0.04\end{array}$ & $\begin{array}{l}0.12 \pm \\
0.06\end{array}$ \\
\hline & $\begin{array}{l}4.9666 \pm \\
0.0004\end{array}$ & $\begin{array}{l}7.9703 \pm \\
0.0006\end{array}$ & $\begin{array}{l}5.7523 \pm \\
0.0005\end{array}$ & $\begin{array}{l}227.69 \\
\pm 0.05 \\
\end{array}$ & $\begin{array}{l}0.3277 \pm \\
0.0026\end{array}$ & $\begin{array}{l}0.01 \pm \\
0.04 \\
\end{array}$ & $\begin{array}{l}0.02 \pm \\
0.06\end{array}$ \\
\hline \multirow[t]{4}{*}{ GB-145* } & $\begin{array}{l}4.9668 \pm \\
0.0006\end{array}$ & $\begin{array}{l}7.9708 \pm \\
0.001\end{array}$ & $\begin{array}{l}5.753 \pm \\
0.0008\end{array}$ & $\begin{array}{l}227.74 \\
\pm 0.07 \\
\end{array}$ & $\begin{array}{l}0.336 \pm \\
0.004\end{array}$ & $\begin{array}{l}-0.02 \pm \\
0.06\end{array}$ & $\begin{array}{l}-0.03 \pm \\
0.09\end{array}$ \\
\hline & $\begin{array}{l}4.9669 \pm \\
0.0006\end{array}$ & $\begin{array}{l}7.9703 \pm \\
0.001\end{array}$ & $\begin{array}{l}5.7527 \pm \\
0.0008\end{array}$ & $\begin{array}{r}227.72 \\
\pm 0.07\end{array}$ & $\begin{array}{l}0.338 \pm \\
0.003\end{array}$ & $\begin{array}{l}-0.02 \pm \\
0.06\end{array}$ & $\begin{array}{l}-0.04 \pm \\
0.09\end{array}$ \\
\hline & $\begin{array}{l}4.9667 \pm \\
0.0006\end{array}$ & $\begin{array}{l}7.9707 \pm \\
0.0009\end{array}$ & $\begin{array}{l}5.7528 \pm \\
0.0007\end{array}$ & $\begin{array}{r}227.73 \\
\pm 0.07\end{array}$ & $\begin{array}{l}0.3263 \pm \\
0.0026\end{array}$ & $\begin{array}{l}0.01 \pm \\
0.06\end{array}$ & $\begin{array}{l}0.02 \pm \\
0.09\end{array}$ \\
\hline & $\begin{array}{l}4.9667 \pm \\
0.0006\end{array}$ & $\begin{array}{l}7.9707 \pm \\
0.0009\end{array}$ & $\begin{array}{l}5.7528 \pm \\
0.0007\end{array}$ & $\begin{array}{r}227.73 \\
\pm 0.07 \\
\end{array}$ & $\begin{array}{l}0.3318 \pm \\
0.0025\end{array}$ & $\begin{array}{l}0.01 \pm \\
0.06 \\
\end{array}$ & $\begin{array}{l}0.02 \pm \\
0.09\end{array}$ \\
\hline \multirow[t]{4}{*}{ GB-146* } & $\begin{array}{l}4.9683 \pm \\
0.0006\end{array}$ & $\begin{array}{l}7.9724 \pm \\
0.001\end{array}$ & $\begin{array}{l}5.7543 \pm \\
0.0008\end{array}$ & $\begin{array}{l}227.91 \\
\pm 0.07 \\
\end{array}$ & $\begin{array}{l}0.3155 \pm \\
0.0019\end{array}$ & $\begin{array}{l}0 \pm \\
0.06\end{array}$ & $\begin{array}{l}0 \pm \\
0.09\end{array}$ \\
\hline & $\begin{array}{l}4.9679 \pm \\
0.0006\end{array}$ & $\begin{array}{l}7.9723 \pm \\
0.001\end{array}$ & $\begin{array}{l}5.7536 \pm \\
0.0008\end{array}$ & $\begin{array}{r}227.86 \\
\pm 0.07\end{array}$ & $\begin{array}{l}0.331 \pm \\
0.003\end{array}$ & $\begin{array}{l}-0.05 \pm \\
0.06\end{array}$ & $\begin{array}{l}-0.07 \pm \\
0.09\end{array}$ \\
\hline & $\begin{array}{l}4.968 \pm \\
0.0006\end{array}$ & $\begin{array}{l}7.9719 \pm \\
0.0009\end{array}$ & $\begin{array}{l}5.7534 \pm \\
0.0007\end{array}$ & $\begin{array}{r}227.85 \\
\pm 0.07\end{array}$ & $\begin{array}{l}0.3087 \pm \\
0.0014\end{array}$ & $\begin{array}{l}-0.04 \pm \\
0.05\end{array}$ & $\begin{array}{l}-0.07 \pm \\
0.08\end{array}$ \\
\hline & $\begin{array}{l}4.9675 \pm \\
0.0005\end{array}$ & $\begin{array}{l}7.9716 \pm \\
0.0009\end{array}$ & $\begin{array}{l}5.7534 \pm \\
0.0007\end{array}$ & $\begin{array}{l}227.82 \\
\pm 0.06\end{array}$ & $\begin{array}{l}0.3167 \pm \\
0.002\end{array}$ & $\begin{array}{l}-0.02 \pm \\
0.05\end{array}$ & $\begin{array}{l}-0.03 \pm \\
0.08\end{array}$ \\
\hline
\end{tabular}




\begin{tabular}{|c|c|c|c|c|c|c|c|}
\hline \multirow[t]{2}{*}{ GQ-47 } & $\begin{array}{l}4.9672 \pm \\
0.0005\end{array}$ & $\begin{array}{l}7.9718 \pm \\
0.0008\end{array}$ & $\begin{array}{l}5.7534 \pm \\
0.0006\end{array}$ & $\begin{array}{l}227.81 \\
\pm 0.05\end{array}$ & $\begin{array}{l}0.3369 \pm \\
0.0029\end{array}$ & $\begin{array}{l}-0.01 \pm \\
0.05\end{array}$ & $\begin{array}{l}-0.01 \pm \\
0.07\end{array}$ \\
\hline & $\begin{array}{l}4.9666 \pm \\
0.0005\end{array}$ & $\begin{array}{l}7.971 \pm \\
0.0008\end{array}$ & $\begin{array}{l}5.7525 \pm \\
0.0006\end{array}$ & $\begin{array}{r}227.72 \\
\pm 0.06\end{array}$ & $\begin{array}{l}0.347 \pm \\
0.004\end{array}$ & $\begin{array}{l}0.01 \pm \\
0.05\end{array}$ & $\begin{array}{l}0.02 \pm \\
0.07\end{array}$ \\
\hline \multirow[t]{2}{*}{-} & $\begin{array}{l}4.968 \pm \\
0.0006\end{array}$ & $\begin{array}{l}7.973 \pm \\
0.001\end{array}$ & $\begin{array}{l}5.7544 \pm \\
0.0008\end{array}$ & $\begin{array}{r}227.92 \\
\pm 0.07 \\
\end{array}$ & $\begin{array}{l}0.342 \pm \\
0.003\end{array}$ & $\begin{array}{l}-0.01 \pm \\
0.07\end{array}$ & $\begin{array}{l}-0.02 \pm \\
0.1\end{array}$ \\
\hline & $\begin{array}{l}4.9677 \pm \\
0.0007\end{array}$ & $\begin{array}{l}7.9726 \pm \\
0.0012\end{array}$ & $\begin{array}{l}5.7547 \pm \\
0.0009\end{array}$ & $\begin{array}{l}227.9 \pm \\
0.08\end{array}$ & $\begin{array}{l}0.334 \pm \\
0.004\end{array}$ & $\begin{array}{l}-0.1 \pm \\
0.08\end{array}$ & $\begin{array}{l}-0.16 \pm \\
0.11\end{array}$ \\
\hline \multirow[t]{4}{*}{ GQ-48* } & $\begin{array}{l}4.9677 \pm \\
0.0005\end{array}$ & $\begin{array}{l}7.9719 \pm \\
0.0008\end{array}$ & $\begin{array}{l}5.7539 \pm \\
0.0006\end{array}$ & $\begin{array}{r}227.85 \\
\pm 0.06 \\
\end{array}$ & $\begin{array}{l}0.339 \pm \\
0.003\end{array}$ & $\begin{array}{l}0 \pm \\
0.06\end{array}$ & $\begin{array}{l}0 \pm \\
0.08\end{array}$ \\
\hline & $\begin{array}{l}4.9678 \pm \\
0.0005\end{array}$ & $\begin{array}{l}7.9727 \pm \\
0.0008\end{array}$ & $\begin{array}{l}5.7537 \pm \\
0.0006\end{array}$ & $\begin{array}{r}227.87 \\
\pm 0.06 \\
\end{array}$ & $\begin{array}{l}0.319 \pm \\
0.0022\end{array}$ & $\begin{array}{l}0.01 \pm \\
0.06\end{array}$ & $\begin{array}{l}0.01 \pm \\
0.09\end{array}$ \\
\hline & $\begin{array}{l}4.9671 \pm \\
0.0006\end{array}$ & $\begin{array}{l}7.9707 \pm \\
0.0009\end{array}$ & $\begin{array}{l}5.7528 \pm \\
0.0007\end{array}$ & $\begin{array}{r}227.75 \\
\pm 0.07 \\
\end{array}$ & $\begin{array}{l}0.337 \pm \\
0.003\end{array}$ & $\begin{array}{l}0.07 \pm \\
0.05\end{array}$ & $\begin{array}{l}0.1 \pm \\
0.08\end{array}$ \\
\hline & $\begin{array}{l}4.967 \pm \\
0.0006\end{array}$ & $\begin{array}{l}7.9707 \pm \\
0.0009\end{array}$ & $\begin{array}{l}5.7525 \pm \\
0.0007\end{array}$ & $\begin{array}{r}227.73 \\
\pm 0.07 \\
\end{array}$ & $\begin{array}{l}0.34 \pm \\
0.0029 \\
\end{array}$ & $\begin{array}{l}0.03 \pm \\
0.05 \\
\end{array}$ & $\begin{array}{l}0.05 \pm \\
0.08\end{array}$ \\
\hline \multirow[t]{4}{*}{ GQ-50* } & $\begin{array}{l}4.9686 \pm \\
0.0005\end{array}$ & $\begin{array}{l}7.9727 \pm \\
0.0008\end{array}$ & $\begin{array}{l}5.755 \pm \\
0.0006\end{array}$ & $\begin{array}{l}227.96 \\
\pm 0.06\end{array}$ & $\begin{array}{l}0.3408 \pm \\
0.0024\end{array}$ & $\begin{array}{l}0.13 \pm \\
0.05\end{array}$ & $\begin{array}{l}0.19 \pm \\
0.08\end{array}$ \\
\hline & $\begin{array}{l}4.9681 \pm \\
0.0005\end{array}$ & $\begin{array}{l}7.9723 \pm \\
0.0009\end{array}$ & $\begin{array}{l}5.7541 \pm \\
0.0007\end{array}$ & $\begin{array}{r}227.89 \\
\pm 0.06 \\
\end{array}$ & $\begin{array}{l}0.353 \pm \\
0.003\end{array}$ & $\begin{array}{l}0.14 \pm \\
0.09\end{array}$ & $\begin{array}{l}0.21 \pm \\
0.14\end{array}$ \\
\hline & $\begin{array}{l}4.9677 \pm \\
0.0005\end{array}$ & $\begin{array}{l}7.9723 \pm \\
0.0009\end{array}$ & $\begin{array}{l}5.7538 \pm \\
0.0007\end{array}$ & $\begin{array}{r}227.86 \\
\pm 0.06 \\
\end{array}$ & $\begin{array}{l}0.3471 \pm \\
0.0026\end{array}$ & $\begin{array}{l}0.12 \pm \\
0.05\end{array}$ & $\begin{array}{l}0.18 \pm \\
0.07\end{array}$ \\
\hline & $\begin{array}{l}4.9674 \pm \\
0.0005\end{array}$ & $\begin{array}{l}7.9715 \pm \\
0.0009\end{array}$ & $\begin{array}{l}5.7532 \pm \\
0.0007\end{array}$ & $\begin{array}{l}227.8 \pm \\
0.06\end{array}$ & $\begin{array}{l}0.3371 \pm \\
0.0026\end{array}$ & $\begin{array}{l}0.14 \pm \\
0.09\end{array}$ & $\begin{array}{l}0.21 \pm \\
0.14\end{array}$ \\
\hline \multirow[t]{4}{*}{ GB-103 } & $\begin{array}{l}4.9675 \pm \\
0.0006\end{array}$ & $\begin{array}{l}7.9707 \pm \\
0.001\end{array}$ & $\begin{array}{l}5.7533 \pm \\
0.0008\end{array}$ & $\begin{array}{r}227.79 \\
\pm 0.07\end{array}$ & $\begin{array}{l}0.3377 \pm \\
0.0024\end{array}$ & $\begin{array}{l}0.19 \pm \\
0.13\end{array}$ & $\begin{array}{l}0.29 \pm \\
0.19\end{array}$ \\
\hline & $\begin{array}{l}4.9672 \pm \\
0.0006\end{array}$ & $\begin{array}{l}7.9706 \pm \\
0.0009\end{array}$ & $\begin{array}{l}5.7527 \pm \\
0.0007\end{array}$ & $\begin{array}{r}227.75 \\
\pm 0.07 \\
\end{array}$ & $\begin{array}{l}0.3298 \pm \\
0.002\end{array}$ & $\begin{array}{l}0.2 \pm \\
0.11\end{array}$ & $\begin{array}{l}0.3 \pm \\
0.17\end{array}$ \\
\hline & $\begin{array}{l}4.9672 \pm \\
0.0008\end{array}$ & $\begin{array}{l}7.9699 \pm \\
0.0013\end{array}$ & $\begin{array}{l}5.7528 \pm \\
0.001\end{array}$ & $\begin{array}{l}227.73 \\
\pm 0.09\end{array}$ & $\begin{array}{l}0.329 \pm \\
0.003\end{array}$ & $\begin{array}{l}0.2 \pm \\
0.1\end{array}$ & $\begin{array}{l}0.3 \pm \\
0.14\end{array}$ \\
\hline & $\begin{array}{l}4.9683 \pm \\
0.001\end{array}$ & $\begin{array}{l}7.9725 \pm \\
0.0017\end{array}$ & $\begin{array}{l}5.7541 \pm \\
0.0013\end{array}$ & $\begin{array}{r}227.91 \\
\pm 0.12 \\
\end{array}$ & $\begin{array}{l}0.323 \pm \\
0.005\end{array}$ & $\begin{array}{l}-0.09 \pm \\
0.12\end{array}$ & $\begin{array}{l}-0.14 \pm \\
0.19\end{array}$ \\
\hline \multirow[t]{4}{*}{ GB-105* } & $\begin{array}{l}4.9678 \pm \\
0.0006\end{array}$ & $\begin{array}{l}7.9693 \pm \\
0.0011\end{array}$ & $\begin{array}{l}5.7537 \pm \\
0.0008\end{array}$ & $\begin{array}{r}227.78 \\
\pm 0.08 \\
\end{array}$ & $\begin{array}{l}0.335 \pm \\
0.004\end{array}$ & $\begin{array}{l}-0.04 \pm \\
0.06\end{array}$ & $\begin{array}{l}-0.06 \pm \\
0.09\end{array}$ \\
\hline & $\begin{array}{l}4.9679 \pm \\
0.0006\end{array}$ & $\begin{array}{l}7.9689 \pm \\
0.0011\end{array}$ & $\begin{array}{l}5.7537 \pm \\
0.0008\end{array}$ & $\begin{array}{r}227.77 \\
\pm 0.08 \\
\end{array}$ & $\begin{array}{l}0.342 \pm \\
0.003\end{array}$ & $\begin{array}{l}-0.02 \pm \\
0.06\end{array}$ & $\begin{array}{l}-0.03 \pm \\
0.09\end{array}$ \\
\hline & $\begin{array}{l}4.9676 \pm \\
0.0006\end{array}$ & $\begin{array}{l}7.969 \pm \\
0.001\end{array}$ & $\begin{array}{l}5.7531 \pm \\
0.0008\end{array}$ & $\begin{array}{r}227.73 \\
\pm 0.07\end{array}$ & $\begin{array}{l}0.332 \pm \\
0.003\end{array}$ & $\begin{array}{l}-0.02 \pm \\
0.06\end{array}$ & $\begin{array}{l}-0.04 \pm \\
0.09\end{array}$ \\
\hline & $\begin{array}{l}4.9672 \pm \\
0.0006\end{array}$ & $\begin{array}{l}7.969 \pm \\
0.001\end{array}$ & $\begin{array}{l}5.7533 \pm \\
0.0008\end{array}$ & $\begin{array}{r}227.72 \\
\pm 0.07 \\
\end{array}$ & $\begin{array}{l}0.3193 \pm \\
0.0022\end{array}$ & $\begin{array}{l}-0.02 \pm \\
0.06\end{array}$ & $\begin{array}{l}-0.03 \pm \\
0.09\end{array}$ \\
\hline GB-141* & $\begin{array}{l}4.9674 \pm \\
0.0005\end{array}$ & $\begin{array}{l}7.9701 \pm \\
0.0008\end{array}$ & $\begin{array}{l}5.7531 \pm \\
0.0006\end{array}$ & $\begin{array}{l}227.76 \\
\pm 0.06\end{array}$ & $\begin{array}{l}0.343 \pm \\
0.003\end{array}$ & $\begin{array}{l}0.3 \pm \\
0.09\end{array}$ & $\begin{array}{l}0.45 \pm \\
0.12\end{array}$ \\
\hline
\end{tabular}




\begin{tabular}{|c|c|c|c|c|c|c|c|}
\hline \multirow[b]{3}{*}{ 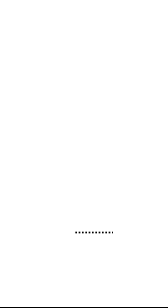 } & $\begin{array}{l}4.9678 \pm \\
0.0005\end{array}$ & $\begin{array}{l}7.9703 \pm \\
0.0009\end{array}$ & $\begin{array}{l}5.7531 \pm \\
0.0007\end{array}$ & $\begin{array}{l}227.78 \\
\pm 0.06\end{array}$ & $\begin{array}{l}0.3396 \pm \\
0.0025\end{array}$ & $\begin{array}{l}0.21 \pm \\
0.09\end{array}$ & $\begin{array}{l}0.32 \pm \\
0.14\end{array}$ \\
\hline & $\begin{array}{l}4.9681 \pm \\
0.0005\end{array}$ & $\begin{array}{l}7.971 \pm \\
0.0009\end{array}$ & $\begin{array}{l}5.754 \pm \\
0.0007\end{array}$ & $\begin{array}{r}227.85 \\
\pm 0.06\end{array}$ & $\begin{array}{l}0.3383 \pm \\
0.0027\end{array}$ & $\begin{array}{l}0.13 \pm \\
0.1\end{array}$ & $\begin{array}{l}0.2 \pm \\
0.15\end{array}$ \\
\hline & $\begin{array}{l}4.9684 \pm \\
0.0006\end{array}$ & $\begin{array}{l}7.971 \pm \\
0.001\end{array}$ & $\begin{array}{l}5.7541 \pm \\
0.0007\end{array}$ & $\begin{array}{r}227.87 \\
\pm 0.07 \\
\end{array}$ & $\begin{array}{l}0.3265 \pm \\
0.0022\end{array}$ & $\begin{array}{l}0.14 \pm \\
0.11\end{array}$ & $\begin{array}{l}0.21 \pm \\
0.16\end{array}$ \\
\hline \multirow[t]{4}{*}{$J C p-1^{*}$} & $\begin{array}{l}4.9675 \pm \\
0.0007\end{array}$ & $\begin{array}{l}7.9768 \pm \\
0.0011\end{array}$ & $\begin{array}{l}5.7529 \pm \\
0.0008\end{array}$ & $\begin{array}{l}227.94 \\
\pm 0.08\end{array}$ & $\begin{array}{l}0.3458 \pm \\
0.0021\end{array}$ & $\begin{array}{l}1.04 \pm \\
0.12\end{array}$ & $\begin{array}{l}1.56 \pm \\
0.17\end{array}$ \\
\hline & $\begin{array}{l}4.9664 \pm \\
0.0006\end{array}$ & $\begin{array}{l}7.9739 \pm \\
0.0011\end{array}$ & $\begin{array}{l}5.7515 \pm \\
0.0008\end{array}$ & $\begin{array}{r}227.75 \\
\pm 0.07\end{array}$ & $\begin{array}{l}0.3435 \pm \\
0.002\end{array}$ & $\begin{array}{l}1.09 \pm \\
0.11\end{array}$ & $\begin{array}{l}1.62 \pm \\
0.17\end{array}$ \\
\hline & $\begin{array}{l}4.9661 \pm \\
0.0006\end{array}$ & $\begin{array}{l}7.9738 \pm \\
0.001\end{array}$ & $\begin{array}{l}5.7516 \pm \\
0.0008\end{array}$ & $\begin{array}{l}227.74 \\
\pm 0.07\end{array}$ & $\begin{array}{l}0.3479 \pm \\
0.0019\end{array}$ & $\begin{array}{l}1.06 \pm \\
0.1\end{array}$ & $\begin{array}{l}1.59 \pm \\
0.16\end{array}$ \\
\hline & $\begin{array}{l}4.9663 \pm \\
0.0006\end{array}$ & $\begin{array}{l}7.9737 \pm \\
0.001\end{array}$ & $\begin{array}{l}5.7516 \pm \\
0.0008\end{array}$ & $\begin{array}{r}227.75 \\
\pm 0.07 \\
\end{array}$ & $\begin{array}{l}0.3529 \pm \\
0.002\end{array}$ & $\begin{array}{l}1.11 \pm \\
0.11\end{array}$ & $\begin{array}{l}1.65 \pm \\
0.16\end{array}$ \\
\hline \multirow[t]{4}{*}{$\begin{array}{l}\text { JCp-1 } \\
\text { organic- } \\
\text { removed }\end{array}$} & $\begin{array}{l}4.9668 \pm \\
0.0009\end{array}$ & $\begin{array}{l}7.9748 \pm \\
0.0016\end{array}$ & $\begin{array}{l}5.7514 \pm \\
0.0012\end{array}$ & $\begin{array}{l}227.8 \pm \\
0.11\end{array}$ & $\begin{array}{l}0.3459 \pm \\
0.0026\end{array}$ & $\begin{array}{l}0.51 \pm \\
0.17\end{array}$ & $\begin{array}{l}0.77 \pm \\
0.26\end{array}$ \\
\hline & $\begin{array}{l}4.9661 \pm \\
0.0008\end{array}$ & $\begin{array}{l}7.9738 \pm \\
0.0013\end{array}$ & $\begin{array}{l}5.7508 \pm \\
0.001\end{array}$ & $\begin{array}{l}227.71 \\
\pm 0.1\end{array}$ & $\begin{array}{l}0.3393 \pm \\
0.0025\end{array}$ & $\begin{array}{l}0.63 \pm \\
0.17\end{array}$ & $\begin{array}{l}0.94 \pm \\
0.25\end{array}$ \\
\hline & $\begin{array}{l}4.9672 \pm \\
0.0009\end{array}$ & $\begin{array}{l}7.9765 \pm \\
0.0015\end{array}$ & $\begin{array}{l}5.7521 \pm \\
0.0011\end{array}$ & $\begin{array}{l}227.89 \\
\pm 0.11\end{array}$ & $\begin{array}{l}0.359 \pm \\
0.003\end{array}$ & $\begin{array}{l}0.6 \pm \\
0.17\end{array}$ & $\begin{array}{l}0.9 \pm \\
0.25\end{array}$ \\
\hline & $\begin{array}{l}4.9664 \pm \\
0.0009\end{array}$ & $\begin{array}{l}7.9746 \pm \\
0.0014\end{array}$ & $\begin{array}{l}5.7511 \pm \\
0.0011\end{array}$ & $\begin{array}{l}227.76 \\
\pm 0.1 \\
\end{array}$ & $\begin{array}{l}0.367 \pm \\
0.004\end{array}$ & $\begin{array}{l}0.61 \pm \\
0.18\end{array}$ & $\begin{array}{l}0.92 \pm \\
0.28\end{array}$ \\
\hline \multirow[t]{4}{*}{ pearl* } & $\begin{array}{l}4.9677 \pm \\
0.0005\end{array}$ & $\begin{array}{l}7.9635 \pm \\
0.0009\end{array}$ & $\begin{array}{l}5.7514 \pm \\
0.0007\end{array}$ & $\begin{array}{r}227.52 \\
\pm 0.07 \\
\end{array}$ & $\begin{array}{l}0.355 \pm \\
0.004\end{array}$ & $\begin{array}{l}0.18 \pm \\
0.09\end{array}$ & $\begin{array}{l}0.26 \pm \\
0.14\end{array}$ \\
\hline & $\begin{array}{l}4.9673 \pm \\
0.0005\end{array}$ & $\begin{array}{l}7.9623 \pm \\
0.0009\end{array}$ & $\begin{array}{l}5.7507 \pm \\
0.0007\end{array}$ & $\begin{array}{l}227.43 \\
\pm 0.06\end{array}$ & $\begin{array}{l}0.356 \pm \\
0.003\end{array}$ & $\begin{array}{l}0.15 \pm \\
0.09\end{array}$ & $\begin{array}{l}0.23 \pm \\
0.13\end{array}$ \\
\hline & $\begin{array}{l}4.9671 \pm \\
0.0005\end{array}$ & $\begin{array}{l}7.9624 \pm \\
0.0008\end{array}$ & $\begin{array}{l}5.7507 \pm \\
0.0006\end{array}$ & $\begin{array}{r}227.43 \\
\pm 0.06\end{array}$ & $\begin{array}{l}0.355 \pm \\
0.004\end{array}$ & $\begin{array}{l}0.15 \pm \\
0.08\end{array}$ & $\begin{array}{l}0.23 \pm \\
0.12\end{array}$ \\
\hline & $\begin{array}{l}4.9674 \pm \\
0.0005\end{array}$ & $\begin{array}{l}7.9625 \pm \\
0.0008\end{array}$ & $\begin{array}{l}5.7513 \pm \\
0.0006\end{array}$ & $\begin{array}{r}227.47 \\
\pm 0.06 \\
\end{array}$ & $\begin{array}{l}0.35 \pm \\
0.003 \\
\end{array}$ & $\begin{array}{l}0.21 \pm \\
0.08\end{array}$ & $\begin{array}{l}0.31 \pm \\
0.12\end{array}$ \\
\hline \multirow[t]{4}{*}{$\begin{array}{l}\text { pearl } \\
\text { organic- } \\
\text { removed }\end{array}$} & $\begin{array}{l}4.9675 \pm \\
0.0006\end{array}$ & $\begin{array}{l}7.9608 \pm \\
0.001\end{array}$ & $\begin{array}{l}5.7509 \pm \\
0.0008\end{array}$ & $\begin{array}{l}227.41 \\
\pm 0.07\end{array}$ & $\begin{array}{l}0.3275 \pm \\
0.002\end{array}$ & $\begin{array}{l}0.21 \pm \\
0.14\end{array}$ & $\begin{array}{l}0.31 \pm \\
0.21\end{array}$ \\
\hline & $\begin{array}{l}4.9666 \pm \\
0.0007\end{array}$ & $\begin{array}{l}7.9602 \pm \\
0.0011\end{array}$ & $\begin{array}{l}5.7505 \pm \\
0.0009\end{array}$ & $\begin{array}{r}227.33 \\
\pm 0.08\end{array}$ & $\begin{array}{l}0.3205 \pm \\
0.0018\end{array}$ & $\begin{array}{l}0.22 \pm \\
0.15\end{array}$ & $\begin{array}{l}0.33 \pm \\
0.22\end{array}$ \\
\hline & $\begin{array}{l}4.9668 \pm \\
0.0011\end{array}$ & $\begin{array}{l}7.9629 \pm \\
0.0018\end{array}$ & $\begin{array}{l}5.7513 \pm \\
0.0014\end{array}$ & $\begin{array}{r}227.45 \\
\pm 0.13\end{array}$ & $\begin{array}{l}0.3296 \pm \\
0.0022\end{array}$ & $\begin{array}{l}-0.15 \pm \\
0.21\end{array}$ & $\begin{array}{l}-0.23 \pm \\
0.32\end{array}$ \\
\hline & $\begin{array}{l}4.967 \pm \\
0.0007\end{array}$ & $\begin{array}{l}7.9612 \pm \\
0.0012\end{array}$ & $\begin{array}{l}5.7503 \pm \\
0.0009\end{array}$ & $\begin{array}{r}227.37 \\
\pm 0.08 \\
\end{array}$ & $\begin{array}{l}0.3308 \pm \\
0.0027\end{array}$ & $\begin{array}{l}0.13 \pm \\
0.08\end{array}$ & $\begin{array}{l}0.2 \pm \\
0.12\end{array}$ \\
\hline f06 & $\begin{array}{l}4.9668 \pm \\
0.0004\end{array}$ & $\begin{array}{l}7.9688 \pm \\
0.0007\end{array}$ & $\begin{array}{l}5.7521 \pm \\
0.0006\end{array}$ & $\begin{array}{l}227.65 \\
\pm 0.05\end{array}$ & $\begin{array}{l}0.321 \pm \\
0.0026\end{array}$ & $\begin{array}{l}0.04 \pm \\
0.05\end{array}$ & $\begin{array}{l}0.06 \pm \\
0.08\end{array}$ \\
\hline
\end{tabular}




\begin{tabular}{|c|c|c|c|c|c|c|c|}
\hline \multirow[b]{3}{*}{$\ldots$} & $\begin{array}{l}4.9668 \pm \\
0.0004\end{array}$ & $\begin{array}{l}7.9693 \pm \\
0.0007\end{array}$ & $\begin{array}{l}5.7525 \pm \\
0.0005\end{array}$ & $\begin{array}{l}227.68 \\
\pm 0.05\end{array}$ & $\begin{array}{l}0.3312 \pm \\
0.0026\end{array}$ & $\begin{array}{l}-0.02 \pm \\
0.04\end{array}$ & $\begin{array}{l}-0.03 \pm \\
0.06\end{array}$ \\
\hline & $\begin{array}{l}4.967 \pm \\
0.0004\end{array}$ & $\begin{array}{l}7.9697 \pm \\
0.0007\end{array}$ & $\begin{array}{l}5.7521 \pm \\
0.0005\end{array}$ & $\begin{array}{l}227.68 \\
\pm 0.05\end{array}$ & $\begin{array}{l}0.3556 \pm \\
0.0029\end{array}$ & $\begin{array}{l}0.04 \pm \\
0.04\end{array}$ & $\begin{array}{l}0.06 \pm \\
0.06\end{array}$ \\
\hline & $\begin{array}{l}4.9671 \pm \\
0.0004\end{array}$ & $\begin{array}{l}7.9699 \pm \\
0.0007\end{array}$ & $\begin{array}{l}5.7525 \pm \\
0.0005\end{array}$ & $\begin{array}{l}227.72 \\
\pm 0.05 \\
\end{array}$ & $\begin{array}{l}0.371 \pm \\
0.004\end{array}$ & $\begin{array}{l}0.02 \pm \\
0.04\end{array}$ & $\begin{array}{l}0.03 \pm \\
0.06\end{array}$ \\
\hline \multirow[t]{4}{*}{ g04 } & $\begin{array}{l}4.9653 \pm \\
0.0006\end{array}$ & $\begin{array}{l}7.974 \pm \\
0.001\end{array}$ & $\begin{array}{l}5.7532 \pm \\
0.0007\end{array}$ & $\begin{array}{l}227.77 \\
\pm 0.07\end{array}$ & $\begin{array}{l}0.337 \pm \\
0.004\end{array}$ & $\begin{array}{l}0.03 \pm \\
0.06\end{array}$ & $\begin{array}{l}0.04 \pm \\
0.09\end{array}$ \\
\hline & $\begin{array}{l}4.9661 \pm \\
0.0006\end{array}$ & $\begin{array}{l}7.9752 \pm \\
0.0011\end{array}$ & $\begin{array}{l}5.7535 \pm \\
0.0008\end{array}$ & $\begin{array}{l}227.86 \\
\pm 0.08\end{array}$ & $\begin{array}{l}0.353 \pm \\
0.005\end{array}$ & $\begin{array}{l}-0.01 \pm \\
0.06\end{array}$ & $\begin{array}{l}-0.02 \pm \\
0.09\end{array}$ \\
\hline & $\begin{array}{l}4.9664 \pm \\
0.0008\end{array}$ & $\begin{array}{l}7.976 \pm \\
0.0014\end{array}$ & $\begin{array}{l}5.7534 \pm \\
0.001\end{array}$ & $\begin{array}{r}227.89 \\
\pm 0.09\end{array}$ & $\begin{array}{l}0.392 \pm \\
0.005\end{array}$ & $\begin{array}{l}-0.05 \pm \\
0.07\end{array}$ & $\begin{array}{l}-0.07 \pm \\
0.11\end{array}$ \\
\hline & $\begin{array}{l}4.9658 \pm \\
0.0008\end{array}$ & $\begin{array}{l}7.9754 \pm \\
0.0014\end{array}$ & $\begin{array}{l}5.7523 \pm \\
0.0011\end{array}$ & $\begin{array}{l}227.81 \\
\pm 0.1\end{array}$ & $\begin{array}{l}0.403 \pm \\
0.007\end{array}$ & $\begin{array}{l}-0.1 \pm \\
0.08\end{array}$ & $\begin{array}{l}-0.15 \pm \\
0.12\end{array}$ \\
\hline \multirow[t]{4}{*}{ g09 } & $\begin{array}{l}4.9673 \pm \\
0.0005\end{array}$ & $\begin{array}{l}7.9723 \pm \\
0.0008\end{array}$ & $\begin{array}{l}5.7545 \pm \\
0.0006\end{array}$ & $\begin{array}{l}227.87 \\
\pm 0.06 \\
\end{array}$ & $\begin{array}{l}0.341 \pm \\
0.004\end{array}$ & $\begin{array}{l}0.16 \pm \\
0.1\end{array}$ & $\begin{array}{l}0.25 \pm \\
0.14\end{array}$ \\
\hline & $\begin{array}{l}4.9669 \pm \\
0.0005\end{array}$ & $\begin{array}{l}7.9728 \pm \\
0.0009\end{array}$ & $\begin{array}{l}5.7542 \pm \\
0.0007\end{array}$ & $\begin{array}{l}227.86 \\
\pm 0.06\end{array}$ & $\begin{array}{l}0.352 \pm \\
0.004\end{array}$ & $\begin{array}{l}0.04 \pm \\
0.05\end{array}$ & $\begin{array}{l}0.06 \pm \\
0.08\end{array}$ \\
\hline & $\begin{array}{l}4.9672 \pm \\
0.0006\end{array}$ & $\begin{array}{l}7.9741 \pm \\
0.0009\end{array}$ & $\begin{array}{l}5.7542 \pm \\
0.0007\end{array}$ & $\begin{array}{l}227.9 \pm \\
0.07\end{array}$ & $\begin{array}{l}0.388 \pm \\
0.005\end{array}$ & $\begin{array}{l}0.04 \pm \\
0.05\end{array}$ & $\begin{array}{l}0.06 \pm \\
0.08\end{array}$ \\
\hline & $\begin{array}{l}4.9677 \pm \\
0.0006\end{array}$ & $\begin{array}{l}7.9735 \pm \\
0.0011\end{array}$ & $\begin{array}{l}5.7545 \pm \\
0.0008\end{array}$ & $\begin{array}{r}227.92 \\
\pm 0.07 \\
\end{array}$ & $\begin{array}{l}0.389 \pm \\
0.008\end{array}$ & $\begin{array}{l}0.05 \pm \\
0.06 \\
\end{array}$ & $\begin{array}{l}0.08 \pm \\
0.09\end{array}$ \\
\hline \multirow[t]{4}{*}{ h01 } & $\begin{array}{l}4.9663 \pm \\
0.0006\end{array}$ & $\begin{array}{l}7.9729 \pm \\
0.001\end{array}$ & $\begin{array}{l}5.7528 \pm \\
0.0007\end{array}$ & $\begin{array}{l}227.77 \\
\pm 0.07\end{array}$ & $\begin{array}{l}0.399 \pm \\
0.007\end{array}$ & $\begin{array}{l}0.05 \pm \\
0.06\end{array}$ & $\begin{array}{l}0.08 \pm \\
0.08\end{array}$ \\
\hline & $\begin{array}{l}4.9665 \pm \\
0.0007\end{array}$ & $\begin{array}{l}7.9739 \pm \\
0.0012\end{array}$ & $\begin{array}{l}5.7532 \pm \\
0.0009\end{array}$ & $\begin{array}{r}227.83 \\
\pm 0.08 \\
\end{array}$ & $\begin{array}{l}0.399 \pm \\
0.008\end{array}$ & $\begin{array}{l}-0.12 \pm \\
0.14\end{array}$ & $\begin{array}{l}-0.19 \pm \\
0.2\end{array}$ \\
\hline & $\begin{array}{l}4.9665 \pm \\
0.0007\end{array}$ & $\begin{array}{l}7.9747 \pm \\
0.0012\end{array}$ & $\begin{array}{l}5.7537 \pm \\
0.0009\end{array}$ & $\begin{array}{r}227.87 \\
\pm 0.09 \\
\end{array}$ & $\begin{array}{l}0.398 \pm \\
0.006\end{array}$ & $\begin{array}{l}-0.13 \pm \\
0.12\end{array}$ & $\begin{array}{l}-0.2 \pm \\
0.19\end{array}$ \\
\hline & $\begin{array}{l}4.9662 \pm \\
0.0007\end{array}$ & $\begin{array}{l}7.9738 \pm \\
0.0013\end{array}$ & $\begin{array}{l}5.7533 \pm \\
0.0009\end{array}$ & $\begin{array}{l}227.81 \\
\pm 0.09 \\
\end{array}$ & $\begin{array}{l}0.3271 \pm \\
0.0025\end{array}$ & $\begin{array}{l}-0.07 \pm \\
0.07\end{array}$ & $\begin{array}{l}-0.11 \pm \\
0.11\end{array}$ \\
\hline \multirow[t]{4}{*}{ ArgSyn } & $\begin{array}{l}4.9639 \pm \\
0.001\end{array}$ & $\begin{array}{l}7.967 \pm \\
0.0017\end{array}$ & $\begin{array}{l}5.7481 \pm \\
0.0013\end{array}$ & $\begin{array}{r}227.31 \\
\pm 0.12 \\
\end{array}$ & $\begin{array}{l}0.339 \pm \\
0.005\end{array}$ & $\begin{array}{l}-0.04 \pm \\
0.12\end{array}$ & $\begin{array}{l}-0.06 \pm \\
0.17\end{array}$ \\
\hline & $\begin{array}{l}4.9633 \pm \\
0.0011\end{array}$ & $\begin{array}{l}7.968 \pm \\
0.0018\end{array}$ & $\begin{array}{l}5.7488 \pm \\
0.0014\end{array}$ & $\begin{array}{r}227.34 \\
\pm 0.13 \\
\end{array}$ & $\begin{array}{l}0.361 \pm \\
0.007\end{array}$ & $\begin{array}{l}-0.06 \pm \\
0.11\end{array}$ & $\begin{array}{l}-0.09 \pm \\
0.17\end{array}$ \\
\hline & $\begin{array}{l}4.9633 \pm \\
0.0011\end{array}$ & $\begin{array}{l}7.9663 \pm \\
0.0018\end{array}$ & $\begin{array}{l}5.748 \pm \\
0.0014\end{array}$ & $\begin{array}{l}227.26 \\
\pm 0.13\end{array}$ & $\begin{array}{l}0.352 \pm \\
0.004\end{array}$ & $\begin{array}{l}-0.03 \pm \\
0.12\end{array}$ & $\begin{array}{l}-0.05 \pm \\
0.18\end{array}$ \\
\hline & $\begin{array}{l}4.9637 \pm \\
0.0011\end{array}$ & $\begin{array}{l}7.9674 \pm \\
0.0018\end{array}$ & $\begin{array}{l}5.7486 \pm \\
0.0014\end{array}$ & $\begin{array}{l}227.33 \\
\pm 0.13 \\
\end{array}$ & $\begin{array}{l}0.363 \pm \\
0.007\end{array}$ & $\begin{array}{l}-0.06 \pm \\
0.12\end{array}$ & $\begin{array}{l}-0.1 \pm \\
0.18\end{array}$ \\
\hline \multirow[t]{2}{*}{ VT-M1010 } & $\begin{array}{l}4.9624 \pm \\
0.0003\end{array}$ & $\begin{array}{l}7.9666 \pm \\
0.0006\end{array}$ & $\begin{array}{l}5.7433 \pm \\
0.0004\end{array}$ & $\begin{array}{l}227.04 \\
\pm 0.04\end{array}$ & $\begin{array}{l}0.352 \pm \\
0.003\end{array}$ & $\begin{array}{l}0.4 \pm \\
0.06\end{array}$ & $\begin{array}{l}0.6 \pm \\
0.09\end{array}$ \\
\hline & $\begin{array}{l}4.9628 \pm \\
0.0004\end{array}$ & $\begin{array}{l}7.9669 \pm \\
0.0007\end{array}$ & $\begin{array}{l}5.7435 \pm \\
0.0005\end{array}$ & $\begin{array}{l}227.07 \\
\pm 0.05\end{array}$ & $\begin{array}{l}0.366 \pm \\
0.004\end{array}$ & $\begin{array}{l}0.44 \pm \\
0.06\end{array}$ & $\begin{array}{l}0.66 \pm \\
0.1\end{array}$ \\
\hline
\end{tabular}




\begin{tabular}{|c|c|c|c|c|c|c|c|}
\hline & $\begin{array}{l}4.9631 \pm \\
0.0004\end{array}$ & $\begin{array}{l}7.9672 \pm \\
0.0006\end{array}$ & $\begin{array}{l}5.7436 \pm \\
0.0005\end{array}$ & $\begin{array}{l}227.1 \pm \\
0.04\end{array}$ & $\begin{array}{l}0.358 \pm \\
0.004\end{array}$ & $\begin{array}{l}0.47 \pm \\
0.06\end{array}$ & $\begin{array}{l}0.7 \pm \\
0.09\end{array}$ \\
\hline & $\begin{array}{l}4.9623 \pm \\
0.0003\end{array}$ & $\begin{array}{l}7.9662 \pm \\
0.0006\end{array}$ & $\begin{array}{l}5.743 \pm \\
0.0004\end{array}$ & $\begin{array}{l}227.01 \\
\pm 0.04 \\
\end{array}$ & $\begin{array}{l}0.3346 \pm \\
0.0026\end{array}$ & $\begin{array}{l}0.46 \pm \\
0.06 \\
\end{array}$ & $\begin{array}{l}0.68 \pm \\
0.08\end{array}$ \\
\hline \multirow[t]{4}{*}{$\begin{array}{l}\text { HARVARD- } \\
116162\end{array}$} & $\begin{array}{l}4.9652 \pm \\
0.0004\end{array}$ & $\begin{array}{l}7.9681 \pm \\
0.0007\end{array}$ & $\begin{array}{l}5.7455 \pm \\
0.0005\end{array}$ & $\begin{array}{l}227.3 \pm \\
0.05\end{array}$ & $\begin{array}{l}0.374 \pm \\
0.005\end{array}$ & $\begin{array}{l}0.44 \pm \\
0.08\end{array}$ & $\begin{array}{l}0.66 \pm \\
0.12\end{array}$ \\
\hline & $\begin{array}{l}4.9651 \pm \\
0.0005\end{array}$ & $\begin{array}{l}7.9684 \pm \\
0.0008\end{array}$ & $\begin{array}{l}5.7452 \pm \\
0.0006\end{array}$ & $\begin{array}{l}227.29 \\
\pm 0.06\end{array}$ & $\begin{array}{l}0.366 \pm \\
0.004\end{array}$ & $\begin{array}{l}0.28 \pm \\
0.08\end{array}$ & $\begin{array}{l}0.41 \pm \\
0.12\end{array}$ \\
\hline & $\begin{array}{l}4.9646 \pm \\
0.0004\end{array}$ & $\begin{array}{l}7.968 \pm \\
0.0006\end{array}$ & $\begin{array}{l}5.7447 \pm \\
0.0005\end{array}$ & $\begin{array}{l}227.23 \\
\pm 0.05\end{array}$ & $\begin{array}{l}0.38 \pm \\
0.004\end{array}$ & $\begin{array}{l}0.41 \pm \\
0.07\end{array}$ & $\begin{array}{l}0.62 \pm \\
0.11\end{array}$ \\
\hline & $\begin{array}{l}4.9644 \pm \\
0.0004\end{array}$ & $\begin{array}{l}7.9678 \pm \\
0.0006\end{array}$ & $\begin{array}{l}5.7449 \pm \\
0.0005\end{array}$ & $\begin{array}{l}227.23 \\
\pm 0.04\end{array}$ & $\begin{array}{l}0.363 \pm \\
0.004\end{array}$ & $\begin{array}{l}0.36 \pm \\
0.07\end{array}$ & $\begin{array}{l}0.54 \pm \\
0.1\end{array}$ \\
\hline \multirow[t]{4}{*}{$\begin{array}{l}\text { HARVARD- } \\
129393\end{array}$} & $\begin{array}{l}4.962 \pm \\
0.0004\end{array}$ & $\begin{array}{l}7.9638 \pm \\
0.0006\end{array}$ & $\begin{array}{l}5.7423 \pm \\
0.0005\end{array}$ & $\begin{array}{l}226.9 \pm \\
0.05\end{array}$ & $\begin{array}{l}0.3041 \pm \\
0.0014\end{array}$ & $\begin{array}{l}0.42 \pm \\
0.08\end{array}$ & $\begin{array}{l}0.63 \pm \\
0.12\end{array}$ \\
\hline & $\begin{array}{l}4.9636 \pm \\
0.0005\end{array}$ & $\begin{array}{l}7.9643 \pm \\
0.0008\end{array}$ & $\begin{array}{l}5.7425 \pm \\
0.0006\end{array}$ & $\begin{array}{l}227 \pm \\
0.06\end{array}$ & $\begin{array}{l}0.3429 \pm \\
0.0028\end{array}$ & $\begin{array}{l}0.38 \pm \\
0.09\end{array}$ & $\begin{array}{l}0.57 \pm \\
0.14\end{array}$ \\
\hline & $\begin{array}{l}4.9643 \pm \\
0.0005\end{array}$ & $\begin{array}{l}7.9658 \pm \\
0.0009\end{array}$ & $\begin{array}{l}5.744 \pm \\
0.0007\end{array}$ & $\begin{array}{l}227.13 \\
\pm 0.06\end{array}$ & $\begin{array}{l}0.3249 \pm \\
0.0028\end{array}$ & $\begin{array}{l}0.34 \pm \\
0.1\end{array}$ & $\begin{array}{l}0.51 \pm \\
0.15\end{array}$ \\
\hline & $\begin{array}{l}4.9637 \pm \\
0.0004\end{array}$ & $\begin{array}{l}7.9658 \pm \\
0.0006\end{array}$ & $\begin{array}{l}5.7436 \pm \\
0.0005\end{array}$ & $\begin{array}{l}227.09 \\
\pm 0.04 \\
\end{array}$ & $\begin{array}{l}0.368 \pm \\
0.005\end{array}$ & $\begin{array}{l}0.42 \pm \\
0.08\end{array}$ & $\begin{array}{l}0.63 \pm \\
0.12\end{array}$ \\
\hline \multirow[t]{4}{*}{$\begin{array}{l}\text { HARVARD- } \\
143853\end{array}$} & $\begin{array}{l}4.964 \pm \\
0.0004\end{array}$ & $\begin{array}{l}7.9697 \pm \\
0.0007\end{array}$ & $\begin{array}{l}5.7463 \pm \\
0.0005\end{array}$ & $\begin{array}{l}227.32 \\
\pm 0.05\end{array}$ & $\begin{array}{l}0.34 \pm \\
0.003\end{array}$ & $\begin{array}{l}0.04 \pm \\
0.06\end{array}$ & $\begin{array}{l}0.06 \pm \\
0.1\end{array}$ \\
\hline & $\begin{array}{l}4.9643 \pm \\
0.0005\end{array}$ & $\begin{array}{l}7.9717 \pm \\
0.0008\end{array}$ & $\begin{array}{l}5.7467 \pm \\
0.0006\end{array}$ & $\begin{array}{l}227.41 \\
\pm 0.06\end{array}$ & $\begin{array}{l}0.347 \pm \\
0.004\end{array}$ & $\begin{array}{l}0.32 \pm \\
0.08\end{array}$ & $\begin{array}{l}0.49 \pm \\
0.12\end{array}$ \\
\hline & $\begin{array}{l}4.9637 \pm \\
0.0005\end{array}$ & $\begin{array}{l}7.9706 \pm \\
0.0008\end{array}$ & $\begin{array}{l}5.7457 \pm \\
0.0006\end{array}$ & $\begin{array}{l}227.31 \\
\pm 0.06\end{array}$ & $\begin{array}{l}0.353 \pm \\
0.004\end{array}$ & $\begin{array}{l}0.09 \pm \\
0.07\end{array}$ & $\begin{array}{l}0.14 \pm \\
0.1\end{array}$ \\
\hline & $\begin{array}{l}4.9649 \pm \\
0.0005\end{array}$ & $\begin{array}{l}7.9714 \pm \\
0.0008\end{array}$ & $\begin{array}{l}5.7468 \pm \\
0.0006\end{array}$ & $\begin{array}{l}227.43 \\
\pm 0.06\end{array}$ & $\begin{array}{l}0.315 \pm \\
0.002\end{array}$ & $\begin{array}{l}-0.06 \pm \\
0.06\end{array}$ & $\begin{array}{l}-0.09 \pm \\
0.09\end{array}$ \\
\hline
\end{tabular}

* coral and biogenic aragonite samples which have not undergone the removal of organics treatment with bleach

TABLE S2.2: Raman spectroscopy measurements for all samples.

\begin{tabular}{lcllllc}
\hline $\begin{array}{l}\text { Sample } \\
\text { names }\end{array}$ & $\begin{array}{l}\text { Raman- } \\
\text { derived } \\
\text { omega }\end{array}$ & $\begin{array}{l}\text { FWHM } \mathbf{v}_{\mathbf{1}} \pm \\
\text { standard } \\
\text { error }\end{array}$ & $\begin{array}{l}\text { wave number } \\
\left(\mathbf{c m}^{-1}\right) \pm \\
\text { standard error }\end{array}$ & $\begin{array}{l}\text { background } \\
\text { intensity } \\
\text { (fluorescence) }\end{array}$ & $\begin{array}{l}\text { number } \\
\text { of good } \\
\text { spectra }\end{array}$ \\
\hline LOPH-CAL & 10.55 & $3.43 \pm 0.05$ & $1085.44 \pm 0.05$ & 682.4182014 & 100 \\
\hline LOPH-GC354 & 11.61 & $3.49 \pm 0.08$ & $1085.39 \pm 0.05$ & 680.3581371 & 93 \\
\hline LOPH-GB535 & 10.88 & $3.45 \pm 0.05$ & $1085.43 \pm 0.05$ & 675.8437119 & 98 \\
\hline LOPH-VK906 & 10.44 & $3.43 \pm 0.04$ & $1085.47 \pm 0.03$ & 693.0215261 & 92 \\
\hline LMG15-09 & 11.97 & $3.5 \pm 0.04$ & $1085.38 \pm 0.03$ & 673.0555798 & 98 \\
\hline KUK220-1 & 9.77 & $3.39 \pm 0.05$ & $1085.4 \pm 0.05$ & 665.6129941 & 100 \\
\hline
\end{tabular}




\begin{tabular}{|c|c|c|c|c|c|}
\hline NBP09-05 & 9.49 & $3.37 \pm 0.05$ & $1085.43 \pm 0.03$ & 672.8392386 & 89 \\
\hline NBP08-05 & 9.56 & $3.38 \pm 0.15$ & $1085.35 \pm 0.11$ & 765.2942888 & 82 \\
\hline 132 & 11.25 & $3.47 \pm 0.05$ & $1085.47 \pm 0.05$ & 673.9920062 & 98 \\
\hline $133^{*}$ & 13.43 & $3.57 \pm 0.07$ & $1085.51 \pm 0.02$ & 669.1513154 & 97 \\
\hline $134^{*}$ & 12.36 & $3.52 \pm 0.05$ & $1085.47 \pm 0.02$ & 675.3591106 & 99 \\
\hline N3-63 & 11.43 & $3.48 \pm 0.05$ & $1085.47 \pm 0.02$ & 679.0857078 & 100 \\
\hline N3-65* & 11.91 & $3.5 \pm 0.06$ & $1085.5 \pm 0.02$ & 671.397376 & 96 \\
\hline N1-52* & 11.79 & $3.5 \pm 0.06$ & $1085.51 \pm 0.03$ & 709.6382277 & 83 \\
\hline GB-113 & 12.86 & $3.55 \pm 0.06$ & $1085.48 \pm 0.03$ & 678.0856064 & 9 \\
\hline GB-148* & 11.95 & $3.5 \pm 0.06$ & $1085.52 \pm 0.02$ & 672.6381508 & 98 \\
\hline GB-174* & 11.55 & $3.48 \pm 0.05$ & $1085.51 \pm 0.02$ & 687.8141866 & 100 \\
\hline GB-144 & 10.85 & $3.45 \pm 0.04$ & $1085.47 \pm 0.02$ & 686.8717932 & 80 \\
\hline GB-145* & 11.68 & $3.49 \pm 0.07$ & $1085.48 \pm 0.03$ & 664.4557364 & 96 \\
\hline GB-146* & 11.23 & $3.47 \pm 0.08$ & $1085.49 \pm 0.03$ & 679.2442384 & 97 \\
\hline GQ-47 & 12.33 & $3.52 \pm 0.06$ & $1085.51 \pm 0.04$ & 675.0861111 & 99 \\
\hline GQ-48* & 11.9 & $3.5 \pm 0.06$ & $1085.47 \pm 0.04$ & 687.8219541 & 99 \\
\hline GQ-50* & 12.3 & $3.52 \pm 0.05$ & $1085.51 \pm 0.03$ & 682.1454646 & 100 \\
\hline GB-103 & 11.78 & $3.5 \pm 0.1$ & $1085.48 \pm 0.05$ & 676.9834853 & 87 \\
\hline GB-105* & 11.29 & $3.47 \pm 0.07$ & $1085.47 \pm 0.03$ & 676.3085485 & 100 \\
\hline GB-141* & 11.52 & $3.48 \pm 0.07$ & $1085.48 \pm 0.03$ & 676.3368904 & 99 \\
\hline$J C p-1^{*}$ & 12.68 & $3.54 \pm 0.07$ & $1085.53 \pm 0.03$ & 675.368701 & 96 \\
\hline \multicolumn{6}{|l|}{$\begin{array}{l}\text { JCp-1 } \\
\text { organic- }\end{array}$} \\
\hline pearl $^{*}$ & 17.57 & $3.72 \pm 0.19$ & $1084.81 \pm 0.24$ & 5913.95568 & 54 \\
\hline \multicolumn{5}{|l|}{ pearl organic- } & 89 \\
\hline f06 & 12.05 & $3.51 \pm 0.05$ & $1085.5 \pm 0.06$ & 687.0016161 & 98 \\
\hline g04 & 21.14 & $3.83 \pm 0.06$ & $1085.58 \pm 0.03$ & 702.6173722 & 97 \\
\hline g09 & 17.83 & $3.73 \pm 0.06$ & $1085.55 \pm 0.02$ & 686.5166567 & 100 \\
\hline h01 & 18.58 & $3.76 \pm 0.07$ & $1085.56 \pm 0.07$ & 676.3486122 & 93 \\
\hline ArgSyn & 15.9 & $3.67 \pm 0.18$ & $1085.28 \pm 0.22$ & 711.0120792 & 79 \\
\hline VT-M1010 & 5.98 & $3.11 \pm 0.08$ & $1085.43 \pm 0.09$ & 730.9857392 & 97 \\
\hline \multicolumn{6}{|l|}{ HARVARD- } \\
\hline 116162 & 7.08 & $3.21 \pm 0.06$ & $1085.44 \pm 0.07$ & 670.8873929 & 97 \\
\hline \multicolumn{6}{|l|}{ HARVARD- } \\
\hline \multicolumn{6}{|l|}{ HARVARD- } \\
\hline 143853 & 6.07 & $3.12 \pm 0.08$ & $1085.25 \pm 0.1$ & 675.8193983 & 99 \\
\hline
\end{tabular}

* coral and biogenic aragonite samples which have not undergone the removal of organics treatment with bleach 
TABLE S2.3: Trace element incorporations in aragonites as element:Ca ratios based on ${ }^{11} \mathrm{~B}$, ${ }^{24} \mathrm{Mg},{ }^{25} \mathrm{Mg},{ }^{88} \mathrm{Sr}$, and ${ }^{138} \mathrm{Ba}$ concentrations.

\begin{tabular}{|c|c|c|c|c|c|}
\hline Sample names & $\begin{array}{l}\mathrm{B} / \mathrm{Ca} \text { ratio } \\
\text { based on } \\
{ }^{11} \mathrm{~B}\end{array}$ & $\begin{array}{l}\mathrm{Mg} / \mathrm{Ca} \text { ratio } \\
\text { based on } \\
{ }^{24} \mathrm{Mg}\end{array}$ & $\begin{array}{l}\mathrm{Mg} / \mathrm{Ca} \text { ratio } \\
\text { based on } \\
{ }^{25} \mathrm{Mg}\end{array}$ & $\begin{array}{l}\mathrm{Sr} / \mathrm{Ca} \text { ratio } \\
\text { based on } \\
{ }^{88} \mathrm{Sr}\end{array}$ & $\begin{array}{l}\mathrm{Ba} / \mathrm{Ca} \\
\text { ratio } \\
\text { based on } \\
{ }^{138} \mathrm{Ba}\end{array}$ \\
\hline LOPH-CAL & $656 \pm 33$ & $2.33 \pm 0.04$ & $2.27 \pm 0.04$ & $8.61 \pm 0.1$ & $8.8 \pm 0.8$ \\
\hline LOPH-GC354 & $747 \pm 38$ & $1.88 \pm 0.04$ & $1.85 \pm 0.04$ & $6.61 \pm 0.08$ & $7.2 \pm 0.6$ \\
\hline LOPH-GB535 & $804 \pm 41$ & $2.74 \pm 0.05$ & $2.64 \pm 0.05$ & $9.89 \pm 0.11$ & $11.1 \pm 1$ \\
\hline LOPH-VK906 & $762 \pm 38$ & $2.59 \pm 0.05$ & $2.54 \pm 0.05$ & $9.49 \pm 0.11$ & $11 \pm 1$ \\
\hline LMG15-09 & $633 \pm 32$ & $2.27 \pm 0.04$ & $2.27 \pm 0.04$ & $10.08 \pm 0.12$ & $20.2 \pm 1.8$ \\
\hline KUK220-1 & $725 \pm 37$ & $2.09 \pm 0.04$ & $2.1 \pm 0.04$ & $9.49 \pm 0.11$ & $7.7 \pm 0.7$ \\
\hline NBP09-05 & $644 \pm 33$ & $2.49 \pm 0.05$ & $2.51 \pm 0.05$ & $8.8 \pm 0.1$ & $10.8 \pm 1$ \\
\hline NBP08-05 & $622 \pm 33$ & $3.84 \pm 0.1$ & $3.85 \pm 0.1$ & $8.66 \pm 0.18$ & $14.8 \pm 1.3$ \\
\hline 132 & $630 \pm 32$ & $3.55 \pm 0.07$ & $3.55 \pm 0.07$ & $9.44 \pm 0.1$ & $7.8 \pm 0.7$ \\
\hline $133^{*}$ & $489 \pm 25$ & $5.59 \pm 0.1$ & $5.64 \pm 0.1$ & $8.28 \pm 0.09$ & $7.2 \pm 0.6$ \\
\hline $134^{*}$ & $490 \pm 25$ & $4.54 \pm 0.09$ & $4.46 \pm 0.08$ & $7.73 \pm 0.09$ & $7.6 \pm 0.7$ \\
\hline N3-63 & $551 \pm 28$ & $4.43 \pm 0.08$ & $4.45 \pm 0.08$ & $8.22 \pm 0.09$ & $6.9 \pm 0.6$ \\
\hline N3-65* & $476 \pm 24$ & $4.01 \pm 0.08$ & $4.07 \pm 0.08$ & $7.33 \pm 0.09$ & $12.2 \pm 1.1$ \\
\hline $\mathrm{N} 1-52^{*}$ & $521 \pm 26$ & $3.39 \pm 0.06$ & $3.41 \pm 0.06$ & $7.81 \pm 0.09$ & $5.1 \pm 0.5$ \\
\hline GB-113 & $626 \pm 32$ & $5.12 \pm 0.09$ & $5.12 \pm 0.09$ & $8.9 \pm 0.1$ & $6.8 \pm 0.6$ \\
\hline GB-148* & $558 \pm 28$ & $4.36 \pm 0.08$ & $4.43 \pm 0.08$ & $8.62 \pm 0.09$ & $7.1 \pm 0.6$ \\
\hline GB-174* & $651 \pm 33$ & $4.4 \pm 0.08$ & $4.38 \pm 0.08$ & $9.38 \pm 0.1$ & $7.5 \pm 0.7$ \\
\hline GB-144 & $516 \pm 26$ & $3.65 \pm 0.07$ & $3.63 \pm 0.07$ & $8.88 \pm 0.1$ & $25.9 \pm 2.3$ \\
\hline GB-145* & $427 \pm 22$ & $3.22 \pm 0.06$ & $3.21 \pm 0.06$ & $6.74 \pm 0.08$ & $17.6 \pm 1.6$ \\
\hline GB-146* & $535 \pm 27$ & $3.62 \pm 0.07$ & $3.59 \pm 0.07$ & $8.79 \pm 0.1$ & $24.4 \pm 2.2$ \\
\hline GQ-47 & $506 \pm 26$ & $3.93 \pm 0.07$ & $3.95 \pm 0.07$ & $8.11 \pm 0.09$ & $35.7 \pm 3.2$ \\
\hline GQ-48* & $565 \pm 29$ & $3.35 \pm 0.06$ & $3.36 \pm 0.06$ & $8.08 \pm 0.09$ & $45.8 \pm 4$ \\
\hline GQ-50* & $625 \pm 31$ & $4.38 \pm 0.08$ & $4.36 \pm 0.08$ & $9.42 \pm 0.1$ & $21.9 \pm 1.9$ \\
\hline GB-103 & $580 \pm 29$ & $4.41 \pm 0.08$ & $4.42 \pm 0.08$ & $8.55 \pm 0.1$ & $5.4 \pm 0.5$ \\
\hline GB-105* & $439 \pm 22$ & $5.04 \pm 0.09$ & $5.07 \pm 0.09$ & $7.87 \pm 0.09$ & $9.5 \pm 0.8$ \\
\hline GB-141* & $500 \pm 25$ & $4.03 \pm 0.08$ & $3.98 \pm 0.07$ & $7.62 \pm 0.09$ & $5.6 \pm 0.5$ \\
\hline $\mathrm{JCp}-1^{*}$ & $460 \pm 23$ & $4.2 \pm 0.07$ & $4.2 \pm 0.07$ & $8.84 \pm 0.04$ & $7.5 \pm 0.7$ \\
\hline $\begin{array}{l}\text { JCp-1 organic- } \\
\text { removed }\end{array}$ & $346 \pm 17$ & $3.12 \pm 0.06$ & $3.11 \pm 0.06$ & $8.77 \pm 0.1$ & $7.8 \pm 0.7$ \\
\hline pearl * & $91 \pm 5$ & $0.61 \pm 0.01$ & $0.57 \pm 0.01$ & $1.36 \pm 0.02$ & $1.7 \pm 0.2$ \\
\hline $\begin{array}{l}\text { pearl organic- } \\
\text { removed }\end{array}$ & $87 \pm 4$ & $0.5 \pm 0.01$ & $0.43 \pm 0.01$ & $1.67 \pm 0.02$ & $2.6 \pm 0.2$ \\
\hline f06 & $506 \pm 25$ & $4.73 \pm 0.09$ & $4.79 \pm 0.09$ & $9.25 \pm 0.1$ & $7.5 \pm 0.7$ \\
\hline g04 & $95 \pm 5$ & $1.29 \pm 0.04$ & $1.31 \pm 0.04$ & $1.55 \pm 0.04$ & $1.7 \pm 0.2$ \\
\hline g09 & $176 \pm 9$ & $7.08 \pm 0.13$ & $7.19 \pm 0.13$ & $9.33 \pm 0.1$ & $9.2 \pm 0.8$ \\
\hline h01 & $605 \pm 31$ & $7.29 \pm 0.14$ & $7.35 \pm 0.14$ & $6.97 \pm 0.09$ & $6.3 \pm 0.6$ \\
\hline
\end{tabular}




\begin{tabular}{llllll} 
ArgSyn & $264 \pm 13$ & $16.9 \pm 0.32$ & $17.01 \pm 0.32$ & $0.09 \pm 0$ & $2.9 \pm 0.3$ \\
\hline VT-M1010 & $21 \pm 1$ & $0.42 \pm 0.01$ & $0.35 \pm 0.01$ & $0.397 \pm 0.004$ & $160 \pm 14$ \\
\hline HARVARD-116162 & $23 \pm 1$ & $0.56 \pm 0.01$ & $0.5 \pm 0.01$ & $5.17 \pm 0.06$ & $25.1 \pm 2.2$ \\
\hline HARVARD-129393 & $33 \pm 2$ & $25.32 \pm 0.47$ & $25.45 \pm 0.47$ & $2.33 \pm 0.03$ & $99 \pm 9$ \\
\hline HARVARD-143853 & $10 \pm 1$ & $0.25 \pm 0$ & $0.17 \pm 0$ & $0.835 \pm 0.009$ & $4 \pm 0.4$ \\
\hline
\end{tabular}




\section{CHAPTER 3. Mineralogy of deep-sea coral aragonites as a function of aragonite saturation state}

Farfan, G. A., Cordes, E. E., Waller, R. G., DeCarlo, T. M., and Hansel, C. M. (in review). Mineralogy of deep-sea coral aragonites as a function of aragonite saturation state. Frontiers in Marine Science, 5. 


\subsection{ABSTRACT}

In an ocean with rapidly changing chemistry, studies have assessed coral skeletal health under projected ocean acidification (OA) scenarios by characterizing morphological distortions in skeletal architecture and measuring bulk properties, such as net calcification and dissolution. Few studies offer more detailed information on skeletal mineralogy. Since aragonite crystallography will at least partially govern the material properties of coral skeletons, such as solubility and strength, it is important to understand how it is influenced by environmental stressors. Here, we take a mineralogical approach using micro X-ray diffraction (XRD) and whole pattern Rietveld refinement analysis to track crystallographic shifts in deep-sea coral Lophelia pertusa samples collected along a natural seawater aragonite saturation state gradient $\left(\Omega_{\mathrm{sw}}=1.15-1.44\right)$ in the Gulf of Mexico. Our results reveal statistically significant linear relationships between rising $\Omega_{\text {sw }}$ and increasing unit cell volume driven by an anisotropic lengthening along the $b$-axis. These structural changes are similarly observed in synthetic aragonites precipitated under various saturation states, indicating that these changes are inherent to the crystallography of aragonite. Increased crystallographic disorder via widening of the full width at half maximum of the main (111) XRD peaks trend with increased Ba substitutions for $\mathrm{Ca}$, however, trace substitutions by $\mathrm{Ba}, \mathrm{Sr}$, and $\mathrm{Mg}$ do not trend with crystal lattice parameters in our samples. Instead, we observe a significant trend of increasing calcite content as a function of both decreasing unit cell parameters as well as decreasing $\Omega_{\text {sw }}$. This may make calcite incorporation an important factor to consider in coral crystallography, especially under varying aragonite saturation states $\left(\Omega_{\mathrm{Ar}}\right)$. Finally, by defining crystallography-based linear relationships between $\Omega_{\mathrm{Ar}}$ of synthetic aragonite analogs and lattice parameters, we predict internal calcifying fluid saturation state $\left(\Omega_{\mathrm{cf}}=11.1-17.3\right.$ calculated from $b$-axis lengths; $15.2-25.2$ calculated from unit cell volumes) for L. pertusa, which may allow this species to calcify despite the local seawater conditions. This study will ideally pave the way for future studies to utilize quantitative XRD in exploring the impact of physical and chemical stressors on biominerals.

\subsection{INTRODUCTION}

Increased fluxes of anthropogenic carbon dioxide into the atmosphere are rapidly absorbed into the world's oceans and are predicted to lower the $\mathrm{pH}$ of the ocean by $0.3-0.5$ units over the next century (Doney et al., 2009) in a process referred to as ocean acidification (OA). The oceanic carbonate system reacts to lower $\mathrm{pHs}$ by decreasing carbonate ion $\left(\mathrm{CO}_{3}{ }^{2-}\right)$ concentrations in favor of bicarbonate ions $\left(\mathrm{HCO}_{3}{ }^{-}\right)$. Carbonate ions are required building blocks for calcium carbonate $\left(\mathrm{CaCO}_{3}\right)$ minerals, such as polymorphs aragonite and calcite, formed by biomineralizing organisms. At depth in the ocean, the concentrations of carbonate ions can fall below levels that are thermodynamically viable to form calcium carbonate minerals. For aragonite, this depth at which the aragonite saturation state $\left(\Omega_{\mathrm{Ar}}\right)$ falls below 1 and aragonite dissolution is favored is referred to as the aragonite saturation horizon (ASH). The ASH has already shoaled over past centuries by $80-150 \mathrm{~m}$ in the North Atlantic Ocean (Chung et al., 2003, Feely et al., 2004), 50-100 m in the North Pacific Ocean (Feely et al., 2008) and 100-200 $\mathrm{m}$ in the Indian Ocean (Sabine et al, 2002), and is projected to continue rising. In addition to a rising $\mathrm{ASH}$, carbonate minerals also become more soluble under colder, higher pressure environments, making them even more vulnerable to dissolution in the deep ocean (Acker et al., 
1987; Mucci, 1983). In recent years, deep-sea coral studies have established baselines for aragonite saturation states and $\mathrm{pH}$ values in environments where deep-sea corals exist, in order to specifically track future effects of OA on the health of deep-sea coral ecosystems (Thresher et al., 2011; Lunden et al., 2013; Georgian et al., 2016a).

Deep-sea corals that live near or below shoaling ASHs are expected to be the first biomineralizing organisms to experience negative net calcification of their skeletons due to decreasing calcification rates and dissolution of existing skeletal structures (Hofmann et al., 2010; Lunden et al., 2013). The preservation of deep-sea corals, and the deep-sea coral ecosystems that they form, is essential for the health of deep-sea ecology and biodiversity, as well as for the economically important fish and invertebrates that they sustain (Roberts et al., 2009).

Field and incubation studies of deep-sea corals under OA conditions reveal that corals can still calcify near or below the ASH with conflicting results about whether or not these coral ecosystems are at risk of death and extensive net dissolution with projected ASH shoaling (Rodolfo-Metalpa et al., 2015). Long-term variable aragonite saturation, $\mathrm{pH}$ and $\mathrm{pCO}_{2}$ incubation studies ( 6 months) also present conflicting results, but overall suggest that deep-sea corals are capable of acclimating to undersaturated/low $\mathrm{pH}$ conditions and continue to calcify, but at slower rates resulting in net dissolution of skeletons (Form and Riebesell, 2012, Maier et al., 2013; Hennige et al., 2015; Kurman et al., 2017). Field studies of deep-sea corals living near or below ASHs show no correlations between $\mathrm{pH}$ and lower skeletal densities or changes in mineral phases with depth (Thresher et al., 2011; Lunden et al., 2013). In contrast, shallow corals are known to form more porous and fragile skeletons with higher organic carbon contents in aragonite undersaturated conditions (Tambutté et al., 2015). Georgian et al., (2016a) suggest that this resilience by live deep-sea corals may be at least partially due to the dissolution of surrounding mounds of dead corals that may increase local saturation states, as evidenced by significantly higher total alkalinity values near coral mounds. Studies of sustained calcification under OA conditions propose that corals may compensate for aragonite undersaturation and the high energy cost of calcification ( $\sim 30 \%$ of energy budget) (Allemand et al., 2011$)$ by manipulating their internal calcifying fluid and raising the $\mathrm{pH} \sim 0.3-0.6$ units (McCulloch et al., 2012a) by increasing heterotrophic feeding (Cohen and Holcomb, 2009; Drenkard et al., 2013; Schoepf et al., 2013; Georgian et al., 2016b). Apart from geochemical explanations for how coral calcification may compensate for aragonite undersaturated conditions, others have proposed that coral biomineralization may not be as susceptible to changes from OA as predicted by geochemical models. This argument is based primarily on the idea that coral aragonite is formed via an amorphous calcium carbonate (ACC) precursor phase (Mass et al., 2017; Von Euw et al., 2017) that is predominantly driven by proteins such as coral acid-rich proteins (CARPs) (Mass et al., 2013) that can precipitate aragonite regardless of surrounding seawater aragonite saturation states. Yet, the notion that calcification is entirely controlled by organic matrices regardless of seawater chemistry is inconsistent with many coral culturing experiments (Chan and Connolly, 2013).

Mineralogical approaches for understanding the effects of OA on coral skeletons are rare compared to studies of calcification rates and bulk skeletal properties, like density and mineral morphology. Juvenile shallow-water corals grown in aragonite undersaturated conditions exhibit morphological shifts to smaller, deformed skeletal architecture with blocky versus acicular crystallites (Cohen et al., 2009; Foster et al., 2016). Distinct abnormal mineralogical morphologies of shorter, cross-hatched crystallites are also observed in solitary micrabaciid 
scleractinian deep-sea corals accustomed to growing in undersaturated waters (Janiszewska et al., 2011). However, no X-ray crystallographic studies have been performed on possible crystallographic distortions that mirror skeletal morphology differences driven by aragonite undersaturated conditions. The most in-depth crystallographic studies on biogenic aragonites are comparisons of biogenic aragonite (mollusk, coral) to geologically-formed aragonite which observe distinct anisotropic lattice distortions ( $a$ - and $c$-axis extensions, $\mathrm{b}$-axis shrinkage) via $\mathrm{X}$ ray diffraction (XRD) in biogenic aragonite (Pokroy et al., 2011). Raman spectroscopy has also recently been used to monitor carbonate vibrational modes in aragonite as a way to observe shifts in the bonding environments of synthetic aragonite coral analogs under varying aragonite saturation (DeCarlo et al., 2017).

The material properties of minerals, such as solubility and strength, are directly linked to their crystal structure. Thus, in addition to other parameters typically recorded in coral ocean acidification studies, such as skeletal morphology and calcification rates, coral skeletal health will likely be dependent on aragonite crystallography. For instance, Hennige et al. (2015) recently observed that incubated deep-sea corals acclimatized to grow in increased $\mathrm{pCO}_{2}$ and temperature conditions, but displayed hidden changes in their crystal organization and aragonite bonding environments, which may weaken overall skeletal health, compromise long-term survival and increase reef solubility upon coral death. The goal of this study is to assess if there are detectable changes to the aragonite crystal structure of natural deep-sea corals as a function of surrounding seawater aragonite saturation state $\left(\Omega_{\mathrm{sw}}\right), \mathrm{pH}$, and other chemical variables, which would ultimately influence the integrity and health of the coral. To do so, we compare the crystal lattice parameters of Lophelia pertusa grown under a modest range of natural seawater aragonite saturation states $\left(1.15-1.44 \Omega_{\mathrm{sw}}\right)$ in the Gulf of Mexico, as well as a suite of other deep-sea coral species from various localities. Despite not having data for the internal calcifying fluid aragonite saturation states $\left(\Omega_{\mathrm{cf}}\right)$, we show that this crystallographic approach is useful in quantitatively assessing the effects of surrounding seawater environments on corals and may be applicable to other biomineralizing systems.

\subsection{MATERIALS AND METHODS}

\subsubsection{Samples}

\subsubsection{Natural deep-sea corals}

Lophelia pertusa colonies ( $\mathrm{n}=5)$ were collected from the Northern Gulf of Mexico by HOV Alvin in May 2014 and represent corals growing in a natural gradient of aragonite saturation $\left(\Omega_{\mathrm{sw}}=1.15-1.44\right)$ described in detail by Lunden et al., (2013) and Georgian et al., (2016) (Supplementary Materials, Figure S3.1). Samples were collected in "live," "recently dead," and "dead" states. An additional L. pertusa sample was collected in the Pacific Ocean from the Southern California Bight (SCB) between April and May 2015 (33⒌ '7.6794' 'N; $119^{\circ} 28^{\prime} 18.84^{\prime}$ ' W) at $\sim 300 \mathrm{~m}$ depth in aragonite undersaturated waters $\left(\Omega_{\mathrm{sw}}=0.81, \mathrm{pH}=7.66\right)$. In order to place the mineralogy of the L. pertusa samples in the context of worldwide deep-sea corals of different species and environments, solitary deep-sea coral samples were collected from Antarctic waters (Burdwood Bank, sample NBP08-05, and the Western Antarctic Penninsula Shelf samples NBP09-02 and LMG15-09) as well as a colonial coral from North-West Atlantic 
waters (Kükenthal Peak, sample KUK220-1). All samples used in this study are presented in Table 3.1.

TABLE 3.1. Corals, synthetic aragonites, and aragonite reference samples analyzed in this study.

\begin{tabular}{|c|c|c|c|c|c|}
\hline Sample Name & Species & $\begin{array}{l}\text { Seawater } \\
\text { pH }\end{array}$ & $\begin{array}{l}\text { Seawater } \\
\Omega_{\mathrm{Ar}}\end{array}$ & $\begin{array}{l}\text { Depth } \\
\text { (m) }\end{array}$ & $\begin{array}{l}\text { Distance } \\
\text { from } \\
\text { seeps (m) }\end{array}$ \\
\hline GC354-Live & Lophelia pertusa & $7.83 \pm 0.02$ & $1.15 \pm 0.05$ & 551 & $\sim 100$ \\
\hline MC751-Live & Lophelia pertusa & $7.86 \pm 0.03$ & $1.29 \pm 0.06$ & 440 & $\sim 10$ \\
\hline \multicolumn{6}{|l|}{ MC751-Recently } \\
\hline Dead & Lophelia pertusa & $7.86 \pm 0.03$ & $1.29 \pm 0.06$ & 440 & $\sim 10$ \\
\hline GB535-Live & Lophelia pertusa & $7.88 \pm 0.04$ & $1.31 \pm 0.15$ & 530 & $<50$ \\
\hline \multicolumn{6}{|l|}{ GB535-Recently } \\
\hline Dead & Lophelia pertusa & $7.88 \pm 0.04$ & $1.31 \pm 0.15$ & 530 & $<50$ \\
\hline GB535-Dead & Lophelia pertusa & $7.88 \pm 0.04$ & $1.31 \pm 0.15$ & 530 & $<50$ \\
\hline VK826-Live & Lophelia pertusa & $7.89 \pm 0.05$ & $1.37 \pm 0.11$ & 480 & $\sim 300$ \\
\hline \multicolumn{6}{|l|}{ VK826-Recently } \\
\hline Dead & Lophelia pertusa & $7.89 \pm 0.05$ & $1.37 \pm 0.11$ & 480 & $\sim 300$ \\
\hline VK826- Dead & Lophelia pertusa & $7.89 \pm 0.05$ & $1.37 \pm 0.11$ & 480 & $\sim 300$ \\
\hline VK906- Live & Lophelia pertusa & $7.9 \pm 0.03$ & $1.44 \pm 0.11$ & 480 & $\sim 500$ \\
\hline \multicolumn{6}{|l|}{ VK906- Recently } \\
\hline Dead & Lophelia pertusa & $7.9 \pm 0.03$ & $1.44 \pm 0.11$ & 480 & $\sim 500$ \\
\hline \multirow[t]{2}{*}{ CAL } & Lophelia pertusa & $7.66 \pm 0.01$ & $0.81 \pm 0.07$ & 300 & -- \\
\hline & $\begin{array}{l}\text { Flabellum } \\
\text { impensum }\end{array}$ & -- & -- & 620 & -- \\
\hline LMG15-09 & $\begin{array}{l}\text { Flabellum } \\
\text { curvatum }\end{array}$ & -- & -- & 652 & -- \\
\hline NBP09-02 & $\begin{array}{l}\text { Balanophyllia } \\
\text { malouensis }\end{array}$ & -- & -- & 820 & -- \\
\hline NBP08-05 & $\begin{array}{l}\text { Enallopsammia } \\
\text { rostrata }\end{array}$ & -- & -- & 1457 & -- \\
\hline f06 & synthetic aragonite & $8.38 \pm 0.01$ & $11 \pm 1$ & -- & -- \\
\hline g04 & synthetic aragonite & $8.48 \pm 0.01$ & $25 \pm 3$ & -- & -- \\
\hline g09 & synthetic aragonite & $7.78 \pm 0.02$ & $23 \pm 5$ & -- & -- \\
\hline h01 & synthetic aragonite & $8.86 \pm 0.01$ & $21 \pm 4$ & -- & -- \\
\hline$J C p-1$ & Porites sp. & $\begin{array}{l}8.51 \pm 0.07 \\
\text { (*internal) }\end{array}$ & $\begin{array}{c}12.3 \pm 0.3 \\
\text { (*internal) } \\
\end{array}$ & & \\
\hline
\end{tabular}

*internal calcifying fluid aragonite saturation states are calculated via Raman spectroscopy in DeCarlo et al., 2017. 


\subsubsection{Synthetic Aragonites}

A suite of synthetic aragonites (f06, g04, g09, and h01) precipitated from seawater at controlled aragonite saturation states and $\mathrm{pH}$ were used for comparison to the corals. These synthetic aragonites were precipitated from seawater at $25^{\circ} \mathrm{C}$ with carbonate chemistry modified by $\mathrm{NaHCO}_{3}$ and $\mathrm{Na}_{2} \mathrm{CO}_{3}$ solutions, which were added to the seawater during precipitation to maintain stable $\mathrm{pH}$ and $\left[\mathrm{CO}_{3}{ }^{2-}\right]$. For detailed methods and previous Raman spectroscopy and trace metal analysis measurements of these samples, see DeCarlo et al., 2015 and Holcomb et al., 2016.

\subsubsection{Coral skeleton sampling and removal of organics}

In order to sample consistently across different coral polyps, genotypes and species, outermost tips (1-3 mm) of coral septa were sampled and gently powdered using an agate mortar and pestle. For the L. pertusa samples from the Gulf of Mexico, 1-2 $\mathrm{mm}$ of skeleton from the outer polyp areas were also sampled to compare to septa samples. Coral powders were bleached to remove any excess tissue or potential crystal scaffolding organic material using a procedure modified from Gaffey and Bronnimann (1993) and Politi et al., (2006): 1). Powdered coral samples (approximately 1-2 mg) were placed in $0.5 \mathrm{~mL}$ microcentrifuge tubes, 2). $20 \mu \mathrm{L}$ of $5 \%$ free chlorine sodium hypochlorite (ACROS) was added, 3). Tubes were vortexed four times to ensure that all powder surfaces were exposed to the bleach. The powders sat in the bleach for a total of 45 minutes. 4). Powders were thoroughly rinsed 6 times to remove any bleach residues by adding $200 \mu \mathrm{L}$ of Milli-Q water, vortexing, allowing powder to settle, centrifuging, and carefully removing supernatant water. 5). Samples were air-dried before being run on X-ray instruments.

\subsubsection{Instrumentation and Analysis}

\subsubsection{X-ray diffraction}

Powder X-ray diffraction was conducted on a Rigaku D/MAX Rapid II micro X-ray diffractometer with a 2D imaging plate detector at the Hansel Lab, Woods Hole Oceanographic Institution using Mo K $\alpha$ radiation $(\lambda=0.709300 \AA)$. Samples were carefully aligned and run for 10 minutes with omega fixed at 0 and phi rotating at 1 degree per second. Four sample replicates were run for each sample.

All samples were gently re-ground in an agate mortar and pestle to achieve an even smaller powder grain size, to keep methods consistent between coral and non-coral samples, and to confirm that we were not inducing phase transformations by using a mortar and pestle. Our natural and synthetic aragonites showed the same results pre- and post- grinding. Powders were mounted on Kapton tips by MiTeGen by using a very thin layer of mineral oil on the tips. A subset of samples were also loaded into $0.8 \mathrm{~mm}$ Kapton capillaries and compared to results from Kapton tips to assure that results did not vary due to sample mounting methods.

XRD image files were background corrected (manual setting $=5$ ) and integrated into intensity versus $2 \theta$ patterns from 3.0 to $45.02 \theta$ degrees and 81.6337 to $430.00 \beta$ using 2DP software. 
Full width at half maximum (FWHM) measurements were performed on the main (111) peak of the coral aragonite diffraction pattern using PDXL 2 Rigaku software by referencing Caspi et al., (2005) for aragonite and Swanson et al., (1953) for calcite.

\subsubsection{Rietveld analysis and Statistics}

The GSASII program (Toby and Von Dreele, 2013) was used to perform the quantitative full-pattern Rietveld refinement fitting method as described by Bish and Post (1993) from 8 to 44 $2 \theta$ degrees using a Chebyschev polynomial background and aragonite (Antao and Hassan, 2009) and calcite (Markgaf and Reeder, 1985) model structures.

A synthetic aragonite reference was used for calibration and refinement of the numbers obtained in Rietveld analysis in response to the specific alignment of the XRD. All Rietveld results are shifted by: $a$-axis $=-0.003375 \AA, b$-axis $=-0.012724 \AA, c$-axis $=-0.005675 \AA$, and volume $=-0.7435 \AA^{3}$, leading to corresponding results between the XRD instrument in the Hansel lab at the Woods Hole Oceanographic Institution and an equivalent instrument in the Department of Mineral Sciences, Smithsonian Institution. Since shifts were applied to all samples, the shifts did not affect the relative differences between samples. Errors in Rietveld refinements are represented as estimated standard deviations and exceed standard deviations between sample replicates.

Principal component analysis (PCA) was run on all variables for live septa samples from the Gulf of Mexico corals. PCA biplots revealed correlations between variables by noting which variable vectors exist close to $0^{\circ}$ and $180^{\circ}$ angles to each other. Based on the relationships identified in the PCA analysis, regression analyses were run on the crystal lattice parameters and calcite contents resulting from Rietveld analyses versus environmental growth conditions (seawater $\mathrm{pH}$, aragonite saturation state, depth) and trace element incorporations ( $\mathrm{Ba}, \mathrm{Sr}, \mathrm{Mg}$ ). Trend lines were plotted for relationships which are statistically significant $(p<0.05)$. Unequal variance $\mathrm{T}$-tests were run on crystallographic lattice parameters to determine any significant differences between populations based on locality (Gulf of Mexico versus other localities) and sampling area of the coral (septa versus outer polyp). One-way ANOVA tests were used to compare state of collection for L. Pertusa from the Gulf of Mexico (live, recently dead and dead). Levene's tests were used to test homogeneity of variances and Kolmogorov-Smirnov tests were utilized to confirm normality of residuals.

\subsubsection{Inductively-coupled mass spectroscopy (ICP-MS)}

Trace metal concentrations of a subset of natural L. pertusa samples were measured using an iCAP ICP-MS at the Woods Hole Oceanographic Institution. Samples were oragnics-removed and rinsed using methods in the "Coral sampling and removal of organics" section above. Dried samples were weighed and digested with concentrated trace metal grade nitric acid (J.T. Baker ULTREX® II Ultrapure Reagent) in trace metal-cleaned $15 \mathrm{~mL}$ Falcon centrifuge tubes and diluted using Milli-Q water for ICP-MS analysis. To account for matrix effects, trace element to $\mathrm{Ca}$ ratios for the corals in this study were calculated based on known ratios in the JCp-1 reference Porites sp. coral (Hathorne et al., 2013) that was also measured with ICP-MS alongside the samples in this study.

\subsubsection{Environmental Scanning Electron Microscopy (ESEM)}

We utilized a Hitachi TM3000 environmental table-top scanning electron microscope (SEM) at the Woods Hole Oceanographic Institution to assess the morphologies of the Gulf of 
Mexico L. pertusa corals over the range of aragonite saturation states measured in this study. Thin sections were cut parallel to the growth direction of the polyps and included regions of septa and outer polyps. All thin-sections were made by High Mesa Petrographics. Photographs were also taken of hand samples prior to sectioning.

\subsection{RESULTS}

\subsubsection{Structural characterization via X-ray diffraction}

X-ray diffraction (XRD) patterns (Figure 3.1) analyzed via Rietveld refinements confirm that all corals measured are composed of aragonite containing only minor traces of calcite (presence of visible main calcite (104) peaks highlighted with black arrows). Unit cell parameters of live deep-sea corals determined by Rietveld refinements are plotted in order in Figure 3.2 as averages of four replicates per sample. Two-tailed T-tests on these samples demonstrate that there are no statistically significant differences in crystal lattice parameters between septa and outer polyp regions of the skeletons of $L$. pertusa samples from a natural $\Omega_{\mathrm{sw}}$ gradient in the Gulf of Mexico or between the septa of $L$. pertusa from the Gulf of Mexico versus septa of other deep-sea coral species and localities (Supplementary Materials, Table S3.1). One-way ANOVA of L. pertusa samples collected in live, recently dead, and dead states from the Gulf of Mexico reveal that unit cell volumes and $c$-axis lengths vary significantly between these three collection states (Supplementary Materials, Table S3.1). $A$ - and $b$-axis lengths are not statistically distinct across the different collection states as indicated by a $p>0.05$, or failure to pass Levene's test of variance.

Since we are interested in learning how coral crystallography and mineralogy shifts as a function of environmental parameters and a series of nested variables, here we use multivariable statistics to unravel the relative impact of the variables measured in this study. Focusing on the septa samples of live L. pertusa from the Gulf of Mexico, PCA of samples (violet circles) as they are influenced by all variables (solid vectors) are plotted as a biplot of principal component (PC) 1 versus PC2 (Figure 3.3). Together, these principal components account for $76.6 \%$ of the variability between samples. In this biplot, vectors that lie at close to 0 or 180 angles to each other represent variables that are correlated and perhaps linked. As expected, vectors for unit cell volume and individual unit cell axes (represented as blue lines) lie at narrow angles to one another, since they are intrinsically linked. The only environmental variable that plots close to these crystallographic parameters is the distance from hydrocarbon seeps where the coral colonies were collected from. The crystallographic parameter vectors lie almost perpendicular to the other environmental variables $\left(\Omega_{\mathrm{sw}}, \mathrm{pH}_{\mathrm{sw}}\right.$ and depth, represented as bold red lines) (Figure 3.3). Thus, we expect these environmental variables to have a minimal impact on coral aragonite crystallography. To confirm these relationships, we ran simple regressions of unit cell volume and some of these environmental variables (Figure 3.4A). Statistically significant relationships are plotted in black solid trend lines. While the PCA biplot does not show a clear relationship between unit cell volume and $\Omega_{\mathrm{sw}}$ or $\mathrm{pH}_{\mathrm{sw}}$, we observe a weak, yet statistically significant, pattern of larger unit cell volume as a function of increasing $\Omega_{\text {sw. }}$. As expected from the close PCA biplot relationship between lattice parameters and distance from hydrocarbon seeps, we do 
observe a stronger relationship of increasing unit cell volume with increasing distance from hydrocarbon seeps (Figure 3.4A).

As a comparison to coral aragonites, we plot the relationships between unit cell volume and formation conditions for synthetic aragonites precipitated from seawater with discrete aragonite-supersaturated and $\mathrm{pH}$-elevated conditions (Figure 3.4B, triangles). Unit cell volumes increase as a function of increasing $\Omega_{\text {sw }}$ (black dashed line). We observe the same statistically significant pattern as we add a natural coral sample (JCp-1, mint-green diamonds) with a known internal calcifying fluid chemistry (mint-green solid line) (DeCarlo et al., 2017). No statistically significant pattern is observed for unit cell volume as a function of $\mathrm{pH}$ of formation. Trends for individual unit cell axes and the FWHM of XRD (111) peaks as a function of $\Omega_{\mathrm{Ar}}$ and $\mathrm{pH}$ for both corals and synthetic aragonites are plotted in the Supplementary Materials, Figures S3.2 and S3.3. Table S3.2 in the Supplementary Materials lists values for $\mathrm{p}, \mathrm{R}^{2}$, and trendline slopes and $\mathrm{y}$-intercepts for all simple regressions run in this study. All error bars in our crystallography versus environmental parameters plots represent estimated standard deviations from our Rietveld refinement measurements. Due to the large standard deviations in some of our relationships, we have also run York regressions on some of the relationships to account for errors along both axes (York, 1968). York regression trend lines are listed in Supplementary Materials, Table S3.2 and demonstrate that the slopes of York regressions do not vary drastically from our simple regressions. 


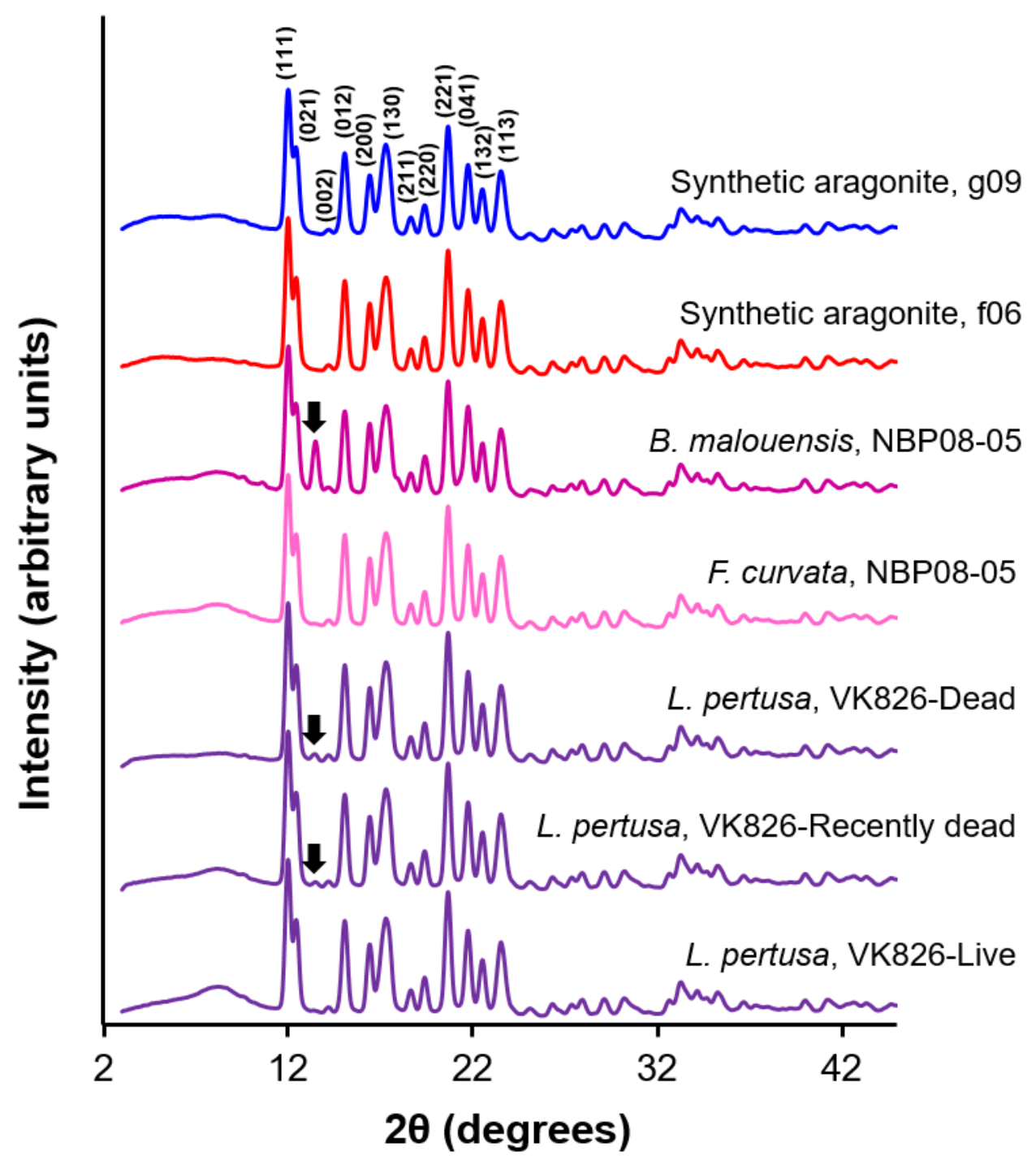

FIGURE 3.1. Representative XRD patterns of deep-sea corals and synthetic aragonites using Mo K $\alpha$ radiation $(\lambda=0.709300 \AA)$. Miller indices are labeled on the g09 synthetic aragonite pattern and all patterns are normalized to the (111) peak heights. Calcite contributions are highlighted with black arrows on certain samples. 

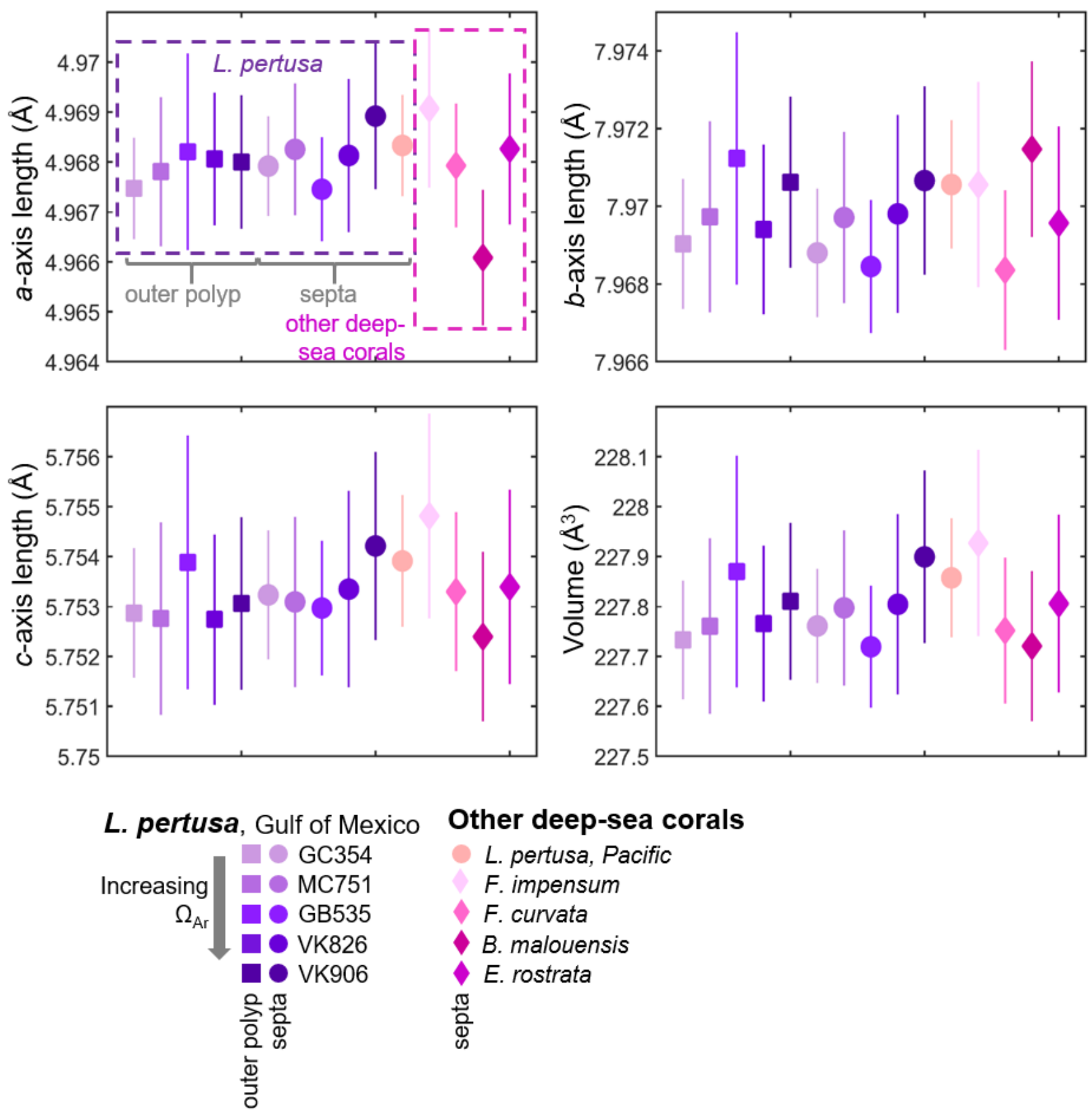

FIGURE 3.2. Crystallographic lattice parameters of L. pertusa aragonites from the Gulf of Mexico, compared to other species and localities of deep-sea corals. Samples are taken from the area outside of the polyps (squares) and from septa (circles and diamonds). Each point is an average of four replicates. Error bars represent estimated standard deviations. 


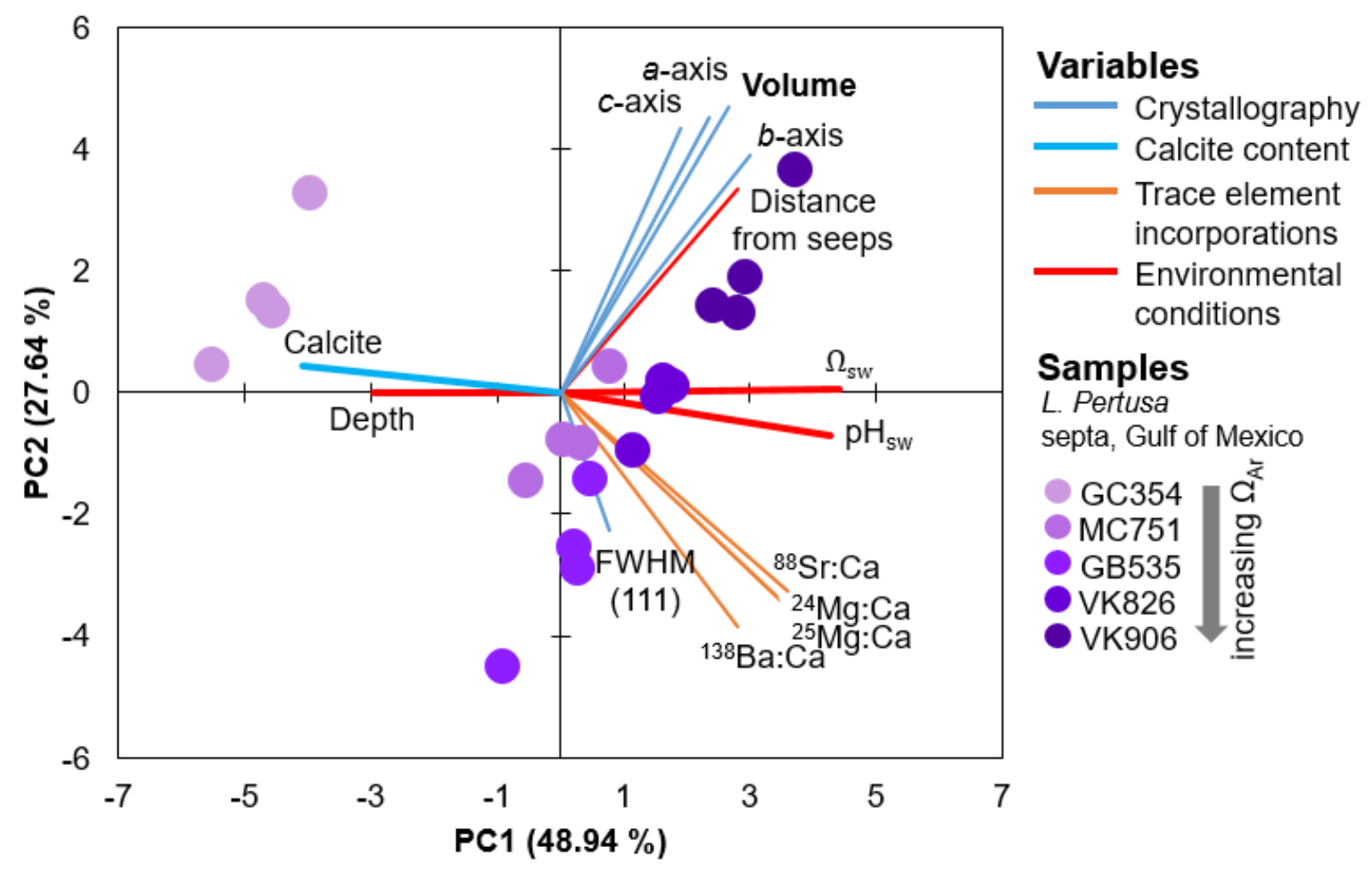

FIGURE 3.3. PCA biplot of component 1 versus 2 which accounts for $75 \%$ of the variability between samples of $L$. pertusa septa from the Gulf of Mexico (purple circles). All of the variables measured in this study are expressed as vectors in solid lines. 
A
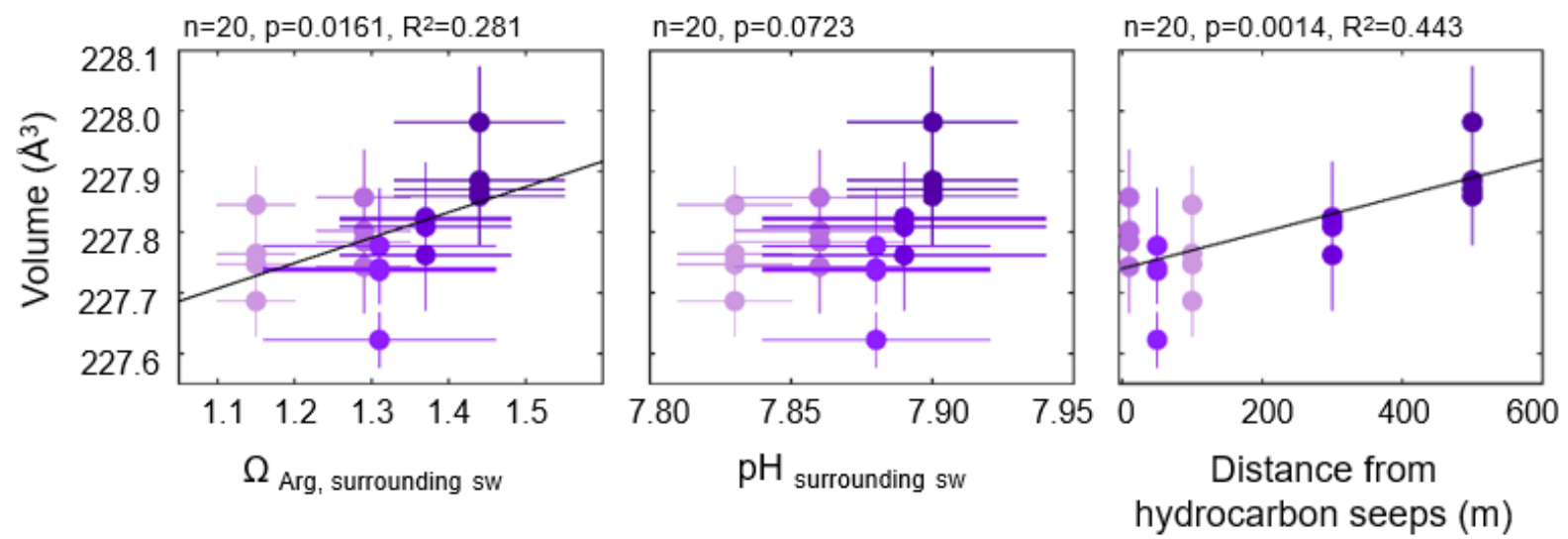

B
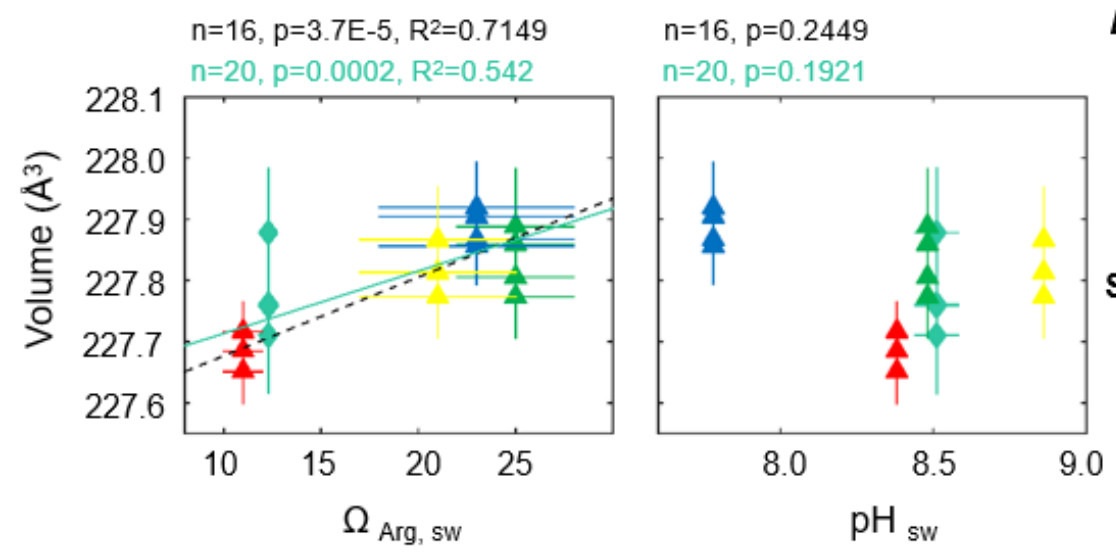

L. pertusa, live septa, Gulf of Mexico

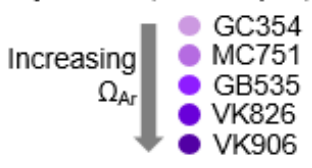

Synthetic aragonites

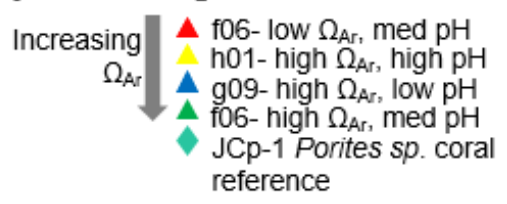

FIGURE 3.4. Unit cell volumes of aragonite as a function of environmental variables for A) Gulf of Mexico L. pertusa live septa samples (violet circles) versus surrounding seawater chemistry at colony collection sites, and B) synthetic aragonites precipitated from seawater versus seawater formation chemistry (triangles, black dashed trend line). A JCp-1 reference coral with known internal calcifying fluid chemistry is also added (mint-green diamonds, solid trend line) as a comparison to synthetic aragonites. 


\subsubsection{Calcite contents in deep sea corals}

Calcite contents (phase percentages) determined by Rietveld refinements reveal that live coral septa and synthetic aragonites contain very low calcite contents $(<1 \%)$, with the exception of Balanophyllia malouensis that has a large calcite peak (8.9\% phase contribution) (Figure 3.1; Supplementary Material Table S3.3). Within L. pertusa septa samples from the Gulf of Mexico, recently dead (yellow sideways triangles) and dead (red inverted triangles) samples stand out as having the highest phase fractions of calcite $(\sim 1-3 \%)$ compared to samples collected in live states (green circles), especially as a function of increasing depth of collection (Figure 3.5). All other weak or trends with calcite content are plotted in the Supplementary Materials Figure S3.4A for all three collection states and in Figure S3.4B for only live coral samples.

Focusing on only the live Gulf of Mexico samples, based on the PCA biplot, we observe that the vector position for calcite contents (bold, light blue vectors) indicates that calcite contents are most likely related to depth, $\Omega_{\mathrm{sw}}$, and $\mathrm{pH}_{\mathrm{sw}}$ (bold, red vectors) (Figure 3.3). These four variables appear to be driving most of the variability in PC1 and lie parallel to the difference between the GC354 coral growing at the lowest surrounding $\Omega_{\mathrm{sw}}$ and the other corals growing at higher surrounding $\Omega_{\text {sw }}$. Thus, we have plotted increasing calcite content as a function these environmental parameters (Figure 3.6A) and observe some moderate inverse trend lines from simple regressions $\left(\mathrm{R}^{2}=0.415\right.$ for $\mathrm{pH}_{\mathrm{sw}}, \mathrm{R}^{2}=0.358$ for $\left.\Omega_{\mathrm{sw}}\right)$. Due to the nested nature of these many variables, we have also plotted how unit cell volume may be shifting as a function of increasing calcite content and observe a weak inverse correlation (Figure 3.6B). All simple regression equations, $\mathrm{p}$-values and $\mathrm{R}^{2}$ values are listed in Supplementary Materials, Table S3.2. It is important to note that while we present regressions for calcite content as a function of individual variables, many of these environmental variables are inter-related and may have varying impacts on calcite content, as is graphically presented in the PCA biplot (Figure 3.3).

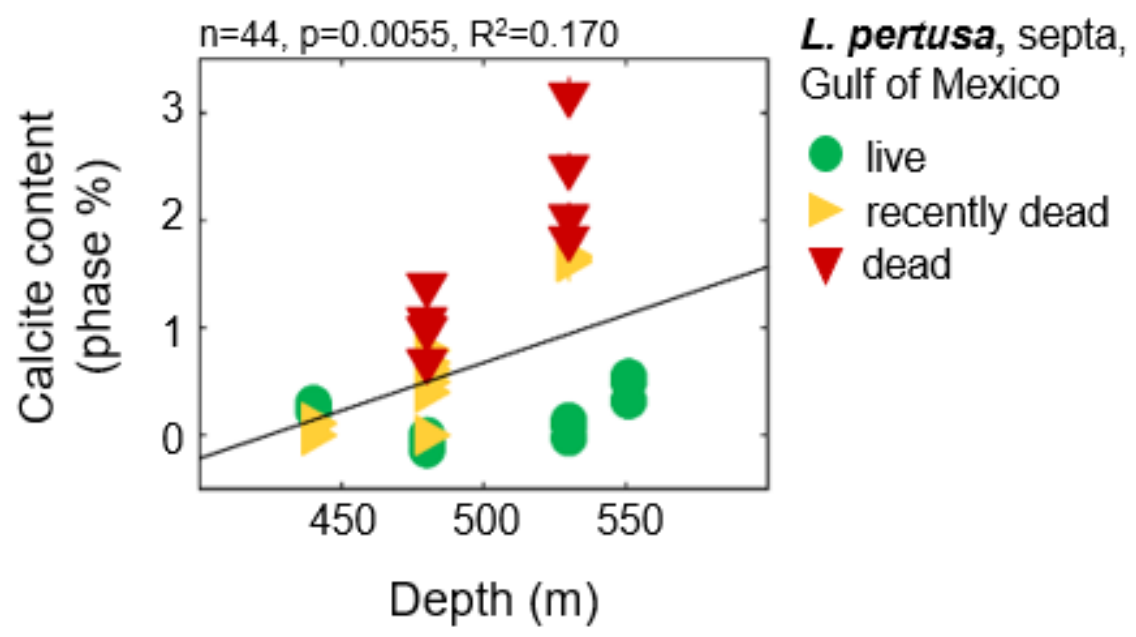

FIGURE 3.5. Calcite contents in Gulf of Mexico L. pertusa septa samples as a function of increasing water column depth, with corals collected at various states- live, recently dead, and dead. 

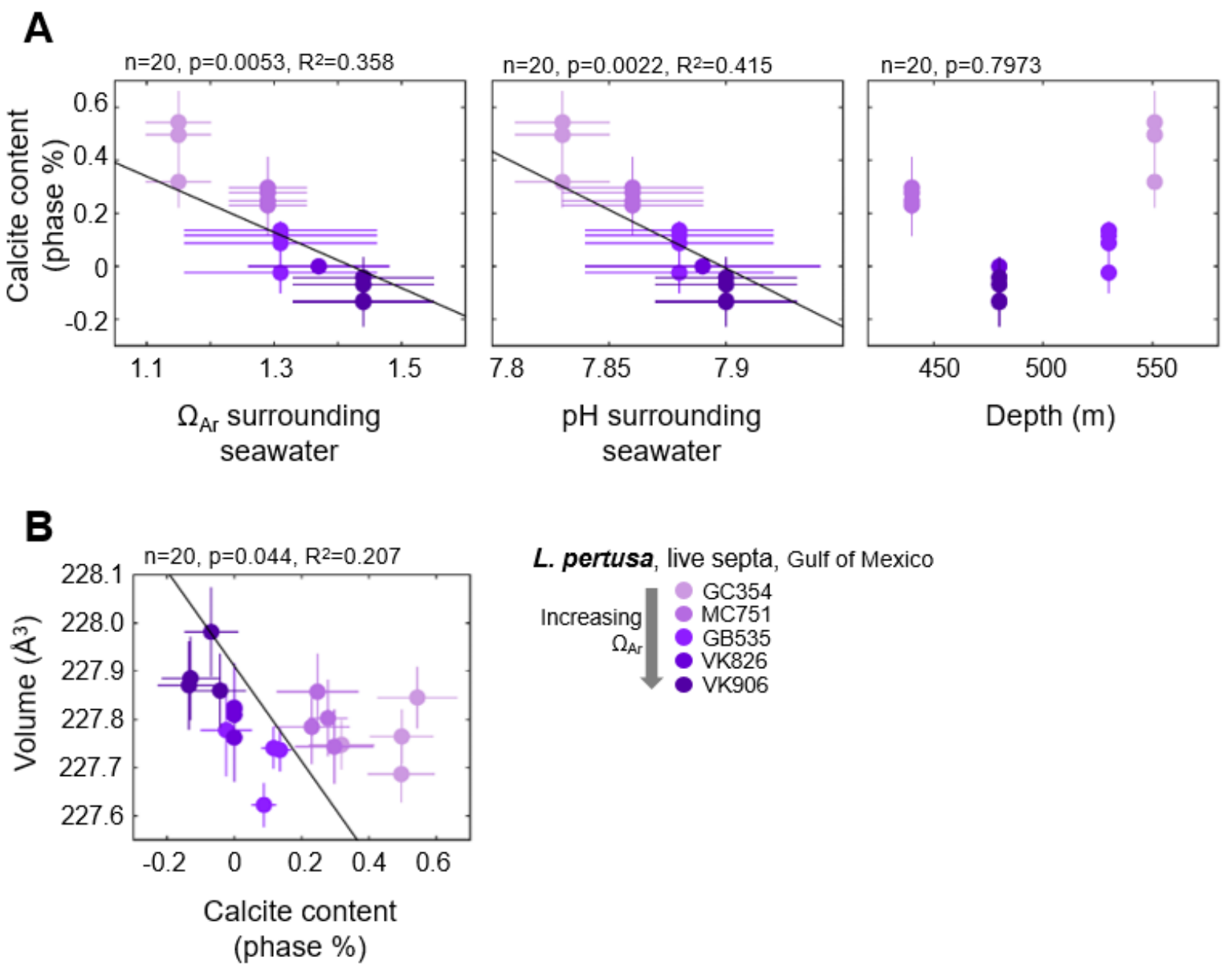

FIGURE 3.6. Gulf of Mexico L. pertusa live septa A) calcite contents as a function of surrounding seawater chemistry and depth, and B) shifts in unit cell volume as a function of increasing calcite contents. 


\subsubsection{Trace metal analysis within coral skeletons}

The only statistically significant relationship between trace element incorporations and crystallography lies between widening of the FWHM (111) aragonite XRD peak as a function of increasing Ba content (Figure 3.7). This strong relationship $\left(\mathrm{R}^{2}=0.853\right)$ is determined both by the parallel position of these variables in the PCA biplot (Figure 3.3). Simple regressions between trace element incorporations versus the many other variables measured in this study do not suggest any other statistically significant relationships (plotted in the Supplementary Materials, Figure S3.5).

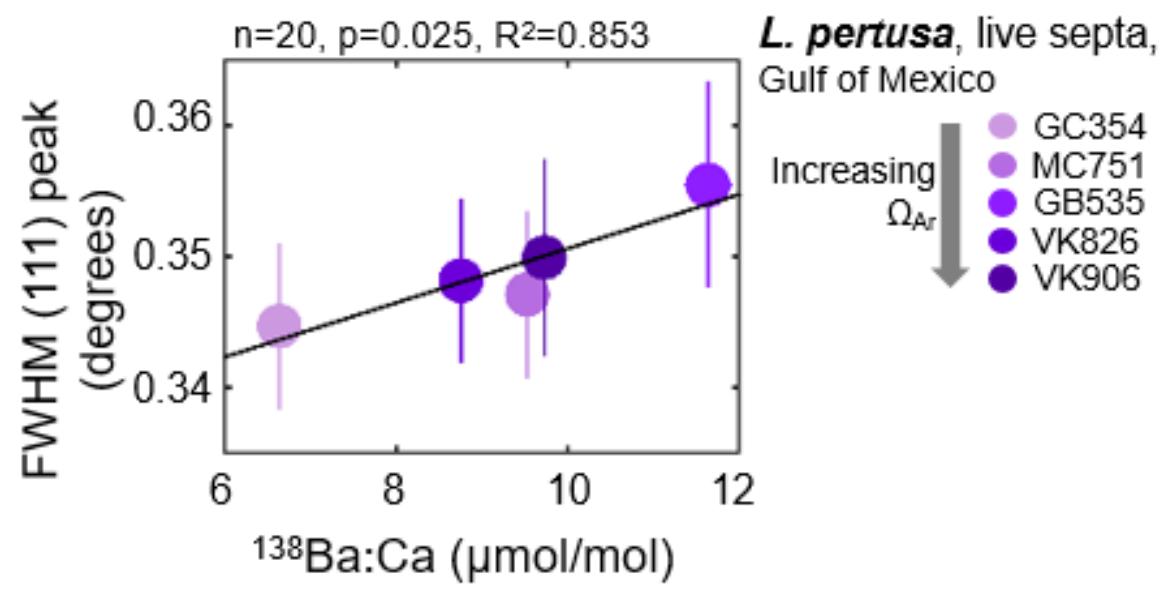

FIGURE 3.7. FWHM of the (111) aragonite XRD peak increasing as a ${ }^{138} \mathrm{Ba}$ :Ca content increases in Gulf of Mexico L. pertusa live septa samples. ${ }^{138} \mathrm{Ba}$ :Ca ratios are calculated based on known ratios in the JCp-1 reference coral (Hathorne et al., 2013).

\subsubsection{Scanning Electron Microscopy of Coral Morphologies}

SEM images of live Gulf of Mexico L. pertusa thin-sections under increasing aragonite saturation states, at magnifications increasing to $1000 \mathrm{x}$ magnification, reveal small morphological differences between the septa (Supplementary material, Figure S3.6) and outer skeletal (Supplementary material, Figure S3.7) regions in corals grown in lower saturation state conditions. Septa in higher-saturated state corals have thinner, more defined septa cross-sections, while samples grown in lower saturation states have wider septa with more etched edges with visible individual crystallites at high magnifications (Supplementary material, Figure S3.6). This is especially true in the septa of $L$. pertusa $\operatorname{GC} 354\left(\Omega_{\mathrm{sw}}=1.15\right)$, which displays etched features similar to corals from previous studies at 2500x magnification (Rodolfo-Metalpa et al., 2011, Hennige et al., 2015) (Supplementary material, Figure S3.8). Nevertheless, overall, the differences in skeletal morphology between $L$. pertusa samples under this relatively small range of saturation states are not substantial. 


\subsection{DISCUSSION}

\subsubsection{Aragonite crystallography from corals of different species and localities, sampling regions, and collection states}

Despite differences in skeletal architecture and drastically different environmental conditions, we observe that the overall aragonite crystallography of deep-sea corals from different global localities does not differ significantly. This is supported by T-tests comparing various coral species, ranging from the solitary coral, Flabellum impensum, from Antarctica to the robust colonial coral, Lophelia pertusa, from the Gulf of Mexico (Table 3.1; Figure 3.2). Within our dataset of L. pertusa from the Gulf of Mexico, we also observe via T-tests that crystallography is not statistically distinct between septa and outer polyp regions of the skeleton (Figure 3.2). This is despite some visual evidence from SEM images that point to outer polyp regions exhibiting more evidence of dissolution (Supplementary material, Figure S3.7) and prior studies that observed how outer polyp regions with potentially less tissue-cover may be more susceptible to dissolution (Hennige et al., 2015). Since crystallography and chemistry are what govern the material properties of skeletal aragonite (solubility, strength), it is important to test whether shifts in morphology (such as signs of increased skeletal dissolution) may be reflected in coral crystallography. While this study observes similar crystallography across many coral species, there may still be nuanced shifts within a particular species growing under varying environmental conditions which could influence aragonite solubility and stability within that coral species.

One variable which appears to have a pronounced effect on mineralogy and crystallography the Gulf of Mexico L. pertusa samples is the state at which the sample was collected: live, recently dead, or dead. One-way ANOVAs reveal some statistically significant variability between these states, especially in terms of overall unit cell volume and $c$-axis lengths (Supplementary material, Tables S3.1 and S3.3). This difference in volume and $c$-axis length for L. pertusa collected in different states may be due to increased phase fractions of calcite in recently dead and dead corals as highlighted with black arrows in Figure 3.1 and plotted in Figure 3.5 and Supplementary Materials, Figure S3.4A.

Comparing our crystallographic findings of deep-sea corals to previous studies, unit cell volumes of live deep-sea corals (227.719-227.927 $\AA^{3}$ ) fall slightly above the range of previous X-ray diffraction studies on mollusk (226.4277-227.774 $\AA^{3}$ ) and coral biogenic aragonites (227.488-227.603 $\AA^{3}$ ) (Pokroy et al., 2004;2006;2007; Stolarski et al., 2007; Roger et al., 2017) (Figure 3.2, Supplementary material Table S3.3). Average anisotropic axis elongations in corals from this study compared to geological aragonite (Pokroy et al., 2007) agree with elongation ratios from Pokroy et al., (2007) along the $a$ - and $c$-axes $\left(\Delta a / a_{\text {Pokroy }}=0.000967, \Delta a / a\right.$ This study $=$ $\left.0.001086 ; \Delta c / c_{\text {Pokroy }}=0.0019, \Delta c / c_{\text {This study }}=0.00199\right)$, but not along the $b$-axis in which we observe elongations rather than a shortening as reported by Pokroy et al., (2007) $\left(\Delta b / b_{\text {Pokroy }}=\right.$ $-0.00037, \Delta b / b_{\text {This study }}=0.00025$ ) (Figure 3.2). It is important to note that the magnitude of change along the $b$-axis is smallest in both our study and prior studies; these changes also approach the margin of error, which may explain the discrepancy between elongation versus shortening in our studies. While changes along the $b$-axis may be minor when comparing to geological aragonites, anisotropic elongations along the $b$-axis are most closely correlated with increasing aragonite saturation state of surrounding seawater in our live L. pertusa septa samples 
$\left(\mathrm{R}^{2}=0.338\right.$, Supplementary Materials, Figure S3.2A), compared to other axes and overall volume (Figure 3.4A).

\subsubsection{Aragonite mineralogy and crystallography as a function of seawater aragonite saturation state}

In this study we explore the mineralogy and crystallography on a subset of Lophelia pertusa samples collected along a natural gradient of aragonite saturation states in the Gulf of Mexico in order to determine whether there are hidden shifts which may impact skeletal dissolution and strength under unfavorable seawater chemistry conditions. Surveying how the many variables which we measured in this study relate to crystal lattice parameters via a PCA biplot, we would not expect any strong relationships between crystallography and most of the environmental or trace element variables measured (Figure 3.3). Despite this, the skeletons of live L. pertusa septa samples still exhibit minor $\left(\mathrm{R}^{2}=0.281\right)$ crystallographic distortions towards larger unit cell volumes as a function of increasing aragonite saturation state (Figure 3.4A). Despite not having aragonite saturation state measurements inside of the coral calcifying fluid, our observations on how surrounding seawater conditions influence coral mineralogy mirror the relatively strong trends we observe in synthetic aragonites precipitated directly from seawater of known aragonite saturation states (black dashed trend line, $\mathrm{R}^{2}=0.7149$ ) as well as for an added reference coral with a known calcifying fluid $\Omega_{\mathrm{Ar}}\left(\Omega_{\mathrm{Ar}, \mathrm{cf}}=12.3\right.$, DeCarlo et al., 2017) (mint-green solid trend line, $\mathrm{R}^{2}=0.542$ ) (Figure 3.4B). Thus, stronger or additional patterns may have been observed here if calcifying fluid aragonite saturation states had been available to compare with crystallographic lattice parameters. Interestingly, L. pertusa and synthetic aragonite samples do not show statistically significant unit cell volume shifts with varying $\mathrm{pH}$ (Figure 3.4).

In parallel with these crystallographic structural distortions, we also find some evidence of increased surface etching and roughness (more corrosion) for corals growing within waters with decreasing $\Omega_{\mathrm{sw}}$ (Supplementary material, Figure S3.1). While previous studies have observed marked distortions in coral skeletons and crystallite morphologies in shallow corals growing in undersaturated conditions (Cohen et al., 2009; Foster et al., 2016; Tambutté et al., 2015; Wu et al., 2017), overall skeleton morphology shifts in deep-sea corals are not as obvious. Instead, L. pertusa colonies express only minor outward morphological differences in undersaturated $\Omega_{\mathrm{sw}}$ conditions with hidden internal crystal morphology towards less ordered, smaller crystallites observable via electron backscatter diffraction (EBSD) (Hennige et al., 2015). Our SEM images suggest a similar lack of major outward morphological changes in L. pertusa. Despite these minor morphological changes, there are detectable changes to the aragonite crystal structure within these corals (Figure 3.4A); albeit not major structural modifications.

There are several explanations for why the crystallographic shifts we observe in these Gulf of Mexico deep-sea corals are minor. First, this is a natural and modest aragonite saturation state gradient $\left(\Omega_{\mathrm{sw}}=1.15\right.$ to 1.44$)$ compared to other incubation studies which have explored geochemical influences on coral mineralogy over a much wider saturation state gradient $\left(\Omega_{\mathrm{Ar}, \mathrm{sw}}\right.$ $=0.22$ to 4.5) (Foster et al., 2015; Cohen et al., 2009). Second, corals may play an active role in raising their internal calcifying fluid $\Omega_{\mathrm{cf}}$ via increased heterotrophic feeding (Drenkard et al., 2013; Georgian et al., 2016b) to compensate for low $\Omega_{\text {sw }}$ in surrounding seawater. Third, recent models for biologically-controlled biomineralization mechanisms suggest that corals may be very resistant to surrounding geochemistry (Von Euw et al., 2017; Mass et al., 2017). Finally, 
deep-sea corals may have naturally more resistant skeletons compared to shallow corals since they have slower growth rates and are more accustomed to extreme conditions (i.e., McCulloch et al., 2012b). Our findings corroborate findings that deep-sea coral mineralogy is relatively resistant to natural low seawater aragonite saturation states, with only minor crystallographic distortions observed. The structural changes that are observed in the L. pertusa skeletons are similar to those observed for abiotic aragonites synthesized under different aragonite saturation states.

Beyond shifts in crystallography with $\Omega_{\mathrm{sw}}$, based on the PCA biplot and regressions, we observe a tighter relationship between crystallography and the distance from which coral colonies were collected with respect to nearby hydrocarbon seeps (Figure 3.4A, $\mathrm{R}^{2}=0.443$ ). While there is no immediate explanation for this, assuming that this relationship is no coincidence, this distance could be indirectly related to growth rate or other crystal growth parameters. For instance, distance away from hydrocarbon seeps could increase food availability and thus available energy for the coral to spend on calcification. This could lead to faster skeletal growth and crystal growth rates, thus influencing crystallography. Furthermore, there is a statistically significant relationship between increasing $\Omega_{\mathrm{sw}}$ with increased distance away from hydrocarbon seeps, indicating a slight unfavorable shift in carbonate chemistry surrounding the seeps $\left(\mathrm{p}=0.0002, \mathrm{R}^{2}=0.538\right)$.

Overall, we observe very weak crystallographic patterns in L. pertusa towards larger unit cell volumes with increasing $\Omega_{\mathrm{sw}}$, which mirrors the slight morphological shifts we observe in hand-specimens and SEM images.

\subsubsection{Models of substitutions for $\mathrm{Ca}$ into aragonite as a function of aragonite saturation state}

The minor shifts in crystallography we observe as a function of $\Omega_{\mathrm{Ar}}$ may be explained by crystal growth parameters, such as growth rate. In this study, we use XRD to track shifts in overall crystallography by quantitatively measuring the aragonite unit cell parameters via Rietveld refinements. Previous studies have similarly interrogated the aragonite carbonate bonding environment via Raman spectroscopy measurements and proposed that aragonites grown in aragonite supersaturated conditions crystallize at faster rates and incorporate more impurities and/or crystal defects. This is observed by clear increases in crystallographic disorder via a widening of the FWHM for the $v_{1}$ symmetric stretching mode of the carbonate groups in aragonite with increasing $\Omega_{\mathrm{Ar}}$ (DeCarlo et al., 2017). This common shift towards more disorder in crystallography and carbonate bonding environment as a function of $\Omega_{\text {Ar }}$ may indicate that crystallography and carbonate bonding environments are linked. For example, an elongation along the $c$-axis, the most dominant trend with increasing $\Omega_{\mathrm{Ar}}$ in synthetic and JCp-1 aragonites (Supplementary Materials, Figure S3.2B, $\mathrm{R}^{2}=0.564$ ), runs perpendicular to the trigonal planar carbonate groups and could be responsible for the static out-of-plane rotations which could cause an observed increase in disorder in the $v_{1}$ Raman mode (Figure 3.8B, not-to-scale). Anisotropic shifts along the $b$-axis, which run parallel to the carbonate groups in aragonite, may specifically influence bonding environments of the carbonate groups along that plane, such as $\mathrm{T}$ (translation, lattice mode) and $v_{4}$ (in-plane bending internal mode) Raman modes. 


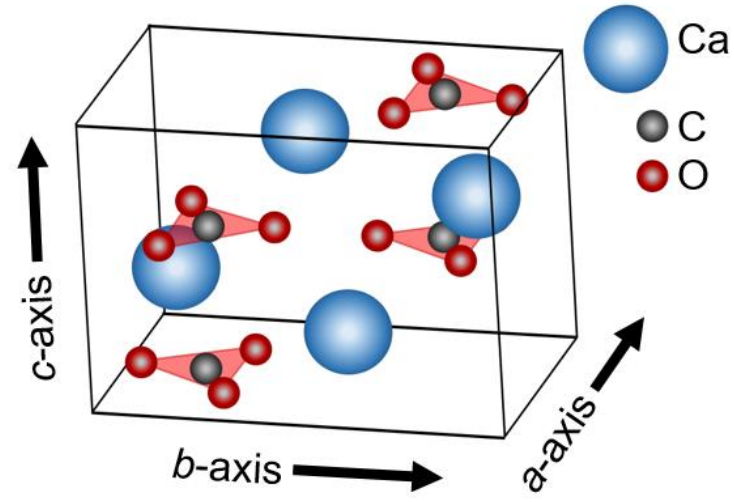

Geological aragonite

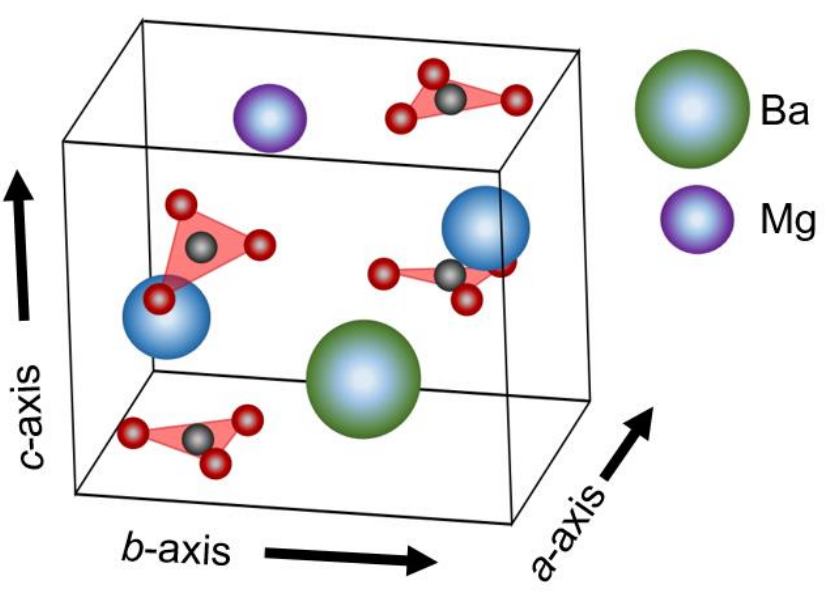

Coral aragonite

FIGURE 3.8. Schematic of the aragonite unit cell with labeled $a$-, $b$ - and $c$-axes and positions of trigonal planar carbonate groups and calcium ions. A). aragonite under normal conditions, B). aragonite with longer axes lengths, larger overall volume, distorted symmetry (static out-of-plane rotations of the carbonate groups), and potential trace-incorporations by other elements for Ca. This figure is not to scale and length expansions, distortions and substitutions are exaggerated for effect.

In another model for crystallographic disorder in carbonates, $\mathrm{Mg}$ calcites have been shown to exhibit wider $v_{1}$ Raman mode FWHM due to out of plane rotations of the trigonal planar carbonate groups attributed to incorporations of over $10 \% \mathrm{Mg}$ substitutions for $\mathrm{Ca}$ (Urmos et al., 1991; Bischoff et al., 1985). Since FWHM widening in aragonite as a function of $\Omega_{\mathrm{Ar}}$ is much smaller compared to that in Mg calcites, it has been suggested that wider FWHM in aragonites could be due to either small crystallite sizes or much less-pronounced crystallographic disorder. Sharma and Urmos (1987) comment that while smaller crystallite sizes are commonly responsible for wider FWHM and shifts in Raman peak frequency, that the slightly higher frequencies observed for $v 1$ and $v 4$ modes in Porites coral aragonite display the opposite effect that small crystallites would have on a Raman spectrum. Thus it is most likely that aragonite FWHM Raman trends are also driven by crystallographic distortions due to element incorporations for $\mathrm{Ca}$, or factors related to increased element incorporations and disorder.

Previous studies on speleothem (i.e., Fairchild and Treble, 2009) and synthetic (i.e., Gaetani and Cohen, 2006; Gabitov et al., 2008; DeCarlo et al., 2015) aragonites attribute tracesubstitutions to be at least partially a function of faster crystallization at increased $\Omega_{\text {Ar. }}$ Faster coral skeletal calcification rates are also observed in increased $\Omega_{\mathrm{Ar} \text {, sw }}$ (Chan and Connolly, 2013; Gattuso et al., 1998). Assuming that this skeletal extension translates into faster aragonite crystal growth rates, observed crystal distortions and disorder in coral aragonite may follow a similar model to that of synthetic aragonites and exhibit element-incorporation-induced crystallographic

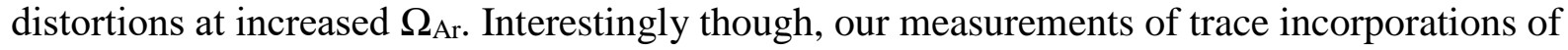
$\mathrm{Ba}, \mathrm{Sr}$ and $\mathrm{Mg}$ do not trend significantly with aragonite saturation state of the surrounding seawater, or with unit cell lattice parameters (Supplementary Materials, Figure S3.5). We do, however, observe a strong relationship between increased overall crystallographic disorder via 
the widening of FWHMs of the main (111) XRD peak (Figure 3.1) as a function of increasing Ba incorporations (Figure 3.7, $\mathrm{R}^{2}=0.853$ ). The widening FWHM (111) peak does not trend with increasing aragonite saturation states (Figure 3.3). Thus, it is likely that the observed coral aragonite unit cell lattice parameter shifts as a function of aragonite saturation state (Figure 3.4) are not primarily driven by an increase of trace-substitutions for $\mathrm{Ca}$. Unfortunately, we do not have measurements for crystal growth rates, but due to the similarities between deep-sea corals and synthetic aragonite shifting towards larger unit cell volumes with increasing $\Omega_{\text {Ar }}$ (Figure 3.4 ), it is likely that faster growth rates play a role in inducing increased crystalline disorder and larger unit cell volumes.

\subsubsection{Calcite contents in deep-sea corals as a function of crystallography and aragonite saturation state}

Since $\mathrm{Ba}, \mathrm{Sr}$, and $\mathrm{Mg}$ incorporations do not significantly trend with shifts in our aragonite unit cell lattice parameters or with surrounding seawater aragonite saturation states, another explanation for shifting unit cell parameters lies in the incorporation of minor calcite phases. Increased calcite contents in live L. pertusa septa as measured via Rietveld refinements trend moderately with decreasing seawater aragonite saturation states $\left(\mathrm{p}=0.0053, \mathrm{R}^{2}=0.358\right)$ and $\mathrm{pH}$ $\left(\mathrm{p}=0.0022, \mathrm{R}^{2}=0.415\right)$ as suggested by the PCA biplot and confirmed by simple regressions (Figures 3.3 and 3.6A). In particular, increased unit cell volumes exhibit a weak pattern with decreasing calcite content (Figure 3.6B). It is important to note that some of these calcite values calculated via Rietveld refinements report negative values for calcite, which clearly are not real and mean that there is no detectable calcite.

It is unclear if these incorporations of calcite are due to calcite formation upon aragonite precipitation or whether they are the results of secondary deposits associated with boring organisms. We suggest that these calcite phase contributions in the live septa samples are most likely intricately linked with aragonite precipitation because calcite contents trend somewhat with aragonite lattice parameters (Figure 3.6B), live septa regions of the corals represent the newest growth and are least likely to be affected by boring organisms, and we observe little to no evidence of boring up to $2500 \times$ magnification via SEM imaging (Supplementary material, Figures S3.6-S3.8). As for the much higher calcite fractions we observe in the recently dead and dead collection states of L. pertusa (Figure 3.5), we suggest that these higher calcite contributions with increased exposure to surrounding seawater, especially at depth, are most likely due to transformations of aragonite, the metastable polymorph of $\mathrm{CaCO}_{3}$, to calcite and possibly boring organisms.

\subsubsection{Relationship between aragonite saturation state in seawater and the internal calcifying fluid of deep-sea corals}

Previous studies have observed that healthy L. pertusa and other deep-sea corals growing in typical seawater saturated with respect to aragonite are known to raise their calcifying fluid $\mathrm{pH}$ ( $\sim 0.6-0.8 \mathrm{pH}$ units) relative to surrounding seawater and maintain an elevated calcifying fluid aragonite saturation state $\left(\Omega_{\mathrm{cf}} \sim 8.5-13\right)$ to promote aragonite precipitation (McCulloch et al., $2012 b$ ). Corals may further raise their $\Omega_{\mathrm{cf}} 5-10$ fold for every $1 \mathrm{pH}$ unit increase in calcifying 
fluid $\mathrm{pH}$ due to $\mathrm{pH}$ upregulation via $\mathrm{Ca}^{2+}$-ATPase pumping (McCulloch et al., 2012b; Allemand et al., 2004; Cohen and McConnaughey, 2003).

Assuming that coral biomineralization is dependent on internal calcifying fluid geochemistry, here we utilize crystallographic trends between the unit cell volumes (Figure 3.3B, black dashed line) and $b$-axis lengths (Figure 3.3B, black dashed lines) of synthetic aragonites versus their $\Omega_{\mathrm{Ar}}$ of formation to approximate values for coral internal calcifying fluid aragonite saturation state $\left(\Omega_{\mathrm{cf}}\right)$ in septa and outside of polyp samples of live Gulf of Mexico L. pertusa $\left(\Omega_{\mathrm{sw}}=1.15-1.44\right)$, as presented in Table 3.2. Our range of estimates for $\Omega_{\mathrm{cf}}=11.1-17.3$ based on $b$-axis length fall around previous $\delta^{11 / 10} \mathrm{~B}$-based estimates $\left(\Omega_{\mathrm{cf}} 8.5-13\right)$ for deep-sea corals (McCulloch et al., 2012b), whereas our estimates based on unit cell volume fall above this range $\left(\Omega_{\mathrm{cf}} 15.2-25.2\right)$ (Table 3.2). However, both of our calculated $\Omega_{\mathrm{cf}}$ estimates fall along the range for shallow water corals as previously calculated by Raman spectroscopy $\left(\Omega_{\mathrm{cf}} \sim 10.8-13.7\right.$, DeCarlo et al., 2017) and $\delta^{11 / 10} \mathrm{~B}$ estimates for $\Omega_{\mathrm{sw}} \sim 4\left(\Omega_{\mathrm{cf}} \sim 15-25\right.$, McCulloch et al., 2012a; McCulloch et al., 2017). Our estimates for the JCp-1 reference coral $\left(\Omega_{\mathrm{cf}}\right.$ based on $b$-axis length $\sim 24.3, \Omega_{\text {cf }}$ based on volume $\sim 18.43$, Table 3.2) are higher than Raman-spectroscopy-based estimates for JCp-1 $\left(\Omega_{\mathrm{cf}}=12.3 \pm 0.3\right.$, DeCarlo et al., 2017). Future studies will aim to create a more robust reference line of saturation state versus unit cell volume (as well as other axes lengths) with more references samples of synthetic aragonites precipitated at controlled saturation states and coral aragonites with known internal $\Omega_{\mathrm{cf}}$ based on $\delta^{11 / 10} \mathrm{~B}$ isotopes and Raman spectroscopy measurements. Our X-ray diffraction-based approach may eventually lend a new method, independent of isotope effect $\mathrm{pH}$ measurements, to complement previous $\delta^{11 / 10} \mathrm{~B}$ isotope-based estimations for $\Omega_{\mathrm{cf}}$ in corals. This ability to raise and maintain their internal $\Omega_{\mathrm{cf}}$ relative to surrounding seawater, despite the relatively harsh low $\Omega_{\mathrm{cf}}$ conditions of the deep-sea, may allow deep-sea corals to survive lower $\mathrm{pH}$ conditions and a shoaling $\mathrm{ASH}$.

TABLE 3.2. Internal calcifying fluid aragonite saturation state $\left(\Omega_{\mathrm{Ar}, \mathrm{cf}}\right)$ estimates in live $L$. pertusa samples from the Gulf of Mexico as calculated by the relationship between aragonite saturation states and $b$-axis lengths or unit cell volumes in synthetic aragonites.

\begin{tabular}{llll} 
Sampling area & Samples & $\begin{array}{l}\text { Calculated } \boldsymbol{\Omega}_{\mathrm{Ar}, \text { cf }} \\
\text { based } \text { on } \boldsymbol{b} \text {-axis } \\
\text { length }\end{array}$ & $\begin{array}{l}\text { Calculated } \boldsymbol{\Omega}_{\mathrm{Ar} \text {, cf }} \\
\text { based on unit cell } \\
\text { volume }\end{array}$ \\
\hline Outside of polyp & GC354-Live & 12.4 & 16 \\
\hline Outside of polyp & MC751-Live & 13.1 & 16.3 \\
\hline Outside of polyp & GB535-Live & 17.3 & 23.6 \\
\hline Outside of polyp & VK826-Live & 13.2 & 17.8 \\
\hline Outside of polyp & VK906-Live & 16 & 20.3 \\
\hline Septa & GC354-Live & 11.9 & 17.5 \\
\hline Septa & MC751-Live & 13.9 & 19.5 \\
\hline Septa & GB535-Live & 11.1 & 15.2 \\
\hline Septa & VK826-Live & 14.1 & 19.9 \\
\hline Septa & VK906-Live & 16.1 & 25.2 \\
\hline Reference & JCp-1 & 24.3 & 18.4 \\
\hline
\end{tabular}




\subsection{CONCLUSIONS}

Tracking mineralogical shifts as a function of $\Omega_{\mathrm{sw}}$ may help to predict how coral skeletal health (i.e., solubility, strength) will respond to a changing ocean. Overall, we observe that crystallography does not differ significantly across deep-sea corals of different species and from different global localities. Despite no clear trends across coral species, we observe weak, but distinct, crystallographic shifts of larger unit cell volumes as a function of increasing $\Omega_{\mathrm{Ar}}$ of surrounding seawater in septa of live L. pertusa deep-sea corals from the Gulf of Mexico. These structural changes are also seen in synthetic aragonites precipitated under various saturation states, indicating that these changes are inherent to the crystallography of aragonite. We also observe increased crystallographic disorder manifested as widening FWHM of main (111) peaks which trend with increasing trace incorporations of $\mathrm{Ba}$ for $\mathrm{Ca}$. However, trace-incorporations by $\mathrm{Ba}, \mathrm{Sr}$ and $\mathrm{Mg}$ do not significantly trend with crystal lattice parameters. Instead, we observe that the incorporation of calcite (up to $8 \%$ in some of our deep-sea corals) trends significantly with both $\Omega_{\mathrm{sw}}$ and crystal lattice parameters. We suggest that this calcite contribution may be related to the calcification process, rather than due to secondary deposits via boring organisms. Thus, despite living along a modest range of saturation states, structural differences are observed within the L. pertusa skeletons. Following tests on the impact of these structural changes on the integrity of the skeleton, such as strength and dissolution behavior, should follow.

In this study we demonstrate that crystallography can be used to observe otherwise hidden shifts in skeletal mineralogy using XRD techniques. We further use crystallographic measurements to provide estimates for internal $\Omega_{\mathrm{cf}}$ for deep-sea corals to suggest that deep-sea corals calcify in exceedingly low $\Omega_{\mathrm{sw}}$ by maintaining elevated internal $\Omega_{\mathrm{cf}}$. Future mineralogical studies should couple $\delta^{11 / 10} \mathrm{~B}$ isotopes (e.g. McCulloch et al., 2014; Wu et al., 2017; Holcomb et al., 2014) and Raman spectroscopy (DeCarlo et al., 2017) estimates of $\Omega_{\text {cf }}$ with X-ray diffraction-based crystallographic estimates shown in this study in order to better understand the nuances of how crystallography shifts as a function of internal aragonite saturation states. This may eventually lead to a crystallography-based independent model for predicting $\Omega_{\mathrm{cf}}$ which would complement other methods. Lastly, this study will ideally lay a foundation for future studies utilizing quantitative XRD to explore the impact of physical and chemical stressors on skeletal mineralogy, and subsequent coral health.

\subsection{Funding and Acknowledgments}

Funding for this project was made possible by Mineralogical Society of America Edward H. Kraus Crystallographic Research Fund and the WHOI Ocean Ventures Fund. G. Farfan was supported by a National Science Foundation Graduate Research Fellowship Grant No. 1122374 and a Ford Foundation Dissertation Fellowship. Sample collections from RGW were funded under NSF grant numbers 1245766, 1127582 and NOAA Ocean Exploration Deep Atlantic Stepping Stones. Collections from the Gulf of Mexico were supported by NSF BIO-OCE grant \#1220478 to E.E.C.

The authors would like to thank Alexis Weinnig and Carlos Gomez with their help in the initial processing of the L. pertusa samples from the Gulf of Mexico and Dr. Peter Etnoyer for the L. pertusa samples from the California margin. The authors would also like to thank Dr. Jeffrey Post from the Smithsonian Nation Museum of Natural History for training on Rietveld 
Refinement analysis, Gretchen Swarr for help with ICP-MS analyses at the Woods Hole Oceanographic Institution (WHOI), Dr. Andrew Solow and Dr. Natalie Cohen for consulting on the statistics at WHOI, and Katherine Sisson for helping to prepare coral powder samples at WHOI. The authors acknowledge Dr. Michael Holcomb for providing the synthetic aragonite samples, which were created in the laboratory of Dr. Glenn Gaetani, WHOI.

\subsubsection{Author Contributions}

G.A.F. conceived the idea, designed the study, performed the analyses, and wrote the manuscript with assistance from C.M.H. E.E.K. and R.G.W. collected the deep-sea coral samples used in the study. T.M.D. precipitated the abiogenic aragonites and provided Raman-based crystallographic knowledge about them. E.E.K., R.G.W., and T.M.D. aided interpreting and editing the final manuscript.

\subsection{References}

Acker, J. G., Byrne, R. H., Ben-Yaakov, S., Feely, R. A., and Betzer, P. R. (1987). The effect of pressure on aragonite dissolution rates in seawater. Geochim. Cosmochim. Acta 51, 2171-2175. doi:10.1016/0016-7037(87)90266-3

Allemand, D., Tambutté, É., Zoccola, D., and Tambutté, S. (2011). Coral calcification, cells to reefs. In Z. Dubinsky and N. Stambler (Eds.), Coral Reefs: An Ecosystem in Transition (pp. 119150). Springer Netherlands. doi:10.1007/978-94-007-0114-4

Allemand, D., Ferrier-Pages C., Furla P., Houlbreque F., Puverel S., Reynaud S., Tambutté, E., Tambutté S., and Zoccola D. (2004). Biomineralisation in reef-building corals: from molecular mechanisms to environmental control. C. R. Palevol. 3, 453-467. doi:10.1016/j.crpv.2004.07.011

Allison, N., Cohen, I., Finch, A. A., Erez, J., and Tudhope, A. W. (2014). Corals concentrate dissolved inorganic carbon to facilitate calcification. Nat. Commun. 5, 1-6. doi:10.1038/ncomms6741

Antao, S. M. and Hassan, I. (2009). The orthorhombic structure of $\mathrm{CaCO}_{3}, \mathrm{SrCO}_{3}, \mathrm{PbCO}_{3}$ and $\mathrm{BaCO}_{3}$ : Linear structural trends. Can. Mineral. 47, 1245-1255. doi:10.3749/canmin.47.5.1245

Bischoff, W. D., Sharma, S. K., and MacKenzie, F. T. (1985). Carbonate ion disorder in synthetic and biogenic magnesian calcites: a Raman spectral study. Am. Mineral. 70, 581-589.

Bish, D. L. and Post, J. E. (1993). Quantitative mineralogical analysis using the Rietveld fullpattern fitting method. Am. Mineral. 78, 932-940.

Caspi, E. N., Pokroy, B., Lee, P. L., Quintana, J. P., and Zolotoyabko, E. (2005). On the structure of aragonite. Acta Cryst. B 61. 129-132. doi:10.1107/S0108768105005240

Chan, N. and Connolly, S. R. (2013). Sensitivity of coral calcification to ocean acidification: a meta-analysis. Glob. Change Bio. 19, 282-290. doi:10.1111/gcb.12011 
Chung, S. N., Lee, K., Feely, R. A., Sabine, C. L., Millero, F. J., Wanninkhof, R., Bullister, J. L., Key, R. M., and Peng, T. H. (2003). Calcium carbonate budget in the Atlantic Ocean based on water column inorganic carbon chemistry. Global Biogeochem. Cy. 17, 1093. doi:10.1029/2002GB002001

Cohen, A., and Holcomb, M. (2009). Why corals care about ocean acidification: Uncovering the mechanism. Oceanography 22, 118-127. doi:10.5670/oceanog.2009.102

Cohen, A. L., McCorkle, D. C., de Putron, S., Gaetani, G. A., and Rose, K. A. (2009). Morphological and compositional changes in the skeletons of new coral recruits reared in acidified seawater: Insights into the biomineralization response to ocean acidification. Geochem. Geophys. Geosyst. 10, 1-12. doi:10.1029/2009GC002411

Cohen, A. L., and McConnaughey T. (2003). Geochemical perspectives on coral mineralization. In Biomineralization (eds. P. Dove, S. Weiner and J. Yoreo). Rev. Mineral. Geochem. 54, 151-187.

DeCarlo, T. M., Gaetani, G. A., Holcomb, M., and Cohen, A. L. (2015). Experimental determination of factors controlling $\mathrm{U} / \mathrm{Ca}$ of aragonite precipitated from seawater: Implications for interpreting coral skeleton. Geochim. Cosmochim. Acta 162, 151-165. doi:10.1016/j.gca.2015.04.016

DeCarlo, T. M., D'Olivo, J. P., Foster, T., Holcomb, M., Becker, T., and McCulloch, M. T. (2017). Coral calcifying fluid aragonite saturation states derived from Raman spectroscopy. Biogeosciences 14, 5253. doi:10.5194/bg-14-5253-2017

Doney, S. C., Fabry, V. J., Feely, R. A., and Kleypas, J. A. (2009). Ocean acidification: the other $\mathrm{CO}_{2}$ problem. Annu. Rev. Mar. Sci. 1, 169-192. doi:10.1146/annurev.marine.010908.163834

Drenkard, E. J., Cohen, A. L., McCorkle, D. C., de Putron, S. J., Starczak, V. R., and Zicht, A. E. (2013). Calcification by juvenile corals under heterotrophy and elevated $\mathrm{CO}_{2}$. Coral Reefs 32, 727-735. doi:10.1007/s00338-013-1021-5

Fairchild, I. J., and Treble, P. C. (2009). Trace elements in speleothems as recorders of environmental change. Quat. Sci. Rev. 28, 449-468. doi:10.1016/j.quascirev.2008.11.007

Feely, R. A., Sabine, C. L., Lee, K., Berelson, W., Kleypas, J., Fabry, V. J., and Millero, F. J. (2004). Impact of anthropogenic $\mathrm{CO}_{2}$ on the $\mathrm{CaCO}_{3}$ system in the oceans. Science 305, 362-366. doi:10.1126/science.1097329

Form, A. U., and Riebesell, U. (2012). Acclimation to ocean acidification during long-term $\mathrm{CO}_{2}$ exposure in the cold-water coral Lophelia pertusa. Global Change Biol. 18, 843-853. doi:10.1111/j.1365-2486.2011.02583.x

Foster, T., Falter, J. L., McCulloch, M. T., and Clode, P. L. (2016). Ocean acidification causes structural deformities in juvenile coral skeletons. Sci. Adv. 2, 1-7. doi:10.1126/sciadv.1501130

Gabitov, R. I., Gaetani, G. A., Watson, E. B., Cohen, A. L., and Ehrlich, H. L. (2008). Experimental determination of growth rate effect on $\mathrm{U}^{6+}$ and $\mathrm{Mg}^{2+}$ partitioning between aragonite and fluid at elevated $\mathrm{U}^{6+}$ concentration. Geochim. Cosmochim. Acta 72, 4058-4068. doi:10.1016/j.gca.2008.05.047 
Gaetani, G. A., and Cohen, A. L. (2006). Element partitioning during precipitation of aragonite from seawater: a framework for understanding paleoproxies. Geochim. Cosmochim. Acta 70, 4617-4634. doi:10.1016/j.gca.2006.07.008

Gaffey, S. J., and Bronnimann, C. E. (1993). Effects of bleaching on organic and mineral phases in biogenic carbonates. J. Sediment. Res. 63, 752-754.

Gattuso, J. P., Frankignoulle, M., Bourge, I., Romaine, S., and Buddemeier, R. W. (1998). Effect of calcium carbonate saturation of seawater on coral calcification. Glob. Planet. Change 18, 37 46. doi:10.1016/S0921-8181(98)00035-6

Georgian, S. E., DeLeo, D., Durkin, A., Gomez, C. E., Kurman, M., Lunden, J. J., and Cordes, E. E. (2016a). Oceanographic patterns and carbonate chemistry in the vicinity of cold-water coral reefs in the Gulf of Mexico: Implications for resilience in a changing ocean. Limnol. Oceanogr. 61, 648-665. doi:10.1002/lno.10242

Georgian S. E., Dupont S., Kurmann M., Butler A., Stromberg S. M., Larsson A. I., and Cordes EE. (2016b). Biogeographic variability in the physiological response of the cold-water coral Lophelia pertusa to ocean acidification. Mar. Ecol. 37, 1345-1359. doi:10.1111/maec.12373

Hathorne, E. C., Gagnon, A., Felis, T., Adkins, J., Asami, R., Boer, W., Caillon, N., Case, D., Cobb, K. M., Douville, E., deMenocal, P., Eisenhauer, A., Garbe-Schönberg, D., Geibert, W., Goldstein, S., Hughen, K., Inoue, M., Kawahata, H., Kölling, M., Cornec, F. L., Linsley, B. K., McGregor, H. V., Montagna, P., Nurhati, I. S., Quinn, T. M., Raddatz, J., Rebaubier, H., Robinson, L., Sadekov, A., Sherrell, R., Sinclair, D., Tudhope, A. W., Wei, G., Wong, H., Wu, H. C., and You, C. F. (2013). Interlaboratory study for coral $\mathrm{Sr} / \mathrm{Ca}$ and other element/Ca ratio measurements. Geochem. Geophys. Geosyst. 4, 3730-3750. doi:10.1002/ggge.20230

Hennige, S. J., Wicks, L. C., Kamenos, N. A., Perna, G., Findlay, H. S., and Roberts, J. M. (2015). Hidden impacts of ocean acidification to live and dead coral framework. Proc. R. Soc. Lond. [Biol] 282, 1-10. doi:10.1098/rspb.2015.0990

Herman, A., Addadi, L., and Weiner, S. (1988). Interactions of sea-urchin skeleton macromolecules with growing calcite crystals - a study of intracrystalline proteins. Nature 331, 546. doi:10.1038/331546a0

Hofmann, G. E., Barry, J. P., Edmunds, P. J., Gates, R. D., Hutchins, D. A., Klinger, T., and Sewell, M. A. (2010). The effect of ocean acidification on calcifying organisms in marine ecosystems: an organism-to-ecosystem perspective. Annu. Rev. Ecol. Evol. Syst. 41, 127-147. doi:10.1146/annurev.ecolsys.110308.120227

Holcomb, M., Venn, A. A., Tambutté, E., Tambutté, S., Allemand, D., Trotter, J., and McCulloch, M. (2014). Coral calcifying fluid $\mathrm{pH}$ dictates response to ocean acidification. Sci. Rep. 4, 1-4. doi:10.1038/srep05207

Holcomb, M., DeCarlo, T. M., Gaetani, G. A., and McCulloch, M. (2016). Factors affecting B/Ca ratios in synthetic aragonite. Chem. Geol. 437, 67-76. doi:10.1016/j.chemgeo.2016.05.007

Janiszewska, K., Stolarski, J., Benzerara, K., Meibom, A., Mazur, M., Kitahara, M. V., and Cairns, S. D. (2011). A unique skeletal microstructure of the deep-sea micrabaciid scleractinian corals. J. Morphol. 272, 191-203. doi:10.1002/jmor.10906 
Kurman, M. D., Gómez, C. E., Georgian, S. E., Lunden, J. J., and Cordes, E. E. (2017). Intraspecific variation reveals potential for adaptation to ocean acidification in a cold-water Coral from the Gulf of Mexico. Front. Mar. Sci. 4, 1-14. doi:10.3389/fmars.2017.00111

Livingston, H. D., and Thompson, G. (1971). Trace element concentrations in some modern corals. Limnol. Oceanogr. 16, 786-796. doi:10.4319/lo.1971.16.5.0786

Lunden, J. J., Georgian, S. E., and Cordes, E. E. (2013). Aragonite saturation states at cold-water coral reefs structured by Lophelia pertusa in the northern Gulf of Mexico. Limnol. Oceanogr. 58, 354-362. doi:10.4319/lo.2013.58.1.0354

Maier, C., Schubert, A., Berzunza-Sánchez, M. M., Weinbauer, M., Watremez, P., Gattuso, J. P., (2013). End of the Century $\mathrm{pCO}_{2}$ levels do not impact calcification in Mediterranean cold-water corals. PloS One 8, e62655. doi:10.1371/journal.pone.0062655

Markgaf, S. A., and Reeder, R. J. (1985). High-temperature structure refinements of calcite and magnesite. Am. Mineral. 70, 590-600. doi:0003-04x185/0506--0590\$02.

Mass, T., Giuffre, A. J., Sun, C. Y., Stifler, C. A., Frazier, M. J., Neder, M., Tamura, N., Stan, C. V., Marcus M. A., and Gilbert P. (2017). Amorphous calcium carbonate particles form coral skeletons. Proc. Natl. Acad. Sci. U.S.A. 114, E7670-E7678. doi:10.1073/pnas.1707890114

Mass, T., Drake, J. L., Haramaty, L., Kim, J. D., Zelzion, E., Bhattacharya, D., and Falkowski, P. G. (2013). Cloning and characterization of four novel coral acid-rich proteins that precipitate carbonates in vitro. Curr. Biol., 23(12), 1126-1131. doi:10.1016/j.cub.2013.05.007

McCulloch, M. T., D’Olivo, J. P., Falter, J., Holcomb, M., and Trotter, J. A. (2017). Coral calcification in a changing World and the interactive dynamics of $\mathrm{pH}$ and DIC upregulation. Nat. Commun. 8, 15686. doi:10.1038/ncomms15686

McCulloch, M. T., Holcomb, M., Rankenburg, K., and Trotter, J. A. (2014). Rapid, highprecision measurements of boron isotopic compositions in marine carbonates. Rapid Commun. Mass Spectrom. 28, 2704-2712. doi:10.1002/rcm.7065

McCulloch, M., Falter, J., Trotter, J., and Montagna, P. (2012a). Coral resilience to ocean acidification and global warming through $\mathrm{pH}$ up-regulation. Nat. Clim. Change 2, 623. doi:10.1038/nclimate1473

McCulloch, M., Trotter, J., Montagna, P., Falter, J., Dunbar, R., Freiwald, A., Försterra, G., LópezCorrea, M., Maier, C., Rüggeberg, A., and Taviani, M. (2012b). Resilience of cold-water scleractinian corals to ocean acidification: Boron isotopic systematics of $\mathrm{pH}$ and saturation state up-regulation. Geochim. Cosmochim. Acta 87, 21-34. doi:10.1016/j.gca.2012.03.027

Mucci, A. (1983). The solubility of calcite and aragonite in seawater at various salinities, temperatures, and one atmosphere total pressure. Am. J. Sci. 283, 780-799.

Politi, Y., Levi-kalisman, Y., Raz, S., Wilt, F., Addadi, L., Weiner, S., and Sagi, I. (2006). Structural characterization of the transient amorphous calcium carbonate precursor phase in sea urchin embryos. Adv. Funct. Mater. 16, 1289-1298. doi:10.1002/adfm.200600134 
Pokroy, B., Quintana, J. P., El'ad, N. C., Berner, A., and Zolotoyabko, E. (2004). Anisotropic lattice distortions in biogenic aragonite. Nat. Mater. 3, 900. doi:10.1038/nmat1263

Pokroy, B., Fitch, A. N., Lee, P. L., Quintana, J. P., El'ad, N. C., and Zolotoyabko, E. (2006). Anisotropic lattice distortions in the mollusk-made aragonite: a widespread phenomenon. $J$. Struct. Biol. 153, 145-150. doi:10.1016/j.jsb.2005.10.009

Pokroy, B., Fieramosca, J. S., Von Dreele, R. B., Fitch, A. N., Caspi, E. N., and Zolotoyabko, E. (2007). Atomic structure of biogenic aragonite. Chem. Mater. 19, 3244-3251. doi: $10.1021 / \mathrm{cm} 070187 \mathrm{u}$

Roberts, J. M., Wheeler, A. J., Freiwald, A., and Cairns, S. D. (2009). Cold-water corals: the biology and geology of deep-sea coral habitats. Cambridge University Press.

Roger, L. M., George, A. D., Shaw, J., Hart, R. D., Roberts, M., Becker, T., McDonald, B. J, and Evans, N. J. (2017). Geochemical and microstructural characterisation of two species of cool-water bivalves (Fulvia tenuicostata and Soletellina biradiata) from Western Australia. Biogeosciences 14, 1721. doi:10.5194/bg-14-1721-2017

Rodolfo-Metalpa, R., Houlbrèque, F., Tambutté, É., Boisson, F., Baggini, C., Patti, F. P., Jeffree, R., Fine, M., Foggo, A., Gattuso, J. P., and Hall-Spencer, J. M. (2011). Coral and mollusc resistance to ocean acidification adversely affected by warming. Nat. Clim. Change 1, 308-312. doi:10.1038/nclimate1200

Rodolfo-Metalpa, R., Montagna, P., Aliani, S., Borghini, M., Canese, S., Hall-Spencer, J. M., Foggo, A., Milazzo, M., Taviani, M., and Houlbrèque, F. (2015). Calcification is not the Achilles' heel of cold-water corals in an acidifying ocean. Global Change Biol. 21, 2238-2248. doi:10.1111/gcb.12867

Sabine, C. L., Feely, R. A., Key, R. M., Bullister, J. L., Millero, F. J., Lee, K., Peng, T. H., Tilbrook, B., Ono, T., and Wong, C. S. (2002). Distribution of anthropogenic $\mathrm{CO}_{2}$ in the Pacific Ocean. Global Biogeochem. Cycles 16. doi:10.1029/2001GB001639

Schoepf, V., Grottoli, A. G., Warner, M. E., Cai, W. J., Melman, T. F., Hoadley, K. D., Pettay, D. T., Hu, X., Li, Q., Xu, H., Wang, Y., Matsui, Y., and Baumann, J. H. (2013). Coral energy reserves and calcification in a high- $\mathrm{CO}_{2}$ world at two temperatures. PloS One 8, e75049. doi:10.1371/journal.pone.0075049

Sharma, S. K., and Urmos, J. P. (1987). Micro-Raman spectroscopic studies of materials at ambient and high pressures with CW and pulsed lasers. Microbeam Analysis, 133-136.

Stolarski, J., Przeniosło, R., Mazur, M., and Brunelli, M. (2007). High-resolution synchrotron radiation studies on natural and thermally annealed scleractinian coral biominerals. J. Appl. Crystallogr. 40, 2-9. doi:10.1107/S002188980604489X

Swanson, H. E., and Fuyat, R. K. (1953). ICDD PDF 05, 0586, Calcite. Natl. Bur. Stand. (US), Circ, 539, 51.

Tambutté, E., Venn, A. A., Holcomb, M., Segonds, N., Techer, N., Zoccola, D., Allemand, D., and Tambutté, S. (2015). Morphological plasticity of the coral skeleton under $\mathrm{CO}_{2}$-driven seawater acidification. Nat. Commun. 6. doi:10.1038/ncomms 8368 
Thresher, R. E., Tilbrook, B., Fallon, S., Wilson, N. C., and Adkins, J. (2011). Effects of chronic low carbonate saturation levels on the distribution, growth and skeletal chemistry of deep-sea corals and other seamount megabenthos. Mar. Ecol. Prog. Ser. 442, 87-96. doi:10.3354/meps09400

Toby, B. H., and Von Dreele, R. B. (2013). GSAS-II: the genesis of a modern open-source all purpose crystallography software package. J. Appl. Crystallogr. 46, 544-549. doi:10.1107/S0021889813003531

Urmos, J., Sharma, S. K., and Mackenzie, F. T. (1991). Characterization of some biogenic carbonates with Raman spectroscopy. Am. Mineral. 76, 641-646. doi:0003-004x/91/0304$064 \mathrm{I} \$ 02.0$

Von Euw, S., Zhang, Q., Manichev, V., Murali, N., Gross, J., Feldman, L. C., Gustafsson, T., Flach, C., Mendelsohn, R., Falkowsk, P. G. (2017). Biological control of aragonite formation in stony corals. Science 356, 933-938. doi:10.1126/science.aam6371

Wu, H. C., Dissard, D., Le Cornec, F., Thil, F., Tribollet, A., Moya, A., and Douville, E. (2017). Primary life stage boron isotope and trace elements incorporation in aposymbiotic Acropora millepora coral under ocean acidification and warming. Front. Mar. Sci. 4, 1-15. doi:10.3389/fmars.2017.00129

York, D. (1968). Least squares fitting of a straight line with correlated errors. Earth Planet. Sci. Lett. 5, 320-324. doi: 10.1016/S0012-821X(68)80059-7 


\subsection{Supplementary Material-Figures}

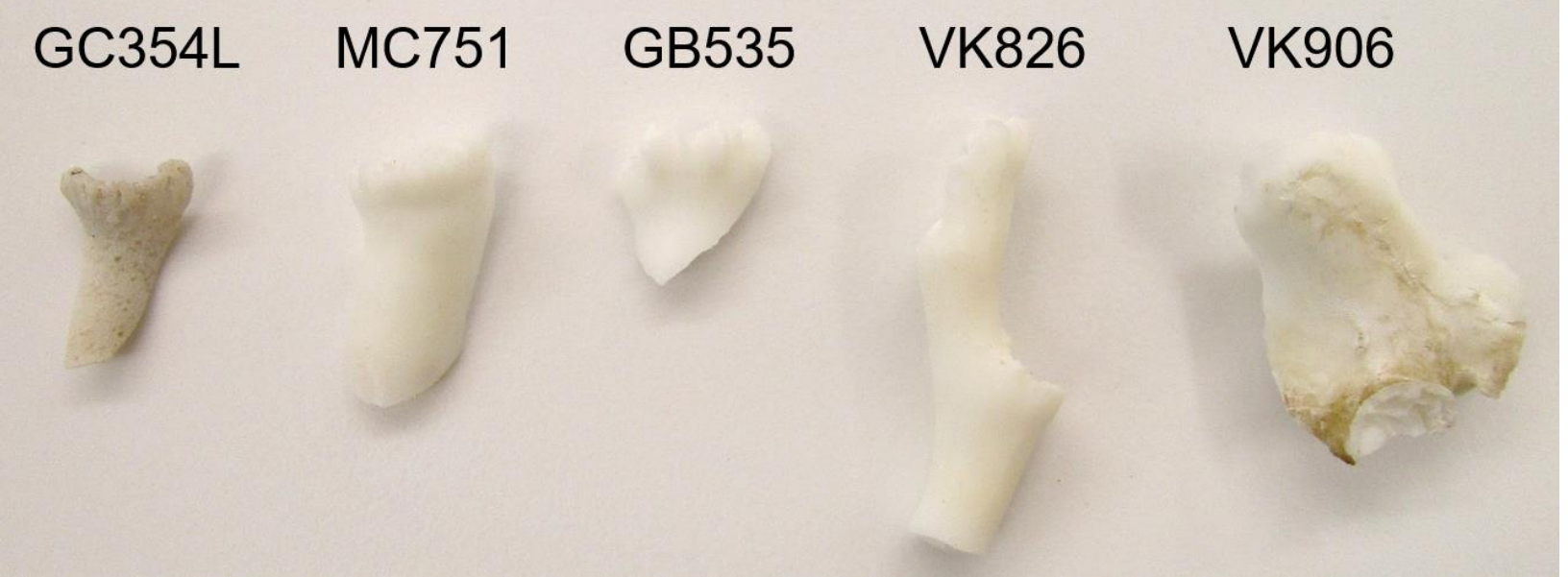

FIGURE S3.1. Photograph of live L. pertusa hand samples from the Gulf of Mexico over a range of seawater aragonite saturation states (see Table 3.1). 

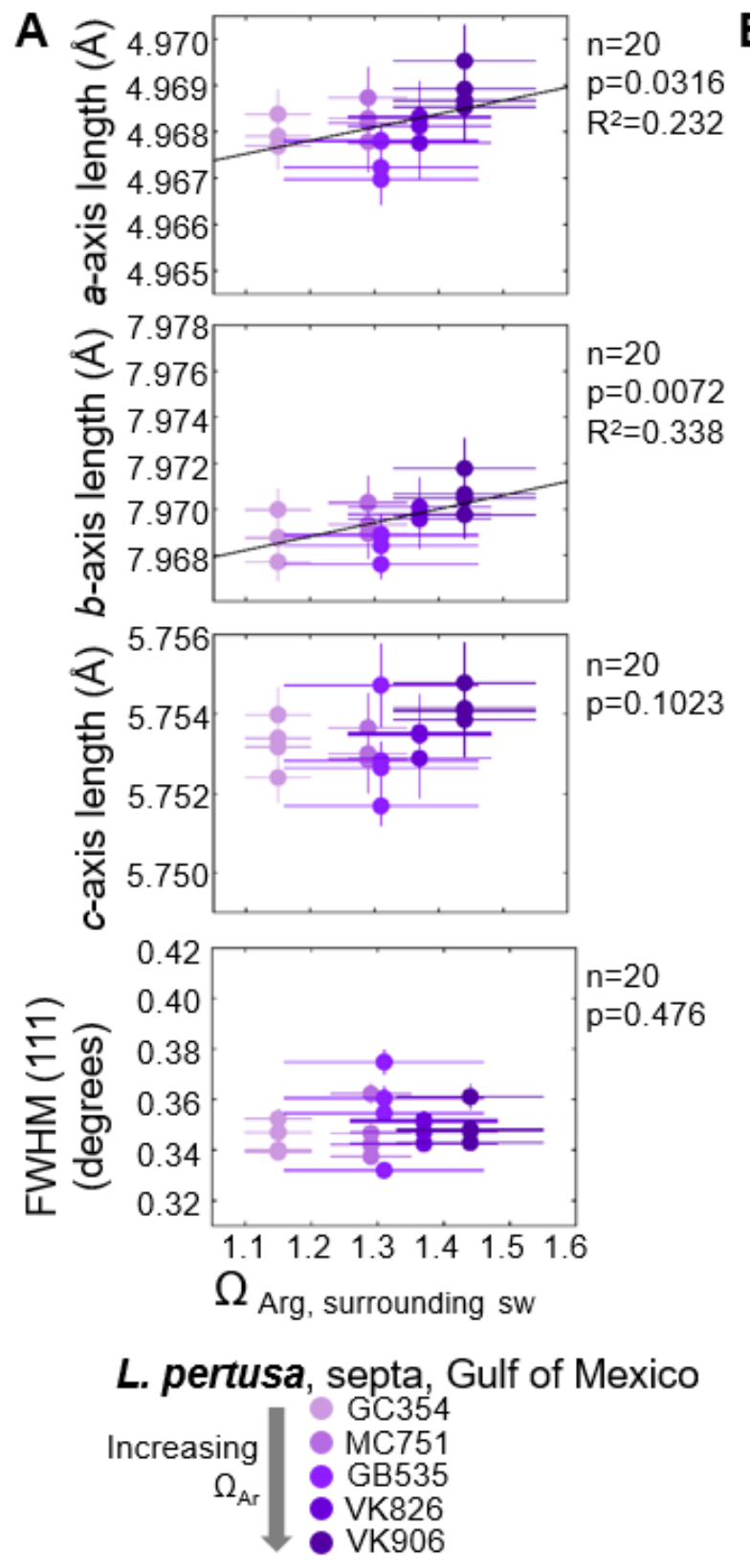
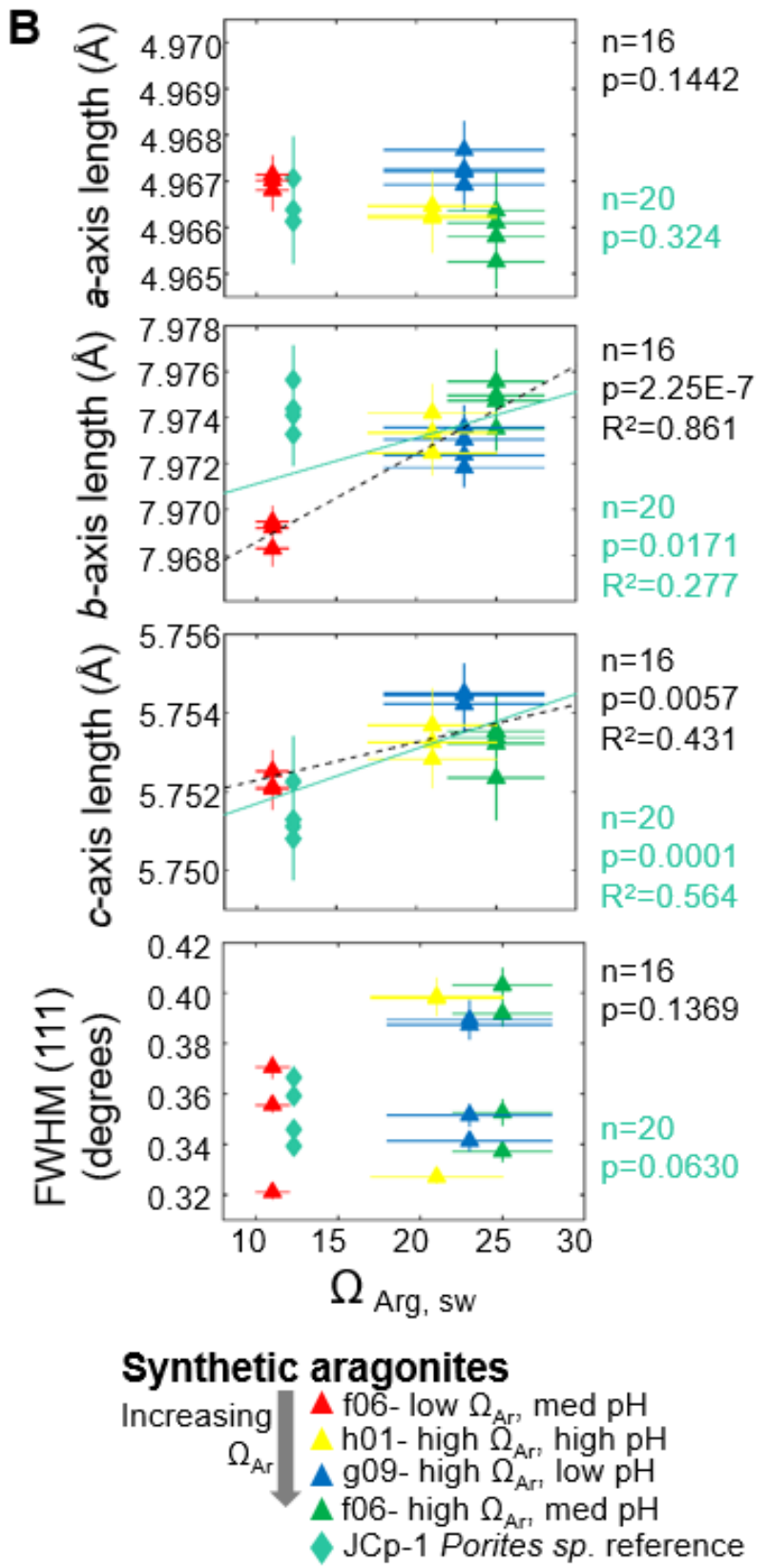

FIGURE S3.2. Crystallographic lattice parameters and main peak (111) full width at half-maximum (FWHM) in (A) Lophelia pertusa deep-sea coral live septa samples (circles) from the Gulf of Mexico as a function of surrounding seawater aragonite saturation states, and (B) synthetic aragonites precipitated from seawater (triangles) and an additional coral reference JCp-1 Porites sp. shallow coral (green diamonds) as a function of the internal aragonite saturation state during precipitation (DeCarlo et al., 2017). Statistically significant linear regressions $(\mathrm{p}<0.05)$ are plotted in black solid lines for L. pertusa samples, black dashed lines for synthetic aragonite samples, and green solid lines for combined JCp-1 coral and synthetic aragonite samples. Error bars represent estimated standard deviations for the lattice parameters and FWHMs and measurement uncertainties for aragonite saturation states. 

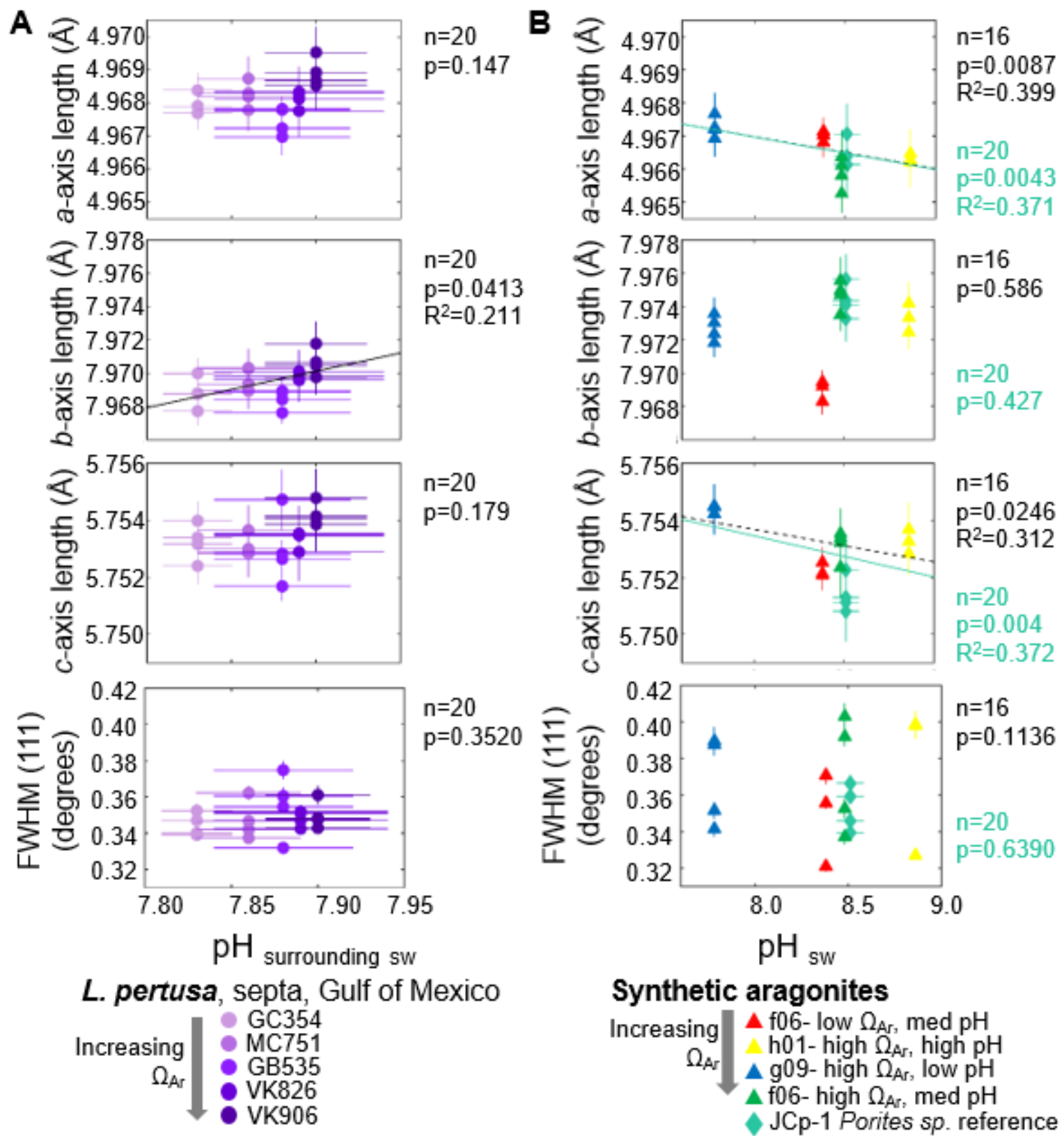

\section{Synthetic aragonites}

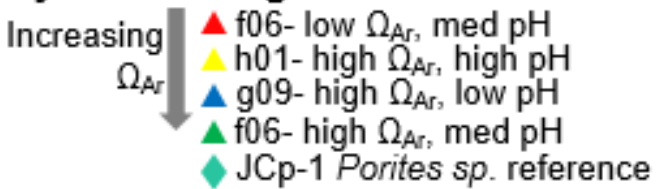

FIGURE S3.3. Crystallographic lattice parameters and main peak (111) full width at half-maximum (FWHM) in (A) Lophelia pertusa deep-sea coral live septa samples (circles) from the Gulf of Mexico as a function of surrounding seawater $\mathrm{pH}$, and (B) synthetic aragonites precipitated from seawater (triangles) and an additional coral reference JCp-1 Porites sp. shallow coral (green diamonds) as a function of the internal $\mathrm{pH}$ during precipitation (DeCarlo et al., 2017). Statistically significant linear regressions $(\mathrm{p}<0.05)$ are plotted in black solid lines for L. pertusa samples, black dashed lines for synthetic aragonite samples, and green solid lines for combined JCp-1 coral and synthetic aragonite samples. Error bars represent estimated standard deviations for the lattice parameters and FWHMs and measurement uncertainties for aragonite saturation states. 
A
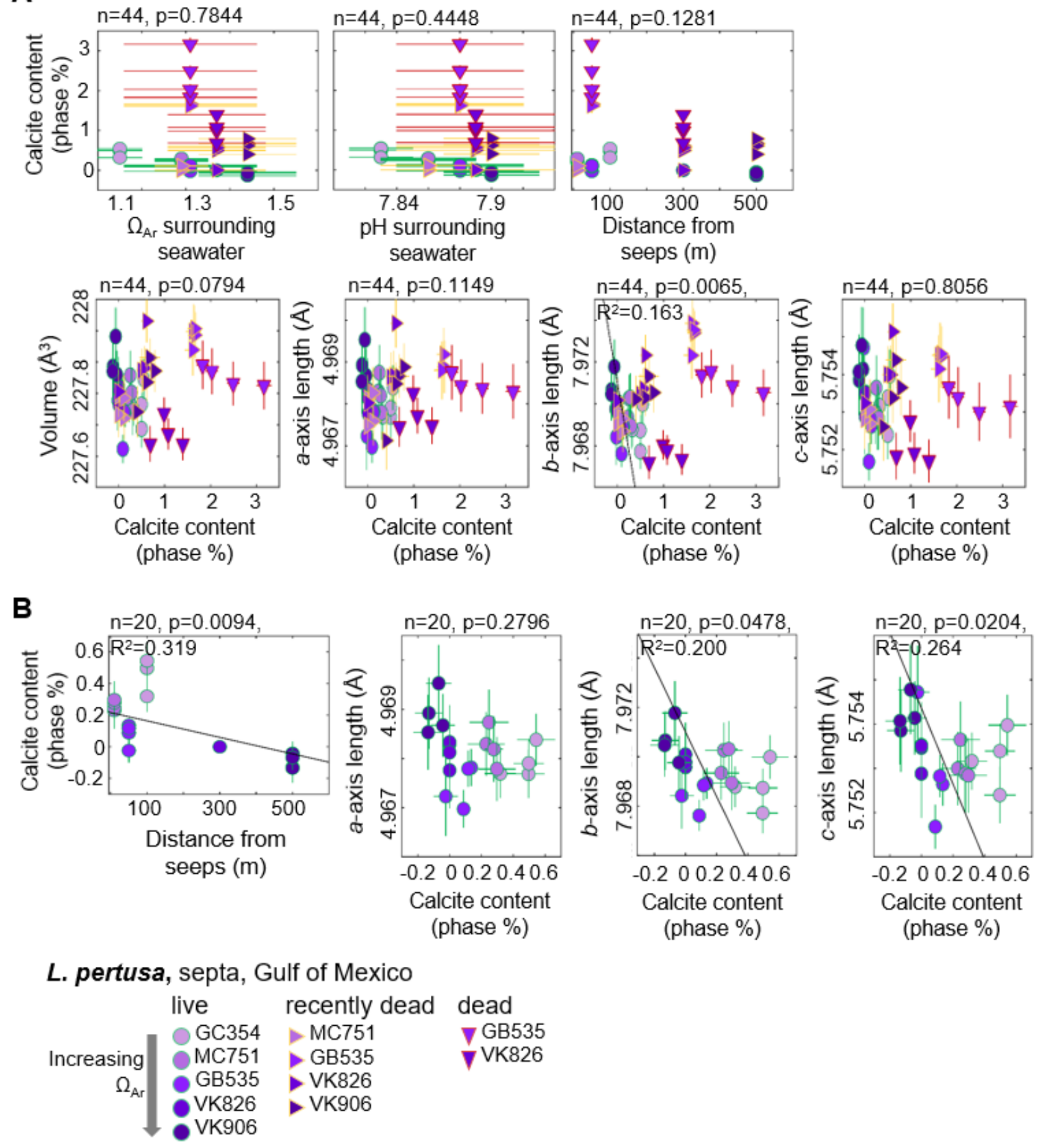

FIGURE S3.4. Relationships between calcite contents (phase \%) in L. pertusa septa from the Gulf of Mexico and crystallography, seawater chemistry and physical parameters for A). all collection states (live, recently dead, and dead) as well as B). only live samples. Statistically significant linear regressions are plotted as black solid lines. Error bars represent estimated standard deviations. 

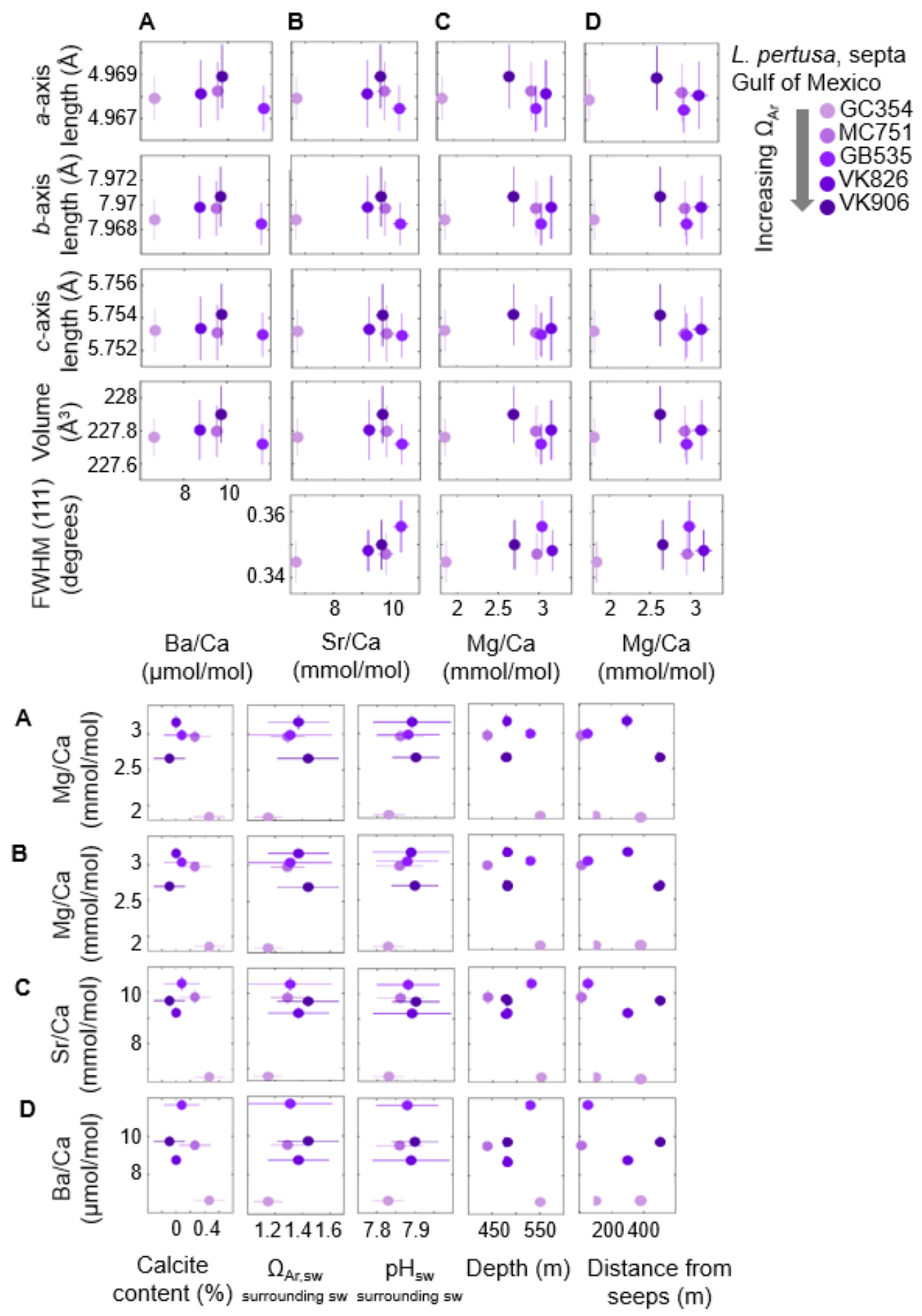

FIGURE S3.5. Relationships of crystallographic lattice parameters, main peak (111) full width at halfmaximum (FWHM), calcite contents (phase \%), seawater aragonite saturation state, seawater pH, depth, and distance from hydrocarbon seeps with incorporations of barium, strontium and magnesium in live Lophelia pertusa deep-sea coral septa samples (circles) from the Gulf of Mexico ( $\mathrm{n}=5)$. Element incorporations are represented as: A). Ba/Ca ratio based on $\left.{ }^{138} \mathrm{Ba}, \mathrm{B}\right) . \mathrm{Sr} / \mathrm{Ca}$ ratio based on ${ }^{88} \mathrm{Sr}, \mathrm{C}$ ). $\mathrm{Mg} / \mathrm{Ca}$ ratio based on ${ }^{24} \mathrm{Mg}$, and $\mathrm{D}$ ). $\mathrm{Mg} / \mathrm{Ca}$ ratio based on ${ }^{25} \mathrm{Mg}$. 


\section{Live L. pertusa, septa}
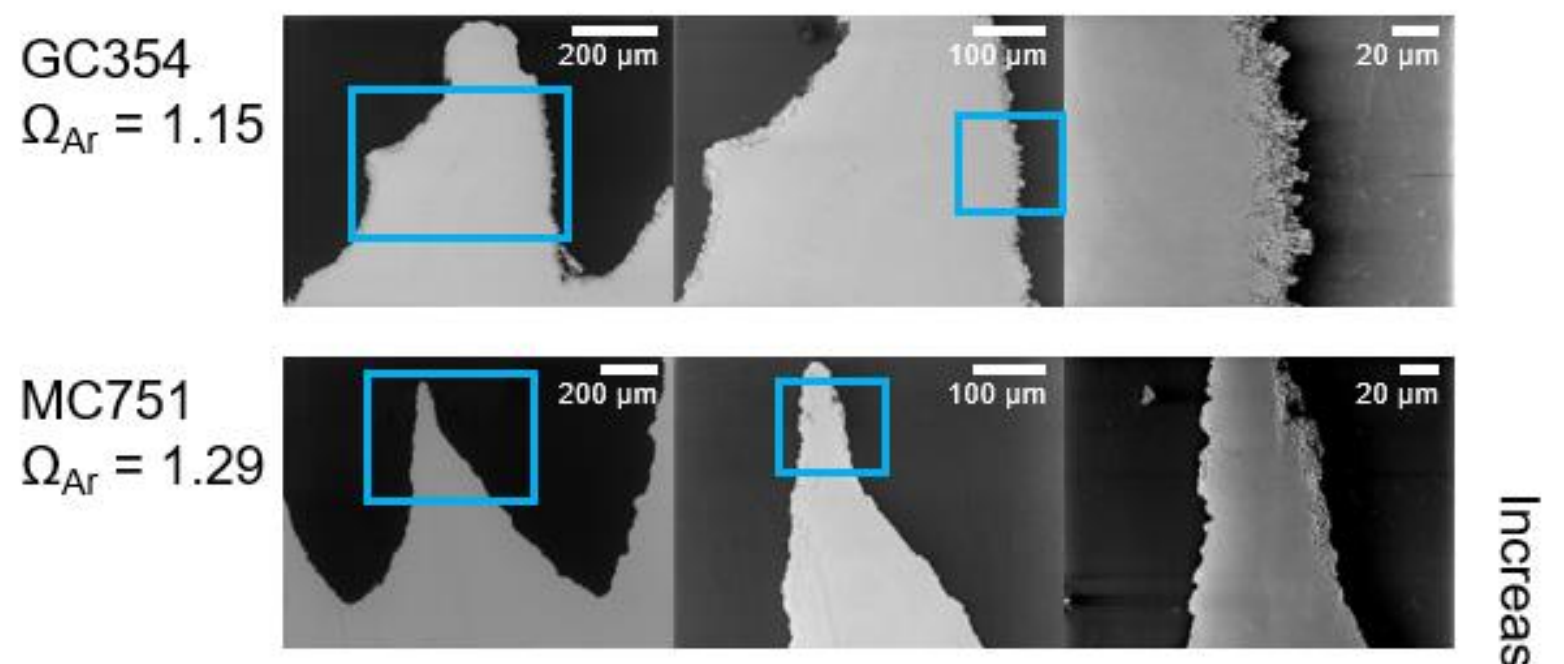

GB535
$\Omega_{\mathrm{Ar}}=1.31$

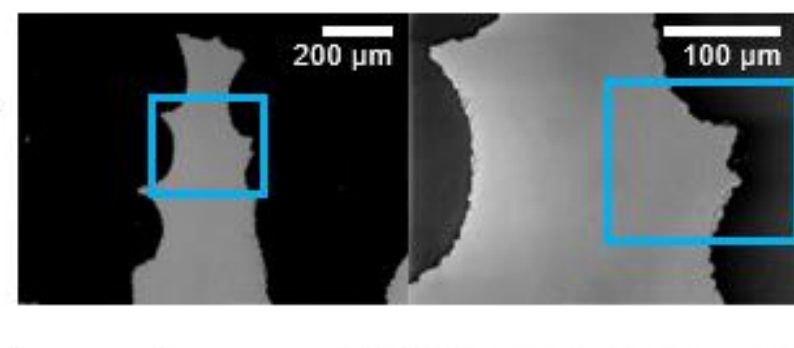

$\underline{\omega}$.

VK826
$\Omega_{\mathrm{Ar}}=1.37$

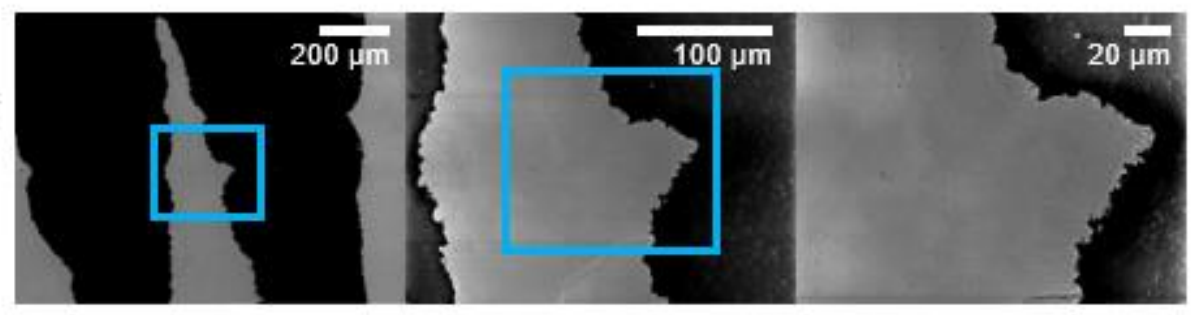

$20 \mu \mathrm{m}$

قै

$\stackrel{2}{2}$

VK906

$\Omega_{\mathrm{Ar}}=1.44$
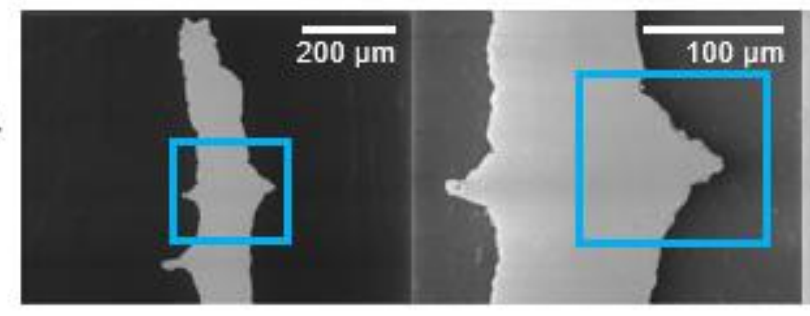

$20 \overline{\mu m}$

Increasing magnification

FIGURE S3.6. SEM images of $L$. pertusa live septa from the Gulf of Mexico over a range of seawater aragonite saturation states. 


\section{Live L. pertusa, outside of polyp}
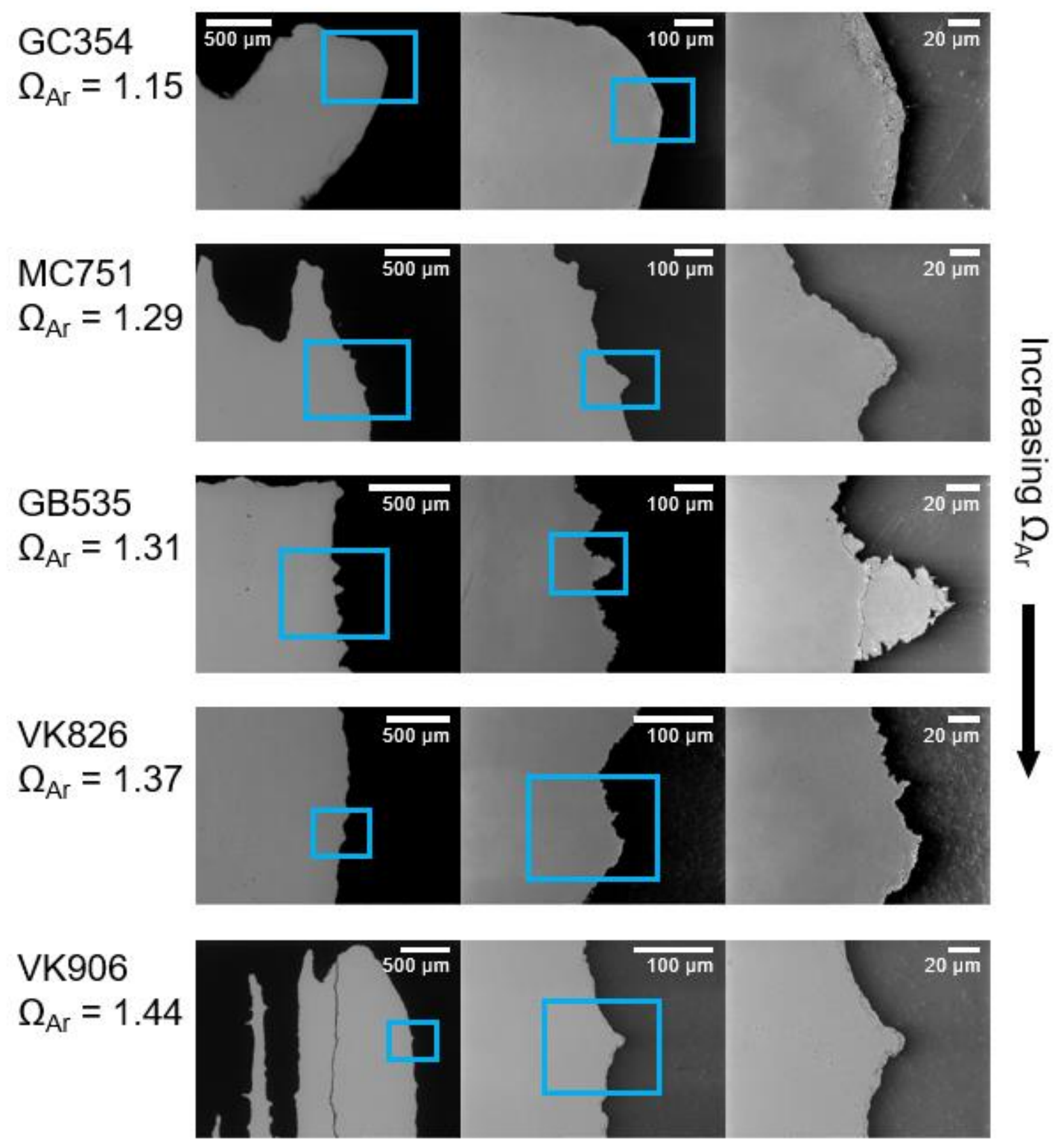

\section{Increasing magnification}

FIGURE S3.7. SEM images of L. pertusa live outer-polyp regions from the Gulf of Mexico over a range of seawater aragonite saturation states. 


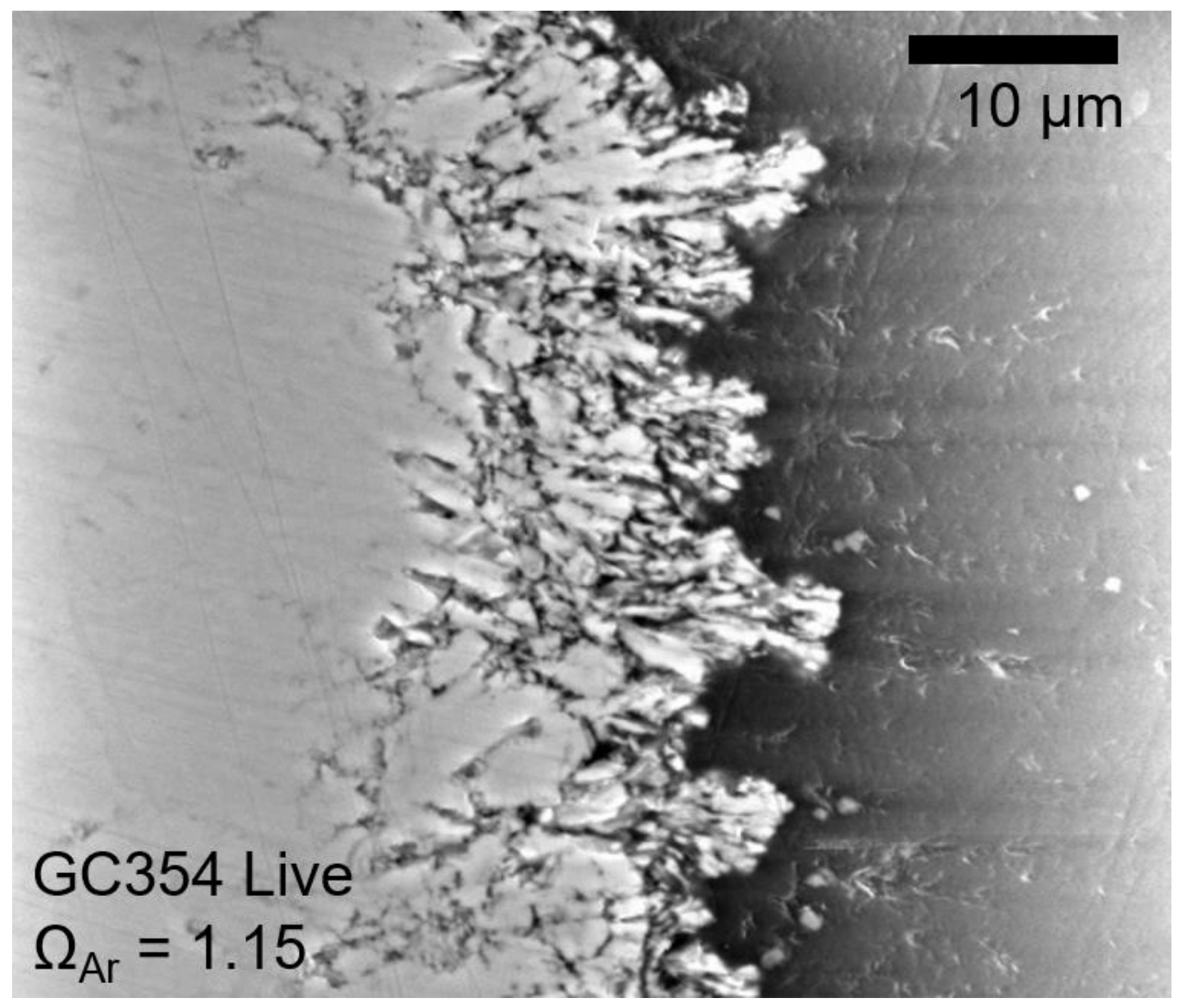

Figure S3.8. Close-up SEM image of live L. pertusa GC354 septa from Figure S2 at 2500x magnification. 


\subsection{Supplementary Material-Tables}

TABLE S2.1. Comparisons of different sample groups by two-tailed T-tests and one-way ANOVA.

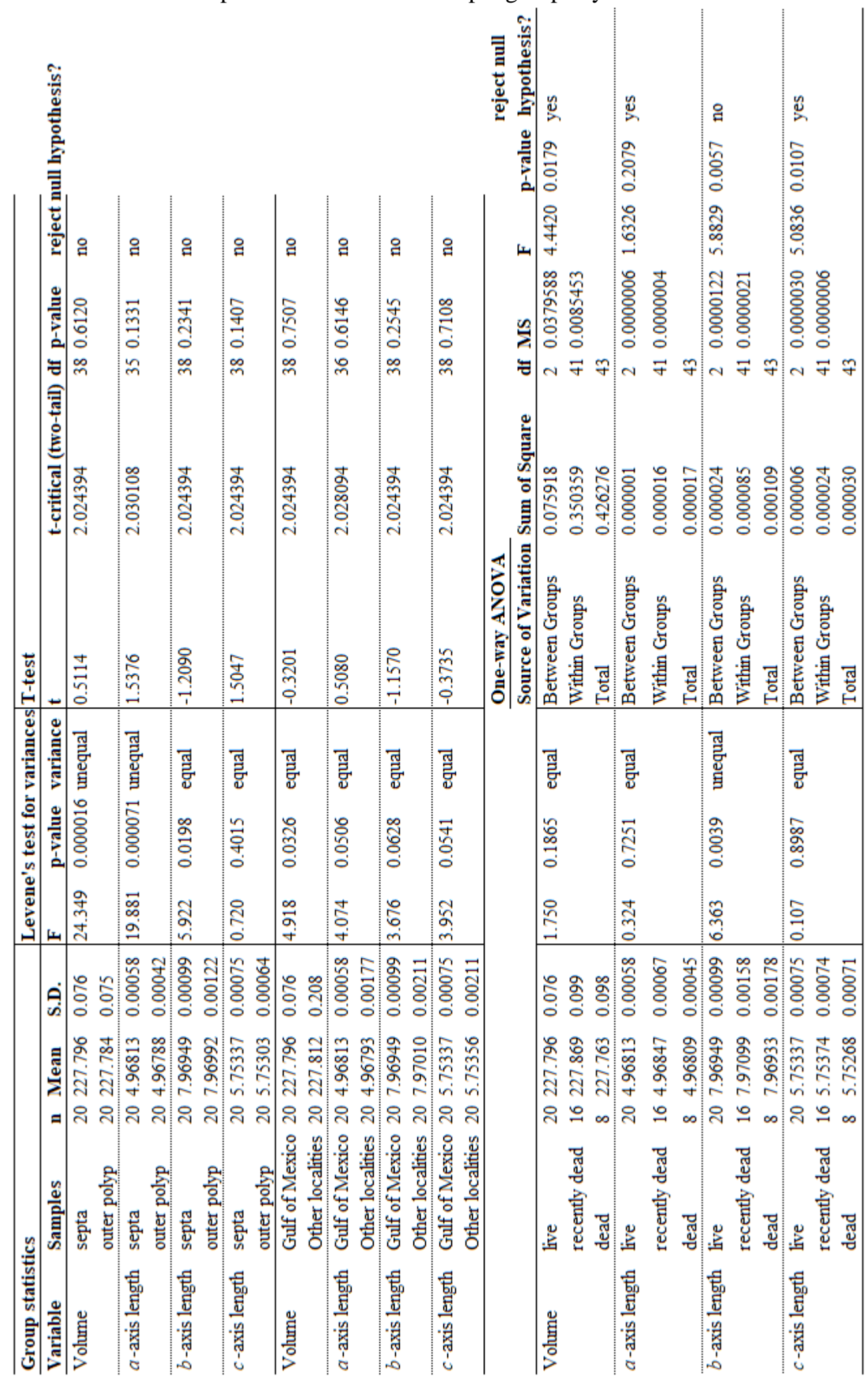


TABLE S3.2. Results of simple linear regressions of statistically significant $(\mathrm{p}<0.05)$ patterns between crystallographic, environmental, and trace element variables measured for Gulf of Mexico L. pertusa live septa samples. P-values in bold signify a statistically significant relationship $(\mathrm{p}<0.05)$. *Asterisk denotes York regression.

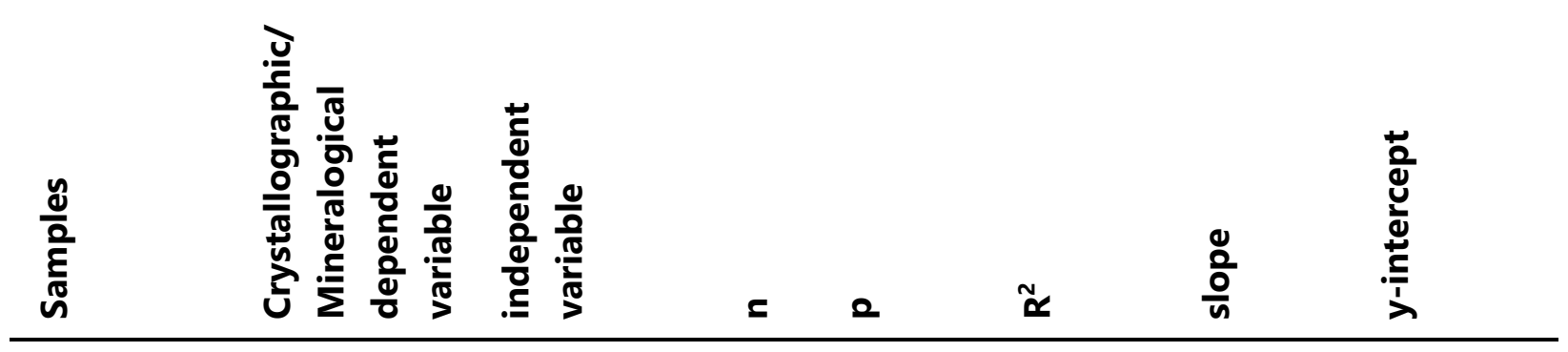

L. pertusa

live septa,

Gulf of

Unit cell

Mexico volume

\begin{tabular}{llllll}
$\Omega_{\mathrm{sw}}$ & 20 & $\mathbf{0 . 0 1 6 1 4}$ & 0.28130 & 0.419 & 227.2458 \\
\hline & & & & $0.660 \pm$ & $226.948 \pm$ \\
${ }^{*} \Omega_{\mathrm{sw}}$ & 20 & & & 0.203 & 0.256 \\
\hline $\mathrm{pH} \mathrm{sw}_{\mathrm{sw}}$ & 20 & 0.07227 & 0.16844 & & \\
\hline Depth & 20 & 0.06344 & 0.17855 & & \\
\hline
\end{tabular}

Distance

from seeps $\quad \begin{array}{lllll}20 & \mathbf{0 . 0 0 1 3 3} & 0.44444 & 0.000 & 227.7400\end{array}$

Calcite

content (\%) $\quad 20 \quad \mathbf{0 . 0 4 4 0 0} \quad 0.20672 \quad-20.435 \quad 227.8200$

a-axis

length

\begin{tabular}{llllll}
$\Omega_{\mathrm{sw}}$ & 20 & $\mathbf{0 . 0 3 1 5 8}$ & 0.23186 & 0.003 & 4.9644 \\
\hline & & & & $0.004 \pm$ & $4.963 \pm$ \\
${ }^{*} \Omega_{\mathrm{sw}}$ & 20 & & & 0.002 & 0.002 \\
\hline $\mathrm{pH} \mathrm{Hw}_{\mathrm{sw}}$ & 20 & 0.14710 & & & \\
\hline Depth & 20 & $\mathbf{0 . 0 3 4 1 7}$ & 0.22593 & 0.000 & 4.9716 \\
\hline
\end{tabular}

Distance

\begin{tabular}{llllll} 
from seeps & 20 & $\mathbf{0 . 0 0 2 6 4}$ & 0.40297 & 0.000 & 4.9678 \\
\hline
\end{tabular}

Calcite

content (\%) $\quad 20 \quad 0.27960 \quad 0.06458$

$b$-axis

length

\begin{tabular}{llllll}
$\Omega_{\mathrm{sw}}$ & 20 & $\mathbf{0 . 0 0 7 2 1}$ & 0.33765 & 0.006 & 7.9617 \\
\hline & & & & $0.009 \pm$ & $7.958 \pm$ \\
${ }^{*} \Omega_{\mathrm{sw}}$ & 20 & & & 0.003 & 0.004 \\
\hline $\mathrm{pH}_{\mathrm{sw}}$ & 20 & $\mathbf{0 . 0 4 1 4 0}$ & 0.21137 & 0.018 & 7.8250 \\
\hline & & & & $0.044 \pm$ & $7.625 \pm$ \\
${ }^{*} \mathrm{pH}_{\mathrm{sw}}$ & 20 & & & 0.016 & 0.130 \\
\hline
\end{tabular}




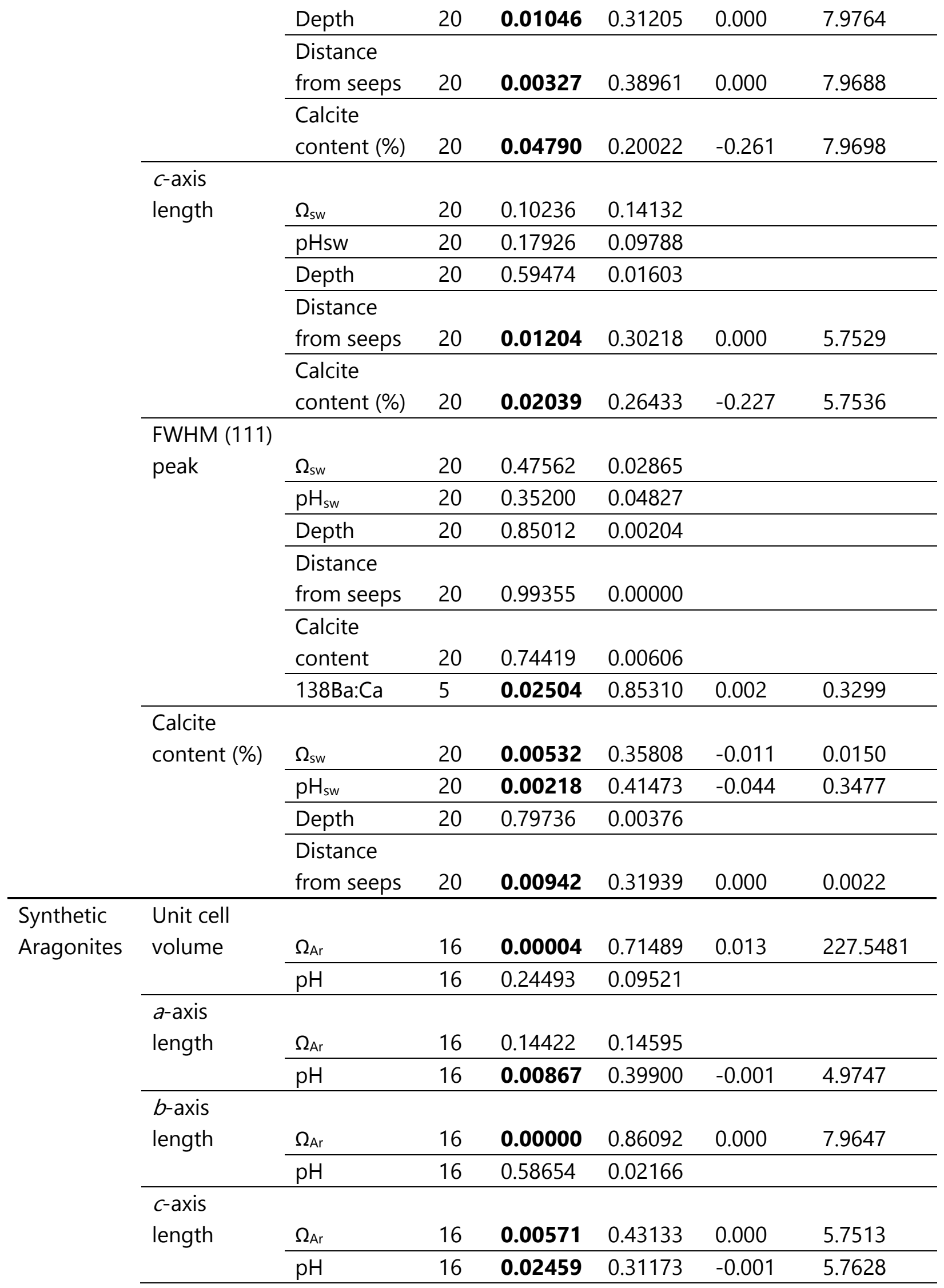


FWHM (111)

peak

\begin{tabular}{llll}
$\Omega_{\mathrm{Ar}}$ & 16 & 0.57941 & 0.02248 \\
\hline $\mathrm{pH}$ & 16 & 0.13695 & 0.15096
\end{tabular}

Calcite

content (\%)

\begin{tabular}{llllll}
$\Omega_{\text {Ar }}$ & 16 & $\mathbf{0 . 0 0 2 7 9}$ & 0.48346 & -0.001 & 0.0112 \\
\hline $\mathrm{pH}$ & 16 & 0.66678 & 0.01363 & &
\end{tabular}

Synthetic

Aragonites

and $\mathrm{JCp}-1$

reference

coral

Unit cell

volume

$\begin{array}{llllll}\Omega_{\mathrm{Ar}} & 20 & \mathbf{0 . 0 0 0 2 1} & 0.54248 & 0.010 & 227.6116\end{array}$

$\begin{array}{llll}\mathrm{pH} & 20 & 0.19208 & 0.09260\end{array}$

a-axis

length

$\begin{array}{llll}\Omega_{\mathrm{Ar}} & 20 & 0.32479 & 0.05387 \\ \mathrm{pH} & 20 & \mathbf{0 . 0 0 4 3 3} & 0.37157\end{array}$

$-0.001 \quad 4.9748$

\begin{tabular}{lllllll}
\hline$b$-axis & & & & & & \\
length & $\Omega_{\mathrm{Ar}}$ & 20 & $\mathbf{0 . 0 1 7 0 9}$ & 0.27718 & 0.000 & 7.9691 \\
\cline { 2 - 7 } & $\mathrm{pH}$ & 20 & 0.42681 & 0.03542 & & \\
\hline
\end{tabular}

c-axis

length

$\Omega_{\mathrm{Ar}}$

$20 \quad \mathbf{0 . 0 0 0 1 4} \quad 0.5640$

0.000

5.7503

FWHM (111)

peak

$\begin{array}{llll}\Omega_{\mathrm{Ar}} & 20 & 0.63905 & 0.01249 \\ \mathrm{pH} & 20 & 0.06302 & 0.17906\end{array}$

Calcite

content (\%)

\begin{tabular}{llll}
$\Omega_{\mathrm{Ar}}$ & 20 & 0.96328 & 0.00012 \\
\hline $\mathrm{pH}$ & 20 & $\mathbf{0 . 0 1 2 9 4}$ & 0.29709
\end{tabular}

0.000

0.0064 
TABLE S3.3: Deep-sea coral crystal lattice parameters, FWHMs and trace element incorporations.

\begin{tabular}{|c|c|c|c|c|c|c|c|c|c|c|c|c|c|}
\hline 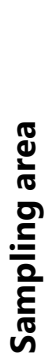 & $\begin{array}{l}\frac{y}{0} \\
\frac{d}{0} \\
\frac{0}{0} \\
\text { o }\end{array}$ & 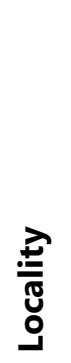 & $\frac{\frac{y}{0}}{\frac{0}{E}}$ & $\begin{array}{l}\widehat{s} \\
\frac{1}{0} \\
0 \\
\frac{0}{0} \\
\frac{n}{x} \\
0 \\
0\end{array}$ & 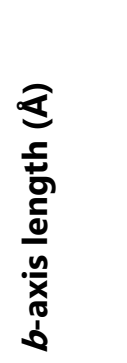 & $\begin{array}{l}\widehat{s} \\
\frac{5}{0} \\
0 \\
\frac{c}{0} \\
\frac{n}{x} \\
0 \\
0\end{array}$ & 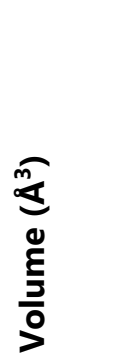 & 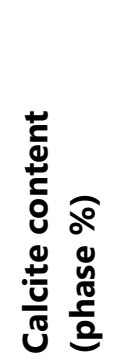 & 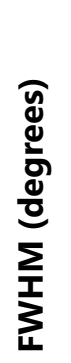 & 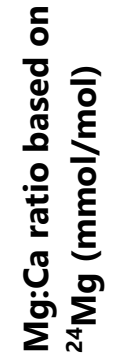 & 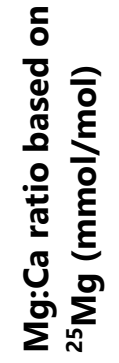 & 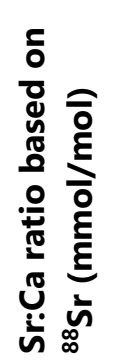 & 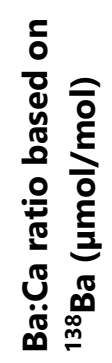 \\
\hline \multirow{9}{*}{$\begin{array}{l}0 \\
\frac{2}{2} \\
0 \\
\frac{0}{0} \\
\frac{1}{0} \\
\frac{1}{0} \\
\frac{0}{2} \\
\frac{1}{2} \\
0\end{array}$} & \multirow{9}{*}{\multicolumn{2}{|c|}{ 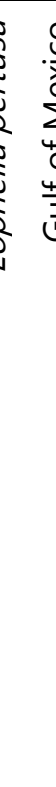 }} & \multirow{9}{*}{ 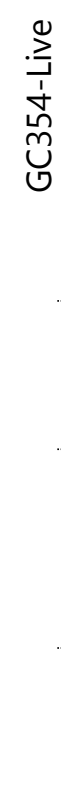 } & 4.9677 & 7.9677 & 5.7524 & 227.69 & 0.005 & & 2.98 & 2.92 & 10.03 & 9.35 \\
\hline & & & & $\begin{array}{l} \pm \\
0.0005\end{array}$ & $\begin{array}{l} \pm \\
0.0008\end{array}$ & $\begin{array}{l} \pm \\
0.0006\end{array}$ & $\begin{array}{l} \pm \\
0.06\end{array}$ & $\begin{array}{l} \pm \\
0.001\end{array}$ & & $\begin{array}{l} \pm \\
0.06\end{array}$ & & $\begin{array}{l} \pm \\
0.22\end{array}$ & 0.2 \\
\hline & & & & 4.9669 & 7.9678 & 5.7522 & 227.64 & 0.0121 & & 2.98 & 2.92 & 10.03 & 9.35 \\
\hline & & & & & & & \pm & \pm & & \pm & \pm & \pm & \pm \\
\hline & & & & 0.0005 & 0.0008 & 0.0006 & 0.05 & 0.001 & & 0.06 & 0.1 & 0.22 & 0.2 \\
\hline & & & & 4.9673 & 7.9695 & 5.753 & 227.75 & 0.0066 & & 2.98 & 2.92 & 10.03 & 9.35 \\
\hline & & & & & & \pm & \pm & \pm & & \pm & \pm & & \pm \\
\hline & & & & 0.0005 & 0.0009 & 0.0007 & 0.06 & 0.0012 & & 0.06 & 0.1 & 0.22 & 0.2 \\
\hline & & 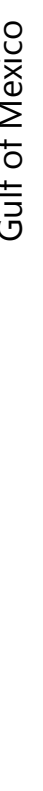 & & $\begin{array}{l}4.968 \\
\pm \\
0.0005\end{array}$ & $\begin{array}{l}7.9711 \\
\pm \\
0.0008\end{array}$ & $\begin{array}{l}5.7538 \\
\pm \\
0.0006\end{array}$ & $\begin{array}{l}227.85 \\
\pm \\
0.06\end{array}$ & $\begin{array}{l}0.0103 \\
\pm \\
0.0012\end{array}$ & & $\begin{array}{l}2.98 \\
\pm \\
0.06\end{array}$ & $\begin{array}{l}2.92 \\
\pm \\
0.1\end{array}$ & $\begin{array}{l}10.03 \\
\pm \\
0.22\end{array}$ & $\begin{array}{l}9.35 \\
\pm \\
0.2\end{array}$ \\
\hline \multirow{11}{*}{ 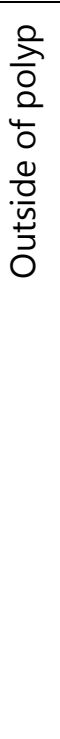 } & \multirow{11}{*}{ 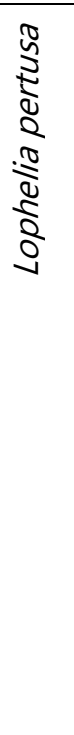 } & \multirow{11}{*}{$\begin{array}{l}\frac{0}{3} \\
\frac{0}{x} \\
\sum_{4}^{0} \\
0 \\
\frac{4}{5} \\
0\end{array}$} & \multirow{11}{*}{ 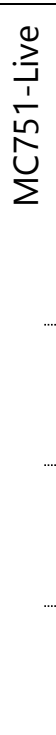 } & 4.9672 & 7.9686 & 5.7522 & 227.68 & -0.0015 & & 2.61 & 2.59 & 9.37 & 8.43 \\
\hline & & & & \pm & & & \pm & & & \pm & \pm & \pm & \pm \\
\hline & & & & 4.968 & 7.9709 & 5.7531 & 227.81 & -0.0005 & & 2.61 & 2.59 & 9.37 & 8.43 \\
\hline & & & & \pm & \pm & \pm & \pm & \pm & & \pm & \pm & \pm & \pm \\
\hline & & & & 0.0008 & 0.0014 & 0.0011 & 0.1 & 0.001 & & 0.04 & 0.09 & 0.18 & 0.19 \\
\hline & & & & 4.968 & 7.9695 & 5.7528 & 227.77 & 0.0003 & & 2.61 & 2.59 & 9.37 & 8.43 \\
\hline & & & & \pm & \pm & \pm & \pm & \pm & & \pm & \pm & \pm & \pm \\
\hline & & & & 0.0007 & 0.0012 & 0.0009 & 0.08 & 0.0011 & & 0.04 & 0.09 & 0.18 & 0.19 \\
\hline & & & & 4.968 & 7.97 & 5.7529 & 227.79 & -0.0001 & & 2.61 & 2.59 & 9.37 & 8.43 \\
\hline & & & & \pm & \pm & \pm & \pm & \pm & & \pm & \pm & \pm & \pm \\
\hline & & & & 0.0007 & 0.0012 & 0.0009 & 0.08 & 0.0011 & & 0.04 & 0.09 & 0.18 & 0.19 \\
\hline
\end{tabular}




\begin{tabular}{|c|c|c|c|c|c|c|c|c|c|c|c|c|}
\hline $\begin{array}{l}\frac{0}{2} \\
\frac{2}{0} \\
\frac{2}{0} \\
\frac{1}{0} \\
\frac{1}{0} \\
\frac{0}{0} \\
\frac{1}{3} \\
0\end{array}$ & 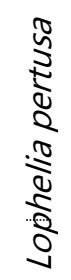 & 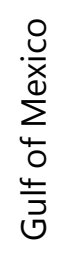 & 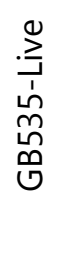 & $\begin{array}{l}4.9677 \\
\pm \\
0.0009\end{array}$ & $\begin{array}{l}7.9698 \\
\pm \\
0.0015\end{array}$ & $\begin{array}{l}5.753 \\
\pm \\
0.0012\end{array}$ & $\begin{array}{l}227.77 \\
\pm \\
0.11\end{array}$ & $\begin{array}{l}0 \\
\pm \\
0\end{array}$ & $\begin{array}{l}2.75 \\
\pm \\
0.04\end{array}$ & $\begin{array}{l}2.71 \\
\pm \\
0.06\end{array}$ & $\begin{array}{l}10 \\
\pm \\
0.2\end{array}$ & $\begin{array}{l}10.4 \\
\pm \\
0.19\end{array}$ \\
\hline
\end{tabular}

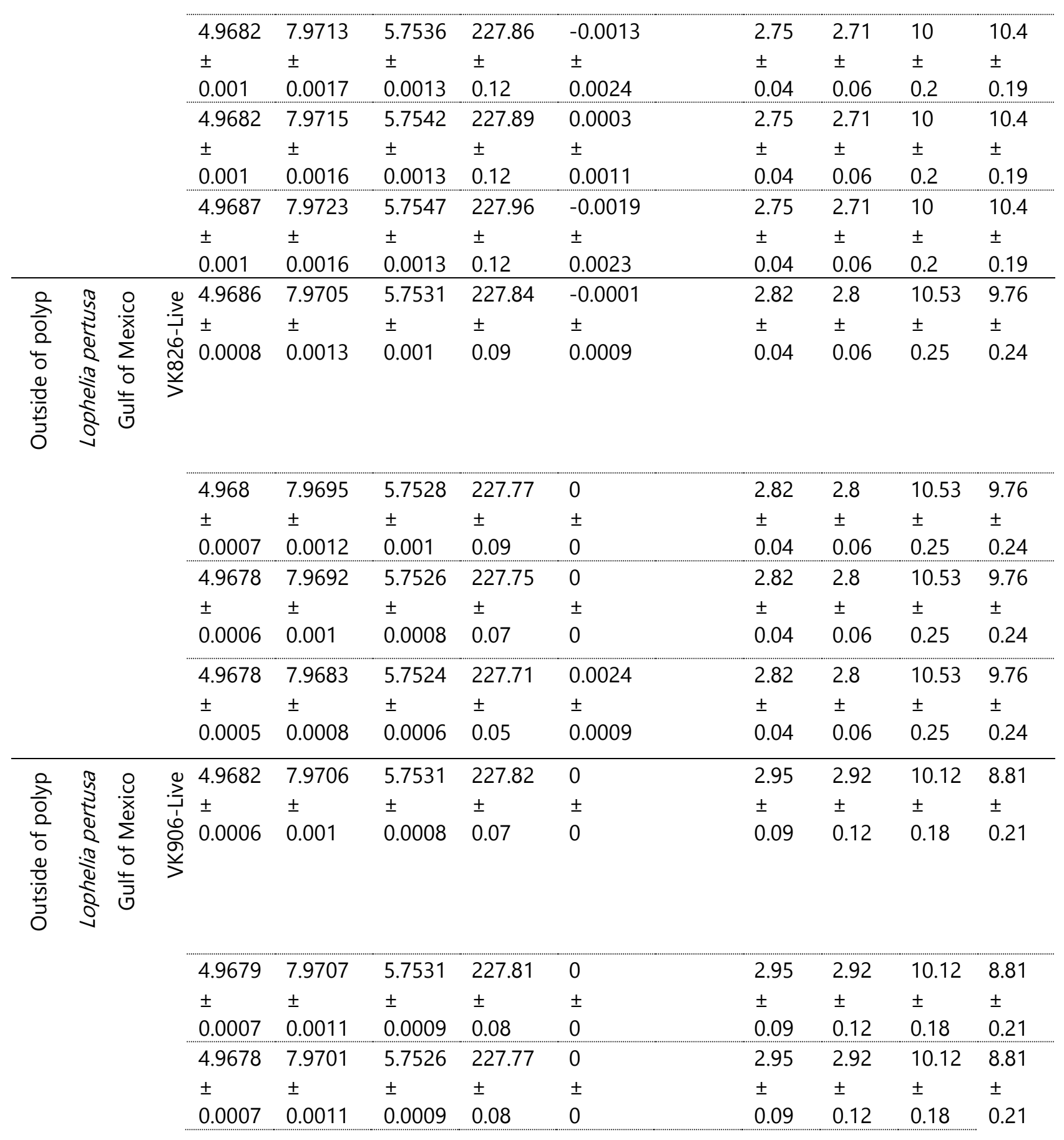




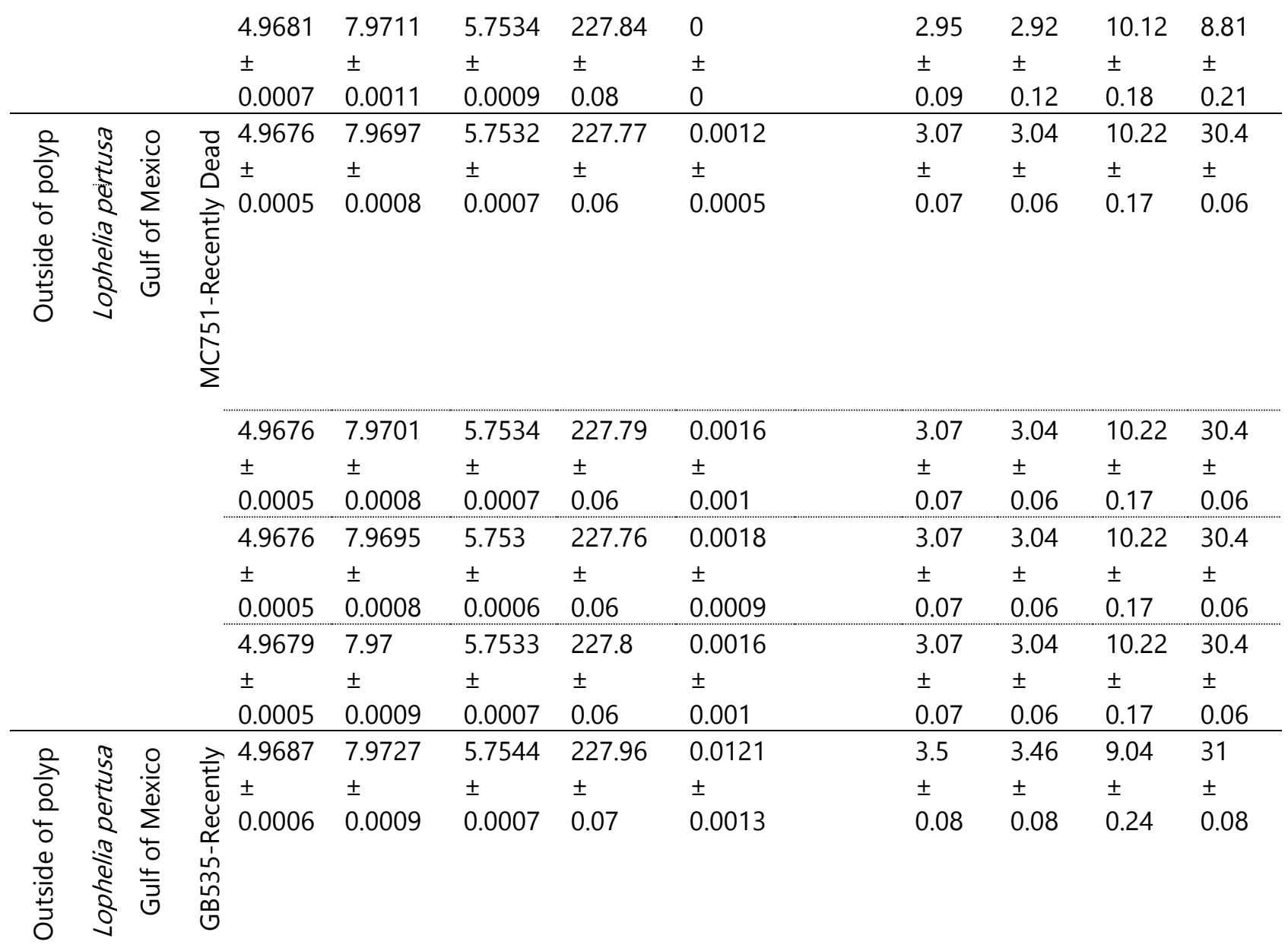

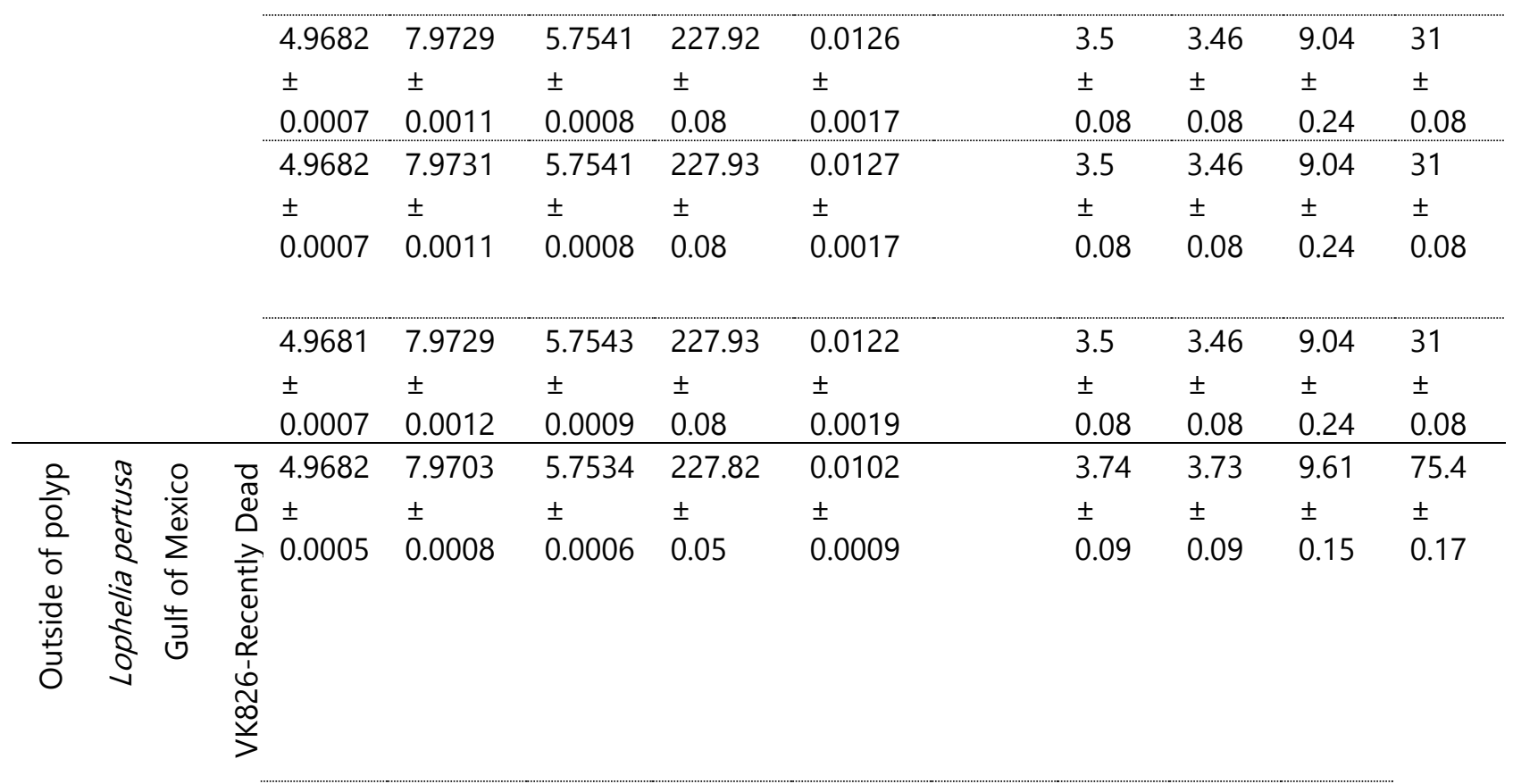




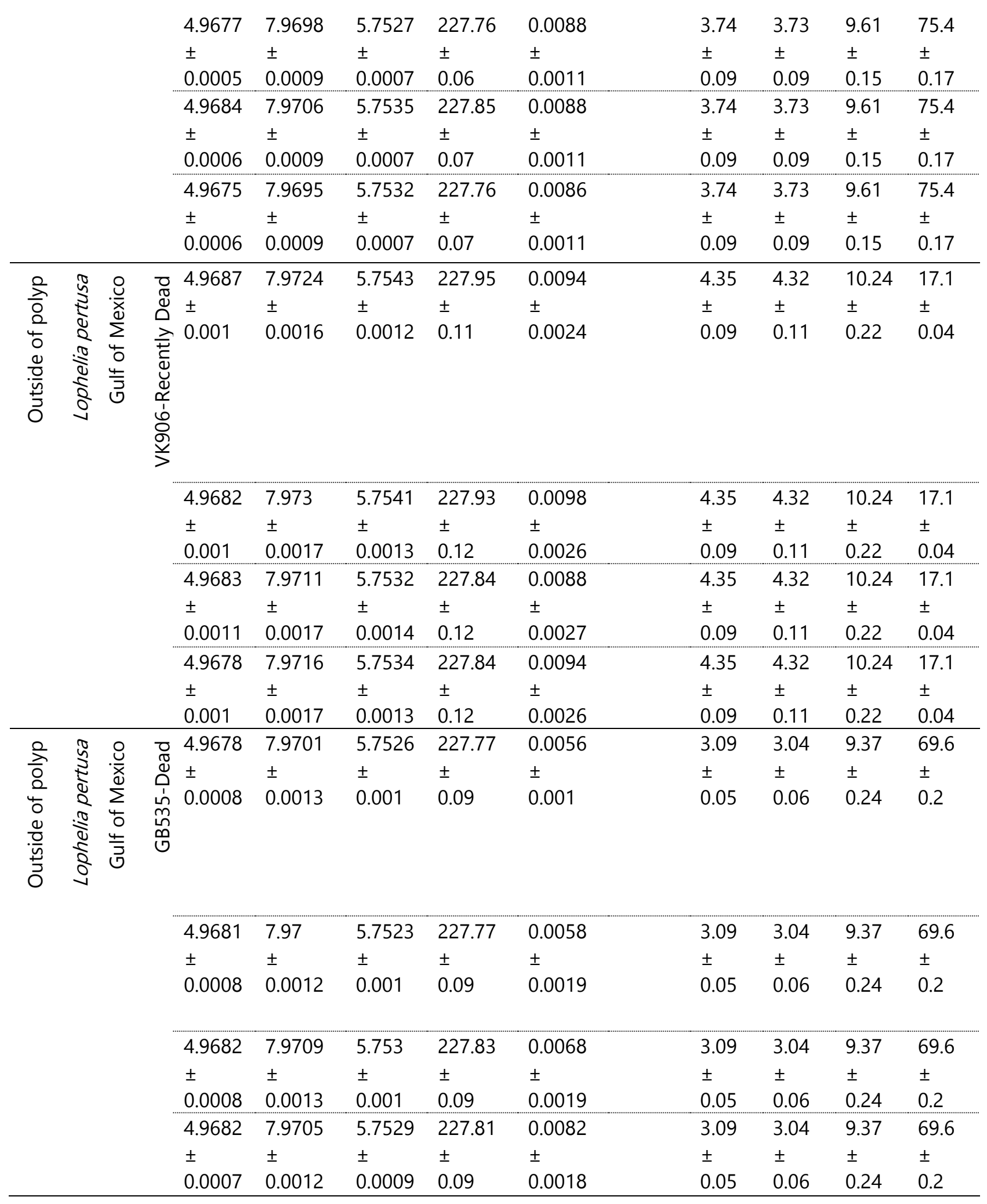




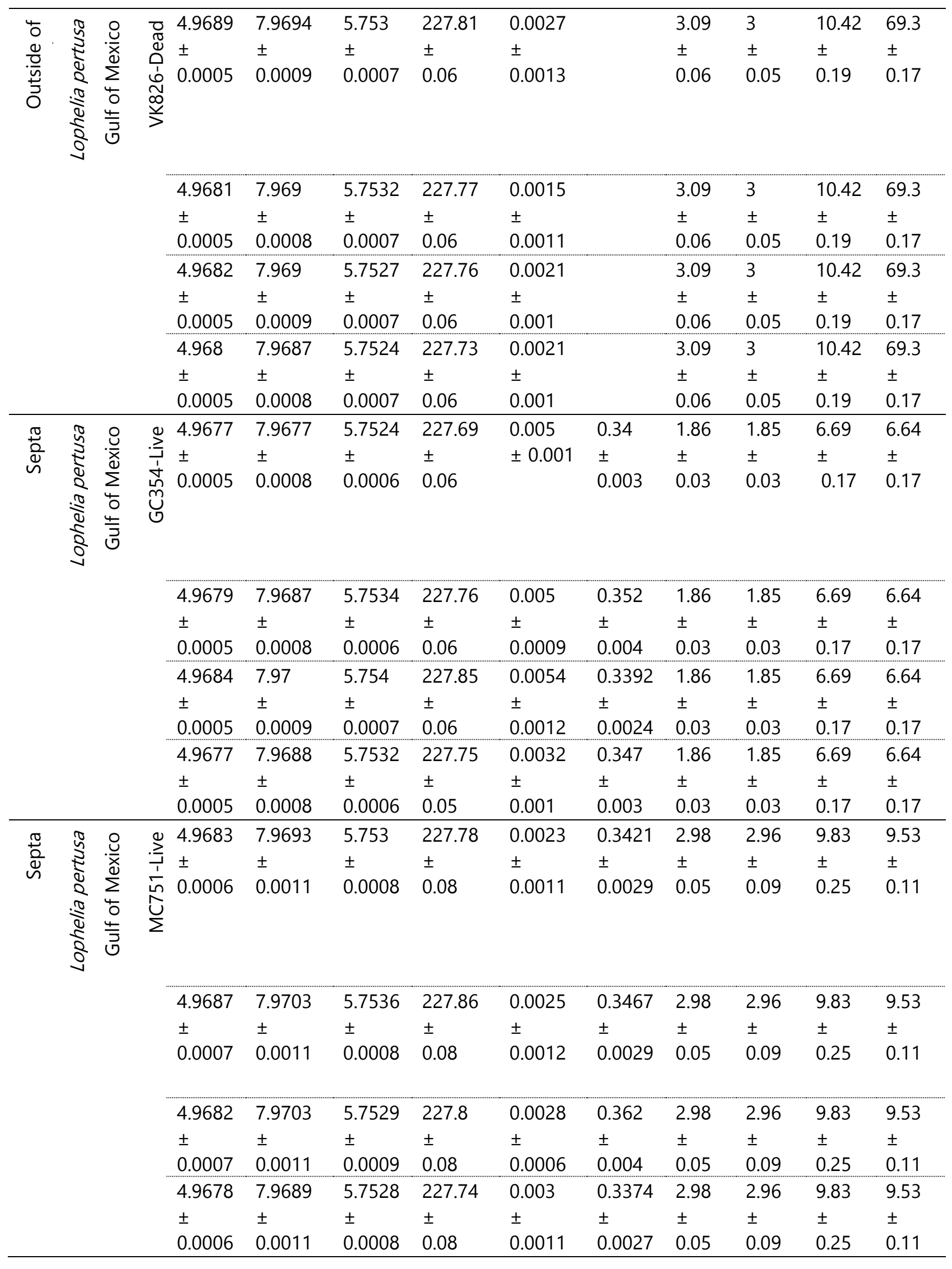




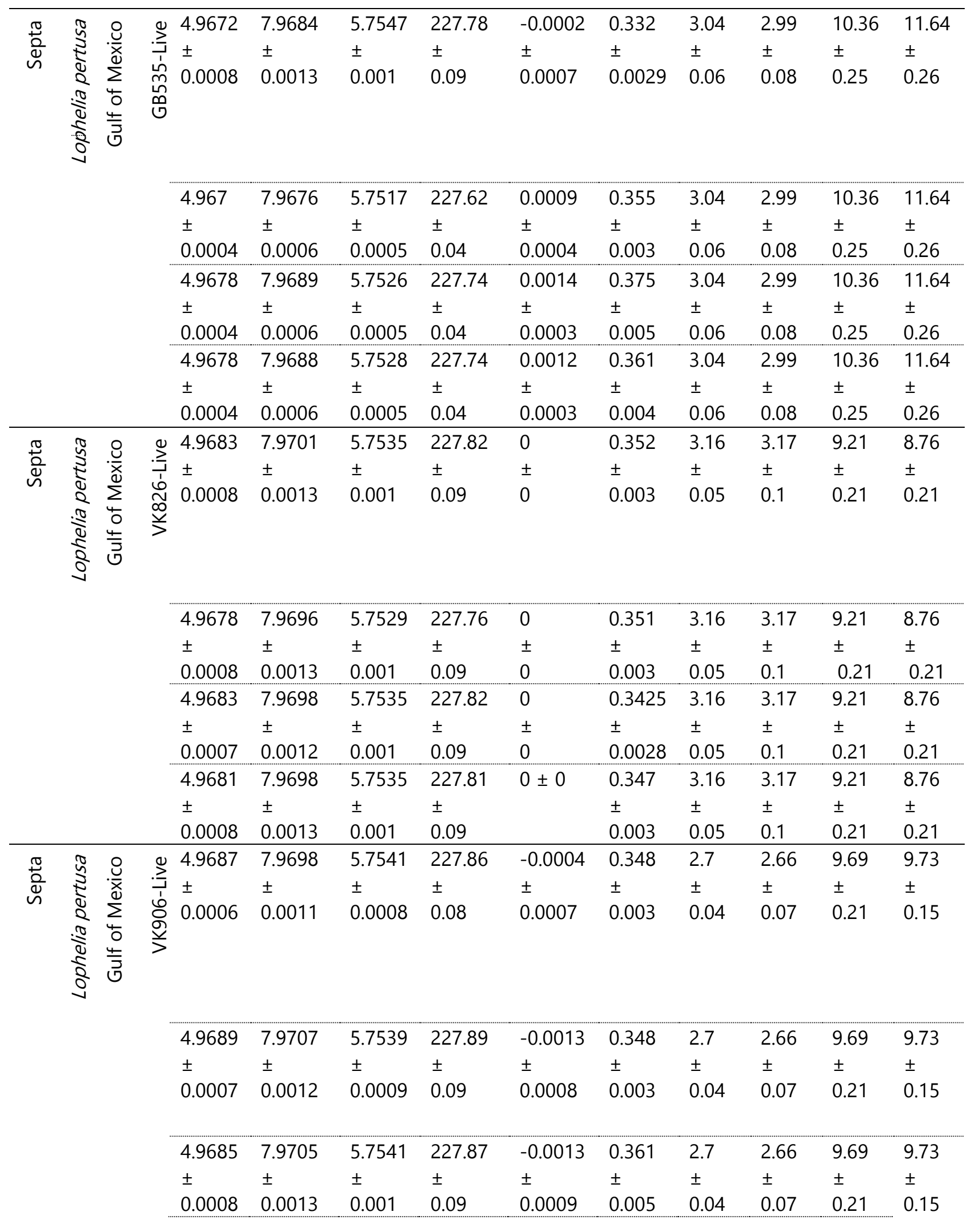




\begin{tabular}{|c|c|c|c|c|c|c|c|c|c|c|c|c|c|}
\hline & & & & $\begin{array}{l}4.9695 \\
\pm \\
0.0008\end{array}$ & $\begin{array}{l}7.9718 \\
\pm \\
0.0013\end{array}$ & $\begin{array}{l}5.7548 \\
\pm \\
0.001\end{array}$ & $\begin{array}{l}227.98 \\
\pm \\
0.09\end{array}$ & $\begin{array}{l}-0.0007 \\
\pm \\
0.0008\end{array}$ & $\begin{array}{l}0.3429 \\
\pm \\
0.0029\end{array}$ & $\begin{array}{l}2.7 \\
\pm \\
0.04\end{array}$ & $\begin{array}{l}2.66 \\
\pm \\
0.07\end{array}$ & $\begin{array}{l}9.69 \\
\pm \\
0.21\end{array}$ & $\begin{array}{l}9.73 \\
\pm \\
0.15\end{array}$ \\
\hline $\begin{array}{l}\frac{\pi}{0} \\
\stackrel{0}{0} \\
\stackrel{n}{n}\end{array}$ & 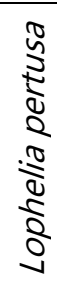 & 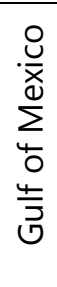 & 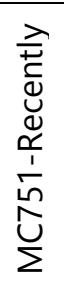 & $\begin{array}{l}4.9676 \\
\pm \\
0.0006\end{array}$ & $\begin{array}{l}7.9687 \\
\pm \\
0.001\end{array}$ & $\begin{array}{l}5.7527 \\
\pm \\
0.0007\end{array}$ & $\begin{array}{l}227.72 \\
\pm \\
0.07\end{array}$ & $\begin{array}{l}0.0011 \\
\pm \\
0.0005\end{array}$ & & $\begin{array}{l}2.88 \\
\pm \\
0.12\end{array}$ & $\begin{array}{l}2.84 \\
\pm \\
0.13\end{array}$ & $\begin{array}{l}9.57 \\
\pm \\
0.19\end{array}$ & $\begin{array}{l}28.1 \\
\pm \\
0.09\end{array}$ \\
\hline
\end{tabular}

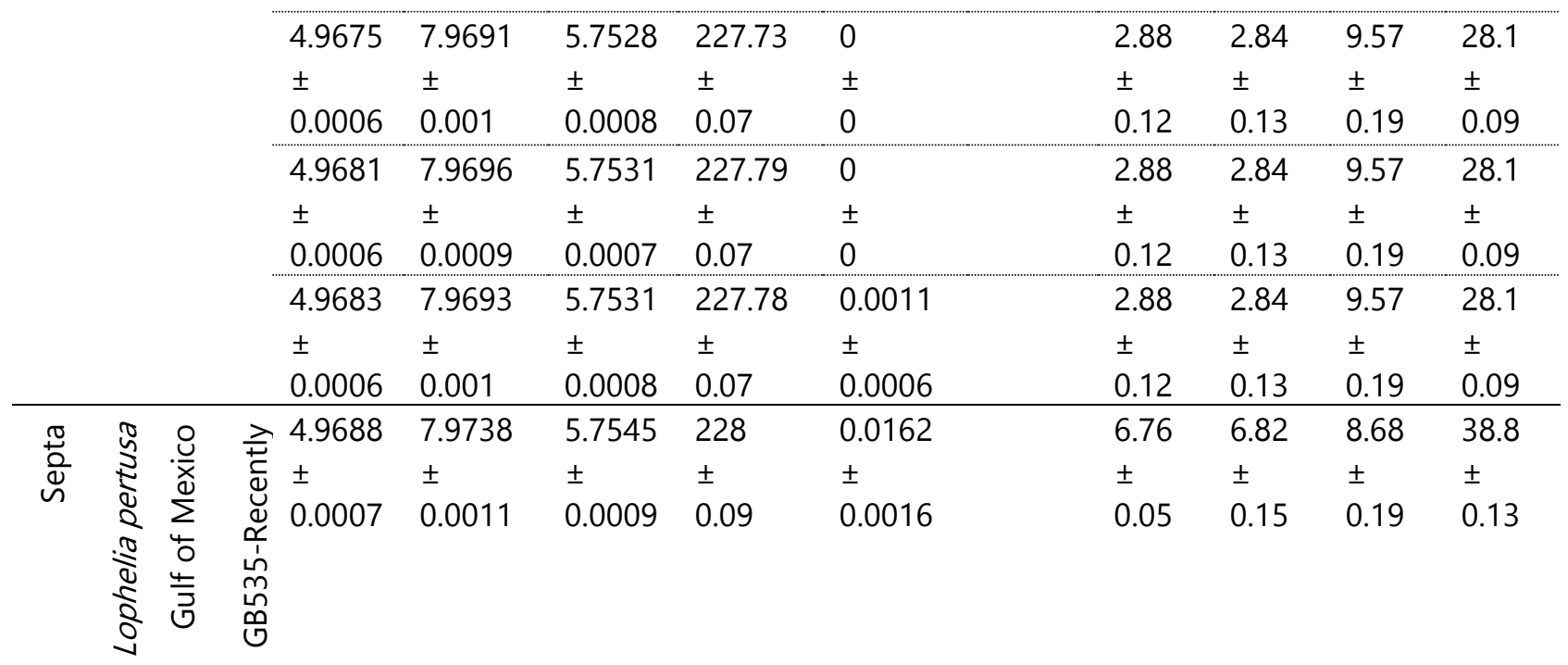

\begin{tabular}{lllllllll}
4.9689 & 7.9734 & 5.7545 & 227.99 & 0.0167 & 6.76 & 6.82 & 8.68 & 38.8 \\
\pm & \pm & \pm & \pm & \pm & \pm & \pm & \pm & \pm \\
0.0006 & 0.001 & 0.0008 & 0.07 & 0.0014 & 0.05 & 0.15 & 0.19 & 0.13 \\
\hline 4.9692 & 7.9735 & 5.7545 & 228.01 & 0.0166 & 6.76 & 6.82 & 8.68 & 38.8 \\
\pm & \pm & \pm & \pm & \pm & \pm & \pm & \pm & \pm \\
0.0006 & 0.001 & 0.0008 & 0.07 & 0.0015 & 0.05 & 0.15 & 0.19 & 0.13 \\
\hline 4.9688 & 7.9723 & 5.7541 & 227.94 & 0.0162 & 6.76 & 6.82 & 8.68 & 38.8 \\
\pm & \pm & \pm & \pm & \pm & \pm & \pm & \pm & \pm \\
0.0007 & 0.0011 & 0.0009 & 0.08 & 0.0017 & 0.05 & 0.15 & 0.19 & 0.13
\end{tabular}




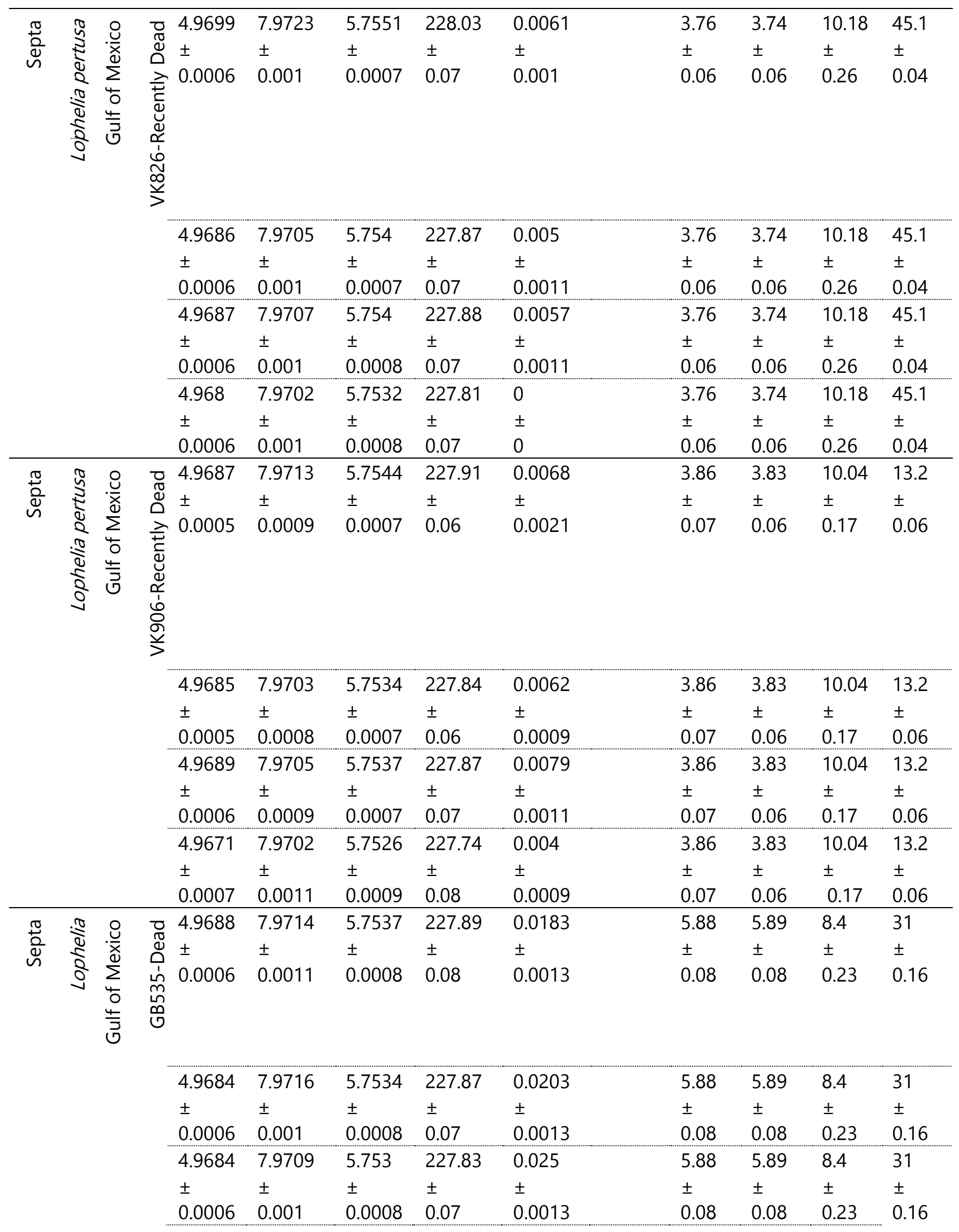




\begin{tabular}{|c|c|c|c|c|c|c|c|c|c|c|c|c|c|}
\hline & & & & $\begin{array}{l}4.9683 \\
\pm \\
0.0006\end{array}$ & $\begin{array}{l}7.9705 \\
\pm \\
0.0011\end{array}$ & $\begin{array}{l}5.7532 \\
\pm \\
0.0008\end{array}$ & $\begin{array}{l}227.82 \\
\pm \\
0.07\end{array}$ & $\begin{array}{l}0.0317 \\
\pm \\
0.0015\end{array}$ & & $\begin{array}{l}5.88 \\
\pm \\
0.08\end{array}$ & $\begin{array}{l}5.89 \\
\pm \\
0.08\end{array}$ & $\begin{array}{l}8.4 \\
\pm \\
0.23\end{array}$ & $\begin{array}{l}31 \\
\pm \\
0.16\end{array}$ \\
\hline \multirow[t]{4}{*}{ 营 } & \multirow[t]{4}{*}{ 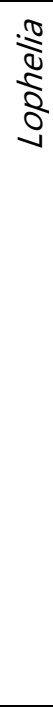 } & \multirow{4}{*}{$\begin{array}{l}0 \\
0 \\
\frac{0}{x} \\
\sum_{4}^{0} \\
0 \\
\frac{4}{5} \\
0 \\
0\end{array}$} & \multirow{4}{*}{ 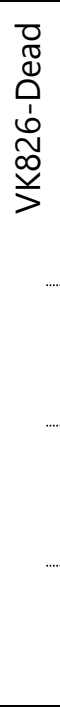 } & $\begin{array}{l}4.9683 \\
\pm \\
0.0004\end{array}$ & $\begin{array}{l}7.968 \pm \\
0.0007\end{array}$ & $\begin{array}{l}5.7528 \\
\pm \\
0.0005\end{array}$ & $\begin{array}{l}227.74 \\
\pm \\
0.05\end{array}$ & $\begin{array}{l}0.0099 \\
\pm \\
0.0008\end{array}$ & & $\begin{array}{l}3.62 \\
\pm \\
0.05\end{array}$ & $\begin{array}{l}3.61 \\
\pm \\
0.06\end{array}$ & $\begin{array}{l}10.5 \\
\pm \\
0.24\end{array}$ & $\begin{array}{l}62.3 \\
\pm \\
0.2\end{array}$ \\
\hline & & & & $\begin{array}{l}4.9677 \\
\pm \\
0.0004\end{array}$ & $\begin{array}{l}7.9678 \\
\pm \\
0.0007\end{array}$ & $\begin{array}{l}5.7519 \\
\pm \\
0.0005\end{array}$ & $\begin{array}{l}227.67 \\
\pm \\
0.05\end{array}$ & $\begin{array}{l}0.0108 \\
\pm \\
0.0008\end{array}$ & & $\begin{array}{l}3.62 \\
\pm \\
0.05\end{array}$ & $\begin{array}{l}3.61 \\
\pm \\
0.06\end{array}$ & $\begin{array}{l}10.5 \\
\pm \\
0.24\end{array}$ & $\begin{array}{l}62.3 \\
\pm \\
0.2\end{array}$ \\
\hline & & & & $\begin{array}{l}4.9675 \\
\pm \\
0.0004\end{array}$ & $\begin{array}{l}7.9673 \\
\pm \\
0.0007\end{array}$ & $\begin{array}{l}5.7517 \\
\pm \\
0.0006\end{array}$ & $\begin{array}{l}227.64 \\
\pm \\
0.05\end{array}$ & $\begin{array}{l}0.014 \\
\pm \\
0.0008\end{array}$ & & $\begin{array}{l}3.62 \\
\pm \\
0.05\end{array}$ & $\begin{array}{l}3.61 \\
\pm \\
0.06\end{array}$ & $\begin{array}{l}10.5 \\
\pm \\
0.24\end{array}$ & $\begin{array}{l}62.3 \\
\pm \\
0.2\end{array}$ \\
\hline & & & & $\begin{array}{l}4.9674 \\
\pm \\
0.0005\end{array}$ & $\begin{array}{l}7.9672 \\
\pm \\
0.0008\end{array}$ & $\begin{array}{l}5.7518 \\
\pm \\
0.0006\end{array}$ & $\begin{array}{l}227.64 \\
\pm \\
0.06\end{array}$ & $\begin{array}{l}0.0069 \\
\pm \\
0.0009\end{array}$ & & $\begin{array}{l}3.62 \\
\pm \\
0.05\end{array}$ & $\begin{array}{l}3.61 \\
\pm \\
0.06\end{array}$ & $\begin{array}{l}10.5 \\
\pm \\
0.24\end{array}$ & $\begin{array}{l}62.3 \\
\pm \\
0.2\end{array}$ \\
\hline$\frac{\pi}{\stackrel{0}{0}}$ & $\frac{\sqrt{2}}{\frac{8}{8}}$ & : & $\vec{\mho}$ & $\begin{array}{l}4.968 \\
\pm \\
0.0005\end{array}$ & $\begin{array}{l}7.9709 \\
\pm \\
0.0008\end{array}$ & $\begin{array}{l}5.754 \\
\pm \\
0.0006\end{array}$ & $\begin{array}{l}227.86 \\
\pm \\
0.06\end{array}$ & $\begin{array}{l}0.0032 \\
\pm \\
0.0008\end{array}$ & $\begin{array}{l}0.3434 \\
\pm \\
0.003\end{array}$ & $\begin{array}{l}2.79 \\
\pm \\
0.05\end{array}$ & $\begin{array}{l}2.76 \\
\pm \\
0.09\end{array}$ & $\begin{array}{l}10.18 \\
\pm \\
0.25\end{array}$ & $\begin{array}{l}9.77 \\
\pm \\
0.3\end{array}$ \\
\hline
\end{tabular}

\begin{tabular}{llllllllll}
4.9683 & 7.9715 & 5.7542 & 227.89 & 0.0029 & 0.3312 & 2.79 & 2.76 & 10.18 & 9.77 \\
\pm & \pm & \pm & \pm & \pm & \pm & \pm & \pm & \pm & \pm \\
0.0005 & 0.0009 & 0.0007 & 0.06 & 0.0009 & 0.0021 & 0.05 & 0.09 & 0.25 & 0.3 \\
\hline 4.9684 & 7.9699 & 5.7538 & 227.84 & 0.0027 & 0.3273 & 2.79 & 2.76 & 10.18 & 9.77 \\
\pm & \pm & \pm & \pm & \pm & \pm & \pm & \pm & \pm & \pm \\
0.0005 & 0.0008 & 0.0006 & 0.06 & 0.0009 & 0.0024 & 0.05 & 0.09 & 0.25 & 0.3 \\
\hline 4.9686 & 7.97 & 5.7536 & 227.84 & 0.0031 & 0.3245 & 2.79 & 2.76 & 10.18 & 9.77 \\
\pm & \pm & \pm & \pm & \pm & \pm & \pm & \pm & \pm & \pm \\
0.0005 & 0.0008 & 0.0006 & 0.06 & 0.0009 & 0.0022 & 0.05 & 0.09 & 0.25 & 0.3
\end{tabular}




\begin{tabular}{|c|c|c|c|c|c|c|c|c|c|c|c|c|}
\hline 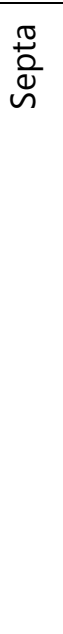 & 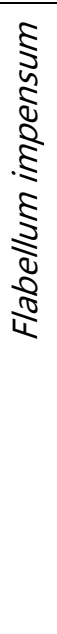 & 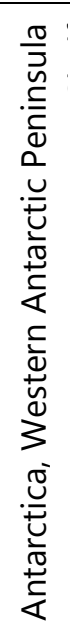 & 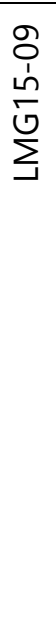 & $\begin{array}{l}4.9687 \\
\pm \\
0.0007\end{array}$ & $\begin{array}{l}7.9702 \\
\pm \\
0.0012\end{array}$ & $\begin{array}{l}5.7546 \\
\pm \\
0.0009\end{array}$ & $\begin{array}{l}227.89 \\
\pm \\
0.08\end{array}$ & $\begin{array}{l}-0.0003 \\
\pm \\
0.0008\end{array}$ & $\begin{array}{l}2.81 \\
\pm \\
0.06\end{array}$ & $\begin{array}{l}2.81 \\
\pm \\
0.07\end{array}$ & $\begin{array}{l}12.6 \\
\pm \\
0.03\end{array}$ & $\begin{array}{l}27 \\
\pm \\
0.06\end{array}$ \\
\hline & & & & $\begin{array}{l}4.9694 \\
\pm \\
0.0008\end{array}$ & $\begin{array}{l}7.9706 \\
\pm \\
0.0013\end{array}$ & $\begin{array}{l}5.755 \\
\pm \\
0.001\end{array}$ & $\begin{array}{l}227.95 \\
\pm \\
0.1\end{array}$ & $\begin{array}{l}-0.0007 \\
\pm \\
0.0009\end{array}$ & $\begin{array}{l}2.81 \\
\pm \\
0.06\end{array}$ & $\begin{array}{l}2.81 \\
\pm \\
0.07\end{array}$ & $\begin{array}{l}12.6 \\
\pm \\
0.03\end{array}$ & $\begin{array}{l}27 \\
\pm \\
0.06\end{array}$ \\
\hline & & & & $\begin{array}{l}4.9692 \\
\pm \\
0.0008\end{array}$ & $\begin{array}{l}7.9707 \\
\pm \\
0.0013\end{array}$ & $\begin{array}{l}5.7548 \\
\pm \\
0.001\end{array}$ & $\begin{array}{l}227.94 \\
\pm \\
0.09\end{array}$ & $\begin{array}{l}-0.0003 \\
\pm \\
0.0009\end{array}$ & $\begin{array}{l}2.81 \\
\pm \\
0.06\end{array}$ & $\begin{array}{l}2.81 \\
\pm \\
0.07\end{array}$ & $\begin{array}{l}12.6 \\
\pm \\
0.03\end{array}$ & $\begin{array}{l}27 \\
\pm \\
0.06\end{array}$ \\
\hline & & & & $\begin{array}{l}4.9691 \\
\pm \\
0.0008\end{array}$ & $\begin{array}{l}7.9707 \\
\pm \\
0.0014\end{array}$ & $\begin{array}{l}5.7548 \\
\pm \\
0.0011\end{array}$ & $\begin{array}{l}227.93 \\
\pm \\
0.1\end{array}$ & $\begin{array}{l}-0.0003 \\
\pm \\
0.0009\end{array}$ & $\begin{array}{l}2.81 \\
\pm \\
0.06\end{array}$ & $\begin{array}{l}2.81 \\
\pm \\
0.07\end{array}$ & $\begin{array}{l}12.6 \\
\pm \\
0.03\end{array}$ & $\begin{array}{l}27 \\
\pm \\
0.06\end{array}$ \\
\hline $\begin{array}{l}\stackrel{\pi}{0} \\
\stackrel{0}{0} \\
\sim\end{array}$ & 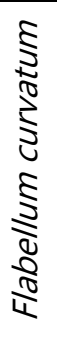 & 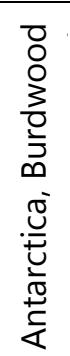 & 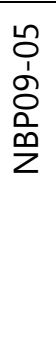 & $\begin{array}{l}4.9673 \\
\pm \\
0.0006\end{array}$ & $\begin{array}{l}7.9677 \\
\pm \\
0.001\end{array}$ & $\begin{array}{l}5.7524 \\
\pm \\
0.0008\end{array}$ & $\begin{array}{l}227.67 \\
\pm \\
0.07\end{array}$ & $\begin{array}{l}0.0011 \\
\pm \\
0.0008\end{array}$ & $\begin{array}{l}3.06 \\
\pm \\
0.04\end{array}$ & $\begin{array}{l}3.07 \\
\pm \\
0.05\end{array}$ & $\begin{array}{l}10.57 \\
\pm \\
0.27\end{array}$ & $\begin{array}{l}12.73 \\
\pm \\
0.3\end{array}$ \\
\hline & & & & $\begin{array}{l}4.9678 \\
\pm \\
0.0006\end{array}$ & $\begin{array}{l}7.9685 \\
\pm \\
0.001\end{array}$ & $\begin{array}{l}5.7534 \\
\pm \\
0.0008\end{array}$ & $\begin{array}{l}227.75 \\
\pm \\
0.07\end{array}$ & $\begin{array}{l}0.0014 \\
\pm \\
0.0007\end{array}$ & $\begin{array}{l}3.06 \\
\pm \\
0.04\end{array}$ & $\begin{array}{l}3.07 \\
\pm \\
0.05\end{array}$ & $\begin{array}{l}10.57 \\
\pm \\
0.27\end{array}$ & $\begin{array}{l}12.73 \\
\pm \\
0.3\end{array}$ \\
\hline & & & & $\begin{array}{l}4.9685 \\
\pm \\
0.0006\end{array}$ & $\begin{array}{l}7.9685 \\
\pm \\
0.001\end{array}$ & $\begin{array}{l}5.7539 \\
\pm \\
0.0008\end{array}$ & $\begin{array}{l}227.81 \\
\pm \\
0.07\end{array}$ & $\begin{array}{l}0.0005 \\
\pm \\
0.0007\end{array}$ & $\begin{array}{l}3.06 \\
\pm \\
0.04\end{array}$ & $\begin{array}{l}3.07 \\
\pm \\
0.05\end{array}$ & $\begin{array}{l}10.57 \\
\pm \\
0.27\end{array}$ & $\begin{array}{l}12.73 \\
\pm \\
0.3\end{array}$ \\
\hline & & & & $\begin{array}{l}4.9682 \\
\pm \\
0.0006\end{array}$ & $\begin{array}{l}7.9687 \\
\pm \\
0.001\end{array}$ & $\begin{array}{l}5.7535 \\
\pm \\
0.0008\end{array}$ & $\begin{array}{l}227.78 \\
\pm \\
0.07\end{array}$ & $\begin{array}{l}0.0007 \\
\pm \\
0.0007\end{array}$ & $\begin{array}{l}3.06 \\
\pm \\
0.04\end{array}$ & $\begin{array}{l}3.07 \\
\pm \\
0.05\end{array}$ & $\begin{array}{l}10.57 \\
\pm \\
0.27\end{array}$ & $\begin{array}{l}12.73 \\
\pm \\
0.3\end{array}$ \\
\hline
\end{tabular}




\begin{tabular}{|c|c|c|c|c|c|c|c|c|c|c|c|c|}
\hline \multirow[t]{4}{*}{$\frac{\pi}{\stackrel{0}{0}}$} & \multirow[t]{4}{*}{ 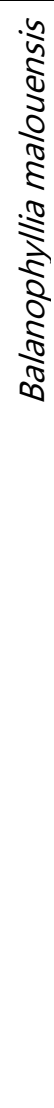 } & \multirow[t]{4}{*}{ 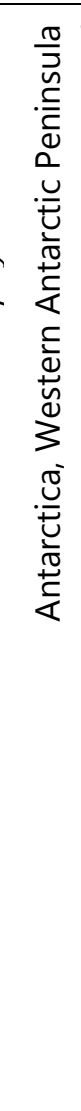 } & \multirow[t]{4}{*}{ 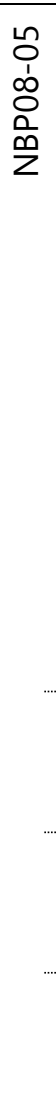 } & $\begin{array}{l}4.9636 \\
\pm \\
0.0006\end{array}$ & $\begin{array}{l}7.9686 \\
\pm \\
0.0011\end{array}$ & $\begin{array}{l}5.7494 \\
\pm \\
0.0008\end{array}$ & $\begin{array}{l}227.4 \\
\pm \\
0.07\end{array}$ & $\begin{array}{l}0.0802 \\
\pm \\
0.002\end{array}$ & $\begin{array}{l}5.7 \\
\pm \\
0.09\end{array}$ & $\begin{array}{l}5.73 \\
\pm \\
0.14\end{array}$ & $\begin{array}{l}9.19 \\
\pm \\
0.2\end{array}$ & $\begin{array}{l}16.9 \\
\pm \\
0.03\end{array}$ \\
\hline & & & & $\begin{array}{l}4.9626 \\
\pm \\
0.0007\end{array}$ & $\begin{array}{l}7.9666 \\
\pm \\
0.0012\end{array}$ & $\begin{array}{l}5.747 \\
\pm \\
0.0008\end{array}$ & $\begin{array}{l}227.21 \\
\pm \\
0.07\end{array}$ & $\begin{array}{l}0.0818 \\
\pm \\
0.0017\end{array}$ & $\begin{array}{l}5.7 \\
\pm \\
0.09\end{array}$ & $\begin{array}{l}5.73 \\
\pm \\
0.14\end{array}$ & $\begin{array}{l}9.19 \\
\pm \\
0.2\end{array}$ & $\begin{array}{l}16.9 \\
\pm \\
0.03\end{array}$ \\
\hline & & & & $\begin{array}{l}4.9701 \\
\pm \\
0.0006\end{array}$ & $\begin{array}{l}7.9747 \\
\pm \\
0.001\end{array}$ & $\begin{array}{l}5.7571 \\
\pm \\
0.0008\end{array}$ & $\begin{array}{l}228.18 \\
\pm \\
0.07\end{array}$ & $\begin{array}{l}0.0773 \\
\pm \\
0.0017\end{array}$ & $\begin{array}{l}5.7 \\
\pm \\
0.09\end{array}$ & $\begin{array}{l}5.73 \\
\pm \\
0.14\end{array}$ & $\begin{array}{l}9.19 \\
\pm \\
0.2\end{array}$ & $\begin{array}{l}16.9 \\
\pm \\
0.03\end{array}$ \\
\hline & & & & $\begin{array}{l}4.9681 \\
\pm \\
0.0007\end{array}$ & $\begin{array}{l}7.9759 \\
\pm \\
0.0012\end{array}$ & $\begin{array}{l}5.756 \\
\pm \\
0.0009\end{array}$ & $\begin{array}{l}228.09 \\
\pm \\
0.09\end{array}$ & $\begin{array}{l}0.0737 \\
\pm \\
0.0017\end{array}$ & $\begin{array}{l}5.7 \\
\pm \\
0.09\end{array}$ & $\begin{array}{l}5.73 \\
\pm \\
0.14\end{array}$ & $\begin{array}{l}9.19 \\
\pm \\
0.2\end{array}$ & $\begin{array}{l}16.9 \\
\pm \\
0.03\end{array}$ \\
\hline \multirow[t]{4}{*}{$\frac{\frac{\pi}{2}}{2}$} & \multirow[t]{4}{*}{ 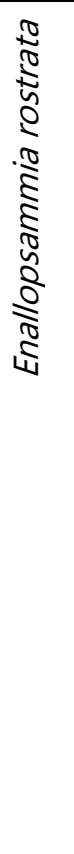 } & \multirow[t]{4}{*}{ 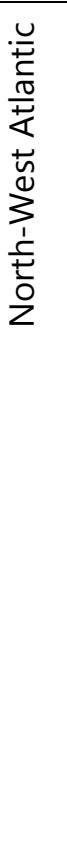 } & 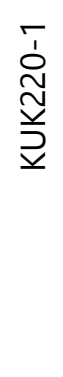 & $\begin{array}{l}4.9674 \\
\pm \\
0.0007\end{array}$ & $\begin{array}{l}7.9687 \\
\pm \\
0.0011\end{array}$ & $\begin{array}{l}5.7527 \\
\pm \\
0.0009\end{array}$ & $\begin{array}{l}227.71 \\
\pm \\
0.08\end{array}$ & $\begin{array}{l}0.002 \\
\pm \\
0.0008\end{array}$ & $\begin{array}{l}2.57 \\
\pm \\
0.03\end{array}$ & $\begin{array}{l}2.55 \\
\pm \\
0.04\end{array}$ & $\begin{array}{l}10.72 \\
\pm \\
0.3\end{array}$ & $\begin{array}{l}9.06 \\
\pm \\
0.27\end{array}$ \\
\hline & & & & $\begin{array}{l}4.9681 \\
\pm \\
0.0008\end{array}$ & $\begin{array}{l}7.9694 \\
\pm \\
0.0013\end{array}$ & $\begin{array}{l}5.7533 \\
\pm \\
0.001\end{array}$ & $\begin{array}{l}227.79 \\
\pm \\
0.09\end{array}$ & $\begin{array}{l}0.0013 \\
\pm \\
0.001\end{array}$ & $\begin{array}{l}2.57 \\
\pm \\
0.03\end{array}$ & $\begin{array}{l}2.55 \\
\pm \\
0.04\end{array}$ & $\begin{array}{l}10.72 \\
\pm \\
0.3\end{array}$ & $\begin{array}{l}9.06 \\
\pm \\
0.27\end{array}$ \\
\hline & & & & $\begin{array}{l}4.9695 \\
\pm \\
0.0008\end{array}$ & $\begin{array}{l}7.9708 \\
\pm \\
0.0013\end{array}$ & $\begin{array}{l}5.7544 \\
\pm \\
0.001\end{array}$ & $\begin{array}{l}227.94 \\
\pm \\
0.09\end{array}$ & $\begin{array}{l}0.0014 \\
\pm \\
0.002\end{array}$ & $\begin{array}{l}2.57 \\
\pm \\
0.03\end{array}$ & $\begin{array}{l}2.55 \\
\pm \\
0.04\end{array}$ & $\begin{array}{l}10.72 \\
\pm \\
0.3\end{array}$ & $\begin{array}{l}9.06 \\
\pm \\
0.27\end{array}$ \\
\hline & & & & $\begin{array}{l}4.9681 \\
\pm \\
0.0008\end{array}$ & $\begin{array}{l}7.9695 \\
\pm \\
0.0013\end{array}$ & $\begin{array}{l}5.7531 \\
\pm \\
0.001\end{array}$ & $\begin{array}{l}227.78 \\
\pm \\
0.09\end{array}$ & $\begin{array}{l}0.0014 \\
\pm \\
0.0017\end{array}$ & $\begin{array}{l}2.57 \\
\pm \\
0.03\end{array}$ & $\begin{array}{l}2.55 \\
\pm \\
0.04\end{array}$ & $\begin{array}{l}10.72 \\
\pm \\
0.3\end{array}$ & $\begin{array}{l}9.06 \\
\pm \\
0.27\end{array}$ \\
\hline
\end{tabular}




\begin{tabular}{|c|c|c|c|c|c|c|c|c|c|c|c|c|c|}
\hline \multirow[t]{4}{*}{ 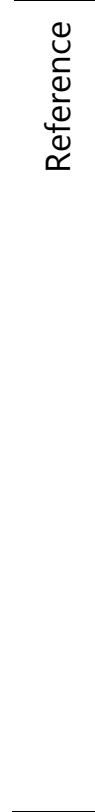 } & \multirow[t]{4}{*}{ 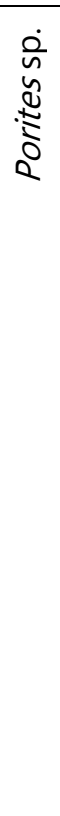 } & \multirow[t]{4}{*}{ 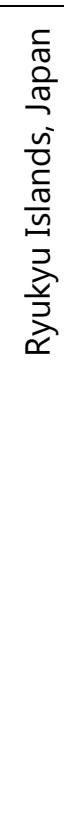 } & \multirow[t]{4}{*}{ 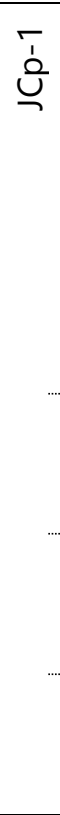 } & $\begin{array}{l}4.9661 \\
\pm \\
0.0009\end{array}$ & $\begin{array}{l}7.9744 \\
\pm \\
0.0015\end{array}$ & $\begin{array}{l}5.7513 \\
\pm \\
0.0012\end{array}$ & $\begin{array}{l}227.76 \\
\pm \\
0.11\end{array}$ & $\begin{array}{l}0.006 \\
\pm \\
0\end{array}$ & $\begin{array}{l}0.3459 \\
\pm \\
0.0026\end{array}$ & $\begin{array}{l}4.199 \\
\pm \\
0.065\end{array}$ & $\begin{array}{l}4.199 \\
\pm \\
0.065\end{array}$ & $\begin{array}{l}8.838 \\
\pm \\
0.089\end{array}$ & $\begin{array}{l}7.465 \\
\pm \\
0.655\end{array}$ \\
\hline & & & & $\begin{array}{l}4.9661 \\
\pm \\
0.0008\end{array}$ & $\begin{array}{l}7.9733 \\
\pm \\
0.0013\end{array}$ & $\begin{array}{l}5.7508 \\
\pm \\
0.001\end{array}$ & $\begin{array}{l}227.71 \\
\pm \\
0.1\end{array}$ & $\begin{array}{l}0.0072 \\
\pm \\
0.0019\end{array}$ & $\begin{array}{l}0.3393 \\
\pm \\
0.0025\end{array}$ & $\begin{array}{l}4.199 \\
\pm \\
0.065\end{array}$ & $\begin{array}{l}4.199 \\
\pm \\
0.065\end{array}$ & $\begin{array}{l}8.838 \\
\pm \\
0.089\end{array}$ & $\begin{array}{l}7.465 \\
\pm \\
0.655\end{array}$ \\
\hline & & & & $\begin{array}{l}4.9671 \\
\pm \\
0.0009\end{array}$ & $\begin{array}{l}7.9756 \\
\pm \\
0.0015\end{array}$ & $\begin{array}{l}5.7523 \\
\pm \\
0.0011\end{array}$ & $\begin{array}{l}227.88 \\
\pm \\
0.11\end{array}$ & $\begin{array}{l}0.0072 \\
\pm \\
0\end{array}$ & $\begin{array}{l}0.359 \\
\pm \\
0.003\end{array}$ & $\begin{array}{l}4.199 \\
\pm \\
0.065\end{array}$ & $\begin{array}{l}4.199 \\
\pm \\
0.065\end{array}$ & $\begin{array}{l}8.838 \\
\pm \\
0.089\end{array}$ & $\begin{array}{l}7.465 \\
\pm \\
0.655\end{array}$ \\
\hline & & & & $\begin{array}{l}4.9664 \\
\pm \\
0.0009\end{array}$ & $\begin{array}{l}7.9741 \\
\pm \\
0.0014\end{array}$ & $\begin{array}{l}5.7511 \\
\pm \\
0.0011\end{array}$ & $\begin{array}{l}227.76 \\
\pm \\
0.1\end{array}$ & $\begin{array}{l}0.0072 \\
\pm \\
0.0022\end{array}$ & $\begin{array}{l}0.367 \\
\pm \\
0.004\end{array}$ & $\begin{array}{l}4.199 \\
\pm \\
0.065\end{array}$ & $\begin{array}{l}4.199 \\
\pm \\
0.065\end{array}$ & $\begin{array}{l}8.838 \\
\pm \\
0.089\end{array}$ & $\begin{array}{l}7.465 \\
\pm \\
0.655\end{array}$ \\
\hline
\end{tabular}




\section{Chapter 4: The influence of skeleton growth parameters and internal calcifying fluid chemistry on the mineralogy and crystallography of shallow-water corals across a natural seawater $\mathrm{pH}$ gradient in Palau}




\subsection{ABSTRACT}

The material properties of minerals, such as solubility and strength, are governed by crystallography and chemistry. Thus, exploring the mineralogy and crystallography of coral skeletons may help to predict how coral skeletal health responds to unfavorable ocean acidification (OA) conditions. Bulk skeletal growth measurements (calcification rates, skeletal density) have been made on corals grown in natural and incubation OA conditions, however few studies have tied these bulk skeletal responses to crystallography. In this study we use X-ray diffraction to correlate skeletal aragonite crystallography with bulk skeletal growth properties and internal calcifying fluid chemistry using a robust dataset from a natural $\mathrm{pH}$ gradient (7.94$8.05 \mathrm{pH}$ units) in Palau. We observe a minimal anisotropic shortening of the $a$-axis of the aragonite lattice unit cell $(4.9670 \pm 0.0007 \AA$ to $4.9675 \pm 0.0009 \AA)$ and a decrease in calcite phase content $(0.53 \pm 0.33$ phase $\%$ calcite to $0.32 \pm 0.27$ phase $\%$ calcite $)$ from the higher to the lower $\mathrm{pH}$ sites in Palau. Linear regressions between crystallography and skeletal growth properties and calcite contents at both Palau sites reveal that statistically significant relationships ( $\mathrm{p}<0.05$ ) exist between decreasing $a$-axis lengths as functions of increasing skeletal density $\left(\mathrm{g} / \mathrm{cm}^{3}\right)$, increasing skeletal growth rates $(\mathrm{cm} / \mathrm{y})$, and increasing calcite contents in skeletons (phase \%). Trace element incorporations into skeletons by $\mathrm{Mg}, \mathrm{Sr}, \mathrm{Ba}$ and $\mathrm{U}$ appear to have minimal to no consistent effects on crystallography across sites. Future studies are required to determine whether the anisotropic distortions we observe in shallow-water Porites sp. along the $a$-axis as a function of skeletal growth properties would significantly influence the material properties of coral skeletons and prove detrimental to coral health, especially under OA conditions.

\subsection{INTRODUCTION}

Scleractinian "stony" corals precipitate calcium carbonate skeletons to make up the architecture of coral reef ecosystems. Global climate models for the next 80 years predict rapid rates of change towards more acidic seawater (down 0.3-0.5 pH units) (Doney et al., 2009) with associated decreases in seawater aragonite saturation states $\left(\Omega_{\mathrm{sw}}\right)$ even falling below saturation $\left(\Omega_{\mathrm{sw}}<1\right)$ in some areas of the ocean, especially at depth. Since corals precipitate their skeletons from aragonite (a polymorph of calcium carbonate), shifts in the ocean carbonate system towards lower $\mathrm{pH}$ and lower aragonite saturation states are expected to adversely impact the health of coral skeletons (Chan and Connolly, 2013).

Field observations of corals in low seawater aragonite saturation states reveal variability in skeletal responses to these non-ideal environments, ranging from deep sea corals which appear to calcify normally in aragonite undersaturated conditions, to individuals in the same study which appear to completely crumble upon collection (Rodolfo-Metalpa et al., 2015). In these dynamic natural systems, the continued calcification of corals may be aided by the dissolution of surrounding dead coral mounds, leading to a negative net calcification of the overall reef (Hofmann et al., 2010; Lunden et al., 2013). In shallow environments it is less likely that conditions reach aragonite under-saturation, yet calcification may still be affected by ocean acidification and its negative effects may be exacerbated by other factors such as increased sea 
surface temperatures (Rodolfo-Metalpa et al., 2015; Foster et al., 2016) and an increase in skeletal boring from other organisms (DeCarlo et al., 2015).

Due to the complex dynamics and many variables in natural systems, incubation studies have attempted to single out the effects of ocean acidification on coral skeletal health by growing corals in low seawater $\mathrm{pH}$ and aragonite saturation states versus control conditions. These studies report variable responses to ocean acidification conditions, depending on coral species (traditionally "hardy" versus "fragile," shallow versus deep-sea coral species), coral age (juvenile versus adults), length of the experiment (weeks to years), and the addition of other variables (temperature, light) (i.e., Cohen et al., 2009; Foster et al., 2016; Hennige et al., 2015; Rodolfo-Metalpa et al., 2015). In very aragonite undersaturated waters, juvenile recruits precipitate highly deformed skeletons with noticeably different aragonite crystal habits (blocky, versus normal acicular needles) (Cohen et al., 2009). These effects are exacerbated under increased temperatures (Foster et al., 2016). In longer, year-long incubations of adult corals, no statistically significant differences were observed in terms of calcification or dissolution rates in deep-sea corals (Rodolfo-Metalpa et al., 2015). However, Hennige et al., (2015) still observed changes in aragonite micro-scale crystallite disorder within deep-sea corals precipitated in nonideal conditions for one year, despite the corals appearing to grow normally on the macro-scale.

Most coral calcification studies agree that corals have the ability to significantly raise their internal calcifying fluid chemistry to compensate for unfavorable low aragonite saturation conditions of surrounding seawater. This is accomplished by organismal homeostasis and elevated energy consumption by the coral, such as via increased heterotrophic feeding in shallow corals (Drenkard et al., 2013). Even in ideal ocean environments, shallow corals spend approximately $30 \%$ of their energy budget on calcification (Allemand et al., 2011), elevate their internal calcifying fluid $\mathrm{pH}\left(\mathrm{pH}_{\mathrm{cf}}\right)$ 0.6-0.8 $\mathrm{pH}$ units above seawater (McCulloch et al., 2012), and increase their calcifying fluid aragonite saturation state $\left(\Omega_{\mathrm{cf}}\right)\left(\Omega_{\mathrm{cf}} \sim 10.8-13.7\right.$ via Raman spectroscopy measurements, DeCarlo et al., 2017; $\Omega_{\mathrm{cf}} \sim 15-25$ via $\delta^{11 / 10} \mathrm{~B}$ measurements, McCulloch et al., 2012; McCulloch et al., 2017) in order to precipitate skeletal aragonite. In this study we assume a geochemically-driven mode of biomineralization based on the morphological, crystallographic, bonding-environment, and geochemical similarities between coral aragonite and synthetic aragonites precipitated from seawater (DeCarlo et al., 2018; Holcomb et al., 2009).

While many studies have explored the relationship between ocean acidification conditions and bulk skeletal properties such as calcification rate, dissolution rate, and strength, (van Woesik et al., 2013; Rodolfo-Metalpa et al., 2015) few studies have correlated seawater and growth conditions with skeletal morphology, mineralogy and crystallography (Hennige et al., 2015; Tambutté et al., 2015). Recently, DeCarlo et al., (2017) observed an increase in disorder in the Raman $v_{1}$ symmetric stretching mode of the carbonate group in skeletal aragonite with increasing coral $\Omega_{\mathrm{cf}}$, indicating that there may be traceable shifts in skeletal crystallography as a function of environment and growth conditions. In chapter 3 we describe the use of X-ray diffraction to trace the mineralogy of deep-sea corals under a range of surrounding $\Omega_{\text {sw }}$ and observed anisotropic crystallographic trends with $\Omega_{\mathrm{sw}}$ and calcite content (Farfan et al., in review). However, in chapter 3 we only had data on surrounding seawater conditions, not $\Omega_{\mathrm{cf}}$ or $\mathrm{pH}_{\mathrm{cf}}$. In this study we explore the mineralogy and crystal lattice parameters of shallow Porites sp. corals from a natural $\mathrm{pH}$ gradient in Palau with samples that have already been described in detail in Mollica et al., 2018. By utilizing the Mollica et al., (2018) dataset, we have access to both external seawater conditions as well as $\Omega_{\mathrm{cf}}$ and $\mathrm{pH}_{\mathrm{cf}}$ values calculated via $\delta^{11 / 10} \mathrm{~B}$ isotope measurements, skeletal growth rates, and skeletal densities to correlate with our mineralogical 
and crystallographic findings. This comparison will allow for a better understanding of how coral calcification dynamics are manifested in skeletal mineralogy and crystallography.

\subsection{MATERIALS AND METHODS}

\subsubsection{Samples and sample treatments}

Cores of Porites sp. were drilled along a natural seawater $\mathrm{pH}\left(\mathrm{pH}_{\mathrm{sw}}\right)$ gradient in Palau from Nikko Bay $\left(\mathrm{pH}_{\mathrm{sw}}=7.84 \mathrm{pH}\right.$ units, $\left.\Omega_{\mathrm{sw}}=2.3\right)$ to the off-shore Dropoff site $\left(\mathrm{pH}_{\mathrm{sw}}=8.05 \mathrm{pH}\right.$ units, $\Omega_{\mathrm{sw}}=3.7$ ) (Figure 4.1). Cores were sub-sampled every 1-2 mm down-core using a miniature diamond drill to create $\sim 1 \mathrm{mg}$ of powder per sample. The coring process and sub-samples are described in detail in Mollica et al., (2018) with the samples utilized in this study only representing sections of the core from the year 2008 and are presented in Table 4.1 along with their seawater and internal calcifying fluid conditions.

All samples were treated with bleach to remove any excess tissue or potential crystal scaffolding organic material using a procedure modified from Gaffey and Bronnimann (1993) and Politi et al., (2006) and described in detail in Chapter 3, "Coral skeleton sampling and removal of organics."

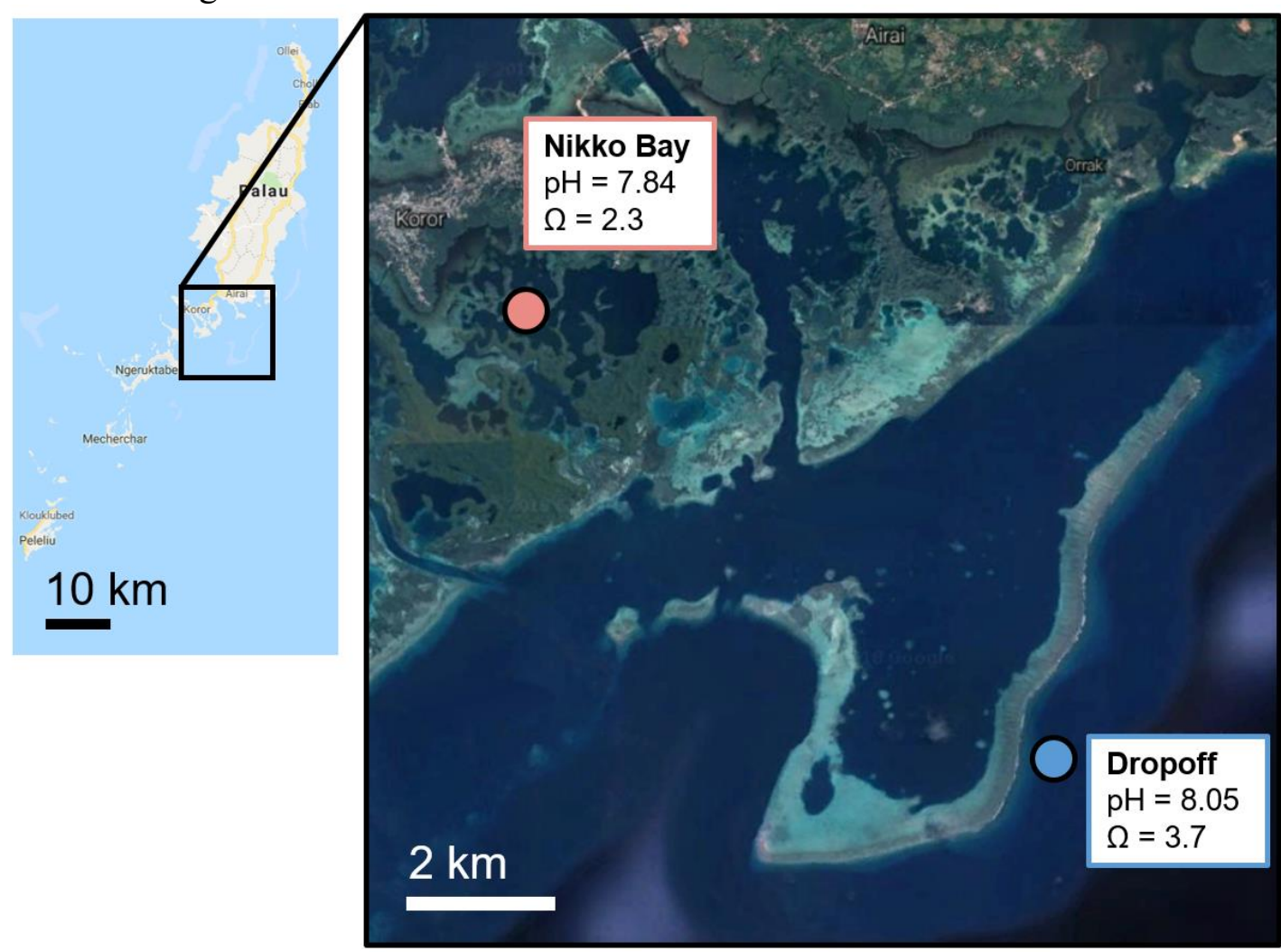

FIGURE 4.1. Sample localities in Palau with a gradient from low $\mathrm{pH}_{\mathrm{sw}}$ and $\Omega_{\mathrm{sw}}$ (Nikko Bay, red dot) to more typical seawater with higher $\mathrm{pH}_{\mathrm{sw}}$ and $\Omega_{\mathrm{sw}}$ conditions (Dropoff, blue dot). Map images are taken from Google maps and Google Earth. 
TABLE 4.1. Porites sp. sub-samples used in this study from coral cores from Palau Dropoff and Nikko Bay sites. Seawater chemistry and internal calcifying fluid chemistry are from Mollica et al., 2018.

\begin{tabular}{|c|c|c|c|c|c|c|c|c|}
\hline$\frac{0}{\frac{0}{0}}$ & 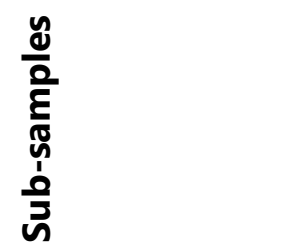 & 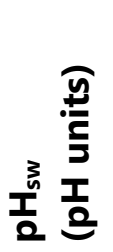 & G & $\begin{array}{r}\frac{5}{\frac{5}{5}} \\
\frac{5}{5} \\
\text { I } \\
\frac{x}{2}\end{array}$ & $\stackrel{\breve{c}}{G}$ & 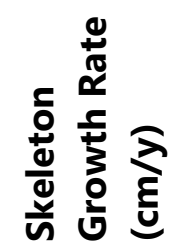 & 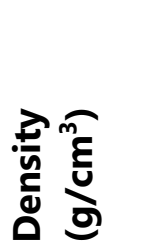 & $\stackrel{\Xi}{J}$ \\
\hline Nikko & & & & & & $0.61 \pm$ & & \\
\hline \multirow[t]{7}{*}{ Bay 168} & Nikko168_29 & 7.84 & 2.3 & $8.33 \pm 0.01$ & $13.2 \pm 0.4$ & 0.06 & 1.19 & 1.03 \\
\hline & Nikko168_31 & 7.84 & 2.3 & $8.34 \pm 0.01$ & $13.7 \pm 0.4$ & $\begin{array}{l}0.72 \pm \\
0.08\end{array}$ & 1.21 & 0.98 \\
\hline & Nikko168_33 & 7.84 & 2.3 & $8.36 \pm 0.02$ & $14.1 \pm 0.5$ & $\begin{array}{l}0.76 \pm \\
0.08\end{array}$ & 1.24 & 1 \\
\hline & Nikko168_35 & 7.84 & 2.3 & $8.36 \pm 0.01$ & $13.8 \pm 0.4$ & $\begin{array}{l}0.63 \pm \\
0.07\end{array}$ & 1.2 & 0.98 \\
\hline & Nikko168_37 & 7.84 & 2.3 & $8.36 \pm 0.01$ & $13.5 \pm 0.5$ & $\begin{array}{l}0.58 \pm \\
0.06\end{array}$ & 1.19 & 0.99 \\
\hline & Nikko168_39 & 7.84 & 2.3 & $8.39 \pm 0.01$ & $14 \pm 0.5$ & $\begin{array}{l}0.56 \pm \\
0.06\end{array}$ & 1.2 & 0.99 \\
\hline & Nikko168_41 & 7.84 & 2.3 & $8.39 \pm 0.01$ & $14.2 \pm 0.5$ & $\begin{array}{l}0.63 \pm \\
0.07 \\
\end{array}$ & 1.18 & 0.98 \\
\hline Nikko & & & & & & $0.71 \pm$ & & \\
\hline \multirow[t]{8}{*}{ Bay 169} & Nikko169_75 & 7.84 & 2.3 & $8.34 \pm 0.02$ & $13.7 \pm 0.5$ & 0.08 & 0.99 & 1.06 \\
\hline & Nikko169_76 & 7.84 & 2.3 & $8.35 \pm 0.02$ & $13.7 \pm 0.5$ & $\begin{array}{l}0.72 \pm \\
0.08\end{array}$ & 1.04 & 1.06 \\
\hline & Nikko169_77 & 7.84 & 2.3 & $8.35 \pm 0.01$ & $13.8 \pm 0.5$ & $\begin{array}{l}0.7 \pm \\
0.08\end{array}$ & 1.12 & 1.08 \\
\hline & Nikko169_78 & 7.84 & 2.3 & $8.36 \pm 0.02$ & $13.5 \pm 0.5$ & $\begin{array}{l}0.59 \pm \\
0.06\end{array}$ & 1.15 & 1.06 \\
\hline & Nikko169_79 & 7.84 & 2.3 & $8.36 \pm 0.01$ & $13.6 \pm 0.4$ & $\begin{array}{l}0.6 \pm \\
0.06\end{array}$ & 1.14 & 1.02 \\
\hline & Nikko169_80 & 7.84 & 2.3 & $8.37 \pm 0.01$ & $13.6 \pm 0.5$ & $\begin{array}{l}0.55 \pm \\
0.06\end{array}$ & 1.1 & 1 \\
\hline & Nikko169_81 & 7.84 & 2.3 & $8.35 \pm 0.01$ & $13.1 \pm 0.4$ & $\begin{array}{l}0.48 \pm \\
0.05\end{array}$ & 1.05 & 1.02 \\
\hline & Nikko169_82 & 7.84 & 2.3 & $8.36 \pm 0.01$ & $13.6 \pm 0.4$ & $\begin{array}{l}0.58 \pm \\
0.06\end{array}$ & 0 & 1.01 \\
\hline \multirow{3}{*}{$\begin{array}{l}\text { Dropoff } \\
221\end{array}$} & & & & & & $0.8 \pm$ & & \\
\hline & Dropoff221_118 & 8.05 & 3.7 & $8.45 \pm 0.02$ & $16.5 \pm 0.6$ & 0.09 & 1.48 & 1 \\
\hline & Dropoff221_120 & 8.05 & 3.7 & $8.43 \pm 0.02$ & $16.2 \pm 0.5$ & $\begin{array}{l}0.84 \pm \\
0.09\end{array}$ & 1.52 & 0.98 \\
\hline
\end{tabular}




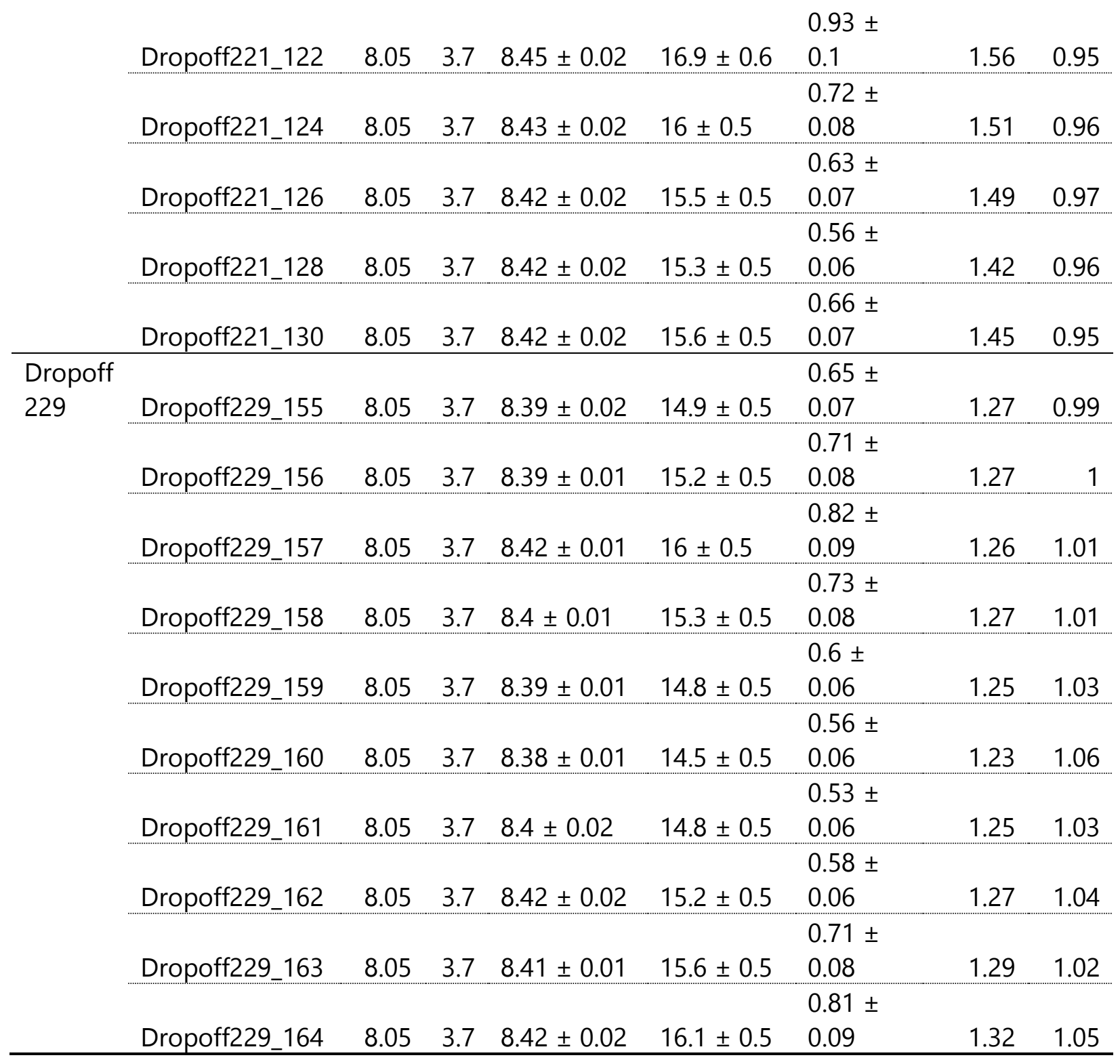

\subsubsection{Instrumentation}

\subsubsection{X-ray diffraction}

Powder X-ray diffraction measurements were conducted on a Rigaku D/MAX Rapid II micro X-ray diffractometer with a 2D imaging plate detector (Hansel Lab, Woods Hole Oceanographic Institution) using Mo K $\alpha$ radiation $(\lambda=0.709300 \AA)$. Samples were aligned and run for 10 minutes with omega fixed at $0^{\circ}$ and phi rotating at 1 degree per second. Four sample replicates were run for each sample. All samples were gently ground in an agate mortar and pestle and mounted on Kapton tips by MiTeGen by using a very thin layer of mineral oil on the tips. XRD image files were background corrected (manual setting= 5) and integrated into 
intensity versus $2 \theta$ patterns from 3.0 to $45.02 \theta$ degrees and 81.6337 to $430.00 \beta$ using $2 \mathrm{DP}$ software. Full width at half maximum (FWHM) measurements were performed on the main (111) peak of the coral aragonite diffraction pattern using PDXL 2 Rigaku software by referencing Caspi et al., (2005) for aragonite and Swanson and Fuyat (1953) for calcite.

\subsubsection{Rietveld analysis and statistics}

We performed quantitative full-pattern Rietveld refinement fitting using GSASII program (Toby and Von Dreele, 2013) as described by Bish and Post (1993). We fit XRD patterns from from 8 to $442 \theta$ degrees using a Chebyschev polynomial background and aragonite (Antao and Hassan, 2009) and calcite (Markgaf and Reeder, 1985) model structures.

A synthetic aragonite reference was used for calibration and refinement of the numbers obtained in Rietveld analysis in response to the specific alignment of the XRD. All Rietveld results are shifted by: $a$-axis $=-0.003375 \AA, b$-axis $=-0.012724 \AA, c$-axis $=-0.005675 \AA$, and volume $=-0.7435 \AA^{3}$, leading to corresponding results between the XRD instrument at WHOI and an equivalent instrument in the Department of Mineral Sciences, Smithsonian Institution. Since shifts were applied to all samples, the shifts did not affect the relative differences between samples. Errors in Rietveld refinements are represented as estimated standard deviations and exceed standard deviations between sample replicates.

Linear regressions were run on crystal lattice parameters and mineralogy versus calcifying fluid chemistry, seawater conditions, and other growth conditions. After testing normality of residuals and homogeneity of variances for sample parameters using KolmogorovSmirnov and Levene's tests, respectively, we ran T-tests on crystallography and growth parameters between the two sample sites.

\subsubsection{Inductively-coupled mass spectroscopy (ICP-MS)}

Incorporations of $\mathrm{Mg}, \mathrm{Sr}$, and Ba were measured using an iCAP ICP-MS (WHOI). Powders were digested in 5\% trace metal grade nitric acid (J.T. Baker ULTREX® II Ultrapure Reagent) in Milli-Q water in trace metal-cleaned $15 \mathrm{~mL}$ Falcon centrifuge tubes. To account for matrix effects, element concentrations were reported as ratios of trace-incorporation metals to $\mathrm{Ca}$ calculated based on known ratios in the JCp-1 reference Porites sp. coral (Hathorne et al, 2013) measured alongside the samples in this study. $\mathrm{Mg}$ ratios were calculated using both ${ }^{24} \mathrm{Mg}$ and

${ }^{25} \mathrm{Mg}$ measurements, while Sr ratios were measured using ${ }^{88} \mathrm{Sr}$ and $\mathrm{Ba}$ was measured using ${ }^{138} \mathrm{Ba}$. $\mathrm{U} / \mathrm{Ca}$ ratios were also previously measured by Mollica et al., 2018 and are included in this study as well.

\subsection{RESULTS}

Skeletal growth parameters, mineralogy and crystallography, and trace element incorporations are plotted alongside each other as down-core transects of skeletal growth across the year 2008 
for all 32 sub-samples of coral skeleton taken from four cores (Dropoff 221, Dropoff 229, Nikko Bay 168, Nikko Bay 169) from the two sample sites (Dropoff and Nikko Bay) in Figure 4.2. Figure 4.2 highlights the variability (or lack thereof) in each of these measurements within a single core. For the mineralogy and crystallography measurements, each point represents the mean of four sample replicates and the error bars represent estimated standard deviations with errors propagated from all four replicates. Averaged XED patterns for each coral sample, used to calculate calculate lattice parameters, are plotted in the Supplementary Materials, Figure S4.1. All individual data points may be referenced in the Supplementary Materials, Table S4.1. Skeletal growth parameters $\left(\mathrm{pH}_{\mathrm{cf}}, \Omega_{\mathrm{cf}}\right.$, skeletal growth rate, and density) as well as U/Ca ratios were measured by Mollica et al., 2018 and denoted with an asterisk in Figure 4.2 and Table 4.2.

We ran two-tailed T-tests to compare each of these variables between the two sites to reveal that there are statistically significant shifts $(\mathrm{p}<0.05)$ in $\mathrm{pH}_{\mathrm{cf}}, \Omega_{\mathrm{cf}}$, and density between the Nikko Bay and Dropoff sites (Table 4.2). In contrast, the only crystallographic parameter that is statistically distinct between sites is the unit cell $a$-axis length, which is significantly longer on average at the Nikko Bay site (mean $=4.9675 \AA$, standard deviation= $0.0009 \AA$ ) compared to the Dropoff site (mean $=4.9670 \AA$, standard deviation $=0.0007 \AA$ ) by an equal variance T-test: $\mathrm{t}(126)=1.979, \mathrm{p}=0.00024$. Calcite contents are also significantly higher at Dropoff $(\mathrm{mean}=0.53$ phase $\%$ calcite, standard deviation $=0.33$ phase $\%$ calcite) than Nikko Bay (mean $=0.32$ phase $\%$ calcite, standard deviation $=0.27$ phase $\%$ calcite) as determined by an equal variance t-test $(\mathrm{t}(126)=1.979, \mathrm{p}=0.00028)($ Table 4.2).

\subsubsection{Crystallography at Dropoff}

From the down core profiles in Figure 4.2, we observe that some crystallographic parameters appear to follow the patterns in skeletal growth parameters, thus, we ran linear regressions to determine which of these relationships is statistically significant ( $\mathrm{p}<0.05$, black trend lines) (Figure 4.3). A-axes are most sensitive to changes in skeletal growth parameters with a minor, yet statistically significant decrease in $a$-axis length $(\sim 0.002 \AA)$ as a function of increasing $\mathrm{pH}_{\text {cf }}$ $\left(\mathrm{R}^{2}=0.108\right), \Omega_{\mathrm{cf}}\left(\mathrm{R}^{2}=0.125\right)$, skeletal growth rate $\left(\mathrm{R}^{2}=0.083\right)$, and density $\left(\mathrm{R}^{2}=0.235\right)$. $B$-axis length increases as a function of $\Omega_{c f}\left(R^{2}=0.288\right)$, skeletal growth rate $\left(R^{2}=0.278\right)$, and density $\left(\mathrm{R}^{2}=0.099\right)$ and $c$-axis length increases with faster skeletal growth rate $\left(\mathrm{R}^{2}=0.060\right)$. The resulting unit cell volume only increases as a function of increasing $\Omega_{\mathrm{cf}}\left(\mathrm{R}^{2}=0.070\right)$ and skeletal growth rate $\left(\mathrm{R}^{2}=0.104\right.$, Figure 4.3$)$. All other relationships between unit cell lattice parameters as a function of growth parameters are plotted in the Supplementary Materials, Figure S4.2. FWHM of the (111) peak did not correlate significantly with any skeletal growth parameters.

\subsubsection{Calcite contents at Dropoff}

XRD patterns of coral aragonite samples from the Dropoff site show calcite contributions by the presence of the (104) main calcite peak, as highlighted with a red arrow in Figure 4.4A. By plotting crystal lattice parameters versus calcite contents, we observe modest yet statistically significant relationships between a shortening of the $a$-axis length and an increase in calcite content $\left(\mathrm{p}=0.00033, \mathrm{R}^{2}=0.178\right)$, as well as a lengthening along the $b$-axis with increasing calcite content $\left(\mathrm{p}=0.00077, \mathrm{R}^{2}=0.159\right)$ (Figure 4.4B). 


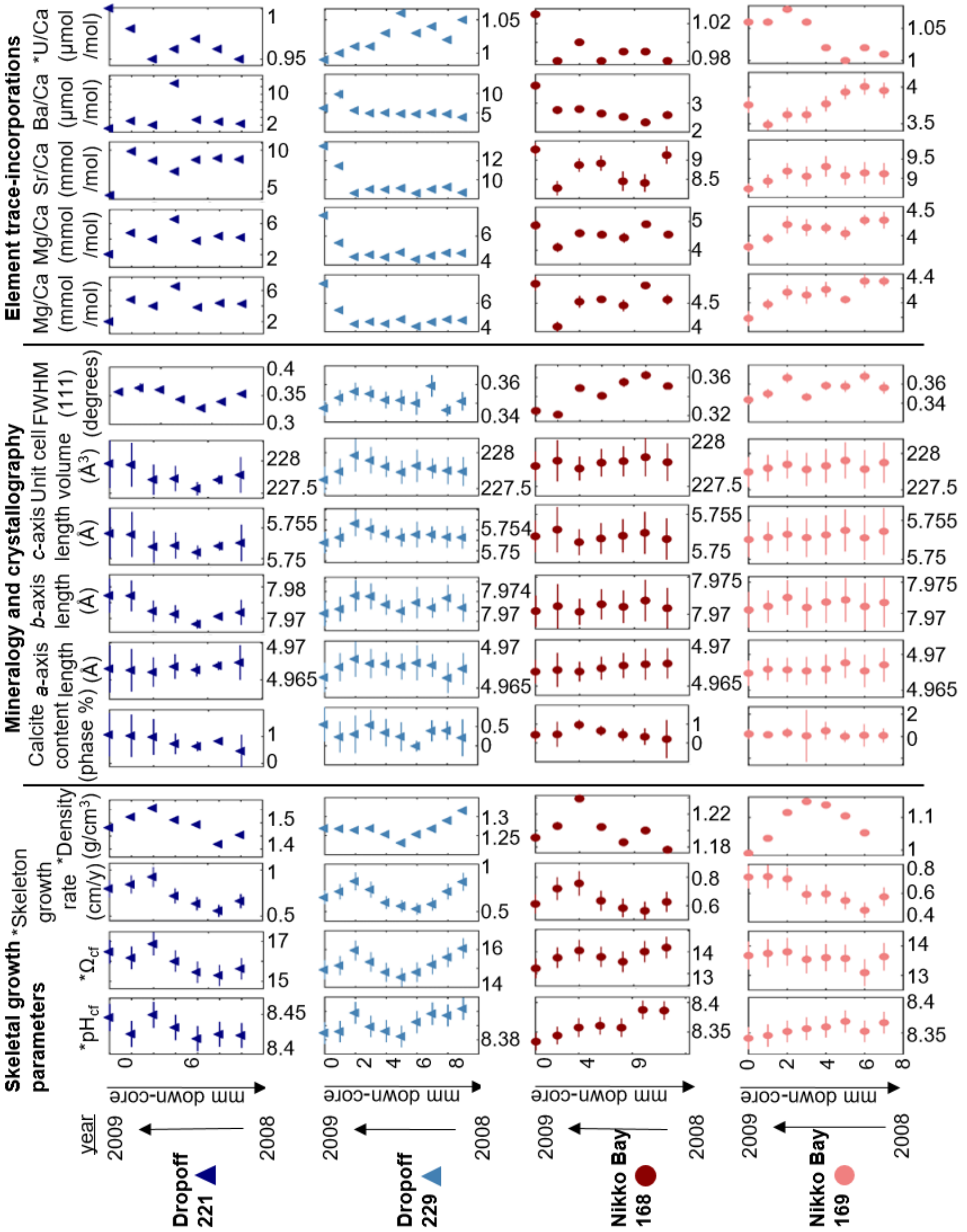

FIGURE 4.2. Down core profiles of skeleton growth parameters, crystallography and trace element incorporations in all four coral cores from Dropoff and Nikko Bay sites. 
TABLE 4.2. Equal-variance T-tests of skeleton growth parameters, mineralogy and crystallography, and trace element incorporations between Dropoff and Nikko Bay populations. Statistically distinct populations are in bold $(\mathrm{p}<0.05)$.

\begin{tabular}{|c|c|c|c|c|c|}
\hline & & $\begin{array}{l}\text { Nikko Bay } \\
\text { (mean } \pm \\
\text { standard } \\
\text { deviation) }\end{array}$ & $\begin{array}{l}\text { Dropoff } \\
\text { (mean } \pm \\
\text { standard } \\
\text { deviation) }\end{array}$ & $\begin{array}{l}\text { T-test } \\
\text { t(df) = } \\
\text { t Critical } \\
\text { two-tail }\end{array}$ & $\mathbf{p}$ \\
\hline \multirow[t]{4}{*}{$\begin{array}{l}\text { Growth } \\
\text { parameters }\end{array}$} & $\begin{array}{l}\mathrm{pH}_{\mathrm{cf}}(\mathrm{pH} \\
\text { units })\end{array}$ & $8.358 \pm 0.014$ & $8.414 \pm 0.02$ & $t(30)=2.042$ & $1.78 \mathrm{E}-11$ \\
\hline & $\Omega_{\mathrm{cf}}$ & $13.68 \pm 0.27$ & $15.5 \pm 0.6$ & $t(30)=2.042$ & 2.07E-10 \\
\hline & $\begin{array}{l}\text { skeletal } \\
\text { growth rate } \\
(\mathrm{cm} / \mathrm{y})\end{array}$ & $0.63 \pm 0.07$ & $0.69 \pm 0.12$ & $t(30)=2.042$ & 0.06 \\
\hline & $\begin{array}{l}\text { density } \\
\left(\mathrm{g} / \mathrm{cm}^{3}\right)\end{array}$ & $1.14 \pm 0.07$ & $1.37 \pm 0.12$ & $t(29)=2.045$ & 1.51E-06 \\
\hline \multirow[t]{5}{*}{$\begin{array}{l}\text { mineralogy and } \\
\text { crystallography }\end{array}$} & $\begin{array}{l}\text { calcite } \\
\text { content } \\
\text { a-axis } \\
\text { length }(\AA)\end{array}$ & $\begin{array}{l}0.32 \pm 0.27 \\
4.9675 \pm \\
0.0009\end{array}$ & $\begin{array}{l}0.53 \pm 0.33 \\
4.967 \pm \\
0.0007\end{array}$ & $\begin{array}{l}t(126)=1.979 \\
t(126)=1.979\end{array}$ & $\begin{array}{l}0.00028 \\
0.00024 \\
\end{array}$ \\
\hline & $\begin{array}{l}\text { b-axis } \\
\text { length }(\AA)\end{array}$ & $\begin{array}{l}7.9712 \pm \\
0.0012\end{array}$ & $\begin{array}{l}7.9719 \pm \\
0.0024\end{array}$ & $t(126)=1.979$ & 0.0609 \\
\hline & $\begin{array}{l}\text { c-axis } \\
\text { length }(\AA)\end{array}$ & $\begin{array}{l}5.7529 \pm \\
0.0008\end{array}$ & $\begin{array}{l}5.7529 \pm \\
0.0012\end{array}$ & $t(126)=1.979$ & 0.77647 \\
\hline & $\begin{array}{l}\text { unit cell } \\
\text { volume }\left(\AA^{3}\right)\end{array}$ & $227.79 \pm 0.1$ & $227.78 \pm 0.13$ & $t(126)=1.979$ & 0.66725 \\
\hline & $\begin{array}{l}\text { FWHM (111) } \\
\text { peak } \\
\text { (degrees) }\end{array}$ & $0.35 \pm 0.013$ & $0.351 \pm 0.008$ & $t(126)=1.979$ & 0.63542 \\
\hline \multirow[t]{5}{*}{$\begin{array}{l}\text { trace element } \\
\text { incorporations }\end{array}$} & $\begin{array}{l}\mathrm{Mg} / \mathrm{Ca} \text { by } \\
{ }^{24} \mathrm{Mg}\end{array}$ & $4.31 \pm 0.3$ & $4.7 \pm 1.2$ & $t(30)=2.042$ & 0.2 \\
\hline & $\begin{array}{l}\mathrm{Mg} / \mathrm{Ca} \text { by } \\
{ }^{25} \mathrm{Mg}\end{array}$ & $4.32 \pm 0.31$ & $4.7 \pm 1.2$ & $t(30)=2.042$ & 0.21 \\
\hline & $\begin{array}{l}\mathrm{Sr} / \mathrm{Ca} \text { by } \\
{ }^{88} \mathrm{Sr}\end{array}$ & $8.92 \pm 0.31$ & $9.051 \pm 1.818$ & $t(30)=2.042$ & 1 \\
\hline & $\begin{array}{l}\mathrm{Ba} / \mathrm{Ca} \text { by } \\
{ }^{138} \mathrm{Ba}\end{array}$ & $3.3 \pm 0.6$ & $4.9 \pm 2.9$ & $t(30)=2.042$ & 0.05 \\
\hline & $\mathrm{U} / \mathrm{Ca}$ & $1.02 \pm 0.03$ & $0.996 \pm 0.033$ & $t(30)=2.042$ & 0.18 \\
\hline
\end{tabular}




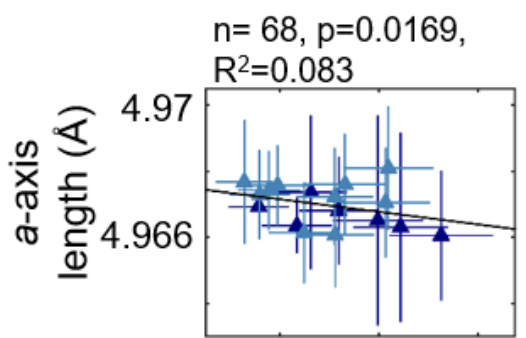

$\mathrm{n}=68, \mathrm{p}=3.8 \mathrm{E}-6$, $\mathrm{R}^{2}=0.278$

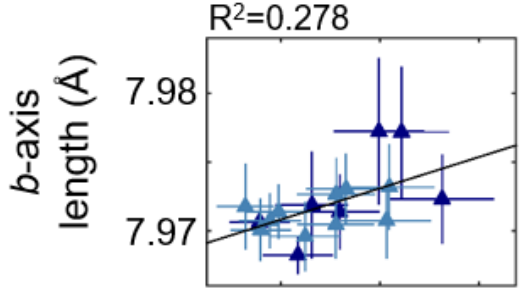

$\mathrm{n}=68, \mathrm{p}=0.0432$,

$\mathrm{R}^{2}=0.060$

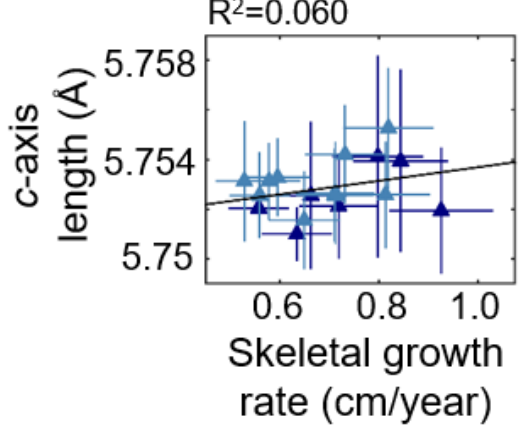

$\mathrm{n}=60, \mathrm{p}=2.7 \mathrm{E}-5$,

$R^{2}=0.235$

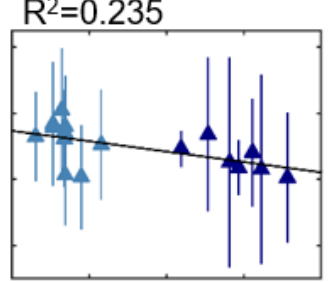

$\mathrm{n}=68, \mathrm{p}=0.0091$,

$\mathrm{R}^{2}=0.099$

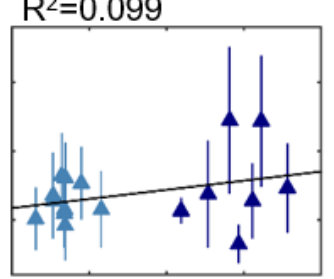

$\begin{array}{lll}1.3 & 1.4 & 1.5\end{array}$

Density $\left(\mathrm{g} / \mathrm{cm}^{3}\right)$

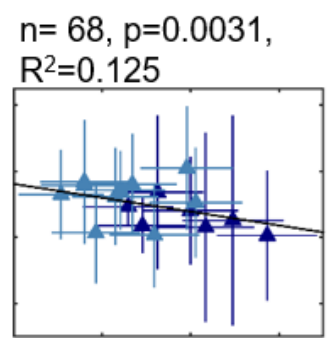

$\mathrm{n}=68, \mathrm{p}=2.4 \mathrm{E}-6$,

$\mathrm{R}^{2}=0.288$

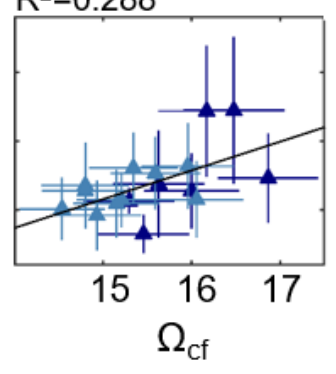

$\mathrm{n}=68, \mathrm{p}=0.0062$,

$R^{2}=0.108$

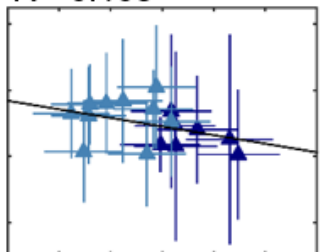

$\begin{array}{lll}8.4 & 8.44 & 8.48\end{array}$

$\mathrm{pH}_{\mathrm{cf}}$ (pH units)

A Dropoff 221

Dropoff 229

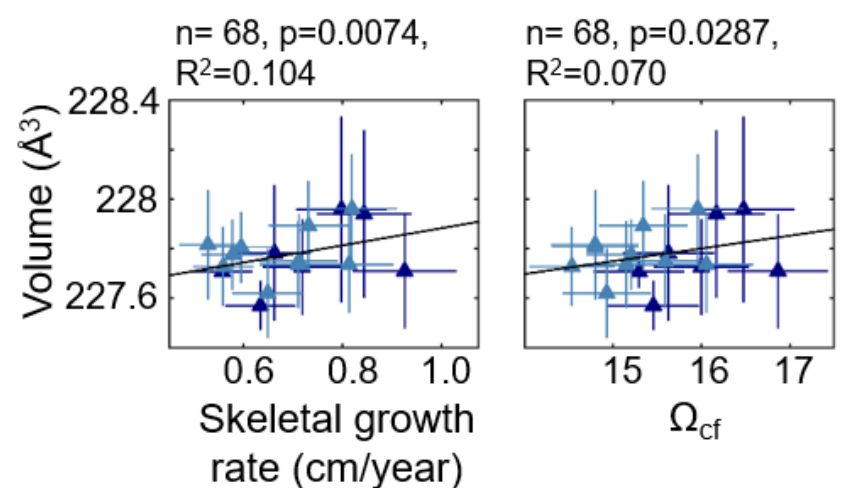

FIGURE 4.3. Skeletal aragonite mineralogical parameters in samples from the Dropoff site as a function of skeleton growth conditions: calcifying fluid $\mathrm{pH}\left(\mathrm{pH}_{\mathrm{cf}}\right)$, calcifying fluid aragonite saturation state $\left(\Omega_{\mathrm{cf}}\right)$, skeletal growth rate, and skeletal density. Linear regression trend lines are included for statistically significant relationships $(\mathrm{p}<0.05)$. 


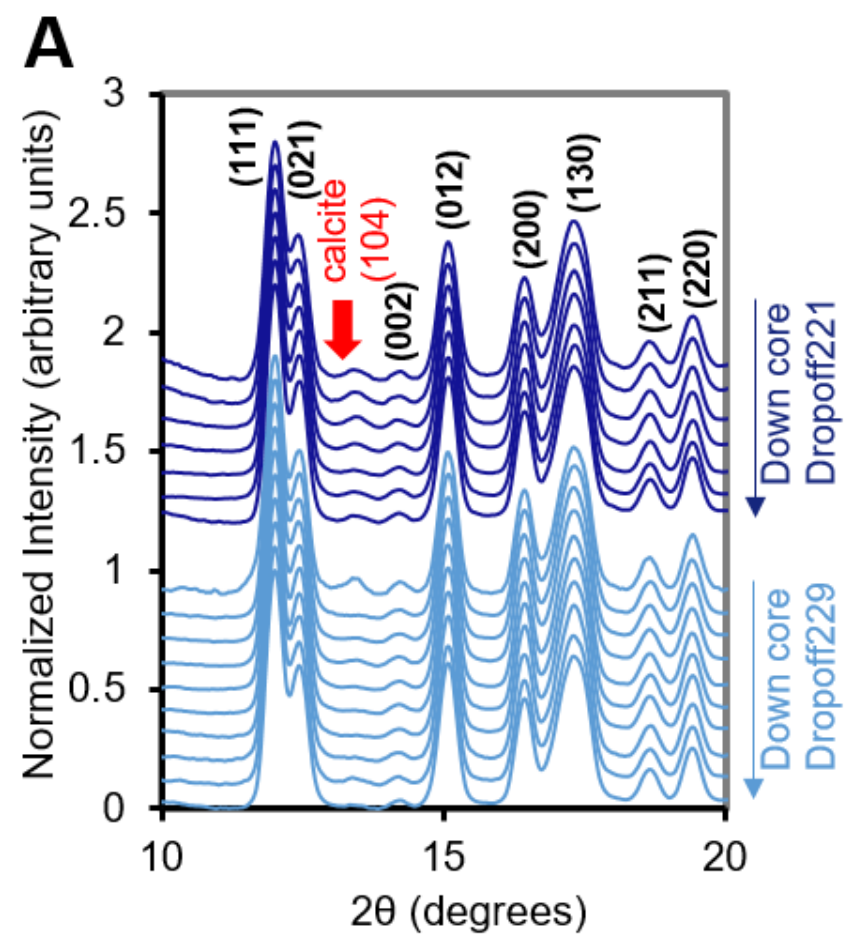

B
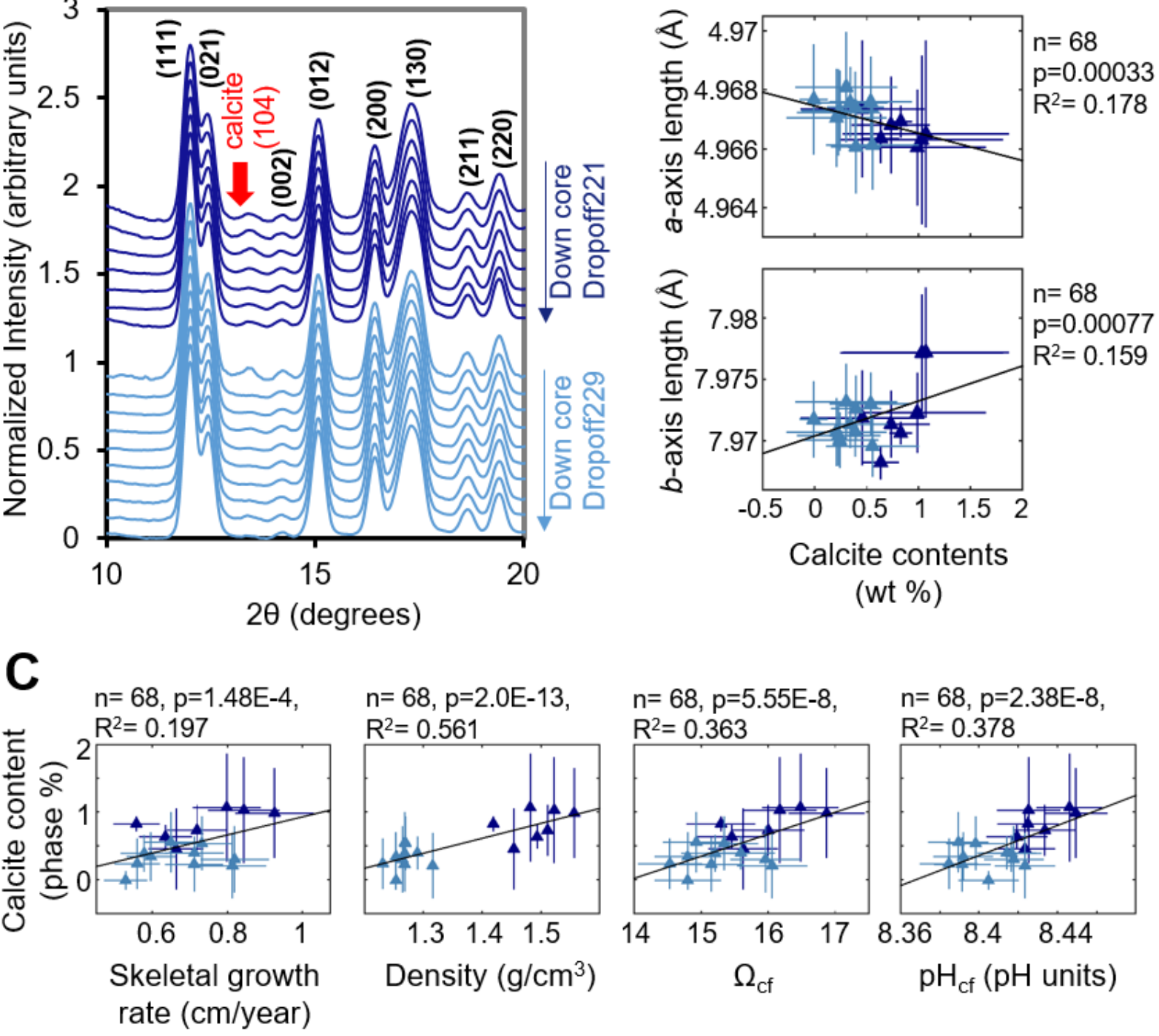

\section{$\Delta$ Dropoff 221 \\ Dropoff 229}

FIGURE 4.4. Calcite contents in skeletons from the Dropoff sites (Dark blue = Dropoff 221 core, Light blue $=$ Dropoff 229 core). A) X-ray diffraction patterns of samples down cores with the presence of a (104) main calcite peak, highlighted in red. B) Aragonite mineralogical parameters as a function of skeletal calcite contents (expressed as phase percentages) calculated via whole-pattern Rietveld analysis of the XRD patterns in part A. C) Calcite contents in Dropoff skeletons as a function of skeleton growth parameters. Black trend lines are included for statistically significant relationships $(\mathrm{p}<0.05)$ calculated from linear regressions. 
Since calcite contents are not constant or distributed in a linear fashion with time as indicated in our down core plots (Figure 4.2), we have also plotted calcite contents as a function of skeletal growth variables (Figure 4.4C), where we observe significant relationships of increasing calcite with an increase in all four skeletal growth variables: skeletal growth rate $\left(\mathrm{p}=1.48 \times 10^{-4}, \mathrm{R}^{2}=\right.$ $0.197)$, density $\left(\mathrm{p}=2.0 \times 10^{-13}, \mathrm{R}^{2}=0.561\right), \Omega_{\mathrm{cf}}\left(\mathrm{p}=5.55 \times 10^{-8}, \mathrm{R}^{2}=0.363\right)$, and $\mathrm{pH}_{\mathrm{cf}}$ $\left(\mathrm{p}=2.38 \times 10^{-8}, \mathrm{R}^{2}=0.378\right)$.

\subsubsection{Trace element incorporations at Dropoff}

Linear regressions of trace-incorporations of elements into Dropoff skeletons versus skeleton growth parameters show significant relationships of lower concentrations (as metal/Ca ratios) of $\mathrm{Mg}\left(\mathrm{R}^{2}=0.242,239\right), \mathrm{Sr}\left(\mathrm{R}^{2}=0.402\right)$ and $\mathrm{U}\left(\mathrm{R}^{2}=0.295\right)$ as a function of increasing $\mathrm{pH}_{\mathrm{cf}}$, as well as lower $U$ concentrations as a function of increasing density (Figure 4.5). All other statistically insignificant relationships between trace element incorporations as a function of growth parameters are plotted in the Supplementary Materials, Figure S4.3.

To investigate how trace element incorporations may influence coral aragonites crystallography, we plot crystal lattice parameters as a function of trace element incorporations and observe a few weak, yet statistically significant, trends in $\left(\mathrm{R}^{2}=0.060-0.369\right)$ in the Dropoff site (Figure 4.6). Overall volume only decreases significantly with increases in $\mathrm{Mg} / \mathrm{Ca}$ and $\mathrm{Sr} / \mathrm{Ca}$ ratios (Figure 4.6). These trends are matched along the $b$ - and $c$-axis. $B$-axes also shrink as a function of increasing $\mathrm{Ba}$ incorporations. In contrast, the $a$-axis and $c$-axes lengthen as a function of increasing $\mathrm{U} / \mathrm{Ca}$ ratios. All four trace element incorporations decrease in the Dropoff samples as a function of the increasing calcite content in the coral aragonites with the strongest trend between decreasing U/Ca with increasing calcite contents $\left(\mathrm{R}^{2}=0.369\right)$ (Figure 4.6). All crystallography versus trace element incorporations are plotted in the Supplementary Materials (Figure S4.4) 

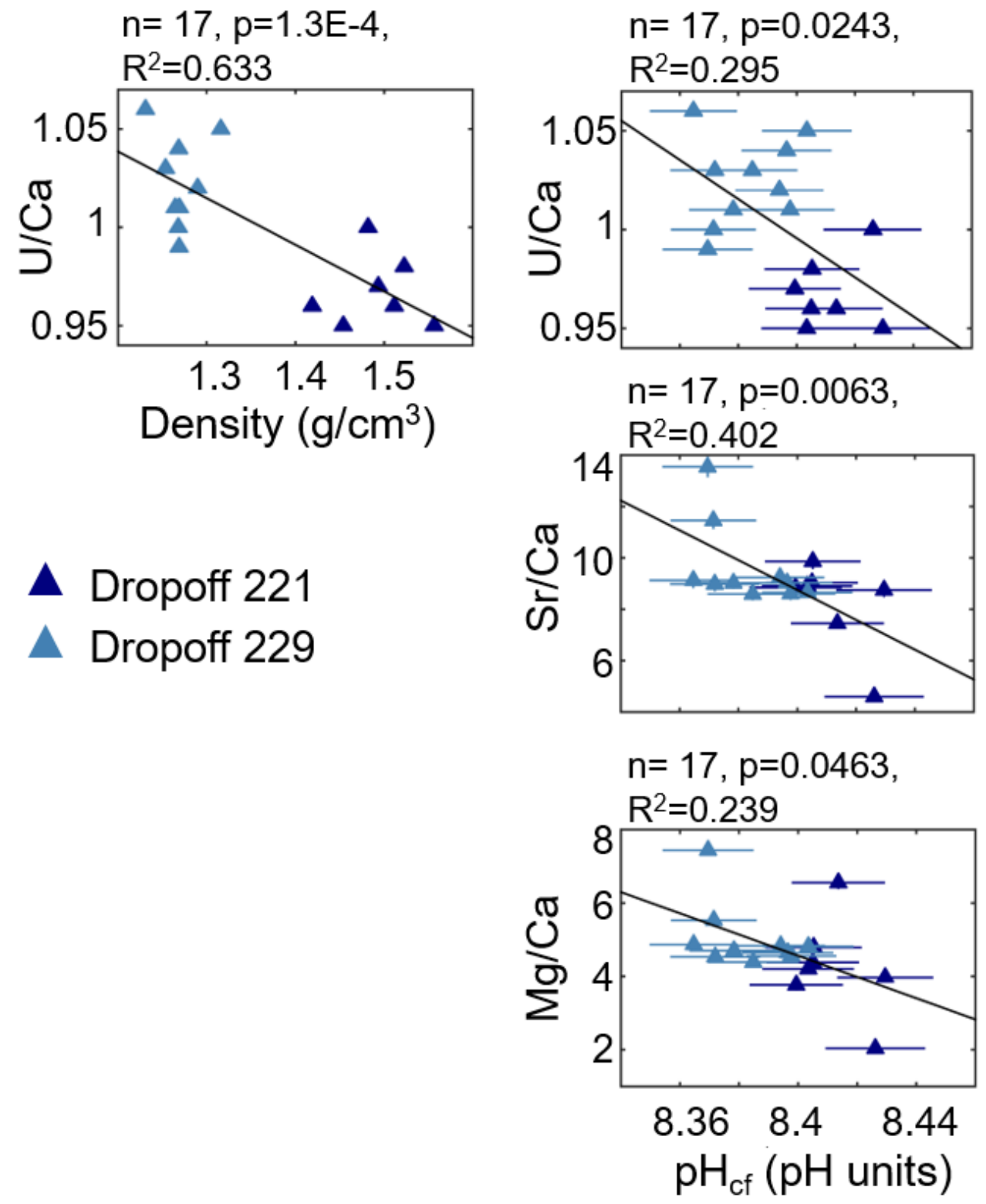

FIGURE 4.5. Trace element incorporations into the Dropoff site skeletons as a function of skeletal growth parameters (calcifying fluid $\mathrm{pH}\left(\mathrm{pH}_{\mathrm{cf}}\right)$, calcifying fluid aragonite saturation state $\left(\Omega_{\mathrm{cf}}\right)$, skeletal growth rate, and skeletal density). $\mathrm{Mg}, \mathrm{Sr}$ and $\mathrm{Ba}$ to $\mathrm{Ca}$ ratios are calculated based on a JCp-1 reference coral measured alongside the samples in this study with values for JCp-1 referenced in Hathorne et al., 2013. $\mathrm{Mg} / \mathrm{Ca}$ ratios are calculated from ${ }^{24} \mathrm{Mg}$ (top row) and ${ }^{25} \mathrm{Mg}$ (second row) concentrations, $\mathrm{Sr} / \mathrm{Ca}$ ratios are calculated from ${ }^{88} \mathrm{Sr}$, and $\mathrm{Ba} / \mathrm{Ca}$ ratios are calculated from ${ }^{138} \mathrm{Ba}$. U concentrations are from values in Mollica et al., 2018. Black trend lines are included for linear regressions which have statistically significant relationships $(\mathrm{p}<0.05)$. 

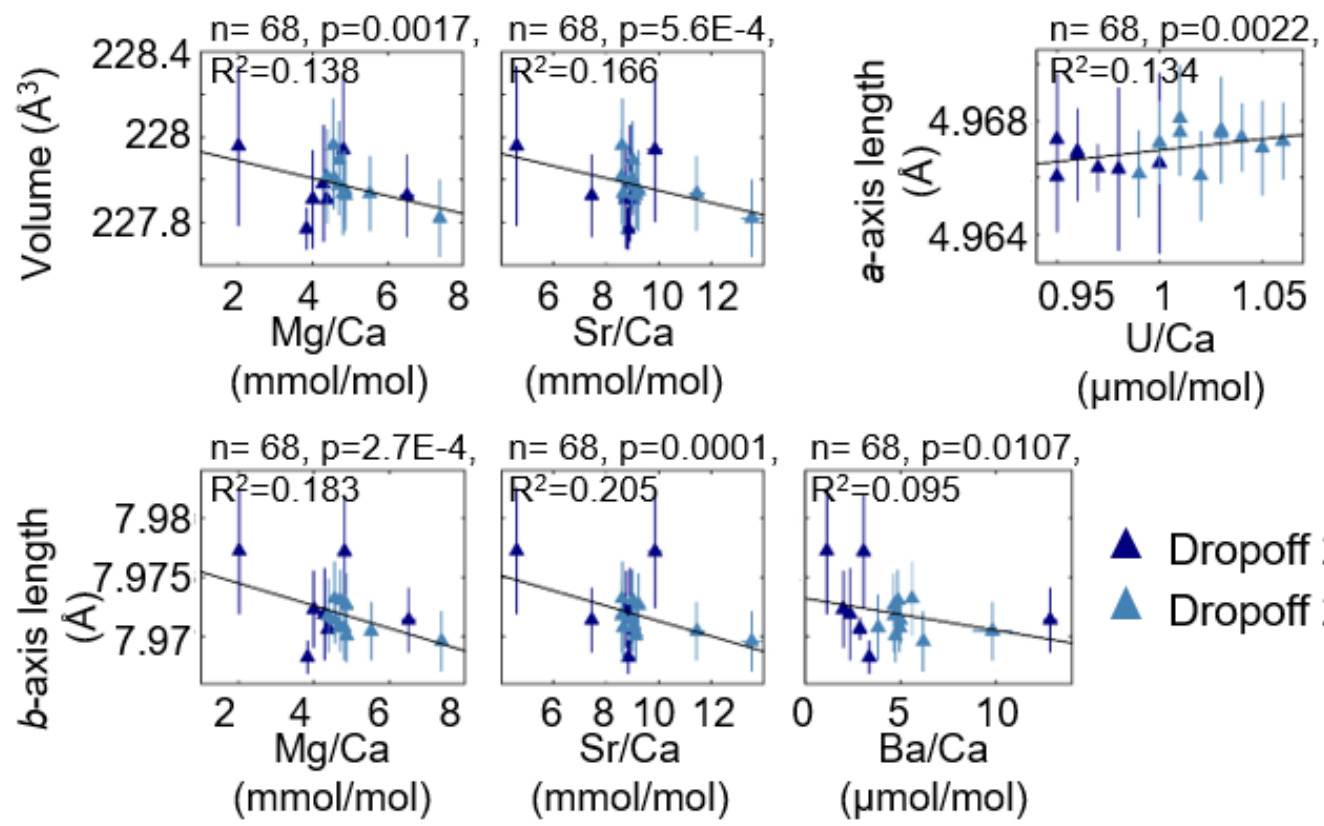

$\begin{array}{ll}\Delta & \text { Dropoff } 221 \\ \Delta & \text { Dropoff } 229\end{array}$
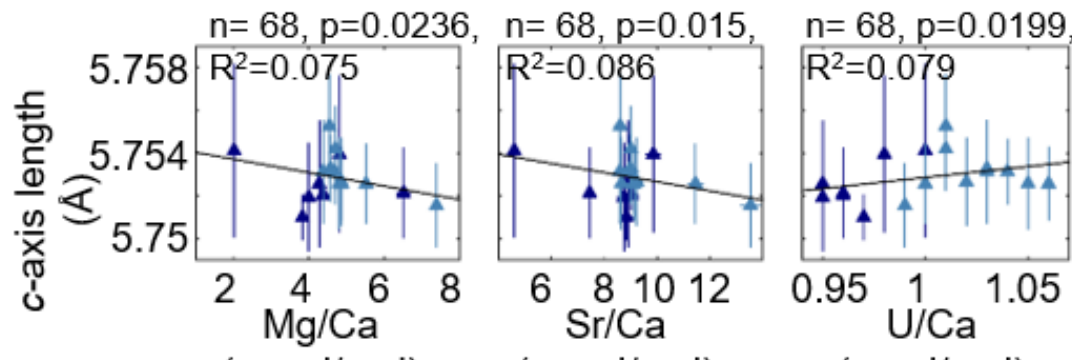

$(\mathrm{mmol} / \mathrm{mol})$

$(\mathrm{mmol} / \mathrm{mol})$

$(\mu \mathrm{mol} / \mathrm{mol})$
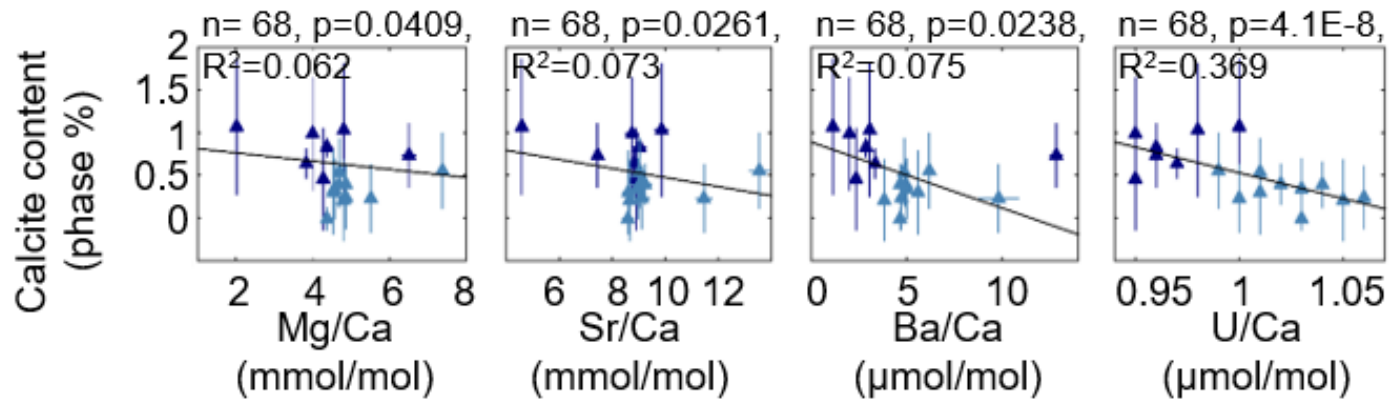

FIGURE 4.6. Coral crystallography (unit cell lattice parameters, FWHM of the (111) main peak) and mineralogy (calcite phase contributions as phase percentages) in Dropoff samples as a function of trace element incorporations. $\mathrm{Mg}, \mathrm{Sr}$ and $\mathrm{Ba}$ to $\mathrm{Ca}$ ratios are calculated based on a JCp-1 reference coral measured alongside the samples in this study with values for JCp-1 referenced in Hathorne et al., 2013. $\mathrm{Mg} / \mathrm{Ca}$ ratios are calculated from ${ }^{24} \mathrm{Mg}$ (first column) and ${ }^{25} \mathrm{Mg}$ (second column) concentrations, $\mathrm{Sr} / \mathrm{Ca}$ ratios are calculated from ${ }^{88} \mathrm{Sr}$, and $\mathrm{Ba} / \mathrm{Ca}$ ratios are calculated from ${ }^{138} \mathrm{Ba}$. $\mathrm{U}$ concentrations are from values in Mollica et al., 2018. Black trend lines are included for linear regressions which have statistically significant relationships $(\mathrm{p}<0.05)$. 


\subsubsection{Crystallography at Nikko Bay}

In Nikko Bay samples, the only statistically significant trends between mineralogy and crystallography versus growth parameters exist between a shortening along the a-axis as a function of faster skeleton growth rates $\left(R^{2}=0.102\right)$ and increasing density $\left(R^{2}=0.184\right)$ (Figure 4.7). There are no clear trends between b-axis length, c-axis length, overall unit cell volume, or FWHM of the (111) main peaks as functions of the $\mathrm{pH}_{\mathrm{cf}}, \Omega_{\mathrm{cf}}$, skeletal growth rate, or density. Other relationships between lattice parameters and skeleton growth parameters are plotted in the Supplementary Materials, Figure S4.5.

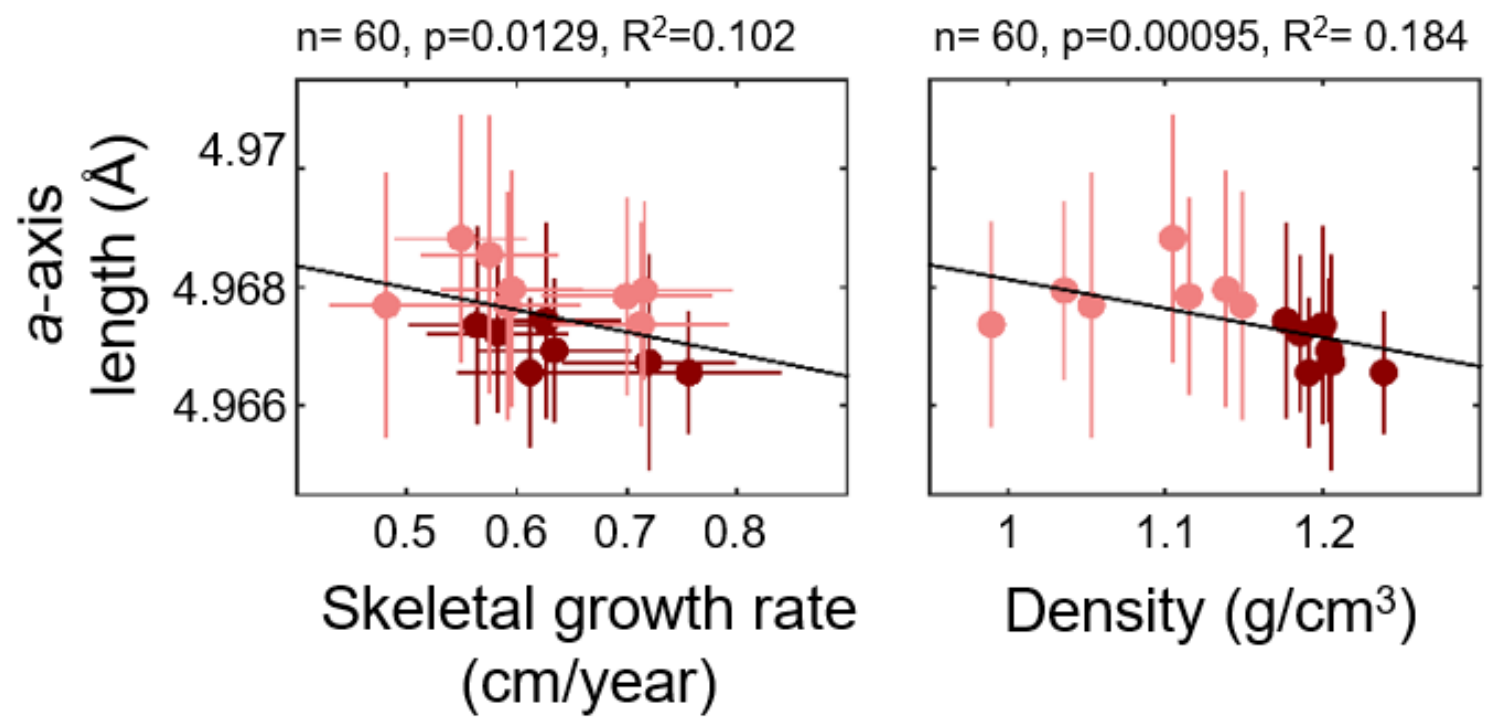

FIGURE 4.7. Skeletal aragonite mineralogical parameters in samples from the low pHsw, low $\Omega$ sw Nikko Bay site as a function of skeleton growth conditions: calcifying fluid $\mathrm{pH}\left(\mathrm{pH}_{\mathrm{cf}}\right)$, calcifying fluid aragonite saturation state $\left(\Omega_{\mathrm{cf}}\right)$, skeletal growth rate, and skeletal density. Linear regression black trend lines are included for statistically significant relationships $(\mathrm{p}<0.05)$.

\subsubsection{Calcite contents at Nikko Bay}

Similar to the Dropoff site, most Nikko Bay XRD spectra exhibit the presence of calcite contributions as observed by the presence of (104) main calcite peaks (Figure 4.8A). Linear regressions of Nikko Bay sample crystallography show that unit cell parameters decrease as a function of increasing calcite content $\left(p \leq 0.0232, R^{2}=0.85-0.335\right.$; Figure $\left.4.8 B\right)$, however, overall crystal disorder as measured by FWHM does not correlate with calcite content ( $\mathrm{p}>0.05)$. Calcite content increases with increasing $\Omega_{\mathrm{cf}}\left(\mathrm{R}^{2}=0.094\right)$, skeletal growth rate $\left(\mathrm{R}^{2}=0.217\right)$, and density $\left(\mathrm{R}^{2}=0.377\right)$, but not $\mathrm{pH}_{\mathrm{cf}}(\mathrm{p}=0.472)$ (Figure $\left.4.8 \mathrm{C}\right)$. 

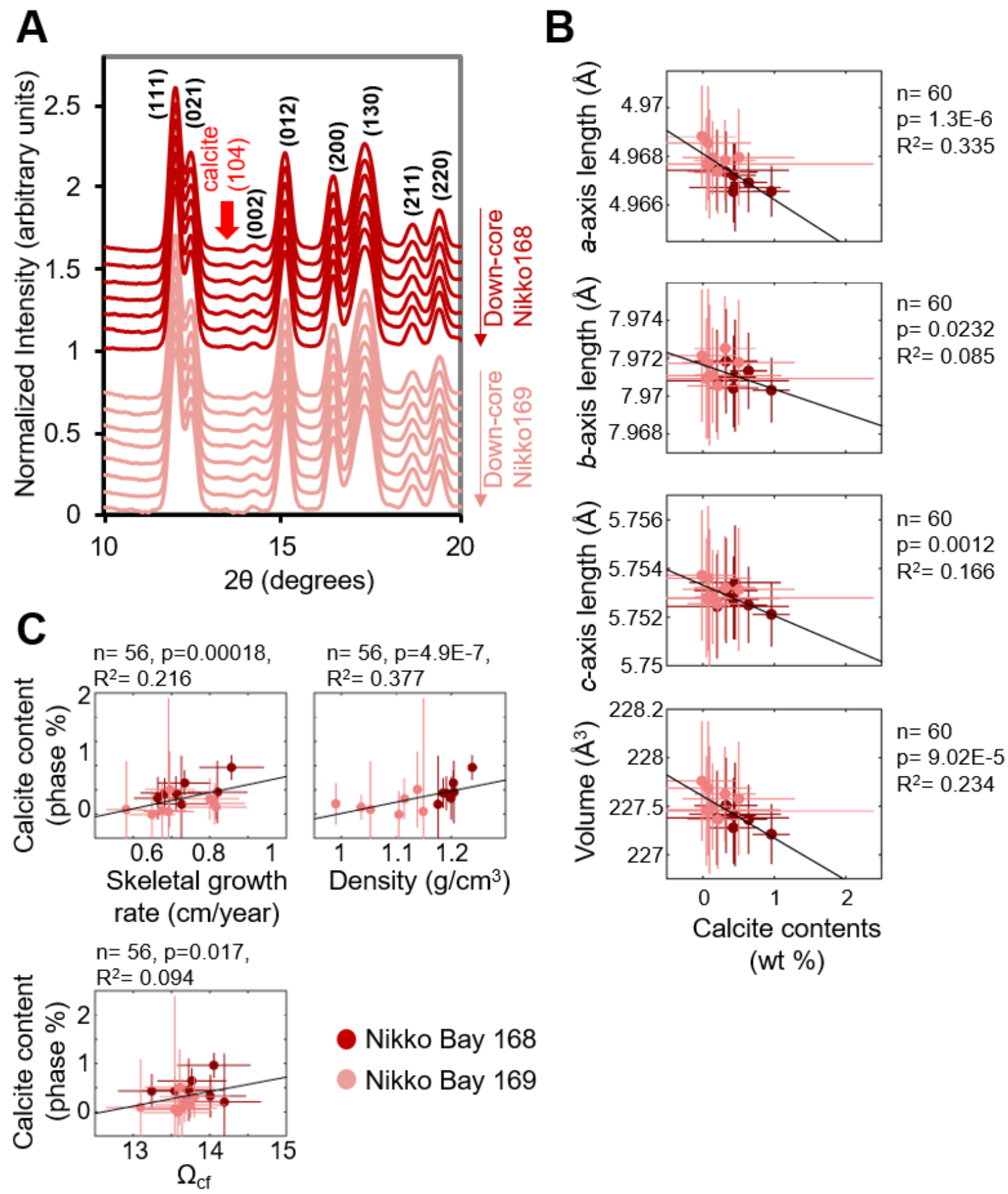

Nikko Bay 168

Nikko Bay 169

FIGURE 4.8. Calcite contents in skeletons from the Dropoff sites (Dark red = Nikko Bay 168 core, Light red = Nikko Bay 169 core). A) X-ray diffraction patterns of samples down cores with the presence of a (104) main calcite peak, highlighted in red. B) Aragonite mineralogical parameters as a function of skeletal calcite contents (expressed as phase percentages) calculated via whole-pattern Rietveld analysis of the XRD patterns in part A. C) Calcite contents in Dropoff skeletons as a function of skeleton growth parameters. Black trend lines are included for statistically significant relationships $(p<0.05)$ calculated from linear regressions. 


\subsubsection{Trace element incorporations at Nikko Bay}

In Nikko Bay, linear regressions of trace element incorporations in coral skeletons as a function of skeleton growth parameters indicate that $\mathrm{Mg} / \mathrm{Ca}$ ratios increase strongly with increasing density $\left(R^{2}=0.529\right)$. $\mathrm{Ba}\left(\mathrm{R}^{2}=0.504\right)$ and $\mathrm{U}\left(\mathrm{R}^{2}=0.425\right)$ incorporations decrease with increasing density (Figure 4.9). Ba/Ca ratios also decrease with increasing $\Omega_{\mathrm{cf}}\left(\mathrm{R}^{2}=0.398\right)$ and $\mathrm{U} / \mathrm{Ca}$ ratios decrease with increasing $\mathrm{pH}_{\mathrm{cf}}\left(\mathrm{R}^{2}=0.268\right)$ (Figure 4.9). Sr incorporations do not trend with any growth parameters and are plotted with all other non-significant relationships in the Supplementary Materials, Figure S4.6.

As for how trace element incorporations potentially influence crystallography, linear regressions show that trace element incorporations weakly correlate with crystal lattice distortions with overall unit cell volume weakly increasing with higher $\mathrm{Ba} / \mathrm{Ca}$ ratios $\left(\mathrm{R}^{2}=0.087\right)$ and overall crystal disorder via wider FWHM (111) peak increasing with higher $\mathrm{Sr} / \mathrm{Ca}$ ratios $\left(\mathrm{R}^{2}=0.069\right)$ (Figure 4.10, top row). Slightly stronger trends exist with $a$-axis length decreasing as a function of increasing $\mathrm{Mg} / \mathrm{Ca}$ ratios $\left(\mathrm{R}^{2}=0.129\right)$ and increases with increasing $\mathrm{Sr} / \mathrm{Ca}\left(\mathrm{R}^{2}=\right.$ $0.082)$ and $\mathrm{Ba} / \mathrm{Ca}\left(\mathrm{R}^{2}=0.202\right)$ ratios (Figure 4.10 , middle row). Both $b$ - and $c$-axis lengths do not correlate with trace element incorporations and are plotted in the Supplementary Materials, Figure S4.7. Calcite content shifts as a function of trace incorporations by increasing calcite content with increasing $\mathrm{Mg} / \mathrm{Ca}$ ratios $\left(\mathrm{R}^{2}=0.161\right.$ for ${ }^{24} \mathrm{Mg}, 0.174$ for $\left.{ }^{25} \mathrm{Mg}\right)$ and decreasing calcite content with increasing $\mathrm{Ba} / \mathrm{Ca}\left(\mathrm{R}^{2}=0.259\right)$ and $\mathrm{U} / \mathrm{Ca}\left(\mathrm{R}^{2}=0.104\right)$ ratios (Figure 4.10, bottom row). 

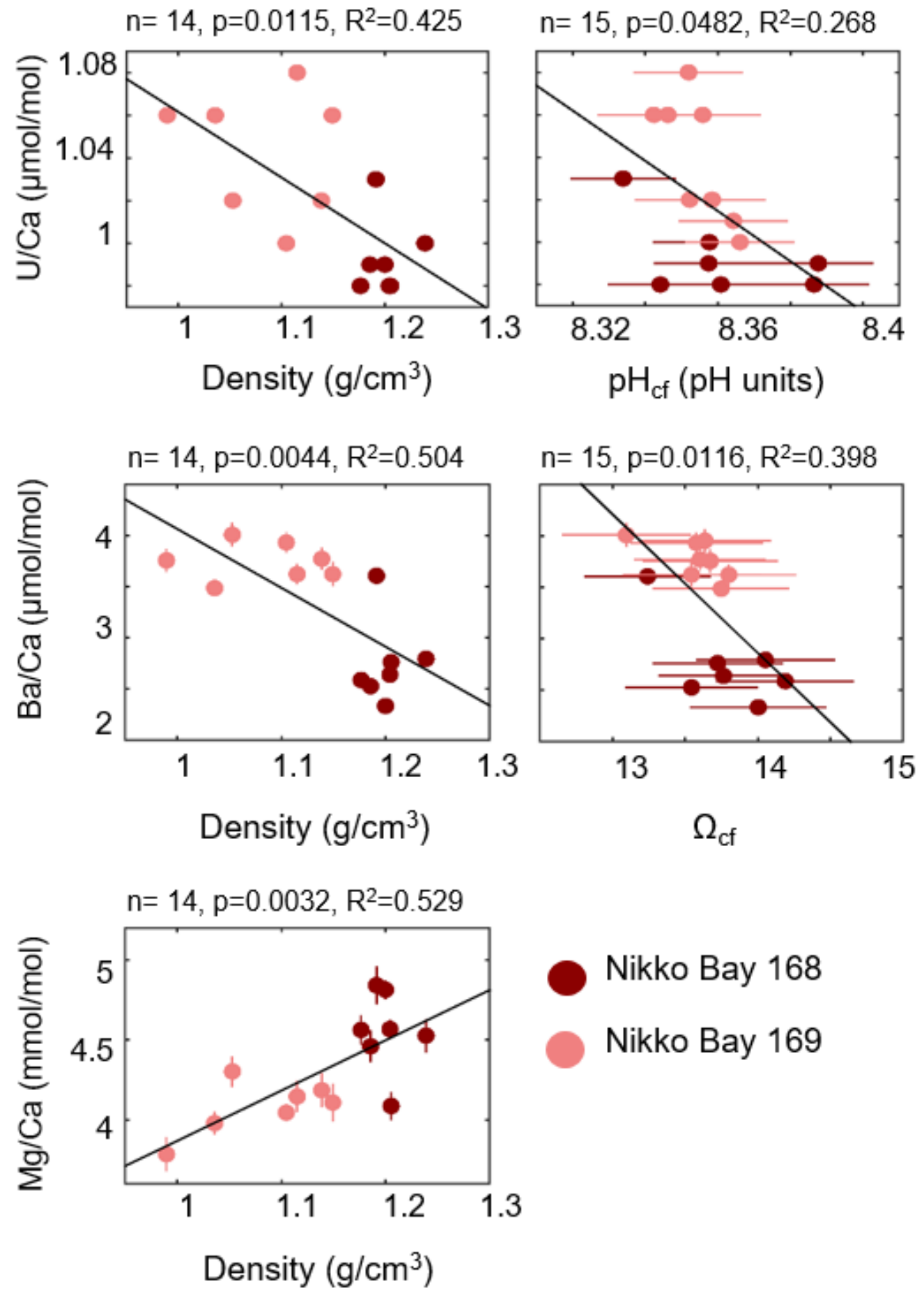

FIGURE 4.9. Trace element incorporations into the Nikko Bay site skeletons as a function of skeletal growth parameters (calcifying fluid $\mathrm{pH}\left(\mathrm{pH}_{\mathrm{cf}}\right)$, calcifying fluid aragonite saturation state $\left(\Omega_{\mathrm{cf}}\right)$, skeletal growth rate, and skeletal density). $\mathrm{Mg}, \mathrm{Sr}$ and $\mathrm{Ba}$ to $\mathrm{Ca}$ ratios are calculated based on a JCp-1 reference coral measured alongside the samples in this study with values for JCp-1 referenced in Hathorne et al., 2013. $\mathrm{Mg} / \mathrm{Ca}$ ratios are calculated from ${ }^{24} \mathrm{Mg}$ (top row) and ${ }^{25} \mathrm{Mg}$ (second row) concentrations, $\mathrm{Sr} / \mathrm{Ca}$ ratios are calculated from ${ }^{88} \mathrm{Sr}$, and $\mathrm{Ba} / \mathrm{Ca}$ ratios are calculated from ${ }^{138} \mathrm{Ba}$. $\mathrm{U}$ concentrations are from values in Mollica et al., 2018. Black trend lines are included for linear regressions which have statistically significant relationships $(\mathrm{p}<0.05)$. 

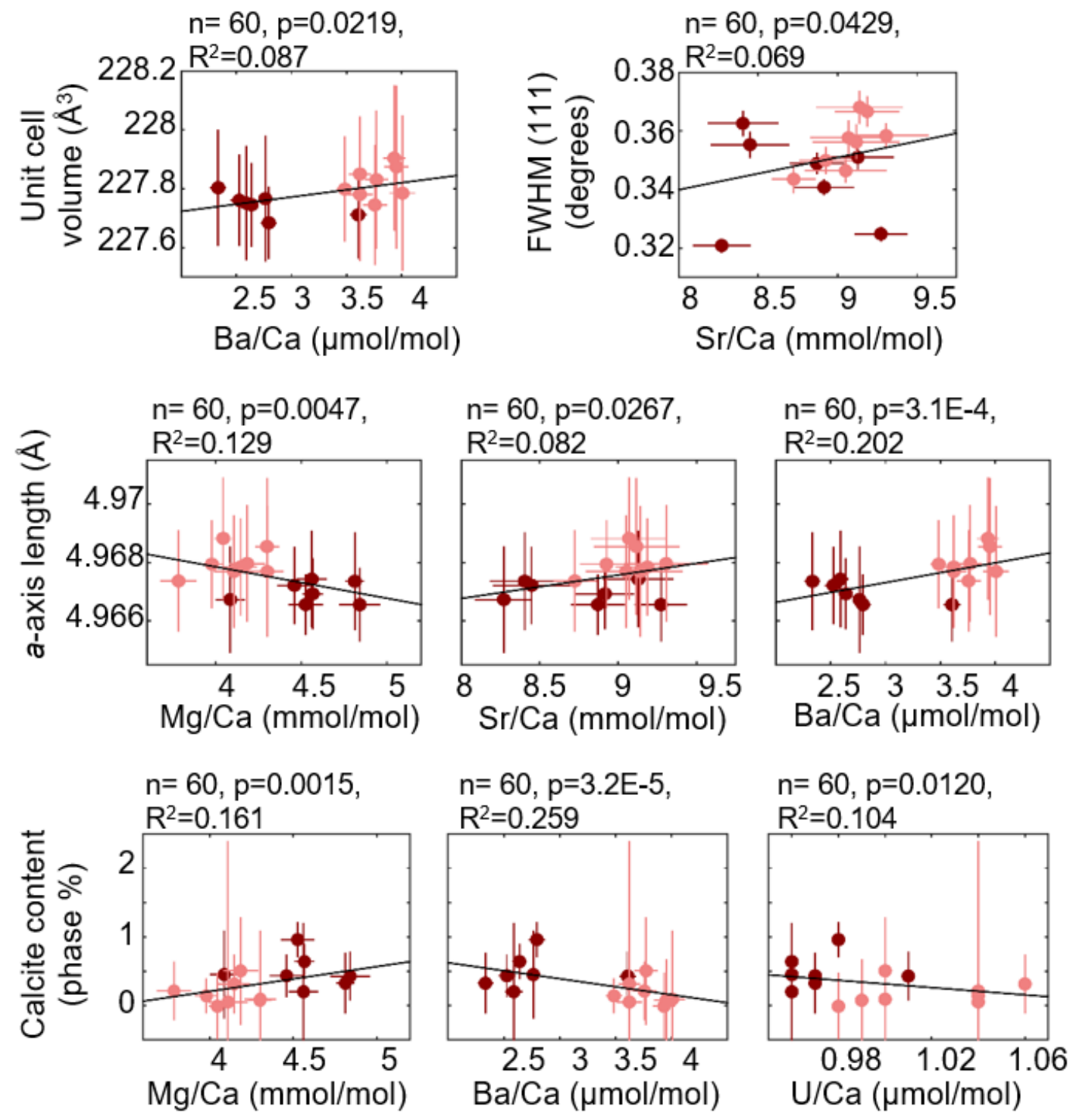

\section{Nikko Bay 168 \\ Nikko Bay 169}

FIGURE 4.10. Coral crystallography (unit cell lattice parameters, FWHM of the (111) main peak) and mineralogy (calcite phase contributions as phase percentages) in Nikko Bay samples as a function of Trace element incorporations. $\mathrm{Mg}, \mathrm{Sr}$ and $\mathrm{Ba}$ to $\mathrm{Ca}$ ratios are calculated based on a JCp-1 reference coral measured alongside the samples in this study with values for JCp-1 referenced in Hathorne et al., 2013. $\mathrm{Mg} / \mathrm{Ca}$ ratios are calculated from ${ }^{24} \mathrm{Mg}$ (first column) and ${ }^{25} \mathrm{Mg}$ (second column) concentrations, $\mathrm{Sr} / \mathrm{Ca}$ ratios are calculated from ${ }^{88} \mathrm{Sr}$, and $\mathrm{Ba} / \mathrm{Ca}$ ratios are calculated from ${ }^{138} \mathrm{Ba}$. U concentrations are from values in Mollica et al., 2018. Black trend lines are included for linear regressions which have statistically significant relationships $(\mathrm{p}<0.05)$. 


\subsection{DISCUSSION}

The statistically significant difference in skeletal growth parameters ( $\mathrm{pH}_{\mathrm{cf}}, \Omega_{\mathrm{cf}}$, density) of corals between the Dropoff and Nikko Bay sites in Palau (Table 4.3) reflect the extreme, yet natural, differences in seawater conditions ( $\mathrm{pH}_{\mathrm{sw}}, \Omega_{\mathrm{sw}}$ ) between these sites (Figure 4.1). Community respiration and restricted circulation drive the low $\mathrm{pH}_{\mathrm{sw}}$ and $\Omega_{\mathrm{sw}}$ conditions at Nikko Bay (Shamberger et al., 2014), which represents a model for understanding how corals may respond to seawater chemistry predicted for the year 2100 due to increasing global levels of $\mathrm{pCO}_{2}$ (Doney et al., 2009). Many studies observe that corals can acclimatize to grow in low $\mathrm{pH}_{\mathrm{sw}}$ conditions (Camp et al., 2017). Yet, Mollica et al., (2018) have also observed that while skeletal growth rates (skeletal extension in $\mathrm{cm} / \mathrm{y}$ ) are seemingly not affected in Nikko Bay corals, skeletal density decreases significantly under ocean acidification conditions. As such, Porites skeletal density could decline by approximately $20.3 \%$ over the $21^{\text {st }}$ century. Since Palau corals represent an example of corals exhibiting differences in bulk skeletal properties as a function of extreme, yet environmentally-relevant, seawater conditions, this is an ideal site to study the effects of environmental conditions on coral mineralogy, crystallography and material properties hidden via macro-scale and bulk observations. The link between the composition and crystal lattice structure of a mineral is what drives shifts in the material properties of a mineral, which may in turn influence how coral skeletons respond to different environments (Wopenka and Pasteris, 2005). Thus, this study explores how coral growth parameters and skeletal chemistry influence the crystallography of corals growing in two sites with distinct seawater chemistries.

\subsubsection{Coral crystallography as a function of skeletal growth parameters}

Our measurements of aragonite unit cell lattice parameters ( $a$-axis length, $b$-axis length, $c$-axis length, and overall volume of the unit cell) and overall disorder via the FWHM of the (111) main aragonite XRD pattern peak, reveal that the only statistically significant trend in coral crystallography as a function of skeletal growth parameters in both the Nikko Bay and Dropoff sites is an anisotropic shortening along the $a$-axis with of increased skeletal growth rates and skeletal density (Figures $4.3 \& 4$.7). Since the $\mathrm{R}^{2}$ values for these trend lines are weak $(0.083-$ $0.235)$, and the $\Delta a$-axis length is small ( $-0.002 \AA$ at both sites) for similar magnitude shifts in skeletal growth rate $(\sim 0.3 \mathrm{~cm} / \mathrm{y})$ and density $\left(\sim 0.3 \mathrm{~g} / \mathrm{cm}^{3}\right)$, we expect that changes in overall unit cell lattice size as a function of different skeletal growth conditions are minor in shallow-water environments that mimic this Palau case-study. All other statistically significant trends observed at the Dropoff site (Figure 4.3) are not observed in the lower pH Nikko Bay site.

\subsubsection{Calcite contents in corals as a function of skeletal growth parameters and how calcite contents influence coral crystallography}

Stronger trends are observed between shortening a-axis lengths $(\sim 0.002 \AA)$ with increasing calcite contents ( $0-1$ skeleton wt $\%)$ with $\mathrm{R}^{2}$ values between $0.159-0.335$ for corals from both sites (Figures 4.4B \& 4.8B). This may indicate that calcite contents play a role in shifting lattice parameter length. Other axes do not change consistently between the two sites. Similar to unit 
cell lattice parameters, we observe that faster skeleton growth rates and increasing density are correlated with increasing calcite contents in both Nikko Bay and Dropoff sites (Figures 4.4C \& $4.8 \mathrm{C})$ with the strongest trend between increasing calcite as a function of increasing density $\left(\mathrm{R}^{2}=\right.$ 0.377 at Nikko Bay and $\mathrm{R}^{2}=0.561$ at Dropoff). Calcite contents also increase with an increase in $\Omega_{\mathrm{cf}}$ in both sites (Figures $4.4 \mathrm{C} \& 4.8 \mathrm{C}$ ). Thus, we expect that calcite contents primarily drive anisotropic change in $a$-axis length, but that skeletal growth parameters and internal calcifying fluid chemistry are what determine calcite content. This may account for the minor trends we observe from skeletal growth rate and density on $a$-axis lengths (Figures $4.3 \& 4.7$ ).

There are a few important things to consider in regards to calcite incorporation into coral skeletons. First, coral cores represent older skeletal aragonite which have been exposed longer to seawater conditions and skeleton micro-boring organisms capable of precipitating calcite phases (Macintyre \& Towe, 1976; Nothdruft et al., 2007). The presence of micro-boring is likely in these environmental samples, however we do not have high-resolution imaging work on a scale to quantify their influence. Skeletal boring is shown to increase under ocean acidification conditions (DeCarlo et al., 2015), but we do not observe a significantly higher presence of calcite in the lower $\mathrm{pH}$ Nikko Bay site corals (Table 4.2), indicating that if micro-boring plays a role in calcite content, it is not proportional to seawater conditions between these sites.

Since calcite contents appear to influence the aragonite unit cell lattice structure in our measurements of anisotropic $a$-axis shortening with increasing calcite content, it is also important to understand how calcite XRD peaks could overlap with aragonite XRD peaks and influence the lattice refinements for aragonite. We have accounted for this by running XRD on mixed standards of aragonite and calcite phases (Supplementary materials, Figure S4.8). We observe that increasing calcite contents (1.3 to 20.6 weight \% natural calcite mixtures with natural aragonite) artificially shorten all three unit cell axes and overall unit cell volume as analyzed by Rietveld refinements in a statistically significant manner (linear regression $\mathrm{p}=$ $0.00045-3.78 \mathrm{E}-5, \mathrm{R}^{2}=0.8024-0.8928$ ). However, it would take approximately $10 \mathrm{wt} \%$ calcite in Rietveld-refinement calculation error in order to induce the same $0.002 \AA$ decrease along the $a$ axis length we observe with only a $1 \mathrm{wt} \%$ calcite content in the coral skeletons. Thus, we confirm that aragonite crystallography in coral skeletons is influenced by calcite-induced anisotropic distortions along the $a$-axis beyond the margin of error introduced by the Rietveld refinement process (Figures 4.4B \& 4.8B). In turn, calcite contents in corals are likely due to coral growth parameters such as skeletal growth rates, skeletal density, and $\Omega_{\mathrm{cf}}$ (Figures $4.4 \mathrm{C} \&$ $4.8 \mathrm{C}$ ), which indicates that environmental conditions play a role in skeletal mineralogy and crystallography.

\subsubsection{Trace element incorporations in coral skeletons as functions of skeleton growth parameters and how they influence coral crystallography}

Trace element incorporations into crystal lattices are shown to reflect seawater chemistry and drive shifts in unit cell lattice parameters and to influence the material properties of minerals (i.e., Titschack et al., 2011; Berner, 1975). $\mathrm{Mg}$, $\mathrm{Sr}$ and Ba commonly substitute for $\mathrm{Ca}$ in coral aragonite lattice structures (Meibom et al., 2008; Hathorne et al., 2013) and are widely assumed to be ideal substitutes for $\mathrm{Ca}$ due to similar ionic radii to $\mathrm{Ca}^{2+}$ (crystal radius= $1.32 \AA$ ) in 9-fold coordination (crystal radii from Shannon, 1976: $\mathrm{Mg}^{2+}=1.03 \AA$ for 8-fold coordination, $0.94 \AA$ reported in Finch \& Allison, 2007; $\mathrm{Sr}^{2+}=1.45 \AA \mathrm{Ba}^{2+}=1.61 \AA$; $\mathrm{U}^{4+}=1.19 \AA$ ) but some 
incorporations may still require significant distortions in the crystal structure to accommodate (Finch \& Allison, 2007). Aragonite bivalve shell experiments grown under varying salinity suggest that $\mathrm{Mg}$ and $\mathrm{Sr}$ incorporations in bivalve aragonite are more likely to be contolled by the organism, while $\mathrm{Ba}$ is more likely to be proxy for salinity with higher partition coeffients at lower salinity (Poulain et al., 2014). U partitioning experiments into synthetic aragonites suggest that $\mathrm{U}$ concentrations increase with decreasing carbonate ion concentrations in seawater and that other $\mathrm{U}$ correlations with $\mathrm{pH}$ and other variables arise indirectly based on the relationships between these other variables and carbonate ion concentration (DeCarlo et al., 2015). Here, we observe that only U/Ca ratios appear to be influenced by skeleton growth parameters in both Dropoff and Nikko Bay sites, namely U/Ca ratios decrease with increasing skeletal density and in $\mathrm{pH}_{\mathrm{cf}}$ (Figures $4.5 \& 4.9$, top rows). Other trends of trace element incorporations of $\mathrm{Mg}, \mathrm{Sr}$ and $\mathrm{Ba}$ for $\mathrm{Ca}$ with skeletal growth parameters are not consistent between sites.

Incorporation of $\mathrm{Mg}, \mathrm{Sr}, \mathrm{Ba}$, and $\mathrm{U}$ do not influence crystal lattice parameters in a consistent manner across sample sites (Figures $4.6 \& 4.10$; Supplementary Materials, Figures S4.4 \& S4.7). These inconsistent crystallographic responses to trace element incorporations likely indicate that element incorporation does not significantly influence coral skeleton crystallography, especially compared to the crystallographic responses with respect to density, skeletal growth rate and calcite contents.

Only calcite contents decrease with increasing $\mathrm{Ba}$ and $\mathrm{U}$ contents at both sites (Figures $4.6 \& 4.10$, bottom rows). This may indicate that $\mathrm{Ba}$ and $\mathrm{U}$ are not incorporated into coral skeletons via calcite phases, or that the correlations we see between calcite and $\mathrm{Ba}$ and $\mathrm{U}$ incorporations are the results of stronger trends between decreasing $\mathrm{U}$ and $\mathrm{Ba}$ with increasing density (Figures $4.5 \& 4.9$ ), which also correlates with increasing calcite content (Figures 4.4C \& 4.8C). One possibile driver for increasing Ba partitioning with decreasing skeletal density is faster crystal growth rates, especially at higher aragonite saturation states, as was recently observed in synthetic aragonite experiments (Mavromatis et al., 2018).

While trace element incorporations are known to drive structural change in aragonite mineralogy, we do not see evidence of it playing a large role in controlling the observed crystallographic shifts along the $a$-axis of Dropoff and Nikko Bay samples. Instead, we suggest that calcite incorporations drive this crystallographic shift and that calcite contents are governed by skeletal growth parameters such as density and skeleton growth rates.

\subsubsection{Mineralogical resilience in Palau corals}

Despite the different seawater environments and resulting decreased skeletal density at Nikko Bay compared to Dropoff, we do not observe marked differences in crystallography, or even calcite contents, between these sites. This may indicate that Porites sp. coral at Nikko Bay are mineralogically acclimated to natural low $\mathrm{pH}$ and $\Omega_{\mathrm{sw}}$ conditions. Porites $\mathrm{sp}$. are known to be especially resilient to other stressors such as increased sea surface temperatures and coral bleaching (Guest et al., 2012), which may indicate that they may also be more capable than other corals of withstanding other stressors such as lower $\Omega_{\text {cf }}$ to continue calcifying aragonite skeletons with minimal crystallographic distortions. Another explanation for the lack of mineralogical shifts with respect to this $\mathrm{pH}$ and $\Omega_{\mathrm{cf}}$ gradient in Palau is that the gradient is too modest to observe dramatic changes in crystallography. The next step is to determine whether the small anisotropic shifts we observe along the $a$-axis associated with changes in skeletal density are 
enough to influence coral aragonite material properties, such as in increase in the solubility constant or decreased skeletal strength, for corals growing in Nikko Bay.

\subsection{CONCLUSIONS}

In this study we compare the crystallography of coral skeletons growing in a natural $\mathrm{pH}$ gradient in Palau to determine whether known shifts in skeletal growth parameters (skeletal density, skeletal growth rates, internal calcifying fluid $\mathrm{pH}\left(\mathrm{pH}_{\mathrm{cf}}\right)$ and saturation state $\left(\Omega_{\mathrm{cf}}\right)$ ) across this gradient may influence the aragonite building blocks that make up coral skeletons. We observe a small shortening along the $a$-axis $(\sim-0.001 \AA)$ of the aragonite unit cell which we suggest is mainly driven by increased calcite contents in the aragonite coral skeletons. Increased calcite contents are likely tied to skeleton growth parameters such as increased skeletal density, faster skeleton growth rates and increased $\Omega_{\mathrm{cf}}$, which explains why shorter $a$-axis lengths are also weakly correlated to increased density and faster growth rates in both Nikko Bay and Dropoff sites. A decrease in $\mathrm{Ba}$ and $\mathrm{U}$ incorporations into the skeleton are also possibly driven by decreasing skeletal density and thus correlate with increasing calcite contents. We do not observe any clear trends between trace element incorporations $(\mathrm{Mg}, \mathrm{Sr}, \mathrm{Ba}, \mathrm{U})$ and unit cell lattice parameters. While we do observe small crystallographic shifts along the $a$-axis, overall, a lack of large crystallographic shifts with respect to differences in seawater chemistry and skeleton growth parameters between the sites suggests that the Porites sp. corals from Palau are mineralogically resilient to this natural gradient. More work is needed to understand what degree of crystallographic distortion is necessary before changes in coral aragonite material properties, such as increased solubility, are manifested and could harm coral skeletal health.

\subsection{Funding and Acknowledgements}

Funding for this project was made possible by Mineralogical Society of America Edward H. Kraus Crystallographic Research Fund and the WHOI Ocean Ventures Fund. G. Farfan was supported by a National Science Foundation Graduate Research Fellowship Grant No. 1122374 and a Ford Foundation Dissertation Fellowship. Coral samples were collected by the Cohen lab with Funding from the National Science Foundation Grant No. OCE-1220529 and OCE1031971, and the WHOI Dalio Explore Fund.

The authors would also like to thank Dr. Jeffrey Post from the Smithsonian Nation Museum of Natural History for training on Rietveld Refinement analysis, and Dr. Huifang Xu from the University of Wisconsin at Madison for consulting on XRD concepts. The authors would also like to acknowledge Gretchen Swarr for help with ICP-MS analyses at the Woods Hole Oceanographic Institution (WHOI) and Katherine Sisson for helping to prepare coral powder samples at WHOI. 


\subsection{References}

Allemand, D., Tambutté, É., Zoccola, D., and Tambutté, S. (2011). Coral calcification, cells to reefs. In Coral reefs: an ecosystem in transition (pp. 119-150). Springer, Dordrecht.

Antao, S. M. and Hassan, I. (2009). The orthorhombic structure of $\mathrm{CaCO}_{3}, \mathrm{SrCO}_{3}, \mathrm{PbCO}_{3}$ and $\mathrm{BaCO}_{3}$ : Linear structural trends. Can. Mineral. 47, 1245-1255. doi:10.3749/canmin.47.5.1245

Berner, R. A. (1975). The role of magnesium in the crystal growth of calcite and aragonite from sea water. Geochim. Cosmochim. Acta. 39(4), 489-504. doi:10.1016/0016-7037(75)90102-7

Bish, D. L., and Post, J. E. (1993). Quantitative mineralogical analysis using the Rietveld full-pattern fitting method. Am. Mineral. 78(9-10), 932-940.

Camp, E. F., Nitschke, M. R., Rodolfo-Metalpa, R., Houlbreque, F., Gardner, S. G., Smith, D. J., Zampighi, M., and Suggett, D. J. (2017). Reef-building corals thrive within hot-acidified and deoxygenated waters. Sci. Rep. 7(1), 2434. doi:10.1038/s41598-017-02383-y

Caspi, E. N., Pokroy, B., Lee, P. L., Quintana, J. P., and Zolotoyabko, E. (2005). On the structure of aragonite. Acta Crystallogr. B. 61(2), 129-132. doi:10.1107/S0108768105005240

Cohen, A. L., McCorkle, D. C., de Putron, S., Gaetani, G. A., and Rose, K. A. (2009). Morphological and compositional changes in the skeletons of new coral recruits reared in acidified seawater: Insights into the biomineralization response to ocean acidification. Geochemistry, Geophysics, Geosystems, 10(7). doi:10.1029/2009GC002411

Chan, N. C., and Connolly, S. R. (2013). Sensitivity of coral calcification to ocean acidification: a metaanalysis. Global Change Biology, 19(1), 282-290. doi:10.1111/gcb.12011

DeCarlo, T. M., Ren, H., and Farfan, G.A. (2018). The origin and role of organic matrix in coral calcification: insights from comparing coral skeleton and abiogenic aragonite. Frontiers in Marine Science, 5, 170. doi:10.3389/fmars.2018.00170

DeCarlo, T. M., D'Olivo, J. P., Foster, T., Holcomb, M., Becker, T., and McCulloch, M. T. (2017). Coral calcifying fluid aragonite saturation states derived from Raman spectroscopy. Biogeosciences, 14(22), 5253-5269. doi:10.5194/bg-14-5253-2017

DeCarlo, T. M., Cohen, A. L., Barkley, H. C., Cobban, Q., Young, C., Shamberger, K. E., Brainard, R. E., and Golbuu, Y. (2015). Coral macrobioerosion is accelerated by ocean acidification and nutrients. Geology, 43(1), 7-10. doi:10.1130/G36147.1

Doney, S. C., Fabry, V. J., Feely, R. A., and Kleypas, J. A. (2009). Ocean acidification: the other $\mathrm{CO}_{2}$ problem. Annu. Rev. Mar. Sci. 1, 169-192. doi:10.1146/annurev.marine.010908.163834

Drenkard, E. J., Cohen, A. L., McCorkle, D. C., de Putron, S. J., Starczak, V. R., and Zicht, A. E. (2013). Calcification by juvenile corals under heterotrophy and elevated $\mathrm{CO}_{2}$. Coral Reefs, 32(3), $727-$ 735. doi:10.1007/s00338-013-1021-5 
Foster, T., Falter, J. L., McCulloch, M. T., and Clode, P. L. (2016). Ocean acidification causes structural deformities in juvenile coral skeletons. Science advances, 2(2), e1501130.

doi:10.1126/sciadv.1501130

Farfan, G. A., Cordes, E. E., Waller, R. G., DeCarlo, T. M., and Hansel, C. M. (in review). Mineralogy of deep-sea coral aragonites as a function of aragonite saturation state. Frontiers in Marine Science, 5 .

Finch, A. A., and Allison, N. (2007). Coordination of $\mathrm{Sr}$ and $\mathrm{Mg}$ in calcite and aragonite. Mineralogical Magazine, 71(5), 539-552. doi:10.1180/minmag.2007.071.5.539

Gaffey, S. J., and Bronnimann, C. E. (1993). Effects of bleaching on organic and mineral phases in biogenic carbonates. Journal of Sedimentary Research, 63(4). doi:10.1306/D4267BE0-2B2611D7-8648000102C1865D

Guest, J.R., A.H. Baird, J.A. Maynard, E. Muttaqin, A.J. Edwards, S.J. Campbell, K. Yewdall, Y.A. Affendi, L.M. Chou. (2012). Contrasting Patterns of Coral Bleaching Susceptibility in 2010 Suggest an Adaptive Response to Thermal Stress. PLoS ONE 7(3): e33353. doi:10.1371/journal.pone.0033353.

Hathorne, E. C., Gagnon, A., Felis, T., Adkins, J., Asami, R., Boer, W., Caillon, N., Case, D., Cobb, K. M., Douville, E., deMenocal, P., Eisenhauer, A., Garbe-Schonberg, D., Geibert, W., Goldstein, S., Hughen, K., Inoue, M., Kawahata, H., Kolling, M., Cornec, F. L., Linsley, B. K., McGregor, H. V., Montagna, P., Nurhati, I. S., Quinn, T. M., Raddatz, J., Rebaubier, H., Robinson, L., Sadekov, A., Sherrell, R., Sinclair, D., Tudhope, A. W., Wei, G., Wong, H., Wu, H. C. and You, C. (2013). Interlaboratory study for coral $\mathrm{Sr} / \mathrm{Ca}$ and other element/Ca ratio measurements. Geochemistry, Geophysics, Geosystems, 14(9), 3730-3750. doi:10.1002/ggge.20230.

Hennige, S. J., Wicks, L. C., Kamenos, N. A., Perna, G., Findlay, H. S., and Roberts, J. M. (2015). Hidden impacts of ocean acidification to live and dead coral framework. Proc. R. Soc. B, 282(1813), 20150990. doi:10.1098/rspb.2015.0990.

Hofmann, G. E., Barry, J. P., Edmunds, P. J., Gates, R. D., Hutchins, D. A., Klinger, T., and Sewell, M. A. (2010). The effect of ocean acidification on calcifying organisms in marine ecosystems: an organism-to-ecosystem perspective. Annual Review of Ecology, Evolution, and Systematics, 41, 127-147. doi:10.1146/annurev.ecolsys.110308.120227

Lunden, J. J., Georgian, S. E., and Cordes, E. E. (2013). Aragonite saturation states at cold-water coral reefs structured by Lophelia pertusa in the northern Gulf of Mexico. Limnol. Oceanogr. 58(1), 354-362. doi:10.4319/lo.2013.58.1.0354

Macintyre, I. G., and Towe, K. M. (1976). Skeletal calcite in living scleractinian corals: microboring fillings, not primary skeletal deposits. Science, 193(4254), 701-702. doi:10.1126/science.193.4254.701

Markgaf and Reeder (1985). High-temperature structure refinements of calcite and magnesite. Am. Mineral. 70, 590-600.

Mavromatis, V., Goetschl, K. E., Grengg, C., Konrad, F., Purgstaller, B., \& Dietzel, M. (2018). Barium partitioning in calcite and aragonite as a function of growth rate. Geochim. Cosmochim. Acta 237, 65-78. Doi:10.1016/j.gca.2018.06.018 
McCulloch, M. T., D’Olivo, J. P., Falter, J., Holcomb, M., and Trotter, J. A. (2017). Coral calcification in a changing world and the interactive dynamics of $\mathrm{pH}$ and DIC upregulation. Nature communications, 8, 15686. doi:10.1038/ncomms15686.

McCulloch, M., Falter, J., Trotter, J., and Montagna, P. (2012). Coral resilience to ocean acidification and global warming through pH up-regulation. Nature Climate Change, 2(8), 623. doi:10.1038/nclimate1473

Meibom, A., Cuif, J. P., Houlbreque, F., Mostefaoui, S., Dauphin, Y., Meibom, K. L., and Dunbar, R. (2008). Compositional variations at ultra-structure length scales in coral skeleton. Geochim. Cosmochim. Acta 72(6), 1555-1569. doi:10.1016/j.gca.2008.01.009

Mollica, N. R., Guo, W., Cohen, A. L., Huang, K. F., Foster, G. L., Donald, H. K., and Solow, A. R. (2018). Ocean acidification affects coral growth by reducing skeletal density. Proc. Nat. Aca. Sci. U.S.A. 115(8), 1754-1759. doi:10.1073/pnas.1712806115

Nothdurft L. E., Webb G. E., Bostrom T. and Rintoul L. (2007). Calcite-filled borings in the most recently deposited skeleton in live-collected Porites (Scleractinia): implications for trace element archives. Geochim. Cosmochim. Acta, 71, 5423-5438. doi:10.1016/j.gca.2007.09.025

Politi, Y., Levi-Kalisman, Y., Raz, S., Wilt, F., Addadi, L., Weiner, S., and Sagi, I. (2006). Structural characterization of the transient amorphous calcium carbonate precursor phase in sea urchin embryos. Adv. Funct. Mater. 16(10), 1289-1298. doi:10.1002/adfm.200600134

Poulain, C., Gillikin, D. P., Thébault, J., Munaron, J. M., Bohn, M., Robert, R., Paulet, Y.-M., and Lorrain, A. (2015). An evaluation of $\mathrm{Mg} / \mathrm{Ca}, \mathrm{Sr} / \mathrm{Ca}$, and $\mathrm{Ba} / \mathrm{Ca}$ ratios as environmental proxies in aragonite bivalve shells. Chemical Geology, 396, 42-50. doi:10.1016/j.chemgeo.2014.12.019

Rodolfo-Metalpa, R., Montagna, P., Aliani, S., Borghini, M., Canese, S., Hall-Spencer, J. M., Andy Foggo, A., Milazzo, M., Taviani, M., and Houlbrèque, F. (2015). Calcification is not the Achilles' heel of cold-water corals in an acidifying ocean. Global Change Biol. 21(6), 2238-2248. doi:10.1111/gcb.12867

Shamberger, K. E. F., A. L. Cohen, Y.Golbuu, D. C. McCorkle, S. J. Lentz, and H. C. Barkley (2014), Diverse coral communities in naturally acidified waters ofa Western Pacific Reef, Geophys. Res. Lett. 41, 499-504. doi:10.1002/2013GL058489

Shannon, R. D. (1976). Revised effective ionic radii and systematic studies of interatomic distances in halides and chalcogenides. Acta Crystallogr. Sect. A. 32(5), 751-767. doi:10.1107/S0567739476001551

Swanson, H. E., and Fuyat, R. K. (1953). ICDD PDF 05, 0586, Calcite. Natl. Bur. Stand. (US), Circ, 539, 51

Tambutté, E., Venn, A. A., Holcomb, M., Segonds, N., Techer, N., Zoccola, D., Allemand, S. and Tambutté, S. (2015). Morphological plasticity of the coral skeleton under CO 2-driven seawater acidification. Nat. Comm. 6, 7368. doi:10.1038/ncomms8368

Titschack, J., Goetz-Neunhoeffer, F., and Neubauer, J. (2011). Magnesium quantification in calcites [(Ca, 
$\mathrm{Mg}) \mathrm{CO}_{3}$ ] by Rietveld-based XRD analysis: revisiting a well-established method. Am. Mineral. 96(7), 1028-1038. doi:10.2138/am.2011.3665

Toby, B. H., and Von Dreele, R. B. (2013). GSAS-II: the genesis of a modern open-source all purpose crystallography software package. J. Appl. Crystallogr. 46(2), 544-549. doi:10.1107/S0021889813003531

van Woesik, R., Van Woesik, K., Van Woesik, L., and Van Woesik, S. (2013). Effects of ocean acidification on the dissolution rates of reef-coral skeletons. PeerJ 1, e208. doi:10.7717/peerj.208

Wopenka, B., and Pasteris, J. D. (2005). A mineralogical perspective on the apatite in bone. Materials Science and Engineering: C, 25(2), 131-143. doi:10.1016/j.msec.2005.01.008 


\subsection{Supplementary Material-Figures}
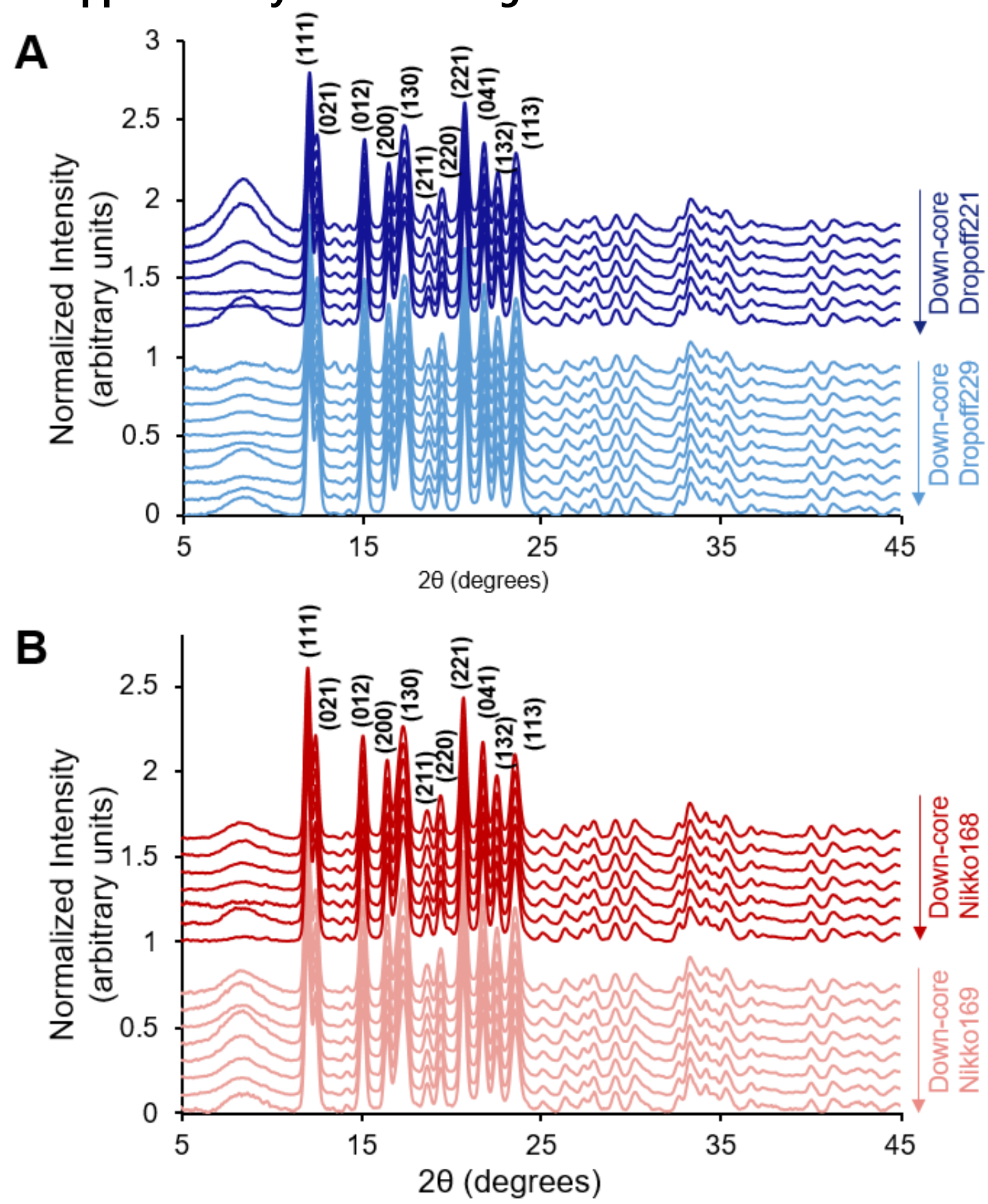

FIGURE S4.1. X-ray diffraction patters of A) Dropoff Site and B) Nikko Bay Site coral aragonite samples. 


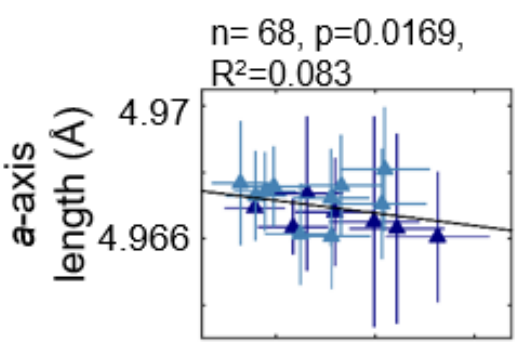

$\mathrm{n}=68, \mathrm{p}=3.8 \mathrm{E}-6$, $\mathrm{R}^{2}=0.278$

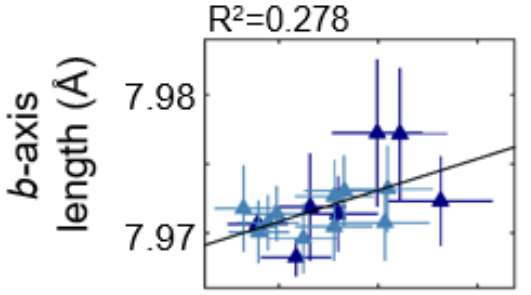

$\mathrm{n}=68, \mathrm{p}=0.0432$, $\mathrm{R}^{2}=0.060$
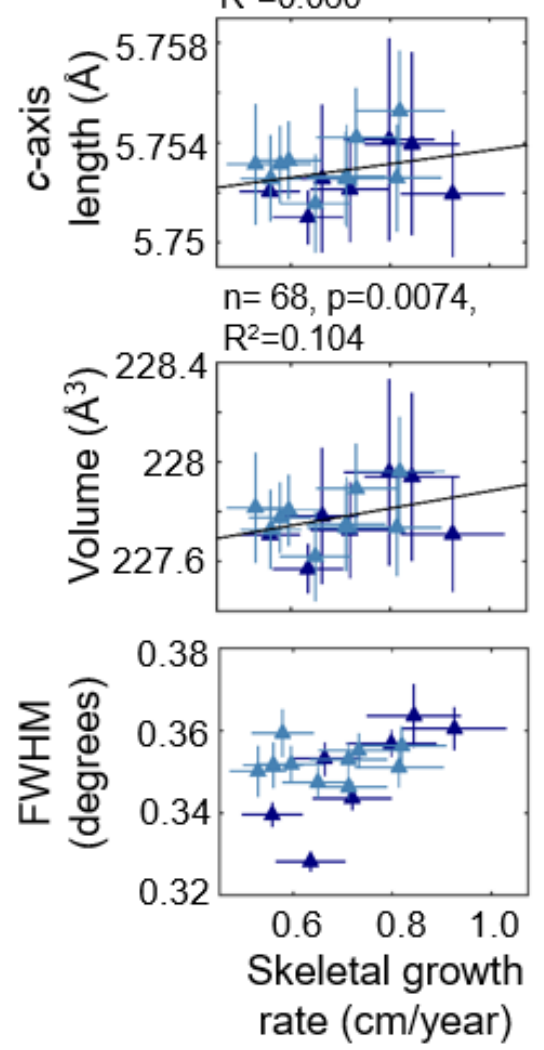

$n=60, p=2.7 E-5$,

$\mathrm{R}^{2}=0.235$.

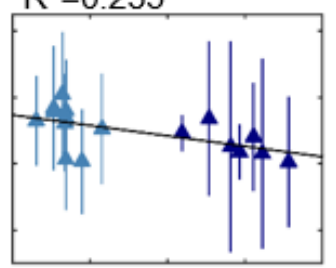

$\mathrm{n}=68, \mathrm{p}=0.0091$, $R^{2}=0.099$.
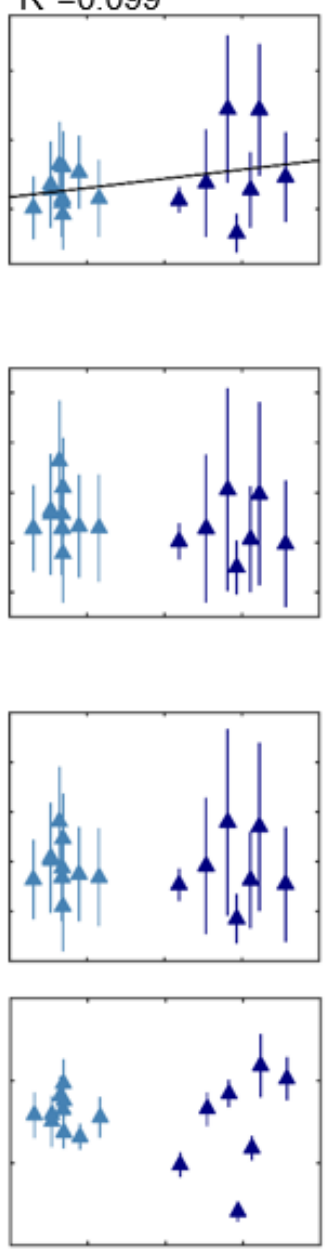

$1.3 \quad 1.4 \quad 1.5$

Density

$\left(\mathrm{g} / \mathrm{cm}^{3}\right)$

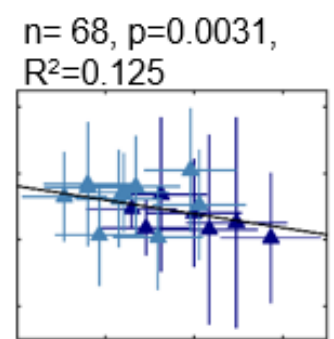

$\mathrm{n}=68, \mathrm{p}=0.0062$,

$\mathrm{R}^{2}=0.108$

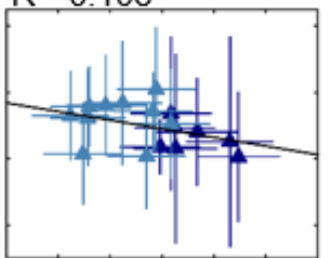

$\mathrm{n}=68, \mathrm{p}=2.4 \mathrm{E}-6$,

$\mathrm{R}^{2}=0.288$
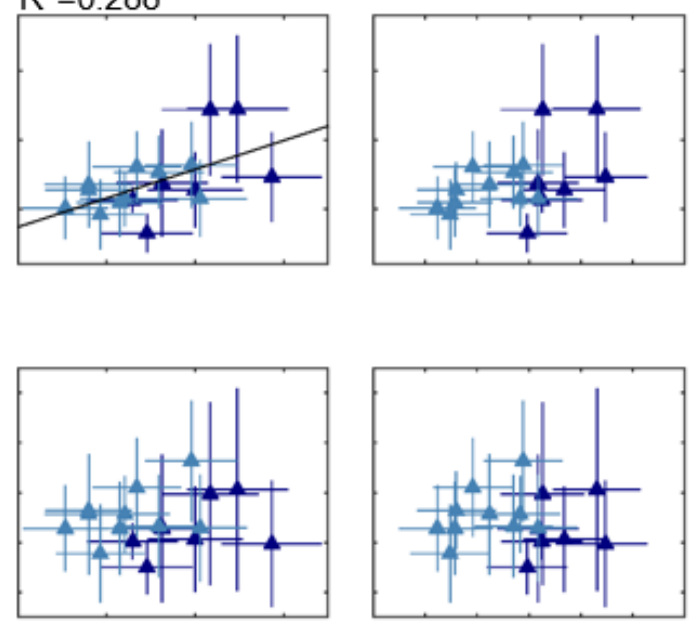

$\mathrm{n}=68, \mathrm{p}=0.0287$,

$\mathrm{R}^{2}=0.070$
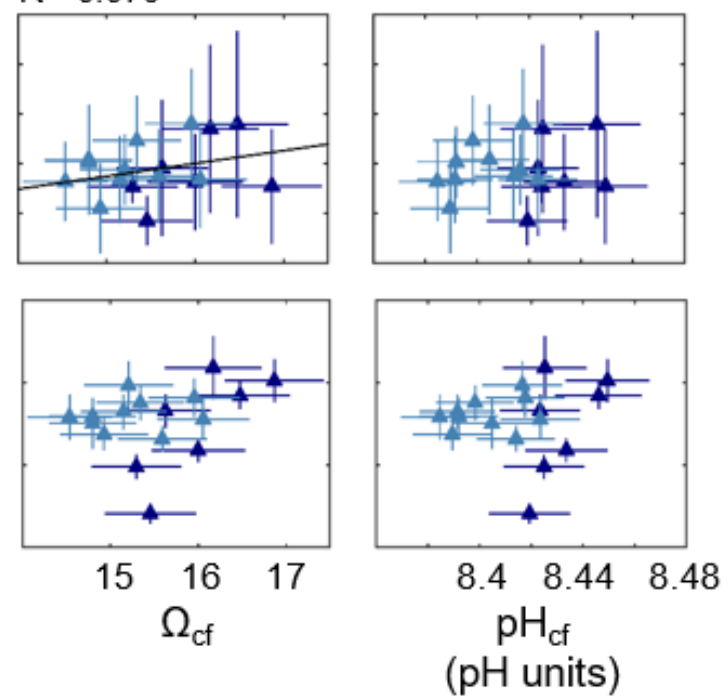

FIGURE S4.2. Skeletal aragonite mineralogical parameters in samples from the Dropoff site as a function of skeleton growth conditions: calcifying fluid $\mathrm{pH}\left(\mathrm{pH}_{\mathrm{cf}}\right)$, calcifying fluid aragonite saturation state $\left(\Omega_{\mathrm{cf}}\right)$, skeletal growth rate, and skeletal density. Linear regression trend lines are included for statistically significant relationships $(\mathrm{p}<0.05)$. 

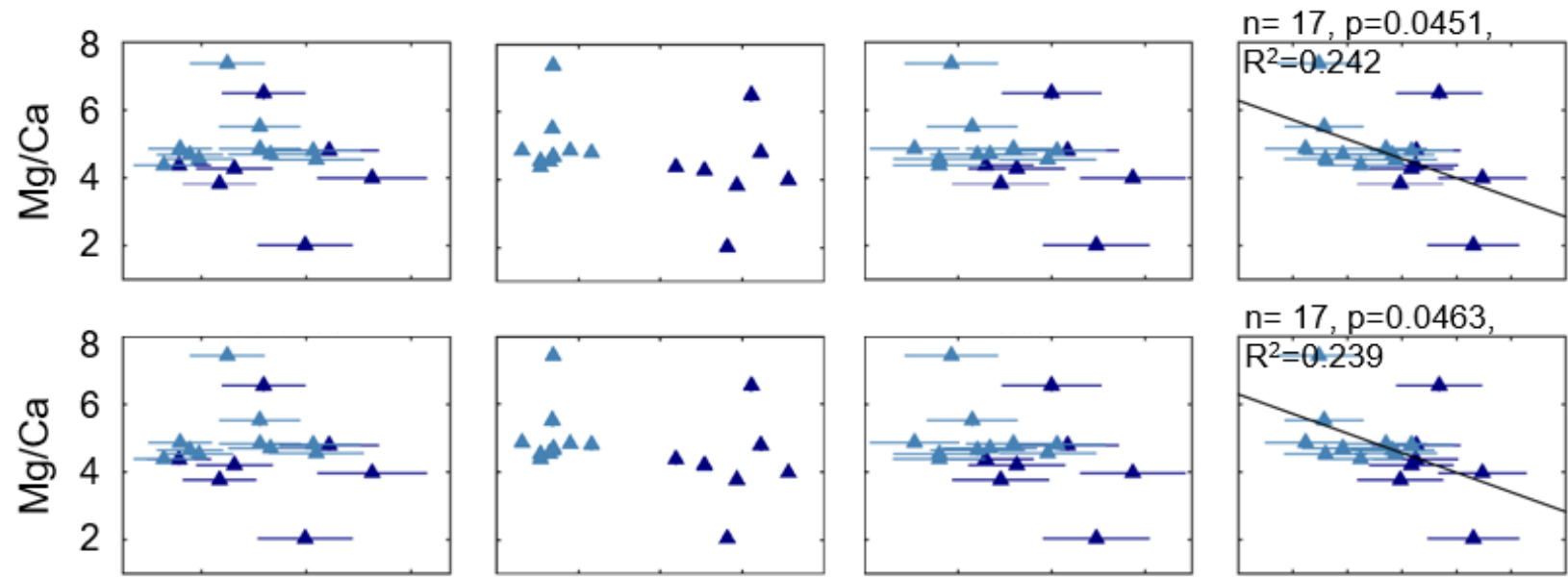

$\mathrm{n}=17, \mathrm{p}=0.0463$,
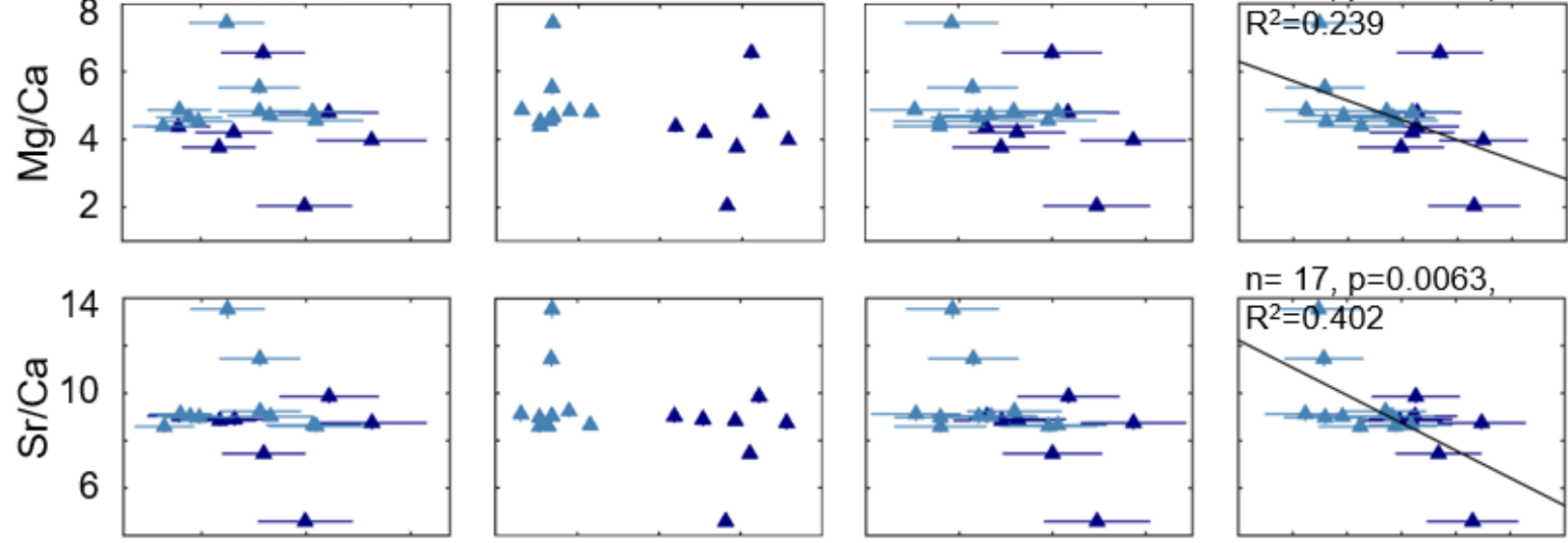

$\mathrm{n}=17, \mathrm{p}=0.0063$,
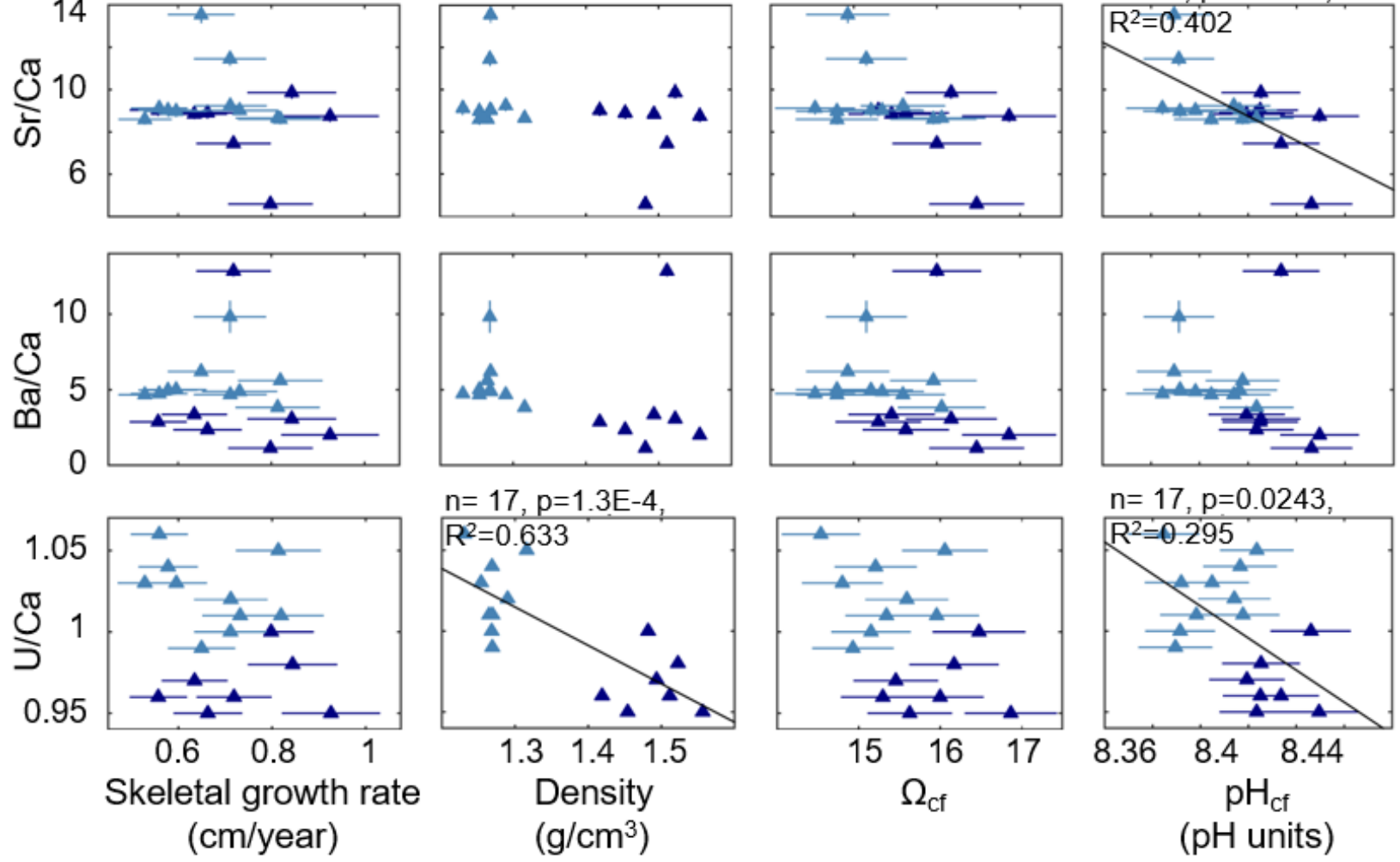

$\mathrm{n}=17, \mathrm{p}=0.0243$,

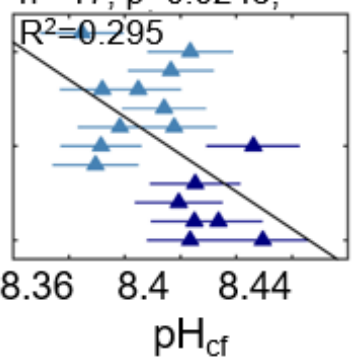

(pH units)

FIGURE S4.3. Skeletal aragonite mineralogical parameters in samples from the Dropoff site as a function of skeleton growth conditions (calcifying fluid $\mathrm{pH}\left(\mathrm{pH}_{\mathrm{cf}}\right)$, calcifying fluid aragonite saturation state $\left(\Omega_{\mathrm{cf}}\right)$, skeletal growth rate, and skeletal density). $\mathrm{Mg}$, Sr and Ba to Ca ratios are calculated based on a JCp-1 reference coral measured alongside the samples in this study with values for JCp-1 referenced in Hathorne et al., 2013. $\mathrm{Mg} / \mathrm{Ca}$ ratios are calculated from ${ }^{24} \mathrm{Mg}$ (top row) and ${ }^{25} \mathrm{Mg}$ (second row) concentrations, $\mathrm{Sr} / \mathrm{Ca}$ ratios are calculated from ${ }^{88} \mathrm{Sr}$, and $\mathrm{Ba} / \mathrm{Ca}$ ratios are calculated from ${ }^{138} \mathrm{Ba}$. U concentrations are from values in Mollica et al., 2018. Black trend lines are included for linear regressions which have statistically significant relationships $(\mathrm{p}<0.05)$. 

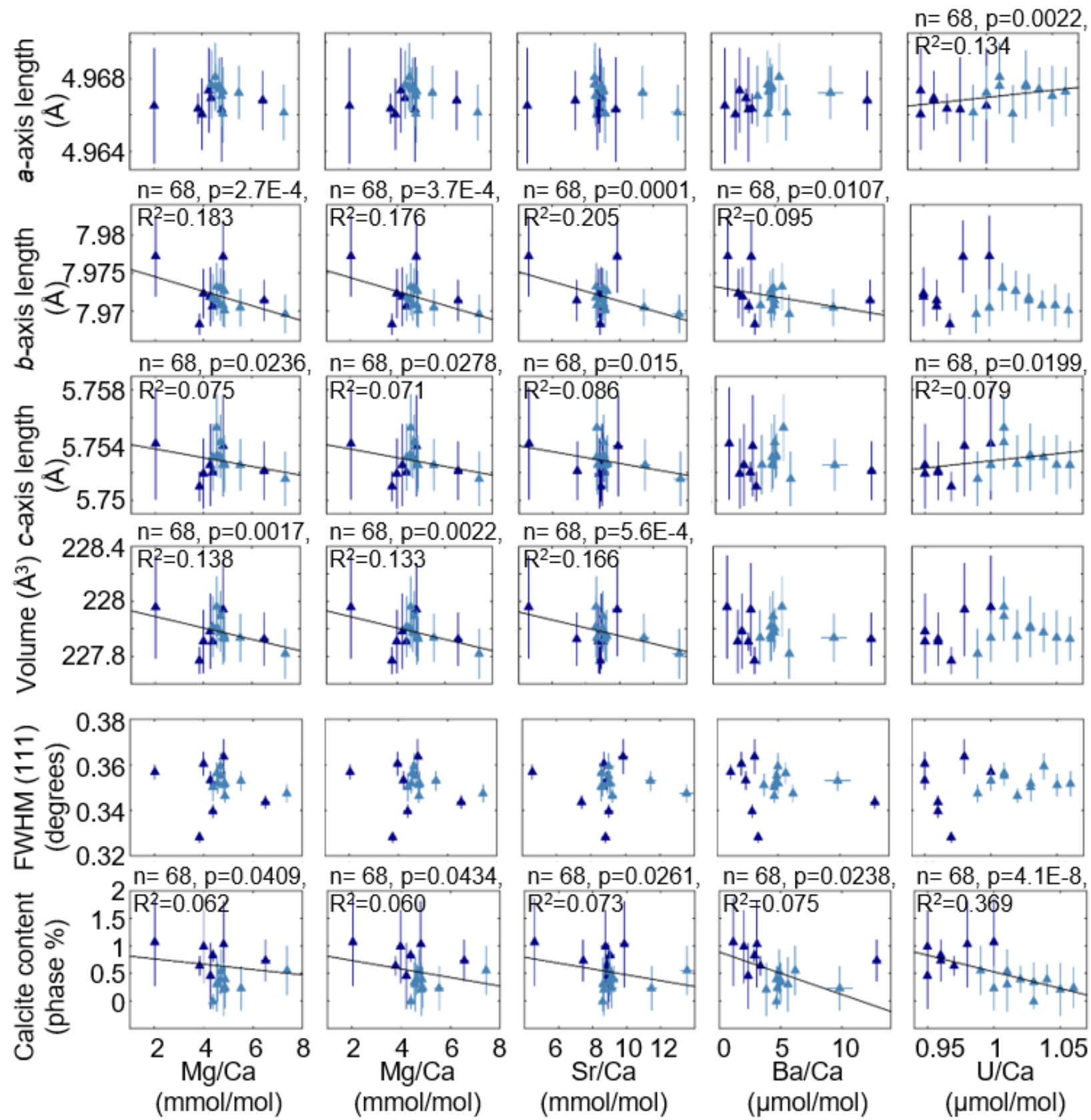

$\Delta$ Dropoff 221

Dropoff 229

FIGURE S4.4. Unit lattice parameters and calcite contents as a function of trace element incorporations in Dropoff site samples. 

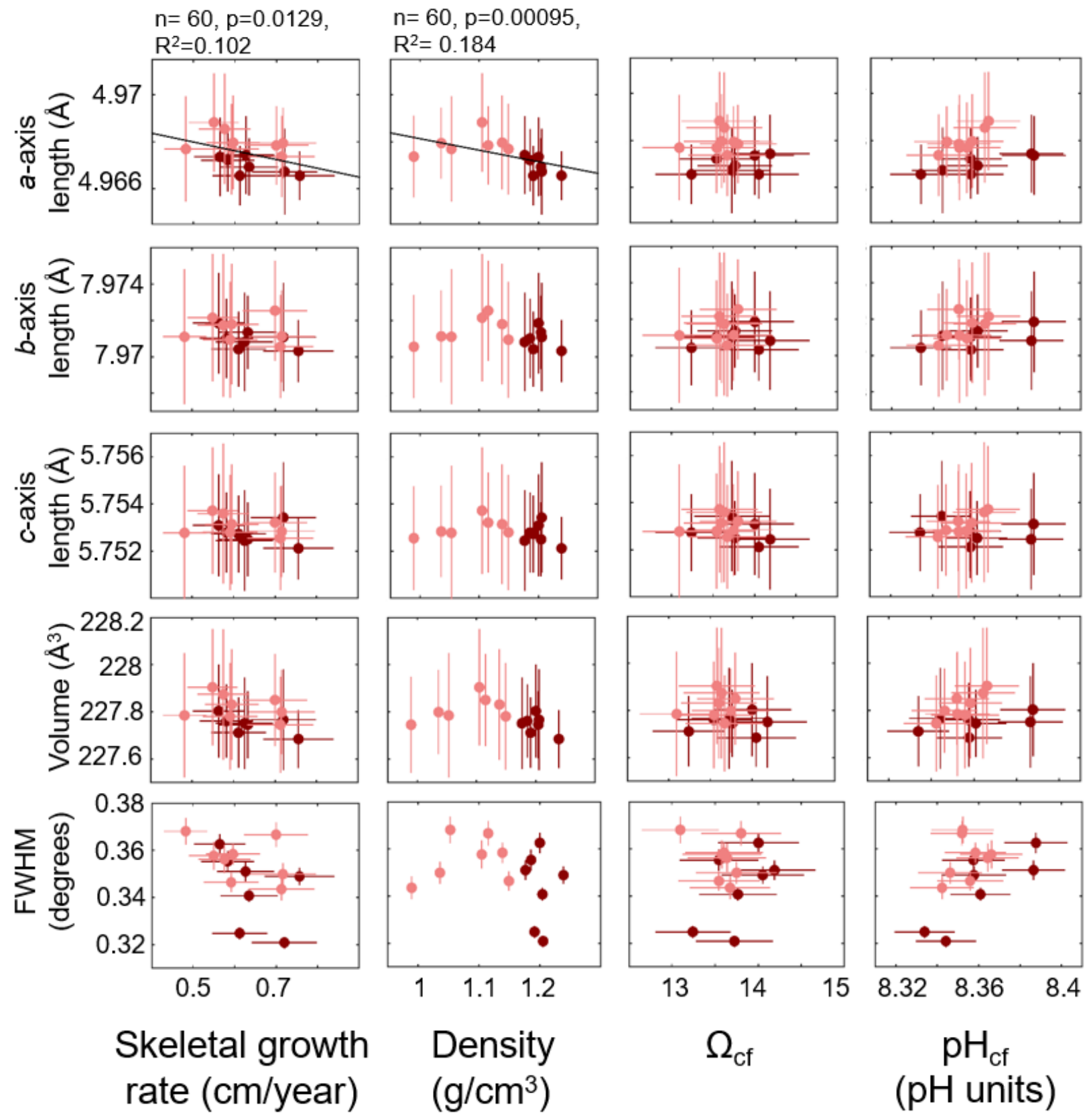

$\Omega_{\mathrm{cf}}$

FIGURE 4.5. Skeletal aragonite mineralogical parameters in samples from the low pHsw, low $\Omega$ sw Nikko Bay site as a function of skeleton growth conditions: calcifying fluid $\mathrm{pH}\left(\mathrm{pH}_{\mathrm{cf}}\right)$, calcifying fluid aragonite saturation state $\left(\Omega_{\mathrm{cf}}\right)$, skeletal growth rate, and skeletal density. Linear regression black trend lines are included for statistically significant relationships $(\mathrm{p}<0.05)$. 

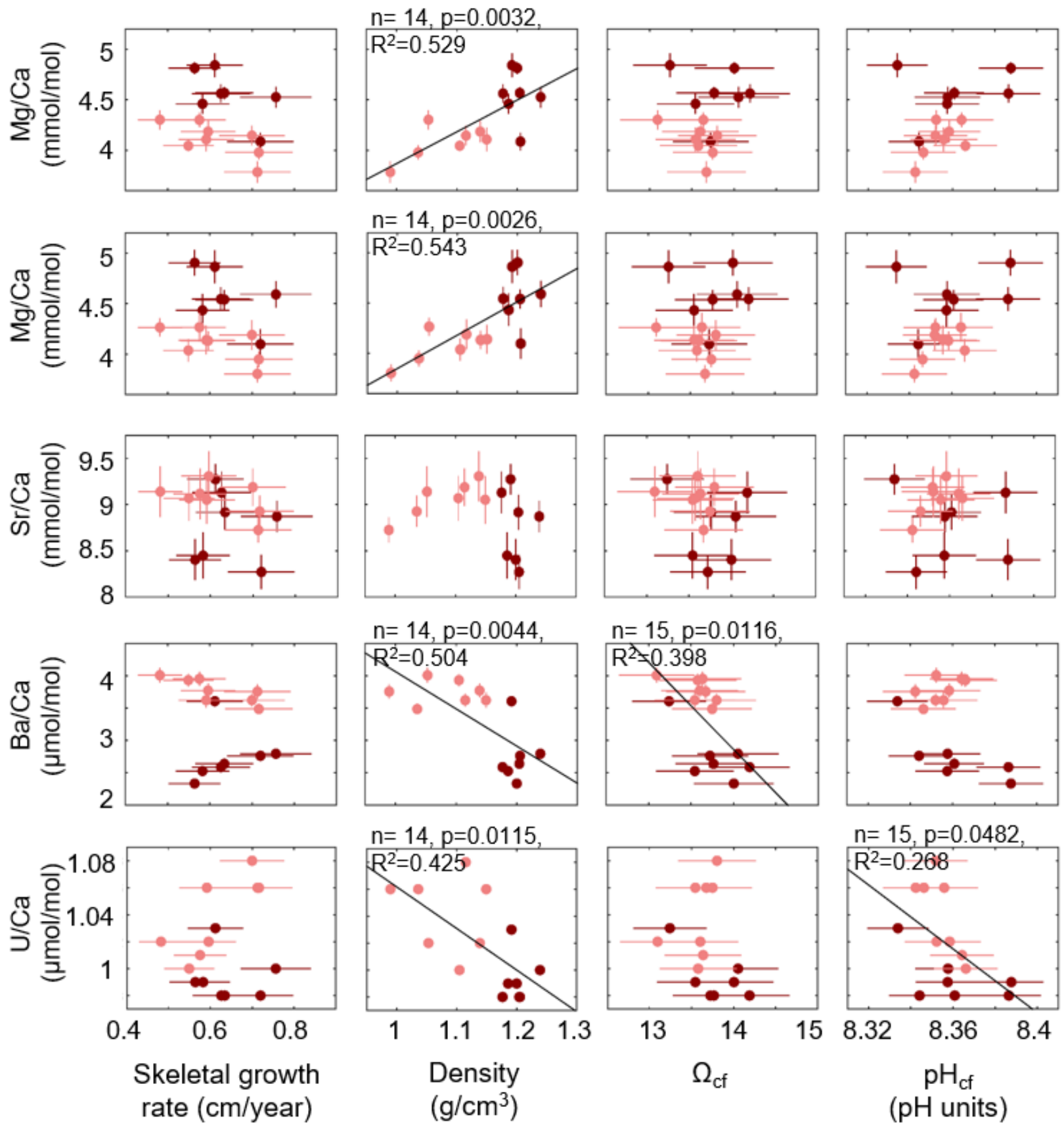

Nikko Bay 168

Nikko Bay 169

FIGURE S4.6. Trace element incorporations in Nikko Bay site samples as a function of skeletal growth parameters. 

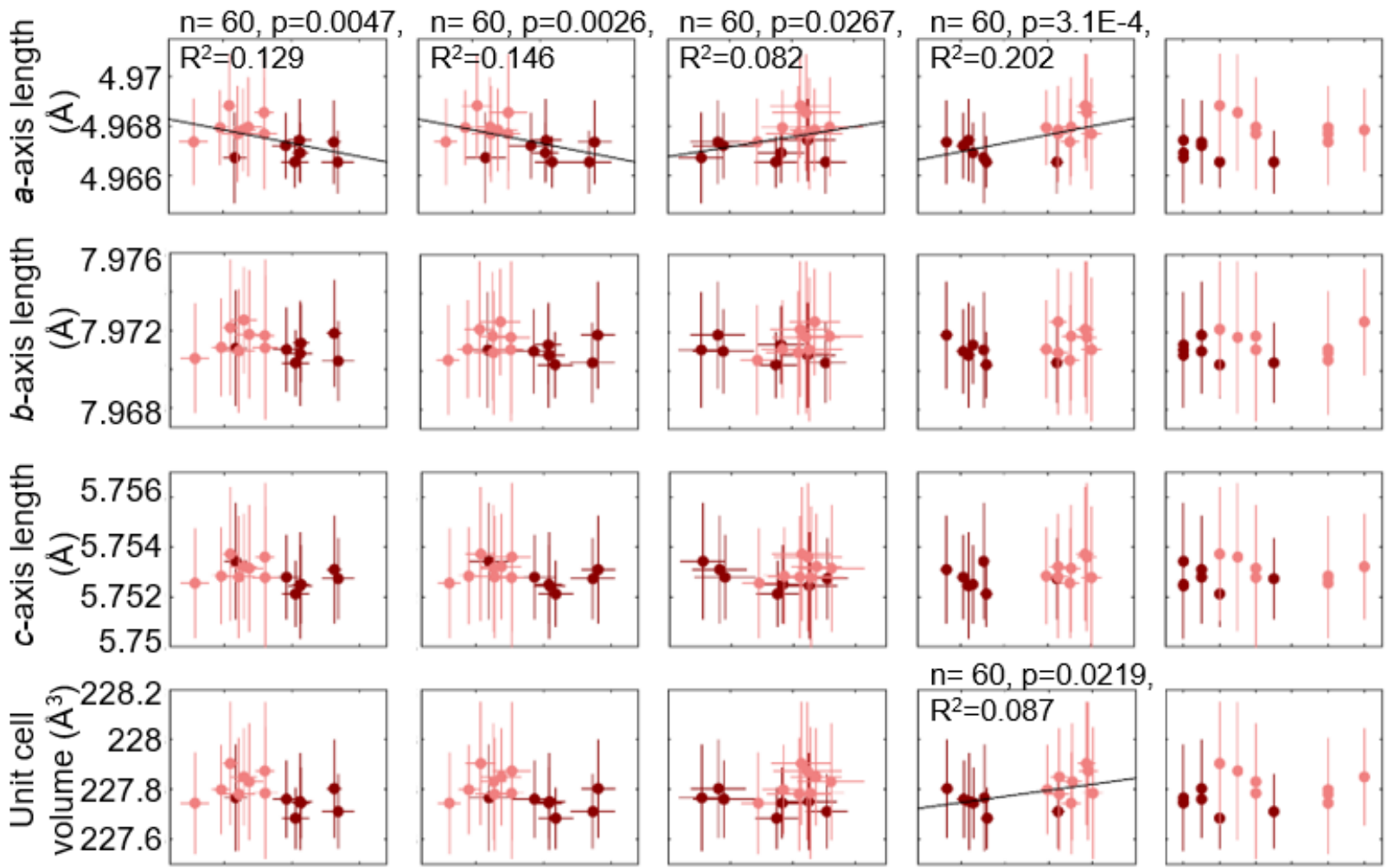

$n=60, p=0.0219$,
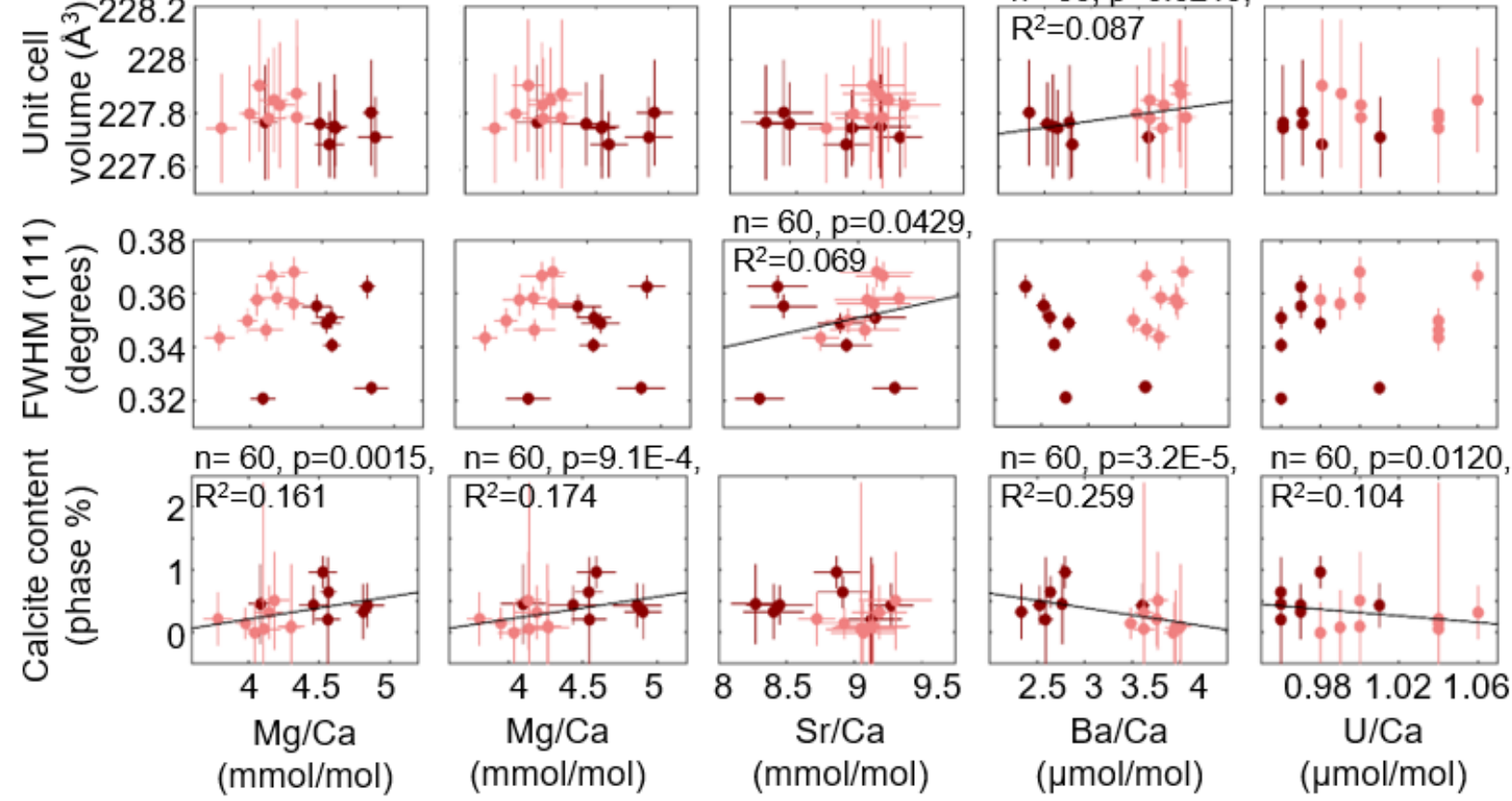

Nikko Bay 168

Nikko Bay 169

FIGURE S4.7. Unit lattice parameters and calcite contents as a function of trace element incorporations in Nikko Bay site samples. 

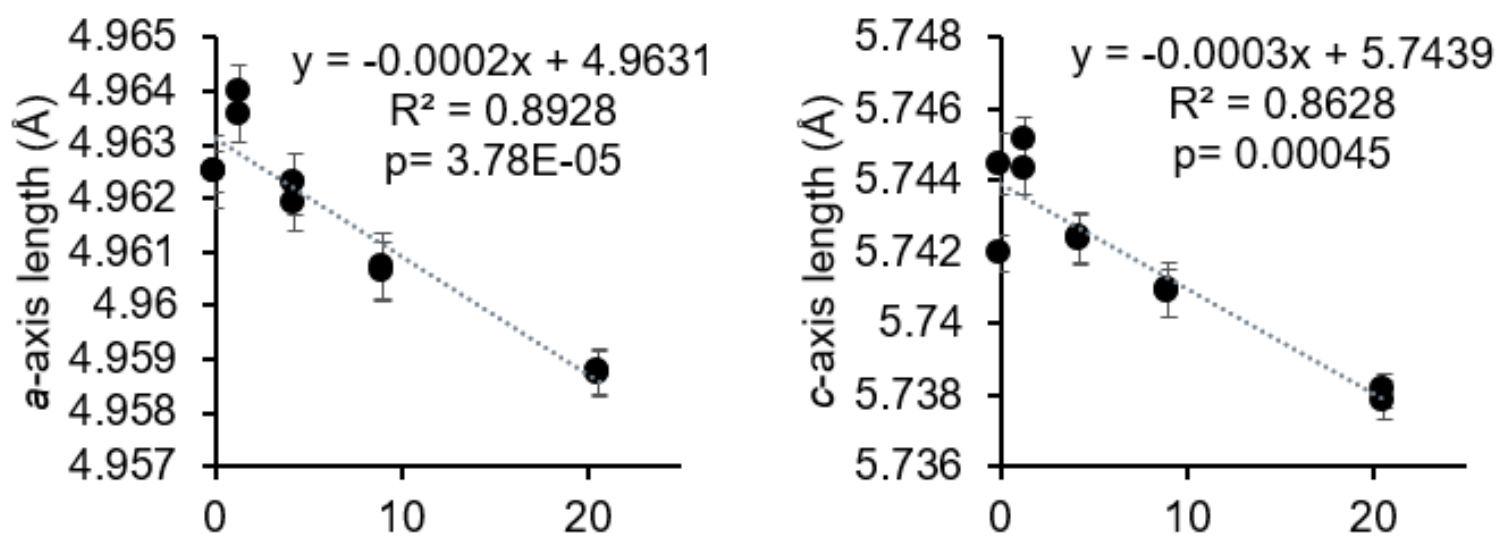

added calcite content (wt \%)

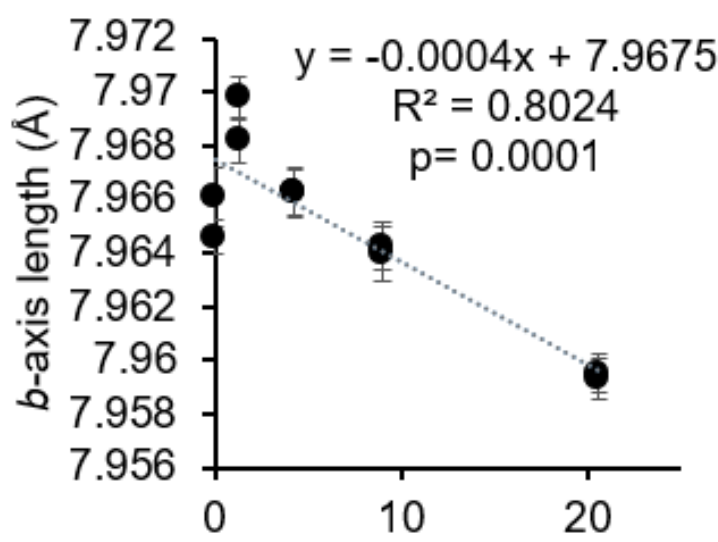

added calcite content (wt \%)

added calcite content (wt \%)
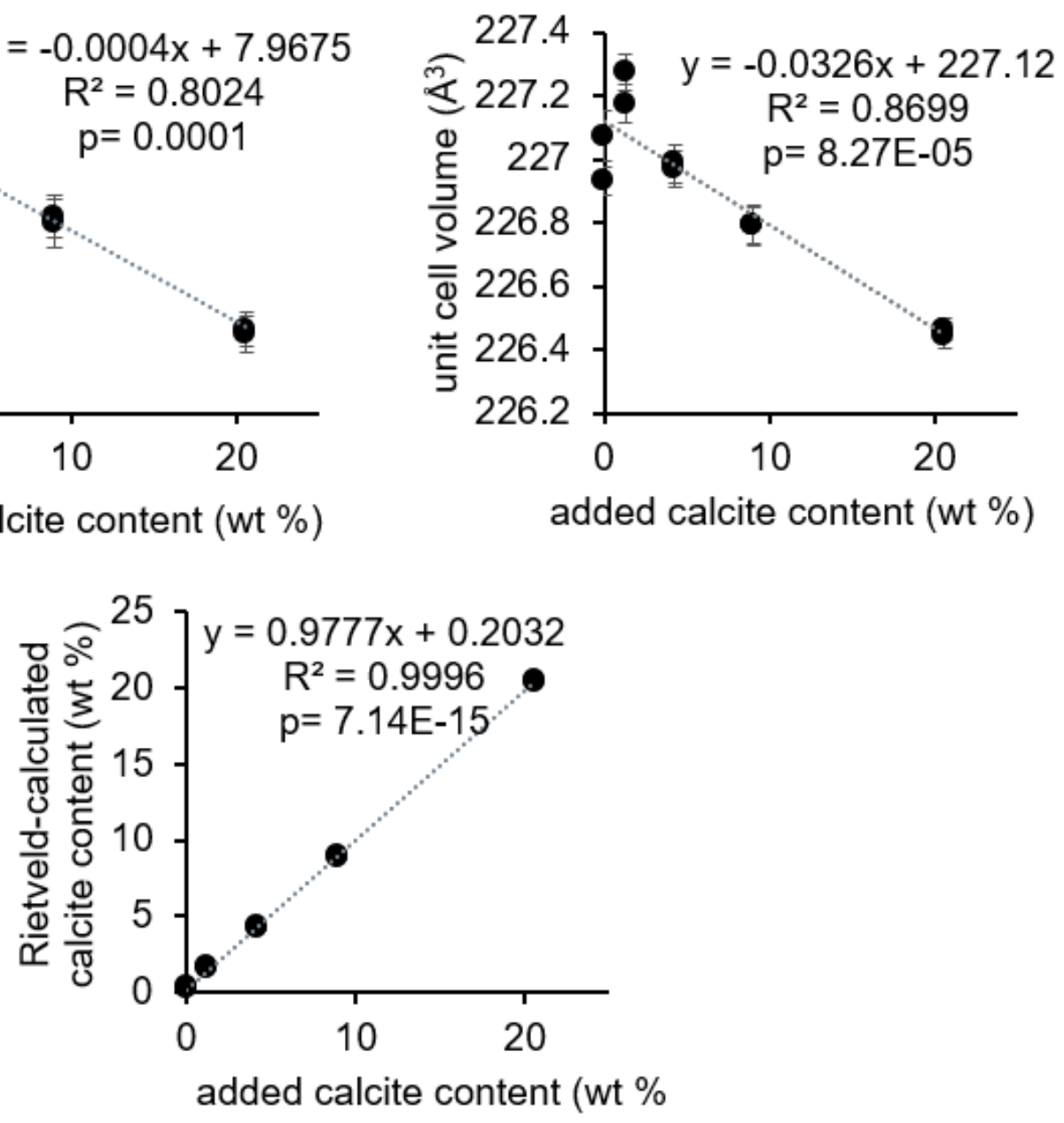

FIGURE S4.8. Unit lattice parameters as a function of calcite contents in mixed calcite:aragonite standards (natural, geologically-formed aragonite and calcite) analyzed with Rietveld refinements. Reitveld-calculated calcite contents (wt \%) versus mixed standards of known calcite contents. 


\subsection{Supplementary Material-Tables}

TABLE S4.1. Unit cell lattice parameters and mineralogy of coral samples from Dropoff and

Nikko Bay.

\begin{tabular}{|c|c|c|c|c|c|c|}
\hline- & $\begin{array}{l}a \text {-axis } \\
\text { length } \\
(\AA)\end{array}$ & $\begin{array}{l}b \text {-axis } \\
\text { length } \\
(\AA)\end{array}$ & $\begin{array}{l}c \text {-axis } \\
\text { length } \\
(\AA)\end{array}$ & $\begin{array}{l}\text { unit cell } \\
\text { volume } \\
\left(\AA^{3}\right)\end{array}$ & $\begin{array}{l}\text { FWHM } \\
\text { (111) peak } \\
\text { (degrees) }\end{array}$ & $\begin{array}{l}\text { Calcite } \\
\text { content } \\
\text { (phase \%) }\end{array}$ \\
\hline \multirow[t]{4}{*}{ Nikko168_29 } & $\begin{array}{l}4.966 \pm \\
0.0009\end{array}$ & $\begin{array}{l}7.97 \pm \\
0.0015\end{array}$ & $\begin{array}{l}5.7535 \pm \\
0.0012\end{array}$ & $\begin{array}{l}227.7 \pm \\
0.11\end{array}$ & $\begin{array}{l}0.3248 \pm \\
0.0022\end{array}$ & $0.3 \pm 0.21$ \\
\hline & $\begin{array}{l}4.9668 \pm \\
0.0006\end{array}$ & $\begin{array}{l}7.9709 \pm \\
0.0009\end{array}$ & $\begin{array}{l}5.7527 \pm \\
0.0007\end{array}$ & $\begin{array}{l}227.73 \pm \\
0.07\end{array}$ & $\begin{array}{l}0.3248 \pm \\
0.0022\end{array}$ & $0.41 \pm 0.12$ \\
\hline & $\begin{array}{l}4.9666 \pm \\
0.0005\end{array}$ & $\begin{array}{l}7.9703 \pm \\
0.0007\end{array}$ & $\begin{array}{l}5.7524 \pm \\
0.0006\end{array}$ & $\begin{array}{l}227.69 \pm \\
0.05\end{array}$ & $\begin{array}{l}0.3248 \pm \\
0.0022\end{array}$ & $0.53 \pm 0.1$ \\
\hline & $\begin{array}{l}4.9669 \pm \\
0.0004\end{array}$ & $\begin{array}{l}7.9705 \pm \\
0.0007\end{array}$ & $\begin{array}{l}5.7524 \pm \\
0.0006\end{array}$ & $\begin{array}{l}227.71 \pm \\
0.05\end{array}$ & $\begin{array}{l}0.3248 \pm \\
0.0022\end{array}$ & $0.48 \pm 0.09$ \\
\hline \multirow[t]{4}{*}{ Nikko168_31 } & $\begin{array}{l}4.9665 \pm \\
0.0012\end{array}$ & $\begin{array}{l}7.9713 \pm \\
0.0019\end{array}$ & $\begin{array}{l}5.7553 \pm \\
0.0015\end{array}$ & $\begin{array}{l}227.84 \pm \\
0.14\end{array}$ & $\begin{array}{l}0.3209 \pm \\
0.0022\end{array}$ & $0.3 \pm 0.33$ \\
\hline & $\begin{array}{l}4.9667 \pm \\
0.0009\end{array}$ & $\begin{array}{l}7.9723 \pm \\
0.0015\end{array}$ & $\begin{array}{l}5.7534 \pm \\
0.0012\end{array}$ & $\begin{array}{l}227.8 \pm \\
0.11\end{array}$ & $\begin{array}{l}0.3209 \pm \\
0.0022\end{array}$ & $0.48 \pm 0.23$ \\
\hline & $\begin{array}{l}4.9669 \pm \\
0.001\end{array}$ & $\begin{array}{l}7.9713 \pm \\
0.0016\end{array}$ & $\begin{array}{l}5.7535 \pm \\
0.0012\end{array}$ & $\begin{array}{l}227.79 \pm \\
0.11\end{array}$ & $\begin{array}{l}0.3209 \pm \\
0.0022\end{array}$ & $0.42 \pm 0.28$ \\
\hline & $\begin{array}{l}4.9668 \pm \\
0.0004\end{array}$ & $\begin{array}{l}7.9694 \pm \\
0.0006\end{array}$ & $\begin{array}{l}5.7515 \pm \\
0.0005\end{array}$ & $\begin{array}{l}227.64 \pm \\
0.04\end{array}$ & $\begin{array}{l}0.3209 \pm \\
0.0022\end{array}$ & $0.61 \pm 0.08$ \\
\hline \multirow[t]{4}{*}{ Nikko168_33 } & $\begin{array}{l}4.9655 \pm \\
0.0005\end{array}$ & $\begin{array}{l}7.9694 \pm \\
0.0008\end{array}$ & $\begin{array}{l}5.7523 \pm \\
0.0006\end{array}$ & $\begin{array}{l}227.62 \pm \\
0.06\end{array}$ & $\begin{array}{l}0.3489 \pm \\
0.0034\end{array}$ & $0.92 \pm 0.12$ \\
\hline & $\begin{array}{l}4.9668 \pm \\
0.0005\end{array}$ & $\begin{array}{l}7.9702 \pm \\
0.0008\end{array}$ & $\begin{array}{l}5.7516 \pm \\
0.0006\end{array}$ & $\begin{array}{l}227.67 \pm \\
0.06\end{array}$ & $\begin{array}{l}0.3489 \pm \\
0.0034\end{array}$ & $0.98 \pm 0.12$ \\
\hline & $\begin{array}{l}4.967 \pm \\
0.0005\end{array}$ & $\begin{array}{l}7.9702 \pm \\
0.0008\end{array}$ & $\begin{array}{l}5.7525 \pm \\
0.0006\end{array}$ & $\begin{array}{l}227.72 \pm \\
0.06\end{array}$ & $\begin{array}{l}0.3489 \pm \\
0.0034\end{array}$ & $0.85 \pm 0.12$ \\
\hline & $\begin{array}{l}4.967 \pm \\
0.0006\end{array}$ & $\begin{array}{l}7.9715 \pm \\
0.001\end{array}$ & $\begin{array}{l}5.752 \pm \\
0.0007 \\
\end{array}$ & $\begin{array}{l}227.73 \pm \\
0.07\end{array}$ & $\begin{array}{l}0.3489 \pm \\
0.0034\end{array}$ & $1.08 \pm 0.14$ \\
\hline \multirow[t]{4}{*}{ Nikko168_35 } & $\begin{array}{l}4.9669 \pm \\
0.0006\end{array}$ & $\begin{array}{l}7.9713 \pm \\
0.001\end{array}$ & $\begin{array}{l}5.7528 \pm \\
0.0008\end{array}$ & $\begin{array}{l}227.76 \pm \\
0.07\end{array}$ & $\begin{array}{l}0.3408 \pm \\
0.0025\end{array}$ & $0.51 \pm 0.14$ \\
\hline & $\begin{array}{l}4.9667 \pm \\
0.0006\end{array}$ & $\begin{array}{l}7.9713 \pm \\
0.0009\end{array}$ & $\begin{array}{l}5.7522 \pm \\
0.0007\end{array}$ & $\begin{array}{l}227.72 \pm \\
0.07\end{array}$ & $\begin{array}{l}0.3408 \pm \\
0.0025\end{array}$ & $0.64 \pm 0.12$ \\
\hline & $\begin{array}{l}4.9668 \pm \\
0.0005\end{array}$ & $\begin{array}{l}7.9709 \pm \\
0.0009\end{array}$ & $\begin{array}{l}5.7522 \pm \\
0.0007\end{array}$ & $\begin{array}{l}227.71 \pm \\
0.06\end{array}$ & $\begin{array}{l}0.3408 \pm \\
0.0025\end{array}$ & $0.67 \pm 0.06$ \\
\hline & $\begin{array}{l}4.9673 \pm \\
0.0007\end{array}$ & $\begin{array}{l}7.9719 \pm \\
0.0011\end{array}$ & $\begin{array}{l}5.7528 \pm \\
0.0009\end{array}$ & $\begin{array}{l}227.79 \pm \\
0.08\end{array}$ & $\begin{array}{l}0.3408 \pm \\
0.0025\end{array}$ & $0.74 \pm 0.14$ \\
\hline \multirow[t]{2}{*}{ Nikko168_37 } & $\begin{array}{l}4.9672 \pm \\
0.0006\end{array}$ & $\begin{array}{l}7.971 \pm \\
0.0011\end{array}$ & $\begin{array}{l}5.753 \pm \\
0.0008\end{array}$ & $\begin{array}{l}227.77 \pm \\
0.08\end{array}$ & $\begin{array}{l}0.355 \pm \\
0.004\end{array}$ & $0.4 \pm 0.14$ \\
\hline & $\begin{array}{l}4.9674 \pm \\
0.0006\end{array}$ & $\begin{array}{l}7.9716 \pm \\
0.001\end{array}$ & $\begin{array}{l}5.7527 \pm \\
0.0008\end{array}$ & $\begin{array}{l}227.78 \pm \\
0.07\end{array}$ & $\begin{array}{l}0.355 \pm \\
0.004\end{array}$ & $46 \pm 0.14$ \\
\hline
\end{tabular}




\begin{tabular}{|c|c|c|c|c|c|c|}
\hline & $\begin{array}{l}4.9672 \pm \\
0.0007\end{array}$ & $\begin{array}{l}7.9709 \pm \\
0.0011\end{array}$ & $\begin{array}{l}5.7529 \pm \\
0.0009\end{array}$ & $\begin{array}{l}227.76 \pm \\
0.08\end{array}$ & $\begin{array}{l}0.355 \pm \\
0.004\end{array}$ & $0.39 \pm 0.16$ \\
\hline & $\begin{array}{l}4.967 \pm \\
0.0007\end{array}$ & $\begin{array}{l}7.9705 \pm \\
0.0011\end{array}$ & $\begin{array}{l}5.7525 \pm \\
0.0008\end{array}$ & $\begin{array}{l}227.73 \pm \\
0.08\end{array}$ & $\begin{array}{l}0.355 \pm \\
0.004\end{array}$ & $0.48 \pm 0.15$ \\
\hline \multirow[t]{4}{*}{ Nikko168_39 } & $\begin{array}{l}4.967 \pm \\
0.0008\end{array}$ & $\begin{array}{l}7.971 \pm \\
0.0014\end{array}$ & $\begin{array}{l}5.7526 \pm \\
0.0011\end{array}$ & $\begin{array}{l}227.74 \pm \\
0.1\end{array}$ & $\begin{array}{l}0.363 \pm \\
0.004\end{array}$ & $0.42 \pm 0.41$ \\
\hline & $\begin{array}{l}4.9677 \pm \\
0.0008\end{array}$ & $\begin{array}{l}7.9723 \pm \\
0.0013\end{array}$ & $\begin{array}{l}5.7536 \pm \\
0.001\end{array}$ & $\begin{array}{l}227.85 \pm \\
0.09\end{array}$ & $\begin{array}{l}0.363 \pm \\
0.004\end{array}$ & $0.34 \pm 0.09$ \\
\hline & $\begin{array}{l}4.9673 \pm \\
0.0008\end{array}$ & $\begin{array}{l}7.9727 \pm \\
0.0014\end{array}$ & $\begin{array}{l}5.7532 \pm \\
0.0011\end{array}$ & $\begin{array}{l}227.83 \pm \\
0.1\end{array}$ & $\begin{array}{l}0.363 \pm \\
0.004\end{array}$ & $0.28 \pm 0.09$ \\
\hline & $\begin{array}{l}4.9674 \pm \\
0.0008\end{array}$ & $\begin{array}{l}7.9714 \pm \\
0.0014\end{array}$ & $\begin{array}{l}5.753 \pm \\
0.0011\end{array}$ & $\begin{array}{l}227.79 \pm \\
0.1\end{array}$ & $\begin{array}{l}0.363 \pm \\
0.004\end{array}$ & $0.25 \pm 0.2$ \\
\hline \multirow[t]{4}{*}{ Nikko168_41 } & $\begin{array}{l}4.9678 \pm \\
0.0007\end{array}$ & $\begin{array}{l}7.9711 \pm \\
0.0011\end{array}$ & $\begin{array}{l}5.7527 \pm \\
0.0009\end{array}$ & $\begin{array}{l}227.79 \pm \\
0.08\end{array}$ & $\begin{array}{l}0.351 \pm \\
0.004\end{array}$ & $0.35 \pm 0.16$ \\
\hline & $\begin{array}{l}4.967 \pm \\
0.001\end{array}$ & $\begin{array}{l}7.9702 \pm \\
0.0016\end{array}$ & $\begin{array}{l}5.752 \pm \\
0.0013\end{array}$ & $\begin{array}{l}227.7 \pm \\
0.12\end{array}$ & $\begin{array}{l}0.351 \pm \\
0.004\end{array}$ & $-0.06 \pm 0.28$ \\
\hline & $\begin{array}{l}4.9677 \pm \\
0.0008\end{array}$ & $\begin{array}{l}7.9717 \pm \\
0.0013\end{array}$ & $\begin{array}{l}5.7527 \pm \\
0.001\end{array}$ & $\begin{array}{l}227.8 \pm \\
0.09\end{array}$ & $\begin{array}{l}0.351 \pm \\
0.004\end{array}$ & $0.25 \pm 0.19$ \\
\hline & $\begin{array}{l}4.9672 \pm \\
0.0008 \\
\end{array}$ & $\begin{array}{l}7.9702 \pm \\
0.0012 \\
\end{array}$ & $\begin{array}{l}5.7524 \pm \\
0.001\end{array}$ & $\begin{array}{l}227.72 \pm \\
0.09\end{array}$ & $\begin{array}{l}0.351 \pm \\
0.004\end{array}$ & $0.27 \pm 0.19$ \\
\hline \multirow[t]{4}{*}{ Nikko169_75 } & $\begin{array}{l}4.9659 \pm \\
0.0006\end{array}$ & $\begin{array}{l}7.9683 \pm \\
0.001\end{array}$ & $\begin{array}{l}5.7509 \pm \\
0.0008\end{array}$ & $\begin{array}{l}227.54 \pm \\
0.07\end{array}$ & $\begin{array}{l}0.344 \pm \\
0.005\end{array}$ & $0.23 \pm 0.17$ \\
\hline & $\begin{array}{l}4.9666 \pm \\
0.0007\end{array}$ & $\begin{array}{l}7.9705 \pm \\
0.0012\end{array}$ & $\begin{array}{l}5.7518 \pm \\
0.0009\end{array}$ & $\begin{array}{l}227.68 \pm \\
0.09\end{array}$ & $\begin{array}{l}0.344 \pm \\
0.005\end{array}$ & $0.32 \pm 0.21$ \\
\hline & $\begin{array}{l}4.9676 \pm \\
0.0009\end{array}$ & $\begin{array}{l}7.97 \pm \\
0.0015\end{array}$ & $\begin{array}{l}5.7532 \pm \\
0.0012\end{array}$ & $\begin{array}{l}227.76 \pm \\
0.11\end{array}$ & $\begin{array}{l}0.344 \pm \\
0.005\end{array}$ & $0.19 \pm 0.14$ \\
\hline & $\begin{array}{l}4.9695 \pm \\
0.001\end{array}$ & $\begin{array}{l}7.9735 \pm \\
0.0017\end{array}$ & $\begin{array}{l}5.7543 \pm \\
0.0013\end{array}$ & $\begin{array}{l}228 \pm \\
0.12 \\
\end{array}$ & $\begin{array}{l}0.344 \pm \\
0.005\end{array}$ & $0.11 \pm 0.16$ \\
\hline \multirow[t]{4}{*}{ Nikko169_76 } & $\begin{array}{l}4.9677 \pm \\
0.0007\end{array}$ & $\begin{array}{l}7.9706 \pm \\
0.0011\end{array}$ & $\begin{array}{l}5.7525 \pm \\
0.0009\end{array}$ & $\begin{array}{l}227.76 \pm \\
0.08\end{array}$ & $\begin{array}{l}0.35 \pm \\
0.004\end{array}$ & $0.18 \pm 0.14$ \\
\hline & $\begin{array}{l}4.9682 \pm \\
0.0007\end{array}$ & $\begin{array}{l}7.9711 \pm \\
0.0012\end{array}$ & $\begin{array}{l}5.753 \pm \\
0.001\end{array}$ & $\begin{array}{l}227.82 \pm \\
0.09\end{array}$ & $\begin{array}{l}0.35 \pm \\
0.004\end{array}$ & $0.14 \pm 0.16$ \\
\hline & $\begin{array}{l}4.968 \pm \\
0.0008\end{array}$ & $\begin{array}{l}7.9713 \pm \\
0.0013\end{array}$ & $\begin{array}{l}5.7531 \pm \\
0.001\end{array}$ & $\begin{array}{l}227.81 \pm \\
0.09\end{array}$ & $\begin{array}{l}0.35 \pm \\
0.004\end{array}$ & $0.11 \pm 0.09$ \\
\hline & $\begin{array}{l}4.9679 \pm \\
0.0008\end{array}$ & $\begin{array}{l}7.9715 \pm \\
0.0013\end{array}$ & $\begin{array}{l}5.7528 \pm \\
0.001\end{array}$ & $\begin{array}{l}227.8 \pm \\
0.1\end{array}$ & $\begin{array}{l}0.35 \pm \\
0.004\end{array}$ & $0.13 \pm 0.09$ \\
\hline \multirow[t]{3}{*}{ Nikko169_77 } & $\begin{array}{l}4.9679 \pm \\
0.0006\end{array}$ & $\begin{array}{l}7.9716 \pm \\
0.001\end{array}$ & $\begin{array}{l}5.7535 \pm \\
0.0008\end{array}$ & $\begin{array}{l}227.84 \pm \\
0.07\end{array}$ & $\begin{array}{l}0.367 \pm \\
0.005\end{array}$ & $0.45 \pm 0.12$ \\
\hline & $\begin{array}{l}4.9681 \pm \\
0.0008\end{array}$ & $\begin{array}{l}7.973 \pm \\
0.0014\end{array}$ & $\begin{array}{l}5.7533 \pm \\
0.0011\end{array}$ & $\begin{array}{l}227.88 \pm \\
0.1\end{array}$ & $\begin{array}{l}0.367 \pm \\
0.005\end{array}$ & $0.3 \pm 0.19$ \\
\hline & $\begin{array}{l}4.9676 \pm \\
0.0009\end{array}$ & $\begin{array}{l}7.9727 \pm \\
0.0015\end{array}$ & $\begin{array}{l}5.7531 \pm \\
0.0011\end{array}$ & $\begin{array}{l}227.84 \pm \\
0.11\end{array}$ & $\begin{array}{l}0.367 \pm \\
0.005\end{array}$ & $0.27 \pm 0.2$ \\
\hline
\end{tabular}




\begin{tabular}{|c|c|c|c|c|c|c|}
\hline & $\begin{array}{l}4.9679 \pm \\
0.0009\end{array}$ & $\begin{array}{l}7.9729 \pm \\
0.0015\end{array}$ & $\begin{array}{l}5.753 \pm \\
0.0011\end{array}$ & $\begin{array}{l}227.85 \pm \\
0.11\end{array}$ & $\begin{array}{l}0.367 \pm \\
0.005\end{array}$ & $0.23 \pm 0.2$ \\
\hline \multirow[t]{4}{*}{ Nikko169_78 } & $\begin{array}{l}4.9679 \pm \\
0.0009\end{array}$ & $\begin{array}{l}7.971 \pm \\
0.0014\end{array}$ & $\begin{array}{l}5.7531 \pm \\
0.0011\end{array}$ & $\begin{array}{l}227.8 \pm \\
0.1\end{array}$ & $\begin{array}{l}0.346 \pm \\
0.004\end{array}$ & $0.11 \pm 0.11$ \\
\hline & $\begin{array}{l}4.9677 \pm \\
0.001\end{array}$ & $\begin{array}{l}7.9709 \pm \\
0.0017\end{array}$ & $\begin{array}{l}5.7528 \pm \\
0.0013\end{array}$ & $\begin{array}{l}227.78 \pm \\
0.12\end{array}$ & $\begin{array}{l}0.346 \pm \\
0.004\end{array}$ & $0 \pm 0.12$ \\
\hline & $\begin{array}{l}4.9672 \pm \\
0.001\end{array}$ & $\begin{array}{l}7.9703 \pm \\
0.0016\end{array}$ & $\begin{array}{l}5.7523 \pm \\
0.0012\end{array}$ & $\begin{array}{l}227.72 \pm \\
0.11\end{array}$ & $\begin{array}{l}0.346 \pm \\
0.004\end{array}$ & $0.06 \pm 0.11$ \\
\hline & $\begin{array}{l}4.968 \pm \\
0.001\end{array}$ & $\begin{array}{l}7.9715 \pm \\
0.0016\end{array}$ & $\begin{array}{l}5.753 \pm \\
0.0012\end{array}$ & $\begin{array}{l}227.82 \pm \\
0.11\end{array}$ & $\begin{array}{l}0.346 \pm \\
0.004\end{array}$ & $0.04 \pm 0.12$ \\
\hline \multirow[t]{4}{*}{ Nikko169_79 } & $\begin{array}{l}4.9691 \pm \\
0.0013\end{array}$ & $\begin{array}{l}7.9745 \pm \\
0.0021\end{array}$ & $\begin{array}{l}5.7547 \pm \\
0.0016\end{array}$ & $\begin{array}{l}228.02 \pm \\
0.15\end{array}$ & $\begin{array}{l}0.358 \pm \\
0.004\end{array}$ & $0.22 \pm 0.31$ \\
\hline & $\begin{array}{l}4.9679 \pm \\
0.0009\end{array}$ & $\begin{array}{l}7.9706 \pm \\
0.0014\end{array}$ & $\begin{array}{l}5.7526 \pm \\
0.0011\end{array}$ & $\begin{array}{l}227.77 \pm \\
0.1\end{array}$ & $\begin{array}{l}0.358 \pm \\
0.004\end{array}$ & $0.54 \pm 0.2$ \\
\hline & $\begin{array}{l}4.9669 \pm \\
0.0009\end{array}$ & $\begin{array}{l}7.9703 \pm \\
0.0014\end{array}$ & $\begin{array}{l}5.7525 \pm \\
0.0011\end{array}$ & $\begin{array}{l}227.71 \pm \\
0.1\end{array}$ & $\begin{array}{l}0.358 \pm \\
0.004\end{array}$ & $0.58 \pm 0.21$ \\
\hline & $\begin{array}{l}4.968 \pm \\
0.0009\end{array}$ & $\begin{array}{l}7.9718 \pm \\
0.0015\end{array}$ & $\begin{array}{l}5.7528 \pm \\
0.0011\end{array}$ & $\begin{array}{l}227.82 \pm \\
0.1\end{array}$ & $\begin{array}{l}0.358 \pm \\
0.004\end{array}$ & $0.67 \pm 0.22$ \\
\hline \multirow[t]{4}{*}{ Nikko169_80 } & $\begin{array}{l}4.9678 \pm \\
0.0008\end{array}$ & $\begin{array}{l}7.9706 \pm \\
0.0013\end{array}$ & $\begin{array}{l}5.7523 \pm \\
0.001\end{array}$ & $\begin{array}{l}227.76 \pm \\
0.09\end{array}$ & $\begin{array}{l}0.358 \pm \\
0.006\end{array}$ & $0.02 \pm 0.09$ \\
\hline & $\begin{array}{l}4.9686 \pm \\
0.001\end{array}$ & $\begin{array}{l}7.9717 \pm \\
0.0017\end{array}$ & $\begin{array}{l}5.7534 \pm \\
0.0013\end{array}$ & $\begin{array}{l}227.87 \pm \\
0.12\end{array}$ & $\begin{array}{l}0.358 \pm \\
0.006\end{array}$ & $0 \pm 0.11$ \\
\hline & $\begin{array}{l}4.9695 \pm \\
0.0012\end{array}$ & $\begin{array}{l}7.9733 \pm \\
0.0021\end{array}$ & $\begin{array}{l}5.7545 \pm \\
0.0016\end{array}$ & $\begin{array}{l}228 \pm \\
0.15\end{array}$ & $\begin{array}{l}0.358 \pm \\
0.006\end{array}$ & $-0.08 \pm 0.14$ \\
\hline & $\begin{array}{l}4.9694 \pm \\
0.001\end{array}$ & $\begin{array}{l}7.973 \pm \\
0.0017\end{array}$ & $\begin{array}{l}5.7547 \pm \\
0.0013\end{array}$ & $\begin{array}{l}227.99 \pm \\
0.12\end{array}$ & $\begin{array}{l}0.358 \pm \\
0.006\end{array}$ & $0.01 \pm 0.12$ \\
\hline \multirow[t]{4}{*}{ Nikko169_81 } & $\begin{array}{l}4.968 \pm \\
0.0009\end{array}$ & $\begin{array}{l}7.9714 \pm \\
0.0015\end{array}$ & $\begin{array}{l}5.7535 \pm \\
0.0012\end{array}$ & $\begin{array}{l}227.84 \pm \\
0.11\end{array}$ & $\begin{array}{l}0.368 \pm \\
0.005\end{array}$ & $0.18 \pm 0.23$ \\
\hline & $\begin{array}{l}4.9684 \pm \\
0.0011\end{array}$ & $\begin{array}{l}7.9717 \pm \\
0.0018\end{array}$ & $\begin{array}{l}5.753 \pm \\
0.0014\end{array}$ & $\begin{array}{l}227.84 \pm \\
0.13\end{array}$ & $\begin{array}{l}0.368 \pm \\
0.005\end{array}$ & $0.05 \pm 0.14$ \\
\hline & $\begin{array}{l}4.9672 \pm \\
0.0012\end{array}$ & $\begin{array}{l}7.9713 \pm \\
0.002\end{array}$ & $\begin{array}{l}5.7524 \pm \\
0.0015\end{array}$ & $\begin{array}{l}227.76 \pm \\
0.14\end{array}$ & $\begin{array}{l}0.368 \pm \\
0.005\end{array}$ & $0.02 \pm 0.15$ \\
\hline & $\begin{array}{l}4.9672 \pm \\
0.0012 \\
\end{array}$ & $\begin{array}{l}7.97 \pm \\
0.002 \\
\end{array}$ & $\begin{array}{l}5.7523 \pm \\
0.0015\end{array}$ & $\begin{array}{l}227.71 \pm \\
0.14\end{array}$ & $\begin{array}{l}0.368 \pm \\
0.005\end{array}$ & $0.12 \pm 0.3$ \\
\hline \multirow[t]{4}{*}{ Nikko169_82 } & $\begin{array}{l}4.9672 \pm \\
0.0007\end{array}$ & $\begin{array}{l}7.9696 \pm \\
0.0011\end{array}$ & $\begin{array}{l}5.7528 \pm \\
0.0009\end{array}$ & $\begin{array}{l}227.72 \pm \\
0.08\end{array}$ & $\begin{array}{l}0.356 \pm \\
0.006\end{array}$ & $0.27 \pm 0.16$ \\
\hline & $\begin{array}{l}4.9678 \pm \\
0.0009\end{array}$ & $\begin{array}{l}7.9701 \pm \\
0.0014\end{array}$ & $\begin{array}{l}5.7524 \pm \\
0.0011\end{array}$ & $\begin{array}{l}227.74 \pm \\
0.1\end{array}$ & $\begin{array}{l}0.356 \pm \\
0.006\end{array}$ & $0.14 \pm 0.19$ \\
\hline & $\begin{array}{l}4.9696 \pm \\
0.0013\end{array}$ & $\begin{array}{l}7.9737 \pm \\
0.0023\end{array}$ & $\begin{array}{l}5.7548 \pm \\
0.0017\end{array}$ & $\begin{array}{l}228.03 \pm \\
0.16\end{array}$ & $\begin{array}{l}0.356 \pm \\
0.006\end{array}$ & $-0.02 \pm 0.16$ \\
\hline & $\begin{array}{l}4.9696 \pm \\
0.0015\end{array}$ & $\begin{array}{l}7.9735 \pm \\
0.0026\end{array}$ & $\begin{array}{l}5.7544 \pm \\
0.002\end{array}$ & $\begin{array}{l}228.01 \pm \\
0.18\end{array}$ & $\begin{array}{l}0.356 \pm \\
0.006\end{array}$ & $-0.08 \pm 0.19$ \\
\hline
\end{tabular}




\begin{tabular}{|c|c|c|c|c|c|c|}
\hline \multirow[t]{4}{*}{ Dropoff221_118 } & $\begin{array}{l}4.966 \pm \\
0.0014\end{array}$ & $\begin{array}{l}7.977 \pm \\
0.0024\end{array}$ & $\begin{array}{l}5.7538 \pm \\
0.0018\end{array}$ & $\begin{array}{l}227.92 \pm \\
0.17\end{array}$ & $\begin{array}{l}0.357 \pm \\
0.003\end{array}$ & $1.06 \pm 0.31$ \\
\hline & $\begin{array}{l}4.9665 \pm \\
0.0017\end{array}$ & $\begin{array}{l}7.9764 \pm \\
0.0028\end{array}$ & $\begin{array}{l}5.7543 \pm \\
0.0021\end{array}$ & $\begin{array}{l}227.94 \pm \\
0.2\end{array}$ & $\begin{array}{l}0.357 \pm \\
0.003\end{array}$ & $0.81 \pm 0.47$ \\
\hline & $\begin{array}{l}4.967 \pm \\
0.0019\end{array}$ & $\begin{array}{l}7.9805 \pm \\
0.0031\end{array}$ & $\begin{array}{l}5.7554 \pm \\
0.0024\end{array}$ & $\begin{array}{l}228.13 \pm \\
0.22\end{array}$ & $\begin{array}{l}0.357 \pm \\
0.003\end{array}$ & $0.85 \pm 0.28$ \\
\hline & $\begin{array}{l}4.9666 \pm \\
0.0013\end{array}$ & $\begin{array}{l}7.975 \pm \\
0.0021\end{array}$ & $\begin{array}{l}5.7529 \pm \\
0.0016\end{array}$ & $\begin{array}{l}227.85 \pm \\
0.15\end{array}$ & $\begin{array}{l}0.357 \pm \\
0.003\end{array}$ & $1.56 \pm 0.15$ \\
\hline \multirow[t]{4}{*}{ Dropoff221_120 } & $\begin{array}{l}4.9662 \pm \\
0.0013\end{array}$ & $\begin{array}{l}7.978 \pm \\
0.0021\end{array}$ & $\begin{array}{l}5.7538 \pm \\
0.0016\end{array}$ & $\begin{array}{l}227.95 \pm \\
0.15\end{array}$ & $\begin{array}{l}0.364 \pm \\
0.007\end{array}$ & $1.27 \pm 0.19$ \\
\hline & $\begin{array}{l}4.966 \pm \\
0.0015\end{array}$ & $\begin{array}{l}7.9768 \pm \\
0.0025\end{array}$ & $\begin{array}{l}5.754 \pm \\
0.0019\end{array}$ & $\begin{array}{l}227.92 \pm \\
0.18\end{array}$ & $\begin{array}{l}0.364 \pm \\
0.007\end{array}$ & $0.92 \pm 0.41$ \\
\hline & $\begin{array}{l}4.9667 \pm \\
0.0015\end{array}$ & $\begin{array}{l}7.977 \pm \\
0.0024\end{array}$ & $\begin{array}{l}5.7538 \pm \\
0.0019\end{array}$ & $\begin{array}{l}227.95 \pm \\
0.17\end{array}$ & $\begin{array}{l}0.364 \pm \\
0.007\end{array}$ & $0.93 \pm 0.4$ \\
\hline & $\begin{array}{l}4.9663 \pm \\
0.0014\end{array}$ & $\begin{array}{l}7.9768 \pm \\
0.0024\end{array}$ & $\begin{array}{l}5.7542 \pm \\
0.0018\end{array}$ & $\begin{array}{l}227.94 \pm \\
0.17\end{array}$ & $\begin{array}{l}0.364 \pm \\
0.007\end{array}$ & $1 \pm 0.4$ \\
\hline \multirow[t]{4}{*}{ Dropoff221_122 } & $\begin{array}{l}4.9663 \pm \\
0.0009\end{array}$ & $\begin{array}{l}7.973 \pm \\
0.0015\end{array}$ & $\begin{array}{l}5.7524 \pm \\
0.0012\end{array}$ & $\begin{array}{l}227.76 \pm \\
0.11\end{array}$ & $\begin{array}{l}0.36 \pm \\
0.005\end{array}$ & $0.96 \pm 0.24$ \\
\hline & $\begin{array}{l}4.966 \pm \\
0.001\end{array}$ & $\begin{array}{l}7.972 \pm \\
0.0016\end{array}$ & $\begin{array}{l}5.7518 \pm \\
0.0012\end{array}$ & $\begin{array}{l}227.69 \pm \\
0.11\end{array}$ & $\begin{array}{l}0.36 \pm \\
0.005\end{array}$ & $0.99 \pm 0.24$ \\
\hline & $\begin{array}{l}4.9664 \pm \\
0.001\end{array}$ & $\begin{array}{l}7.9725 \pm \\
0.0016\end{array}$ & $\begin{array}{l}5.7521 \pm \\
0.0013\end{array}$ & $\begin{array}{l}227.74 \pm \\
0.12\end{array}$ & $\begin{array}{l}0.36 \pm \\
0.005\end{array}$ & $0.97 \pm 0.24$ \\
\hline & $\begin{array}{l}4.9655 \pm \\
0.001\end{array}$ & $\begin{array}{l}7.9717 \pm \\
0.0017\end{array}$ & $\begin{array}{l}5.7515 \pm \\
0.0013\end{array}$ & $\begin{array}{l}227.65 \pm \\
0.12\end{array}$ & $\begin{array}{l}0.36 \pm \\
0.005\end{array}$ & $1.02 \pm 0.52$ \\
\hline \multirow[t]{4}{*}{ Dropoff221_124 } & $\begin{array}{l}4.9668 \pm \\
0.0008\end{array}$ & $\begin{array}{l}7.9712 \pm \\
0.0013\end{array}$ & $\begin{array}{l}5.752 \pm \\
0.001\end{array}$ & $\begin{array}{l}227.71 \pm \\
0.09\end{array}$ & $\begin{array}{l}0.3436 \pm \\
0.0027\end{array}$ & $0.73 \pm 0.17$ \\
\hline & $\begin{array}{l}4.9664 \pm \\
0.0008\end{array}$ & $\begin{array}{l}7.9713 \pm \\
0.0014\end{array}$ & $\begin{array}{l}5.7521 \pm \\
0.0011\end{array}$ & $\begin{array}{l}227.7 \pm \\
0.1\end{array}$ & $\begin{array}{l}0.3436 \pm \\
0.0027\end{array}$ & $0.73 \pm 0.19$ \\
\hline & $\begin{array}{l}4.967 \pm \\
0.0008\end{array}$ & $\begin{array}{l}7.9718 \pm \\
0.0013\end{array}$ & $\begin{array}{l}5.7523 \pm \\
0.0011\end{array}$ & $\begin{array}{l}227.76 \pm \\
0.1\end{array}$ & $\begin{array}{l}0.3436 \pm \\
0.0027\end{array}$ & $0.75 \pm 0.19$ \\
\hline & $\begin{array}{l}4.967 \pm \\
0.0008\end{array}$ & $\begin{array}{l}7.9712 \pm \\
0.0013\end{array}$ & $\begin{array}{l}5.7521 \pm \\
0.0011\end{array}$ & $\begin{array}{l}227.73 \pm \\
0.1\end{array}$ & $\begin{array}{l}0.3436 \pm \\
0.0027\end{array}$ & $0.72 \pm 0.19$ \\
\hline \multirow[t]{4}{*}{ Dropoff221_126 } & $\begin{array}{l}4.9664 \pm \\
0.0004\end{array}$ & $\begin{array}{l}7.9675 \pm \\
0.0006\end{array}$ & $\begin{array}{l}5.751 \pm \\
0.0005\end{array}$ & $\begin{array}{l}227.55 \pm \\
0.05\end{array}$ & $\begin{array}{l}0.3282 \pm \\
0.0022\end{array}$ & $0.68 \pm 0.09$ \\
\hline & $\begin{array}{l}4.9662 \pm \\
0.0004\end{array}$ & $\begin{array}{l}7.9683 \pm \\
0.0006\end{array}$ & $\begin{array}{l}5.7508 \pm \\
0.0005\end{array}$ & $\begin{array}{l}227.56 \pm \\
0.05\end{array}$ & $\begin{array}{l}0.3282 \pm \\
0.0022\end{array}$ & $0.63 \pm 0.08$ \\
\hline & $\begin{array}{l}4.9662 \pm \\
0.0004\end{array}$ & $\begin{array}{l}7.9683 \pm \\
0.0006\end{array}$ & $\begin{array}{l}5.7508 \pm \\
0.0005\end{array}$ & $\begin{array}{l}227.56 \pm \\
0.05\end{array}$ & $\begin{array}{l}0.3282 \pm \\
0.0022\end{array}$ & $0.63 \pm 0.08$ \\
\hline & $\begin{array}{l}4.9667 \pm \\
0.0004\end{array}$ & $\begin{array}{l}7.9689 \pm \\
0.0007\end{array}$ & $\begin{array}{l}5.7513 \pm \\
0.0006\end{array}$ & $\begin{array}{l}227.62 \pm \\
0.05\end{array}$ & $\begin{array}{l}0.3282 \pm \\
0.0022\end{array}$ & $0.6 \pm 0.09$ \\
\hline Dropoff221_128 & $\begin{array}{l}4.9667 \pm \\
0.0004\end{array}$ & $\begin{array}{l}7.9703 \pm \\
0.0007\end{array}$ & $\begin{array}{l}5.7519 \pm \\
0.0005\end{array}$ & $\begin{array}{l}227.68 \pm \\
0.05\end{array}$ & $\begin{array}{l}0.3395 \pm \\
0.0027\end{array}$ & $0.79 \pm 0.08$ \\
\hline
\end{tabular}




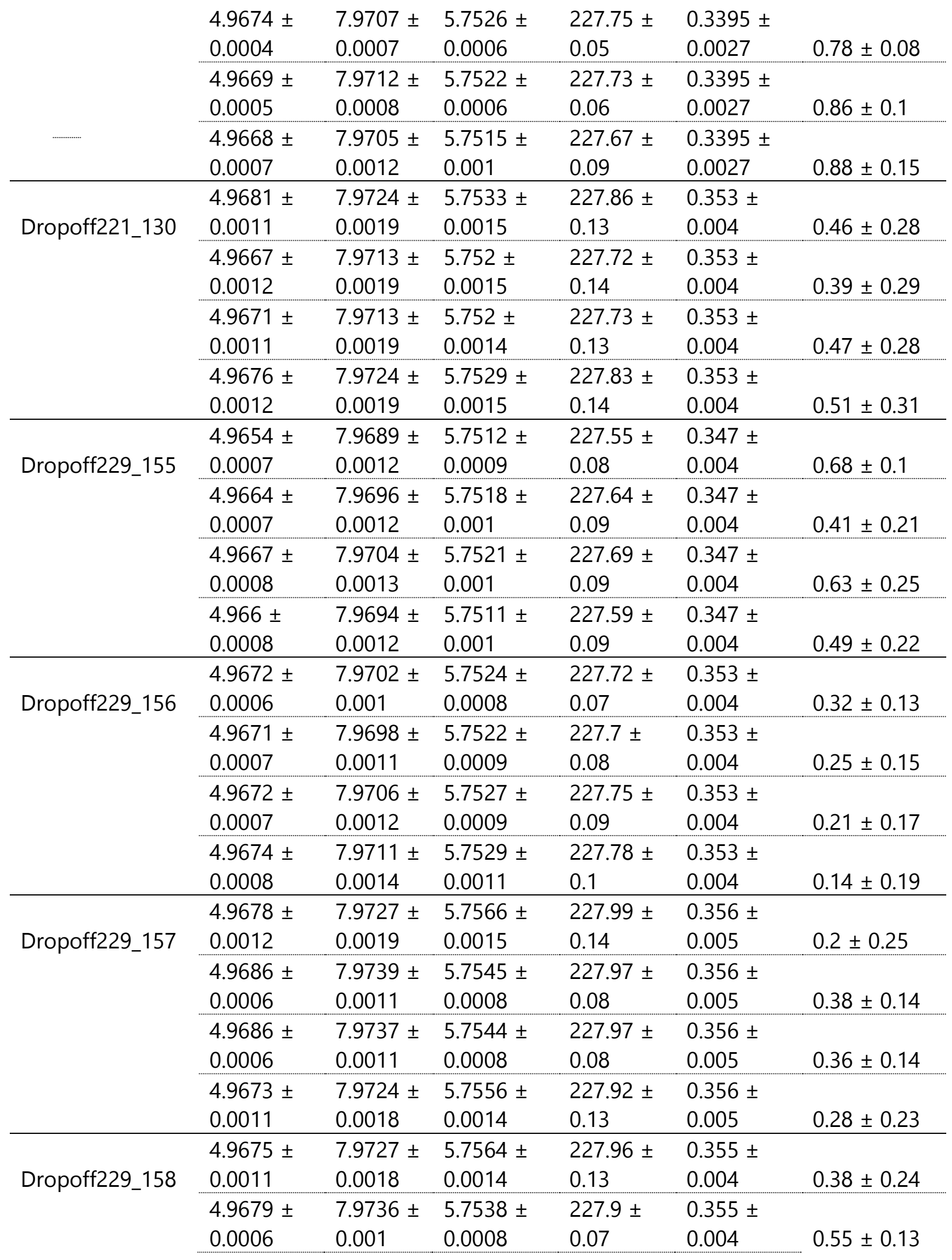




\begin{tabular}{|c|c|c|c|c|c|c|}
\hline & $\begin{array}{l}4.9674 \pm \\
0.0006\end{array}$ & $\begin{array}{l}7.9721 \pm \\
0.001\end{array}$ & $\begin{array}{l}5.7529 \pm \\
0.0008\end{array}$ & $\begin{array}{l}227.81 \pm \\
0.07\end{array}$ & $\begin{array}{l}0.355 \pm \\
0.004\end{array}$ & $0.58 \pm 0.13$ \\
\hline & $\begin{array}{l}4.9676 \pm \\
0.0006\end{array}$ & $\begin{array}{l}7.9738 \pm \\
0.0009\end{array}$ & $\begin{array}{l}5.7536 \pm \\
0.0007\end{array}$ & $\begin{array}{l}227.89 \pm \\
0.07\end{array}$ & $\begin{array}{l}0.355 \pm \\
0.004\end{array}$ & $0.64 \pm 0.12$ \\
\hline \multirow[t]{4}{*}{ Dropoff229_159 } & $\begin{array}{l}4.9676 \pm \\
0.0009\end{array}$ & $\begin{array}{l}7.972 \pm \\
0.0014\end{array}$ & $\begin{array}{l}5.7556 \pm \\
0.0011\end{array}$ & $\begin{array}{l}227.92 \pm \\
0.1\end{array}$ & $\begin{array}{l}0.352 \pm \\
0.004\end{array}$ & $0.19 \pm 0.18$ \\
\hline & $\begin{array}{l}4.9678 \pm \\
0.0005\end{array}$ & $\begin{array}{l}7.9718 \pm \\
0.0008\end{array}$ & $\begin{array}{l}5.753 \pm \\
0.0006\end{array}$ & $\begin{array}{l}227.82 \pm \\
0.05\end{array}$ & $\begin{array}{l}0.352 \pm \\
0.004\end{array}$ & $0.3 \pm 0.09$ \\
\hline & $\begin{array}{l}4.9673 \pm \\
0.0005\end{array}$ & $\begin{array}{l}7.9709 \pm \\
0.0008\end{array}$ & $\begin{array}{l}5.7522 \pm \\
0.0006\end{array}$ & $\begin{array}{l}227.74 \pm \\
0.06\end{array}$ & $\begin{array}{l}0.352 \pm \\
0.004\end{array}$ & $0.4 \pm 0.1$ \\
\hline & $\begin{array}{l}4.9675 \pm \\
0.0005\end{array}$ & $\begin{array}{l}7.9708 \pm \\
0.0008\end{array}$ & $\begin{array}{l}5.7523 \pm \\
0.0006\end{array}$ & $\begin{array}{l}227.75 \pm \\
0.06\end{array}$ & $\begin{array}{l}0.352 \pm \\
0.004\end{array}$ & $0.48 \pm 0.1$ \\
\hline \multirow[t]{4}{*}{ Dropoff229_160 } & $\begin{array}{l}4.9671 \pm \\
0.0005\end{array}$ & $\begin{array}{l}7.9696 \pm \\
0.0008\end{array}$ & $\begin{array}{l}5.7524 \pm \\
0.0006\end{array}$ & $\begin{array}{l}227.7 \pm \\
0.06\end{array}$ & $\begin{array}{l}0.352 \pm \\
0.005\end{array}$ & $0.33 \pm 0.1$ \\
\hline & $\begin{array}{l}4.9671 \pm \\
0.0006\end{array}$ & $\begin{array}{l}7.9696 \pm \\
0.0009\end{array}$ & $\begin{array}{l}5.7523 \pm \\
0.0007\end{array}$ & $\begin{array}{l}227.7 \pm \\
0.07\end{array}$ & $\begin{array}{l}0.352 \pm \\
0.005\end{array}$ & $0.29 \pm 0.11$ \\
\hline & $\begin{array}{l}4.9674 \pm \\
0.0007\end{array}$ & $\begin{array}{l}7.9705 \pm \\
0.0012\end{array}$ & $\begin{array}{l}5.7526 \pm \\
0.0009\end{array}$ & $\begin{array}{l}227.74 \pm \\
0.08\end{array}$ & $\begin{array}{l}0.352 \pm \\
0.005\end{array}$ & $0.18 \pm 0.15$ \\
\hline & $\begin{array}{l}4.9676 \pm \\
0.0008\end{array}$ & $\begin{array}{l}7.9706 \pm \\
0.0014\end{array}$ & $\begin{array}{l}5.7529 \pm \\
0.0011\end{array}$ & $\begin{array}{l}227.77 \pm \\
0.1\end{array}$ & $\begin{array}{l}0.352 \pm \\
0.005\end{array}$ & $0.16 \pm 0.19$ \\
\hline \multirow[t]{4}{*}{ Dropoff229_161 } & $\begin{array}{l}4.9671 \pm \\
0.0008\end{array}$ & $\begin{array}{l}7.9707 \pm \\
0.0014\end{array}$ & $\begin{array}{l}5.7522 \pm \\
0.0011\end{array}$ & $\begin{array}{l}227.72 \pm \\
0.1\end{array}$ & $\begin{array}{l}0.35 \pm \\
0.006\end{array}$ & $-0.02 \pm 0.11$ \\
\hline & $\begin{array}{l}4.9672 \pm \\
0.0009\end{array}$ & $\begin{array}{l}7.9706 \pm \\
0.0015\end{array}$ & $\begin{array}{l}5.7524 \pm \\
0.0012\end{array}$ & $\begin{array}{l}227.73 \pm \\
0.11\end{array}$ & $\begin{array}{l}0.35 \pm \\
0.006\end{array}$ & $-0.02 \pm 0.11$ \\
\hline & $\begin{array}{l}4.9679 \pm \\
0.0009\end{array}$ & $\begin{array}{l}7.9722 \pm \\
0.0014\end{array}$ & $\begin{array}{l}5.7536 \pm \\
0.0011\end{array}$ & $\begin{array}{l}227.86 \pm \\
0.1\end{array}$ & $\begin{array}{l}0.35 \pm \\
0.006\end{array}$ & $0.02 \pm 0.11$ \\
\hline & $\begin{array}{l}4.9685 \pm \\
0.0011\end{array}$ & $\begin{array}{l}7.9736 \pm \\
0.0018\end{array}$ & $\begin{array}{l}5.7543 \pm \\
0.0014\end{array}$ & $\begin{array}{l}227.96 \pm \\
0.13\end{array}$ & $\begin{array}{l}0.35 \pm \\
0.006 \\
\end{array}$ & $-0.01 \pm 0.13$ \\
\hline \multirow[t]{4}{*}{ Dropoff229_162 } & $\begin{array}{l}4.9669 \pm \\
0.0004\end{array}$ & $\begin{array}{l}7.9703 \pm \\
0.0007\end{array}$ & $\begin{array}{l}5.7527 \pm \\
0.0006\end{array}$ & $\begin{array}{l}227.72 \pm \\
0.05\end{array}$ & $\begin{array}{l}0.359 \pm \\
0.006\end{array}$ & $0.39 \pm 0.09$ \\
\hline & $\begin{array}{l}4.9678 \pm \\
0.0006\end{array}$ & $\begin{array}{l}7.9716 \pm \\
0.0011\end{array}$ & $\begin{array}{l}5.7539 \pm \\
0.0008\end{array}$ & $\begin{array}{l}227.85 \pm \\
0.08\end{array}$ & $\begin{array}{l}0.359 \pm \\
0.006\end{array}$ & $0.46 \pm 0.13$ \\
\hline & $\begin{array}{l}4.9674 \pm \\
0.0006\end{array}$ & $\begin{array}{l}7.9707 \pm \\
0.0009\end{array}$ & $\begin{array}{l}5.7531 \pm \\
0.0007\end{array}$ & $\begin{array}{l}227.77 \pm \\
0.07\end{array}$ & $\begin{array}{l}0.359 \pm \\
0.006\end{array}$ & $0.36 \pm 0.13$ \\
\hline & $\begin{array}{l}4.9677 \pm \\
0.0007\end{array}$ & $\begin{array}{l}7.9703 \pm \\
0.0011\end{array}$ & $\begin{array}{l}5.7527 \pm \\
0.0009\end{array}$ & $\begin{array}{l}227.76 \pm \\
0.08\end{array}$ & $\begin{array}{l}0.359 \pm \\
0.006\end{array}$ & $0.35 \pm 0.16$ \\
\hline \multirow[t]{3}{*}{ Dropoff229_163 } & $\begin{array}{l}4.9669 \pm \\
0.0007\end{array}$ & $\begin{array}{l}7.9735 \pm \\
0.0012\end{array}$ & $\begin{array}{l}5.754 \pm \\
0.0009\end{array}$ & $\begin{array}{l}227.87 \pm \\
0.09\end{array}$ & $\begin{array}{l}0.3463 \pm \\
0.0029\end{array}$ & $0.59 \pm 0.18$ \\
\hline & $\begin{array}{l}4.9659 \pm \\
0.0007\end{array}$ & $\begin{array}{l}7.9716 \pm \\
0.0012\end{array}$ & $\begin{array}{l}5.752 \pm \\
0.0009\end{array}$ & $\begin{array}{l}227.68 \pm \\
0.09\end{array}$ & $\begin{array}{l}0.3463 \pm \\
0.0029\end{array}$ & $0.61 \pm 0.18$ \\
\hline & $\begin{array}{l}4.9647 \pm \\
0.001\end{array}$ & $\begin{array}{l}7.9732 \pm \\
0.0016\end{array}$ & $\begin{array}{l}5.7522 \pm \\
0.0013\end{array}$ & $\begin{array}{l}227.69 \pm \\
0.11\end{array}$ & $\begin{array}{l}0.3463 \pm \\
0.0029\end{array}$ & $-0.32 \pm 0.11$ \\
\hline
\end{tabular}




\begin{tabular}{lllllll} 
& $4.9667 \pm$ & $7.9724 \pm$ & $5.7524 \pm$ & $227.76 \pm$ & $0.3463 \pm$ & \\
& 0.0007 & 0.0011 & 0.0009 & 0.08 & 0.0029 & $0.7 \pm 0.15$ \\
\hline \multirow{3}{*}{ Dropoff229_164 } & $4.9668 \pm$ & $7.9701 \pm$ & $5.7524 \pm$ & $227.7 \pm$ & $0.351 \pm$ & \\
& 0.0007 & 0.0012 & 0.0009 & 0.08 & 0.005 & $0.33 \pm 0.17$ \\
\cline { 2 - 6 } & $4.9667 \pm$ & $7.97 \pm$ & $5.7521 \pm$ & $227.68 \pm$ & $0.351 \pm$ & \\
& 0.0008 & 0.0014 & 0.0011 & 0.1 & 0.005 & $0.21 \pm 0.21$ \\
\hline & $4.9676 \pm$ & $7.972 \pm$ & $5.753 \pm$ & $227.81 \pm$ & $0.351 \pm$ & \\
& 0.0009 & 0.0015 & 0.0012 & 0.11 & 0.005 & $0.13 \pm 0.21$ \\
\cline { 2 - 6 } & $4.9671 \pm$ & $7.9709 \pm$ & $5.7529 \pm$ & $227.76 \pm$ & $0.351 \pm$ & \\
& 0.0008 & 0.0014 & 0.0011 & 0.1 & 0.005 & $0.17 \pm 0.2$ \\
\hline
\end{tabular}




\section{CHAPTER 5. Coupled X-ray fluorescence and X-ray absorption spectroscopy for microscale imaging and identification of sulfur species within tissues and skeletons of scleractinian corals}

This chapter is reproduced with permission from Analytical Chemistry, in press. Unpublished work copyright 2018 American Chemical Society.

Farfan, G.A., Apprill, A., Webb, S. M., and Hansel, C. M. (2018). Coupled X-ray fluorescence and X-ray absorption spectroscopy for microscale imaging and identification of sulfur species within tissues and skeletons of scleractinian corals. Analytical chemistry. doi:10.1021/acs.analchem.8b02638 


\subsection{ABSTRACT}

Identifying and mapping the wide range of sulfur species within complex matrices presents a challenge for understanding the distribution of these important biomolecules within environmental and biological systems. Here, we present a coupled micro X-ray fluorescence $(\mu \mathrm{XRF})$ and X-ray absorption near edge structure (XANES) spectroscopy method for determining the presence of specific sulfur species in coral tissues and skeletons at high spatial resolution. By using multiple energy stacks and principal component analysis of a large spectral database, we were able to more accurately identify sulfur species components and distinguish different species and distributions of sulfur formerly unresolved by previous studies. Specifically, coral tissues were dominated by more reduced sulfur species, such as glutathione disulfide, cysteine and sulfoxide, as well as organic sulfate as represented by chondroitin sulfate. Sulfoxide distributions were visually correlated with the presence of zooxanthellae endosymbionts. Coral skeletons were composed primarily of carbonate-associated sulfate (CAS), along with minor contributions from organic sulfate and a separate inorganic sulfate likely in the form of adsorbed sulfate. This coupled XRF-XANES approach allows for a more accurate and informative view of sulfur within biological systems in situ, and holds great promise for pairing with other techniques to allow for a more encompassing understanding of elemental distributions within the environment.

\subsection{INTRODUCTION}

Scleractinian corals compose the structural and biological framework of corals reefs, which are vital ocean ecosystems that host hotspots of biodiversity, provide ample marine resources and help to drive tourism-based economies (Spurgeon, 1992). Sulfur (S) is ubiquitous as an essential element for life, as it is involved in organosulfur compounds such as amino acids (cysteine, methionine) and as a cofactor in proteins such as glutathione disulfide. It is also common in many oxidation states as building blocks for minerals ranging from elemental sulfur, to reduced sulfide minerals (pyrite) and oxidized sulfate minerals (gypsum). In corals, sulfur is present in both the living tissues and non-living skeletal components as both organic and inorganic phases. Thus, sulfur in corals has been studied from many perspectives, including characterizing sulfate incorporations into aragonitic skeletons as a way to better understand skeletal growth and deduce the role of organics in biomineralization mechanisms (Dauphin, 2001; Cuif et al., 2003; Nguyen et al., 2014; Vielzeuf et al., 2013; Tamenori et al., 2014), quantifying dimethylsulphoniopropionate (DMSP) production in the tissues and endosymbionts as an elevated temperature stress signal during coral bleaching events (Raina et al., 2013), and measuring $\mathrm{S}$ isotopes in carbonate-associated sulfate (CAS) as a paleoproxy (Present et al., 2015). Furthermore, sulfur is an important trace metal ligand and its cycling and attenuation in coral reefs may be intricately linked to bio-limiting trace metal cycles that control biological productivity in these oligotrophic ecosystems. Understanding the spatial distributions of the many sulfur species in corals is thus essential to further unlocking questions surrounding these biogeochemical processes.

The utility of synchrotron radiation techniques for speciating sulfur and investigating the role of sulfur molecules and ligands in situ has proven useful in environmental contexts such as 
organic matter (Manceau and Nagy, 2012), metabolites (Rompel et al., 1998), soils (Xia et al., 1998), brachiopods (Cusack et al., 2008), mollusks (Dauphin et al., 2005), and coral skeletons (Cuif et al., 2003; Tamenori et al., 2014; Perrin et al., 2017). Specifically, synchrotron-based studies on corals (mostly on precious red octocorals) have identified a range of sulfur species present in corals via single-point X-ray absorption near edge structure (XANES) spectroscopy. While this approach tells us what $\mathrm{S}$ functional groups are most likely present in corals as a whole, the extent to which each species plays a role in the coral and where it is distributed depends on visual correlations (Nguyen et al., 2014; Tamenori et al., 2014; Perrin et al., 2017). Some studies have taken this approach further and mapped the distributions of reduced versus oxidized sulfur regions by using micro X-ray fluorescence spectroscopy ( $\mu$ XRF) raster maps to overlay two single-energy maps representing reduced versus oxidized $\mathrm{S}$ energies. These studies observed that oxidized S regions visually correlated with skeletal regions and are made up of sulfate-dominated XANES points, while reduced sulfur regions align with the coenenchyme and comprise XANES points of reduced organosulfur species (Tamenori et al., 2014; Perrin et al., 2017).

In this study, we extend the capacity for pairing synchrotron-based XANES with $\mu$ XRF maps to better interrogate the distribution of individual sulfur functional groups within skeletons and specific coral tissues at micron-scale resolution. Similar approaches have been successful in

evaluating the distributions and bonding environments of metals within other environmental and geological systems (Templeton and Knowles, 2009; Vázquez-Rodríguez et al., 2015). For instance, Mayhew et al., (2011) introduced a method combining Fe XANES with Fe multiple energy $\mu \mathrm{XRF}$ maps to determine oxidation state, speciation, and distributions of Fe in heterogeneous samples of fluid-mineral interactions that resulted in the successful mapping of a wide range of reduced and oxidized Fe species within a single sample. Our study builds on previous sulfur in coral synchrotron-based studies that map reduced sulfur (or organic sulfur) versus oxidized sulfur (or sulfate) (Tamenori et al., 2014; Perrin et al., 2017) by adapting the multiple energy (ME) $\mu \mathrm{XRF}$ mapping technique by Mayhew et al., with extensive XANES points to obtain high-resolution spatially-resolved maps of specific sulfur species in tissues and skeletons (Mayhew et al., 2011). Using these S species-specific maps, we detail how sulfur species relate to specific coral tissues and endosymbiont distributions in aragonitic scleractinian corals.

\subsection{MATERIALS AND METHODS}

\subsubsection{Samples}

We obtained scleractinian coral samples of Diploria labyrinthiformis from Carmabi, Curaçao, Porites astreoides from Water Factory, Curaçao, and Diploastrea heliopora from Yap Island, Federated States of Micronesia. Samples were rinsed of excess mucus, preserved in trace-metal grade paraformaldehyde (Electron Microscopy Sciences), diluted with sterile seawater (4\% final concentration), and stored at $4^{\circ} \mathrm{C}$. Samples were later partially dehydrated and kept in $70 \%$ ethanol at $-20^{\circ} \mathrm{C}$. Samples from Carmabi, Curaçao represent corals growing in more anthropogenically-influenced waters (some samples from Carmabi were growing on metal 
structures) while those from Water Factory, Curaçao, Florida Keys, USA and Yap Island, Micronesia represent corals grown in a range of other geographic locations.

\subsubsection{Thin Sections}

Tissues and skeletons were impregnated with a low-sulfur and low-fluorescence Struers® EpoFix epoxy to preserve the tissue morphologies for thin-sectioning. The samples were cut vertically across the polyps (to expose tissue layers and cross-sections of coral septa) and polished into $30 \mu \mathrm{m}$-thick standard geologic thin-sections using Beta Diamond Inc. products and a polishing paper with minimal trace metals (confirmed via $\mu \mathrm{XRF}$ ). All thin-sections were made by High Mesa Petrographics, Los Alamos, New Mexico. Optical images (Life Technologies, EVOS FL Auto, Woods Hole Oceanographic Institution) and environmental scanning electron microscopy (ESEM) (Hitachi TM300, Woods Hole Oceanographic Institution) images were taken of the thin-sections to identify regions of interest for $\mu \mathrm{XRF}$ mapping and to confirm that these regions contained minimal algal boring or other alterations.

\subsubsection{Low Energy X-ray $\mu$ XRF mapping}

For determining in situ sulfur distributions, Synchrotron-based fluorescence maps ( $\mu \mathrm{XRF})$ and sulfur X-ray absorption near edge spectroscopy (S XANES) were measured at BL 14-3 at the Stanford Synchrotron Radiation Lightsource (SSRL) using a $\operatorname{Si}(111)(\Phi=90)$ double crystal monochromator. The monochromator was calibrated at the thiol pre-edge energy of a sodium thiosulfate powder to be $2472.02 \mathrm{eV}$. The fluorescence lines of interest were measured with a Si Vortex Si drift detector (SII Nano Technology) using Xspress3 pulse processing electronics (Quantum Detectors) that deliver superior count rates without significant dead times. The X-ray beam was focused using Kirkpatrick-Baez (K-B) mirrors to a size of $5 \times 5 \mu \mathrm{m}$ at a flux of $\sim 2 \times$ $10^{10}$ photons per second. To determine sulfur speciation at specific points within the sample, absorption spectra (S XANES) were collected from 2460 to $2536 \mathrm{eV}$ at $0.2 \mathrm{eV}$ steps to capture the range of energies for the absorption edges of possible common sulfur compounds. Multiple sweeps were acquired at each point to confirm that the absorption edge energies did not shift to lower energies due to photoreduction by beam damage to the sample.

To map the distributions of different sulfur species within the corals, fluorescence maps were obtained at multiple energies $(2472.8,2473.9,2475.1,2476.4,2481.4,2482.4$, and 2484.7 $\mathrm{eV}$, as well as 2488.0 for normalization). These energies were chosen based on unique absorption edge positions of common biologically-relevant sulfur species (Figure 5.1) and preliminary $\mathrm{S}$ XANES points taken across the $P$. astreoides sample from Water Factory, Curaçao. Multiple energy (ME) $\mu$ XRF maps were collected with a $5 \times 5 \mu \mathrm{m}$ pixel resolution and a dwell time of $50 \mathrm{~ms}$ per pixel. 


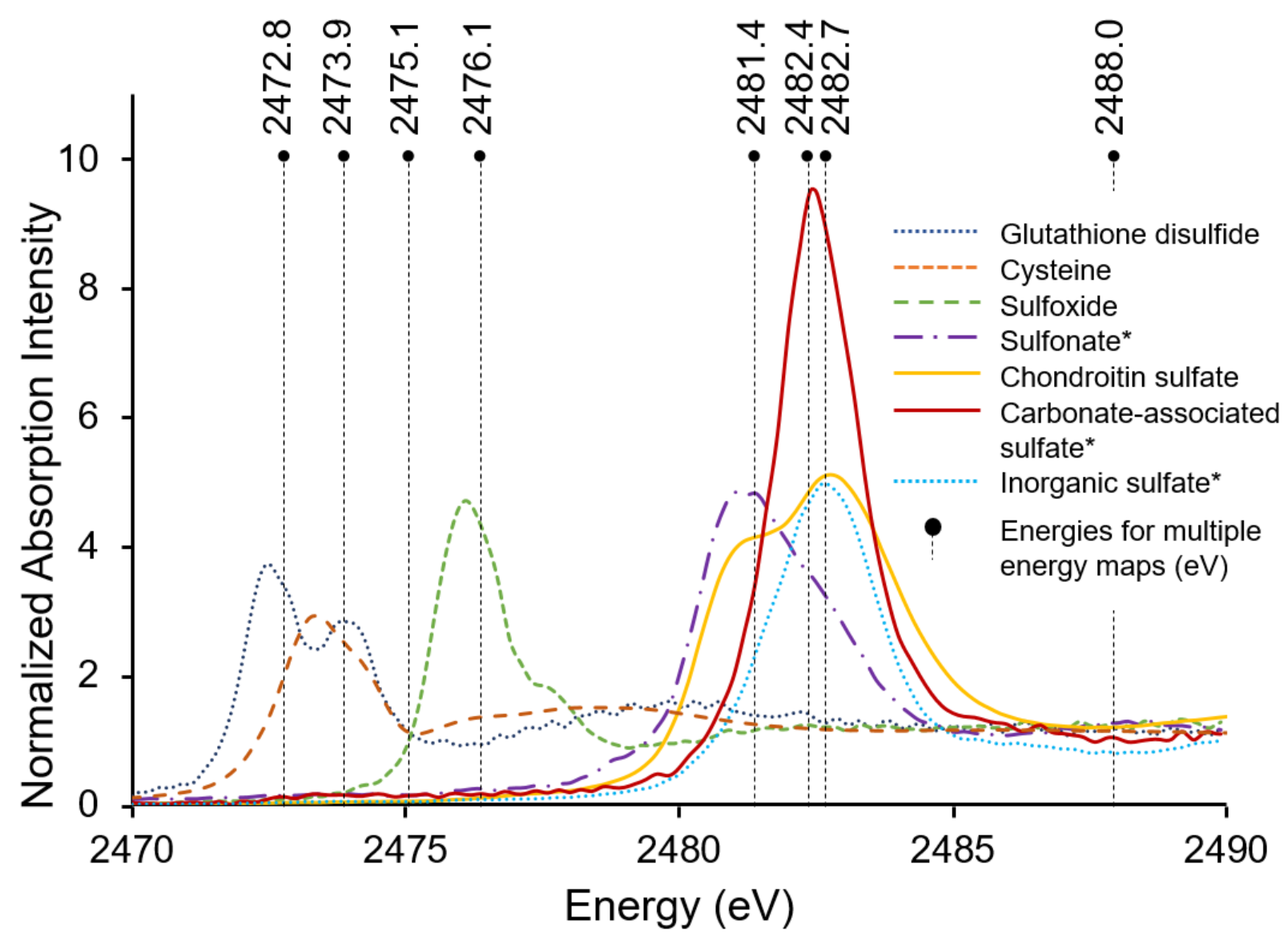

FIGURE 5.1. Normalized standard $S$ XANES spectra selected for fitting multiple energy (ME) sulfur maps (with the exception of inorganic sulfate). Energies (eV) selected for ME maps are marked with filled black circles and dashed lines through the spectra. Asterisk denotes S XANES spectra used as internal standards obtained directly from our coral samples and identified as an end-members via PCA analysis.

\subsubsection{Fitting Sulfur ME Maps with S XANES}

In order to successfully describe the distribution of sulfur bonding environments in a heterogeneous coral sample using ME maps, it was crucial to select the appropriate number and variety of standard sulfur compounds that best describes the coral sulfur system. Rather than only relying on the main absorption peak energies of a set of standards and assuming that XRF maps collected at those energies reflect the distributions of those standards (Nguyen et al., 2014; Tamenori et al., 2014), we utilized a stack of ME maps and fit standard S XANES spectra to the entire stack of maps to provide a more accurate distribution of each sulfur standard. Utilizing a stack of energies and several representative absorption features, rather than only one dominant peak, eliminates bias from overlapping XRF signals from neighboring lower energies and allows for better resolution between standards that have main peaks at similar energies. This method of using XANES spectral analysis to fit XANES to ME maps was first reported by Mayhew et al. (2011), to investigate the distribution of iron compounds in fluid-mineral reactions and is also 
similarly employed in scanning X-ray transmission microscopy near edge X-ray absorption fine structure (STXM-NEXAFS) spectroscopic imaging (Keiluweit et al., 2015; (Benzerara et al., 2006).

Properly fitting ME maps with XANES, as described by Mayhew et al., 2011 and as modified in this study for sulfur, requires combining PCA analysis of ME $\mu$ XRF maps, PCA of XANES, and linear combination fitting of XANES spectra using XANES standards and XANES PCA end-members using SIX-PACK (Webb, 2005) and Microanalysis Toolkit (Webb, 2011) software in order to identify the number of components required to properly fit the stack of maps with the most representative standards for the sample with the following steps: 1) ME S $\mu$ XRF maps were collected at energies selected based on positions on preliminary $S$ XANES spectra that differed significantly from one another. These energies correspond to main peak positions of S XANES standards (Figure 5.1) used to fit the ME maps in the following steps. These multiple energy maps were stacked using Microanalysis Toolkit (Webb, 2011). 2) 30-43 S XANES were collected per sample to represent the variability found in the samples, as guided by distinct components identified via PCA of the stacked ME maps, Kmeans clustering, and visual features identified in optical microscopic analysis of the thin-sections (Supplementary Material, Figures S5.1, S5.2). S XANES spectra of typical coral tissues and skeletons are presented in Figure 5.2 with linear combination fits using the $S$ species used to represent the system in Figure 5.1. 3) PCA analyses of the S XANES taken from the ME sulfur $\mu$ XRF maps were conducted (at a 2470 to $2490 \mathrm{eV}$ span) using the SIXPACK software package (Webb, 2011). The number of principal components ( 6 to 7 in this study) was identified from the S XANES by determining where additional components no longer contributed to the signal and the scree plot reached a plateau. 4) Next, end-member spectra identified by PCA component score plots were fit using linear combination fitting in SIXPACK (Webb, 2005) with S XANES standards from sulfur spectral libraries acquired from the European Synchrotron Radiation Facility (it includes more than 60 sulfur standards, including a broad spectrum of inorganic and organic sulfur species) and a set of spectra from our personal S XANES library measured at SSRL, BL14-3, including glutathione, cysteine and sulfoxide. Spectra obtained from the ESRF database are consistent with those collected at SSRL in peak shape and position (Supplementary Material, Figure S5.3). Overall, most end-members were describable using these standards, however a few end-members were not sufficiently described by the standard library compounds and were thus selected to be internal standards for fitting the coral ME maps. These spectra include a sulfonate-like compound, carbonate-associated sulfate, and another inorganic sulfate, all three of which are presented with an asterisk in Figure 5.1. In total we selected seven (the number determined by Step \#3) S standard compounds representing different $\mathrm{S}$ bonding environments needed to describe the system. S XANES of these seven compounds are plotted in Figure 5.1. 5) Target transforms of these standard S XANES spectra to the seven principal components identified via PCA in part 3 (using PC Analysis in SIXPACK(Webb, 2005)) were used to confirm the effectiveness of the seven standard S XANES spectra in defining the coral sulfur system. 6) Due to some maps being over-constrained with seven standards, six of the seven standard S XANES (Figure 5.1) were fit to the stack of ME maps using MicroAnalysis Toolkit (Webb, 2011), resulting in maps of the distributions of six standard sulfur species (Figure 5.3). It is important to stress that while PCA analysis, linear combination fittings, and target transforms are used to select the final standard S XANES (steps 2, 4, 5, and 6), these S XANES are real data from discrete points on our samples or from data repositories and they are not subject to any statistical treatments or changes that would alter their peak position or shape. 7) In order to validate the 
accuracy of our fitted maps, we plotted the contributions of S standards to all of our S XANES collected in a sample by linear combination fitting, versus the contributions of the standards determined by the fitted maps for each position where the S XANES points were collected (Supplementary Material, Figures S5.1, S5.2, and S5.4; Tables S5.1 and S5.2). A highly accurate fit should be a 1:1 line between linear combination fits versus map fits.
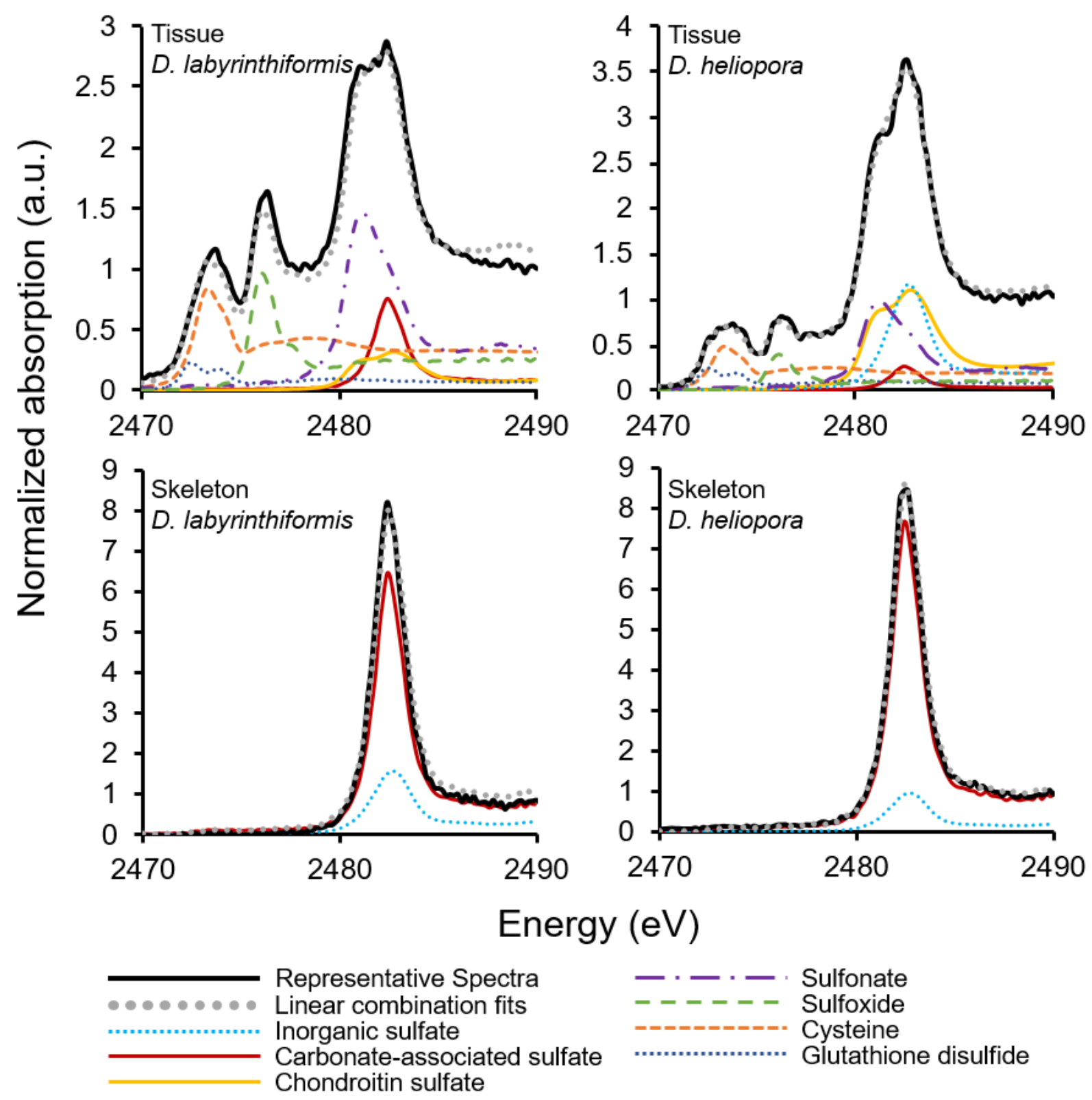

FIGURE 5.2. Linear combination fits (grey dotted lines) of micro-S XANES spectra from typical tissues and skeletons of $D$. labyrinthiformis and $D$. heliopora (black lines) underlain by the relative contributions from $\mathrm{S} X \mathrm{X}$ NES standards used for the fitting. 


\subsection{RESULTS}

Using our approach for fitting ME $\mu$ XRF maps with real S XANES spectra, we mapped the distributions of six S bonding environments across heterogeneous coral samples using S XANES of the following standard compounds: glutathione disulfide (hereinafter referred to as glutathione), cysteine, sulfoxide, a sulfonate-like S XANES spectrum (hereinafter referred to as sulfonate), organic sulfate (represented by a chondroitin sulfate standard, hereinafter referred to as organic sulfate), CAS, and another form of sulfate that is unlike CAS or chondroitin sulfate (hereinafter referred to as inorganic sulfate) (Figure 5.1). Four of these standards were selected from spectral libraries, while sulfonate, CAS and inorganic sulfate components are internal standards identified from coral S XANES collected in this study (marked with an asterisk in Figure 5.1). Upon validating our results, we removed the inorganic sulfate standard from our map fits because the seven-standard fits proved to be over-constrained, however the inorganic sulfate standard was kept in the S XANES linear combination fits.

\subsubsection{Reduced sulfur species}

Three reduced sulfur species were identified via PCA analysis and spectral fitting — glutathione, cysteine and sulfoxide - all of which have biological relevance in coral tissues. Of the various glutathione standards, the oxidized form, glutathione disulfide, fit the data best and was used to represent glutathione-like molecules. The amino acids, cysteine and methionine, have overlapping absorption edges, thus only one was used for the fitting. Cysteine was chosen as the representative species for these absorption energies because it fit better in the target transform analyses. A sulfoxide standard was selected as representative for dimethylsulfoniopropionate (DMSP). Finally, a distinct sulfonate-like endmember was also identified from the coral S XANES spectra PCA analysis ( $2481.20 \mathrm{eV}$, labeled as "sulfonate"). Sulfonate was identified as a minor component in some maps and thus the spectrum was included in the fit, however it is important to note that these signals came from areas that may represent contamination from either detritus or a filled bubble in the epoxy and polishing process (Supplementary Material, Figure S5.5).

\subsubsection{Sulfate species}

Our study identified three different bonding environments for sulfate in coral skeletons and tissues: CAS (absorption edge peak at $2482.44 \mathrm{eV}$ ), another inorganic sulfate $(2482.65 \mathrm{eV})$ and organic sulfate (strongest peak at $2482.74 \mathrm{eV}$ split with a minor peak at $2481.4 \mathrm{eV}$, represented by chondroitin sulfate). We designate our dominant sulfate signal associated with the aragonite skeletons as CAS because its absorption peak is shifted to lower energies than the gypsum standard and the other inorganic sulfate, as would be expected for a structurally (substituted) bound sulfate within the aragonite lattice. The inorganic sulfate end member is also dissimilar to gypsum because its S XANES spectrum lacks a post edge feature observed in gypsum at 2486 $\mathrm{eV}$. While the bonding environment of this other inorganic sulfate species is unknown at present, it is likely a sorbed species within the skeleton based on the higher energy shift. Despite gypsum being used as a representative sulfate standard in previous studies (Nguyen et al., 2014; 
Tamenori et al., 2014), skeletal sulfate spectra fit more accurately with our CAS and inorganic sulfate end-members, rather than gypsum, using linear combination fitting in SIXPACK (Figure 5.2). Furthermore, gypsum was not included in our fits because it was not observable in coral skeletons via Raman spectroscopy (Cuif et al., 2003) and S XANES studies of sulfate in carbonates confirm that sulfate is not incorporated as gypsum or anhydrite in carbonates (Webb, 2011).

\subsubsection{Fitted ME $\mu$ XRF Maps}

Fitted ME $\mu$ XRF maps of sulfur species distributions are presented as heat maps (Figure 5.3) and tricolor plots (Figure 5.4). The major sulfur components within the tissue regions are sulfur species most similar to glutathione disulfide, cysteine, sulfoxide and organic sulfate. Cysteineand glutathione-like compounds are mostly anti-correlated throughout the tissues with glutathione occurring in concentrated points, especially in P. astreoides (Figure 5.4B). Sulfoxide-like species are loosely correlated with cysteine and glutathione distributions and anticorrelated with organic sulfate. Zoomed-in views of tissue regions rich in zooxanthellae in the gastroderm (labeled g), correlate visually with distributions of sulfoxide (Figure 5.5). CAS is dominant in the skeletons and mostly anti-correlated with all other sulfur species. 


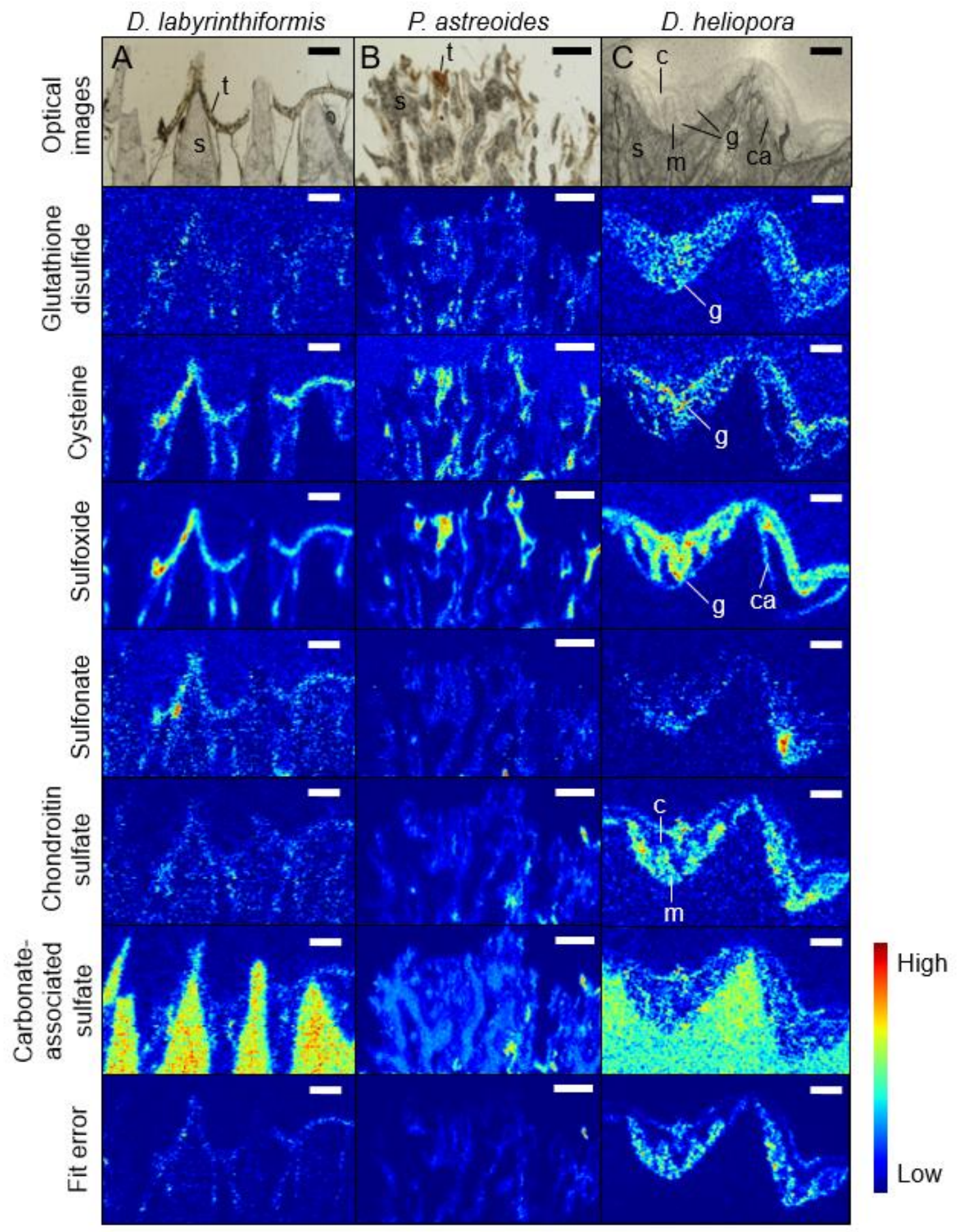

FIGURE 5.3. Multiple energy (ME) sulfur $\mu$ XRF maps fit with the sulfur XANES standards (Fig. 1) presented as heat maps (blue $=$ low relative concentration, red $=$ high relative concentrations) of A. $D$. labyrinthiformis, Carmabi, Curaçao (scale bar $=100 \mu \mathrm{m}$ ), B. P. astreoides, Water Factory, Curaçao (scale bar $=200 \mu \mathrm{m}$ ) and C. D. heliopora, Yap Island, Federated States of Micronesia (scale bar $=100 \mu \mathrm{m}$ ). Less-abundant skeletal chondroitin sulfate and inorganic sulfate features in the skeletons are pointed out with yellow arrows. Top optical images illustrate the location of the skeleton ( $\mathrm{s}=$ skeleton) and tissues $(\mathrm{t}=$ tissue). Specific tissue layers are also labeled on $\mathrm{C}: \mathrm{g}=$ gastroderm, $\mathrm{m}=$ mesoglea, $\mathrm{c}=$ coelenteron, $\mathrm{ca}=$ calicoderm. 


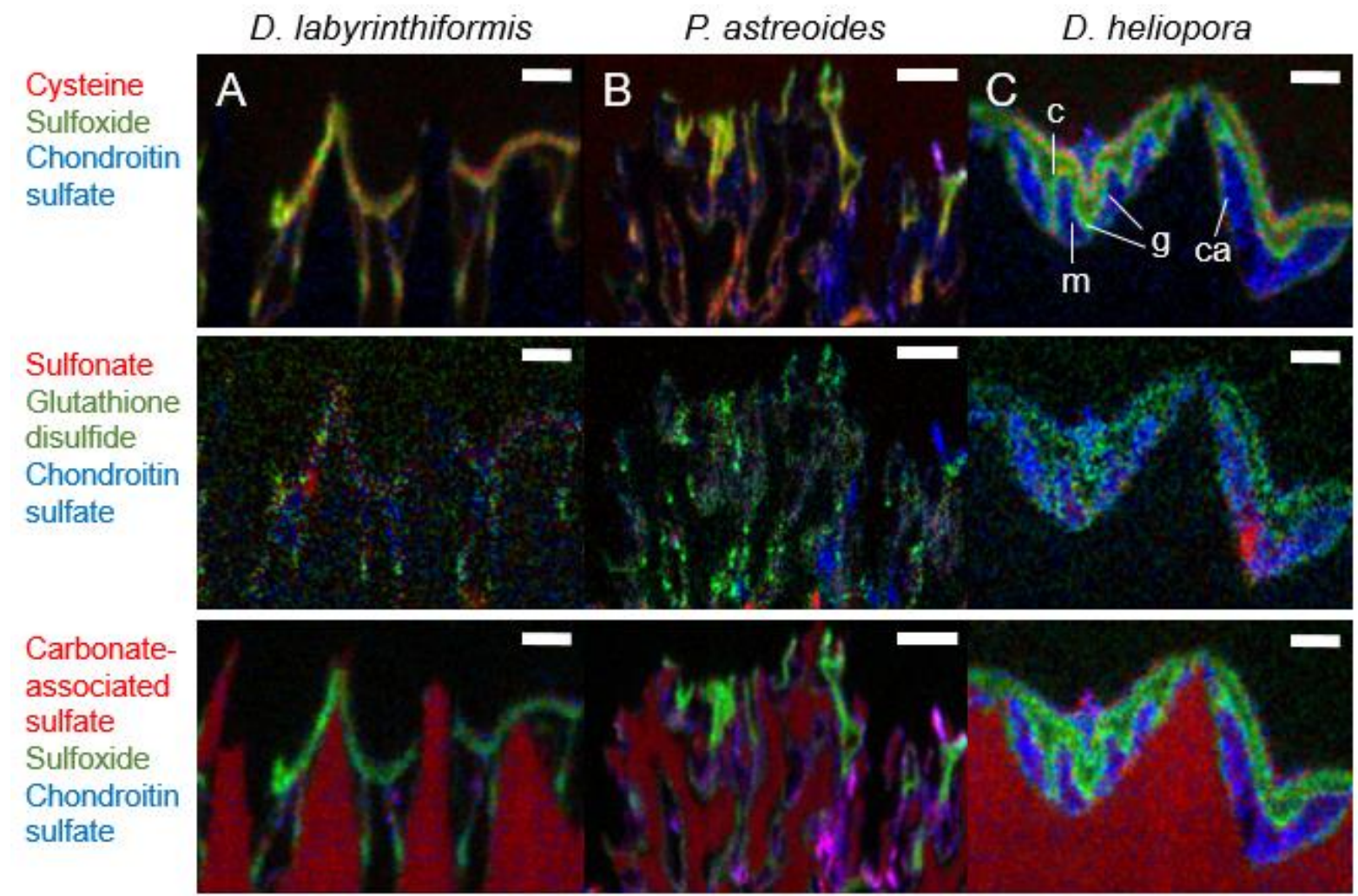

FIGURE 5.4. Tricolor plots of distributions of different sulfur species in A. D. labyrinthiformis, Carmabi, Curaçao (scale bar $=100 \mu \mathrm{m})$, B. P. astreoides, Water Factory, Curaçao (scale bar= $200 \mu \mathrm{m}$ ) and C. D. heliopora, Yap Island, Federated States of Micronesia (scale bar $=100 \mu \mathrm{m}$ ). The location of the skeleton is indicated by the bottom panel as carbonate-associated sulfate. Specific tissue layers are labeled on $\mathrm{C}$ : $\mathrm{g}=$ gastroderm, $\mathrm{m}=$ mesoglea, $\mathrm{c}=$ coelenteron, $\mathrm{ca}=$ calicoderm. 


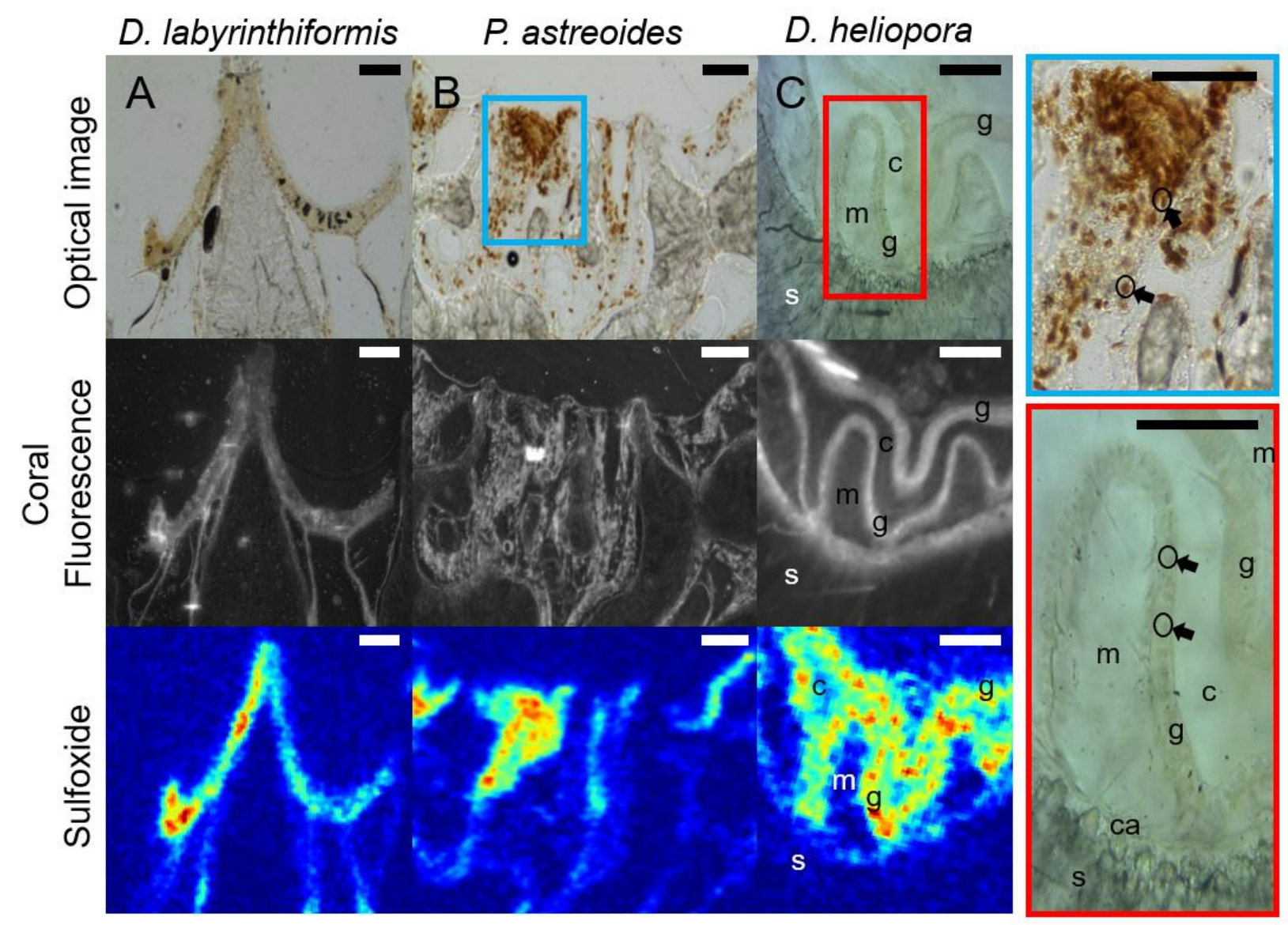

FIGURE 5.5. Correlations observed between the distributions of zooxanthellae and tissues (optical and fluorescence maps) with sulfoxide ( $\mu$ XRF maps). Samples include A). D. labyrinthiformis, Carmabi, Curaçao, B). P. astreoides, Water Factory, Curaçao, and C). D. heliopora, Yap Island, Federated States of Micronesia. Black open circles with arrows point out zooxanthellae. Specific tissue layers $(\mathrm{g}=$ gastroderm, $\mathrm{m}=$ mesoglea, $\mathrm{c}=$ coelenteron, $\mathrm{ca}=$ calicoderm) and skeleton $(\mathrm{s})$ and are labeled on $\mathrm{C}$. Scale bars are $100 \mu \mathrm{m}$. 


\subsection{DISCUSSION}

\subsubsection{Comparison to previous XRF mapping techniques}

Previous studies have provided spatial maps detailing the distribution of oxidized and reduced S regions of corals (Tamenori et al., 2014; Perrin et al., 2017). Here, we expand on synchrotronbased paired XANES- $\mu$ XRF methods to identify and map specific $S$ functional groups and species in situ at high spatial resolution. Further, rather than relying on single-energy maps that contain background fluorescence signals from lower energy absorption peaks or subtracting reduced energy maps from total energy maps, ME fitting separates the signals from individual species and allows for more accurate species-specific mapping. To aid in presenting this distinction, comparisons of single energy maps versus ME fitted maps are included in the Supplementary Material (Figure S5.6) along with validation steps for our fitting method (Figures S5.1, S5.2, S5.4; Table S5.1, S5.2). PCA analysis of an extensive XANES library further increases the accuracy of this method by properly constraining the number of components necessary to describe the system. Lastly, smaller energy step-sizes $(0.2 \mathrm{eV})$ in XANES spectra and higher-resolution $\mu$ XRF maps ( 5 x $5 \mu \mathrm{m}$ steps) allowed for differentiating between previously unresolved sulfate variations in corals. In combination, this approach allowed for high-resolution, species-specific maps of sulfur within and across the tissue-skeleton interface in corals. In our validation step, compound compositions extracted from our map fits compared to the XANES linear combination fits of our standards in our $D$. heliopora example did not always fit ideal 1:1 lines (Supplementary Material, Figure S5.4). This is likely due to the highly heterogeneous nature of the sample and the relatively low concentrations of certain compounds throughout the $D$. heliopora example that makes fitting more difficult.

\subsubsection{Sulfur species in tissues}

Four representative sulfur compounds, glutathione, cysteine, sulfoxide and organic sulfate, represent the array of sulfur species observed in the coral tissues explored here (Figures 5.1 and 5.3). Until recently, synchrotron-based studies had only utilized cysteine and methionine as standards to describe the reduced sulfur species observed in the coenenchyme of octocorals (Tamenori et al., 2014; Yoshimura et al., 2013), however, a recent study has identified or inferred a similar assemblage of sulfur species in octocoral tissues (i.e., glutathione, thioether, disulfide, sulfoxide, sulfonate and sulfate) as we observe in scleractinian corals, and which we use to fit our ME maps) (Perrin et al., 2017). Our fitted ME maps and S XANES spectra demonstrate that overall abundances and distributions of these selected sulfur bonding environments remain similar across coral species (Figures 5.2 and 5.3).

The distributions of these different $\mathrm{S}$ species point to their biological roles within coral tissues. Individual tissue layers were identified by referencing Allemand et al. (Allemand et al., 2004; Allemand et al., 2011) The most distinct sulfur feature identified across the coral tissues measured in this study is the presence of a sulfoxide-like compound concentrated in the gastroderm, the layer of tissue which hosts zooxanthellae, and which co-occurs with high concentrations of zooxanthellae (Figure 5.5, gastroderm labeled with a "g"). This sulfoxide signal is likely dimethylsulfoniopropionate (DMSP), an antioxidant which is produced at elevated levels by zooxanthellae, as well as by the coral tissues themselves (but to a lesser 
degree) when these organisms are exposed to oxidative and heat stress (Raina et al., 2013; McLenon and DiTullio, 2012). This sulfoxide is also correlated with a cysteine-like component, a sulfur-bearing amino acid, which occurs in high concentrations in protein-rich regions, such as around zooxanthellae or other metabolically-active coral tissues (Figures 5.4 and 5.5). One difference is that that sulfoxide is mostly restricted to the gastroderm while the cysteine-like species is also present in other areas of the tissue (Figures 5.3-5.5). Cysteine and a sulfur species resembling glutathione both occur throughout the tissues, however, they are loosely anticorrelated. A glutathione-like species is likewise present in the gastroderm but also occurs as hot spots in other tissues likely associated with high concentrations of endosymbiotic bacteria known to use glutathione for their sulfur metabolisms and redox regulation, especially in $P$. astreoides (Figures 5.3B and 5.4B) (Wegley et al., 2007). Organic sulfate (represented by a chondroitin sulfate S XANES standard) is anti-correlated with all of the reduced sulfur species, likely because chondroitin sulfate is a common structure-building polysaccharide in animal tissues and in our samples is present in the mesoglea, an extracellular matrix composed predominantly of water and collagen most clearly detailed in D. heliopora (Figures 5.3C and 5.4C) (Allemand et al., 2004). Furthermore, this organic sulfate is not associated with the unicellular endosymbionts correlating with the sulfoxide, cysteine and glutathione distributions.

\subsubsection{Sulfur in the skeletons}

This study introduces a method to speciate and localize the variety of sulfate bonding environments in the skeleton. We observe that carbonate-associated sulfate (CAS) is the dominant sulfur signal observed in the aragonitic coral skeletons and that it is especially concentrated along centers of calcification (Figure 5.3). This finding corroborates previous studies that focused on mapping sulfur in coral skeletal microstructures and similarly observed a higher concentration of sulfate in centers of calcification (Cuif et al., 2003). Our CAS is distinguishable via S XANES from another inorganic sulfate species within the skeleton and from gypsum. The presence of CAS corroborates previous studies of other aragonite and calcite coral skeletons suggesting that skeletal sulfur is composed predominantly of substitutions of $\mathrm{SO}_{4}{ }^{2-}$ for $\mathrm{CO}_{3}{ }^{2-}$ in the crystal structure (Nguyen et al., 2014: Tamenori et al., 2014; Pingitore et al., 1995), despite the incorporation of $\mathrm{SO}_{4}{ }^{2-}$ into the aragonite structure being energetically unfavorable compared to other carbonates such as calcite (Takano et al., 1980; Busenberg and Plummer, 1985; Fernández-Díaz et al., 2010). This inorganic substitution of sulfate for carbonate groups in the crystal structure was originally proposed as a mechanism for the incorporation of sulfate in marine biogenic carbonates based on IR measurements and is still considered to be the most likely method for sulfate incorporation in biogenic carbonates (Takano, 1985). Since then, postulated mechanisms for sulfur incorporation in carbonates have included sulfide, sulfite and sulfate substitutions for carbonate, sulfate-bearing mineral inclusions, native sulfur incorporations, sulfate fluid inclusions, adsorption of sulfate onto carbonate surfaces and intraand inter-crystalline S-bearing organic matter (Perrin et al., 2017; Pingitore et al., 1995; Takano et al., 1980). CAS is also described in calcite and calcitic corals as structurally substituted sulfur (SSS) (Vielzeuf et al., 2013; Kampschulte and Strauss, 2004).

Another inorganic sulfate component was clearly differentiated from the CAS by a 0.2 $\mathrm{eV}$ shift in the absorption edge for these two species (Figure 5.1), however it was present in too low of concentrations to be included in our map fits (Figure 5.3). We propose that this is likely a 
sorbed sulfate species within the skeleton. By using PCA on the extensive collection of S XANES points to identify representative end-member species in the corals, this minor sulfate species was able to observed and identified.

Results of our fitted ME maps reveal a minor presence of organic sulfur species in the skeletons which is anti-correlated with CAS. This observation is consistent with previous studies that identified both inorganic sulfate and organic sulfur species in calcite and aragonite coral skeletons (Figure 5.3) (Nguyen et al., 2014; Vielzeuf et al., 2013; Tamenori et al., 2014; Pingitore et al., 1995). As these are natural, heterogeneous samples, this organic sulfate signal in the skeletons could be associated with boring algae or with a skeletal organic matrix. While organic sulfate has been proposed as both a major (Cuif et al., 2003) and minor (Nguyen et al., 2014; Tamenori et al., 2014) sulfur component within coral skeletons, our S XANES observations, along with more recent synchrotron-based and complementary studies, suggest that organic sulfate is a minor sulfur component in coral skeletons and that CAS comprises most of the observed sulfur signal. Mass balance calculations from previous studies indicate that structurally-substituted sulfur and organo-sulfur species were present at approximately a 20:1 ratio in the calcite skeletons of P. japonicum (Nguyen et al., 2014; Vielzeuf et al., 2013; Allemand et al., 1994) with an upper bound for total sulfate in biogenic carbonates as $5000 \mathrm{ppm}$ in aragonitic coral skeletons (Webb, 2011) and $3100 \pm 400 \mu \mathrm{g} / \mathrm{g}$ in calcitic Corallium rubrum skeletons (Vielzeuf et al., 2013). Despite the lack of a major organic sulfate presence in the skeletons, our thin-sectioned samples of combined skeleton and tissues reveal that organic sulfate species are much more pronounced in coral tissues relative to in the skeleton (Figures 5.3 and 5.4).

\subsection{CONCLUSIONS}

Synchrotron-based methods offer a unique approach to observing in situ elemental distributions and bonding environments in complex environmental samples. Here, sulfur $\mu$ XRF ME maps with end-members and standards from extensive S XANES observations and analyses allowed for distinguishing between different species and distributions of sulfur formerly unresolved by previous studies. Specifically, tissues are composed of reduced sulfur species similar to glutathione, cysteine and sulfoxide, as well as organic sulfate, while skeletal sulfur is dominated by CAS with very minor amounts of (ad)sorbed sulfate and organic sulfate. Sulfur distributions follow consistent spatial patterns in coral tissues and skeletons, regardless of species and locality. For example, CAS is concentrated along centers of calcification, along the septa of skeletons, while sulfoxide is located in tissues that are especially concentrated with zooxanthellae. Our method of coupling $\mu \mathrm{XRF}$ with XANES produces more accurate representations of sulfur species distributions compared to single-energy maps or XANES fittings with $\mu$ XRF maps that use less-representative standards, such as gypsum to represent sulfate, from spectral databases. Future directions for this method could include combining these low-energy X-ray maps with metal species data obtained on high-energy beamlines as well as microbial distributions using spatial biological techniques such as fluorescent in situ hybridization probes. 


\subsection{Funding and Acknowledgments}

We thank Ray Dalio for funding the Micronesian expedition and K. Hughen, M. Neave, J. Ossolinski, A. Santoro, C. Smith, and the crew of the M/V Alucia for sampling support and the Federated States of Micronesia for collection permits FM12-11-03S and FM12-11-05S. In Curaçao, we are grateful to Mark Vermeij, Kristen Marhaver and the CARMABI Research Institute for logistical support and permit AN-001 issued by Curaçao.

Use of the Stanford Synchrotron Radiation Lightsource, SLAC National Accelerator Laboratory, is supported by the U.S. Department of Energy, Office of Science, Office of Basic Energy Sciences under Contract No. DE-AC02-76SF00515. The SSRL Structural Molecular Biology Program is supported by the DOE Office of Biological and Environmental Research, and by the National Institutes of Health, National Institute of General Medical Sciences (including P41GM103393). The contents of this publication are solely the responsibility of the authors and do not necessarily represent the official views of NIGMS or NIH.

The authors would also like to acknowledge Courtney Krest (SSRL) for help with BL 143, Horst Marschall and Adam Sarafian (WHOI) for help with SEM measurements and Anne Cohen (WHOI) and Konrad Hughen (WHOI) for helpful coral discussions. This material is based upon work supported by the National Science Foundation Graduate Research Fellowship under Grant No. 1122374 and a Ford Foundation Dissertation Fellowship for Gabriela Farfan.

\subsubsection{Author Contributions}

G.A.F. collected and analyzed all $\mu$ XRF and XANES data. S.W. provided expertise on the ME map fitting method and helped interpret final maps with C.M.H and G.A.F. A.A. provided the coral samples and interpreted relevance to biological tissues with C.M.H. and G.A.F. G.A.F wrote the manuscript with assistance from C.M.H. All authors have given approval to the final version of the manuscript.

\subsection{References}

Allemand, D., Cuif, J. P., Watabe, N., Oishi, M.: Kawaguchi, T. (1994). The organic matrix of skeletal structures of the Mediterranean red coral, Corallium rubrum. Bull. Inst. océanogr. (Monaco) 14(1)129-140.

Allemand, D., Ferrier-Pagès, C., Furla, P., Houlbrèque, F., Puverel, S., Reynaud, S., Tambutté, É., Tambutté, S., Zoccola, D. (2004). Biomineralisation in reef-building corals: from molecular mechanisms to environmental control. C. R. Palevol. 3, 453-467. doi:0.1016/j.crpv.2004.07.011

Allemand, D., Tambutté, É., Zoccola, D., Tambutté, S. (2011). Coral Calcification, Cells to Reefs. In: Coral Reefs: An Ecosystem in Transition (eds. Z. Dubinsky and N. Stambler). Springer Netherlands 119-150. doi:10.1007/978-94-007-0114-4 
Benzerara, K., Menguy, N., López-García, P., Yoon, T. H., Kazmierczak, J., Tyliszczak, T., Brown, G. E. (2006). Nanoscale detection of organic signatures in carbonate microbialites. Proc. Natl. Acad. Sci., 103(25), 9440-9445. doi:10.1073/pnas.0603255103

Busenberg, E., Plummer, N. L. (1985). Kinetic and thermodynamic factors controlling the distribution of $\mathrm{SO}_{4}{ }^{2-}$ and $\mathrm{Na}^{+}$in calcites and selected aragonites. Geochim. Cosmochim. Acta 49, 713-725. doi:10.1016/0016-7037(85)90166-8

Cuif, J. P., Dauphin, Y. Y., Doucet, J., Salome, M., Susini, J. (2003). XANES mapping of organic sulfate in three scleractinian coral skeletons. Geochim. Cosmochim. Acta. 67, 75-78. doi:10.1016/S00167037(02)01041-4

Cusack, M., Dauphin, Y., Cuif, J. P., Salome, M., Freer, A., Yin, H. (2008). Micro-XANES mapping of sulphur and its association with magnesium and phosphorus in the shell of the brachiopod, Terebratulina retusa. Chem. Geol. 253, 172-179. doi:10.1016/j.chemgeo.2008.05.007

Dauphin, Y. (2001). Comparative studies of skeletal soluble matrices from some Scleractinian corals and Molluscs. Int. J. Biol. Macromol. 28, 293-304. doi:10.1016/S0141-8130(01)00124-6

Dauphin, Y., Cuif, J. P., Salome, C., Susini, J. (2005). Speciation and distribution of sulfur in a mollusk shell as revealed by in situ maps using X-ray absorption near-edge structure (XANES) spectroscopy at the S K-edge. Am. Mineral. 90, 1748-1758. doi:10.2138/am.2005.1640

Fernández-Díaz, L., Fernández-González, Á., Prieto, M. (2010). The role of sulphate groups in controlling $\mathrm{CaCO}_{3}$ polymorphism. Geochim. Cosmochim. Acta 74, 6064-6076. doi:10.1016/j.gca.2010.08.010

Kampschulte, A., Strauss, H. (2004). The sulfur isotopic evolution of Phanerozoic seawater based on the analysis of structurally substituted sulfate in carbonates. Chem. Geol. 204, 255-286. doi:10.1016/j.chemgeo.2003.11.013

Keiluweit, M., Bougoure, J. J., Nico, P. S., Pett-Ridge, J., Weber, P. K., Kleber, M. (2015). Mineral protection of soil carbon counteracted by root exudates. Nat. Clim. Change 5, 588-595.

Manceau, A. and Nagy, K. L. (2012). Quantitative analysis of sulfur functional groups in natural organic matter by XANES spectroscopy. Geochim. Cosmochim. Acta. 99, 206-223.

Mayhew, L. E., Webb, S. M., Templeton, A. S. (2011). Microscale imaging and identification of Fe speciation and distribution during fluid-mineral reactions under highly reducing conditions. Environ. Sci. Technol. 45, 4468-4474. doi:10.1021/es104292n

McLenon, A. L., DiTullio, G. R. (2012). Effects of increased temperature on dimethylsulfoniopropionate (DMSP) concentration and methionine synthase activity in Symbiodinium microadriaticum. Biogeochemistry 110, 17-29. doi:10.1007/s10533-012-9733-0

Nguyen, L. T., Rahman, M. A., Maki, T., Tamenori, Y., Yoshimura, T., Suzuki, A., Iwasaki, N., Hasegawa, H. (2014). Distribution of trace element in Japanese red coral (Paracorallium japonicum) by $\mu$ XRF and sulfur speciation by XANES: Linkage between trace element distribution and growth ring formation. Geochim. Cosmochim. Acta 127, 1-9. doi:10.1016/j.gca.2013.11.023 
Perrin, J., Rivard, C., Vielzeuf, D., Laporte, D., Fonquernie, C., Ricolleau, A., Cotte, M., Floquet, N. (2017). The coordination of sulfur in synthetic and biogenic Mg calcites: The red coral case. Geochim. Cosmochim. Acta. 197, 226-244. doi:10.1016/j.gca.2016.10.017

Pingitore, N. E., Meitzner, G., Love, K. M. (1995). Identification of sulfate in natural carbonates by X-ray absorption spectroscopy. Geochim. Cosmochim. Acta, 59, 2477-2483. doi:10.1016/00167037(95)00142-5

Present, T., Paris, G., Burke, A., Fischer, W. W., Adkins, J. F. (2015). Large carbonate associated sulfate isotopic variability between brachiopods, micrite, and other sedimentary components in Late Ordovician strata. Earth Planet. Sci. Lett. 432, 187-198. doi:10.1016/j.eps1.2015.10.005

Raina, J. B., Tapiolas, D. M., Foret, S., Lutz, A., Abrego, D., Ceh, J., Seneca, F., Clode, P. L., Bourne, D. G., Willis, B. L., Motti, C. A. (2013). DMSP biosynthesis by an animal and its role in coral thermal stress response. Nature 502, 677-680. doi:10.1038/nature 12677

Rompel, A., Cinco, R. M., Latimer, M. J., McDermott, A. E., Guiles, R. D., Quintanilha, A., Krauss, R. M., Sauer, K., Yachandra, V. K., Klein, M. P. (1998). Sulfur K-edge x-ray absorption spectroscopy: A spectroscopic tool to examine the redox state of S-containing metabolites in vivo. Proc. Natl. Acad. Sci. 95(11), 6122-6127. doi:10.1073/pnas.95.11.6122

Spurgeon, J. P. G. (1992). The economic valuation of coral reefs. Mar. Pollut. Bull. 24, 529-536.

Takano, B. (1985). Geochemical implications of sulfate in sedimentary carbonates. Chem. Geol. 49, 393403.

Takano, B., Asano, Y., Watanuki, K. (1980). Characterization of Sulfate Ion in Travertine. Contrib. to Mineral. Petrol. 72, 197-203.

Tamenori, Y., Yoshimura, T., Luan, N. T., Hasegawa, H., Suzuki, A., Kawahata, H., Iwasaki, N. (2014). Identification of the chemical form of sulfur compounds in the Japanese pink coral (Corallium elatius) skeleton using $\mu$-XRF/XAS speciation mapping. J. Struct. Biol. 186(2), 214-23. doi:10.1016/j.jsb.2014.04.001

Templeton, A., Knowles, E. (2009). Microbial transformations of minerals and metals: Recent advances in geomicrobiology derived from synchrotron-based X-Ray spectroscopy and X-Ray microscopy. Annu. Rev. Earth Planet. Sci. 37, 367-391. doi:10.1146/annurev.earth.36.031207.124346

Vázquez-Rodríguez, A. I., Hansel, C. M., Zhang, T., Lamborg, C. H., Santelli, C. M., Webb, S. M., Brooks, S. C. (2015). Microbial- and thiosulfate-mediated dissolution of mercury sulfide minerals and transformation to gaseous mercury. Front. Microbiol., 6, 1-11. doi:10.3389/fmicb.2015.00596

Vielzeuf, D., Garrabou, J., Gagnon, A., Ricolleau, A., Adkins, J., Günther, D., Hametner, K., Devidal, J. L., Reusser, E., Perrin, J., Floquet, N. (2013). Distribution of sulphur and magnesium in the red coral. Chem. Geol. 355, 13-27. doi:10.1016/j.chemgeo.2013.07.008

Webb S. M. (2005). SIXpack: a graphical user interface for XAS analysis using IFEFFIT. Phys. Scr. T115, 1011-1014. 
Webb S. M. (2011). The MicroAnalysis Toolkit: X-ray fluorescence image processing software. AIP Conf. Proc. 1365, 196-199.

Wegley, L., Edwards, R., Rodriguez-Brito, B., Liu, H., Rohwer, F. (2007). Metagenomic analysis of the microbial community associated with the coral Porites astreoides. Environ. Microbiol. 9, 27072719. doi:10.1111/j.1462-2920.2007.01383.x

Xia, K., Weesner, F., Bleam, W. F., Bloom, P. R., Skyllberg, U. L., Helmke, P. A. (1998). XANES studies of oxidation states of sulfur in aquatic and soil humic substances. Soil Sci. Soc. Am. J. 62, 1240 1246. doi:10.2136/sssaj1998.03615995006200050014x

Yoshimura, T., Tamenori, Y., Suzuki, A., Nakashima, R., Iwasaki, H. H., Kawahara, H. (2013). Element profile and chemical environment of sulfur in a giant clam shell: Insights from $\mu$-XRF and X-ray absorption near-edge structure. Chem. Geol. 352, 170-175. doi:10.1016/j.chemgeo.2013.05.035 


\subsection{Supplementary Material_Figures}
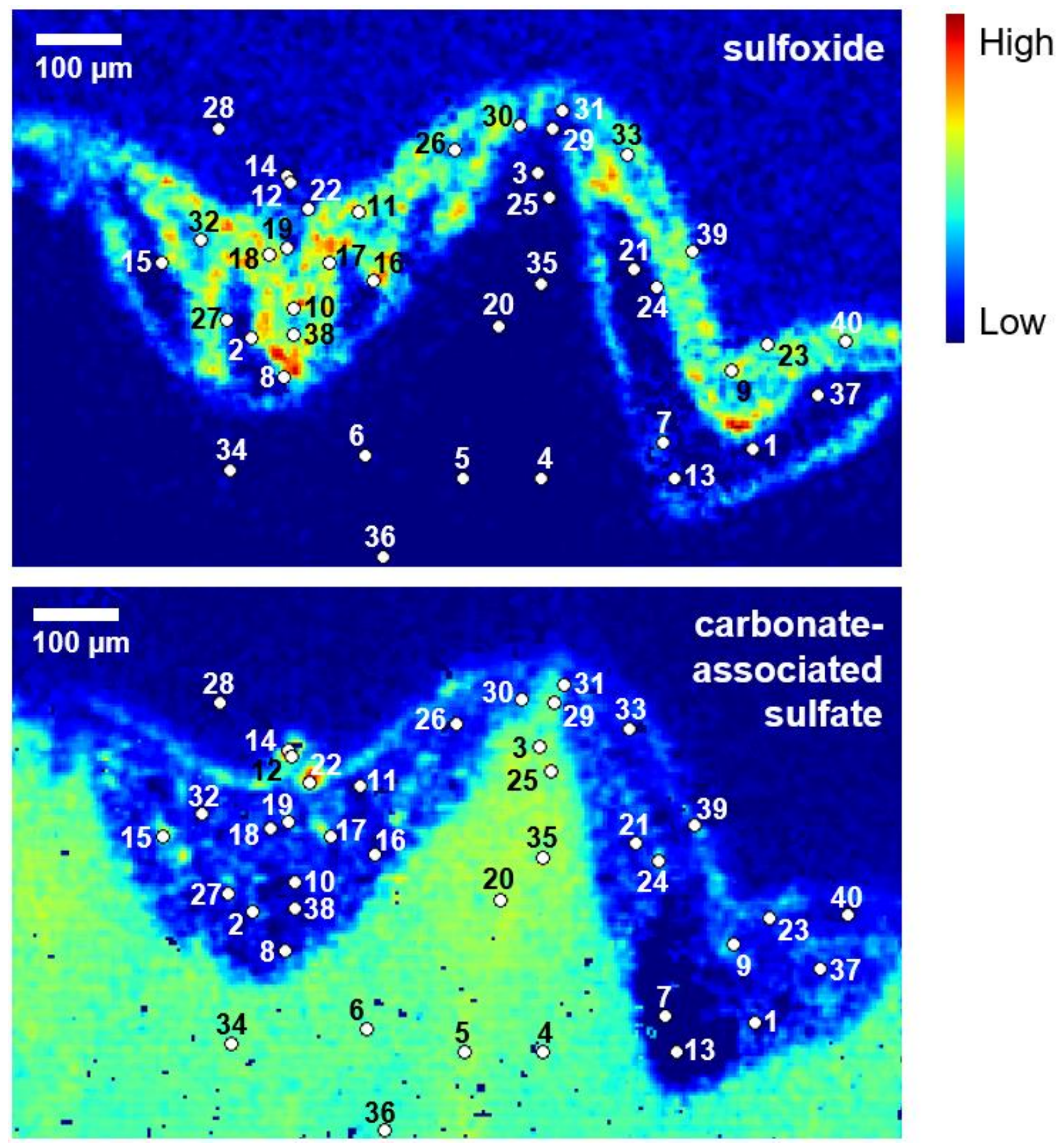

FIGURE S5.1. $40 \mathrm{~S}$ XANES points on D. heliopora sample, shown on the sulfoxide and carbonateassociated sulfate distribution heat maps. 


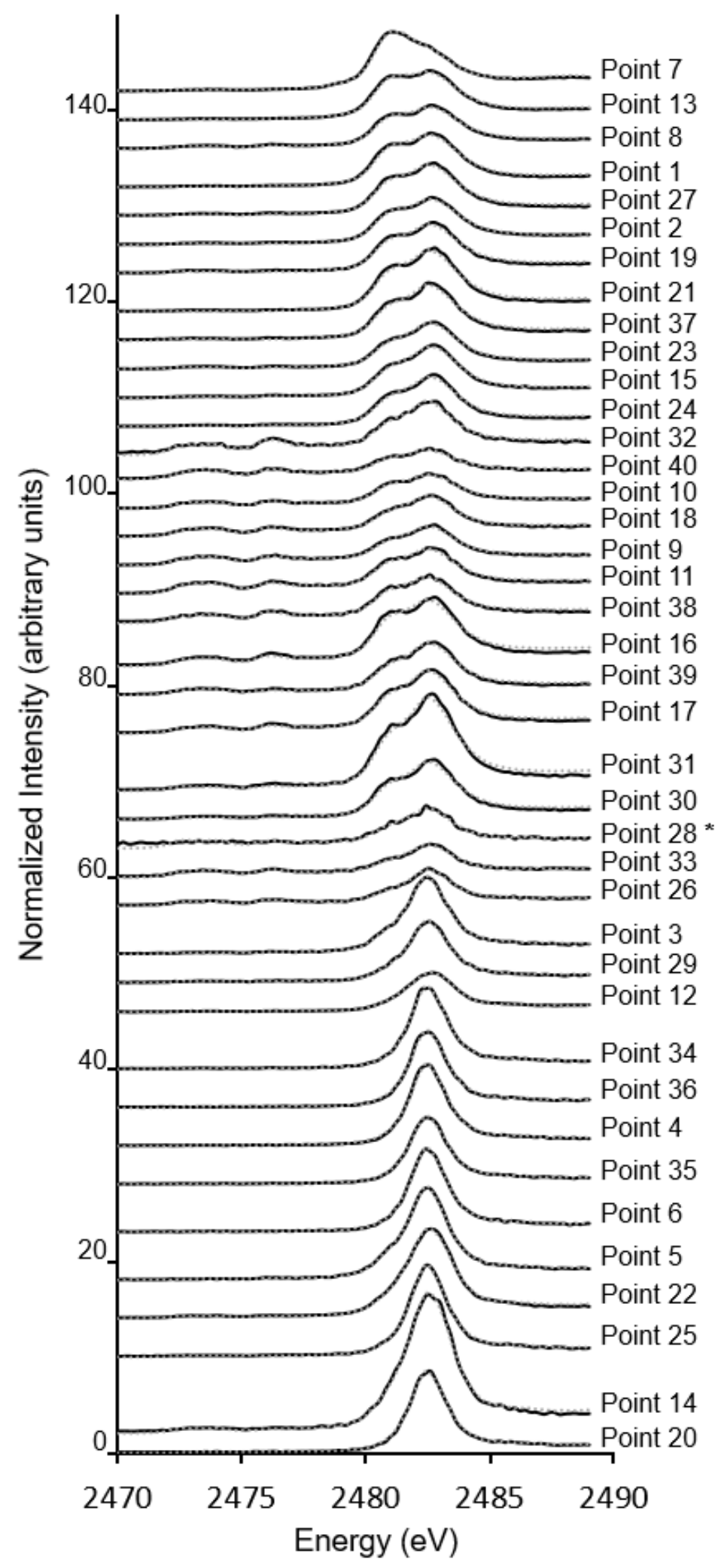

FIGURE S5.2. 40 normalized S XANES spectra collected on D. heliopora sample (black solid lines) with results of linear combination fitting with the seven representative S XANES species (grey dotted lines). Spectra correspond to points on Figure S1. * indicates a point on the epoxy. 


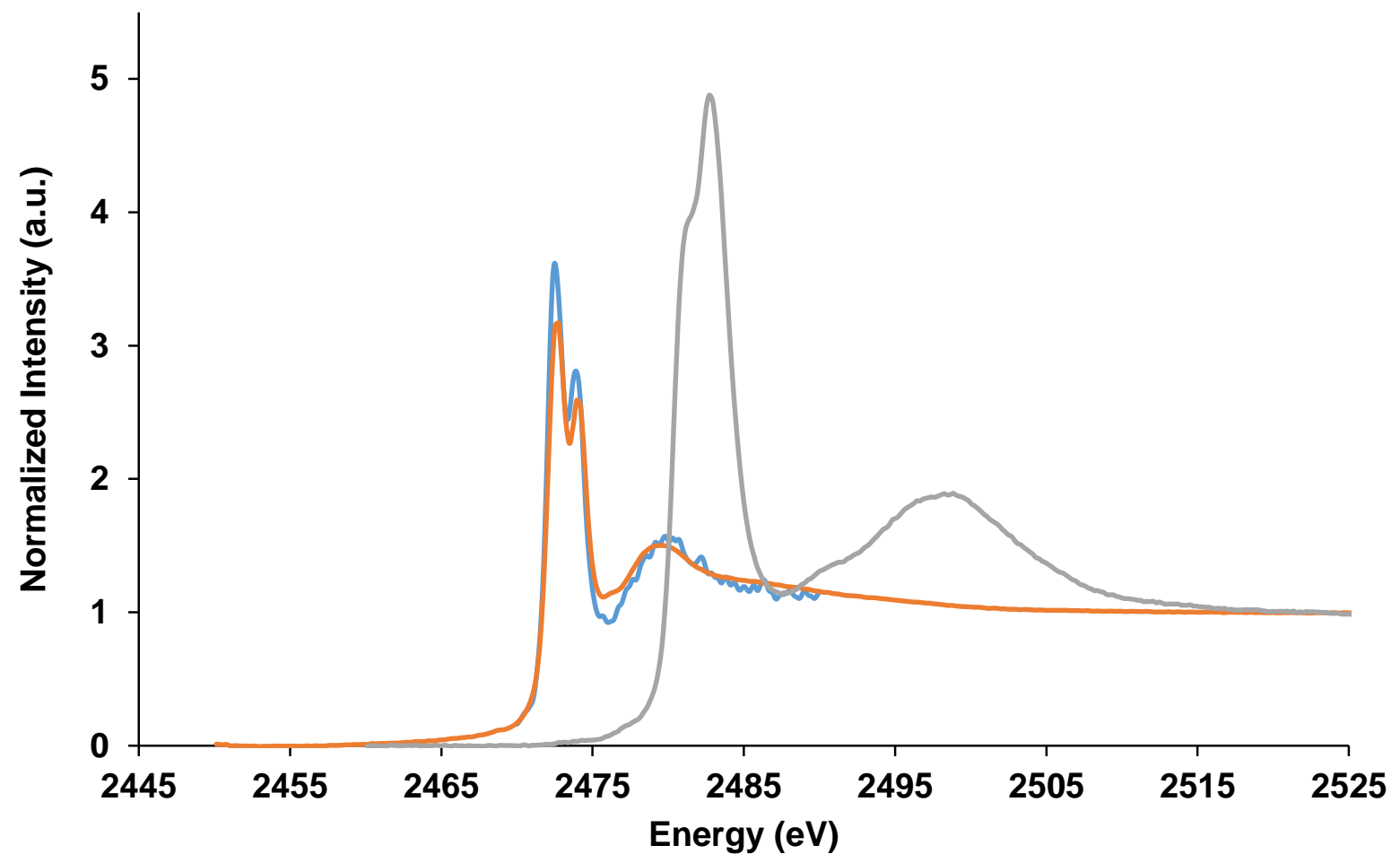

\section{- Glutathione from SSRL - Glutatione from ESRF Chondroitin sulfate from ESRF}

FIGURE S5.3. A comparison of reference spectra collected at two different beamlines shows that overall peak shape and positions are consistent between beamlines (SSRL and the ESRF database). In this example we show the similarities between glutathione samples measured at SSRL (blue) and from the ESRF database (orange). These glutathione compounds produce very different spectra from other $S$ compounds, such as this chondroitin sulfate in grey from the ESRF database. 

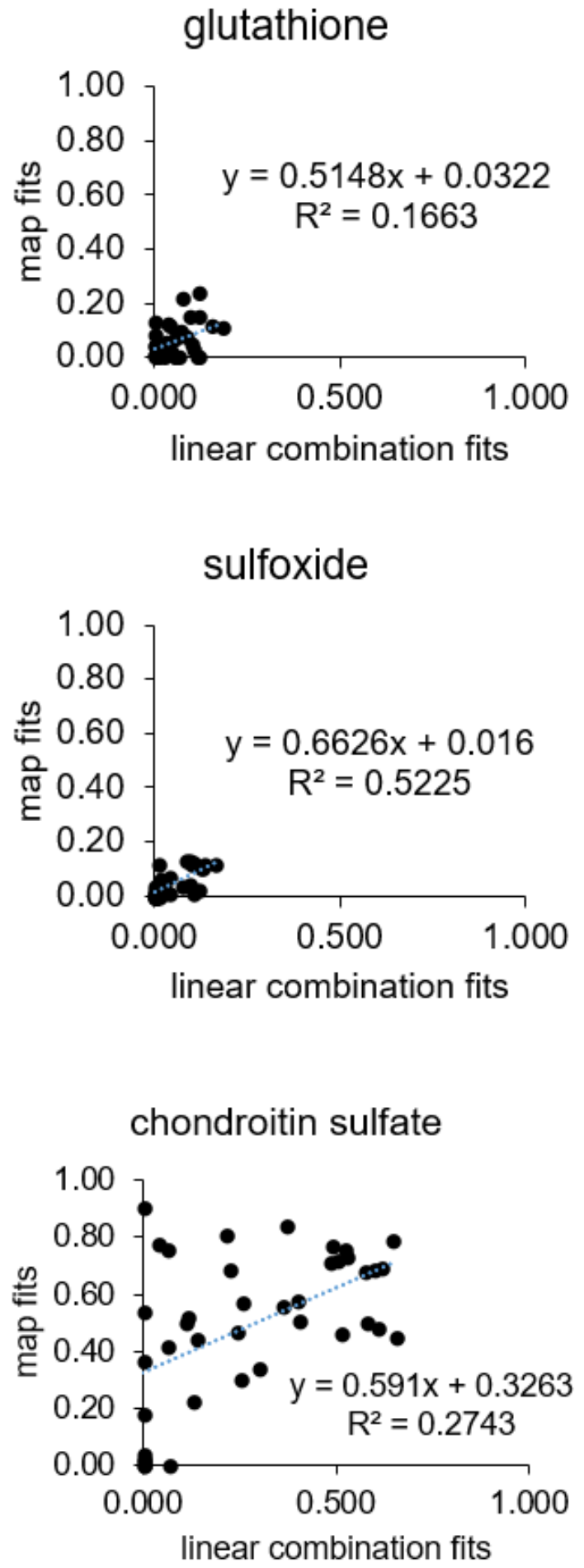
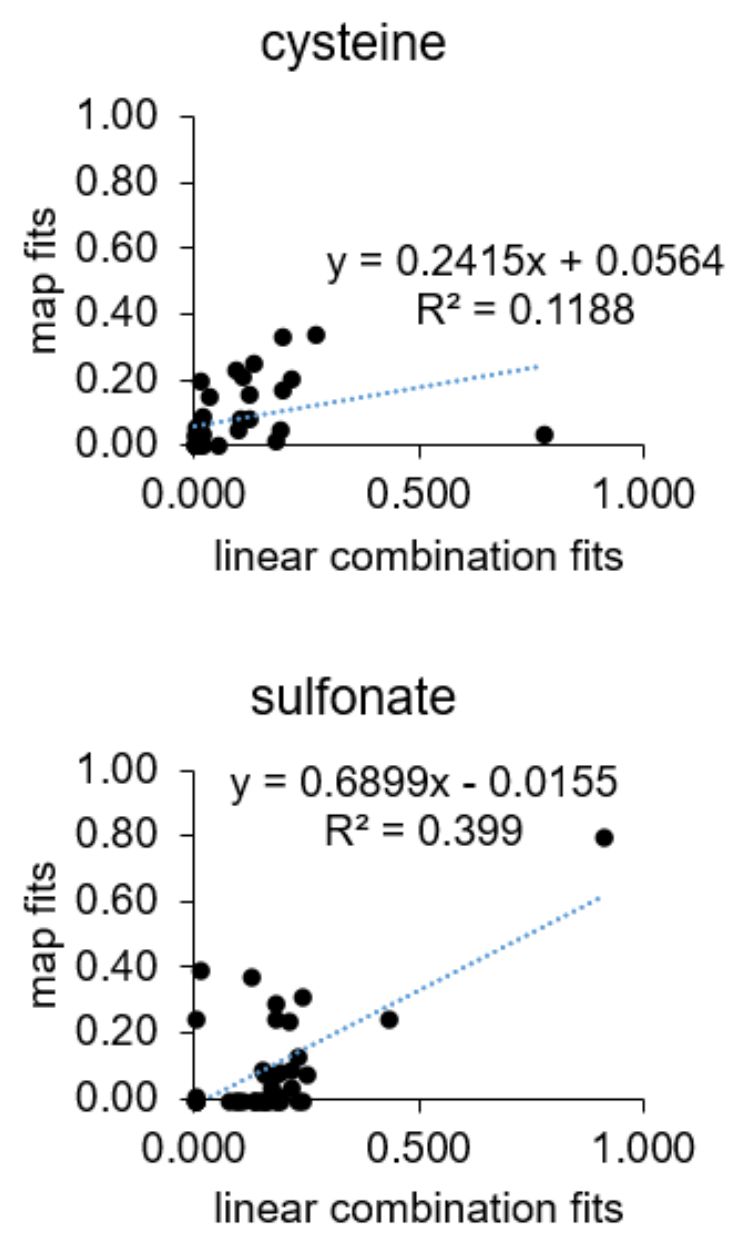

\section{carbonate-associated}

sulfate

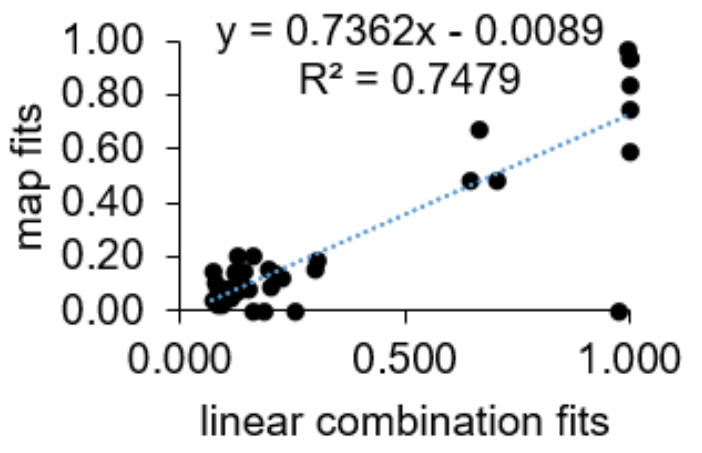

FIGURE S5.4. Validation step for ME map fittings. Fraction contributions of different $\mathrm{S}$ compounds calculated by linear combination fitting versus map fitting on S XANES for the D. heliopora sample. An ideal correlation between XANES versus map fits should yield a 1:1 relationship. Due to the very heterogeneous nature of the sample, as well as the difficulty fitting compounds present in low concentrations, these slopes are not always an ideal 1:1 fit. 


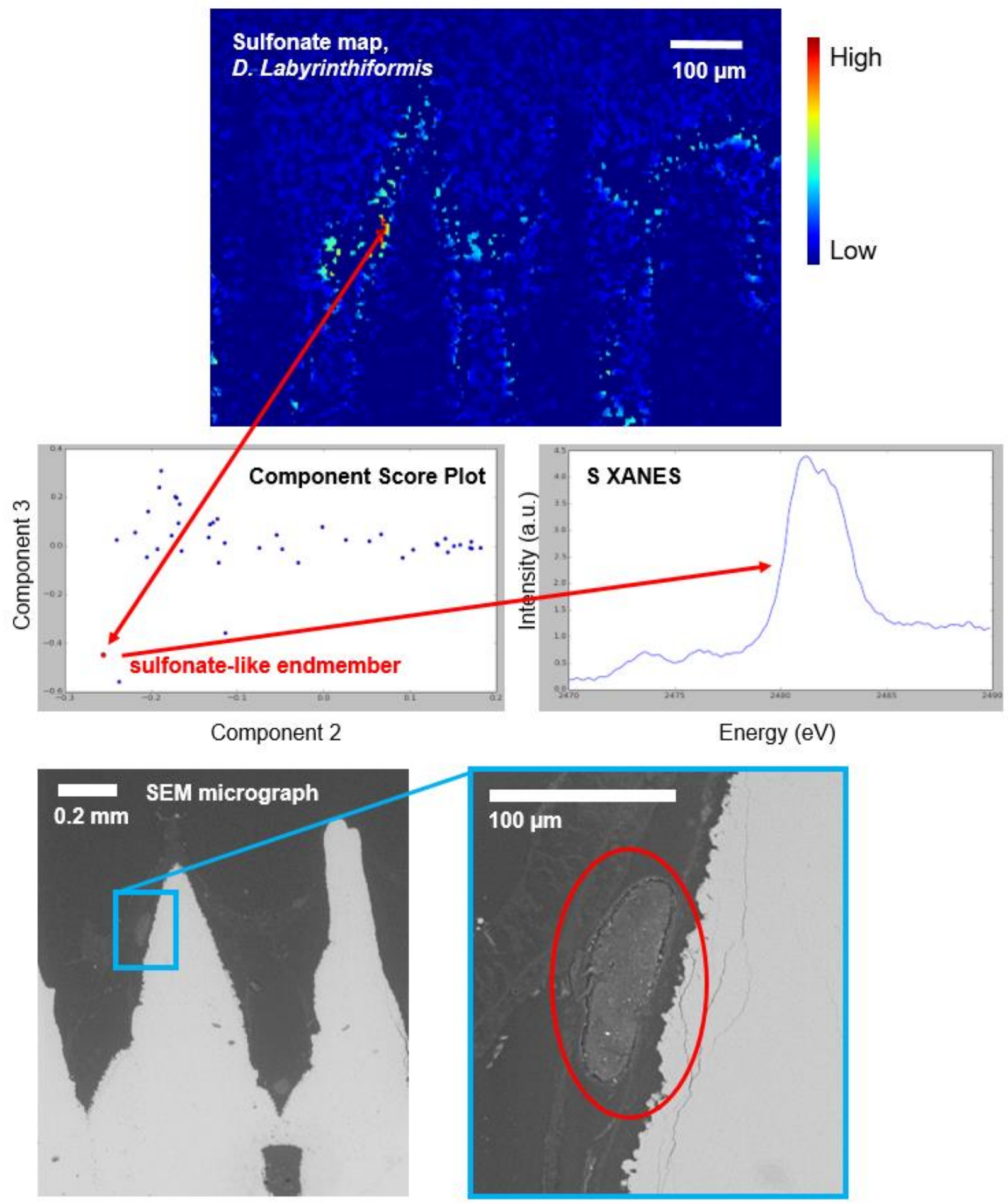

FIGURE S5.5. Potential contamination from the polishing process as shown by SEM micrographs of a filled bubble region correlated with a concentrated distribution of a sulfonate-like species that is also an end-member S XANES spectrum in our PCA component 3 vs. component 2 score plot. 
Single-energy Maps

$2472.8 \mathrm{eV}$

$2475.1 \mathrm{eV}$

$2476.1 \mathrm{eV}$

$2481.4 \mathrm{eV}$

$2482.4 \mathrm{eV}$

$2482.7 \mathrm{eV}$

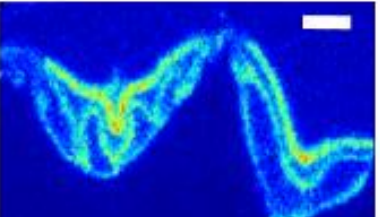

$2473.9 \mathrm{eV}$

$2488.0 \mathrm{eV}$ (total S)

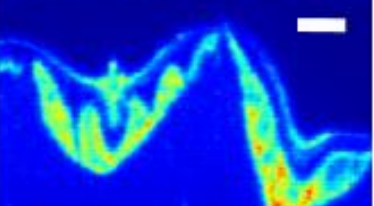

ME Fitted Maps
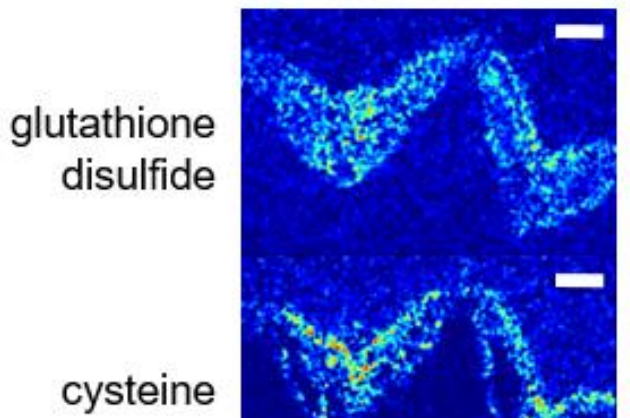

sulfoxide

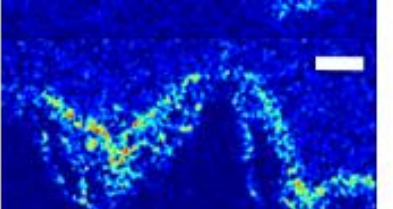

sulfonate
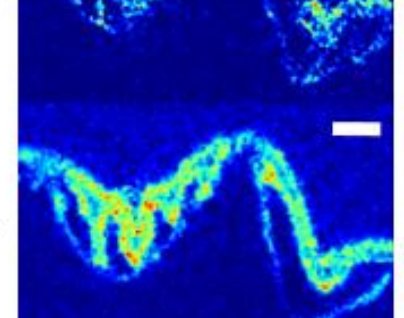

chondroitin

sulfate
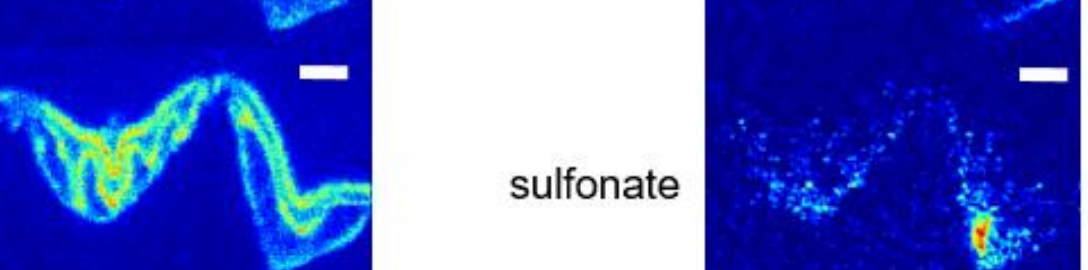

carbonateassociated

sulfate

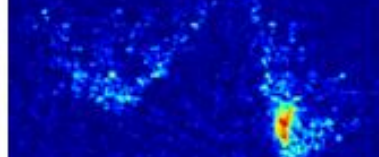

fit error
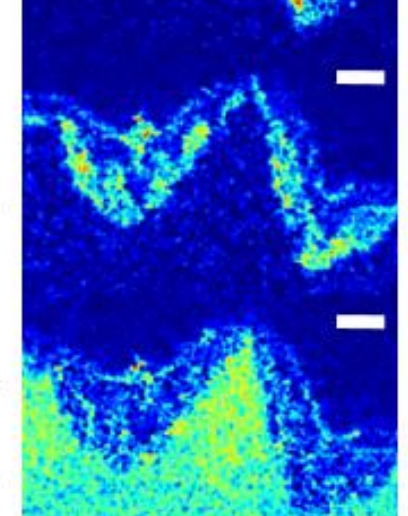

High

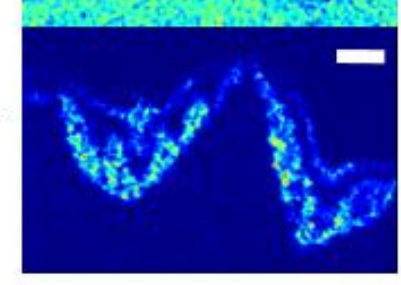

Low

FIGURE S5.6. Comparison of single-energy maps (left) versus stacked multiple energy (ME) maps fitted to S XANES of standard S compounds (right) shows how ME fitted maps present more accurate distributions of individual $\mathrm{S}$ bonding environments in D. heliopora. Scale bars are $100 \mu \mathrm{m}$. 


\subsection{Supplementary Material-Tables}

TABLE S5.1. D. heliopora S XANES spectra (Supplementary Materials Figure S5.2)

representing points on Supplementary Materials Figure S5.1 fit with S XANES standards (Figure

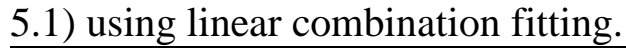

\begin{tabular}{|c|c|c|c|c|c|c|c|c|c|c|}
\hline $\begin{array}{l}\stackrel{\ddot{I}}{\circ} \\
\stackrel{0}{2}\end{array}$ & 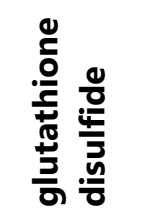 & 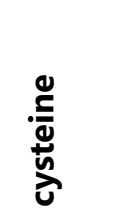 & $\begin{array}{l}\frac{0}{0} \\
\frac{0}{x} \\
\frac{0}{5} \\
\tilde{u}\end{array}$ & 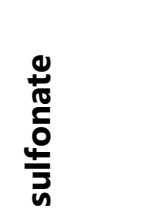 & 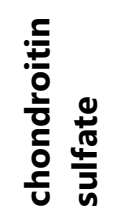 & 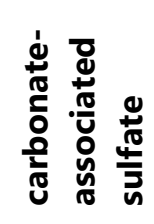 & 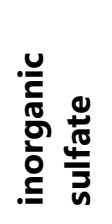 & 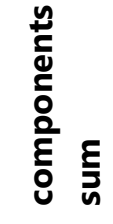 & 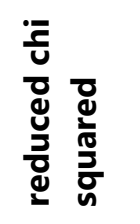 & 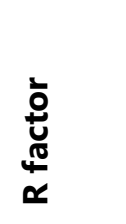 \\
\hline 1 & $\begin{array}{l}0.007 \pm \\
0.005\end{array}$ & & & $\begin{array}{l}0.283 \pm \\
0.012\end{array}$ & $\begin{array}{l}0.736 \pm \\
0.016\end{array}$ & $\begin{array}{l}0.106 \pm \\
0.007\end{array}$ & & 1.13 & 0.01635 & 0.0033 \\
\hline 2 & $\begin{array}{l}0.023 \pm \\
0.009\end{array}$ & $\begin{array}{l}0.016 \pm \\
0.012\end{array}$ & $\begin{array}{l}0.012 \pm \\
0.004\end{array}$ & $\begin{array}{l}0.184 \pm \\
0.013\end{array}$ & $\begin{array}{l}0.604 \pm \\
0.025\end{array}$ & $\begin{array}{l}0.076 \pm \\
0.016\end{array}$ & $\begin{array}{l}0.1 \pm \\
0.04\end{array}$ & 0.98 & 0.00648 & 0.00178 \\
\hline 3 & $\begin{array}{l}0.023 \pm \\
0.003\end{array}$ & & $\begin{array}{l}0.012 \pm \\
0.003\end{array}$ & $\begin{array}{l}0.259 \pm \\
0.007\end{array}$ & $\begin{array}{l}0.076 \pm \\
0.009\end{array}$ & $\begin{array}{l}0.719 \pm \\
0.004\end{array}$ & & 1.09 & 0.0049 & 0.00081 \\
\hline 4 & & & & & & $\begin{array}{l}0.902 \pm \\
0.002\end{array}$ & & 0.90 & 0.00763 & 0.00136 \\
\hline 5 & & & $\begin{array}{l}0.005 \pm \\
0.003\end{array}$ & $\begin{array}{l}0.29 \pm \\
0.006 \\
\end{array}$ & $\begin{array}{l}0.082 \pm \\
0.008\end{array}$ & $\begin{array}{l}0.884 \pm \\
0.004\end{array}$ & & 1.26 & 0.00414 & 0.00048 \\
\hline 6 & & & & & & $\begin{array}{l}0.927 \pm \\
0.001\end{array}$ & & 0.93 & 0.00339 & 0.00057 \\
\hline 7 & & & & $\begin{array}{l}1.19 \pm \\
0.007 \\
\end{array}$ & & $\begin{array}{l}0.117 \pm \\
0.007\end{array}$ & & 1.31 & 0.00788 & 0.00142 \\
\hline 8 & $\begin{array}{l}0.04 \pm \\
0.012 \\
\end{array}$ & $\begin{array}{l}0.05 \pm \\
0.016 \\
\end{array}$ & $\begin{array}{l}0.039 \pm \\
0.006\end{array}$ & $\begin{array}{l}0.202 \pm \\
0.01\end{array}$ & $\begin{array}{l}0.574 \pm \\
0.013 \\
\end{array}$ & $\begin{array}{l}0.083 \pm \\
0.006\end{array}$ & & 0.99 & 0.01181 & 0.00359 \\
\hline 9 & $\begin{array}{l}0.106 \pm \\
0.01\end{array}$ & $\begin{array}{l}0.234 \pm \\
0.012 \\
\end{array}$ & $\begin{array}{l}0.112 \pm \\
0.005\end{array}$ & $\begin{array}{l}0.163 \pm \\
0.014 \\
\end{array}$ & $\begin{array}{l}0.276 \pm \\
0.027 \\
\end{array}$ & $\begin{array}{l}0.128 \pm \\
0.017 \\
\end{array}$ & $\begin{array}{l}0.11 \pm \\
0.05\end{array}$ & 1.09 & 0.00728 & 0.00238 \\
\hline 10 & $\begin{array}{l}0.069 \pm \\
0.007\end{array}$ & $\begin{array}{l}0.163 \pm \\
0.009 \\
\end{array}$ & $\begin{array}{l}0.086 \pm \\
0.003 \\
\end{array}$ & $\begin{array}{l}0.149 \pm \\
0.01\end{array}$ & $\begin{array}{l}0.333 \pm \\
0.019\end{array}$ & $\begin{array}{l}0.097 \pm \\
0.012 \\
\end{array}$ & $\begin{array}{l}0.04 \pm \\
0.03\end{array}$ & 0.92 & 0.00362 & 0.00159 \\
\hline 11 & $\begin{array}{l}0.16 \pm \\
0.014 \\
\end{array}$ & $\begin{array}{l}0.263 \pm \\
0.019\end{array}$ & $\begin{array}{l}0.145 \pm \\
0.007\end{array}$ & $\begin{array}{l}0.207 \pm \\
0.012\end{array}$ & $\begin{array}{l}0.403 \pm \\
0.016\end{array}$ & $\begin{array}{l}0.159 \pm \\
0.007\end{array}$ & & 1.34 & 0.01639 & 0.0037 \\
\hline 12 & $\begin{array}{l}0.006 \pm \\
0.003\end{array}$ & $\begin{array}{l}0.005 \pm \\
0.004\end{array}$ & $\begin{array}{l}0.002 \pm \\
0.001\end{array}$ & $\begin{array}{l}0.044 \pm \\
0.001\end{array}$ & & $\begin{array}{l}0.042 \pm \\
0.003\end{array}$ & $\begin{array}{l}0.719 \\
\pm \\
0.005\end{array}$ & 0.58 & 0.01033 & 0.00576 \\
\hline 13 & $\begin{array}{l}0.005 \pm \\
0.005\end{array}$ & & & $\begin{array}{l}0.477 \pm \\
0.01\end{array}$ & $\begin{array}{l}0.538 \pm \\
0.014\end{array}$ & $\begin{array}{l}0.089 \pm \\
0.006\end{array}$ & & 1.11 & 0.01211 & 0.00269 \\
\hline 14 & $\begin{array}{l}0.111 \pm \\
0.023\end{array}$ & $\begin{array}{l}0.026 \pm \\
0.03\end{array}$ & $\begin{array}{l}0.022 \pm \\
0.011\end{array}$ & $\begin{array}{l}0.232 \pm \\
0.033\end{array}$ & $\begin{array}{l}0.14 \pm \\
0.06\end{array}$ & $\begin{array}{l}0.65 \pm \\
0.04\end{array}$ & $\begin{array}{l}1.43 \pm \\
0.11\end{array}$ & 2.13 & 0.06335 & 0.00284 \\
\hline 15 & $\begin{array}{l}0.031 \pm \\
0.011\end{array}$ & $\begin{array}{l}0.013 \pm \\
0.014\end{array}$ & $\begin{array}{l}0.021 \pm \\
0.005\end{array}$ & $\begin{array}{l}0.133 \pm \\
0.015\end{array}$ & $\begin{array}{l}0.54 \pm \\
0.029 \\
\end{array}$ & $\begin{array}{l}0.074 \pm \\
0.019\end{array}$ & $\begin{array}{l}0.32 \pm \\
0.05\end{array}$ & 1.02 & 0.00959 & 0.00229 \\
\hline 16 & $\begin{array}{l}0.12 \pm \\
0.031\end{array}$ & $\begin{array}{l}0.16 \pm \\
0.04\end{array}$ & $\begin{array}{l}0.142 \pm \\
0.014\end{array}$ & $\begin{array}{l}0.392 \pm \\
0.025\end{array}$ & $\begin{array}{l}0.68 \pm \\
0.03\end{array}$ & $\begin{array}{l}0.201 \pm \\
0.015\end{array}$ & & 1.69 & 0.07397 & 0.00871 \\
\hline 17 & $\begin{array}{l}0.091 \pm \\
0.019\end{array}$ & $\begin{array}{l}0.124 \pm \\
0.024\end{array}$ & $\begin{array}{l}0.107 \pm \\
0.009\end{array}$ & $\begin{array}{l}0.252 \pm \\
0.016\end{array}$ & $\begin{array}{l}0.57 \pm \\
0.021\end{array}$ & $\begin{array}{l}0.282 \pm \\
0.009\end{array}$ & & 1.43 & 0.02781 & 0.00426 \\
\hline
\end{tabular}




\begin{tabular}{|c|c|c|c|c|c|c|c|c|c|c|}
\hline 18 & $\begin{array}{l}0.107 \pm \\
0.01\end{array}$ & $\begin{array}{l}0.206 \pm \\
0.013\end{array}$ & $\begin{array}{l}0.115 \pm \\
0.005\end{array}$ & $\begin{array}{l}0.195 \pm \\
0.014\end{array}$ & $\begin{array}{l}0.235 \pm \\
0.027\end{array}$ & $\begin{array}{l}0.133 \pm \\
0.017\end{array}$ & $\begin{array}{l}0.16 \pm \\
0.05\end{array}$ & 1.10 & 0.00768 & 0.00243 \\
\hline 19 & $\begin{array}{l}0.059 \pm \\
0.016\end{array}$ & $\begin{array}{l}0.012 \pm \\
0.021\end{array}$ & $\begin{array}{l}0.012 \pm \\
0.008\end{array}$ & $\begin{array}{l}0.178 \pm \\
0.023\end{array}$ & $\begin{array}{l}0.64 \pm \\
0.04\end{array}$ & $\begin{array}{l}0.138 \pm \\
0.029\end{array}$ & $\begin{array}{l}0.02 \pm \\
0.08\end{array}$ & 1.05 & 0.02037 & 0.00493 \\
\hline 20 & & & & & & $\begin{array}{l}0.898 \pm \\
0.002 \\
\end{array}$ & & 0.90 & 0.00612 & 0.0011 \\
\hline 21 & $\begin{array}{l}0.008 \pm \\
0.008\end{array}$ & & & $\begin{array}{l}0.22 \pm \\
0.018\end{array}$ & $\begin{array}{l}0.8 \pm \\
0.023\end{array}$ & $\begin{array}{l}0.194 \pm \\
0.01\end{array}$ & & 1.22 & 0.03582 & 0.00587 \\
\hline 22 & $\begin{array}{l}0.057 \pm \\
0.005\end{array}$ & $\begin{array}{l}1.015 \pm \\
0.066\end{array}$ & $\begin{array}{l}0.009 \pm \\
0.005\end{array}$ & $\begin{array}{l}0.128 \pm \\
0.019\end{array}$ & $\begin{array}{l}0.05 \pm \\
0.04\end{array}$ & $\begin{array}{l}0.39 \pm \\
0.024\end{array}$ & & 1.32 & 0.02781 & 0.00311 \\
\hline 23 & $\begin{array}{l}0.046 \pm \\
0.011\end{array}$ & $\begin{array}{l}0.027 \pm \\
0.014\end{array}$ & $\begin{array}{l}0.015 \pm \\
0.005\end{array}$ & $\begin{array}{l}0.128 \pm \\
0.016\end{array}$ & $\begin{array}{l}0.472 \pm \\
0.03\end{array}$ & $\begin{array}{l}0.122 \pm \\
0.019\end{array}$ & $\begin{array}{l}0.18 \pm \\
0.05\end{array}$ & 0.93 & 0.00969 & 0.00291 \\
\hline 24 & $\begin{array}{l}0.031 \pm \\
0.006\end{array}$ & & $\begin{array}{l}0.007 \pm \\
0.006\end{array}$ & $\begin{array}{l}0.172 \pm \\
0.021\end{array}$ & $\begin{array}{l}0.5 \pm \\
0.04 \\
\end{array}$ & $\begin{array}{l}0.119 \pm \\
0.027\end{array}$ & $\begin{array}{l}0.22 \pm \\
0.07 \\
\end{array}$ & 0.98 & 0.01812 & 0.00467 \\
\hline 25 & $\begin{array}{l}0.015 \pm \\
0.004\end{array}$ & & $\begin{array}{l}0 \pm \\
0.003\end{array}$ & $\begin{array}{l}0.013 \pm \\
0.004\end{array}$ & & $\begin{array}{l}1.004 \pm \\
0.003\end{array}$ & & 1.03 & 0.0062 & 0.00087 \\
\hline 26 & $\begin{array}{l}0.093 \pm \\
0.008\end{array}$ & $\begin{array}{l}0.092 \pm \\
0.01\end{array}$ & $\begin{array}{l}0.093 \pm \\
0.004\end{array}$ & $\begin{array}{l}0.097 \pm \\
0.011\end{array}$ & $\begin{array}{l}0.103 \pm \\
0.021\end{array}$ & $\begin{array}{l}0.2 \pm \\
0.013 \\
\end{array}$ & $\begin{array}{l}0.16 \pm \\
0.04 \\
\end{array}$ & 0.78 & 0.0047 & 0.00249 \\
\hline 27 & $\begin{array}{l}0.042 \pm \\
0.006\end{array}$ & & $\begin{array}{l}0.011 \pm \\
0.006\end{array}$ & $\begin{array}{l}0.226 \pm \\
0.013\end{array}$ & $\begin{array}{l}0.643 \pm \\
0.018 \\
\end{array}$ & $\begin{array}{l}0.155 \pm \\
0.008\end{array}$ & & 1.08 & 0.02048 & 0.00462 \\
\hline 28 & $\begin{array}{l}0.186 \pm \\
0.021\end{array}$ & $\begin{array}{l}0.107 \pm \\
0.027\end{array}$ & $\begin{array}{l}0.095 \pm \\
0.01\end{array}$ & $\begin{array}{l}0.212 \pm \\
0.03\end{array}$ & $\begin{array}{l}0.12 \pm \\
0.06\end{array}$ & $\begin{array}{l}0.14 \pm \\
0.04\end{array}$ & $\begin{array}{l}0.22 \pm \\
0.103 \\
\end{array}$ & 1.01 & 0.03613 & 0.01287 \\
\hline 29 & $\begin{array}{l}0.035 \pm \\
0.003\end{array}$ & & $\begin{array}{l}0.016 \pm \\
0.003\end{array}$ & $\begin{array}{l}0.073 \pm \\
0.01\end{array}$ & $\begin{array}{l}0.117 \pm \\
0.02\end{array}$ & $\begin{array}{l}0.545 \pm \\
0.013\end{array}$ & $\begin{array}{l}0.1 \pm \\
0.03\end{array}$ & 0.85 & 0.00409 & 0.00106 \\
\hline 30 & $\begin{array}{l}0.062 \pm \\
0.021 \\
\end{array}$ & $\begin{array}{l}0.023 \pm \\
0.027\end{array}$ & $\begin{array}{l}0.022 \pm \\
0.01\end{array}$ & $\begin{array}{l}0.213 \pm \\
0.018\end{array}$ & $\begin{array}{l}0.615 \pm \\
0.023 \\
\end{array}$ & $\begin{array}{l}0.245 \pm \\
0.01\end{array}$ & & 1.18 & 0.03525 & 0.00664 \\
\hline 31 & $\begin{array}{l}0.098 \pm \\
0.035\end{array}$ & $\begin{array}{l}0.03 \pm \\
0.05\end{array}$ & $\begin{array}{l}0.049 \pm \\
0.017\end{array}$ & $\begin{array}{l}0.361 \pm \\
0.029\end{array}$ & $\begin{array}{l}0.92 \pm \\
0.04 \\
\end{array}$ & $\begin{array}{l}0.423 \pm \\
0.017\end{array}$ & & 1.88 & 0.09829 & 0.00729 \\
\hline 32 & $\begin{array}{l}0.222 \pm \\
0.017 \\
\end{array}$ & $\begin{array}{l}0.172 \pm \\
0.022 \\
\end{array}$ & $\begin{array}{l}0.244 \pm \\
0.008 \\
\end{array}$ & $\begin{array}{l}0.234 \pm \\
0.025 \\
\end{array}$ & $\begin{array}{l}0.33 \pm \\
0.05 \\
\end{array}$ & $\begin{array}{l}0.268 \pm \\
0.031\end{array}$ & $\begin{array}{l}0 \pm \\
0.08 \\
\end{array}$ & 1.47 & 0.02384 & 0.00433 \\
\hline 33 & $\begin{array}{l}0.097 \pm \\
0.008\end{array}$ & $\begin{array}{l}0.164 \pm \\
0.011\end{array}$ & $\begin{array}{l}0.107 \pm \\
0.004\end{array}$ & $\begin{array}{l}0.122 \pm \\
0.012\end{array}$ & $\begin{array}{l}0.092 \pm \\
0.023\end{array}$ & $\begin{array}{l}0.102 \pm \\
0.015\end{array}$ & $\begin{array}{l}0.237 \\
\pm 0.04 \\
\end{array}$ & 0.84 & 0.0058 & 0.00312 \\
\hline 34 & $\begin{array}{l}0.008 \pm \\
0.002 \\
\end{array}$ & & & $\begin{array}{l}0.001 \pm \\
0.003\end{array}$ & & $\begin{array}{l}0.914 \pm \\
0.002 \\
\end{array}$ & & 0.92 & 0.00359 & 0.00062 \\
\hline 35 & & & & & & $\begin{array}{l}0.752 \pm \\
0.001\end{array}$ & & 0.75 & 0.00364 & 0.00094 \\
\hline 36 & & & & & & $\begin{array}{l}0.85 \pm \\
0.002 \\
\end{array}$ & & 0.85 & 0.00771 & 0.00155 \\
\hline 37 & $\begin{array}{l}0.04 \pm \\
0.007\end{array}$ & & $\begin{array}{l}0 \pm \\
0.007\end{array}$ & $\begin{array}{l}0.209 \pm \\
0.015\end{array}$ & $\begin{array}{l}0.631 \pm \\
0.02\end{array}$ & $\begin{array}{l}0.216 \pm \\
0.009\end{array}$ & & 1.10 & 0.02707 & 0.00561 \\
\hline 38 & $\begin{array}{l}0.14 \pm \\
0.016 \\
\end{array}$ & $\begin{array}{l}0.164 \pm \\
0.02\end{array}$ & $\begin{array}{l}0.161 \pm \\
0.007\end{array}$ & $\begin{array}{l}0.299 \pm \\
0.013\end{array}$ & $\begin{array}{l}0.325 \pm \\
0.017\end{array}$ & $\begin{array}{l}0.185 \pm \\
0.008\end{array}$ & & 1.27 & 0.01898 & 0.00448 \\
\hline 39 & $\begin{array}{l}0.097 \pm \\
0.016\end{array}$ & $\begin{array}{l}0.114 \pm \\
0.021\end{array}$ & $\begin{array}{l}0.047 \pm \\
0.008\end{array}$ & $\begin{array}{l}0.173 \pm \\
0.023\end{array}$ & $\begin{array}{l}0.42 \pm \\
0.05\end{array}$ & $\begin{array}{l}0.185 \pm \\
0.029\end{array}$ & $\begin{array}{l}0.17 \pm \\
0.08\end{array}$ & 1.15 & 0.02079 & 0.00473 \\
\hline 40 & $\begin{array}{l}0.101 \pm \\
0.008\end{array}$ & $\begin{array}{l}0.26 \pm \\
0.01\end{array}$ & $\begin{array}{l}0.132 \pm \\
0.004\end{array}$ & $\begin{array}{l}0.133 \pm \\
0.007\end{array}$ & $\begin{array}{l}0.238 \pm \\
0.009\end{array}$ & $\begin{array}{l}0.106 \pm \\
0.004\end{array}$ & & 0.97 & 0.00501 & 0.00235 \\
\hline
\end{tabular}


TABLE S5.2. D. heliopora S XANES points from Supplementary Materials Figure S5.1 fit with Multiple Energy (ME) maps.

\begin{tabular}{|c|c|c|c|c|c|c|c|}
\hline 芯 & 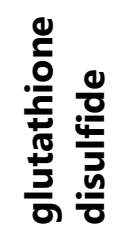 & 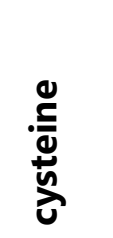 & $\begin{array}{l}\frac{0}{0} \\
\frac{0}{x} \\
\frac{0}{5} \\
\frac{5}{5}\end{array}$ & 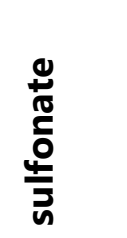 & 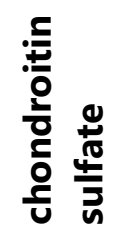 & 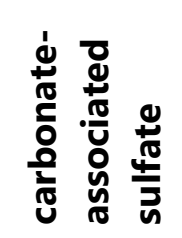 & 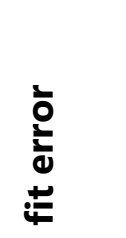 \\
\hline 1 & 4.10 & -2.07 & 0.95 & 6.81 & 65.47 & 6.27 & 394.08 \\
\hline 2 & 3.14 & 2.87 & 2.65 & 7.03 & 54.28 & 8.73 & 239.90 \\
\hline 3 & -0.03 & 0.32 & 0.23 & 7.60 & -3.73 & 16.26 & 2.12 \\
\hline 4 & 0.51 & -0.91 & 0.16 & 0.19 & -0.21 & 11.59 & 0.00 \\
\hline 5 & 1.78 & -2.32 & 0.43 & -2.99 & 9.10 & 10.62 & 22.85 \\
\hline 6 & 0.64 & -0.74 & 0.23 & -4.26 & 6.09 & 10.15 & 3.42 \\
\hline 7 & 0.82 & -0.73 & -0.84 & 54.97 & 12.08 & 1.07 & 81.50 \\
\hline 8 & 8.30 & -1.70 & 5.24 & 17.61 & 36.77 & 5.64 & 442.41 \\
\hline 9 & 5.66 & 7.57 & 4.52 & 3.77 & 11.31 & 5.26 & 47.56 \\
\hline 10 & 10.53 & 0.70 & 6.37 & -1.19 & 26.32 & 3.60 & 103.59 \\
\hline 11 & 5.25 & 6.28 & 4.62 & 2.96 & 12.42 & 5.46 & 13.98 \\
\hline 12 & 0.98 & 5.26 & 1.03 & -37.10 & 92.71 & 3.79 & 103.99 \\
\hline 13 & 0.31 & 2.44 & -0.34 & 20.89 & 58.87 & 1.26 & 71.37 \\
\hline 14 & -0.08 & 5.40 & 0.18 & -23.25 & 59.14 & 14.33 & 4.49 \\
\hline 15 & 3.65 & 1.43 & 4.82 & -9.03 & 58.05 & 11.54 & 140.17 \\
\hline 16 & 4.30 & 2.04 & 6.15 & 5.96 & 22.46 & 3.68 & 157.35 \\
\hline 17 & -4.44 & 12.95 & 2.33 & 4.55 & 33.27 & 4.93 & 228.34 \\
\hline 18 & 3.23 & 3.04 & 0.87 & -0.74 & 53.90 & 5.82 & 255.87 \\
\hline 19 & 3.75 & 8.80 & 5.58 & 1.80 & 21.51 & 4.03 & 78.48 \\
\hline 20 & 2.24 & -3.10 & 0.45 & -0.63 & 0.20 & 14.82 & 8.02 \\
\hline 21 & 2.38 & -2.61 & 0.27 & 15.30 & 22.97 & 10.48 & 158.00 \\
\hline 22 & 2.53 & 3.29 & 0.89 & -27.07 & 75.52 & 15.78 & 356.87 \\
\hline 23 & 0.83 & 7.37 & 1.14 & -0.49 & 35.43 & 4.78 & 245.90 \\
\hline 24 & 2.75 & 0.05 & 1.41 & 11.73 & 21.26 & 9.36 & 239.02 \\
\hline 25 & 1.19 & 0.50 & -4.61 & 8.99 & 12.23 & -1.17 & 20.71 \\
\hline 26 & 3.76 & 2.38 & 0.31 & 5.97 & 3.45 & -0.44 & 2.98 \\
\hline 27 & 3.16 & -1.34 & 1.16 & 5.26 & 36.88 & 7.87 & 210.64 \\
\hline 28 & 0.57 & 1.08 & 0.24 & 0.22 & 2.70 & 0.44 & 6.63 \\
\hline 29 & 0.43 & 1.28 & 0.20 & -1.76 & 9.74 & 10.79 & 26.30 \\
\hline 30 & 3.17 & -0.28 & 1.94 & -2.13 & 34.56 & 6.26 & 131.78 \\
\hline 31 & -0.34 & 3.66 & 1.22 & -4.26 & 31.29 & 4.60 & 50.67 \\
\hline 32 & 2.55 & 1.88 & 2.75 & -5.81 & 15.38 & -0.62 & 7.09 \\
\hline 33 & 0.09 & 9.64 & 3.05 & -4.61 & 14.50 & 1.85 & 21.15 \\
\hline 34 & -0.09 & 0.25 & -0.01 & 0.00 & 0.16 & 11.15 & 3.73 \\
\hline 35 & 0.14 & -0.42 & -0.17 & 6.00 & -9.11 & 17.74 & 3.04 \\
\hline
\end{tabular}




\begin{tabular}{llllllll}
36 & -0.06 & 0.37 & -0.01 & -1.63 & 0.36 & 10.30 & 0.96 \\
\hline 37 & 3.76 & -3.37 & 1.17 & 0.60 & 21.41 & 4.88 & 76.98 \\
\hline 38 & -0.14 & 6.10 & 2.49 & -1.88 & 13.63 & 1.78 & 23.99 \\
\hline 39 & 3.12 & 3.63 & 0.58 & -9.31 & 37.15 & -1.50 & 219.05 \\
\hline 40 & 0.55 & 7.71 & 2.65 & -0.88 & 10.54 & 0.99 & 17.97 \\
\hline
\end{tabular}


Chapter 6. Conclusions 
In this thesis we quantitatively measure the mineralogy and chemistry of both deep-sea and shallow-water corals in order answer the following questions: 1) how do corals form their skeletons, and 2) how sensitive is coral mineralogy to shifts in surrounding ocean conditions.

\subsection{Biomineralization via geochemical processes}

In Chapter 2 we demonstrate that the anisotropic differences in unit cell axis lengths between coral aragonite and geologically-formed aragonite mimics that of synthetic aragonites precipitated from seawater (Figure 2.2; Table 2.2). I suggest that this indicates that coral biomineralization is primarily driven by geochemistry inside of the coral calcifying fluid, rather than by primarily by biomolecules. This supports previous geochemical perspectives on coral biomineralization (DeCarlo et al., 2018; Holcomb et al., 2009; Gaetani and Cohen, 2006; Constanz, 1993). Instead of anisotropic crystallographic differences caused by intra-crystalline biomolecules, as is proposed in mollusk aragonite, distortions in coral aragonite are likely driven by the trace incorporations of other elements such as Sr and B (Figure 2.7).

Another line of evidence for the dominance of inorganic processes in coral biomineralization is the presence of carbonate-associated sulfate bonding environments (CAS) which are ubiquitous in the coral skeletons and greatly outweigh any contributions by organic Sbonding environments in the skeleton. This is demonstrated in Chapter 5 by our improved method for fitting synchrotron-based multiple energy sulfur $\mu$ XRF maps with representative $S$ XANES spectra that represent potential S-bonding environments in corals with heterogeneous skeleton and tissue components (Figure 5.3).

\subsection{Minor anisotropic lattice distortions in coral aragonites growing in natural low $\Omega_{\text {sw }}$ conditions driven by skeleton growth parameters}

In both deep-sea (Chapter 3) and shallow-water (Chapter 4) environments we observe that corals exhibit very minor anisotropic shifts in aragonite crystallography as a function of growing under a decreased $\Omega_{\mathrm{sw}}$ (1.15-1.44 gradient in the Gulf of Mexico; 2.3-3.7 from Nikko Bay to Dropoff sites in Palau). Overall, these crystallographic shifts for corals under lower $\Omega_{\text {sw }}$ are very small in magnitude $\left(\sim-0.2 \AA^{3}\right.$ overall unit cell volume for Gulf of Mexico Lophelia pertusa corals, Figures 3.2 and $3.3 ; \sim+0.0005 \AA$ along the $a$-axis of Palau Porites sp. corals, Table 4.2 ) and it is unclear whether or not these crystallographic distortions would deteriorate the stability of coral skeletons as a whole or whether these distortions are too minor and signify that corals are mineralogically resilient to these modest, natural $\Omega_{\mathrm{sw}}$ gradients.

In the deep-sea Gulf of Mexico samples, we only observe that declining $\Omega_{\mathrm{sw}}$, and no other variables measured, are correlated with decreasing unit cell volumes, driven by a shortening along the $a$ - and $b$-axes (Figure 3.3). Unfortunately, we do not have skeletal density or growth rate data for this Gulf of Mexico dataset. In the Palau shallow-water system, we observe that a shortening along the $a$-axis is likely due to increased incorporations of calcite in the skeleton (Figures 4.4B and 4.8B). Calcite contents increase as a function of skeletal density, skeletal growth rates, and $\Omega$ of coral calcifying fluid $\left(\Omega_{\mathrm{cf}}\right)$ (Figures $4.4 \mathrm{C}$ and $4.8 \mathrm{C}$ ). 


\subsection{Future directions}

In order to determine how the anisotropic shifts in crystallography that we observe in the corals in this thesis manifest in the material properties of skeletons (solubility constants, strength constants), more experimental and crystal modeling work is required. Future studies of coral crystallography under shifting ocean chemistry could benefit from incubations run under more controlled conditions and at more extreme $\Omega_{\mathrm{sw}}$ gradients in order to separate which variables control coral aragonite crystallography and to quantify what the maximum crystallographic shifts might be in coral aragonite. Experiments of synthetic aragonites grown from seawater at controlled crystal growth rates and densities could also be investigated with the same crystallographic methods utilized in this thesis to model coral aragonite.

As for crystallographic modelling, since we observed that calcite contents could influence $a$-axis lengths in our corals, it would be beneficial to model how small incorporations of trigonal calcite symmetry in an overall orthorhombic aragonite lattice would influence aragonite lattice parameters.

From Chapters $2-4$, we observe that coral mineralogy, crystallography and chemistry is dependent on many different variables $(\Omega \mathrm{Ar}, \mathrm{pH}$, temperature, growth rates, calcite contents, trace element incorporations), many of which have nested interactions. Thus, these complex environmental datasets would benefit from a multivariate approach to assess which parameters are most dominant in crystal growth and in shifting unit cell parameters. Our first attempt at this is in Chapter 3, where we use PCA biplots to visualize the relative contribution of different variables to the observed differences between samples. A multivariable approach could similarly be applied in Chapters 2 and 4 as well as in furture experimental studies.

Overall, this thesis answers pressing questions on the nature of coral biomineralization from a mineralogical and chemical perspective using standard and novel crystallographic and chemical techniques. By characterizing the crystallography and chemistry of coral skeletons, we observe similarities between coral aragonite and synthetic aragonites precipitated from seawater. This suggests that coral biomineralization is likely controlled by geochemical, rather than biological processes. Under the various environmental conditions explored in this thesis, we observe minor shifts in coral aragonite crystallography as a function of $\Omega_{\mathrm{sw}}$, skeletal growth parameters (density, growth rate, $\Omega_{\mathrm{cf}}$ ), and skeletal incorporations of calcite and metals. More experiments and modelling are required to determine whether these crystallographic shifts may be enough to trigger further skeletal deterioration in corals, or if they are too minor and indicate a mineralogical resilience in corals living under stressful ocean conditions.

\subsection{References}

Constantz, B. R. (1986). Coral skeleton construction: a physiochemically dominated process. Palaios, 152-157. doi: $10.2307 / 3514508$

DeCarlo, T. M., Ren, H., and Farfan, G. A. (2018). The origin and role of organic matrix in coral calcification: insights from comparing coral skeleton and abiogenic aragonite. Front Mar Sci, 5, 170. doi:10.3389/fmars.2018.00170 
Gaetani, G. A., and Cohen, A. L. (2006). Element partitioning during precipitation of aragonite from seawater: a framework for understanding paleoproxies. Geochim. Cosmochim. Acta, 70, 4617-4634. doi:10.1016/j.gca.2006.07.008

Holcomb, M., Cohen, A. L., Gabitov, R. I., and Hutter, J. L. (2009). Compositional and morphological features of aragonite precipitated experimentally from seawater and biogenically by corals. Geochim. Cosmochim. Acta, 73(14), 4166-4179. doi:10.1016/j.gca.2009.04.015 